\title{
$9-2017$
}

\section{History of North Dakota}

Elwyn B. Robinson

University of North Dakota

How does access to this work benefit you? Let us know!

Follow this and additional works at: https://commons.und.edu/oers

Part of the History Commons

\section{Recommended Citation}

Robinson, Elwyn B., "History of North Dakota" (2017). Open Educational Resources. 1.

https://commons.und.edu/oers/1

This Textbook is brought to you for free and open access by UND Scholarly Commons. It has been accepted for inclusion in Open Educational Resources by an authorized administrator of UND Scholarly Commons. For more information, please contact und.commons@library.und.edu. 

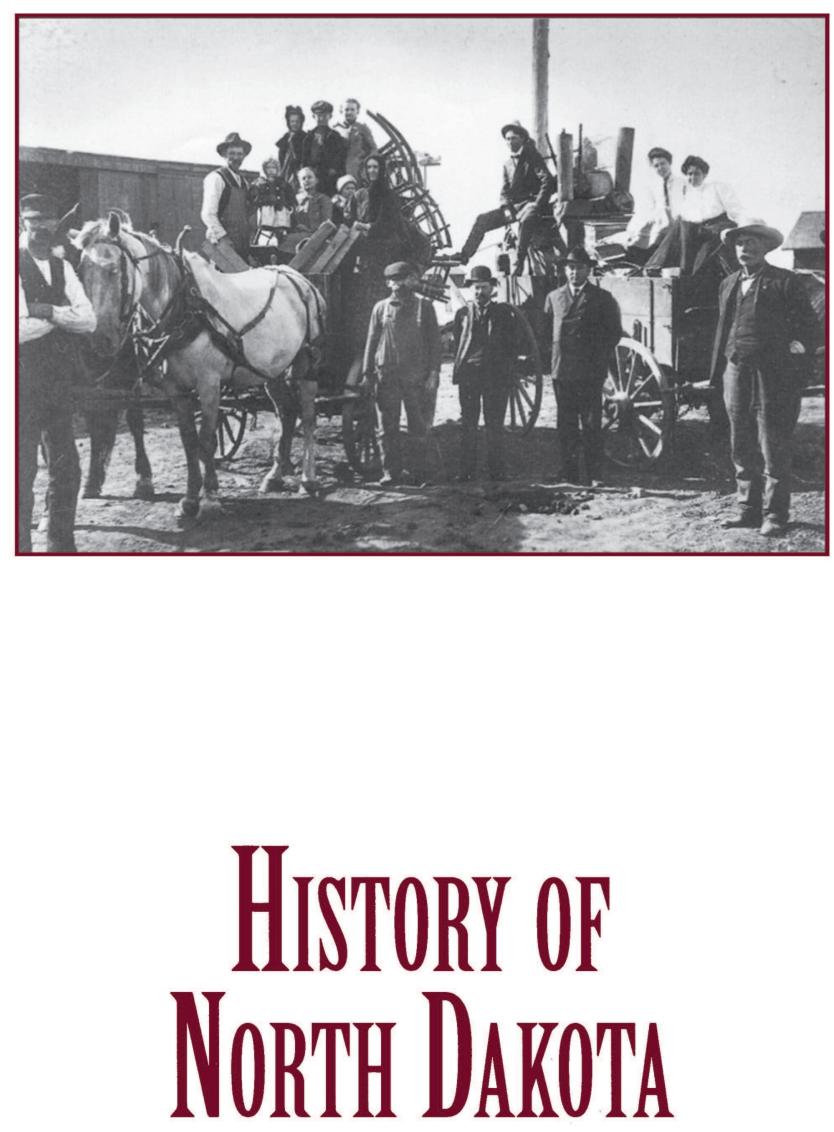

Robinson

with a new preface and postscript 


\section{Preface to the North Dakota edition}

\section{Elwyn B. Robinson and the Themes of North Dakota}

RAVE REVIEWS greeted Elwyn B. Robinson's History of North Dakota when it appeared in 1966. To describe the book reviewers used terms such as "astonishingly comprehensive," “absorbing account," "well documented," "balanced,” and “fascinating.” More important, historians recognized the two features that set Robinson's history apart from most other state histories: breadth and interpretation. Writing in Arizona and the West, Robert G. Athearn, professor of history at the University of Colorado, observed, "This latest state history is all the more valuable because the author has not limited himself entirely to local history, but has ignored artificial geographic boundaries and has integrated his story with national development." Robinson did indeed place North Dakota in the larger context; the fur trade moves westwardly along the Great Lakes into the Red River Valley and northwardly along the Missouri into western North Dakota. The North Dakota fur trade is but a part of a continental movement. The bossism of Alexander McKenzie and the reform zeal of the early twentieth century become reflections of the national political mood. North Dakota's plight during the 1930s mirrors the nationwide dilemma of the Great Depression. Robinson realized that North Dakota did not develop in a vacuum.

“The title of Elwyn Robinson's book is a gross understatement," Hiram Drache of Concordia College (Moorhead, MN) wrote in the Journal of American History. "It is anthropology, geography, sociology, economics, ethnology, political science, nature study, and theology interwoven into one well-compiled volume.” Robinson's history possessed breadth not only in context but also in content. Believing that geography is a powerful 


\section{Elwyn Robinson}

historical force. throughout the volume he is painstakingly careful to deal with the state and its people in the natural setting. Too, Robinson accepts the premise that people are more than political and economic beings. Most of the state histories that appeared prior to Robinson's placed primary emphasis upon political and economic institutions and developments. As Drache points out, Robinson looked at North Dakota's people in the broadest possible way. He was uniquely comfortable whether he was writing about the grasslands, church life, wheat varieties, the arts, education, or political parties.

Interpretation underpinned the breadth of Robinson's work. In the American Historical Review Arthur J. Larsen of the University of Minnesota, Duluth, saw this: "His recurrent theme is that of the influence of geography in the state's development." Larsen concludes that the history "helps us to understand the dilemma of the Plains states." Herbert S. Schell, professor of history at the University of South Dakota and the author of a history of that state in 1961, told readers of Minnesota History: "In this absorbing account. the author makes geography the major key to an understanding of North Dakota's development. From its location on the northern edge of the Great Plains spring five themes which dominate the entire North Dakota story: remoteness, dependence, economic disadvantage, the 'Too-Much Mistake,' and the need for adaptation to environment. Within this frame of reference, Professor Robinson tells a fascinating story.”

To Robinson, history had to have meaning. History without interpretation was useless. His History of North Dakota was written within the context of place. He was essentially a geographic determinist. North Dakota's past was the way it was because of location.

Robinson's history had breadth, but more important to him, it had interpretation. Perhaps John Schlebecker of the Smithsonian Institution said it best in the Journal of Economic History: "This history could well be used as a model for other state histories. Practitioners of this art have produced some excellent work of late, but this is, I think, the best so far.” This was a model history in the 1960s; it remains a model history in the 1990s.

Elwyn Burns Robinson was not a likely person to have undertaken the formidable task of researching and writing a history of North Dakota. He was born on October 13, 1905, in Ohio on a Geauga County farm not far from Cleveland. Nine years later the Robinson family moved to Chagrin Falls, just outside of Cleveland, where his father opened a photographic studio. (Elwyn carried on a life-long love affair with photography.) He attended Oberlin College, not far from home, and although he took some European history 
courses, he had more interest in sports than American history. He was a marksman, played tennis and handball, and earned a letter in football. He was an English major.

After graduation from Oberlin College in 1929, he became principal and English teacher at the small high school in New Lyme, Ohio. After school hours, he coached basketball, track, and baseball. In 1930 he took an English teaching position at the Old Trail School in an Akron suburb. A voracious reader. Robinson devoted his spare time to Mark Sullivan's Our Times: The United States, 1900-1925. Sullivan had a knack for bringing American history to life with his interesting anecdotes and emphasis upon social and personal history. The Sullivan multi-volume work had a profound and lasting influence on Robinson. He appreciated "people history" and decided to pursue graduate study in American history at Ohio's Western Reserve University. By 1932 he completed his thesis, "John W. Forney and the Philadelphia Press," which he wrote under the direction of Arthur C. Cole who was preparing a volume in the History of American Life. Like Mark Sullivan, Professor Cole turned Robinson's historical direction toward the social and literary side of American development and convinced his student to continue in the history of journalism with the dissertation topic, "The Public Press of Philadelphia During the Civil War.”

In 1935 with his dissertation almost completed, Robinson accepted a position at the University of North Dakota. Teaching jobs were indeed scarce in the midst of the Great Depression, and, although he knew very little about North Dakota, he jumped at the opportunity of full-time employment. (He received his Ph.D. the following year.) At the University of North Dakota he joined the three-person Department of American History which Orin G. Libby chaired. (Because Libby had denounced the university's president, in 1920 he had lost the three European historians to a new Department of European History.) In Libby, Robinson found a serious scholar whom Frederick Jackson Turner had trained at the University of Wisconsin. Libby had revitalized the State Historical Society in North Dakota, had written about the state's "colonial period," and had collected and edited scores of documents on North Dakota's early years. North Dakota was Libby's domain, and Robinson busied himself teaching five courses each semester and preparing a series of five articles on the history of Pennsylvania journalism for the Pennsylvania Magazine of History. The pieces appeared between 1937 and 1941.

Although the young professor had reviewed three books on Minnesota history by 1943, he did not indicate an interest in North Dakota history until after Libby's retirement in 1944. In 1947 he began preparing forty fifteen- 


\section{Elwyn Robinson}

minute radio biographical sketches on North Dakota personalities for KFJM, the university's radio station. Recordings of his "Heroes of Dakota" played on stations across the state. In 1948 the University of North Dakota turned his scripts into book form and distributed them to schools and libraries. Soon he began to teach a course on North Dakota's history and encouraged graduate students to pursue North Dakota topics for their seminar papers and theses. The Ohioan had developed a keen interest in his adopted state.

The "Heroes of Dakota" started Robinson's quest for an understanding of North Dakota's past. In 1958 as part of the University of North Dakota's seventy-fifth anniversary celebration, he shared the results of almost ten years of research with the public. In an address entitled "The Themes of North Dakota History" he laid out the context for his study of the state. He explained that "as thoughtful people we are always seeking to understand the world around us. One way is the observation of patterns, of the recurrence of somewhat similar events. Recurrence may reveal relationships or truths.... Historical themes are patterns of many events." He continued, "That is what I am attempting to do, to relate the events of North Dakota history to a handful of themes." Robinson enunciated six themes: remoteness, dependence, radicalism, a position of economic disadvantage, the Too-Much Mistake, and adjustment.

He held that all six themes sprang from geographic facts: the state's location in the continental center, the cool and subhumid climate, and the differences in climate between the state's eastern and western regions. "The influence of these facts," Robinson maintained, "Is seen in every aspect of North Dakota history."

Robinson defined remoteness as "the influence of the great distance between North Dakota and the chief centers of population, industry, finance, culture, and political decision in the nation and in the Western World." He pointed out that the horse came late to the Native People and that the waves of white people (the explorers, the fur traders, ranchers, and farmers) arrived late in North Dakota. "More fundamental," he concluded, "remoteness has always meant high transportation costs for North Dakota, and so it is one of the chief reasons for the lack of manufacturing in the state."

Perhaps because it was so obvious, Robinson devoted only one paragraph of his lengthy address to remoteness. Remoteness, however, created the second theme: dependence. He explained that dependence "stands for North Dakota's status as a colonial hinterland." Remoteness helped make and keep the state as a colonial hinterland, and as a hinterland North Dakota always had been dependent upon outside finance, trade, and manufacturing. This 
dependence led to a "real degree of their control."

Robinson presented three primary examples of dependence and outside control. Colonial status began, he argued, with the Indian trade. The Native People became dependent upon the goods which the white traders could provide. Access to fur markets was in the hands of the white traders. According to Robinson, "Need placed them under the control of the traders."

White settlers became far more dependent than Native People on the factories of the East. Wheat had to reach distant markets. That access to markets was controlled by "the owners and managers of the railroads, the flour mills, the lines of elevators, the grain exchanges, and the banks which furnished credit for the whole complex operation.” To Robinson, the railroads were "the key." The powerful transcontinentals, the Great Northern and the Northern Pacific, controlled the economic and political lives of North Dakotans. North Dakota become a colony of the Twin Cities and a hostage of the corporate decisions that were made there. North Dakotans had little control over their destinies.

Government, too, contributed to the dependent condition. In the Louisiana Purchase, the coming of military posts, and the years of territorial status, Robinson felt that "North Dakota was the plaything of outside forces." In later years dependence upon the federal government took the shape of massive aid during the Great Depression, highway construction, Missouri Basin development, rural electrification, and farm/conservation programs.

Robinson held that dependence gave rise to agrarian radicalism, the struggle against colonial status and the outside exploitation that went with it. According to Robinson, this struggle began with Indian resistance to white encroachment and continued down to the 1950s with the cooperative movement. He used three primary examples of agrarian radicalism: The Farmers' Alliance, the Nonpartisan League, and the many leading residents who took up causes against outside exploitation.

The Farmers' Alliance and Independent Party of the 1880s and early 1890s sought protection for the state against "the encroachments of concentrated capital.” The two principal targets were railroads and grain-elevator abuses. The Alliance and its political arm, the Independent Party, failed in their mission but stand as symbols of agrarian radicalism. The Nonpartisan League (NPL), however, succeeded. Organized in 1915, the NPL espoused a program of state ownership a bank, mill and elevator, creamery, hail insurance, home building association. In the election of 1918 the NPL captured all three branches of government and enacted its program of "state socialism." Its radicalism captured national attention until 1921-1922 when it crumbled and 


\section{Elwyn Robinson}

lost control of the government's machinery. Robinson presented a long list of individual groups and leaders who waged campaigns against exploitation. For examples, agricultural-college chemist Edwin F. Ladd crusaded for wheat grades based on protein content; the Fargo Chamber of Commerce led the fight for lower freight rates; editor George Winship of the Grand Forks Herald organized the movement against bossism and for honest government. William D. Walker, the Episcopal bishop, gave voice to radicalism when he called bankers "human vampires." The list was long and convincing.

By the position of economic disadvantage Robinson meant "the wide fluctuations in North Dakota's income and to the lower-than-average per capita income that North Dakota as an agricultural state has generally received in good times and bad alike.” He believed that this economic disadvantage resulted from the subhumid character of the country and the dominance of agriculture in the economy. His analysis of crop yields, commodity prices, and per capita income concluded that "the theme of economic disadvantage runs through the North Dakota story." Only once (1947) had the state's per capita personal income risen above the national average.

Robinson coined the term, the "Too-Much Mistake," as his name for "too many farms, too many miles of railroads and roads, too many towns, banks, schools, colleges, churches, and governmental institutions, and more people than opportunities-numbers of all that history shows have been far beyond the ability of the state to maintain.” He maintained that the Too-Much Mistake resulted essentially from three conditions. First, the white settlers who first came to and controlled the state were not familiar with the subhumid grasslands. They arrived from the Canadian and American easts where rainfall was plentiful and places thickly populated. They incorrectly viewed North Dakota as being the same as the places they had left. Second, the Homestead Act provided for farms of 160 acres-adequate in the East but far from adequate in a subhumid state such as North Dakota. Third, the optimism and boosterism of the 1880s (a time of above average rainfall) led to an unbridled exuberance for building both public and private enterprises.

To Robinson. the real proof that the Too-Much Mistake was a "real mistake" rested with the evidence of "too little use, of too heavy cost per capita-needs pressing too hard upon limited income, and, most irrefutably, in the record of retrenchment and abandonment."

Adjustment, the last theme, "means both the painful cutting back of the oversupply of the Too-Much Mistake and the slow forging of more suitable ways of living in a subhumid grassland.” In the late 1950s, the UND professor was struck by how slowly North Dakota had moved to deal with the Too- 
Much Mistake. Other than the consolidation of some public schools and the failures of some private enterprises (especially banks in the 1920s and early 1930s) little "progress" had been made.

The subhumid grassland, however, had forced adjustment. Native People who came from the woodlands of the East changed their ways of living on the Plains. Farmers adjusted their practices, enlarged their farms, employed conservation methods, and attempted diversification. Robinson seemed to lament the fact that "for many people the adjustment has been simply to leave the state."

In presenting "the Themes of North Dakota History," Professor Robinson constructed the framework for serious study of the state's past. The six themes provided a context for his history of North Dakota and for a generation of historians who have continued to research and write about the state.

Elwyn Burns Robinson retired from the University of North Dakota in 1974 with the school's highest rank-University Professor. That distinction reflected the excellence of his scholarship, his skill in the classroom, and his dedicated service in many capacities within the university, the state, and the profession. Until his death in 1988 he continued to reflect upon and write about the Great Plains experience.

D. JEROME TWETON

UNIVERSITY OF NORTH DAKOTA 


\section{Preface}

THERE ARE TWO KEYS to understanding the history of North Dakota. The first concerns the context of historical movements in Europe and North America during which North Dakota was explored, settled, and developed. The second deals with North Dakota's geographical location and the various ways in which that location influenced the course of events within the state. Studied together, they give form and meaning to the story of how a modern, civilized society was carved out of the wilderness of the Northern Great Plains.

Of the two keys, location is more important because from it spring six themes which dominate the North Dakota story: remoteness, dependence, economic disadvantage, agrarian radicalism, the "Too- Much Mistake" (trying to do too much too fast with too little), and adaptation to environment. Every event in the history of the state is related in some way to one or more of them.

In writing this volume, I have utilized these concepts as a means of interpreting the North Dakota experience, not only for North Dakotans, but for all who would understand the state and its people. I have therefore sought to view North Dakota's history in broad perspective, relating it to major events in the history of the Western world, and to demonstrate how the conditions of existence shaped the character of the men and women who 
settled the state. For it is my conviction that an adequate knowledge of North Dakota's past provides the best foundation for making public decisions which will determine its future. I have incurred numerous obligations in preparing this book. To the many students and other friends who have expressed interest in its progress, I extend heartfelt thanks. At the University of North Dakota, the late President John C. West and Dean R. B. Witmer made clear their warm approval. When Dr. George W. Starcher became president in 1954, he encouraged me by his keen interest. On two occasions the administration lightened my teaching load, and the Faculty Research Committee has given me research grants. Most of the work, however, has been done during long summer vacations.

I owe much to the graduate students whose theses and dissertations are listed in the Bibliographical Essay. I thank the Greater North Dakota Association, the State Soil Conservation Committee, the Great Northern Railway Company, North Dakota State University, the University of North Dakota, and others who supplied photographs. Miss Margaret Rose, librarian of the North Dakota State Historical Society, was especially helpful in selecting pictures from the excellent collection under her management. Professor Robert K. Snortland, chairman of the University of North Dakota's Department of Engineering Drawing, prepared the maps.

Special thanks go to Dr. Robert P. Wilkins, long my colleague in the Department of History at the University of North Dakota, for encouraging words, for interesting items from his own research, for reading the manuscript, and for much conversation about the meaning of the North Dakota experience. My thinking was clarified by the opportunity afforded me through Dr. William E. Koenker's invitation to lecture on "The Themes of North Dakota History" at the university's seventy-fifth anniversary celebration in the fall of 1958. To my wife, Eva, I owe most: for typing, for aid in stylistic revision and checking the manuscript, for listening to endless talk about North Dakota history, and for sacrificing for many years time which might otherwise have been used for family recreation. Only such sacrifice has made this book possible.

ELWYN B. ROBINSON 


\section{List of Maps}

Topography of North Dakota 9

Indian Tribes in 1750 24

Indian Tribes in 1850

Early Trade Routes to North Dakota 39

Early Forts, Trails, Towns, and Indian Villiages 91

Extent of Settlement, 1800 152

Extent of Settlement, 1900 152

Largest Foreign White Stock in Each Country 282

Farming Areas of North Dakota 445

Following page 368 is a pictorial review. 


\section{CHAPTER 1}

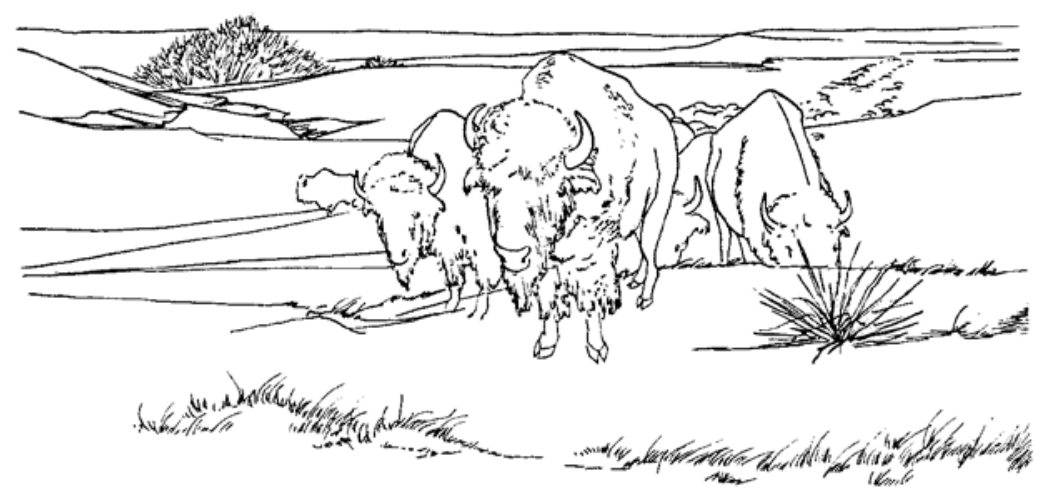

\section{The Grassland Setting}

THE STORY OF NORTH DAKOTA begins with geology. Invasions of a great salt sea laid down the strata in which oil and other mineral deposits are found, and, later, fresh-water rivers formed strata containing lignite beds. Erosion, caused by wind, water, and glacial ice sheets, shaped the surface of the land, leaving what is now North Dakota as part of two significant physiographic provinces of North America: the Central Lowlands and the Great Plains. Within the state, the Central Lowlands Province is subdivided into the Drift Prairie and the Red River Valley and is separated from the Great Plains Province by the Missouri Escarpment.

Thus divided into three distinct regions, North Dakota is a rather 
large state, a rectangle some 335 miles from east to west and 210 miles north to south, with an area of 70,665 square miles. It is located at the center of the continent, roughly 1,500 miles from the Atlantic Ocean and also from the Pacific, and about the same distance from the Gulf of Mexico and the Arctic Archipelago.

\section{GEOLOGY}

The Williston Basin, a saucer-like depression in the igneous granite crust of the earth's surface, had its origin half a billion years ago when the granite crust began to sink, a process which continued several million years. It now extends over some 130,000 square miles, about 50,000 square miles of which underlie North Dakota. The basin reaches from eastern North Dakota (Devils Lake and Jamestown are near its eastern edge) into Montana, and from northwestern South Dakota into Manitoba and Saskatchewan. At its center, near the Killdeer Mountains, the granite lies 15,000 feet below the surface.

For hundreds of millions of years the Williston Basin and the area surrounding it were intermittently covered by a salt sea stretching from the Gulf of Mexico to the Arctic. Sediment carried into the sea by flowing water was deposited on the bottom and slowly compacted into strata, or layers, of sedimentary rock made up of clay, shale, sandstone, and limestone. During the long periods when the sea withdrew, the exposed surface was eroded. Thus the strata are thicker in the deeper parts of the basin, covered longer by water, than they are in its shallower parts or outside it. All of the strata become thinner toward the eastern part of the state, where the basin floor slopes gently upward. In that section the granite lies only 200 to 800 feet below the surface.

Oil was formed in the deepest strata, probably from the remains of plants and animals buried in deposits at the bottom of the sea. 
In some places, such as the Nesson Anticline south of Tioga, oil pools were created. North Dakota oil has been produced principally from the Mississippian Madison formation, the pay zone of the Clarence Iverson No. 1, the discovery well, but it has also been found in many strata above and below the Madison at depths of from 8,000 to 14,000 feet.

About a hundred million years ago the Dakota sandstone, a thin layer of mud and sand, was deposited under eastern North Dakota. At one time more than six thousand artesian wells brought up much water from this formation, especially in the southeastern part of the state.

Overlying the Dakota sandstone are the Niobrara strata, containing a great profusion of microscopic Globigerina whose calcareous shells have made the formations nearly pure limestone. These strata are the well-known "cement rock" which outcrops along the face of the Pembina Mountains and in the gorge of the Pembina River. For a few years, from 1897 to 1907, it was used for the manufacture of cement at Concrete in Pembina County. Above the Niobrara is a thin bed of fuller's earth clays, used in the filtration of edible fats.

At the beginning of the Cenozoic Era, or Age of Mammals, some seventy million years ago, the ancient sea withdrew for the last time, and all later rock formations were laid down in freshwater rivers and lakes or by glacial ice sheets. Large rivers ran eastward from the Rocky Mountains, carrying huge quantities of gravel, sand, and clay. They dropped much of this material on the Dakotas, turning from side to side to build an extensive alluvial plain and leaving behind scattered swamps with large conifers (cypress and sequoia) and other kinds of trees and shrubs. As the partially decomposed vegetation was buried by sand and clay, it was transformed into lignite, a soft brown coal, most of which is found in the Tongue River strata. The numerous beds of it show 
that western North Dakota was occupied again and again by swamps covering hundreds and even thousands of square miles. They built up seams of lignite, varying in thickness from a few inches to forty feet, which underlie 28,000 square miles of western North Dakota, or about 40 per cent of the state. By conservative estimate, there are in workable beds some 351 billion tons of lignite, the largest supply of solid fuel in the United States. ${ }^{1}$

Although lignite-some of which contains uranium-and oil are perhaps the most valuable, North Dakota has other mineral deposits. There is clay suitable for ceramic products and lightweight concrete aggregate, and lakes in the northwest corner of the state contain more than twenty million tons of Glauber's salt.

After the final withdrawal of the sea, erosion carved high ridges and buttes, such as the Killdeer Mountains and Sentinel Butte. Running water carried away a thousand feet or more of sedimentary deposits in western North Dakota and largely created the Badlands and the present- day landscape west of the Missouri River. The process was accelerated by an uplift to the west which caused the Missouri, Little Missouri, and Yellowstone rivers to empty their muddy waters into Hudson Bay. Erosion also wore down the land surface in eastern North Dakota. A northward-flowing river cut the broad valley of the Red River of the North some nine hundred feet into Cretaceous and older rocks.

About a million years ago the climate grew colder and the Pleistocene Epoch, or Ice Age, began. Snow piled up around

\footnotetext{
${ }^{1}$ Russell A. Brant, Lignite Resources of North Dakota, United States Geological Survey Circular 226 (Washington, 1953), p. I.

I have listed in the footnotes and the Bibliographical Essay the principal sources used in the preparation of this volume, avoiding, as far as was practical, duplication between the two. The most important books and articles, as well as those most likely to be interesting and available to the reader, are described in the Bibliographical Essay. Instead of using specific citations for statistical data, I have included a description of their sources in the essay. And to avoid an excessive number of footnotes, I have sometimes cited in a single note sources for a diverse variety of material.
} 
Hudson Bay, compacted into ice, and began to flow slowly outward. A series of continental ice sheets, or glaciers, moved south, retreated, then moved south again. Two and possibly four separate ice sheets invaded North Dakota. The first covered all of the state except the southwest corner, reaching forty to sixty miles beyond the Missouri River, but it left behind only a thin layer of glacial debris consisting of boulders and gravel. The Missouri Slope, that part of North Dakota which lies west of the river, is not glacial but erosion topography-formed by running water.

The last glacier, the Wisconsin, shaped the land surface of the rest of the state. The mighty mass of ice gouged out or pried off rocks and earth, picked up boulders, gravel, sand, and clay, and carried them along. It planed off ridges, filled up valleys, and pushed up onto the Missouri Plateau, but did not reach the Missouri River. Then, as the climate became milder, the leading edge of the glacier remained stationary for a time as melting equaled its forward movement. The melting ice dropped its earth burden, leaving as an end moraine a belt of rough, hilly country, from ten to twenty miles wide, known as the Coteau du Missouri, or Hills of the Missouri. Some maps label it the Altamont Moraine, and geologists have renamed its northern portion the Max Moraine. It is dotted with lakes and potholes and is part of the great flyway for ducks from Canada to the Gulf of Mexico. Including those in the Coteau du Missouri, North Dakota has an estimated 8,659 such permanent water areas with an average size of 65 acres. $^{2}$

When the Wisconsin Glacier retreated, about 25,000 years ago, it not only filled the Red River Valley with 200 feet of debris but also dropped a mantle of glacial drift in the form of ground moraines and, where it paused, smaller end moraines.

\footnotetext{
${ }^{2}$ Roy N. Bach, "North Dakota Water Areas," North Dakota Outdoors (April 1952), p. 16.
} 
The ground moraines buried the landscape under 200 to 300 feet of boulders, clay, sand, and gravel and contoured the land into the gently rolling prairie so characteristic of much of North Dakota. The end moraines, such as those south of Devils Lake, are picturesque hills covered with timber-ideal refuges for game. Indeed, when the first white men entered the region, they found the Devils Lake country to be a favorite haunt of the grizzly bear.

The copious quantities of water produced by the melting ice also helped to shape the terrain. Since the land sloped downward toward the north, the leading edge of the glacier became a gigantic dam which altered the course of the Missouri and its tributaries so that, instead of pouring into Hudson Bay as before, they turned south. Rushing water sorted the debris released by the ice sheet and created scattered veins and lenses at its base and throughout the glacial drift. These became gravel pits and the most prolific source of well water in the state.

Backed-up water from the rivers and melting ice formed many glacial lakes, the largest of which were in the valleys of the Mouse, James, and Red rivers: Lake Souris, Lake Dakota, and Lake Agassiz. Lake Souris covered much of Bottineau and McHenry counties, while eastern Dickey and northwestern Ransom counties were submerged by Lake Dakota. Lake Agassiz, named for the Swiss glacial geologist, spread out over some 110,000 square miles on both sides of the Red River of the North, mostly in Canada. At first, Lake Agassiz found an outlet to the south through the glacial River Warren, which cut the broad Minnesota River Valley on its way to the Mississippi, but as the ice sheet retreated, the outlet became Lake Superior. Later the waters ran north to Hudson Bay. Lakes · Winnipeg and Manitoba are remnants of Lake Agassiz.

Water from melting ice carried much silt into the glacial 
lakes, whose water spread it evenly to make flat plains of their bottoms. Some rivers formed deltas where their heavily burdened waters rushed into Lake Agassiz: the Sheyenne delta (800 square miles, with many sand dunes, in Richland and Ransom counties), the Elk River Valley Delta (stretching for 50 miles from Fordville to Portland), and the Pembina Delta (known locally as the First Mountain and seen in the sandy country east of Walhalla). As it drained, Lake Agassiz marked succeeding water levels with sand and gravel beaches. Rising from ten to twenty feet above the land surface on the lake side, these have made good farmsteads with adequate wellsites. They have also been frequently used as gravel pits, supplying material for road construction. ${ }^{3}$

\section{TOPOGRAPHY}

North Dakota is part of two physiographic provinces, the Central Lowlands and the Great Plains, each of which occupies about half the state. The Central Lowlands Province, stretching westward from the Allegheny Plateau, confronts the Great Plains, extending to the east from the Rocky Mountains, along an escarpment which runs from Saskatchewan to Texas. In North Dakota this dividing line, a marked rise of from 300 to 400 feet, is called the Missouri Escarpment and forms an arc from the Canadian boundary in eastern Divide County to South Dakota in western Dickey County. That portion of the Great Plains lying within the state is known as the Missouri Plateau, while the Central Lowlands Province consists of two regions, the Red River Valley and the Drift Prairie. The land rises from east to west in three broad steps: the Red River Valley, the Drift Prairie, and the Missouri Plateau. These are the

\footnotetext{
${ }^{3}$ Wilson M. Laird, Guide for Geologic Field Trip in Northeastern North Dakota, North Dakota Geological Survey Bulletin 30 (Grand Forks, 1956), pp. 8-16.
} 
fundamental divisions of the state: They differ in origin, climate, surface features, soil, and native vegetation and roughly mark off economic and even political and ethnic differences.

The Red River Valley reaches westward for thirty or forty miles from the Red River of the North to make up about 10 per cent of the state's area. Once the bottom of Lake Agassiz, it is a flat land lying 800 to 1,000 feet above sea level and sloping down toward the north; Pembina, the lowest point in North Dakota, is 792 feet above sea level. The rivers in this region drain into Hudson Bay, for the valley rises to the west, where the Pembina Escarpment separates it from the Drift Prairie. In the north the escarpment is the Pembina Mountains, a range of wooded bluffs which rise abruptly from 300 to 500 feet above the valley floor. They disappear in Walsh County, and the escarpment becomes almost unnoticeable. Near the South Dakota line, however, it is again striking in the Coteau des Prairies, a hilly country beginning in southeastern Sargent County.

West of the Red River Valley lies the Drift Prairie. More than two hundred miles wide along the Canadian boundary, it narrows to seventy miles along the South Dakota line and occupies some 40 per cent of North Dakota. The altitude of the Drift Prairie varies from 1,300 to 1,650 feet above sea level, and the landscape is youthful, having been changed little by erosion. There are few rivers; some counties have none, but an abundance of lakes, ponds, and sloughs reveal the drainage system. In this region, along the Canadian border in Bottineau and Rolette counties, are the Turtle Mountains. Rising to 800 feet, they are a heavily wooded island of timber, sprinkled with lakes, in the treeless prairie.

To the west of the Drift Prairie stands the Missouri Plateau, a rugged, open country stretching away to the Rocky Mountains. It makes up half the area of North Dakota. East of the M issouri, the plateau is from 1,800 to 2,000 feet above sea level; west of the river, 
it ranges from 2,000 to 2,500 feet. Rhame, the state's highest town, stands at 3,184 feet, while White Butte, in Slope County, is the highest geographical point at 3,506 feet. The portion of the plateau west of the river is called the Missouri Slope, or simply the Slope. It has many high, flat-topped buttes, such as Camels Hump, Bullion Butte, Sentinel Butte, and the Killdeer Mountains.

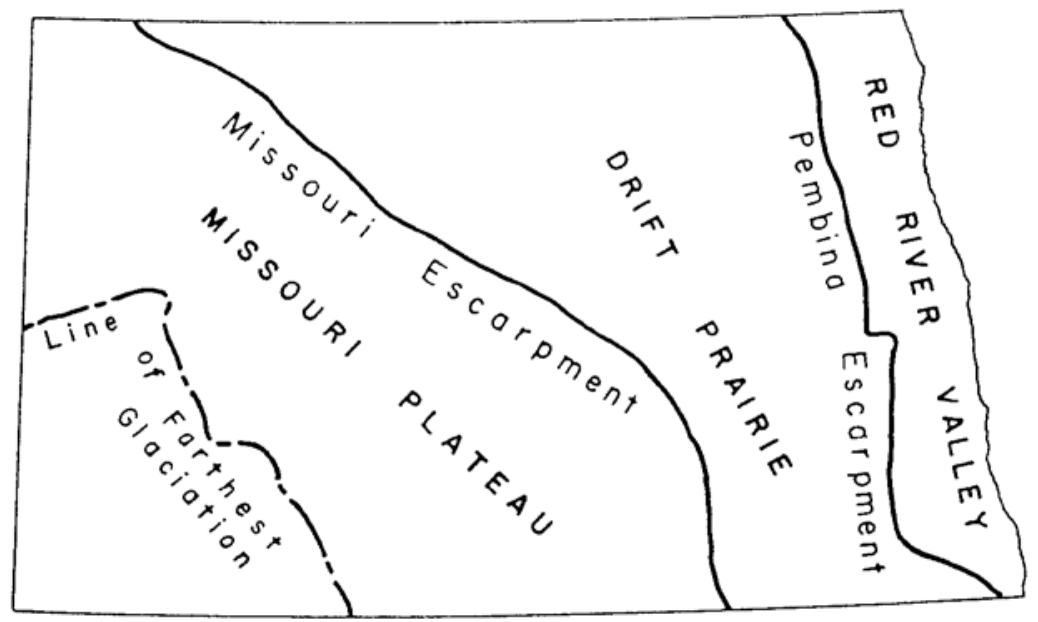

TOPOGRAPHY OF NORTH DAKOTA

The landscape of the Slope contrasts with that east of the Missouri. East of the river the Missouri Plateau has a youthful, rolling topography formed by glacial drift, but the Slope was carved by running water working on the soft, poorly cemented sands and clays of the exposed rocks. The Slope's scanty vegetation has done little to check this erosive work, whose most spectacular results are seen in the Badlands along the Little Missouri River. There streams have cut the land into innumerable canyons, gorges, and ravines and have produced an incredible waste of bluffs and pinnacles, often colored in shades of red from masses of scoria, the clinker of clays fused by burning lignite beds. 


\section{CLIMATE}

Semiaridity makes North Dakota a borderland between the humid East and the arid West. As such, it exhibits, two climatic provinces. The western half of the state, part of the Great Plains, is a grazing and wheat land with light rainfall, short grasses, and dark-brown Chestnut soils. The eastern half, east of the Missouri Escarpment, is the semiarid extension of a cold, humid continental zone running from Maine to Manitoba. In North Dakota the zone is a tall-grass country with black Chernozem soils. The soil line, the grass line, and the climate line- really transition zones rather than lines-all follow the Missouri Escarpment.

North Dakota has a continental climate. There are cold winters and hot summers, warm days and cool nights, light rainfall, low humidity, and much sunshine. It is a climate of extremes. The coldest temperature on record is 60 degrees below zero (Parshall, February 15, 1936); the hottest, 121 above (Steele, July 6, 1936). January, the coldest month, has an average temperature of $7^{\circ} \mathrm{F}$., and July, the warmest, averages $68^{\circ} \mathrm{F}$. The mean temperature is $40^{\circ} \mathrm{F}$., the lowest of any state until the admission of Alaska. North Dakota's mean annual rainfall is a scanty 17.16 inches. The relative humidity is low, averaging 68 per cent. Long days and an abundance of sunshine compensate for a short growing season. The wind blows much of the time.

The North Dakota climate is a result of the state's location at the center of the continent. Winds move freely over the great central plain of North America, influencing both temperature and rainfall. Warm winds sweeping up from the Gulf of Mexico bring rain, but because North Dakota is nearly 1,500 miles from the Gulf, it receives little precipitation from that source, certainly much -less than the Great Plains states farther south. Within North Dakota, the northern and western counties, farther 
from the Gulf, get the least rain.

There is a significant difference in the amount of rainfall received in the three parts of the state. The Red River Valley gets the most, the Missouri Plateau the least, and the Drift Prairie stands between the two: the farther west, the less rain. Fargo, in the southern part of the Red River Valley, has an average annual precipitation of 21.5 inches. Valley City, on the Drift Prairie, averages 19.6 inches. Dickinson, on the Missouri Plateau, receives 15.8 inches. The eastern third of the state averages 19.4 inches, the middle third 16.6 inches, the western third 15.4 inches. The four-inch advantage the east enjoys over the west is enhanced by temperature differences: the west has higher temperatures and so higher rates of evaporation. Moreover, the lighter Chestnut soils of the west do not hold the moisture as well as the Chernozem soils of the east. Fortunately, 77 per cent of North Dakota's precipitation comes in the growing season.

Winds account for rapid changes in temperature. Cold air from the subarctic McKenzie Valley brings rapid drops and sometimes blizzards.

Warm air from the Gulf creates summer heat waves and milder temperatures in winter. Chinooks (warm, dry winds from across the Rockies), which can raise the winter temperature in the southwestern part of the state as much as seventy-five degrees in twenty-four hours, make winters milder in the west. Dickinson has an average January temperature of $10.6^{\circ} \mathrm{F}$., compared with $1.8^{\circ} \mathrm{F}$. at Devils Lake. In summer, differences in temperature between east and west are small. with two-thirds of the state averaging less than seventeen inches of precipitation annually, semiaridity was and is the most important aspect of the North Dakota environment. Semiaridity explains much about the state: the character of the soil, the native vegetation, the importance of wheat and cattle in the 
economy, the increasing size of farms, the scattered population, the steady out-migration of young people, and the high cost of schools, roads, and other social services.

If the rain had always come when it was needed, North Dakota would have enjoyed continuous prosperity, but frequent droughts have brought poor crops and instability of income. There is no exact statistical measure of drought, for both timeliness and annual amount of precipitation are important to growing crops, but it is likely that when the annual precipitation falls below fourteen inches, drought seriously reduces yields for most farmers. The western third of the state has had less than fourteen inches in 36 per cent of the years from 1889 to 1962, the middle third less than fourteen inches in 16 per cent of the years, and the eastern third less than fourteen inches in 8 per cent of the years. Put in another way, the western third had twenty-seven years with less than fourteen inches' annual precipitation in the seventy-four years from 1889 to 1962, the middle third had twelve such years, and the eastern third had only six. Thus drought has been a much greater hazard in the west than in the east.

But there have been many years of plentiful rainfall. From 1889 to 1962 the western third of the state had eighteen years with more than 17 inches, the middle third thirty-five such years, and the eastern third sixty-one years. Precipitation in the western third ranged from 6.6 inches in 1934 to 22.2 inches in 1941. As one pioneer exclaimed, "Dakota is a great land for extremes, either too hot or too cold, too wet or too dry." 4 The threat of drought has made all North Dakotans weather conscious, however, and a current of anxiety always runs beneath the surface.

Drought has been a long-standing experience. George F. Will's

${ }^{4}$ Mary Dodge Woodward, The Checkered Years (Caldwell, Idaho: The Caxton Printers, Ltd., 1937), pp. 38-39. 
studies of tree-ring growth show that periodic drought has been the rule in the region around Bismarck since 1406. The worst droughts since white settlement came in 1934 (9.5 inches of precipitation) and 1936 (8.8 inches). In the latter year no prairie grass grew outside the Red River Valley; farmers shipped out their livestock for lack of feed and water; dust storms obscured the sun. In the bitter years from 1935 to 1940; some 86,000 persons fled the state.

In terms of agriculture and economics, rainfall, or the lack of it, has marked off four regions in North Dakota: a range-livestock region along the Little Missouri Valley; a wheat and rangelivestock region west of the Missouri; a wheat region from the Missouri to the Red River Valley; and a wheat and general-farming region in the Red River Valley and the southeast corner of the state. These divisions roughly parallel the three broad steps of North Dakota's topography; although they merge into one another, each of the latter has its own characteristic agricultural-economic base. ${ }^{5}$

For the most part, however, North Dakota is a small-grain country where wheat is king, so much so that pioneers liked to call it "the land of the No.1 hard." Wheat needs only a 100-day growing season (the average in North Dakota is 130 days) and does best on less than thirty inches of rainfall per year (more rain increases losses from disease, the lodging of grain, and the leaching of nitrates in the soil). Dry regions produce a hard, flinty, high-protein grain that is ideal for making bread, ${ }^{6}$ and North Dakota lies in the heart of just such an area, a hard-springwheat belt extending from Minnesota and South Dakota to the

\footnotetext{
${ }^{5} \mathrm{~A}$ map of farming areas is in Baldur H. Kristjanson and C. J. Heltemes, Handbook of Facts about North Dakota Agriculture, North Dakota Agricultural Experiment Station Bulletin. 357 (Fargo, 1950), p. 18.

${ }^{6}$ S. C. Salmon, "Climate and Small Grains," Climate and Man: Yearbook of Agriculture, 1941 (Washington : Government Printing Office, 1941), pp. 32-33, 321-342.
} 
Peace River district northwest of Edmonton, Alberta. As a result, North Dakota ranks first among the states in the production of durum and spring wheat and is second only to Kansas (a winterwheat state) in total wheat production. In fact, wheat is the chief source of income, accounting for 35 to 45 per cent of the gross annual farm income. North Dakota also raises more barley, flax, and rye than any other state, and in the 1950's, small grain made up 60 to 65 per cent of the gross farm income.

Such heavy dependence on small grains has put North Dakota at the mercy of the uncertain rainfall. Over the years, crop yields and farm income have fluctuated widely throughout the state, with the Missouri Plateau suffering most. From 1916 to 1920, for example, North Dakota did not have a single good wheat crop. Yet in spite of it all, North Dakotans feel that their state has been slandered when it is pictured as a land of drought, blizzards, and severe cold.

There is a measure of justification in this defensive loyalty, for North Dakota's continental climate, with its sunshine, variations of temperature, and low humidity, is healthful and stimulating. Promoters have often boasted of it; in 1887 an official publication designed to attract settlers noted that the air was "dry, pure and full of invigoration." Perhaps this accounts for the state's low death rate. From 1924 to 1940, with the exception of 1935, North Dakota had the lowest death rate in the nation, and in the 1950's it was still below both the national average and that of neighboring states.

Many people have testified to the energy-giving qualities of the North Dakota climate. Meriwether Lewis and William Clark, wintering near Stanton in 1804-1805, were surprised at the Mandan Indians' resistance to the cold. In 1884, Theodore Roosevelt wrote to his sister from the Badlands: "I have never been in better health than on this trip. Bill Sewall, his Maine guide, observed that "it is a dirty country and very dirty people 
on an average, but I think it is healthy." Also in the 1880's, Mary Dodge Woodward, keeping a diary on a bonanza farm near Fargo, commented that North Dakota farmers were "more energetic" than those back home in 'Wisconsin. "They rush things here," she said.

One word best describes the result of plant adaptation to the environment in North Dakota: grassland. Light rainfall, autumn drought, and prairie fires discouraged trees, so grass, a droughtenduring flora, became the dominant vegetation. Before settlement, 95 per cent of North Dakota was covered by three large grass communities, each of which developed its own type of soil.

Originally the Red River Valley was a "true prairie" of tall and medium grasses in which tall grasses, growing from four to six feet in height, were dominant. By far the most outstanding type was big bluestem, a tall grass from which the bluestem sod, the grass community of the valley, takes its name. But there were also a number of medium (one and one-half to three feet) and short (onehalf to one and one-half feet) grasses. Some of the important medium grasses were feather bunch grass, slender wheat grass, and western wheat grass; prairie June grass was a short grass. Together they formed the black Chernozem soils of the Red River Valley. Most of these soils are of the Fargo-Bearden variety of Chernozem, that is, soils which were developed from materials filling old lake basins and which are noted for their production of small grains. ${ }^{7}$

A somewhat different grass community occupied the Drift Prairie. As rainfall decreased to the west, the tall grasses gradually dropped out, except in the wetter places, and the medium grasses became

\footnotetext{
${ }^{7}$ United States Department of Agriculture, Soils and Man: Yearbook of Agriculture, 1938 (Washington: Government Printing Office, 1938), pp. 970-971, 1077; Philip V. Wells, "Scarp Woodlands, Transported Grassland Soils, and Concept of Grassland Climate in the Great Plains Region," Science, CXLVIII (April 9, 1965), 246-249.
} 
shorter. Drought dwarfed the plants. Medium and short grasses became more important than they were in the Red River Valley, the dominant species in most places on the Drift Prairie being needle and thread, western wheat grass, slender wheat grass, prairie June grass, and blue grama. The grasses of the Drift Prairie composed a transitional community between the "true prairie" of the Red River Valley and the "mixed prairie" of the drier Missouri Plateau. ${ }^{8}$ The soil they built is Chernozem, generally of the BarnesParnell type, formed on uplands of calcareous drift laid down by the Wisconsin Glacier. Barnes-Parnell Chernozem is the darkest upland soil in the United States, and the finest spring-wheat country in the nation has been developed on it.

The grass community of the Missouri Plateau is a "mixed prairie." It differs from that of the Drift Prairie, although the grasses are largely the same. With less rainfall, some of the medium grasses drop out or become smaller, and more of the short ones become dominant. The principal varieties are blue grama, niggerwool (a dry-land sedge rather than a grass), needle and thread, and western wheat grass. The first two are short, the second two of medium height. Blue grama and needle and thread are bunch grasses; the other two tend to form a continuous sod cover. Blue grama is the best range grass in North Dakota. All four, however, are drought resistant and make good forage. They grow throughout the state but are most abundant in the drier central and western sections. It is significant that big bluestem, before settlement the dominant grass of the Red River Valley, is found in moist places, even in the western part of the state, and that the drier ridges in eastern North Dakota have grasses characteristic of the western end. The medium and short grasses

\footnotetext{
${ }^{8}$ A. L. Shantz and Raphael Zon, Natural Vegetation: Atlas of American Agriculture (Washington: Government Printing Office, 1924), p. 14.
} 
of the Missouri Plateau have formed dark-brown Chestnut soils. Because the grass cover is thinner than on the Drift Prairie, the soils are also thinner and lighter than the Chernozem soils of the Drift Prairie and the Red River Valley.

North Dakota's grasses, especially the medium and short varieties, have made productive use of the limited moisture in adapting to their environment. They are long-lived perennials, begin to grow early in the spring, produce seed quickly, and go into a dormant stage during summer and fall drought. They are hardy enough to withstand extremes of heat and cold, flood and drought. They are not only palatable to livestock but quite nutritious as well. Cured on the stem, they supply forage both summer and winter and can re-establish themselves after injury from overgrazing. They protect the soil from wind and water erosion and provide shelter and food for wildlife. In sum, the grasses are, next to the soil, the great natural resource of the state. As hay and forage for livestock, they were producing much more wealth in the late 1950's than either oil or lignite.

Other plants adapted themselves to the nature of the land in North Dakota. Some kinds grew throughout the state, others only in certain parts. Several species of trees from the broad-leaved eastern forest - such as bur oak, green ash, elm, box elder, and cottonwood, which could best adapt to the semiarid climatecame into the state, but these retreated to the riverbanks. They grew only along streams in most of the state until settlers began to plant windbreaks, becoming scarcer in the western and northern areas. Aspen and balsam poplar, trees of a cold forest, entered the Pembina Hills and Turtle Mountains from Canada. A trace of the Rocky Mountain forest (western yellow pine, red cedar, and dwarf juniper) invaded the warmer and drier southwestern section of North Dakota, especially the Badlands. The Ranger Grove of western yellow pine in Slope County was a 
northeastern outpost of the species. Where trees could not survive, a great variety of shrubs (wolf berry, buffalo berry, dwarf sage, and creeping cedar) grew.

\section{ANIMAL LIFE}

In bird and animal life, North Dakota was a meeting place for species from north and south, from east and west. The Red River Valley seems to have been the dividing line between some eastern and western species, and the only North Dakota breeding grounds of the sage grouse lay west of the Badlands. ${ }^{9}$ Birds of the forest, such as thrushes and warblers, clung to the wooded stream banks. Other birds, such as the western meadowlark (the state bird), Franklin's gull, and the far- flying longspur, lived on the open grassland. The snowy owl came into the colder sections of the state from Canada, the burrowing owl into the warmer parts from the south. More ducks nested in North Dakota every summer than in any other state, their heaviest concentration being on the Drift Prairie and the Coteau du Missouri. North Dakota was a transition zone for amphibians and reptiles; some species were eastern, others western. The rattlesnake was apparently found only on the Missouri Plateau.

The distribution of early North Dakota wildlife demonstrated practical adaptation to variations in environment. Short-legged Nebraska cottontail rabbits favored brushy cover along streams in eastern North Dakota and as far west as the Missouri and Mouse rivers, while the long-legged Wyoming cottontails took to the open country of the Bad- lands. Jack rabbits ranged all of the state except the forested areas. Tree squirrels and woodchucks lived along the Red River and those streams which carried lines of timber into the

${ }^{9}$ Norman A. Wood, A Preliminary Survey of the Bird Life of North Dakota, University of Michigan Museum of Zoology: Miscellaneous Publication 10 (Ann Arbor, 1923), pp. 6-10. 
prairie. Ground squirrels replaced them in the open grassland, and prairie dogs lived in the Badlands. The Hudson Bay drainage in the wetter eastern and northern sections of the state was occupied by the large, dark Canada beaver, the drier Missouri drainage by a smaller, light-brown species. White-tailed deer and black bears liked the cover of brush and woods along the streams; elk were equally at home in timber and on the grassland; buffalo, antelope, and mule deer lived only in the open country.

In one way or another, all living things had to adapt to conditions on the vast, open plain, with its drought and bitter winter cold. Some became sparing in the use of water; others became strong runners or fliers; many developed a flocking habit or took on a pallid coloration; a few went underground to escape from their enemies or from the cold. Outside the valleys, plants became small and used large root systems to protect themselves from drought. Several kinds developed a greenish-gray outer coat to check drying out. Some animals used little water: the prairie hen drank only dew, the antelope could endure long periods with no water, and the pocket gopher lived without drinking.

The level, treeless plain encouraged migration and flocking. Birds of the plain flocked together and, because they had to span long distances between watering places, became strong fliers. Building their nests on or even in the ground, many birds were good runners, and their pallid coloration helped them to hide. Buffalo and antelope traveled far and wide in large herds. Fleetfooted wolves, coyotes, and jack rabbits could quickly cover extensive areas in search of food, travel far for water, and even migrate to avoid summer drought or winter frost. Most of the animals, of course, were herbivores, depending on the grasses for food, but since the carnivores ate the herbivores, one can say that all subsisted on the grasses.

Such adaptation to the nature of the country allowed some 
species not only to survive but to flourish. 'When Alexander Henry, the first man to record the appearance of the Red River Valley, rode south from Pembina in the fall of 1800, he was astonished at the many herds of elk and buffalo. The buffalo "were so numerous," he wrote in his diary, that they "only turned to stare at us." He saw two small lakes "covered with swans, geese and ducks of various kinds" and observed elk and black bears continually crossing the Red River. The buffalo had made many paths to the river and in one place had packed down the bank like a pavement. At his trading post on Park River, Henry was awakened at daybreak on January 14, 1801, by bellowing buffalo: "I dressed and climbed my oak for a better view. I had seen almost incredible numbers of buffalo in the fall, but nothing in comparison to what I now beheld. The ground was covered at every point of the compass, as far as the eye could reach, and every animal was in motion." He often saw wolves following the buffalo and heard them keep up "a terrible howling" about the fort at night. Henry also watched black bears tear up the plum trees and oaks in search of fruit and acorns. ${ }^{10}$

The Missouri Valley, too, had an abundance of game. when the Lewis and Clark Expedition entered what is now North Dakota in the fall of 1804, they saw large herds of buffalo, elk, and antelope, as well as many grizzly bears, along the Missouri River: A wounded grizzly once chased Lewis seventy paces; the grizzly was, the expedition journal noted, "very remarkable for the wounds it will bear without dying." One day the men "counted 52 Gangues of Buffalow \& 3 of Elk at one View."11

\footnotetext{
${ }^{10}$ Elliott Coues (ed.), New Light on the Early History of the Greater Northwest: The Manuscript Journals of Alexander Henry ... and of David Thompson . . 1799-1814 (3 vols.; New York: Francis P. Harper, 1897), I, 83, 84, 88, 167.

${ }^{11}$ Russell Reid (ed.), "Lewis and Clark in North Dakota," North Dakota History, XIV (January 1947), 29.
} 
Lewis and Clark sometimes observed buffalo swimming across the Missouri, and in the spring they saw large numbers of drowned ones floating down the river or lying stranded along the shore. In 1811, Henry M. Brackenridge, another early visitor to the Upper Missouri, saw "armies of buffalo all in motion as far as the eye could distinguish in every direction." Thirty-two years later, in the fall of 1843, John James Audubon heard buffalo bulls "roaring like the long continued roll of a hundred drums" for miles along the Missouri. And in the 1860 's, steamboats sometimes had to tie up to the riverbank for hours while a migrating herd swam the river. The buffalo's days were numbered, however, for in 1871, white settlement of the region that was to become the state of North Dakota would begin in earnest. 


\section{CHAPTER 2}

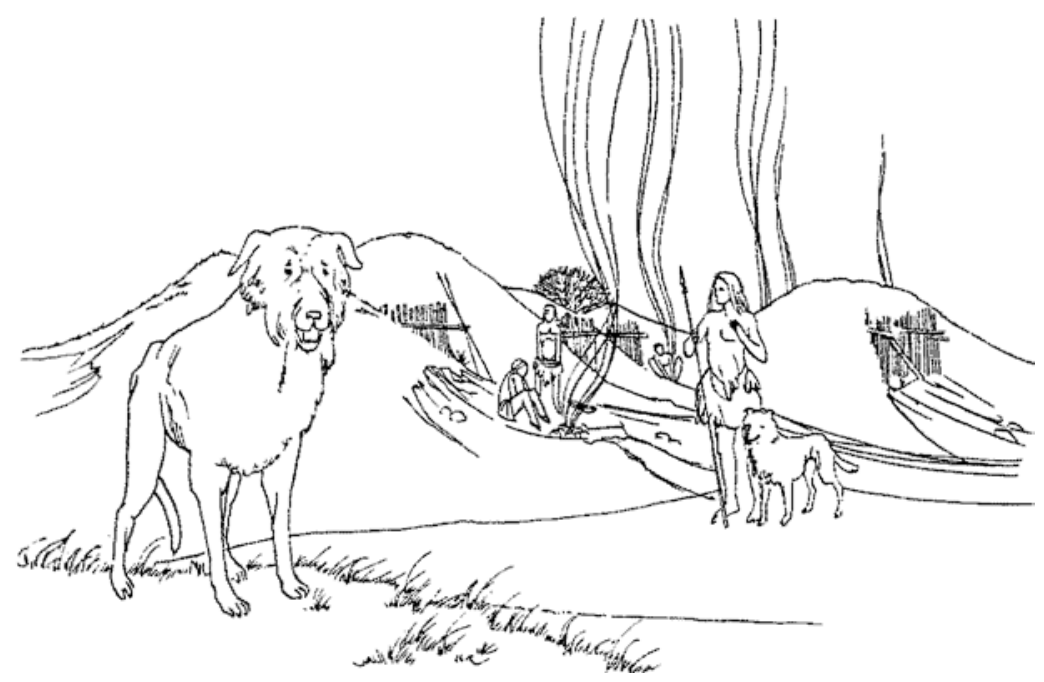

\section{Indians of the Plains and Prairies}

BEFORE THE ADVENT of recorded history, the region that was to become North Dakota had many changes of climate and consequently many human migrations. Moist times attracted new occupants; periods of drought drove them out. These prehistoric peoples had to adapt themselves to the nature of the country or, if that proved impossible, to leave. Later the area was occupied by Indian tribes who moved in from humid lands to the east and south and adapted their ways of life to the semiarid grassland. Thus the culture of the North Dakota Indians was much like that of the Plains and Prairie Indians farther south. The horse came to play a leading role where vast distances made mobility important. Even before the first white men saw North Dakota, white trade goods were beginning to make the Indians of the region dependent and to 
change their way of life. Soon the white man's diseases would drastically reduce their numbers.

\section{PREHISTORIC PEOPLE}

About twenty thousand years ago, late in the Ice Age, wandering, hungry Paleo-Indians of Mongoloid and other racial stocks crossed a land or ice bridge from Asia to Alaska. The migrants were familiar with fire and with the manufacture of clothing and shelter. They were big-game hunters, using spears and butchering tools. Eventually they turned south. Following an ice-free lane east of the Rocky Mountains, they entered the Great Plains region approximately fifteen thousand years ago. These first men in the Missouri Basin lived south of the line of farthest penetration by the Wisconsin Glacier. They traveled in small bands, hunting prehistoric mammoths, mastodons, and bison and gathering certain types of plants for food. They made no pottery, raised no crops. They carried their meager possessions on their backs as they drifted from one campsite to another on the banks of shallow, marshy lakes.

The climate was humid; wet winds from the melting ice sheet dropped much rain. Lakes and marshes were abundant, and the open plain was a hunter's paradise. In addition to mammoths, mastodons, and bison, these early big-game hunters killed prehistoric horses, camels, saber-toothed cats, and musk oxen. They chipped spear points from flint and fashioned knives, scrapers, choppers, drills, awls, needles, and other implements from rock and bone. Archaeological remains of their culture are widely scattered over the Plains; some have been found in the western Dakotas.

With the advances and retreats of the Wisconsin Glacier, the climate changed, sometimes growing colder and wetter, sometimes warmer and drier. The vegetation also changed, and Ice Age mammoths, mastodons, and other animals disappeared, giving way to bison, or, as they are more commonly known, buffalo. In all probability, long droughts drove the human population from the Great Plains as lakes dried up and game became scarce, for there was a warm, dry interval of two thousand years or more from about 4000 B.C. to 2000 B.C. Later, increased moisture attracted these early people to the Plains again.

It is impossible to chart climatic changes and migrations with 
any exactness; dates can only be informed guesses. Perhaps two thousand years ago, Indians with a Woodland culture moved from the forests of Minnesota and Wisconsin to the grasslands of the eastern Dakotas. They roamed about in small bands, hunting and gathering as the earlier inhabitants had done, but they also made pottery, and by A.D. 1300 some of them may have had small gardens of squash and gourds. They grew no corn. About this same time, other migrations brought in cultural traits from the Lower Mississippi River.

In the centuries just before the discovery and settlement of North America by Europeans, Indians were living along the rivers of eastern North Dakota. Shunning the lonely, open plain, they made small camps or short-lived villages on the Red and Forest rivers, on the terraces along the Sheyenne and James. They apparently preferred the Red River Valley and the Drift Prairie to the drier Missouri Plateau. The rivers furnished water for drinking; brushy cover along their banks attracted game and supplied firewood, and their moist bottom lands provided tillable soil. These people left flint chips, sherds of pottery, scrapers and knives, and grooved mauls on campsites which have been buried by wind-blown soil, suggesting a long drought and probably abandonment.

Little is known about their way of life. Some of them dug a smoky, dark-brown flint from quarries or bowl-like depressions along the Knife River (the name is a translation of an Indian word). They pounded wet clay with cordwrapped paddles to make rough but strong pottery. They used bone for awls, fleshers, and beads, and occasionally they shaped a hard stone into a grooved maul. They adorned themselves with pendants of mussel shell, with gorgets of whelk shells from the Gulf of Mexico (polished and incised with animal pictures), and with neckbands of thin elk horn. ${ }^{1}$

There are many mysteries. These people or earlier ones probably made both the circles of stone called "tipi rings" and the "writing rocks," or petrographs, such as that discovered near Alkabo in Divide County. And someone made boulder effigies of turtles; one composed of 183 stones was found west of Sanger in Oliver County.

${ }^{1}$ Jesse D. Jennings, Plainsmen of the Past: A Review of the Prehistory of the Plains, National Park Service, Region Two (Mimeographed; [Omaha], 1948), pp. 8, 11-35. 
The Indians of eastern North Dakota placed their dead on scaffolds or in trees. Now and then they would gather the bones of a few skeletons into bundles and put them, along with a few artifacts (a bit of pottery, some fragments of flint, a pipe), into a burial pit. Often the pit was on a high bluff overlooking a river. Sometimes the bones were smeared with red ocher. Above the pit was built a commemorative mound, either round, oval, or linear. The Drift Prairie was the western fringe of the mound-building cultural area embracing the woodlands of Minnesota, Wisconsin, and Iowa and lay about one thousand miles from its center in southern Ohio. There are many mounds-much less elaborate than the Ohio ones-in the valleys of the Red, Sheyenne, and James rivers and around Devils Lake, but they thin out toward the Missouri. Mound building virtually stopped at the Missouri Plateau, although there is one on Apple Creek near Bismarck. None have been found west of the Missouri River. ${ }^{2}$

\section{THE MANDANS}

The cultural roots of the mound-building Woodland people of the Red River Valley and the Drift Prairie sprang from the east, not the west, so their culture was marginal in the Great Plains region. The distinctive culture of western North Dakota was that of the agricultural villages along the Missouri River. This began about A.D. 1300 when the ancestors of the Mandans, the first historic tribe in the state, moved west from the Mississippi Valley and then up the Missouri, bringing with them a rather sedentary culture much like that of tribes living in earth lodges from Kansas to South Dakota. They constructed most of their small, unfortified villages on the west bank of the Missouri, scattering them from the Grand River in South Dakota to the Knife River in North Dakota. They fished, hunted, and raised corn, beans, pumpkins, and squash on the Missouri River bottoms. Although they lived in twenty-odd villages of twenty to forty lodges each, there are fifty or more of these early sites, indicating that now and then a village would

\footnotetext{
${ }^{2}$ Walter N. Hlady, "Mound C, Fordville Mound Group, Walsh County, North Dakota; Its Excavation and Archaeology," North Dakota History, XVII (October 1950), 253-260; Gordon W. Hewes, "Burial Mounds in the Baldhill Area, North Dakota," American Antiquity, XIV (April 1949), 322-328.
} 
be abandoned and a new one built.

Mandan lodges were rectangular (about twenty-eight by forty feet), widely spaced, and placed in regular rows. They were frames of heavy poles and posts covered with brush, hay, and earth. From the outside they looked like dome-shaped mounds of earth. The Mandans worked their gardens with bison-scapula hoes and stored their surplus corn in bell-shaped cache pits. They made coarse cord-marked gray pots, decorating the rims with simple designs. These were used for cooking, their owners scooping out hollows in the fire pits so that the round-bottomed pots would sit upright. Besides pottery, the Mandans made bone tools, incised bone ornaments, circular shell beads, scrapers, projectile points, knives, choppers, scapula hoes, and bison-rib reamers.

The Mandans may have moved to the lakes and woods of Minnesota and Wisconsin during a long drought, for they possessed cultural traits common to both the people living farther down the Missouri and those living in Wisconsin and Minnesota. George F. Will's 1946 study of growth rings from a great oak cut near Bismarck reveals that there were forty dry years out of forty-seven from 1471 to 1518.

About 1450 the Mandans began to fortify their villages with ditches and palisades. At first they fortified old sites, sometimes palisading only a portion of the circumference and leaving part of it protected by a bluff dropping down to the river. But in the old villages the lodges were too widely spaced, the palisades and ditches too long for warriors to defend. The Mandans still lived in about twenty places along the Missouri, all but two or three of them on the west bank, extending from the mouth of the Cannonball to the mouth of the Knife.

They raised beans, squash, and sunflowers but especially corn in their gardens. They also gathered seeds, wild fruit, and roots: astringent chokecherries, buffalo berries, June berries, wild grapes and plums, ground beans, the starchy roots of the tipsin, or Indian bread-root, and the tubers of the wild artichoke. They hunted buffalo, elk, deer, and antelope with arrows tipped with Knife River flint or gray chert picked up on the prairie. They also knocked down small game, rabbits and such, and caught fish in the river with bone hooks. With time and prosperity, they put more decoration on their pottery, cord- pressed patterns and punched or incised designs, and made light-tan, 
gray, brown, and red pots of good quality with ears, lugs, and knobs. $^{3}$

About 1600 the Mandans came under attack, apparently from some nomadic foe, although no tribe on the Northern Plains then had horses. They began to draw together in larger villages, concentrated near the mouth of the Heart River. There were seven rather large ones, but probably only six were occupied at any one time. Three were on the east bank of the Missouri and four on the west side. The most famous was Slant Village, located in what is now Fort Abraham Lincoln State Park, five miles south of Mandan. By comparing growth rings, George F. Will has dated the earliest and latest timbers recovered from Slant Village as cut in 1652 and 1735, respectively. ${ }^{4}$ To get as many dwellings as possible inside the protecting ditch and palisade, the Mandans began to build oval and, later, round lodges, about forty feet in diameter, instead of rectangular ones. To shorten the perimeter to be defended, they no longer put the lodges in streets but crowded them together.

Mandan culture showed traits from the southeastern Mississippian cultures: peace and war chiefs, clan and moiety divisions, village squares and ceremonial centers, and confederacies with other tribes. But by 1700 these traits were overlain by recent borrowings from the eastern Woodland culture (pottery and certain ceremonial practices) and the Plains culture (the vision quest and buffalo hunting). The six or eight thousand Mandans living near the mouth of the Heart were probably one of the major concentrations of population on the Upper Missouri.

Their way of life continued to change. They made better pottery. They had dogs but as yet no horses, although some of their neighbors to the south had them soon after 1700 . They carried on a profitable trade in corn with the Cheyennes, who came from the Black Hills with horses, the first seen by the Mandans. They began to hear about white men-the Spanish in the Southwest, the English on Hudson Bay, and the French

${ }^{3}$ George F. Will and Thad C. Hecker, "Upper Missouri River Valley Aboriginal Culture in North Dakota," North Dakota Historical Quarterly, XI (January-April 1944), 5-126.

${ }^{4}$ George F. Will, Tree Ring Studies in North Dakota, North Dakota Agricultural Experiment Station Bulletin 338 (Fargo, 1946), pp. 7, 1116. 
around Lake Superior. About 1700 they began to get some white trade goods from the English through the Assiniboins, who acted as middlemen.

Thus by the beginning of the eighteenth century the Mandans had become well adjusted to their environment. A hardy people, they had learned to resist the bitter cold of winter and to endure the heat and drought of summer. By drawing together in villages, or even clusters of villages, they could enjoy both the amenities of group living and a stout defense against enemies. And by locating their villages along the Missouri, they had easy access to wood for fuel and building purposes, plus rich bottom land on which to raise crops. As a matter of fact, each group had two villages, one near the gardens for summer living and the other in the woods for maximum protection against winter weather. In their quest for food to supplement domestic crops, they used many of the plants native to the region, but the great bounty of the grassland was buffalo, which provided not only meat and fat but hides for robes and bones for implements. To this abundance the Mandans added a luxury: they made sugar from the sap of the box elder. ${ }^{5}$

\section{THE COMING OF EASTERN TRIBES}

After the Mandans and before the first white men, other tribes came to North Dakota. All but the Mandans and Arikaras were from humid, forested eastern regions. Perhaps they were half-driven out of their old homes by enemies, halfenticed to the new by the countless herds of buffalo, a rich food supply. Whatever the reason, eight tribes-the Hidatsas, Crows, Cheyennes, Crees, Assiniboins, Yanktonai Dakotas, Teton Dakotas, and Chippewas-moved westward from Minnesota or the Great Lakes area. ${ }^{6}$ Not many of these tribes

${ }^{5}$ Melvin R. Gilmore, "Uses of Plants by the Indians of the Missouri River Region," Bureau of American Ethnology, Thirty-third Annual Report, 1911-12 (Washington; Government Printing Office, 1919), pp. 56, 88, 92, 100; H. E. Ederstrom, "The Cold-and Physiological Fact," North Dakota Quarterly, XXIV (Winter 1956), 21-25; Alfred W. Bowers, "A History of the Mandan and Hidatsa" (Unpublished Ph.D. dissertation, University of Chicago, 1948).

${ }^{6}$ See articles on the tribes in Frederick W. Hodge (ed.), Handbook of American Indians North of Alexico, Bureau of American Ethnology 
made their principal home in North Dakota. They merely visited the region, or perhaps left a remnant of the tribe there.

Sometime in the seventeenth century, the Hidatsas, driven out by the Chippewas or Dakotas, moved from their old home in western Minnesota and northeastern North Dakota to the Missouri River. There some of them sett1ed near the Mandans, built earth-lodge villages at the mouth of the Knife River and at Painted Woods, and learned river-bottom agriculture from their new neighbors. They became close allies of the Mandans-both were Siouan-speaking peoples-and the two tribes held the country on both sides of the Missouri roughly from the mouth of the Cannonball to the Little Missouri. But one band of Hidatsas, although they had a large earth-lodge village on the north bank of the Knife and raised corn, generally lived as wandering hunters, ranging about the Missouri above the Knife and in the Mouse River country and the Turtle Mountains.

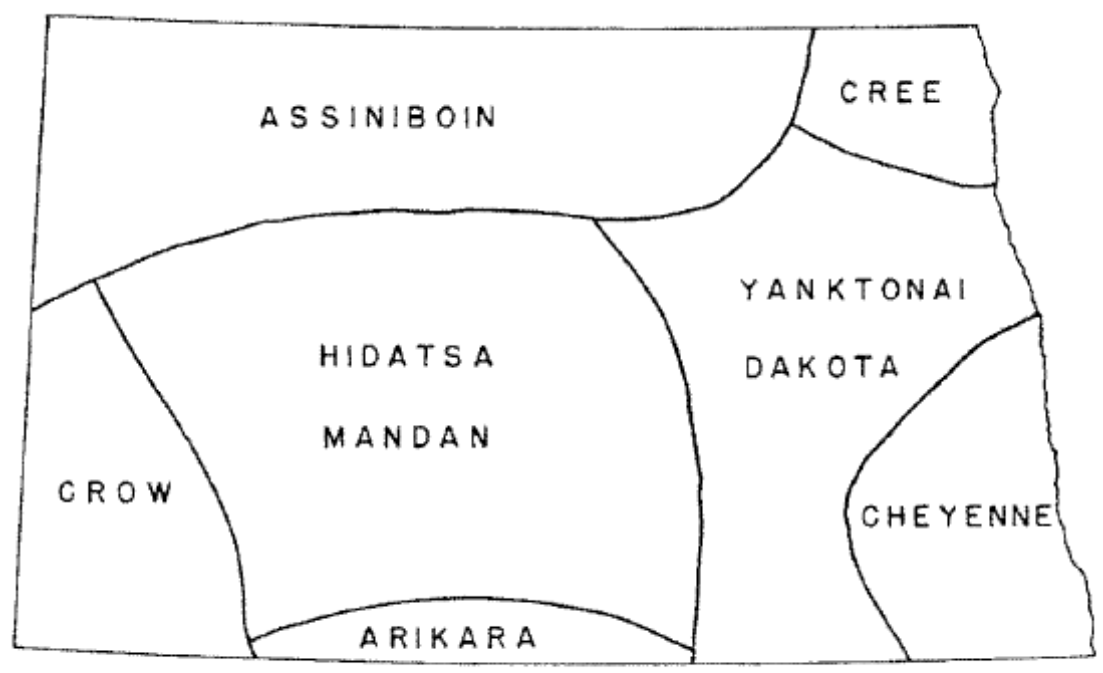

INDIAN TRIBES IN 1750

Bulletin 30 (2 vols.; Washington: Government Printing Office, 19071910). 


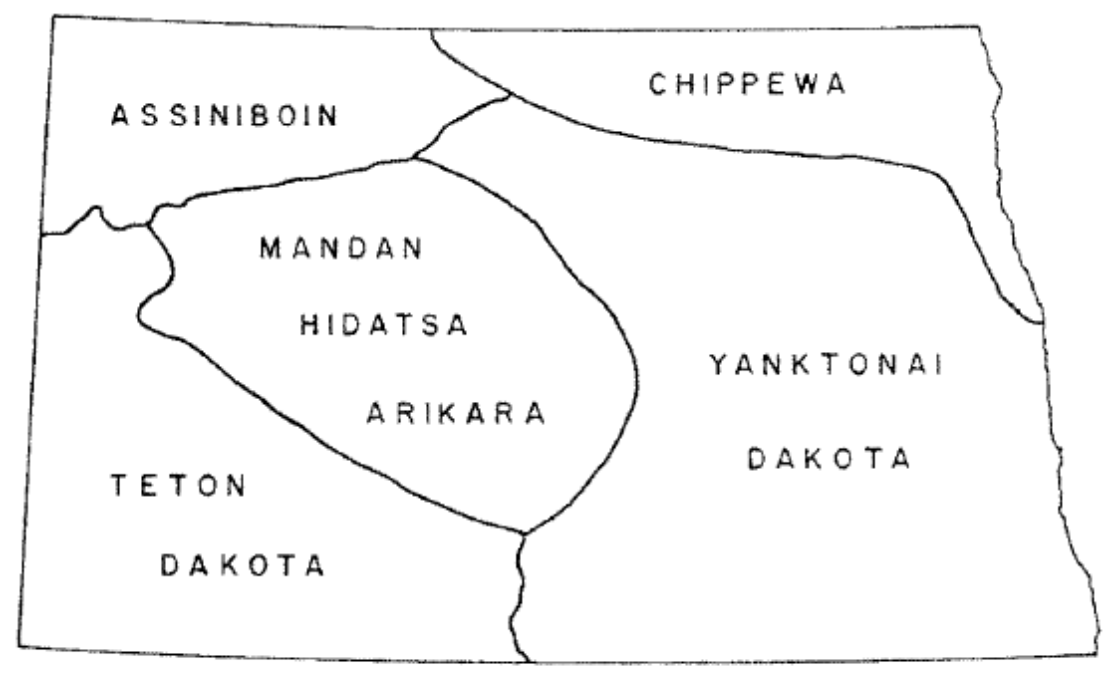

INDIAN TRIBES IN 1850 
The Crows, a closely related people, had moved to the Missouri with the Hidatsas, but quarreled with them over the division of some game and went farther west. They settled in eastern Montana, became buffalo-hunting nomads, and roved the western portion of North Dakota.

The Cheyennes, an Algonquian-speaking people, also moved west and changed their culture. They were living by means of agriculture and hunting in south-central Minnesota in the seventeenth century when the Chippewas and Dakotas, armed through trade with the French, pushed them out. One band of Cheyennes built an earth-lodge village of some seventy lodges, protected by a ditch, about twelve miles southeast of Lisbon, North Dakota, on the Sheyenne River. There they made pottery, farmed with bison-scapula hoes, fished in the Sheyenne, and hunted buffalo and other game. They had both dogs and horses and traded for white goods through Indian middlemen. Their culture was much like that of the Mandans, with whom they were doubtless in contact, but they differed from their Missouri River neighbors in their northeastern type of pottery, their use of birch bark, and their shell knives. About 1770 (the date is quite uncertain) the Chippewas attacked and burned the village. Some of the Cheyennes were already living in the Black Hills of South Dakota, and by 1800 the rest of the tribe had moved there. They soon became typical nomadic buffalo hunters without pottery, gardens, or earth-lodges.

In the seventeenth century two Dakota tribes (more commonly called Sioux-Chippewa for "lesser enemies") were driven out of Minnesota by the Chippewas. In 1642 the Yanktonai and Teton Dakotas were living in the Minnesota woods, probably in villages of bark houses. Later they moved west, but few crossed the Missouri River before 1750 . Eventually the Tetons (from Títonwàna, meaning "dwellers on the prairies") made their home in the country west of the Missouri from the Platte in northern Nebraska to the Cannonball in North Dakota. The Yanktonai Dakotas, moving west from Mille Lacs about 1700, made their home on the headwaters of the Big Sioux, James, and Red rivers, that is, on the Drift Prairie of North and South

Dakota. The warlike temper of the Dakotas constantly menaced the other tribes, restricted their hunting, and forced them out of their homes.

Close relatives of the Yanktonai Dakotas, the Assiniboins broke off with them before 1640 . The name is Algonquian for "stone people," meaning people who cooked by boiling 
water with hot stones. The Assiniboins called themselves Nakota, a dialect form of Dakota. Their tradition holds that they broke with the Yanktonais while living on the Upper Mississippi and then moved north to join the Crees. In 1658 they were living between Lake Superior and Hudson Bay, but before 1738 they had moved west and were living at least part of the time in northern North Dakota as well as west of Lake Winnipeg and on the Assiniboine and Saskatchewan rivers. A large tribe, the Assiniboins had both forest and prairie bands.

The Siouan-speaking Assiniboins intermarried with their allies the Crees, a large tribe of the Algonquian linguistic family. The Crees lived in Manitoba between the Red and Saskatchewan rivers but ranged down to Hudson Bay. Their hunting grounds touched only the northeastern corner of North Dakota. Though forest Indians, they were attracted by the buffalo herds of the Plains and assimilated the Plains culture from the Assiniboins. As with the forest and prairie bands of the Assiniboins, there came to be both Crees of the Woods, expert canoemen, and Crees of the Plains.

The Crees passed the Plains culture on to some of the Chippewas, also a tribe of the Algonquian linguistic family. The Chippewas, or Ojibways, as they were also called, one of the largest tribes north of Mexico, were living on both shores of Lake Huron and Lake Superior and at Sault Ste Marie when the French Jesuits first visited them in 1642. By the end of the eighteenth century the westernmost band, the latest Indians to enter the North Dakota grassland from the east, was moving out of the Minnesota woods onto the Great Plains in northeastern North Dakota and southern Manitoba near Pembina. The Plains Chippewas, or Plains Ojibways, became a distinct tribe and later moved on to the Turtle Mountains, to northeastern Montana, and to eastern Saskatchewan.

About the same time, the Arikaras, often called the Rees, were approaching North Dakota by coming up the Missouri River from Nebraska. This tribe belonged to the Caddoan linguistic family and was closely related to the Pawnees, the oldest Nebraska tribe. They planted corn and made pottery. Corn rites were prominent in their ceremonies, and in sign language they were the "corn eaters"-fingers simulated the gnawing of kernels from a cob. They had horses in 1738. In 
1770, French traders found them on the Missouri River below the Cheyenne River in central South Dakota. In 1804 they had three earth-lodge villages between the Grand and Cannonball rivers, where they tended their gardens and hunted buffalo. Like the Mandans, whose culture was much the same, they bartered corn with the Cheyennes and other tribes for buffalo robes and meat.

Life in the earth-lodge villages of agricultural tribes such as the Arikaras and Mandans was influenced by the vast grassland, with its herds of buffalo, especially after the Indians acquired horses. Thus when the Chippewas, Cheyennes, Dakotas, and other tribes moved from the forest to the open plain, they faced the necessity of changing their way of life. In the forest, they were expert canoemen, ate fish and wild rice, built bark-covered wigwams, boiled maple sap into sugar, wore soft-soled moccasins, and used long bows. These customs were well suited to the forest and lake country of Minnesota, but the grassland was far different; there the forest people had to adjust to an entirely different environment.

They did so quickly. In their new home they rode horses, ate buffalo meat and tipsin roots, slept in skin tipis, made sugar from box-elder sap, wore hard-soled moccasins, and hunted with short bows. Horses gave them mobility and enabled them to follow the migrating buffalo. Tipis afforded ideal shelter for a wandering people. Horsemen could handle short bows more easily. Soft-soled moccasins were good for silent stalking in the forest, but hard-soled ones protected the feet from cactus needles and sharp stones, and silence was of little value on the open plain.

Even the social organization and religion of the tribes changed with their migration. The Chippewas who came to the Plains abandoned the Grand Medicine Society and took over the Sun Dance, a ceremony to call the buffalo. Forest villages with bark wigwams scattered at random gave way to organized camp circles of skin tipis. Large numbers cooperated in travel, in the organization of the camp, and in the buffalo hunt.

The cultural differences of the closely related Dakota tribes (Santees, Yanktonais, and Tetons) living in different environments reveal the changes made by those who moved 
west. The Santee Dakotas still lived in the woods of central and southern Minnesota, with the western- most Santees coming into the southern Red River Valley. After their migration, the Yanktonai Dakotas lived on the Drift Prairie east of the Missouri. The Teton Dakotas found a new home on the Missouri Plateau west of the river.

Location influenced their cultures. For shelter, the Santees built large gable-roofed bark houses or small cattail-mat or bark wigwams. The Yanktonais had skin tipis or skin-covered wickiups. The Tetons used skin tipis. The Santees ate mostly venison, fish, wild rice, and maple sugar. The Yanktonais did some fishing, but not so much as the Santees; they planted river-bottom gardens (corn, beans, and squash) and went on two buffalo hunts each year. The Tetons, on the other hand, despised fish as unclean food, rarely had gardens, and depended mainly on the buffalo for food. The Santees wore softsoled moccasins, the Yanktonais and Tetons hard-soled ones. The Santees chose leaders more for their kinship and clan ties than for their personal ability. The Tetons had no clans and chose their leaders only for ability; even captured enemies might become chiefs. The Santees and Yanktonais made pottery, but the Tetons made none. Plainly, the Yanktonais, like the soils and grasses of the Drift Prairie where they lived, occupied a middle ground between their Dakota kinsmen of humid, forested Minnesota and those of the dry, short-grass Missouri Plateau. ${ }^{7}$

Fundamentally, however, life on the Plains depended upon the acquisition of horses. Only with horses could the tribesmen conquer the vast distances, run down the herds, and lead the wandering life of the true buffalo hunters. Plains culture meant a horse culture; Plains Indians were horse Indians. This was a perfect adaptation to the environment, for buffalo were the great wealth of the grassland. Horses allowed the Plains Indians to take that wealth easily, and they became rich.

None of the western tribes had horses until they began to get them from Spanish outposts in New Mexico, probably after 1650. Horses spread slowly northward from tribe to tribe, and before the end of the eighteenth century, even the Indians of the

7 James H. Howard, "The Cultural Position of the Dakota: A Reassessment" (Unpublished MS lent by author, 1958); John Hesketh, "History of the Turtle Mountain Chippewa," North Dakota Historical Society Collections, V (1923), 89-100. 
Northern Plains had them. The Tetons, Crows, and Cheyennes, typical Great Plains tribes, possessed large herds of horses. The Hidatsas, Arikaras, Mandans, Assiniboins, and Plains Chippewas did not have nearly so many.

\section{LA VÉRENDRYE's VISIT}

The earliest written record of North Dakota Indians was made by Pierre Gaultier de Varennes, Sieur de La Vérendrye, the first white man to visit the future state. A hardy, courageous man, La Vérendrye had grown up at Three Rivers, Quebec, entered the army at the age of twelve, and fought for France in bloody raids on the New England frontier and in major battles in Europe, where, as a lieutenant in the Régiment de Bretagne, he suffered many wounds. Returning to Canada, he entered the fur trade and eventually took charge of the post on Lake Nipigon, north of Lake Superior on the outer edge of New France. At that time there was much talk of finding an overland route to the Western Sea. At Lake Nipigon, La Vérendrye heard about a great river flowing westward. After the Indian Auchagah drew a map of the waterways leading west from Lake Superior, La Vérendrye devised a plan for exploration through the lands of the friendly Crees and Assiniboins. The king of France gave him a monopoly of the fur trade in the new country, the profits of which were to support western exploration. La Vérendrye formed a partnership with some Montreal merchants and started west in 1731 with a party which included three of his sons and his nephew. During the next few years they built a line of forts on the canoe route from Lake Superior to Lake Winnipeg and the Red River of the North. It was dangerous work: his nephew died, and a son and others were killed by the Dakotas.

But La Vérendrye, still fascinated at fifty-three by the wilderness and determined to go as far west as he could, visited the Mandans in the fall of 1738. He had long been hearing about them from the Crees and Assiniboins, and he wanted to learn more about the westward- flowing river. Late in September he found ten wigwams of Crees at the junction of the Red and Assiniboine rivers, a favorite Indian camping ground and now the site of Winnipeg. La Vérendrye's men built Fort Rouge there that fall. The Crees were in the habit of going every year to trade with the English at York Factory on Hudson Bay. When La Vérendrye 
rebuked them for this, they promised to trade with the French. The Crees, however, tried to discourage him from going up the Assiniboine River, saying that the Assiniboins, their close friends and allies, were people without intelligence who did not know how to hunt beaver (every tribe wanted to keep the white traders from their neighbors; then they might profit as middlemen).

La Vérendrye pushed up the river and soon fell in with bands of Assiniboins. They told him to stop where a portage started across the prairies to Lake Manitoba (probably present-day Portage la Prairie) on the road to the English at Hudson Bay. Many people would pass this way, they said. Here La Vérendrye built Fort La Reine. When he gave the Assiniboins presents of powder, ball, tobacco, axes, knives, hatchets, and awls, they burst into tears of joy. La Vérendrye adopted them as children of the French governor, urged them to hunt beaver, and asked them to stay at peace with their neighbors his standard routine with each new band.

Then, on October 18, 1738, leaving a garrison of thirteen men at Fort La Reine, he set off across the prairies for the Mandans. He had a party of fifty-two, about half Indians and half whites. On the way they met a large band of Assiniboins, who accompanied them to the Mandans. The combined party, probably numbering more than a thousand, moved slowly south, hunting as it went. The Assiniboins wanted a good supply of fat to eat with Mandan corn, for the Mandans had "for the most part neither meat nor fat," or so the Assiniboins told La Vérendrye.

The Assiniboins moved in good order and in three columns, with scouts in front and on the flanks and a rear guard to avoid surprise. When buffalo were sighted, a cry was raised, and all of the most active men hurried forward to surround the herd and kill what they could. These Indians had no horses, and on the march, La Vérendrye noticed that "the women and dogs carried all the baggage." Often the dogs were loaded with firewood, for clumps of trees were found only at intervals. "Every day they talked to us," La Vérendrye wrote in his journal, "about the whites we were going to see, Frenchmen like our-selves, who said that they were descended from us." They seemed on the verge of a great discovery. Guided by the Indians, the party followed a wandering route 
and traveled, La Vérendrye thought, nearly twice the distance which would have been necessary. At last, after forty-six days, they came to a Mandan earth-lodge village on December 3, 1738.

The village was probably the one whose ruins can now be seen on Apple Creek at Menoken, about thirteen miles east of Bismarck. For many years there was controversy about both the tribe and the location of the village visited by La Vérendrye. Professor Orin G. Libby of the University of North Dakota, an authority on the early history of the state, believed that La Vérendrye came to a Hidatsa village near Sanish. George F. 'Will, also an authority on early North Dakota history, argued that La Vérendrye must have visited a Mandan village near Bismarck. The discovery of the village site at Menoken in 1936 seems to uphold Will because it fits much of the description in La Vérendrye's journal. ${ }^{8}$

As La Vérendrye's party approached the village, which was still several days' journey away, some of the Mandans came out to greet them. To La Vérendrye's surprise, they did not differ much from the Assiniboins "being naked except for a garment of buffalo skin carelessly worn without any breechcloth." A Mandan chief, speaking Assiniboin, welcomed La Vérendrye with expressions of great joy and begged him to stay at his village-the smallest of six and the only one at some distance from the Missouri River. When they arrived, the Mandans carried La Vérendrye into the village and begged to be made his children. He fulfilled their request by putting his hands on the head of each chief. meanwhile, La Vérendrye's son visited the closest village on the Missouri and was cordially received.

The village in which La Vérendrye himself stayed had 130 lodges and was surrounded by a palisade and a deep ditch. He set down in his journal an interesting description of the people and their way of life:

${ }^{8}$ Orin G. Libby, "Some Vérendrye Enigmas," Mississippi Valley Historical Review, III (September 1916), 143-60; George F. Will, "A Criticism of 'Some Vérendrye Enigmas,"' American Anthropologist, XIX (April-June 1917), 291-297; Russell Reid, " Vérendrye's Journey to North Dakota in 1738," North Dakota History, XXXII (April 1965), 117-129. 
This tribe is mixed white and black. The women are fairly good looking, especially the light colored ones; many of them have blond or fair hair. Both the men and the women of this tribe are very industrious. Their lodges are large and spacious, and are separated into several apartments by broad planks. Nothing is left lying about, for all their belongings are kept in large bags which are hung on posts. Their beds are made like tombs, surrounded by skins. All go to bed naked, men and women. The men are always naked and for covering they use buffalo robes. Most of the women go naked like the men, with this difference, that they wear a loin cloth about a hand breadth wide and a span long, sewed to a girdle in front.... Their fort has a great number of caches in which are stored such things as corn, meat, fat, dressed buffalo robes and bearskins.... They make wicker work very skillfully, both flat and in the form of baskets. They use earthen pots for cooking their food which they manufacture like many other tribes. They are for the most part great eaters and they are extremely fond of feasting.... The men are of good size and tall, very alert and for the most part good looking. They have fine features and are very affable. Most of the women do not have the Indian features. The men take part in a sort of ball play in the open places. ${ }^{9}$

La Vérendrye saw how the Mandans bartered with the Assiniboins, trading the latter corn, tobacco, painted buffalo robes, and well-tanned and decorated deerskins for muskets, axes, kettles, powder, bullets, knives, and awls. These articles the Assiniboins bought from the English on Hudson Bay. The Assiniboins apparently began to go there in the 1680's, acting as middlemen for tribes to the south of them. Whatever the date, La Vérendrye's 1738 account is the earliest record of white trade goods in North Dakota.

After a ten-day visit, La Vérendrye, though ill, walked back across the prairies to Fort La Reine, a desperate undertaking 
in the dead of winter from December 13 to February 10. "Never in my life have I experienced so much misery, pain and fatigue as on that journey," he wrote. In April, 1742, he sent two sons, Louis-Joseph the Chevalier and François, to search again for the western Sea. From Fort La Reine they went to the Mandans and then visited other tribes to the southwest. It is impossible to trace their course from their journal, but they probably did not go beyond the Black Hills. Near present-day Fort Pierre they buried an inscribed lead plate, which was found by some school children on February 16, 1913.

Although La Vérendrye failed to find a route to the Western Sea and withdrew from exploration in 1744, he and his sons were the first white men to see Manitoba, the Dakotas, and possibly Montana. They were also the first to move on the waters of the Red and Assiniboine rivers and to see long stretches of the Upper Missouri. One son built the first forts on Lake Winnipegosis and the Saskatchewan River.

\section{WHITE IMPACT: HORSES AND SMALLPOX}

For about half a century after the visits of the La Vérendryes, no white men came to North Dakota. But during this time, two things from the whites greatly influenced the Indians of the region: horses, which gave them new freedom and power, and smallpox, which cut them down. Horses opened "a new world," so the Hidatsa legend ran, to the Missouri River tribes. In summer, the range of daily hunting parties increased, and instead of nibbling at the buffalo herds, they began to take deep bites from them. Almost the whole village could move out onto the prairies for the summer hunt, so the earth-lodge dwellers began to use tipis on their hunting trips. The surround replaced the corral, and game pits were used less.

Horses gave wandering tribesmen an advantage over sedentary agriculturists, both in hunting and in war, and made the Plains Indian more nomadic and so more addicted to warfare. Unimpeded by growing crops, he was ever prepared for war, ever ready to move. Moreover, the nomadic tribes suffered less during smallpox epidemics than the sedentary Indians. In 1782 (some sources say 1786), smallpox ravaged all 
of the tribes on the Northern Plains. A large number of the Mandans and Hidatsas died. During the epidemic the Dakotas attacked two Mandan villages (Slant Village in present-day Fort Abraham State Park and Double-Ditch Village, now a state park, a few miles north of Bismarck), burned them, killed many of the inhabitants, and made others prisoners.

After the epidemic had run its course, the surviving Mandans abandoned the region about the mouth of Heart River. They united under the leadership of Good Boy and moved up the Missouri River, first to the Lake Mandan-Painted Woods region and then, in the 1790 's, to the mouth of Knife River (present-day Stanton). Six large Mandan villages had been reduced to two small ones, and there were also two Hidatsa villages and one village made up of both Mandan and Hidatsa families at the mouth of the Knife. The place had been the home of two of the three bands of Hidatsas since they came to the Upper Missouri country, but not until after the 1782 epidemic did the nomadic Hidatsas, who generally ranged north of the Knife, come to live permanently in the large Hidatsa village on the north bank of the river.

The epidemic and the Dakotas had wiped out about threefourths of the Mandans and half the Hidatsas. In 1794, David Thompson estimated the population of the two tribes at 1,520 Mandans and 1,330 Hidatsas. When Lewis and Clark visited the Knife River villages in 1804, they estimated that there were 1,250 Mandans and 2,700 Hidatsas. This brief contact with a white man's disease had raised much havoc among the Northern Plains Indians, but the worst was yet to come. 


\section{CHAPTER 3}

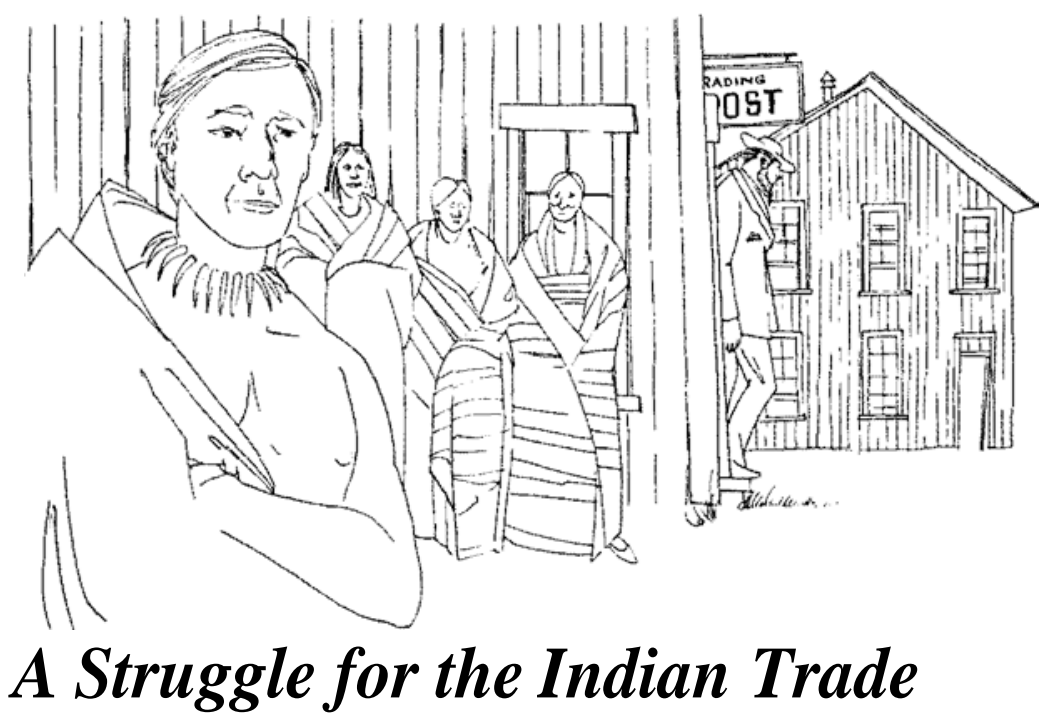

THE DISCOVERY OF AMERICA set in motion great events. For one thing, it added millions of square miles of land to the territorial resources which Europeans could use. For another, it provided a new source of potential income for the European economy. A golden opportunity was at hand, and the nations of Europe responded by staking out colonial empires. As the wealth of the New World poured in, it brought about a 400-year boom and transformed European institutions.

Rivalry for empire brought nations into conflict over the globe. It reached North Dakota when fur traders of three nationalities struggled to control the Upper Missouri country. First the British, coming from Hudson Bay and Montreal, dominated trade with the Knife River villages. Then the Spanish, working out of St. Louis, tried to dislodge the British, but distance and the hostility of Indians along the Missouri 
caused them to fail. After the Louisiana Purchase, Lewis and Clark claimed the Upper Missouri for the United States, and Americans from St. Louis began to seek trade there. They encountered the same obstacles which had stopped the Spanish, however, and with the War of 1812 , they withdrew from North Dakota, leaving it still in British hands.

\section{THE ARRIVAL OF BRITISH TRADERS}

When the British captured Montreal in 1760, the French abandoned their posts in the Indian country and the Indians were compelled to carry all of their furs to Hudson Bay. Before long, however, British traders from both the Bay and Montreal began to venture into the region west of Lake Superior, and by 1780 they had forts on the Assiniboine River. In 1793 the Hudson's Bay Company built Brandon House on the Assiniboine two miles above its junction with the Souris. The following year, the North West Company, an enterprise of Montreal merchants and Scottish traders, built Fort La Souris nearby.

The forts traded mainly with the Assiniboins, Plains Chippewas, and Crees, but they also sent merchandise to the Mandan and Hidatsa villages on the Missouri River at the mouth of the Knife. "This trade," wrote "Big John" McDonnell of Fort La Souris, "was carried on by the men taking upon credit a certain number of skins, as suited their circumstances, at the price of the post and paying at their return."

In the 1790's, René Jusseaume, later an interpreter for Lewis and Clark, was the principal trader with the Knife River villages. His expedition of 1794 illustrates the business. That October, he and six hired men packed five horses at Fort La Souris with merchandise, powder, and guns and set out on the 250-mile journey to the Missouri. Keeping a watchful eye for the Sioux, they arrived safely at the river in eleven days and were welcomed by the Mandans.

Jusseaume divided his merchandise. He gave part of it to one Menard to trade with the Mandans, while he himself took the rest to a Hidatsa village four or five miles away. He put his men to work building a small fort between the Mandan and Hidatsa villages, the first trading post on North Dakota soil. The following April, Jusseaume carried his peltries back to Fort La 
Souris, leaving four men to work on the fort. They Were to run up the British flag, the symbol of sovereignty, every Sunday.

\section{SPANISH EXPEDITIONS FROM ST. LOUIS}

The activities of Jusseaume and his fellow traders alarmed Spanish authorities at New Orleans and St. Louis. France had ceded Louisiana to Spain in 1763, and in 1764 some New Orleans merchants founded St. Louis. Soon St. Louis traders were ascending the Missouri, opening trade with tribes farther and farther upstream. In 1790, one of them, Jacques d'Eglise, reached the Mandans and observed the activities of British traders from the Assiniboine forts. This in itself was disturbing, but foreigners were threatening Spanish lands at other points, too: Americans along the Mississippi, Americans and British in Oregon, and Russians in California.

To check the intruders on the Upper Missouri, Jacques Clamorgan and other St. Louis merchants organized the Commercial Company for the Discovery of the Nations of the Upper Missouri (commonly called the Missouri Company) in the spring of 1794 . It was to open trade with the Mandans, stop British trade among them, and find a way to the Pacific Ocean. The Spanish governor at New Orleans offered two thousand dollars (later raised to three thousand) to the first Spanish subject to reach the Pacific by way of the Missouri. ${ }^{1}$

The company sent three expeditions to the Upper Missouri in 1794-1795, choosing Jean Baptiste Truteau to lead the first. He was instructed to build a fort among the Mandans and to determine the distance to the Rocky Mountains. Truteau, a schoolteacher in St. Louis, had lived with the Yankton Dakotas and spoke their language. He set out from St. Louis on June 7, 1794, with eight men and a large pirogue loaded with twenty thousand pesos' worth of trade goods. He had to pass many Indians living along the Missouri, a difficult undertaking, for none of them wanted traders to visit tribes beyond them, preferring instead to trade with their friends themselves and thereby make a profit.

${ }^{1}$ Abraham P. Nasatir, "Jacques d'Eglise on the Upper Missouri, 17911795," Mississippi Valley Historical Review, XIV (June 1927), 47-71; Abraham P. Nasatir, "Anglo-Spanish Rivalry on the Upper Missouri," Mississippi Valley Historical Review, XVI (December 1929), 359-382, and XVI (March 1930), 507-528. 
They also wanted to keep their enemies from obtaining guns and ammunition.

By taking care not to fire their weapons, Truteau's men passed the Omahas (near present-day Omaha) unnoticed, but in central South Dakota a hunting party of Teton and Yankton Dakotas stopped them. "They took from me," wrote Truteau in his journal, "powder, balls, cloth, white blanket, hatchet, pickax, vermillion, knives, etc. without giving me time to count their hides, yet less to settle on a price." ${ }^{2}$ With the help of some old acquaintances among the Yanktons, Truteau finally escaped with his pirogue and some of the merchandise. He spent the winter with the Omahas and Poncas and in the spring of 1795 went upstream to the Arikara villages at the mouth of the Grand River. He could not, however, reach the Mandans to forbid the British trade.

The Poncas pillaged the second Missouri Company expedition, which had been sent out to help Truteau in April, 1795. That August, the company organized a third expedition: James Mackay, with thirty-three men, four pirogues, and fifty thousand pesos' worth of merchandise, started up the Missouri. He was to build forts to protect Spanish trade from the British and after that was done to press on to the Pacific Ocean. But the Omahas waylaid him that fall.

In the spring of 1796, Mackay sent young John Evans and a small party to the Mandans. Evans, a-welshman, had come to America to find the welsh Indians, the supposed descendants of a legendary Prince Madoc who was believed to have discovered America in A.D. 1170. Evans had learned about the Mandans at St. Louis, and because of stories that they were white, he thought they might be the people he sought. So he had joined Mackay's party.

On June 8, 1796, Evans started up the Missouri from the Omaha village. As he went, he made a careful map, a copy of which Thomas Jefferson was later to send to Lewis and Clark as the latter prepared for their famous journey. At first the Arikaras would not permit Evans to pass, but after a few weeks they let him go on with a small outfit of trade goods. He

2 "Journal of Jean Baptiste Truteau on the Upper Missouri, 'Première Partie,' June 7, 1794-March 26, 1795," American Historical Review, XIX (January 1914), 299-333; "Trudeau's Journal," South Dakota Department of History Collections, VII (1914), 403-474, especially 422, 450. 
reached the Mandans on September 23 and was kindly received. Evans presented the chiefs with medals and flags in the name of the Spanish king, took the British traders' property away from them and gave them Mackay's proclamation forbidding their trade, and ran up the Spanish flag.

The British needed horses, corn, and buffalo robes from the Knife River villages. Though affable at first, they were soon talking about taking possession of the Missouri by force. Evans had few trade goods, however, and when he stopped the British trade, the hostility of the Indians forced him back down the Missouri. He reached St. Louis on July 15, $1797 .^{3}$

Never again did Spanish traders ascend the river as far as North Dakota, although they continued to trade on the Upper Missouri until Louisiana was transferred to the United States in 1803 (Spain had retroceded Louisiana to France in 1800, but France did not take possession until just before she transferred the territory to the United States). The Indians along the Missouri disliked high Spanish prices; they could buy more cheaply from the British, who came from Mackinac and Prairie du Chien to the Minnesota River and were their friends. Accordingly, they regularly plundered Spanish traders and did not pay their debts. The Spanish would not fight back, so the Missouri tribes came to believe, according to Meriwether Lewis, that "the white men [Spanish] are like dogs, the more you beat them and plunder them, the more goods they will bring you and the cheaper they will sell them."

The Knife River villages, moreover, were too remote for the traders of St. Louis and the sovereignty of the Spanish king. Distance and the tribes along the river highway made it too difficult to carry the necessary goods to North Dakota. So the British from the Assiniboine River forts dominated trade with the Mandans and Hidatsas, while other British traders, spreading westward from Prairie du Chien on the Upper Mississippi, monopolized the trade of the Minnesota-Iowa country and even that of the Omahas and Poncas. All encouraged their customers to plunder the Spanish. ${ }^{4}$

${ }^{3}$ David Williams, "John Evans' Strange Journey, Part II, Following the Trail," American Historical Review, LIV (April 1949), 512520, 528.

${ }^{4}$ Meriwether Lewis has an excellent description of the trade under the Spanish in Reuben Gold Thwaites (ed.), Original Journals of the 


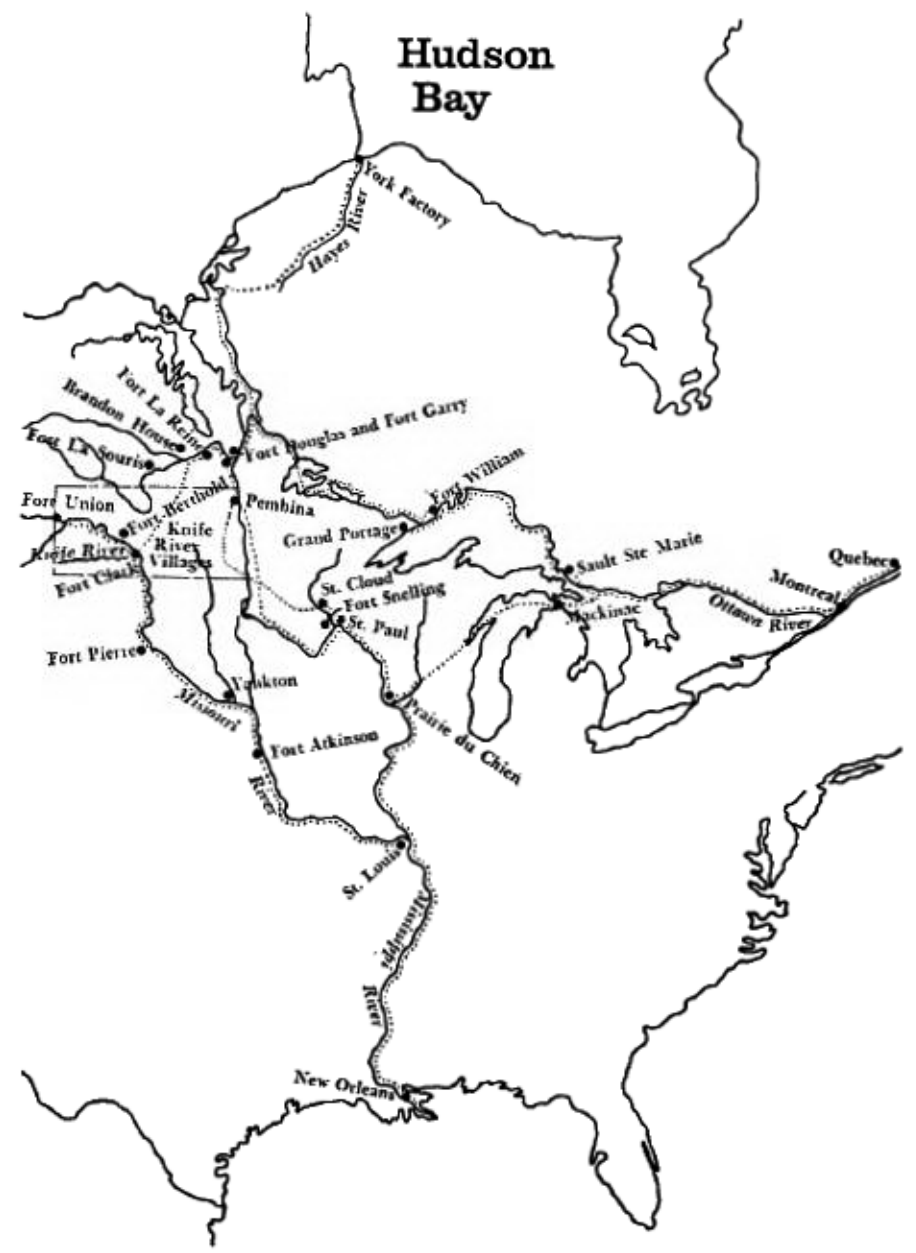

EARLY TRADE ROUTES TO NORTH DAKOTA

Lewis and Clark Expedition, 1804- 1806 (8 vols.; New York: Dodd, Mead and Company, 1904-1905), VII, 369-388. For estimates of the value of the trade, see VI, 82-83, 89-91. 


\section{TRADE WITH THE ASSINIBOINE FORTS}

Trade between the British forts on the Assiniboine and the Mandan and Hidatsa villages on the Missouri continued from the 1780's until after the War of 1812. It was carried on by free traders, by the Cree and Assiniboine Indians, and by employees of the Hudson's Bay and North West companies. The fur companies were not interested at first, but later they entered the trade for a time.

The operation was a simple one. In late fall, free traders would buy small outfits (merchandise worth from forty to sixty beaver pelts) on credit at Fort La Souris or Brandon House. Then a group of seven to ten of them would travel overland, some on horseback, some on foot, to the villages on the Missouri. They carried their trade goods on pack horses or, in winter, on dog sleds (two dogs to a sled), buying the dogs, half-wolf, from the Assiniboins.

The overland trip was fraught with danger and hardship. Sioux might be lying in wait to plunder and kill them at Dogden Butte, a sheltered spot with wooded ravines and springs in northeastern McLean County. Or some of the Assiniboins, jealous of white competition in a trade they considered their own, might attack them. Storms and bitter cold also menaced their lives. The trail, about 250 miles long, followed the Souris, cut across to the Turtle Mountains, then struck for Dogden Butte, and reached the Missouri near the mouth of the Knife. Ordinarily the traders, traveling as rapidly as they could, covered the distance in ten to fifteen days, killing buffalo on the trail for themselves and their dogs; one party carried roasted ears of corn.

At the villages they stayed in the Indians' lodges, for which hospitality they presented their hosts with gifts. Some settled there permanently, took Indian wives (fair and graceful women), and raised families. The traders exchanged their goods-guns, powder, ball, strouds, capotes, and ironware-for furs, mostly wolf and fox pelts, with only a few beaver. They also bought corn, horses, buffalo robes, and occasionally a female captive. In 1804, Lewis and Clark estimated that Indians annually bought goods worth $\$ 3,300$ at St. Louis prices and paid for them with articles worth $\$ 10,500$ at St. Louis. The difference shows the high cost of transportation and the middleman's profits in a risky enterprise. 


\section{THE LEWIS AND CLARK EXPEDITION}

Interest in trade on the Upper Missouri, especially with the Mandans, was part of the motivation behind the famous Lewis and Clark Expedition. The expedition itself illustrates how decisions in the capitals of the Western world-centers of powerinfluence events in even the most remote regions. Though isolated by distance, North Dakota was deeply affected by world currents. Because Napoleon failed in Santo Domingo and then planned to renew war with England, he sold the vast Louisiana country, including most of North Dakota, to the United States in 1803. Because Thomas Jefferson, a man long curious about the wilderness beyond the Mississippi, became President in 1801, Lewis and Clark crossed the continent to the Pacific.

The expedition was the first effort by the United States to explore and to extend its sovereignty over North Dakota. Although the North Dakota phase was incidental to the expedition's main purpose, it looms large in the history of the state. Lewis and Clark spent more time in and made a fuller record of North Dakota than any other region through which they passed.

On January 18, 1803, Jefferson asked Congress to authorize a party of ten or twelve men under the leadership of an army officer to visit the Upper Missouri. He speciously reasoned that the information secured by the party would enable Americans to take the trade of the Knife River villages (still under Spanish sovereignty) away from the British. Having gone that far, Jefferson continued, the party might as well complete the crossing of the continent. He quietly presented his daring scheme as merely "an additional gratification," an almost incidental afterthought. The unexpected purchase of Louisiana on May 2, 1803, changed Jefferson's subterfuge to an honest purpose and gave the project a practical as well as a scientific objective. Jefferson amended his instructions: Lewis should tell the Indians that "their late fathers, the Spaniards," had surrendered the country to the United States and that "henceforward we become their fathers and friends."

Jefferson's choice of Lewis and Clark as leaders of the expedition was a wise one. Both had spent some years as army officers, commanding men and dealing with Indians on the 
frontier; both were members of the landholding gentry and had managed plantations. Jefferson thought that Lewis, then twenty-nine, was "brave, prudent, habituated to the woods, \& familiar with Indian manners and character." Clark, thirtythree, was a cou-ageous, red-headed six-footer with a bluff, direct manner of speaking and acting-a person at home in the back- woods. For their party the leaders chose, in Lewis' words, "good hunters, stout, healthy unmarried young men, accustomed to the woods, and capable of bearing bodily fatigue in a pretty considerable degree." They took along much scientific apparatus-a chronometer, sextants, a surveyor's compass, thermometers, and so forth. They also took camp equipment, medicines, and arms, as well as twentyone bales of presents for the Indians, including scissors, awls, brass kettles, needles, and fishhooks. Such useful items, far beyond the Indian technology, ensured their welcome.

Starting from its camp near St. Louis on May 14, 1804, the party of some forty-four men moved up the Missouri River in a 55-foot keelboat and two pirogues. Here and there Lewis and Clark stopped to hold a council with an Indian tribe, giving medals and flags to the chiefs and telling them the wishes of their new "father" in Washington. They said that the Indians must give up their Spanish flags and medals, that the Great American Father would allow only the boats of his own traders to come up the river, and that these traders would soon bring them all the merchandise they needed. But, Lewis and Clark said, if the red children displeased the Great American Father, he could cut off their supply of trade goods; they should open their ears to the words of the Great Father.

By means of such councils, Lewis and Clark were taking possession of the Missouri Valley for the United States. Only once did they have any trouble. Near the mouth of the Bad River in South Dakota, some Teton Dakotas, an "ill looking". and poorly armed lot, tried to stop them. Vigilance and courage saved the expedition. At one point, Clark, surrounded by young Tetons with their bows and arrows ready, pulled out his sword and spoke "in verry [sic] positive terms." The following spring, Clark told an Arikara chief that the Great Father would not let the Tetons "have any more good Guns 
\&c." 5

Late in October the expedition reached the cluster of five villages at the mouth of the Knife River, where they planned to spend the winter. The Mandans and Hidatsas flocked down to the riverbank to give the white men a friendly welcome. Two days later, Lewis and Clark made their usual speech at a council and put medals on the chiefs (this was called "making chiefs"), thereby asserting American sovereignty. But Indian dependence on white trade goods was the main prop of sovereignty, and the Mandan-Hidatsa goods were coming-and for some years would continue to come-from the British forts on the Assiniboine, not from American merchants in St. Louis. Sensing American weakness, Le Borgne ("The One-Eyed"), the grand chief of the Hidatsas, contemptuously stayed away from the council.

Whatever impression of strength Lewis and Clark could give with their keelboat and its swivel gun, their armed men, and their own courage would help the American cause. So they built Fort Mandan, their winter camp, as strong as possible. Four miles downstream from the lower Mandan village, it was a triangle of huts and pickets with an outer wall eighteen feet high. It seemed, wrote a North West trader, "made so strong as to be almost cannon ball proof."

Lewis and Clark asserted authority in other ways. They made peace between the Arikaras and the Mandans and Hidatsas, for peace would be essential to white traders ascending the river. They persuaded the Mandans to restore several traps stolen from two Frenchmen and offered to punish some Sioux who had killed and robbed members of a Mandan hunting party. They did not interfere with trade from the British forts but offered their protection to all well-disposed traders. They did, however, forbid the British to give out any medals or flags or to make any chiefs. They told the Indians that they must not accept British medals or flags unless they wished to "incur the displeasure of their Great American Father."

Such actions impressed the Indians. On March 9, 1805, Le Borgne himself finally visited Fort Mandan. Lewis fired two guns in his honor and gave him a medal, a gorget, arm bands,

${ }^{5}$ Ibid., I, 286; V, 282-286. For other quotations, see V, 299-301; VII, 208-209,227, 292-293. 
a flag, and a shirt. Le Borgne-a strong, self-possessed giant who looked like a fearful demon-was much pleased. In July, 1806, Alexander Henry, a North West trader, saw Le Borgne wrap himself in his American flag for peace ceremonies with the Cheyennes. That same July, Big White, a Mandan chief, tried to get Henry and his fellow traders to salute the American flag flying from the roof of his earth lodge. The Britons pretended not to understand.

To impress the Indians, Lewis and Clark wanted a number of chiefs to visit the President in Washington. On such a trip they would see the vast resources of the United States, gain confidence in its ability to protect them, and conclude that submission was the wisest course of action they could take. In 1805, when the keelboat and a part of the expedition returned to St. Louis, they took along some Arikaras (one a highly respected chief), who visited President Jefferson. In 1806, Lewis and Clark planned to take some Mandans, Hidatsas, and Sioux with them on their return, but only Big White consented to go. He, his family, and Jusseaume, who went along as interpreter, were finally returned home, after great difficulty and expense, on September 24, 1809.

Before these events, however, the expedition had spent an interesting winter (1804-1805) at Fort Mandan. Although December was very cold, some of the men went hunting almost every day, bringing in many deer, elk, and buffalo to hang in the smokehouses. At Christmas they fired the cannon when they raised the flag, and Clark treated them to rum and issued flour, pepper, and dried apples for the Christmas feast. Scarcely a day passed without some Mandans coming to visit the fort; the chiefs liked to spend the night there.

Lewis and Clark soon learned about Sakakawea, a young Shoshoni woman of seventeen who had been captured in the Rockies by a war party of Hidatsas. ${ }^{6}$ Toussaint Charbonneau,

${ }^{6}$ There is controversy over the spelling of the name "Sakakawea" or "Sacajawea." The Reverend Charles L. Hall has argued persuasively that the correct spelling is "Sakakawea." He had been a Congregational missionary to the Hidatsas and Mandans on the Fort Berthold Reservation for thirty years and was an authority on the Hidatsa (Gros Ventre) language when he wrote "The Grosventre Spelling of the Name, Bird Woman," North Dakota Historical Society Collections, I (1906), 69-72. "Sacajawea" is Shoshone for "Boat Launcher" and has 
a Frenchman living in the Knife River villages, had bought her. Now Lewis and Clark hired him as an interpreter in order to secure the services of his wife as guide. The couple moved to Fort Mandan, where, on February 11, 1805, Sakakawea gave birth to "a fine boy." The baby, Baptiste, was taken along on the journey to the Pacific.

Finding Sakakawea was a master stroke. Perhaps no single act contributed so much to the success of the expedition, for she was, according to Lewis, their "only dependence for a friendly negociation with the Snake [Shoshoni] Indians on whom we depend for horses to assist us in our portage from the Missouri to the columbia river." Clark, especially, came to have a high regard for her, calling her "Janey," and she-a gentle, brave, attractive girl-returned his affection. He later educated Baptiste in St. Louis, and after her death in 1812, he adopted her daughter.

For her part in the great enterprise, Sakakawea won undying fame with the American public. She has had more memorials dedicated to her than any other American woman: a river; a mountain pass; statues in bronze at St. Louis, Portland, and Bismarck; a bronze tablet at Three Forks, Montana; a monument at Armstead, Montana; a public fountain at Lewiston, Idaho; and a cement shaft on the Shoshoni Reservation in Wyoming.

After wintering at Fort Mandan, Lewis and Clark concluded that the Mandans were "the most friendly, well disposed Indians inhabiting the Missouri," a judgment that was to become typical for the tribe. No doubt part of the friendliness of the Indians, even the Mandans, resulted from their dependence on white trade goods. The expedition's blacksmiths had become great favorites during the winter by making battle-axes for the Indians and mending their guns, axes, hoes, and iron tools, for which the women gratefully brought corn in payment. The Indians were "extravegantly fond" of sheet iron for making arrowheads and scraping buffalo hides, so the smiths sold them pieces four inches square for seven or eight gallons of corn. Later the Mandans broke up a corn mill, given them by Lewis and Clark, to make arrow- heads. Le Borgne, the haughty Hidatsa chief, thought that "the only two sensible men" in the expedition 
were "the worker of iron and the mender of guns."

\section{TRADE AMONG THE UPPER MISSOURI TRIBES}

At the beginning of the nineteenth century, trade brought the tribes of the Upper Missouri many of the necessities and comforts of life. The important items of exchange were white-manufactured goods, horses and mules, corn, buffalo robes, and a variety of furs-wolf, fox (or kit, a small prairie fox), and beaver. Beans, tobacco, grease, leather, and slave women were also traded.

Some articles came thousands of miles to the tipis and earth lodges of these peoples; others of their own production found distant markets overseas. Many items, of course, moved much shorter distances. The merchandise of white manufacture-guns, powder, ball, knives, axes, kettles, blankets (often called strouds), capotes (cloaks with hoods), awls, fishhooks, and so forth-came largely from the British Isles by way of York Factory, Montreal, or New Orleans, passing through such intermediate points as Sault Ste Marie, Prairie du Chien, and St. Louis. The horses and mules came from Spanish settlements in New Mexico and possibly farther south. Before 1800, whites saw Spanish saddles and bridles on the horses of the Mandans. A surplus of corn, beans, and tobacco was grown by the agricultural tribes along the Missouri. Buffalo robes entered trade largely, but not entirely, as a surplus of the more typical Plains Indians. All of the tribes gathered some peltries for trade. Liquor seems to have played only a small part at this time; the Arikaras even resented treats of strong drink.

Traders faced many difficulties. Distances were long. War and uneasy relations between tribes were common, for no tribe wanted to see its enemies supplied with guns and ammunition. The Sioux and Assiniboins made the trail between the British forts and the Knife River villages

7 Thwaites, Original Journals of Lewis and Clark, I, 227, 242-243, 254-255. See also I, 214, 227 n., 228-232, 249, 27u ; $\bar{V}, 282-286,338-$ 341. For Le Borgne's comment, see Elliott Coues (ed.), New Light on the History of the Greater Northwest: The Manuscript Journals of Alexander Henry... and of David Thompson...1799-1814 (3 vols.; New York: Francis P. Harper, 1897), I, 329. 
unsafe, and the Sioux earned the epithet "pirates of the Missouri": they delighted in plundering traders ascending the river. Because of such obstacles, the North Dakota tribes suffered more than others from the economic disadvantages arising from high transportation costs, the profits of many middlemen, and a small quantity of goods. The more remote the tribe, the higher the price it paid for white goods and the smaller the quantity it received.

Each tribe, of course, traded what it had for what it needed. The Cheyennes and Crows, western neighbors of the agricultural tribes, would undertake month-long expeditions to New Mexico to steal Horses and mules from the Spanish settlements. They would then go to the Arikaras, Mandans, and Hidatsas and trade horses, buffalo robes, dried meat, furs, women slaves, and leather lodges for corn, beans, and tobacco. They also bartered for goods which the agricultural tribes, being closer to the forts and living along the river, had secured from white traders. The Mandans did not have many horses in 1797; the Arikaras and Hidatsas had more, some Hidatsa families having from twenty to thirty.

In their turn, the Arikaras would trade some of their horses, along with corn and beans, to the Tetons living east of the Missouri. Each May, the Tetons held a trade fair on the James River, where they exchanged horses for white goods with the Yanktonai and Sisseton Dakotas, who secured them from British posts on the Minnesota River. The Mandans and Hidatsas traded horses and corn to the Crees and Assiniboins living farther north; they also exchanged horses, corn, female slaves, buffalo robes, and a variety of furs (wolf, fox, and beaver) for white goods with traders from the Assiniboine forts. In the general pattern of exchange, horses and mules moved north and east from New Mexico, white goods moved west and south from the British posts, and corn and beans moved east, west, and north from the agricultural tribes.

Sometimes the tribes engaged in a mass exchange called "trading on a pipe" because a pipe of peace was smoked. In 1805, for example, the Crows and Hidatsas came together for such a trade. The Crows put up 250 horses, as well as buffalo robes and leather leggings and shirts; the Hidatsas put up 200 guns, with 100 rounds of ammunition for each, in addition to 100 bushels of corn and a quantity of kettles, axes, and cloth. 
Apparently, a horse was roughly equal to a gun. In 1811 a trader paid eleven balls and eleven charges of powder for a buffalo robe.

How well did the traders supply Indian needs? The testimony is conflicting. One trader said in 1795 that the Mandans "were all well provided with guns, pistols, and swords," but two years later, David Thompson reported that the Mandans and Hidatsas had only a few guns and sometimes went for many days without ammunition. They used arrows for hunting, saving their guns for war. In 1804, Lewis and Clark thought that "a great proportion" of the five or six hundred Arikara men had guns. On the other hand, only a few Crows had guns in 1805, and the Tetons still depended on bows and arrows. Yet Charles MacKenzie, a British trader, wrote in 1805: "It is incredible the great quantity of merchandise which the Missouri Indians have accumulated." ${ }^{8}$

Trade naturally, perhaps inevitably, brought dependence and exploitation. Where war was always present, guns were important. Kettles, knives, axes, awls, fishhooks, and many other items of white manufacture were far superior to Indian articles used for the same purposes. So the Hidatsas, closer to the sources of supply, charged the Crows double prices and would not let white traders deal with them. Other tribes also held their more remote neighbors in subjection. The Mandans had to swallow the insults of the Crees and the Assiniboins, the middlemen who brought them goods and controlled the route from the forts on the Assiniboine River. The Tetons ruthlessly bullied and exploited the Arikaras. The Hidatsas, a fierce and haughty people, feigned friendship for the whites out of need; Le Borgne, their cruel chief, was friend and protector to traders.

Indeed, all chiefs preached friendship with the traders. Some French- men lived for years in perfect safety with the tribes of the Upper Missouri (Menard, Charbonneau, and Jusseaume for example), taking Indian wives and learning the language. The reasons were eloquently expressed by some Yanktons in 1794: "The people whom the French [traders] did not

${ }^{8}$ Louis F. R. Masson (ed.), Les Bourgeois de la Compagnie du Nord-Ouest: Recits de Voyages, Lettres et Rapports Inédits au NordOuest Canadien (2 vols.; Quebec: A. Coté et Cie, 1889), I, 344. 
frequent were miserable, exposed to die of hunger, and to be conquered by their enemies, from want of defensive arms." 9 The traders, grateful for protection, always gave presents to the chiefs.

Eager as they were to have white goods, the Indians realized and resented their exploitation. Jean Baptiste Truteau wrote in 1795 that the Arikaras, once unsurpassed in "gentleness and kindness towards us," were turning "sour" because of the influence of wicked and dissolute traders and were "giving nothing for nothing and never doing us a service without reward."

The purchase of Louisiana started American traders and trappers up the Missouri River. Returning from the Pacific in 1806, Lewis and Clark met eleven separate parties coming upstream in twenty boats loaded with trade goods and supplies. Some planned to trade for peltries, others to hunt and trap on their own account. Thus rivalry between American and British traders was extended along the Canadian boundary of the Upper Missouri country.

To aid American traders, General James Wilkinson issued a proclamation in 1805 excluding foreign traders from the Missouri River. Jay's Treaty, 1795, permitted the British to trade within the United States, but Wilkinson claimed that it did not apply to the land acquired in 1803.

The reports of Lewis and Clark excited more American interest, and in 1807, two large parties left St. Louis for the Upper Missouri. The first, the Pryor-Chouteau party, was a combined group of traders, soldiers, and Indians; the second was Manuel Lisa's expedition to the Yellowstone River.

The Pryor-Chouteau group had several missions. The government was sending Ensign Nathaniel Pryor and thirteen soldiers to escort Big White, a Mandan chief, and his family to the mouth of the Knife River. Other soldiers were returning to their homes some Sioux who had been visiting St. Louis. Pierre Chouteau, Sr., and thirty-two men were going to trade with the Mandans; "Young Dorion" and ten men sought trade with the Sioux. In all, there were ninety-five persons in the Pryor-Chouteau party when it left St. Louis in several keelboats in May, 1807. 
After some members of the group stopped in the Sioux country, the rest went on to the Arikara villages. There they found that the Arikaras and their Sioux allies (then visiting in the villages) were at war with the Mandans. The Arikaras were unfriendly toward the Americans because one of their chiefs had died on a visit to President Jefferson in Washington, so they and the Sioux decided to prevent the traders from going upstream to their enemies. They spurned Chouteau's offer to leave half his goods and a trader with them and demanded instead that the whites surrender all of their guns. Soon the Indians began firing on the boats, killing four men and wounding ten. Pryor and Chouteau were forced to turn back to St. Louis, and for the next two years, licenses issued to traders forbade them to deal with the Arikaras. The attack upon the Pryor-Chouteau party was the beginning of Arikara hostility toward Americans; it may well have been stimulated by British traders. ${ }^{10}$

The failure of the Pryor-Chouteau party contrasted with the success of the one led by Manuel Lisa. Before the War of 1812, Lisa did more than any other St. Louis merchant to tie the Upper Missouri country to his city. Born in New Orleans of Spanish parents in 1772, he went to St. Louis in 1790 and entered the fur trade. He was ideally suited for the business; his body could withstand its hardships, his spirit outface its dangers. Ever alert, he learned the character of the Indians and the methods of the trade: when to be tactful, when generous with presents, when bold and daring, when to show the muskets of his men, the swivel gun on his keelboat. In a dangerous country and among a rough and uncivilized people, he was acknowledged master. Yet he became the trusted friend of the Indians.

Lisa liked to boast of his benefactions. He had carried to the Indians the seeds of many vegetables and also a plow. His

${ }^{10}$ Hiram M. Chittenden, The American Fur Trade of the Far West (2 vols.; Stanford: Academic Reprints, 1954), I, 119-123; Clarence E. Carter (ed.), Territorial Papers of the United States, Vol. XIV, The Territory of Louisiana-Missouri, 1806-1814: (Washington: Government Printing Office, 1949), pp. 108-109, 122, 126, 153, 222, and, especially, 350; Wayne E. Stevens, "Fur Trading Companies of the Northwest, 1760-1816," Mississippi Valley Historical Association Proceedings, IX (1915-1918), 288- 289. 
blacksmiths worked for them, charging nothing. He lent them traps, asking only preference in their trade. His forts became a refuge for the weak and for the old men no longer able to follow the nomadic wanderings of the bands. Lisa naturally got much rich fur; in one season alone his boats brought $\$ 35,000$ worth down the river. But Lisa worked hard for such returns, spending much of his time in the wilderness. From 1807 to his death in 1820 , he traveled some 26,000 miles on the Missouri and its tributaries. ${ }^{11}$

In 1806, Lisa, stirred by the reports of Lewis and Clark, formed a partnership with William Morrison and Pierre Menard (veterans of the fur trade from Kaskaskia, Illinois) to exploit the new country. In the spring of 1807, Lisa and his men left St. Louis in a keel boat laden with merchandise, the first large-scale American effort to open the Upper Missouri. The party safely passed the river tribes, although two or three hundred Arikaras were waiting to stop them and even the Mandans were in an ugly mood. They ascended the Yellowstone, built a post at the mouth of the Big Horn-the first American fort in Montana-and passed a profitable winter trading with the Crows before returning to St. Louis in the spring of 1808.

Manuel Lisa's success brought the chief traders of St. Louis together in the Missouri Fur Company. In June, 1809, the company sent Pierre Chouteau up the river with a party of 350 men (some sources say 150), many keelboats, and enough merchandise for five or six posts. Lisa himself stopped to build Fort Lisa on the Missouri twelve miles above the mouth of the Knife. Other groups had dropped off to establish posts for trading with the Sioux (at Cedar Island) and with the Arikaras (at Grand River).

The forts were a measure of appeasement. Meriwether Lewis, then governor of Louisiana Territory, told Chouteau that British traders were not permitted to trade or hunt on the

${ }^{11}$ Irving B. Richman, "Manuel Lisa," Dictionary of American Biography (New York: Charles Scribner's Sons, 19:28-1958), XI, 291; Kathryn M. French, "Manuel Lisa," South Dakota Department of History Collections, IV (1908), 121-124; Henry M. Brackenridge, Journal of a Voyage up the Missouri, Performed in 181I (Vol. VI of Early Western Travels, 1748-1846, ed. Reuben Gold Thwaites; Cleveland: A. H. Clark Company, 1904), p. 29. 
Upper Missouri; he was instructed to give any he might find twenty-four hours' notice to leave the territory. If they refused, he was to arrest them and bring them to St. Louis. Lewis believed that control of the Indians depended on cutting off British supplies, and this, he felt, was the way to do it.

After reaching Knife River, Chouteau returned to St. Louis, but most of the party went on to Montana to trade and trap about the Three Forks of the Missouri-rich beaver country in the Rockies. By 1811 the hostility of the Blackfeet had driven the company out of Montana, whereupon Fort Lisa, serving the Knife River villages, became the company's most distant trading post.

The fort, located south of present-day Mannhaven on the west bank of the Missouri, consisted of a square blockhouse and some small outhouses surrounded by a palisade about fifteen feet high. In 1811, Reuben Lewis, a younger brother of Meriwether, and some of the hunters were living in the upper story of the blockhouse; the lower was a storeroom for furs. A vegetable garden, proudly tended by an Irish- man, lay near the fort. Francis M. Benoit, the chief factor there in 1811, charged exorbitant prices-ten dollars a quart for whiskey.

High prices were a result of the remoteness of the Dakota country, an isolation that was somewhat relieved by the Missouri River. Yet that stream's swift, muddy current, its shifting channel and threatening driftwood, and the Indian tribes along its banks posed serious problems for the traders. The Sioux, especially, blocked the river. The Sioux country itself contained little of interest to the traders; they preferred the richer fur regions farther upstream. Bu t the Sioux often pillaged them or imposed their own terms for passage.

The Missouri, a watery highway into the wilderness, rose in a giant spiral, without falls or rapids, from just above St. Louis to central Montana, a distance of 2,285 miles. Dugout canoes or pirogues and keelboats were used to ascend its winding course. And these and other craft-Mackinaw boats, buffaloskin canoes, and rafts made by lashing two canoes togetherfloated downstream with cargoes of peltries.

A keel boat was fifty to seventy feet long, had a beam of fourteen to sixteen feet, and could carry a cargo of some twenty tons. It had a mast with sails and a cabin, or cargo box, that rose four or five feet above the deck. Manned by a 
crew of twenty hardy young French Canadians or Creoles from St. Louis, it was propelled upstream, according to circumstance, by sails, oars, poles, or a long towline called a cordelle. The crew was well armed, and the boat had a light cannon, known as a swivel gun, mounted in the bow.

When a keelboat set off up the Missouri in early spring, the crew would indulge in a last drunken frolic. The first night out, however, gloom would spread over them as they thought of the dangers ahead. Each morning they would make an early start; each night they would camp on shore, sleeping in blankets or buffalo robes about a fire. The fare was plain: corn hominy for breakfast, a slice of fat pork and a biscuit at midday, a pot of mush with a pound of melted lard for supper. A hunter, ranging ahead, might bring in game, bear or deer lower down the river and buffalo when they reached the Dakota country.

The toil was exhausting. Dead buffalo, logs, even whole trees came floating down the swift flood. Sometimes fallen trees matted into great rafts and barred the way. Trees held fast in the river bed, called planters or sawyers, threatened the boat with their bobbing branches. The men fought the current, grabbing the oars or poles or scrambling along the shore with the cordelle. In such a struggle Manuel Lisa was a spirited leader. One moment, wrote Henry Brackenridge in 1811, Lisa would be "at the helm, at another with the grappling iron at the bow, and often with a pole....His voice, his orders, and cheering exclamations, infused new energy." He would pass out grog and raise a song, making the woods ring with his shouts of encouragement.

During the famous race of 1811 when Lisa's keelboat overcame a three-week lead by Wilson Price Hunt's Astorians, Lisa's men covered long distances-20, 27, 30, 33, and once even 75 miles in a single day when they sailed with a favorable wind far into the night. Making a heroic effort, they covered the 1,600 miles from St. Charles, the starting point near St. Louis, to the Knife River villages in a little less than three months. In 1804 the keelboat of the Lewis and Clark Expedition, usually traveling from 8 to 20 miles a day, covered the same distance in about five months. The return trip downstream could be made in about two weeks. In 1806, Lewis and Clark traveled from 40 to 70 miles a day while descending the Missouri. 


\section{EFFECTS OF THE WAR OF 1812}

After the promising start of the Missouri Fur Company, the War of 1812 broke the weak tie between the tribes in North Dakota and the American traders at St. Louis. Before the war, British influence among the tribes of the Upper Missouri and Upper Mississippi remained strong. Throughout the wilderness, British traders were instruments of British sovereignty, teaching the Indians to regard the British king "as their Great Father, who sent the Traders to supply them with Goods, and to purchase their Furs." In 1813, after the outbreak of war, Lisa and the Missouri Fur Company abandoned their three forts (one at Cedar Island, another near Grand River, and the third close to the Knife River villages) in North and South Dakota.

British free traders and the men of the North West Company apparently swung the sympathies of most of the Upper Missouri tribes over to the British side. According to rumor at St. Louis, the North West Company even built a post among the Mandans. True or not, trade from St. Louis came to an end. The tribes of the Upper Mississippi were even more clearly aligned with the British. Encouraged by trader Robert Dickson, some Indians from Minnesota went east to aid the British armies.

The North West Company and the Indians with whom they traded, however, took little part in the War of 1812. The company furnished the British government with merchandise for presents to the Indians. It also lost some property at Sault Ste Marie, pillaged by the Americans, and some vessels on the Great Lakes, but in 1814 it safely sent a million dollars' worth of furs from the upper country to Montreal. ${ }^{12}$

To counteract British influence on the Upper Missouri, William Clark, then Superintendent of Indian Affairs at St. Louis, in August, 1814, appointed Manuel Lisa as subagent for all of the Missouri tribes above the mouth of the Kansas River. Clark gave Lisa $\$ 1,335$ worth of merchandise to win over the Indians. Lisa went up the Missouri to his fort a short distance

12 Gordon C. Davidson, The North West Company (Berkeley: University of California Press, 1918), pp. 139-142, 289; John C. Luttig, Journal of a Fur-Trading Expedition on the Upper Missouri, 1812-1813, ed. Stella M. Drumm (St. Louis: Missouri Historical Society, 1920); Louis A. Tohill, Robert Dickson, British Trader on the Upper Mississippi: A Story of Trade, War, and Diplomacy [Ann Arbor: Edwards Brothers, 1927], pp. 
above present-day Omaha, where he worked successfully to keep the Omahas and nearby tribes loyal to the United States. He even organized war parties against the pro-British Indians on the Upper Mississippi. His activities did not extend to the Indians in North Dakota, however. Those tribes were too remote to be drawn into the war by either side.

During the peace negotiations, British fur interests asked their government to secure a new boundary with the United States. All of the lines they suggested as being satisfactory ran up the Missouri River to the Rocky Mountains. Their proposals would have placed the larger part of North Dakota in British territory, but none of them were included in the peace treaty. It did provide, however, that the United States make peace with all the tribes with which it was at war. As a result, "William Clark, Ninian Edwards, and Auguste Chouteau signed treaties with many tribes in the summer of 1815 at Portage des Sioux, a small French village near the junction of the Mississippi and Missouri rivers.

Most of the tribes at the peace council were from the Upper Mississippi, but Lisa brought forty-three chiefs and headmen (Yanktons, Tetons, Omahas, and other tribes) from the Missouri. None of them, however, represented tribes in North Dakota. Lisa brought down Partisan, the Teton chief who had tried to stop Lewis and Clark in 1804-, and also Black Buffalo, the Teton who had helped them. One observer said that the wildest, least sophisticated Indians at the council were those from the remote Upper Missouri. ${ }^{13}$

The old obstacles, distance and hostile tribes, that had frustrated the Spanish still frustrated the Americans. In spite of the Louisiana Purchase, the Lewis and Clark Expedition, and the efforts of Manuel Lisa and other traders, the Upper Missouri country, especially the more remote portions in North Dakota and Montana, was still not tied to St. Louis in 1815.

\footnotetext{
${ }^{13}$ Robert L. Fisher, "The Treaties of Portage des Sioux," Mississippi Valley Historical Review, XIX (March 1933), 495-508. A long document in Carter, Territorial Papers, XIV, 614-621, considers the Indian problem on the northwest frontier but does not mention the Upper Missouri.
} 


\section{CHAPTER 4}

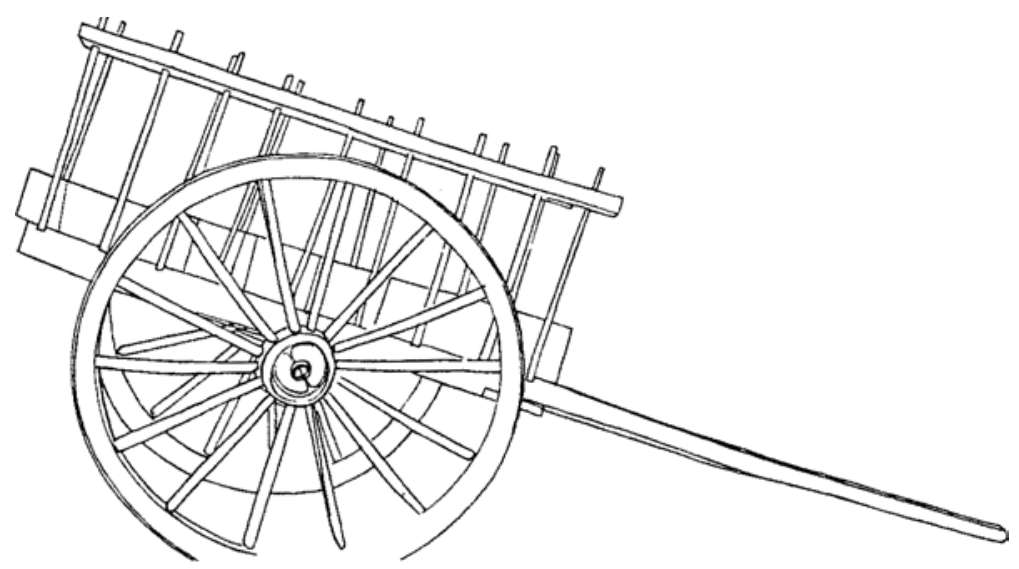

\section{Indian, Métis, and White in the Red River Valley}

THE RED RIVER COUNTRY was part of a remote region at the center of the North American continent. West of the river was a vast grassland, the Northern Great Plains, supporting immense herds of buffalo; north of the prairies, stretching northwest of Hudson Bay, lay the fur forest, producing fine peltries. Three waterways led into the area: The Hudson Bay-Hayes River-Lake Winnipeg route; the St. Lawrence-Ottawa-Great Lakes-Lake of the Woods route; and the Mississippi-Missouri route. These connected it with the outside world, with centers of population and commerce in the eastern United States and western Europe.

Outsiders came by way of the Bay and the Great Lakes to exploit the fur forests; they came by way of the Mississippi and Missouri rivers to exploit the buffalo plains. Their aim was to make the region a colonial hinterland of some outside center of trade. As they struggled for supremacy, they made the Indian dependent upon their trade goods; they debauched 
him with liquor; they married Indian women and produced a new race of mixed blood, the métis; and they established an agricultural settlement, the Selkirk colony, on the Red River of the North.

For many years the fine peltries of the fur forest went to English and European markets. Eventually, the Hudson's Bay Company (coming from England by way of the Bay) beat out the North West Company (coming from Montreal by way of the Great Lakes). But later the métis and the settlers of the Selkirk colony, aided by American traders from the Mississippi, revolted against the monopoly of the Hudson's Bay Company and tied the Reel River region to St. Paul and American markets. Buffalo robes and pemmican, products of the grassland, began to flow southward.

The flow of trade changed because the Red River cart solved the problem of freighting on the level grassland. It became the foundation of both the métis buffalo hunt-the first non-Indian exploitation of the grassland-and of trade with St. Paul. And it was the métis' use of the Red River cart which finally broke the isolation of the Red River Valley and made it a commercial highway serving outside markets.

\section{ORGANIZATION OF THE INDIAN TRADE}

The valley of the Red River of the north played a part in the fur trade of British North America as well as in that or the northwestern United States. Three British groups came to the valley: The Hudson's Bay Company, the North West Company, and small traders from Mackinac.

In 1670, Charles II granted the Hudson's Bay Company a monopoly on trade in Rupert's Land, the region draining into Hudson Bay. The company soon built forts on the Bay, one of the most important being York Factory, located between the mouths of the Nelson and Hayes rivers. For more than a century the company remained on the Bay while the Indians carried their peltries to its forts. After France surrendered Canada to Britain in 1763, traders from Montreal began to infiltrate the old French trading country west of Lake Superior. Because these men went to the Indians, the company called them "pedlars."

In 1783-1781 the pedlars, facing ruin from competition among themselves, joined the Scottish merchants of Montreal who supplied their trade goods in a partnership known as the North West Company. Thereafter the Nor'Westers-the pedlars from the Indian country and the Montreal merchants- 
met each summer at Grand Portage on the northern shore of Lake Superior to exchange furs for goods and to plan the next season's business. From Grand Portage a canoe route ran along the present international boundary to the Lake of the Woods and then on to Lake Winnipeg and Red River. After 1804, Fort William, some miles to the east, replaced Grand Portage as the summer rendezvous.

The small Montreal traders who went to Mackinac spread out, as had the French before them, from that strategic point into Michigan, Wisconsin. and Minnesota. Some paddled their canoes from Green Bay up the Fox River, made a portage to the Wisconsin River, and followed the latter stream to Prairie du Chien on the Mississippi. From Prairie du Chien, an old French town, the Scotsmen Murdock Cameron and Robert Dirkson went up the Minnesota River to trade with the Sioux.

In 1787, Dickson took his first canoeload of gods up the Minnesota. About 1800 he built a fort on Lake Traverse, his home and headquarters for the rest of his life. A tall, commanding man of sterling qualities, he became the most influential trader in the region. He read much, learned Chippewa, Sioux, and French, won the respect of the Indians, and married a sister of Red Thunder, a Yankton Dakota chief.

At Lake Traverse, Dickson lived beside a favorite camping ground of the Yanktons and Yanktonais, who roamed the plains to the west. He was also near the Sisseton bands of the Upper Minnesota and Upper Red rivers. Indian gardens flourished by the lake; buffalo ranged the plains; beaver and otter swam in the rivers and lakes. The territory of the Dakotas (Yanktons, Yanktonais, Sissetons, and Wahpetons) extended north on the Red to present-day Wahpeton. Beyond that they hunted only when pre pared for war. As far north as the Turtle River lay a debatable country claimed by both the Dakotas and the Chippewas.

Dickson and the other traders from Mackinac, losing money and falling heavily into debt, combined to eliminate competition. Too many traders overstocked the Indian country with goods, raising the price of furs, and, by stimulating hunting, and, by stimulating hunting, reduced the amount of game. In 1805 a new firm, Robert Dickson and Company, united many of the leading traders of the Upper Mississippi. On the last day of 1806 another new combination, the Michilimackinac Company, replaced it. The Michilimackinac Company divided the region with the North West Company, which gave up some of its posts south of Lake Superior and promised not to trade on the Mississippi south of the mouth of 
the Crow Wing, or on the Red south of the mouth of the Sheyenne. Thus the Indians, like the white farmers who were to come later, often had to deal with a monopoly. 1

Dickson and other traders working out of Mackinac dealt with the Indians of what was to become southeastern North Dakota; the traders from Hudson Bay and Grand Portage came into the northeastern portion of the future state. Competition for furs in the country between Lake Superior and the Rockies forced the Hudson's Bay Company to build forts in the interior. By the 1790's its men and the Nor'Westers were constructing forts side by side throughout much of the region. When the two firms united in 1821, the Hudson's Bay Company had seventy-six posts, the North West Company ninety-seven.

Their competition involved distances and routes to the sea. The finest furs came from the Athabasca country in the drainage basin of the Mackenzie River; indeed, half the profits of the North West Company were said to come over Methye Portage, the thirteen-mile trail that connected the waters of the Athabasca River with those flowing to the south and east. With regard to distance, the Hudson's Bay Company held the advantage. Its ships carried trade goods almost to the heart of the continent. The Nor'Westers, on the other hand, had an expensive fifteen-hundred-mile canoe journey from Montreal to the fur country and so double transportation costs. The direct water route to the Bay meant cheaper goods at Hudson's Bay Company posts.

But other advantages lay with the Nor'Westers. They were a hard, experienced lot- "Lords of the Lakes and Forests," Washington Irving called them-and knew the Indian languages. They brought in great quantities of liquor to win over their customers. Cruel and reckless, on occasion they robbed and murdered Hudson's Bay men, who were under strict orders to keep the peace. More than that, the North West Company's business was built on the freight-carrying canoe of the Canadians, on the French Canadian and half-breed voyageurs' amazing capacity for labor, on Indian corn and pemmican, and on the organizing ability of Scottish merchants and traders. The Scottish genius for business enterprise showed up well in the hazardous fur trade, where the courage,

${ }^{1}$ Louis A. Tohill, "Robert Dickson, British Fur Trader on the Upper Mississippi," North Dakota Historical Quarterly, III (October 1928), 9, 12-14, 23-32. 
shrewd ness, and adaptability of the race were valuable. These men loved the rushing river and open lake, the empty plain and dark woodland.

The common goal of the competing firms was to secure high-quality furs, the finest of which, with deeper color and better luster, came from densely wooded districts; the animals of the open plain had coarse fur. The companies, however, especially the North West Company, needed provisions from the plains to feed their men at the northern forest posts, where the food supply was both uncertain and scanty. Particularly was this the case for the canoe brigades, which made the long trip to the Grand Portage rendezvous each summer. The staple item was pemmican, a nourishing and long-keeping food which the Indians made by drying long strips of buffalo meat in the sun or over a fire, pounding these to a powder, and mixing the powder with melted fat in a bag of green buffalo hide. Much pemmican, a bag of which weighed ninety pounds, was made at forts on the Assiniboine River and later at Pembina. 2

The fur companies were slow in building trading posts on the Red River of the North. Before 1789, Peter Grant, a clerk of the North West Company, constructed a fort on the right bank of the river near present-day St. Vincent, Minnesota, and in the fall of 1797, Charles Jean Baptiste Chaboillez, also a Nor'Wester and a 55-year-old veteran of the fur trade, built on the high riverbanks where Pembina now stands. The Hudson's Bay Company was erecting a post nearby in charge of a Mr. Richards. But it was Alexander Henry, a wintering partner of the North West Company, who made a permanent establishment at Pembina in 1801 and opened up the valley to the south. The diaries of Chaboillez and Henry give an excellent account of the trade.

In the summer of 1800, Henry started west from grand Portage with a brigade of eight canoes. Each canoe, manned by four of five French Canadian voyageurs, carried twentyeight packs of trade goods and provisions: corn, grease, tobacco, general merchandise, hardware, guns, gunpowder,

${ }^{2}$ Arthur S. Morton, A History of the Canadian West to 1870-1871 (London: T. Nelson and Sons, Ltd., [1939]), pp. 2, 22-26, 300-308, 426-431, 508-530; Douglas MacKay, The Honourable Company: A History of the Hudson's Bay Company (2nd ed.; Toronto: McClelland and Stewart, [1949]), pp. 36, 84, 108-111, 122-130; Gordon C. Davidson, The North West Company (Berkeley: University of California Press, 1918), pp. 9-16, 22-26, 121. 
lead, flour, sugar, and high wine (concentrated alcohol to be watered before it was given to the Indians). Such packs weighed ninety pounds. The canoe used west of Grand Portage was the "North canoe," about twenty-five feet long and capable of carrying three thousand pounds of freight besides its crew. The larger "Montreal canoe," thirty-five to forty feet long, made the trip from Montreal to Grand Portage. In 1805, some 156 North canoes went west from Lake Superior.

Henry's brigade followed the regular route-from Grand Portage to Pigeon River, Rainy Lake, Lake of the Woods, Winnipeg River, Lake Winnipeg, and finally to the Red River. Having many wild rapids, it was both beautiful and dangerous. 3 The voyageurs, "smart, active men” in Henry's phrase, faced a grueling, month-long journey. They had to carry the canoes and cargoes over sixty-two portages-muddy paths up to a thousand yards long. On such a trip many would become ill, lame, or emaciated from fatigue. Sometimes a man drowned when a canoe was smashed in a rapids.

Going up the Red, Henry sent four of his canoes west along the Assiniboine River while he himself sought the virgin fur country south of Pembina. He left some of his men to build a trading post at Roseau River, then pushed south with eight Chippewas and their families, all he could persuade to accompany him toward the no man's land between the Chippewa and Sioux territories. Henry's Chippewas were daily alarmed that the Sioux might be nearby, but the trader coolly refused to show any fear. When they reached Park River (so named because the Assiniboins once made a park, or pound, for buffalo there), the danger posed by the Sioux began to seem real even to Henry.

He built a fort a quarter of a mile up the Park River, and his Indians and voyageurs had a profitable hunt that season. But the Park river fort seemed to close to the Sioux. In the spring of 1801, Henry abandoned it and built a new one on the north bank of the Pembina River a hundred paces from the Red River of the North. His men put up a high stockade, a storehouse, a stable for horses, a blacksmith shop, and some whitewashed houses. A new storehouse built in 1802 was twenty by one hundred feet; a new stable in 1807 accommodated fifty horses. Except for some years between 1823 and 1840, Pembina has been occupied continuously

${ }^{3}$ Grace Lee Nute, The Voyageur's Highway, Minnesota's Border Lake Land (St. Paul: Minnesota Historical Society, 1941), pp. 35-38. 
from 1801 to present-day.

From his fort at Pembina, Henry supervised outlying wintering houses in the valleys of the Red and Lower Assiniboine rivers. The trading year began in August when he arrived from Grand Portage or Fort William with a new outfit. He would send part of the goods up the Assiniboine to Portage la Prairie, and at Pembina he would make up assortments of goods and send them out with traders to winter in the Pembina Hills, at Grand Forks or Turtle River, and sometimes at Red Lake. Then Henry's Indians (he traded mostly with Chippewas but also with some Crees and Assiniboins) would take goods worth twenty beaver skins on credit and set off on the fall hunt. Before they left, the trader might distribute some small gifts (flints, needles, awls, net thread, tobacco) and treat them with liquor to encourage them to hunt well and to pay their debts. In a few weeks the Indians would come in to pay their debts and contract new ones, after which activity declined until the spring hunt.

In the fall Henry would set his voyageurs to making hay and harvesting vegetables. In 1803 they gathered 420 bushels of potatoes, as well as cabbages, carrots, onions, and turnips. Henry hired a Chippewa to hunt meat for the fort, and in 1802 his choice was Le Boeuf, a tall, spare man and a remarkable runner. Le Boeuf could chase buffalo on foot, loading and firing as he ran, and keep in the thick of the herd until he had killed as many as he wished.

In 1801 and 1802, Henry saw an incredible number of buffalo; sometimes they passed in droves within a hundred yards of the fort. To bring meat in 1801, Henry's men made a cart with solid wheels sawed from the trunk of a tree. A year later they worked out crude wheels with spokes. This was the beginning of the famous Red River carts, which were made entirely of wood. In winter Henry's men made salt, soap, snowshoes, and dog sleds. With dogs and sleds, they could go trading en derouine, that is, to the Indian villages.

Spring brought new activities at Pembina. The Indian women made sugar from box-elder sap, and Henry's men set nets in the river, once taking 120 sturgeon weighing 60 to 150 pounds each within twenty-four hours. They also planted gardens, repaired canoes, and made pemmican. At the end of May, the canoes left for Grand Portage or Fort William with the year's peltries.

The most important returns from Pembina, however, were provisions for the northern posts and their canoe brigades. Beaver was the most desired fur. Henry's posts on the Red and 
Lower Assiniboine rivers took 2,736 beaver pelts in the 18011805 season but only 696 in 1807-1808; disease and overtrapping had brought a rapid decline. In 1804-1805, Henry made up 144 packs of furs and 125 bags of pemmican; in 1807-1808 he had 60 packs of furs and 334 bags of pemmican. Most of the pemmican was made at Pembina. Henry's returns in the 1807-1808 season included 48 kegs of sugar, mostly from Leech Lake, and 46 kegs of grease. The buffalo of the grasslands were furnishing provisions for the trade, but Henry sent no buffalo robes to Fort William.

For a time he had to compete with the Hudson's Bay Company and the X. Y. Company, which built forts near his own in 1801. Competition made the firms increase the number of their wintering houses, cut prices, spoil the Indians with presents, and extend credit freely. In 1804 the North West Company took over the X. Y. Company. The next year, Henry made a friendly agreement with the Hudson's Bay Company man to eliminate competition; they divided the Indians between them, cut the number of wintering houses, and forced the Indians to pay their debts.

Henry lived close to fifty or sixty Chippewa families who spent much of the year at his fort. But he did not know, apparently, that one of his customers was John Tanner, a white man taken captive as a child in 1789 in southern Ohio. Tanner had been raised by an Indian woman among the Ottawas near Lake Huron and came west to the Red River with some of them in the 1790's. Lord Selkirk later restored Tanner to his own family. He became an interpreter for the Indian agent at Sault Ste Marie and told his story to Edwin James. It was published

as Narrative of the Captivity and Adventures of John Tanner during Thirty Years' Residence among Indians (New York, 1830). Tanner, a skilled hunter, was an erect, hardy man, with an unconquerable spirit. Ranging up the Assiniboine River and along the Red with his Indian companions, he trapped beaver, built canoes and made sugar, went on war parties, visited the Mandan villages on the Missouri, bought watered liquor, and courted and married an Indian girl. His narrative is a remarkable account of Indian life on the Red and Assiniboine Rivers.

Sometimes war parties of Dakotas (probably Yanktons, Yanktonais, Sissetons, and Wahpetons) attacked the Chippewas at or near the Pembina fort. In 1805 about three hundred Yankton warriors killed ten Chippewas on the Tongue River; Henry's father-in-law and mother- in-law 
(Henry had an Indian wife) were among the victims.

Losses in hunting and war reduced the number of men in the Indian population. In 1805 there were 160 men, 190 women, and 250 children in Henry's department on the Lower Red Rived. That year, a North West Company census of Indians showed 7,502 men, 16,995 women and 58,871 children in its territory.

White contact hurt the Indians. Many of the Chippewas had bad coughs and died of pulmonary consumption. Henry would frequently treat his Indian customers with liquor-to celebrate his arrivals and departures and the payment of their debts, and sometimes to bribe them to some course of action. "Men and women have been drinking a match for three days and three nights." He wrote in his diary, "during which it has been drink, fight-drink, fight, drink and fight again-guns, axes, and knives their weapons-very disagreeable.” Again he wrote: "Grande Gueule stabbed Capot Rouge, Le Boeuf stabbed his young wife in the arm, Little Shell almost beat his old mother's brains out with a club, and there was terrible fighting among them."

The result, Henry saw, was the decay of Indian life: "The Indians totally neglect their ancient customs; and to what can this degeneracy be ascribed but to their intercourse with us, particularly as they are so unfortunate as to have a continual succession of opposition parties [the fur companies] to teach them roguery, and to destroy both mind and body with that pernicious article, rum?" The Indians, however, had to profess friendship for the whites because they had become dependent on trade goods ("their necessaries," Henry called the goods). But, Henry wrote, they "despise us in their hearts." Although they were often insolent to Henry and tried to frighten him, they never pillaged him, as they did some traders. He kept his nerve and outfaced them convincing them, as he said, that he "would prove a tough bone for them to gnaw."

\section{THE SELKIRK COLONY}

Before the conflicts of Indian and white were resolved, the Indian trade itself was threatened by the coming of agricultural settlers to the Red River. In 1812, Thomas Douglas, the fifth Earl of Selkirk, founded a colony of Scots and Irish at the junction of the Red and Assiniboine rivers, the location of present-day Winnipeg. Selkirk, a Scottish nobleman of humanitarian sympathies, had become interested in 
emigration as a solution for the difficulties of the Scottish and Irish peasantry. The Highlanders were being driven from the land by an enclosure movement which accompanied the shift from crops to sheep raising. Homeless people drifted to a precarious living by fishing or to the new industrial centers to become wage slaves in Factories. Selkirk, touring the Highlands in 1792, thought that emigration "was the only solution for a bad situation." He later decided that the social and economic evils of Ireland called for the same solution. Wanting to keep the emigrants within the British Empire, he came to believe that the Red River Country would offer them an opportunity for a better life.

In 1811 the Hudson's Bay Company voted Selkirk, a stockholder, a grant of 116,000 square miles on the Red River of the North for an agricultural colony. The grant, named the District of Assiniboia, extended south from Big Island in Lake Winnipeg to the high land separating the Red River Valley from the Mississippi drainage system, and from near the source of the Assiniboine River on the west to the Lake of the Woods on the east. The colony would benefit the company by producing foodstuffs, for many Hudson's Bay employees were Orkneymen who did not relish pemmican. Moreover, an agricultural colony would relieve the company of the heavy expense of importing food from Britain. It might also, in the future, be a convenient source of employees.

The North West Company, however, believed that the fur trade and agriculture were incompatible and that the colony would be a barrier across its lines of communication to the west. The Nor'Westers bought stock in the Hudson's Bay Company in a vain effort to block the grant. They also sent out agents to thwart the recruitment of settlers.

But Selkirk, gathering recruits in Ireland, the Hebrides, Glasgow, the Highlands, and later even in Switzerland and Lower Canada, sent a series of small parties to the Red River. Some-the Swiss watch-makers and the De Meurons (former soldiers of many nationalities from a mercenary regiment disbanded in Canada)-were not good farmers. The best were steady Scots from Kildonan Parish in Sutherland. Most came by ship to Hudson Bay and York Factory, and then up the difficult Hayes River to Lake Winnipeg and on to Fort Douglas, the center of the colony at the forks of the Red and 
Assiniboine. The first settlers arrived there in the summer of 1812 after spending a quarrelsome, mutinous, scurvy-ridden winter at York Factory.

The establishment of the colony was a most difficult matter: distance and obstacles to communication between the Red River and the sea (seven hundred miles, or fifty-five days of travel), the uncertain food supply, the doubtful character of many of the immigrants, and the lack of farm stock and tools. Moreover, the Nor'Westers made a determined effort to destroy the colony. The struggle was over pemmican. In January, 1814, many of the colonists were without food. Miles Macdonnell, the man Selkirk had made governor, issued a proclamation forbidding any fur trader to take flesh, fish, grain, or vegetables out of the colony. He later seized six hundred bags of pemmican from a North West Company post out on the Assiniboine River.

Thus Macdonnell threatened the very existence of the North West Company. The Nor'Westers, in turn, made an armed attack on the colony in June, 1815, and sent Macdonnell under arrest to Montreal. They also transported to Canada 133 settlers who were ready to give up, and burned their cabins, the storehouse, and the mill. But Colin Robertson, an able lieutenant of Selkirk, revived the colony with ninety new settlers from Scotland. The conflict reached a climax with the Massacre of Seven Oaks in June, 1816. Half-breeds, led by Cuthbert Grant and egged on by the Nor'Westers, attacked the colony and killed twenty settlers. The colony, however, survived the massacre and the North West Company united, bringing peace to the fur country. 4

Selkirk himself visited the colony in 1817 and bought a strip of land along the Red River from the Crees and Chippewas. He was to pay a hundred pounds of tobacco annually to each tribe. The strip, two miles wide, extended from the mouth of the Red at Lake Winnipeg to Grand Forks; at Fort Douglas, Pembina, and Grand Forks, Selkirk's land was to be six miles wide. Selkirk returned to England in 1818 . Worn out by the struggle against the North West Company and discouraged by

${ }^{4}$ Morton, History of the Canadian West, pp. 527-534, 556-578, 623630; W. L. Morton, Manitoba: A History (Toronto: University of Toronto Press, 1957), pp. 45-59. 
his failure to secure the punishment of the culprits for Seven Oaks, he died in southern France in 1820.

\section{THE SETTLEMENT IN PEMBINA}

The story of the Selkirk colony is largely the story of the beginnings of Manitoba, but the colony was saved in its early years by the buffalo herds near Pembina. Lacking provisions for the first winter, most of the settlers went to Pembina and built cabins, a storehouse, and a stockade, which they named Fort Daer (Selkirk was also Lord Daer). They subsisted on buffalo through the winter. Although they returned to Fort Douglas in the spring, each winter for several years most of them went to Pembina in order to hunt buffalo.

The colony was slow in raising the food it needed to survive. In 1818 and again in 1819, grasshoppers destroyed much of the crops. Some of the métis, or half-breeds, encouraged by Governor Macdonnell, settled at Pembina. A few of the colonists also lived there, but most of them made their homes near Fort Douglas.

The growth of Pembina was helped along by the missionary Father Sévère Dumoulin. Selkirk and Bishop Plessis of Quebec took the lead in sending out two young Roman Catholic missionaries to the Red River in the summer of 1818. Selkirk hoped that they could prevent another outbreak of violence against the colony. Plessis instructed them to urge peace and good behavior, to help "delinquent Christians," to prepare for baptism Indian women "who live as concubines of Christian men," and to plant high crosses along the routes where the voyageurs passed. Father Joseph Norbert Provencher established a mission across the Red River from Fort Douglas, the beginning of St. Boniface.

Father Dumoulin, however, went to Pembina, where he built a chapel (thirty by sixty feet), a presbytery, and a store. At first the workflourished more at Pembina than it did at St. Boniface. Father Dumoulin baptized thirty persons in 1819, prepared some for their first communion, and married a number of freemen, after much persuasion, to their Indian women. The missionaries found that liquor, given out freely by the fur companies, was the chief obstacle to their work. Yet they soon acquired much influence among the métis. In 
all, Father Dumoulin baptized 313 persons and performed 53 marriages at Pembina.

He was, therefore, bitterly disappointed when the Hudson's Bay Company forced the métis and white settlers to abandon Pembina. In 1818 the United States and Great Britain signed a treaty establishing the international boundary at the fortyninth parallel from the Lake of the Woods to the Rocky Mountains. In 1823, Secretary of War John C. Calhoun sent Major Stephen H. Long to locate the boundary. That summer, Long's soldiers set up an oak post, marked "U.S." on one side and "G.B." on the other, at the forty-ninth parallel on the Red River. The American flag was run up, a salute fired, and Long read a proclamation that the land south of the marker was within the United States. The Pembina settlement, except for a single cabin, lay south of the marker. The settlers watching the ceremony at once said that all the buffalo, the great object of their interest, would be on the American side of the line.

Even before Long marked the boundary, Sir George Simpson and other officials of the Hudson's Bay Company in Rupert's Land, as well as the representative of the Selkirk estate, and decided to break up the settlement at Pembina. They believed that the division of the settlers, some at Pembina and some at Fort Douglas, weakened the colony. Further, Pembina might become an American base for operations against the colony. So the colonists pulled down Fort Daer and the Hudson's Bay Company fort, floating the timbers down river to use at Fort Douglas. The French settlers who had come from Quebec in 1818 and some of the métis moved to St. Boniface. The rest of the métis went to live at White Horse Plain, sixteen miles west of Fort Douglas. Father Dumoulin sadly gave up his mission and returned to Quebec.

For a while some of the métis and settlers stayed on at Pembina. Long reported that 350 persons, mostly métis, were living there in 60 cabins in the summer of 1823. All eventually moved away, however, and when Martin McLeod passed by in 1836, no one was living in Pembina. The Treaty of 1818 placed a large part of the Selkirk's grant of Assiniboia within the boundaries of the United States. He, and later his heirs, made fruitless efforts to acquire a good American title to the land.

Although the colony cost Selkirk some $£ 100,000$ and 
probably his life (his fatal illness seems to have been related to his conflict with the North West Company), it had become firmly established. Selkirk himself stopped paying for the recruitment of settlers after the unfortunate Swiss who came in 1821; they were the last from across the Atlantic. The union of the of the Hudson's Bay Company and the North West Company in 1821 brought the discharge of hundreds of men, and the majority of them settled down in the colony, doubling its population (about two thousand in 1824). For Garry, near the junction of the Red and Assiniboine Rivers, was the center of the settlement.

The Hudson's Bay Company aided the colonists by selling them imports at cost and issuing note which served as currency. It was, of course, the principal market for their farm produce. In 1834, Selkirk's heirs had returned Assiniboia to the company. It was just as well, for after Selkirk's death in 1820, company officials became the principal voice in the colony's government.

Although it could do little for the peasantry of Ireland and Scotland, Selkirk's dream of an agricultural colony on the Red River had become a reality. He had defeated, in the end, the remoteness, the cold, all the obstacles of the wilderness, and even the North West Company's bitter opposition. Selkirk had laid the foundations for Manitoba, and in doing, he profoundly influenced the history of the Red River Valley south of the international boundary. From its first days the colony felt the pull of the plains south of the line. As long as the buffalo lasted, the métis visited the plains, and out of their hunt grew the trade that tied the Red River settlement, as Selkirk's colony came to be called, to the growing American outpost on the Upper Mississippi at St. Paul. Swiss and other discontented people, abandoning the Red River settlement, provided the first nonmilitary settlers at St. Paul. The Red River Valley became a highway between the two settlements, and the resulting trade opened the valley below the forty-ninth parallel.

\section{THE MÉTIS OF RED RIVER}

Composing by far the largest element in the population of the Red River settlement were the half-breeds, the offspring of white fathers (French Canadian, Scottish, and English) and 
Indian mothers (Chippewa, Cree, and Assiniboin). Most were of French and Chippewa stock. They were called bois brûlés (French for "burned wood"-from their olive complexion) or métis (French for "mixed breed”). The fur traders-bourgeois, clerks, engagés, or voyageurs-usually took Indian wives after the custom of the country. Although some whites soon deserted their Indian mates, such unions were frequently permanent. The officials of the fur companies sometimes sent their children to eastern Canada to be educated.

Many freemen also took Indian women. The freemen were whites living in the Indian country but not employed by a trading company. The first of them on the Red River were left there without employment when the X. Y. Company dissolved in 1805. The number increased greatly with the merger of the Hudson's Bay Company and the North West Company in 1821. Even in 1808 many freemen, with their wives and métis children, were living in camps on the Park River and in the Pembina Hills. They owned many horses and carts and were busy making provisions to sell to the fort at Pembina.

By 1850 more than half of the five or six thousand people living in the Red River settlement about Fort Garry were métis. Many of them lived in St. Boniface and at White Horse Plain, some miles west of Fort Garry. There were contradictory reports about the number south of the boundary. In 1849, Norman W. Kittson, enumerator in a special census for Minnesota Territory, counted 637 inhabitants at Pembina on the American side. But that same year, Major Samuel Woods reported that the white and half-breed population at Pembina was 1,026 and that these people had 600 carts, 300 oxen, 300 work horses, 150 horses for the chase, 1,500 horned cattle, a few hogs. and no sheep. The United States Census of 1850 counted 1,116 persons at Pembina and reported that most of them had been born north of the boundary. Most of the men gave their occupation as "hunter," In 1853, Isaac I. Stevens heard that four thousand lived about the Pembina Hills.

In physical constitution, character, dress, and way of life, the métis were midway between their white and Indian forebears. Their hair and eyes were black, their complexion a deep olive. The men were strong, good runners and horsemen, and able to endure much fatigue. They dressed in woolens, wearing what was called a Hudson's Bay coat with a hood, or 
capot, attached. They secured the coat with a sash about the waist, and slung powder horn and shot bag with beaded bands over the shoulder. They would don a calico shirt, leather leggings, and moccasins, but frequently went without a hat. The women, often not so handsome as the men, dressed in gaudy calicoes and moccasins. They were skilled in making moccasins and all sorts of beadwork. The métis spoke a patois of French, Chippewa, and other Indian tongues.

They were a gay, improvident, prodigal people who loved gaming, the music of the violin, and, too often, strong drink. But they were gentle, kind, and warmhearted. Some thought them idle and indolent; even their friend Father George A. Belcourt wrote that they were "not over anxious of becoming rich." In 1853, Isaac I. Stevens found them "a hardy, willing, enduring class, inured to hardships, the most obedient and hard-working fellows in the world." He praised them for being "industrious and frugal in their habits, leading a virtuous and pious life." They were intelligent, quick and eager to learn, and much attached to their priests. In 1821 the mission school at Pembina had begun to teach some of the children Latin and French, as well as reading and writing. The métis came to think of themselves as the "lords of the land" and as "a new nation" in the Northwest.

Many of the métis became notable men. The Hudson's Bay Company made Cuthbert Grant, a man of great influence, warden of the plains and a member of the council of Assiniboia. Pierre Bottineau led many expeditions across the Northern Plains; a county and a town in North Dakota were later named for him. In 1879 the leading men of Minnesotaformer governors, congressmen, judges, army officers, and bankers-petitioned Congress to give Bottineau a pension in recognition of his notable services. Bottineau, Paul Boulieau, Antione B. Gingras, and other métis became members of the territorial legislature of Minnesota. Gingras, fat and jolly, shrewd and successful in the cart trade with St. Paul, was said to be worth sixty thousand dollars and the wealthiest man in northern Dakota. What is now Well County was originally named Gingras County after him. Jean Baptiste Wilkie (“a man...of fine appearance and pleasant manners," wrote Stevens) was also a respected métis leader living at St. Joseph, now Walhalla. 
The métis both north and south of the international boundary farmed small plots of about fifteen acres. All the farms fronted on the rivers, following the Red up to Pembina and also going out the Assiniboine River. Most of the métis were squatters, with no title to the land. Though some were solid farmers like Selkirk's Scottish settlers, most were careless and slovenly. They planted Indian corn, barely, potatoes, some tobacco, vegetable gardens, and a bearded variety of wheat which would yield twenty-five bushels per acre. They also raised fast horses for the buffalo hunt, but used oxen (valued at fifty or sixty dollars a yoke) for farm work. In frontier style, they broadcast the cereals by hand, harvested with a sickle (later a cradle) and threshed with a flail. Eighteen windmills and two water mills ground the wheat into flour. Some of the métis sold agricultural products to the Hudson's Bay Company. In 1823, prices were high, with wheat two dollars a bushel and corn and barley (much used in soup) both three dollars. ${ }^{5}$

Most of the métis took part in the organized buffalo hunts across the plains to the southwest. The hunt came to be a mania, the focal point of their lives. They rode out on two hunts each year, a summer hunt beginning in the middle of June after the crops were planted and a fall hunt starting in October. The summer hunt was for provisions-pemmican, dried meat, and grease-and leather for moccasins and tipis. The fall hunt, too, was for provisions (the buffalo were fatter then), but also for buffalo robes. The summer hunt was the larger; only a third of

5"United States Census of 1850, for Pembina District, Minnesota Territory, "North Dakota Historical Society Collections, I (1906, 384411; Major Woods's report is in House Executive Document 51, 31 Cong., 1 Sess.; Isaac I. Stevens, Narrative and Final Report of Explorations for a Route for a Pacific Railroad near the Forty-Seventh and Forty-Ninth Parallels of North Latitude from St. Paul to Puget Sound, in Reports of Explorations and Surveys to Ascertain the Most Practical and Economical Route for a Railroad from the Mississippi River to the Pacific Ocean, 1853-1855 (Washington, 1860), Vol. XII, Pt. I, pp. 40-41, 63, 70: George A. Belcourt, "Department of Hudson's Bay," Minnesota Historical Society Collections, I (1872), 224-225; Morton, History of the Canadian West, pp. 575, 658-659, 805-808, 856, 873; Vernice M. Aldrich, "Father George Antoine Belcourt, Red River Missionary," North Dakota Historical Quarterly, II (October 1927), 33. 
the men took part in the fall hunt. Sometimes the métis divided into two parties; sometimes all would go out to the plains together.

As the time for the hunt approached, the métis and their families, horses, oxen, and carts went into a rendezvous on the Pembina River, pitching their tipis and making preparations until all had gathered. A Catholic priest frequently went along. They would elect a governor of the hunt, captains for each parish, guards and guides, and adopt the customary rules. The rules forbade running buffalo or traveling on the Sabbath. No party was to fork off, lag behind, or forge ahead without permission; no hunter was to run buffalo before the general order was given. The rules sought to give everyone a fair share of the game. If the hunters failed to abide by them, quarreling, hatred, and an unsuccessful hunt resulted. The presence of the priest helped to ensure respect for the rules, that is, for the rights of the poorer hunters on the slower horses.

With the hunt organized, the métis broke camp and the caravan of Red River carts moved out to the southwest, led by a guide bearing a flag. Each night the men placed the carts in a tight circle, enclosing the tipis and stock, and posted a guard. Sometimes the Sioux, hating the métis for killing the buffalo, their own livelihood, attacked the camp. Each day the priest said Mass and catechized the children; occasionally he preached in Chippewa instead of French in order to please the people. In 1819 a teacher from the mission at Pembina had forty children in school on the prairie as he followed the hunters. The caravan might march many days, going two hundred miles or more across the Sheyenne River and on to Dogden Butte, before they found a buffalo herd.

When a herd was found, the hunters, as many as four hundred men, formed a long line on their horses and, riding abreast, advanced slowly toward it in order to get as close as possible before the buffalo became frightened. When the buffalo fled, the hunters galloped into the herd, shooting them down at close range. They picked out the cows (tenderer meat), their horses, unguided, following the twists and turns of the quarry. The hunter rode at full speed with a mouth full of balls. After each shot he poured another charge of powder down the muzzle, spat in a ball, jarred it home with a slap of the gun butt against thigh or saddle, and fired again. 
The average hunter could kill three or four buffalo in a halfhour chase: those with the fastest horses might get ten or twelve. On the fall hunt of 1845, the 55 hunters killed 169 cows one day, 177 another, 114 another, and 168 another; in all they killed l,776 cows. Each hunter could identify own kill. The galloping men, the rapid firing on every side, badger holes and uneven ground, the maddened buffalo, the dust and noise and confusion-all made the hunt dangerous. Frequently, accidents killed or maimed a hunter.

After a run, the women came up with the carts to help the hunters skin and cut up the kill. They cut the flesh in to thin strips and hung these on poles to dry in the sun or over a buffalo-chip fire. They rendered the fat in sheet-iron kettles and made the dried meat into pemmican or tied it into bundles. The marrow fat was preserved in the bladders of the animals.

The métis wasted much of the carcass. They had to kill eight or ten cows, weighing probably a thousand pounds each, to load a cart with eight or nine hundred pounds of meat. They commonly spent two months or more on a hunt in order to fill three or four carts for each hunter. After the hunt, the métis kept half the provisions for their own use and sold the other half and the buffalo robes to the fur companies or carried them to St. Paul to exchange for dry goods, sugar, coffee, and other necessaries.

The métis hunts caused a decline in the number of buffalo. The size of the hunt grew rapidly; there were 540 carts in 1820, 820 in 1830, 970 in 1835, and 1,210 in 1840. The Sioux, American traders, the United States government, and the Chippewas of the Turtle Mountains all protested against the destruction of the herds on American soil by people living north of the boundary. In 1845 the United States Army sent Captain Edwin V. Sumner with a troop of dragoons from Fort Atkinson to the Northern Plains to ward off the métis buffalo hunters. And in 1849 the army sent Major Samuel Woods, commandant at Fort Snelling, to Pembina, where it was considering the establishment of a military post. Woods urged the Pembina métis to use force to stop the hunters from across the boundary. In 1856, Lieutenant Colonel C. F. Smith again warned the métis. Such warnings must have encouraged some métis to settle south of the boundary. In 1852, Chief Green Setting Feather of the Turtle Mountain Chippewas 
complained of the métis: "The manner of his hunt is such as not only to kill, but also to drive away the few he leaves, and waste even those he kills."

Even though it was wasteful, the métis hunt was the first large utilization of the buffalo-the great product of the grasslands-by non-Indian people. The hunt tied eastern and central North Dakota to the Red River settlement north of the boundary and to the fur trade of western Canada. More important, it produced the chief commodity carried by the métis to the growing American market on the Upper Mississippi.

\section{AMERICANS ON THE UPPER MISSISSIPPI}

The Red River Valley did not become a trade route until Americans established themselves on the Upper Mississippi River. Before the War of 1812, British traders from Mackinac still conducted the Indian trade of Wisconsin and Minnesota, although the region had been part of the United States since the close of the American Revolution. American troops moved into Mackinac in 1796, but British traders continued to keep Americans out of the country west of Lake Michigan. The Canadian government persisted in giving the Indians of Wisconsin and Minnesota presents, medals, and flags: all Wisconsin chiefs wore silver medals bearing the image of George III. But Zebulon Montgomery Pike's expedition to the Upper Mississippi (1805-1806) and the United States customhouse and trading factory at Mackinac were beginning to check the British by 1809. During the War of 1812, however, the British continued to control Mackinac and also Prairie du Chien, the center of the Upper Mississippi trade.

At the end of the war the Treaty of Ghent paved the way for the advance of American traders. British troops gave up Prairie du Chien in May, 1815, and that year the United States made peace with the Indians of Wisconsin and Minnesota at Portage des Sioux. In 1816, Congress passed a law which limited licenses for trade with the Indians to United States citizens. John Jacob Astor's American Fur Company, chartered in 1808, bought the posts of all British traders south of the boundary. The company established its headquarters at Mackinac and was soon doing business throughout the Upper Mississippi Valley. 
The United States Army moved into the region. In 1816 it built Fort Crawford at Prairie du Chien. In 1819 it sent Lieutenant Colonel Henry Leavenworth up the Mississippi to the mouth of the Minnesota River. The following year, the army began to build Fort St. Anthony at that strategic point, soon renaming it Fort Snelling. The fort aided the traders. In two years (1819-1821), Major Lawrence Taliaferro, Indian agent at Fort Snelling, talked the Indian chiefs into giving up thirty-six medals of George III, twenty-eight British flags, and eighteen gorgets. 6

The Indian trade of the region grew in part through the efforts of well-established British traders. Men like Roben Dickson, Joseph Rolette, Sr., Jean Baptiste Faribault, Alexis Bailly, and Joseph Renville took out naturalization papers and stayed on in the country they knew and where they held the confidence of the Indians. In 1816-1817, Robert Dickson-he who had rallied the Indians to the British cause so well during the War of 1812 -again had a post on Lake Traverse and brought goods from the Selkirk colony in Red River carts. Joseph Renville and others who had recently fought against the United States (Renville gave up his British pension to become an American citizen) put together the Columbia Fur Company in 1822 and had six posts in Minnesota by 1826. Some of them were at Lake Traverse, at the confluence of the Red and Sheyenne rivers, near Devils Lake, and at Grand Forks.

The American Fur Company, however, controlled the bulk of the trade. In 1826 it held ten of the seventeen posts in the region, with a headquarters post at Mendota, across the Minnesota River from Fort Snelling. It had no post at Pembina until 1829 or 1830, when it sent William Aitkin to trade there. The Hudson's Bay Company came back to Pembina (it had left in 1823) and drove Aitkin out. Then for a number of years it paid the American Fur Company an annual fee to stay out of the border region, in effect leasing the area from Pembina to Lake Superior.

The trade in Minnesota was carried on by means of 
partnerships. The representative of the American Fur Company formed partner ships with the men who did the actual trading. The company furnished the goods, the trader his time, and both shared the profits. The region was divided among "outfits" in order to prevent competition. The trader sold the goods on credit to the Indians, who then went out on their hunts, settling their debts (if they could) in the spring. The chief fur was muskrat, but by 1823 the posts on the Minnesota River were buying many buffalo robes.

In 1834, Henry Hastings Sibley, after a five-year apprenticeship at Mackinac, came to Mendota to take charge of the country north of Lake Pepin for the American Fur Company. His territory included the valleys of the Minnesota and Red rivers down to Pembina. Sibley, at twenty-three, was well-educated (two years of law study), athletic, a master of canoe and rifle, strong and steady; he was to remain the most prominent figure in Minnesota until his death in 1891. His large stone house at Mendota, the first built in Minnesota, is now a museum.7

As American traders were moving north, the people pf the Selkirk colony were reaching south. In 1817, Selkirk returned to the east by way of Prairie du Chien, the northernmost settlement on the Mississippi. When grasshoppers destroyed the crop at Fort Douglas, some of the settlers went to Prairie du Chien in the winter of 1819-1820 for a new supply of seed. The colony needed cattle. Enterprising Americans drove in herds, principally from Missouri, in the 1820's and sold them at good prices. They did not fare so well with sheep. In 1833, only 60 of a flock of 1,270 sheep survived a drive from Kentucky.

When some of Selkirk's colonists were ready to give up the pioneering struggle, they hired Red River carts and guides and

${ }^{7}$ Alvin C. Gluek, Jr., "The Struggle for the British Northwest: A Study in Canadian-American Relations” (Ph.D. dissertation, University of Minnesota, 1953), pp. 15, 21, 36 (Gluek's dissertation was published in 1965 by the University of Toronto Press under the title Minnesota and the Manifest Destiny of the Canadian Northwest: A Study in Canadian-American Relations); John P. Pritchett, "Some Red River Fur-Trade Activities," Minnesota History Bulletin, V. (May 1924), 408; Wilson P. Shortridge, "Henry Hastings Sibley and the Minnesota Frontier," Minnesota History Bulletin, III (August 1919), 115-125. 
crossed the prairies to Fort Snelling. Most of the Swiss and some of the De Meurons traveled that way. The first large exodus came after the destructive flood of 1826. Probably five hundred left the Selkirk colony for the United States from 1820 to 1835.

Commerical connections soon expanded. The presence of Americans on the Upper Mississippi gave the Red River settlers a chance to compete with the Hudson's Bay Company, to break in on its monopoly. From 1823 on, the company, relaxing its legal right to conduct all trade, allowed settlers to import goods on company ships to sell or trade to the Indians or others for furs, robes, and provisions, provided the articles received were for the settlers' own use and not for sale. The export of furs to outside markets would still be handled by the company.

The company found it impossible to keep its monopoly intact. Many of the Red River settlers were discharged employees of the fur companies who often became independent traders instead of farmers. With a supply of clothing, ammunition, and other merchandise, they would slip out onto the plains to barter with the Indians and métis for furs. A market lay across the boundary with some American trader or at a post on the Mississippi. For young men, smuggling a few packs across the line was a lark, and Pembina became a smugglers' rendezvous. In 1831 the company placed a 7.5 percent duty on imports from the United States.

Most of the illegal traders were métis. There is no direct evidence concerning the volume of their trade, but they were selling pemmican to American traders (four thousand pounds to Joseph Brown in 1836), and before 1840 they were making annual excursions to St. Paul and Mendota with Red River carts loaded with furs, buffalo robes, and pemmican to exchange for merchandise. In 1835 the métis stated in a petition against the import duty that they "had already made several trips to the Mississippi exporting horn cattle, horses, furs, and some articles of colonial industry, and, on their return, bringing home cotton goods, groceries, ammunition, tobacco, etc., etc.”

Yielding somewhat to the métis' protest, the Hudson's Bay Company reduced the import duty to 5 percent and then to 4 percent. But it also tried to stop illegal trade by licensing 
traders, controlling the mails, searching travelers bound for Minnesota, and seizing furs. Such trade grew after Norman W. Kittson established a post at Pembina for the American Fur Company in 1844, and as it grew, so did the métis' opposition to the monopoly. Father George A. Belcourt, a devoted missionary, sided with the métis and was driven from the settlement by the Hudson's Bay Company (he built a new mission at Pembina in 1848). The year 1849 saw the climax of the struggle and the end of the company's monopoly. A métis, Guillaume Sayer, was tried and convicted of trading furs, but his fellow métis, gathered in force, made it impossible to punish him. "Le commerce est libre-vive la liberté," they shouted. The company gave up trying to enforce its monopoly, and from 1849 on, open trade with St. Paul developed rapidly.

\section{NORMAN W. KITTSON AT PEMBINA}

Developments on the Upper Mississippi had helped the métis in their struggle for free trade. Although the whole of Minnesota was Indian country and so not legally open to white settlement, a little community had grown up at Mendota, beside Fort Snelling, in the 1820's. In 1837 the United States bought the land between the St. Croix and Mississippi rivers from the Chippewas and Sioux and opened it to settlement, the first in Minnesota. The primary purpose in buying it was to secure the magnificent pine forests on the upper reaches of the St. Croix. Lumbering soon began, and farms sprang up to supply the lumber camps. The village of Stillwater, the early market for logs from upstream, started the manufacture of lumber in 1844.

When soldiers evicted the squatters living on the military reserve about Fort Snelling in 1840, the latter moved to the east bank of the Mississippi on the newly ceded land. Their village took its name from the Chapel of St. Paul, built in 1841. Other whites settled by the Falls of St. Anthony, a valuable source of water power, and in 1849 platted the village of St. Anthony, just above St. Paul and, like it, on ceded land east of the river. In 1847 a regular line of steamboats came to St. Paul from cities, such as St. Louis, farther down the river. In 1849, Congress created Minnesota Territory, including the country as far west as the Missouri River. Its population was 
4,535, excluding the military garrison but including people at Pembina and on the Missouri.8 St. Paul itself had 910 inhabitants.

Fur traders Henry Hastings Sibley and Norman W. Kittson built up the growing trade between the Red River settlement and the Mendota-St. Paul community. In 1840, Sibley sent Joseph Rolette to Pembina, but he did not have a free hand against the Hudson's Bay Company until Pierre Chouteau, Jr., and Company of St. Louis supplanted the American Fur Company in 1842 (the old firm name was still commonly used). Sibley took a partnership in the new organization. The old arrangement, by terms of which the Hudson's Bay Company was to stay away from the border, was dead.

Sibley had other concerns. On June 30, 1842, he and Franklin Steele agreed to supply Kittson with goods for trade with the Sioux. Kittson's posts were to be at Big Stone Lake and on the Sheyenne and James rivers. Kittson was born in Lower Canada and had served, like Sibley, an apprenticeship with the American Fur Company. In 1842 he was an intelligent, sprightly young man of twenty-eight, a trader and merchant near Fort Snelling, and an old friend of Sibley.

In the fall of 1844, Kittson gave up his posts among the Sioux and moved to Pembina. The first year's trade was a failure. Then, in the fall of 1845, Sibley and Kittson made a deal with James Sinclair and Andrew McDermott, the leading independent traders in the Red River settlement about Fort Garry. They were to smuggle furs across the boundary to Kittson at Pembina. Kittson would pay for them in cash; Sinclair and McDermott could buy American goods. At Pembina, Kittson would also gather buffalo robes from the métis.

Kittson's trade grew. In 1846-1847, Sibley gave him credit of some twelve thousand dollars, the largest extended to any of Sibley's partners. At Pembina, Kittson built a collection of straw-thatched cabins around a square: residences, warehouses, a trading house, an icehouse, and a blacksmith shop. Occasionally a crowd of métis and Indians, with their lodges, horses, cattle, carts, and dogs, would fill the square.

${ }^{8}$ William W. Folwell, A History of Minnesota (4 vols.; St. Paul: Minnesota Historical Society, 1921-1930), I, 213-265, 351-352. 
“Toward the river," wrote an observer in 1851, "are barns and stables, haystacks, etc., with numerous horses and cattle feeding, and a general appearance of thrift, comfort, and industry pervades the scene." ${ }^{9}$ In 1851, Kittson, alarmed by the flood of 1851, moved his headquarters to St. Joseph (present-day Walhalla).

Kittson traded with the Chippewas and métis, as well as with free traders from north of the boundary. He found the Chippewas as destitute-generally without traps, ammunition, or even axes, and living through the winter largely on fish. When in 1849 and 1850 the corn and rice crops failed and an epidemic wiped out the rabbits, the Indians became desperate. When conditions improved in 1851, many were too enfeebled to hunt. The métis supplied Kittson with pemmican. They expected a year's credit on their purchases and frequently did not pay their debts. Kittson stopped giving them credit in 1850.

He made a determined effort to take the trade of the region away from the Hudson's Bay Company, writing once that he was sparing "no trouble in giving them the 'Devil."” He placed outposts along the boundary: to the west, one in the Turtle Mountains and another on the Mouse River for buffalo robes and pemmican; to the east, one on Lake of the Woods and another on Rainy Lake for the finer furs of the fisher, marten, and lynx. He usually kept four outposts; at one time he had one on Rush Lake to the west and another on Red Lake to the east.

The Hudson's Bay Company fought back. It put an able man in charge of its post just north of Pembina, built posts to match Kittson's along the boundary, paid high prices for furs, and even brought in rum. Kittson may not have used liquor; he and Sibley could have lost their trading license if they had. Kittson complained about its use by the Hudson's Bay Company and by some Cree traders who smuggled in twenty barrels of whiskey from St. Paul in 1847.

But Kittson was in a losing game. He had to pay high prices in cash for furs, well knowing that his customers might use the money to buy merchandise from the Hudson's Bay Company.

${ }^{9}$ Clarence W. Rife, "Norman W. Kittson, A Fur-Trader at Pembina," Minnesota History, VI (September 1925), 225-252. 
It had the goods most esteemed by the Indians, and at a lower cost than Kittson could offer. Though he took business away from his competitor, he lost money steadily and gave up in 1854 to return to St. Paul. Rolette took charge in his place.

Kittson had done much to consolidate trade between the Red and Mississippi rivers. By coming to Pembina, he had brought the American market to the door of the Red River settlement north of the boundary and had also helped the métis to destroy the Hudson's Bay Company's monopoly. The crux of the matter was that Kittson and the American market would take the métis' buffalo robes and pemmican, the chief products of the plains. The Hudson's Bay Company would not, for it could not use buffalo robes; the difficult water route to Hudson Bay, with its many portages, forbade such an arrangement. And the company could buy only a limited amount of pemmican.

Products of the buffalo hunt demanded a market. "Pembina is the natural gate," wrote Major Samuel Woods in 1849, "through which all intercourse between the U.S. and the Hudson Bay territories will find its passage.” Pembina united the complementary economies developing on the Northern Plains and the Upper Mississippi through the Red River Valley. Along it the products of the grassland were carried cheaply in the unimposing yet sturdy Red River carts.

The métis built the carts entirely of wood, simply and inexpensively. They used two large wheels, wrapping them with buffalo rawhide instead of iron tires. Such wheels would not sink into marshy ground as readily as ordinary ones. The boxlike body of the cart, resting on the wooden axle, rode high, making the fording of streams easier. A single ox (or horse or mule) could pull a cart with a load of eight or nine hundred pounds. One métis usually drove from two to six carts. Except for the ox pulling the first cart, each would be tied, by means of a strap about its horns, to the tail of the cart ahead. Though crudely made and noisy because of the wheels' screeching on the wooden axles, the carts provided effective transportation. They were a means of conquering distance, of overcoming the remoteness of the Red River country. They and the level, treeless plain made it possible to carry freight to St. Paul and Mendota for a fraction of the cost of transporting an equivalent amount by water to Hudson Bay. The métis and their carts found outside markets for the Red River settlement. 
Except for fine furs, Selkirk and the Hudson's Bay Company had failed to do so.

The cart trains might follow one of three trails. The earliest led up the Red River from Pembina to Lake Traverse and then followed the Minnesota River to Traverse des Sioux. There the métis unloaded the carts, placing the cargo on keelboats or steamers for river shipment to Mendota. They then reloaded the carts with merchandise from the Traverse des Sioux warehouses and turned back toward Pembina. This route came to be known as Kittson's Trail. It might go either east or west of Red River, but it passed within twenty miles or so of the river in order to make the crossing of the Red's tributaries easier. The disadvantage of Kittson's Trail was the uncertain passage from Traverse des Sioux to Mendota. Low water might make the river un-navigable; marsh and forest made overland travel difficult.

Kittson continued, however, to use the route when others were turning to the Sauk Valley or Plains Trail from St. Paul to Pembina. St. Paul had better port facilities for steamboats from the south than had Mendota; it was also well located to be the metropolis for the northern trade. A high, dry road ran north along the east bank of the Mississippi to Sauk Rapids and St. Cloud. Cart trains followed the road, forded the river at St. Cloud, and drove up the Sauk Valley to the northwest. They could either cross the Bois des Sioux River to join Kittson's Trail west of the Red (easier travel) or go down the east side to Pembina (approximately present-day U.S. 52). In 1851 a steamboat began to operate between St. Anthony and St. Cloud, after which cart trains could be accommodated at St. Cloud. This route, the Sauk Valley or Plains Trail, became the most traveled one. Later it was used by the stage line linking the Mississippi and Red River steamboats. Another route, the Woods Trail, went up the Mississippi to Crow Wing and joined the others near Moorhead (roughly U.S. 10). The Woods Trail, which had more sloughs and wetter ground, was traveled more in winter by dog sled. Kittson used it when he attended sessions of the legislature at St. Paul. ${ }^{10}$

${ }^{10}$ Grace Lee Nute, "The Red River Trails," Minnesota History, VI (September 1925), 279-282; "The Red River Trail," Harper's New Monthly Magazine, XVIII (April 1859), 602-620, and XIX (June 1859), 37-54. 
By whatever route, the cart trains would leave Pembina in mid-June when the trail was firm and the grass ready to furnish grazing for the oxen. The métis loaded the carts heavily, protecting the cargo of furs and pemmican with a buffalo robe. The carts started each day at dawn, moved in a single file, and covered some fifteen miles a day. The creaking and groaning of their greaseless wheels could be heard for miles.

A month of travel brought them to St. Paul, a journey of nearly five hundred miles. The colorful arrivals and departures of the carts excited the town, for much of its early wealth came from the goods they carried. As the number of cart trains increased, St. Paul gathered in more and more of the riches produced on the distant prairies. Kittson sent six carts over the trail in 1844; by 1850, hundreds of carts were going to St. Paul each summer. 


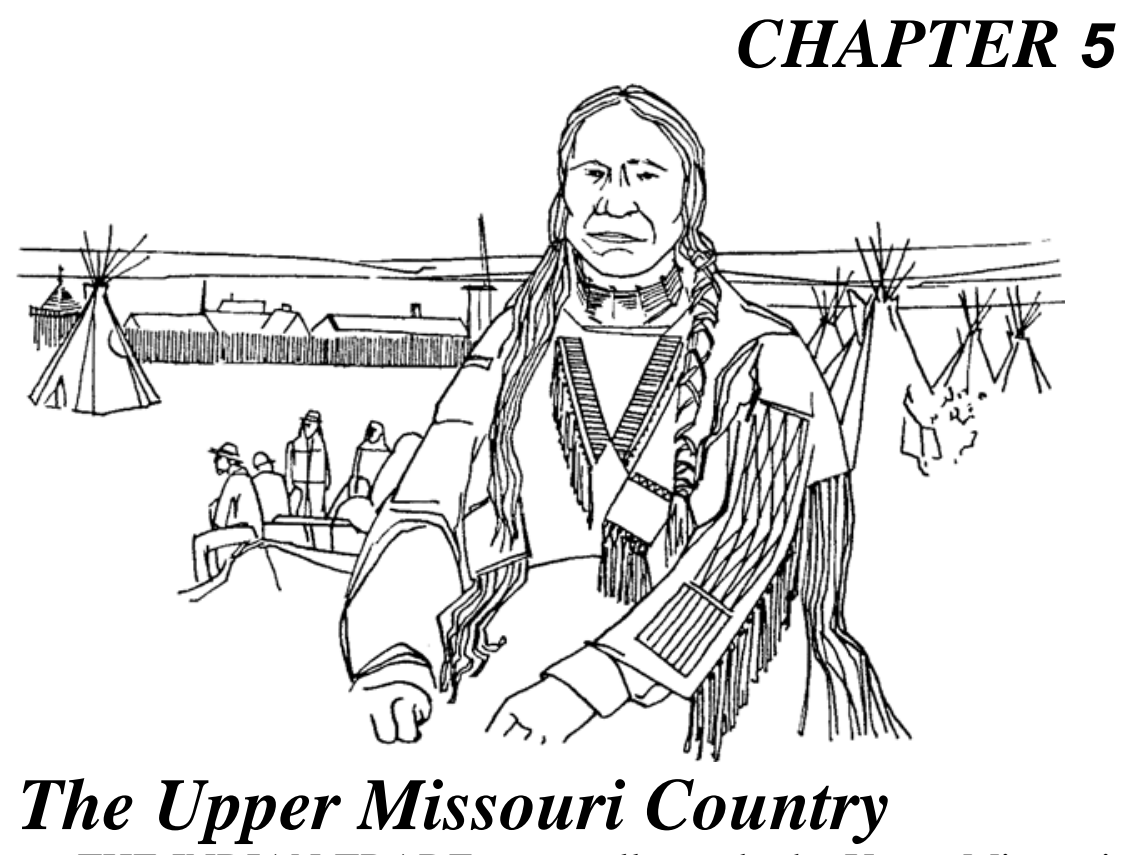

THE INDIAN TRADE eventually made the Upper Missouri country a colonial hinterland of St. Louis. Three factors had long delayed the process: the great distance to the more remote parts, the refusal of Congress to place a military force among the Mandans, and the hostility of some of the Indians. Finally the American Fur Company, Kenneth McKenzie, and the steamboat tied the region to St. Louis, and the Missouri River became the major artery of the fur trade. Holding a monopoly, the American Fur Company exploited the buffalo (buffalo robes were the chief item of trade), the Indians, and its own employees. The Indians became more dependent on the traders' goods, more demoralized by their liquor.

The fur trade was, of course, only a transitory phase in the development of the region. First, smallpox wiped out many of the Indians and started the decline of the trade. Then Indian hostility, the establishment of military posts, and the destruction of fur-bearing animals ended it. The coming of the Northern Pacific Railroad to the Missouri River opened a new era. In North Dakota, the Upper Missouri country, as well as the Red River Valley and the Drift Prairie, was to become a hinterland of the twin cities of Minneapolis and St. Paul.

\section{THE YELLOWSTONE EXPEDITION}

After the War of 1812 the merchants of St. Louis again 
sought to exploit the Upper Missouri country. They were aided by John C. Calhoun, then Secretary of War and a strong nationalist. "To extend and protect our trade with the Indians," he wrote, he planned to advance the authority of the United States up both the Missouri and Mississippi rivers into regions still under British influence. Although at first he had chosen the mouth of the Yellowstone, he decided to put the army post for the Missouri beside the Mandan and Hidatsa villages at the mouth of the Knife River. He also planned another fort on the Mississippi at the mouth of the Minnesota River. Calhoun believed that the Mandan post should be supported by a second one at Council Bluffs. St. Louis-especially Thomas Hart Benton's St. Louis Enquirercheered the idea: it would add to the security of the West, keep the Indians in check, destroy British influence among them, protect the fur trade, and be a step toward the "actual possession of the whole American Territory."

The remoteness of the Mandan villages caused Calhoun's plan to end in partial failure. Colonel Henry Leavenworth reached the mouth of the Minnesota easily enough and began building the post there (later named Fort Snelling) in the summer of 1819. But when Colonel Henry Atkinson, in command of the Yellowstone Expedition, started up the Missouri with a thousand men the same summer. his steamboats (the first ever used on that river) broke down or found the water too low. Atkinson could only reach Council Bluffs. He built a post there (named Fort Atkinson in 1821) and spent the winter. The delay and unwise contracts for supplies rather unfairly discredited the Yellowstone Expedition. Congress cut the appropriations for it so much that it could not go on to the Mandan villages. In the debate a senator from North Carolina opposed "sending military expeditions to such extremely remote points."

Nevertheless, the fort at Council Bluffs did advance the military frontier several hundred miles. For the first time the Plains Indians witnessed the military strength of the United States. Atkinson paraded his soldiers and demonstrated the steamboat Expedition to impress them. But this was not enough. He wrote to Calhoun in November, 1820: "It is more than probable if our traders do not make establishments among them [the Indians of the Upper Missouri], under the 
protection and influence of a respectable detachment of troops, they will be so far drawn away by British influence that it may be impossible to recall them." ${ }^{1}$ Atkinson argued for an annual excursion of troops up the Missouri from Council Bluffs until a fort could be built higher up. Calhoun felt that the hostility of Congress made such an excursion inadvisable.

\section{THE ARIKARA WAR}

The experiences of the traders revealed the strength of barriers posed by distance and Indian hostility. As with Manuel Lisa earlier, North Dakota and other grassland areas were on the route of the traders, not their goal. In 1821 and 1822, William H. Ashley and Joshua Pilcher took the lead in seeking to exploit the more remote Upper Missouri. Both sought the beaver of the Rockies rather than the buffalo of the Great Plains. Both used the Missouri River as a highway and then gave it up. In 1821, Pilcher built Fort Benton at the mouth of the Big Horn. The next year, he built Fort Vanderburgh among the Mandans and sent two men, Jones and Immel, with 180 trappers to the Rockies. He then had about 300 men trapping beaver in the mountains, the first venture in that region since the War of 1812. In the fall of 1822 , his men sent some $\$ 25,000$ worth of furs down the river to St. Louis.

That spring, Ashley sent one hundred men led by Andrew Henry, a veteran of the business, to the Three Forks of the Missouri in southwestern Montana. Starting in the river with two keelboats and fifty horses, they were scarcely underway when one of the keelboats struck a snag and sank with a loss of ten thousand dollars in property. Above the Mandan villages the Assiniboin Indians, feigning friendship, stole the horses being ridden along the bank. Henry's men spent the winter trapping near the mouth of the Yellowstone River and in the spring set out for the Blackfoot country in northern Montana. Ashley himself recruited another hundred men and went up the Missouri with two keelboats.

${ }^{1}$ Clarence E. Carter (ed.), Territorial Papers of the United States, vol.

$\mathrm{XV}$, The Territory of Louisiana-Missouri, 1815-1821 (Washington: Government Printing Office, 1949), pp. 673-674, 685; Edgar B. Wesley, “스 Still Larger View of the So-Called Yellowstone Expedition," North Dakota Historical Quarterly, V (July 1931), 220-233. 
Disaster struck in the spring of 1823. The Blackfeet, possibly egged on by British traders, killed four of Henry's men near Great Falls and drove him out of the country. On the Yellowstone they killed Immel, Jones, and five other men, taking horses, traps, and furs worth fifteen thousand dollars. Three days later, June 3, the Arikaras attacked Ashley's party at their villages. Ashley had stopped there, at the mouth of the Grand River in northern South Dakota, to buy horses. After pretending friendship, the Arikaras struck Ashley's camp on the riverbank at dawn. Within fifteen minutes they had killed fourteen men and nearly all of the horses they had sold the whites the day before. Ashley took the survivors down the river and sent a message to Colonel Henry Leavenworth at Fort Atkinson.

Leavenworth set out at once to punish the Arikaras, in his words "to open and make good this great road." He had 220 soldiers and 4 keelboats. Ashley joined him with 80 of his mountaineers; Pilcher added 40 more and talked 400 or 500 Sioux into joining the force to plunder their enemies. Leavenworth approached the Arikara villages on August 9, the Sioux rushing ahead.

The Arikaras came out to fight the Sioux, but went back into their villages when they saw the whites. The Sioux then plundered the corn fields, but Leavenworth did nothing until the next day, when he fired his two six-pounders and his howitzer into the villages. The artillery fire caused little damage. Leavenworth then planned an assault, but when the Sioux would not take part, he gave it up. His refusal to fight aroused the contempt of the Sioux, who rode off, stealing some of his horses and mules as they left.

Leavenworth signed a treaty with the Arikaras by which they agreed to return Ashley's property. They gave up only three guns, one horse, and sixteen robes, then ran away. Leavenworth returned to Fort Atkinson. He had lost no men in fighting, but seven drowned when one of his keelboats sank. His conduct angered the trappers; some of them set the abandoned villages on fire. Pilcher believed that Leavenworth's weakness would increase the outrages against the whites: "You came," he wrote Leavenworth, "to 'open and make good this great road'; instead of which you have, by the imbecility of your conduct and operations, 
created and left impassable barriers.” Pilcher gave up trading above Council Bluffs. Ashley, after some more misadventures, finally abandoned the Missouri and went overland, out the Platte River, to the Rockies. For many years the Arikaras continued to harass whites who ascended the Upper Missouri. $^{2}$

\section{THE ATKINSON-O'FALLON EXPEDITION}

Within a few years, however, a show of military strength, a strong combination of traders, and the steamboat made the Upper Missouri a useful trade route. In 1824, Congress authorized an expedition to regain the prestige lost by Leavenworth. The following spring, General Henry Atkinson, accompanied by Indian Agent Benjamin O'Fallon, led 476 soldiers up the Missouri from Council Bluffs. Eight keelboats carried most of the men; forty rode horses along the riverbank.

Atkinson and O'Fallon held councils and signed treaties with sixteen tribes from Council Bluffs to the Knife River. They staged military parades and fired off rockets and cannons to impress the Indians. They also handed out presents, but they gave the Arikaras a reprimand for misconduct and only four hundred plugs of tobacco.

Under terms of these treaties, signed in 1825, the Indians promised to protect the traders licensed by the United States government, not to sell any guns or ammunition to any tribe not in amity with the United States, and to turn over to officers of the United States for punishment any foreign trader or any Indian who injured a white man. Toussaint Charbonneau, the husband of Sakakawea, signed (as a witness) the treaty negotiated at Knife River. It was the first between the United States and the Mandans and Hidatsas. In the council, both tribes disavowed the killing of some of Ashley's men by attributing the action "to the imprudence of their young men" who "fired in the night upon camps of the whites under the impression that they were Indians.”

The Crows became very hostile in their council at the Knife River villages. When they started to take the presents before they

${ }^{2}$ Hiram M. Chittenden, The American Fur Trade of the Far West (2 vols.; Stanford: Academic Reprints, 1954), I, 150-155, 248-249, 262-264, 270-280, II, 588-606. 
were told to do so, O'Fallon struck three or four chiefs over the head with his pistol. But there was no bloodshed, and the next morning the chiefs and braves came for more presents, saying that "they would throw all that had passed behind them."

Upon his return, Atkinson reported that he had impressed the Indians, that he had found no evidence of British influence among them, and that no fort was needed above Fort Atkinson at Council Bluffs. ${ }^{3}$

\section{AMERICAN FUR COMPANY OPERATIONS}

Although the army established no post on the Missouri River above Council Bluffs until the declining days of the trade, the American Fur Company advanced up the river. The firm, created by John Jacob Astor, was the first great monopoly in the United States. When Astor, a barrel-chested German immigrant, consolidated his fur-trading interests in the American Fur Company, he was the second richest American. When he died in 1848, his private fortune (made, for the most part, in New York real estate) was by far the largest in America. James Parton, his biographer, thought him "one of the ablest, boldest, and most successful operators that ever lived," but selfish, grasping, and ruthless.

The American Fur Company was chartered in 1808 by New York State and had a capital of one million dollars. Astor exerted great influence in Washington, where he had the support of Lewis Cass, for a time governor of fur-rich Michigan Territory and later Democratic candidate for President, and of Thomas Hart Benton, for thirty years United States senator from Missouri. In 1822, Cass and Benton secured the abolition of government trading factories, which sold goods to the Indians at cost. Soon after, the American Fur Company hired Senator Benton as its attorney.

After the War of 1812 the company, with its headquarters at Mackinac, acquired a monopoly of the Indian trade around the Great Lakes and the Upper Mississippi River. It was

${ }^{3}$ Russell Reid and Clell G. Gannon (eds.), "Journal of the AtkinsonO'Fallon Expedition," North Dakota Historical Quarterly, IV (October 1929), 5-56. 
aided by an act of 1816, lobbied through Congress by Astor, excluding British traders. The firm soon began to look farther west. Astor at first made agreements with St. Louis merchants by which the American Fur Company sold them trade goods (largely imported) and had the first option to buy their furs. For these privileges it promised not to supply their competitors or to compete itself for their Indian trade. But in 1822 the company gave up such agreements and established its own Western Department in St. Louis. It made an agreement with a St. Louis firm and in 1827 changed its St. Louis partner to Bernard Pratte and Company. The American Fur Company supplied the trade goods and marketed the furs; the St. Louis partner supervised the business with the Indians. Profits or losses were shared equally. The leading man in the St. Louis house was soon Pierre Chouteau, Jr., a businessman of Astor's own ruthless quality. The firm name changed from Bernard Pratte and Company to Pratte, Chouteau and Company and then to Pierre Chouteau, Jr., and Company.

Astor's allies in St. Louis were the old French nabobs of the fur trade, united by business interests and social ties. William Clark, Thomas Hart Benton, and Lewis Cass were their friends and spokesmen in the national government. Chouteau married a sister of Bartholomew Berthold (a partner of Bernard Pratte); Ramsay Crooks, Astor's chief lieutenant, married a daughter of Bernard Pratte. Their very names were to leave marks on the Upper Missouri country: Fort Pierre, Fort Clark, Fort Cass, Fort Benton, and Fort Berthold. The combination was powerful and aggressive. Annie Heloise Abel, a student of its operations, has written:

Between the Chouteaus and Astor there had never been any appreciable difference, any dissimilarity of methods or of public morals. All of them were resourceful, eternally vigilant, unscrupulous, notoriously selfish, adept at the shaping of national policies to private ends, brazen in their defiance of the law, remorseless in their exploitation of the Indians. ${ }^{4}$

${ }^{4}$ Annie Heloise Abel (ed.), Chardon's Journal at Fort Clark, 1834-1839 (Pierre, S.D.: Privately printed, 1932), p. xvi; Kenneth W. Porter, John Jacob Astor: Business Man (2 vols.; Cambridge: Harvard University Press, 1931). I, 164-168’ II, 686-718, 739, 744-745, 751-752. 
Such were the men, living in their great houses in New York and St. Louis, who directed the trade and garnered the profits of the Upper Missouri hinterland of which western North Dakota was a part.

General Atkinson and his troops had helped, but American exploitation of fur resources in much of the Upper Missouri country actually came about through the work of some young Scotsmen. Kenneth McKenzie, Daniel Lamont, and William Laidlaw had served apprenticeships with British firms. When the North West Company and the Hudson's Bay Company united in 1821, they came to the United States, took out naturalization papers at St. Louis, and joined Joseph Renville and others in the Columbia Fur Company.

Renville and his partners located their principal post on Lake Traverse and had others at Prairie du Chien and Green Bay. In 1822 and 1823 they built three posts on the Upper Missouri: Fort Lookout (above present-day Chamberlain, South Dakota), Fort Tecumseh (two or three miles above the mouth of the Teton River), and an unnamed fort at the Knife River villages. The Arikaras soon drove two of their employees, James Kipp and J. P. Tilton, out of the Knife River post, whereupon the pair put up a trading house in one of the Mandan villages. Kipp learned the Mandan language and traded with the tribe for many years. In 1825-1826 he built a fort at the mouth of the White Earth River, 140 miles above the Mandans, for trade with the Assiniboins.

The Columbia Fur Company was competing with Astor's American Fur Company from Lake Michigan to the Upper Missouri. For all their ruthlessness, Astor's men could not crush it. So, in 1826, Ramsay Crooks, managing Astor's fur empire, began negotiations with McKenzie, by then the leader of the Columbia partners, for a consolidation of interests. Crooks wanted to secure McKenzie's talents for the American Fur Company, as well as to end the profitkilling competition. He was willing to take in the others, who were good traders.

Crooks and McKenzie reached an agreement in the summer of 1827. McKenzie, Laidlaw, and Lamont were to take charge of a new division of the Western Department of the American Fur Company, the Upper Missouri Outfit. They would withdraw from the Great Lakes and Upper 
Mississippi. As compensation, they would have a free hand on the Missouri above the mouth of the Big Sioux River. McKenzie was to have a salary of $\$ 1,500$ per year, as well as a share of the profits. He brought with him to the Upper Missouri Outfit most of the middle-rank men, such as Kipp, of the Columbia Fur Company. The inventory of the company's property on the Missouri at the time of the transfer was about $\$ 17,000(\$ 14,453$ of it at Fort Tecumseh).

The agreement, together with others Crooks made about the same time with smaller companies, eliminated competition in the Upper Missouri country. The Indians, except for brief intervals, had to deal with a monopoly practically as long as the fur trade lasted. The position of the American Fur Company thus became a key factor in the development of the region. Monopoly meant greater exploitation of the Indians, those of North Dakota along with the rest.

McKenzie's energy and Astor's resources brought rapid expansion. In the fall of 1828, McKenzie sent Kipp with the keelboat Otter to build a post at the mouth of the Yellowstone River. McKenzie wanted beaver, and that fall he sent Étienne Provost to invite the Rocky Mountain trappers to bring their catch to the new post. Located at the junction of the Yellowstone and the Missouri, it could be a base of operations for the upper country. In 1830, McKenzie changed its name from Fort Floyd to Fort Union. He made it his headquarters, and it became the most important post on the Upper Missouri.

McKenzie sought trade with the Blackfeet, a tribe which had been hostile toward Americans ever since Meriwether Lewis killed two of its warriors on the Marias River in 1806. The Piegans, one division of the tribe, trapped beaver and would allow no white men in their country. In 1830, McKenzie sent out

an old trapper named Berger to induce the Blackfeet to trade with Fort Union. Berger had worked at a Hudson's Bay Company post which served the tribe and knew their language and customs, as well as many individual members of the tribe. Berger brought in the Blackfeet, an astonishing feat.

Kenneth McKenzie won their friendship, sent them an itinerant trader, and promised them a fort in their own country. In 1831 he made a peace treaty between the Blackfeet and the Assiniboins: "So long as the water runs, or the grass grows, they 
may hail each other as brethren.” He sent James Kipp and twenty-five men to build a post, Fort Piegan, at the mouth of the Marias River. Kipp traded for 2,400 beaver- pelts in ten days, winning the Piegans from the Hudson's Bay trader with liquor. In the fall of 1832, David D. Mitchell built Fort McKenzie on the Missouri River six miles above the mouth of the Marias, to replace Fort Piegan, and for many years it was the center of Blackfoot trade.

At first, McKenzie sent itinerant traders up the Yellowstone to the Crows, but in 1832, Samuel Tulloch built Fort Cass for them at the mouth of the Big Horn River. It served both the Crows and the white trappers of the mountains. In 1831, Kipp built Fort Clark at the Knife River villages; in 1831-1832 a new post, Fort Pierre, took the place of nearby Fort Tecumseh and 


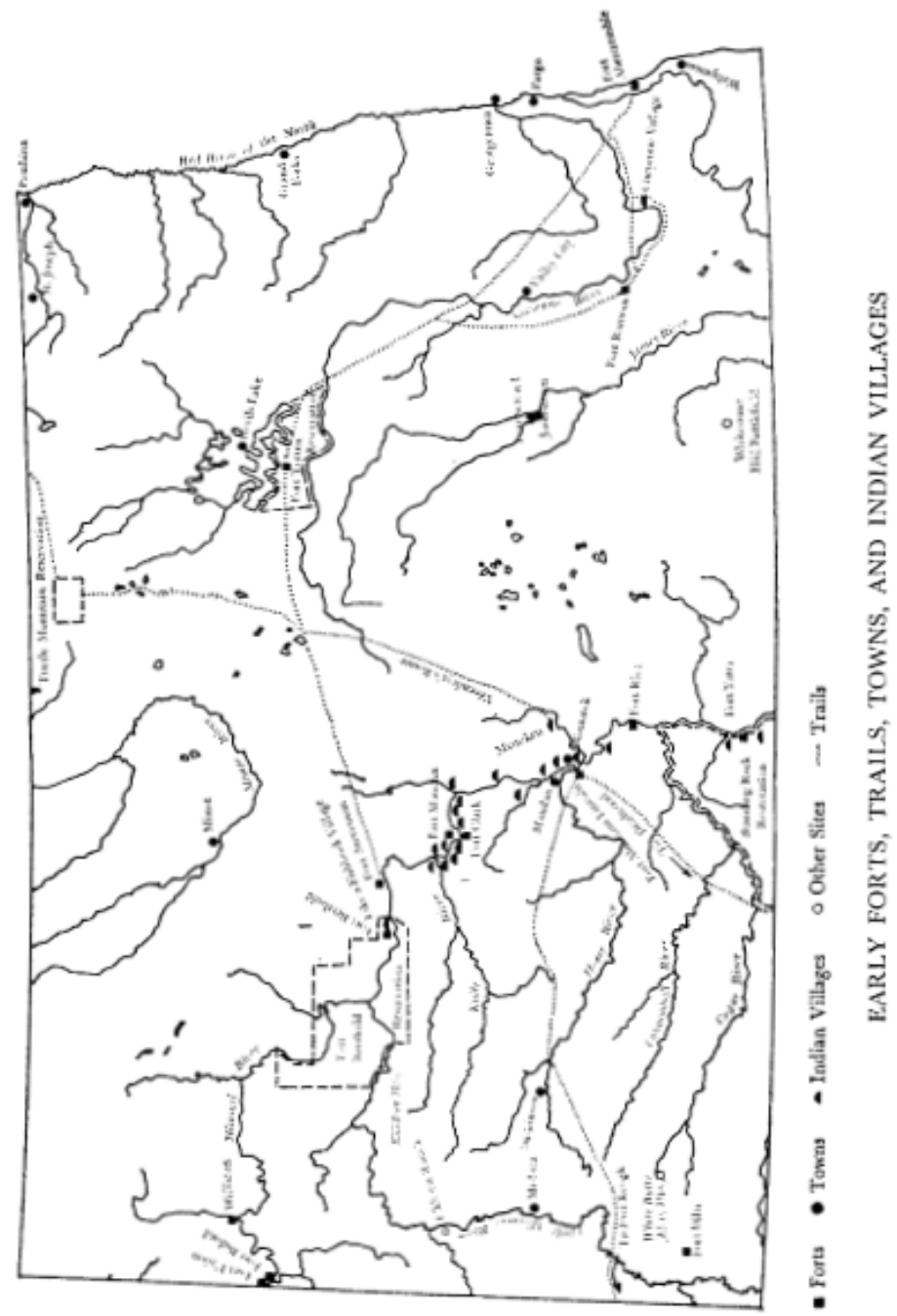


served the Sioux. Thus in its first five years the Upper Missouri Outfit had built five important posts (not counting Fort Piegan, which had been abandoned and burned), opened up a vast region, and secured beaver from the mountains. ${ }^{5}$

Exploitation of the far reaches of Upper Missouri country called for better transportation. Keelboats, built at Pittsburgh for two or three thousand dollars, required large crews for small cargoes-twenty-five French voyageurs for twenty-five tons of freight. They also needed the whole summer to get goods to the more remote posts. Although steam navigation was just beginning on the Lower Missouri in 1830, McKenzie and Chouteau wanted to try a small steamboat on the upper river. They believed that such a boat, costing about eight thousand dollars, would save time and expense.

They had the Yellowstone built. It was 130 feet long, had a draft of 66 inches, and could carry 144 tons of freight. The Yellowstone went up to Fort Pierre in 1831, and the next year it reached Fort Union, an achievement noticed even in European newspapers. Every spring after that, the American Fur Company sent one or two steamboats up to Fort Union or beyond. They started their return trip soon after reaching the head of navigation, while the water was still high. In time, larger steamboats were used on the Missouri (carrying up to 500 tons), but their draft averaged only 50 inches. In 1849, freight cost six to eight dollars per hundredweight from St. Louis to Fort Union, and a steamboat could ascend the Missouri to that point in eight or ten weeks; a record set in 1843 was forty-nine days. Snags, low water, and the shifting channel endangered the steamboats, however, so that their average life on the river was only three years. Yet they saved time and money and tied the Upper Missouri country to St. Louis until the coming of the railroad.

Older methods of transportation were used even after the advent of the steamboat. Small traders still took goods up the river by pack horse. Kenneth McKenzie usually went on horseback from Fort Pierre to Fort Union in the fall. He sent keelboats to the posts above Fort Union and regularly used mackinaw boats to take the returns of the trade to St. Louis in the summer and fall. 
Forts Pierre and Union had boatyards, (called chantiers) where work-men built the mackinaws-flat-bottomed boats forty or fifty feet long. These required a crew of only five and would carry a cargo of fifteen tons. The mackinaws made only one trip down the river, rushing along at one hundred miles per day, and were then sold at St. Louis for five dollars each. For twenty years James Kipp herded a fleet of mackinaws down the Missouri each summer. Their crews would secure liquor in settlements along the way and become unruly, and Kipp would have to struggle to get the furs to St. Louis. Then he would return overland to his post. ${ }^{6}$

The Upper Missouri Outfit located its principal posts on the river close to some tribe. Only five were staffed the year round, but these had many dependent wintering houses which were occupied each fall and abandoned each spring. The permanent forts stocked $\$ 15,000$ to $\$ 20,000$ worth of goods and employed 15 to 20 men. The wintering houses might have from \$500 to $\$ 3,000$ worth of goods and from 3 to 6 men. In 1835, Kenneth McKenzie had 84 men at the 4 forts in his charge (Union, Clark, Cass. and McKenzie), a reduction from an earlier number.

Each fort had a stockade some sixteen feet high and a strong gate. Within the stockade stood the residences (some with glass windows) of the trader and his man, along with stables, warehouses, blacksmith and carpenter shops, a powder magazine, and rooms for trading. Accommodation varied from fort to fort. Fort Union, the most elaborate, had barracks for Indian visitors. Blockhouses generally guarded two corners of the stockade with cannon. There were always horses and dogs at the forts, and sometimes cattle and chickens (milk and eggs were treats in the wilderness) and a garden. The stockades enclosed a considerable area, Fort Pierre, the largest, was 325 feet by 340 feet; Fort Union was 220 feet by 240 feet; Fort Clark was 132 feet by 147 feet; Fort Jackson, a wintering house in Montana, was only 50 feet square.

Staffing the forts, in addition to the company partners, were clerks, interpreters, hunters and engagés. A clerk might have

${ }^{6}$ Louis C. Hunter, Steamboats on the Western Rivers: An Economic and Technological History (Cambridge: Harvard University Press, 1949), pp. 48, 101, 117, 224, 235-236, 377. 
charge of a post or wintering house and so had to be able to keep records: several clerks assisted McKenzie at Fort Union. The interpreters, or course, played an important role in bargaining with the Indians. The hunters supplied the fort with meat. The other employees, or engagés, held a variety of jobs; some were skilled craftsmen, smiths and carpenters, and others built the forts, handled boats, herded horses, transported goods, put up hay, and helped with the trade. Some were white men, but on the Upper Missouri, many were Red River half-breeds, or métis.

Men of every rank, from McKenzie to the lowly engagés, took Indian wives and raised families of half-breed children. Alexander Culbertson, long in command of Fort Union, married a beautiful Blackfoot woman (a graceful swimmer and horsewoman); they sent their children to the best schools in the United States.

Life at the forts varied. Dried or fresh buffalo meat was the chief food, but when buffalo could not be found, the people living at a fort might have to subsist on boiled corn. At Fort Union, however, Kenneth McKenzie dined in state (he was long known as the King of the Missouri): his clerks wore coats; a white cloth covered the table; two waiters, one of them a Negro, served milk, cream, butter, coffee, wine, and bread made with white flour, as well as the usual fare. McKenzie imported other luxuries, including French brandy, plums, almonds, newspapers, and cigars.

James Archdale Hamilton, an English aristocrat who clerked at Fort Union, ordered fashionable clothes from London each year. To the amazement of the engagés, he took a bath and put on a clean shirt every day. Christmas meant special treats of eatables and often a drunken spree. Hunting was, of course, a common amusement. In 1843, John James Audubon took part in a ball at Fort Union; Culbertson played the fiddle and the clerks and engagés danced reels and cotillions with the Indian women, dressed in their best for the festivity. Yet a sense of loneliness often depressed Francis A. Chardon at Fort Clark, and probably many another trader.

The focal point of activity at the forts was barter with the Indians. In late winter, Astor shipped trade goods, usually imported from England, from New York to St. Louis. When 
the river ice broke up, Chouteau sent them up the Missouri to the various posts. By fall, the clerks would be sorting them into smaller outfits and going out to their wintering houses, using carts (probably of the Red River variety) or pack horses. By fall, too, Chardon would be lending traps to those Mandans who wanted to go out for beaver. In winter, the clerk in charge of a fort might send out two or three men with an assortment of goods by sled to an Indian camp to trade for a few weeks.

The Indians wanted mostly coarse woolen goods of English manufacture, such as red and blue strouds, blankets, and blue cloth, but they also needed guns, powder and lead, tobacco, knives, flints, and kettles (brass, copper, or tin). For the 18401841 season, for example, Chouteau ordered six thousand pairs of French blankets, three hundred North West guns (\$5.62 each), and three hundred dozen butcher knives as well as other goods.

Trade started in the fall. At Fort Union, McKenzie sold much liquor (a noisy, drunken business conducted at night) to keep the Indians away from the Hudson's Bay Company traders. At Fort Clark the company sold no liquor, for the Mandans preferred water and were fond of tea and coffee. The traders gave presents to start the trade, but on the Upper Missouri they apparently did not extend credit, practically a universal practice in the Indian trade. Chardon's journal, McKenzie's letters from Fort Union, Charles Larpenteur's recollections-none mention Indian credit. At Fort Clark in the 1830's, Chardon frequently bought beaver pelts from white trappers. With the Indians he traded for buffalo robes, beaver and other furs, and meat and corn. He sold them horses as well as the usual trade goods.

In the spring the engagés, using a press, made up the peltries into packs weighing a hundred pounds each. Ten buffalo robes or sixty (sometimes more) beaver pelts made a pack. In spring or summer the packs went down the river to St. Louis, where they were opened, counted, weighed, and then shipped to New York by way of' New Orleans. Astor sold some in New York, shipped some to Europe and some to China.

Comprising most of the returns from the Upper Missouri were buffalo robes. Since the life of Plains Indians turned on the buffalo hunt, they naturally brought robes to the traders and also some meat, especially tongues. In 1833 the Yellowstone took on 7,000 robes at Fort Union. In July, 1835, the steamboat Assiniboine burned just below Heart River with 1,100 packs of 
robes and other furs and property, a $\$ 60,000$ to $\$ 80,000$ loss, for the boat and cargo were not insured. Fort Clark's receipts best show the returns from North Dakota. It received 3,270 robes and 1,140 beaver pelts in 1835, 3,130 robes and 442 beaver in 1836, 3,200 robes and 436 beaver in 1837, and 2,870 robes and 404 beaver in 1838 . At the fort the robes were valued at three dollars, the beaver at four. The returns also included a few wolf, fox, and muskrat skins.

Although one Indian woman could dress only ten robes a year, the American Fur Company received great quantities of them at St. Louis, about seventy thousand robes a year from 1834 to 1844. Ramsay Crooks could not find a market for them in Europe, so they were sold in the United States for about four dollars apiece. Books and articles dealing with the trade do not identify the purchasers, but whoever they were, they would not give much for the principal product of the Great Plains. ${ }^{7}$

Yet the American Fur Company wrung profits from its operations. The company's competitors, known as the "opposition" on the river, raised the price of furs, increased the number and expense of trading posts and engagés, flooded the Indian country with goods, and wiped out profits. Now and then the company encountered competition, for it was a simple matter of experienced men, often former employees, to get an outfit on credit and go up the Missouri to the Indian country, but such opposition never lasted very long. McKenzie would raise the price of furs, giving a blanket for a robe or paying twelve dollars for beaver (three times the usual value). The competitors could not stand the losses and would give up or sell out. The company might even use violence; Joseph La Barge believed that it had plotted his murder when he was a member of the opposition. Although the Indians liked competition for their furs, they were generally loyal to established traders. They knew that

${ }^{7}$ Abel, Chardon's Journal, passim; Maximilian, Prince of Wied, Travels in the Interior of North America (Vols. XXII, XXIII, XXIV of Early Western Travels, 1748-1846, ed. Reuben Gold Thwaites; Cleveland: A. H. Clark Company, 1905-1906), passim; Merrill G. Burlingame, "The Buffalo in Trade and Commerce," North Dakota Historical Quarterly III (July 1929), 273. 
the newcomers would soon be gone

Many things strengthened the American Fur Company's monopoly. It benefitted from the influence of Lewis Cass and Thomas Hart Benton in Washington and so escaped penalties for taking liquor into the Indian country. It benefited from the distribution of government presents to the tribes. The subagents for the Missouri River tribes, generally independent traders or former employees of the company, came up the river with company traders and handed out the presents with the trader standing by, or even turned them over to the trader for distribution. One of the agents, John F. A. Sanford, married the daughter of Pierre Choteau and later became a partner in the company.

The company also used liquor to retain the loyalty of the Indians. Congress had forbidden liquor in the Indian trade in 1802 and had strengthened the prohibition in 1834. McKenzie believed, however, that it was an absolute necessity, especially to prevent the Indians from going north of the boundary to the Hudson's Bay Company. The American Fur Company always managed to get liquor past the inspectors. In 1831, William Clark refused to search its outfit, saying that he trusted the "good faith" of the company.

In 1833, McKenzie took a still up to Fort Union and manufactured his own liquor (he bragged of his "Fort Union wine") until he was reported the next year. The company, however, did not lose its license. The Fort Union inventory in 1832 showed forty barrels of alcohol, two of whiskey, one of Jamaica rum, and one of shrub. In 1842 the company secured the appointment of Andrew Drips, one of its own traders, as Indian agent for the Upper Missouri. Drips stopped the liquor trade of the opposition but did not disturb the company.

The liquor trade was part of a ruthless exploitation of the Indians. In January, 1844, for example, Charles Larpenteur went from Fort Union to a Cree camp north of the boundary at Woody Mountain. Although the thermometer stood well below zero (it was so cold that one of the mules froze to death standing up), he traded five gallons of alcohol for 180 robes, about all there was in camp.

Many eyewitnesses have testified that contact with the traders demoralized the Indians and made them lazy, wretched, and even poor hunters. Certainly it often meant prostitution for 
Indian women and girls, their husbands or fathers lending them for small sums. The Tetons called the Indians who hung around the forts "Loafers" and "Flat Bottles." Yet all of the Indians had become dependent on white goods. The trade bred ill will, and because force was the only law in the Indian country, violence was common. "At present the intercourse between the parties," wrote veteran trader William Gordon in 1831, “depends but too often for profit to their relative strength; taking alternate advantages of each other-hence a spirit of mutual bad feeling obtains, alike injurious to both parties." ${ }^{8}$ The trader had plundered the Indian, or the Indian plundered the trader. Many traders died at the hands of Indians, but in 1844, Alexander Harvey and Francis Chardon turned the tables and murdered six Blackfeet at Fort McKenzie. The traders, however, were generally honest men who stimulated the industry of the Indians, created a new desire for goods, made peace between the tribes, and introduced firearms, kettles, and other tools which added to Indian comfort.

The traders exploited their engagés. These men signed three-year contracts for about one hundred dollars per year; in comparison, James Kipp, a clerk, was paid six hundred dollars a year. Except for provisions secured in the Indian country, a blanket, and an outfit of clothing, the engagés had to buy all of their necessities and comforts from company posts at high prices-coffee and sugar, for example, at a dollar a pint. They often ended their term of employment owing the company from one to two hundred dollars. Many of them deserted, sometimes making off with company property. Stories were also told of engagés mysteriously disappearing while on their way to St. Louis to collect three years' wages.

The merchants, in turn, exploited the traders. Astor and Chouteau imported goods and turned them over to the traders on credit at a large advance over original cost. They also determined the prices at which fur returns were credited against the traders' debts. The traders, then, could not determine the price at which they bought or sold; the monopoly had them. The profit or loss of the business venture was shared, but if the traders suffered losses, the 
merchants still made a profit in supplying the goods and marketing the furs. As Chouteau wrote Astor in 1833, "generally the loss falls upon the traders."

There is much evidence to bear this out. Astor and Chouteau became rich; the chief traders in the Indian country did not. Manuel Lisa was said to have died insolvent. After forty years, Charles Larpenteur had very little. On the Upper Mississippi River, Joseph Rolette, Sr. (“King Rolette”), lost his property to the American Fur Company; Ramsay Crooks failed in 1842.

The real profits of the trade were far less than the difference (200 to 2,000 percent) between the cost of the goods and their selling price would suggest. The trader had to have two or three times as many men to protect himself and his property as the business would otherwise require. The risks were considerable, the expenses large for the capital involved. "We are satisfied," wrote Lewis Cass and William Clark in 1828, "that the average profits of the fur trade are not in proportion to the enterprise and skill required to prosecute it and to the risk attending it."9

The partnership agreements between the merchants and traders commonly ran for three or four years. Changes were frequent. When his agreement ran out in 1834, Astor, then seventy and ill, retired. He sold the Northern Department (trading from Mackinac with the Great Lakes and Upper Mississippi regions) to Ramsay Crooks and others, and the Western Department to Pratte, Chouteau and Company. Both groups continued to be popularly known as the American Fur Company. In 1835, Daniel Lamont pulled out of the Upper Missouri Outfit to enter a mercantile business in St. Louis, and David D. Mitchell became a partner in his place. About 1839, Kenneth McKenzie also withdrew to go into business in St. Louis; he made a fortune there, appropriately, as a wholesale liquor dealer. Honoré Picotte took McKenzie’s place as agent in charge of the Upper Missouri Outfit and made Fort Pierre his headquarters. In 1838, Pratte, Chouteau and Company became Pierre Chouteau, Jr., and Company, and in 1864 the firm sold out to the Northwestern Fur Company. 


\section{THE GREAT SMALLPOX EPIDEMIC}

A smallpox epidemic brought about a decline in the fur trade, for it wiped out about fifteen thousand Indians on the Upper Missouri. The American Fur Company steamboat St. Peter's brought the disease to Fort Clark and Fort Union in June, 1837. By August, eight or ten Mandans were dying every day. But the Hidatsas and Arikaras, also living near Fort Clark, did not suffer so heavily. Neither did the Sioux, whose nomadic habits checked the spread of the disease. Finally the sedentary Indians, terrified by the toll, scattered over the prairie. On August 11 the Mandans abandoned their village, leaving the sick behind, and moved across the Mis\$tuerIndians blamed the whites for the calamity and made many threats of vengeance. An Arikara shot one of Chardon's men at Fort Clark. Four Bears, long a friend of the whites, called on the Mandans and Arikaras to kill them. "I have Never Called a White Man a Dog," he said while dying, "but today I do Pronounce them to be a set of Black harted Dogs.”

No one can know just how many Indians dies, At Fort Union, Charles Laerpenteur though that half the Assiniboines were gone. The Mandan population fell in a few months from about 1,800 to some 125 . In 1854, E. T. Denig, a trader at Fort Union, estimated that war and disease had reduced the Crees by an eighth, the Arikaras by a fifth, the Blackfeet and Sioux by a third, the Assiniboines and Crows by half, and the Mandans by three-fourths of their former numbers. With such losses among its customers, the Indian trade could not help but decline. ${ }^{10}$

After the epidemic, the Mandans and Hidatsas moved up the Missouri River and the Arikaras took over the abandoned village beside Fort Clark. In 1845 the Hidatsas began to build Like-a-Fish-Hook Village (so named for a bend in the Missouri) about forty-two miles above the mouth of Knife River. They asked for a trader, and in 1845 the Indian women helped Francis Chardon build Fort Berthold beside their village. During the next few years, the Mandans also moved to Like-a-Fish-Hook Village, and in 1862 the Arikaras 
joined them.

The Mandans, Hidatsas, and Arikaras who lived beside Fort Berthold became known as the Three Tribes. They suffered much. A cholera epidemic hit them in 1851, and smallpox again in 1866. The Yanktonais attacked them so often that the Three Tribes did not dare go far from the village to hunt. Often hungry, the asked the Indian agent for protection.

\section{WHITE INTRUDERS IN THE INDIAN COUNTRY}

All Plains tribes were threatened by a white invasion of the Indian country. It began in 1849 when Congress organized Minnesota Territory and when thousands of gold seekers began to take the overland trail to California. In 1851 the Santee Sioux gave up most of southern Minnesota to the United States. That same year, the tribes of the Northern Great Plains promised to allow white travel along the Platte River. When the Indians molested the emigrants going out the Platte, the army punished them. It then bought Fort Pierre for a military post in 1855, and built Fort Randall downstream in 1857.

The settlement of Iowa (admitted as a state in 1846) and Minnesota (admitted in 1858) stimulated beginnings in southeastern Dakota. The Yanktons ceded fourteen million acres between the Missouri and Big Sioux rivers in 1858. Settlements sprang up at Sioux Falls, Vermillion, and Yankton, and in 1861, Congress organized Dakota Territory.

The discovery of gold in Montana in 1862 increased travel through the Indian country. Gold seekers rode Missouri River steamboats to Fort Benton, where they took wagons overland to Virginia City and Helena. In 1860, only two steamboats went up to Fort Benton; in 1866, thirty-one made the trip; and in 1867, thirty-nine arrived.

Such traffic brought about the establishment of woodyards along the river. Reckless and hardy "woodhawks” earned good money providing fuel for steamboats. Living lonely lives, they fortified their cabins with stockades and sold, in addition to wood, fresh meat to passing steamboats. In the fall, miners would descend the Missouri in mackinaw boats. On November 17, 1864, a total of 17 mackinaws with 180 men stopped at Yankton on their way downstream.

The Montana gold rush created some overland traffic across 
North Dakota. Congress appropriated funds to protect the emigrants, and in 1862 the Secretary of War placed James L. Fisk in charge of a party gathering at Fort Abercrombie. Hiring Pierre Bottineau as a guide, Fisk conducted the emigrant train (117 men and 13 women) to Fort Union and on to Fort Benton. Each night the men formed the wagons into a corral to protect the stock. As the train moved across North Dakota, a young couple were married, a mother gave birth to a baby, the women washed clothes and baked bread, a mule drowned, and a wagon upset in a river. On Sundays, N. P. Langford, a layman, read the Episcopal service. The grass was parched, water poor and scarce, and wood wanting.

That same year, another train went to Montana by way of Pembina to avoid the Sioux. In 1863, Fisk led a train of fifty-three men and twenty wagons from Fort Abercrombie to Fort Benton. In 1864' he set off with eighty-eight wagons and nearly two hundred persons besides a cavalry escort of fifty. This time, Fisk's train and another took a more southerly route through Fort Rice. One member of his party thought that the desolate plain was "in fact literally and emphatically good for nothing to the white man." 11

Steamboat and overland travel aroused the Sioux, but war started outside North Dakota. In the summer of 1862 the Santee Sioux, living on reservations along the Minnesota River, attacked the settlement and killed several hundred whites. When an army under Henry Hastings Sibley crushed the uprising, many of the Santees fled west to join Sioux bands about Devil's Lake. Others, their property and annuities confiscated, were removed to Crow Creek Agency in South Dakota.

To satisfy the desire of Minnesotans for revenge and to teach the Sioux a lesson, the army planned to trap them with a pincers movement near Devil's Lake. Sibley would lead 2,800 men against them from Minnesota; General Alfred Sully, a West Point graduate, would come up the Missouri River with 2,000 cavalrymen to cut off their escape to the west. With Pierre Bottineau and his métis scouting ahead for

${ }^{11}$ Documents on the Fisk expedition are in North Dakota Historical Society Collections, II (1908), Pt. I, pp. 421-461; Pt. II, pp. 34-85. 
Indian sign, Sibley swung his force westward north of presentday U.S. 10.

He fought the retreating Sioux, most of whom had taken no pare in the Minnesota Massacre, in three battles: Big Mound (seven miles north of present-day Tappen), Dead Buffalo Lake (north of Dawson), and Stony Lake (northwest of Driscoll). Sibley's artillery, six-pounders and mountain howitzers, scattered the Indians. They were not on the warpath and were, of course, burdened with their families and all their possessions. At big Mound, Sibley reported, the white soldiers collected and burned "vast quantities of dried meat, tallow, and buffalo robes, cooking utensils, and other indispensable articles."

Following the fight at Stony Lake, the Sioux crossed the Missouri River near present-day Bismarck; under fire from Sibley's troopers, many women and children drowned. His men then burned between 120 and 150 abandoned wagons and carts. Sully had not come up to cut off the Sioux retreat, and Sibley's men were too exhausted from their march in dry, hot summer weather to pursue the Indians across the river. Sibley thought that he might have killed or wounded 150 Indians; his own losses amounted to 9 men. He hoped that his destruction of Indian property would cause "many, perhaps most of them, to perish miserably in their utter destitution during the coming fall and winter.”

After Sibley and his soldiers turned back toward Minnesota, the Sioux recrossed the Missouri and set out on a buffalo hunt on the James River. Sully, finally arriving, found their camp in what is now northwestern Dickey County. The Indians were willing to give up some chiefs as a guarantee of good behavior, but they would not agree to unconditional surrender. When the Indians began to abandon their camp, Sully attacked. His troopers shot down fleeing men, women, and children, killing about 150. They took some 156 prisoners (picking up babies on the prairie), burned 300 lodges and from 400,000 to 500,000 pounds of dried buffalo meat, and shot the captured horses. Sully lost 20 men. This was the Battle of Whitestone Hill, September 3, 1863-the bloodiest ever fought on North Dakota soil.

The Sioux, however, were still defiant. In 1864 the War Department sent Sully and 2,500 men to crush them. In July he came up the Missouri with steamboats and built Fort Rice six or 
seven miles above the mouth of the Cannonball River. On July 28, Sully found the Sioux camp in the Killdeer Mountains. There were bands of Tetons and Yanktonais and even some Santees from Minnesota. Sully's artillery drove the Indians from their camp, but he could not pursue them in the broken country to the north. His men, he reported, burned much abandoned property: "tons of dried buffalo meat packed in buffalo skin cases, great quantities of dried berries, buffalo robes, tanned buffalo, elk, and antelope skins, household utensils, such as brass and copper kettles, mess pans, \&c., riding saddles, dray poles for ponies and dogs.”

Sully then marched west to the Yellowstone River and returned down the Missouri to Fort Rice. In the Badlands the Sioux fired on his pickets and stampeded some horses, but Sully's force pushed ahead, as he said, "fighting, hunting a road, and digging it out." From the Little Missouri River to the Yellowstone, the country, Sully wrote, was "covered with myriads of grasshoppers.... My animals were almost starved." Some were abandoned and shot. Sully left a company of soldiers at Fort Union and another at Fort Berthold. $^{12}$

\section{THE MILITARY FORTS AND SIOUX HOSTILITIES}

In 1864, Sully had built Fort Rice, the first military post on the Missouri River in North Dakota. The next few years saw a thoroughgoing military occupation of the region. In 1866 the army built Fort Buford three miles below the mouth of the Yellowstone River, and in 1867, Fort Stevenson, Fort Totten, and Fort Ransom were constructed. Fort Stevenson, on the north bank of the Missouri about seventeen miles east of Fort Berthold, would protect the Three Tribes. Fort Totten, on the southern shore of Devils Lake, would control a reservation for some of the Yanktonais and Santee Sioux. Fort Ransom, on the Sheyenne River about fifteen miles above present-day Lisbon, would guard a trail from Fort Abercrombie to the Missouri; in 1872 it was replaced by Fort Seward at Jamestown. In 1870 the army built

\footnotetext{
${ }^{12}$ Reports of Sibley and his officers and of Sully and his officers are in War of the Rebellion: A Compilation of the Official Records of the Union and Confederate Armies, ed. R. N. Scott et al. (130 vols.; Washington:
} Government Printing Office, 1880-1901), Series I, Vol. XXII, Pts. $\underline{\text { I }}$ and II; Vol. XLI, Pt. I. 
Fort Pembina and in 1872 Fort McKeen on the west bank of the Missouri about five miles south of Mandan. The latter was renamed Fort Abraham Lincoln that fall and enlarged in 1873. It was to protect the engineers and work party of the Northern Pacific Railroad.

At first the forts were collections of cottonwood-log huts with pole-and-earth roofs, though some were built of sawed timbers or adobe. They generally had stockades, but Fort Stevenson had none. Their garrisons consisted of one hundred to five hundred men, many of them immigrants who were unaccustomed to frontier life, poor horsemen, and afraid of the Sioux. Red River often performed the more dangerous duties, such as carrying the mail from fort to fort. The death rate was high, for the soldiers suffered from dysentery and scurvy on a winter diet of salt pork and fish without fresh vegetables. Life was monotonous; drunkenness and desertion were common.

The forts were to control the Indians and to protect the routes to Montana, but they only increased the hostility of the Sioux, especially the Yanktonais and Tetons. Sitting Bull's band of Hunkpapas (a division of the Tetons) led the resistance. Some mail carriers from Fort Stevenson reported a talk with Sitting Bull:

His business, he says, is to kill whites, and he will kill them as long as he and his band last. He boasts that war is more profitable to him than peace; that it brings him arms, ammunition, clothing, and especially great numbers of horses and mules, while the tribes who have submitted are dying of misery and hunger in the places where the whites have penned them up. 13

The Sioux struck at the whites everywhere. They attacked steamboats on the Missouri, especially those which went aground on sand bars. They killed mail carriers traveling between military posts. They wiped out miners descending the river in mackinaw boats. Rumor had it that Fred Ferard, a trader at Fort Berthold, recovered $\$ 75,000$ to $\$ 100,000$ from a concealed compartment in such a boat after the Indians had killed the miners. In 1864 the Sioux killed twelve of the Fisk party and besieged the rest in Fort Dilts (present Bowman County), saying, "Go home and come back no more."

When troops were building Fort Buford, Sitting Bull warned them to leave the country at once. Much of the time, the Sioux held the Missouri River forts in a state of semisiege. They almost

\footnotetext{
${ }^{13}$ Lucile M. Kane (trans. And ed.), Military Life in Dakota: The Journal of Philippe Régis de Trobriand (St. Paul: Alvord Memorial Commission, 1951), pp. 289-290. See also pp. 171, 259, 261, 264-265, 341-342, and, especially, 6364.
} 
never attacked, but would come sneaking in to run off the beef herd, steal horses and mules, cut off a wood party, or take the scalp of a careless soldier. When discovered, they would sit on their horses at a safe distance, making insulting gestures.

The army could not cow the Sioux. Infantrymen obviously could not catch them. General Philippe Régis de Trobriand, in command of Fort Stevenson, explained why cavalrymen were equally helpless:

Each [Sioux] warrior carries with him a piece of buffalo meat that has been dried in the sun. This is all the food he needs for a few weeks. His horse eats no grain; he gets enough nourishment by grazing on the prairie.... There is no equipment to carry. His saddle is nothing; his bridle just a lasso of buffalo leather, and he hardly uses that. If he must go up a hill on the gallop while being pursued, he will run alongside his horse in order to spare him.... The Indian pony without stopping can cover a distance of from sixty to eighty miles between sunrise and sunset, while most of our horses are tired out at the end of thirty or forty miles.... In brief, the movement of Indian horsemen is lighter, swifter, and longer range than that of our cavalry, which means that they always get away from us.

\section{INDIAN TREATIES AND RESERVATIONS}

Even though white troops were ineffective, many of the Indians were ready to quit fighting. De Trobriand described them as "tired of war, miserable, harassed, and hungry." The Fort Berthold tribes opposed resistance, and in 1868 the Arikaras began to enlist as army scouts at Fort Stevenson.

The United States government itself persistently sought peace. In the fall of 1865 it signed treaties with many of the Teton bands: the Indians promised to withdraw from the routes of travel for annuities of thirty dollars for each lodge. In 1865, 1866, and 1867, government representatives talked peace with the Sioux at Fort Rice. In 1868 many of them signed a treaty, some at Fort Laramie (eastern Wyoming) and others at Fort Rice. The treaty-the basic one with the Siouxis known as the Fort Laramie Treaty or the Sherman Treaty (William Tecumseh Sherman headed the peace commission).

By its terms the United States closed the Bozeman Trail, and the Sioux accepted as a reservation roughly the portion of present-day South Dakota lying west of the Missouri River. The United States promised help to each family when 
it began to farm: tools and equipment, the services of a blacksmith, instruction in farming methods, a cow and a team of oxen, and the assistance of teachers, physicians, and carpenters. It offered rations (a pound of meat and a pound of flour daily for each person) during the transition to an agricultural life. It agreed that the Sioux could hunt in the country west of the reservation "as long as the buffalo are in sufficient numbers to justify the chase," but they could not live there permanently. ${ }^{14}$

The treaty was generous, much more generous than the treaties with tribes which had not fought the United States. But its purpose, of course, was to destroy the Teton way of life by placing the people on a reservation. In 1868 and 1869 the Indian Bureau established the Cheyenne River Agency and the Grand River Agency, both on the Missouri, as places of distribution for rations. By 1869 there were 4,500 Sioux (Hunkpapas, Yanktonais, Cut Heads, and Blackfoot Sioux) at Grand River Agency.

Both sides, however, violated the treaty. Many Sioux, still defiant, continued to live away from the reservation, to run off stock from the forts, and to commit other warlike acts. Sitting Bull and several other Sioux leaders had not signed the treaty. For its part, the United States failed to keep whites out of the unceded Indian country.

The government had no trouble with the Three Tribes. Poverty stricken and hungry, their members often went begging at Fort Stevenson. Sioux raiders killed many of them. In summer their crops failed; in winter they suffered from scurvy. Small pox took its toll in 1866. The Three Tribes did receive government aid, however. In 1864, General Alfred Sully left a company of soldiers at Fort Berthold to protect them. Two years later, the Three Tribes gave the United States the right to build roads and telegraph lines across their country; they also ceded the land for Fort Stevenson. In 1868 the government set up an agency, with a resident agent, for them at Fort Berthold. Before then, an agent had visited them only to distribute annuity goods under terms of the Fort Laramie Treaty of 1851. In 1868, however, Mahlon S.

\footnotetext{
${ }^{14}$ Charles J. Kappler (comp.), Indian Affairs: Laws and Treaties (3 vols.; Washington: Government Printing Office, 1903, 1913), II, 676-678, 686-693, 770-775.
} 
Wilkinson, their first resident agent, built blacksmith and carpenter shops and a saw- and gristmill. Unfortunately, he also robbed them when he distributed annuities.

The Three Tribes were gradually beginning to occupy a dependent position on a restricted reservation. The Fort Laramie Treaty of 1851 defined their territory as lying west and south of the Missouri between the Heart and Yellowstone rivers. It ran west to the sources of the Heart and Little Missouri. In 1870 the President of the United States reduced their lands when he set aside a reservation for them by executive order. They lost the region from Fort Berthold to the mouth of the Heart River on the west side of the Missouri, but at the same time they gained land north of the Mis\$य Fort Berthold. About half of them, however, were away hunting, serving as army scouts at the military posts, or wintering at camps between Fort Buford and Fort Peck, Montana. At the agency, about half lived in log cabins and half in earth lodges. A tenth were seriously ill. They complained that although they had never made war on the United States, as the Sioux had, the government lied to them, cheated them, and allowed them to starve. In 1876 the American Board of Commissioners for Foreign Missions sent the Reverend and Mrs. Charles L. Hall to establish a mission for them. ${ }^{15}$

Some Santee and Yanktonai Sioux gathered on a reservation south of Devils Lake. On February 19, 1867, the Sissetons, Wahpetons, and Cut Heads (a band of the Yanktonais) signed a treaty for a reservation there. The army built Fort Totten that summer, and when winter came, the commander sent two traders and an interpreter to invite the Sioux on the Mouse River to come in to the fort. Cold and starving, they came willingly and settled nearby. The region, once rich with buffalo, had been hunted bare by the métis, who had a permanent camp south of Devils Lake. The commander at Fort Totten issued rations to 681 Indians

${ }^{15}$ Adrian R. Dunn, “A History of Old Fort Berthold” (M.A. thesis [later published], University of North Dakota, 1951), pp. x, 59-61, 65, 70, 74-76, 78. Dunn's thesis was published in North Dakota History, XXX (October 1963), 157-240. 
during the winter.

Once on the reservation, these Sioux made rapid progress. They began to raise corn, potatoes, and turnips and to cut hay. In 1871 they cultivated more than one hundred acres. That summer, William H. Forbes, their first agent, and his assistant, James McLaughlin, came to live at the old fort (the army had built itself new quarters of brick). McLaughlin, a young Scotch-Irish immigrant from Canada, had learned the Sioux language and had married a talented woman of mixed Scotch, French, and Sioux ancestry in southern Minnesota. A man of dignity, honesty, and force, he was to become one of the best Indian agents in the nation and to serve the Indian Bureau for fifty-two years. At Fort Totten he abolished the Sun Dance and taught the Indians to work. They received no free rations, such as were given to the western Sioux by the Fort Laramie Treaty of 1868, but were paid in subsistence and clothing for cutting wood.

In 1872 there were 725 Indians attached to Fort Totten Agency. Forbes built a saw- and gristmill for them and made other improvements worth five thousand dollars. He persuaded the Grey Nuns of Montreal to start a school at Fort Totten in 1874. The Indians themselves built a two-story brick house for the nuns. To promote the school and mission, three chiefs had gone with Forbes to visit Bishop Grace in St. Paul. The chiefs told the Bishop that they wanted "the man with the cross not with the gun.” Father Jerome Hunt, an able priest, came in 1882. He started a little newspaper in the Sioux language and also published three religious books in that tongue. ${ }^{16}$

\section{THE DECLINE OF THE FUR TRADE}

The Indian wars, followed by reservation life with government rations and annuities, brought the fur trade to a close. Its decline had begun with the reduction of the Indian population by the smallpox epidemic of 1837. Then, as the hunts of the Red River métis expanded, buffalo became less abundant. White gold seekers crossing the Great Plains also diminished the amount of

${ }^{16}$ Charles De Noyer, “The History of Fort Totten,” Historical Society Collections, III (1910), 183-184, 188, 199, 237-240; James McLaughlin, My Friend the Indian (Boston: Houghton Mifflin Company, 1910), pp. 7-14, 22-24, 29, 32. 
game; an Assiniboin chief noted in 1853 that "as the white man advances, our means of life grow less.” In the 1860's war hastened the decline of the trade.

As traffic increased on the Upper Missouri, steamboats became common carriers, making business life easier for independent traders. Smaller companies entered the trade even before the American Fur Company withdrew. The latter sold Fort Pierre to the army in 1855, abandoned Fort Clark sometime before 1862, and sold out to Hubbell and Hawley-the Northwestern Fur Company-in 1864. J. B. Hubbell of St. Paul was president of the firm. The other important company of these later years was Durfee and Peck, said to be the A. J. Smith Company of Chicago. Both the Northwestern Fur Company and Durfee and Peck owned steamboats.

The military posts, offering protection and new customers, attracted the trading companies. When Fort Rice was built, Durfee and Peck set up a store for both soldiers and Indians. When Fort Stevenson was constructed, the traders moved over from Fort Berthold, though still keeping a place of business at the old location. When Fort Buford was enlarged in 1867, the commanding officer bought old Fort Union and used its timbers at Buford. At the same time, the traders moved down the river to the military post. In 1871, Durfee and Peck sold Fort Berthold to the government (for use as an Indian Agency) for eight thousand dollars. All of the old fur-trading forts were now gone. The traders had become sutlers at the military posts.

A new monopoly soon appeared. In 1870, Congress decreed that there could be only one sutler at each post. The rest lost their licenses and had to leave. The law opened the way to graft. The post trader at Fort Berthold was said to have paid a thousand dollars to Orville Grant, brother of the President, for his appointment. Durfee and Peck were the sutlers at Fort Stevenson from 1870 to 1872 .

These latter-day traders, like the earlier ones, still faced the problem of distance. In spite of the increase in steamboat traffic, transportation costs were high. To take a steamboat up the Missouri River cost $\$ 250$ a day, $\$ 100$ for wood alone. Freight charges were correspondingly high-ten cents a pound from St. Louis to Fort Benton in 1867-making prices very high at the military posts.

In the declining years of the fur trade, Durfee and Peck employed Pierre Garreau as an interpreter at Fort Berthold. Then in his sixties, Garreau, son of a Cree woman and a Turtle Mountain Frenchman, had spent his life in the Missouri River trade. A man of enormous strength and courage, he was honest, 
temperate, devout Catholic and a legendary hero of great influence among the Indians. In 1866 he outfaced a hundred Sioux who were about to attack Fort Berthold. Joining their circle, he showed them his left hand (the one which had squeezed the Assiniboin-another legend), taunted them about their relatives whom he had killed, and called them old women when none of them would fight him. Cowed, the Sioux rode off. ${ }^{17}$

At Fort Berthold in the 1860's about half of the trade was with the Three Tribes and half with their enemies the Sioux. When the Sioux came in for a few days to trade, they would have a truce, visit in friendly fashion with the Three Tribes, and trade horses for corn. At the fort, Garreau would smoke for an hour or more and tell all the news of the region. On beginning the trade, the Indians first bought sugar, coffee, and hard bread. The traders were forbidden to sell guns or liquor. A buffalo robe, worth $\$ 2.50$, was the unit of value; a three-point blanket cost three robes, sugar thirty cents a pound. When the trading was over, the trader gave a present to each family. When the Indians were herded onto reservations and the Indian agents and sutlers of the military posts replaced the fur traders, the first stage in the exploitation of the Upper Missouri country had come to an end. The Northern Pacific Railroad reached Bismarck in 1873. It's coming opened a new era. The fur companies had made the Upper Missouri a hinterland of St. Louis; the railroads were to make the North Dakota portion of it a hinterland of St. Paul and Minneapolis. By 1873 the Missouri River, so long a great highway, was about to lose some of its historic significance.

${ }^{17}$ Ethel A. Collins, "Pioneer Experiences of Horatio A. Larned," North Dakota Historical Society Collections, VII (1925), 39-48. 


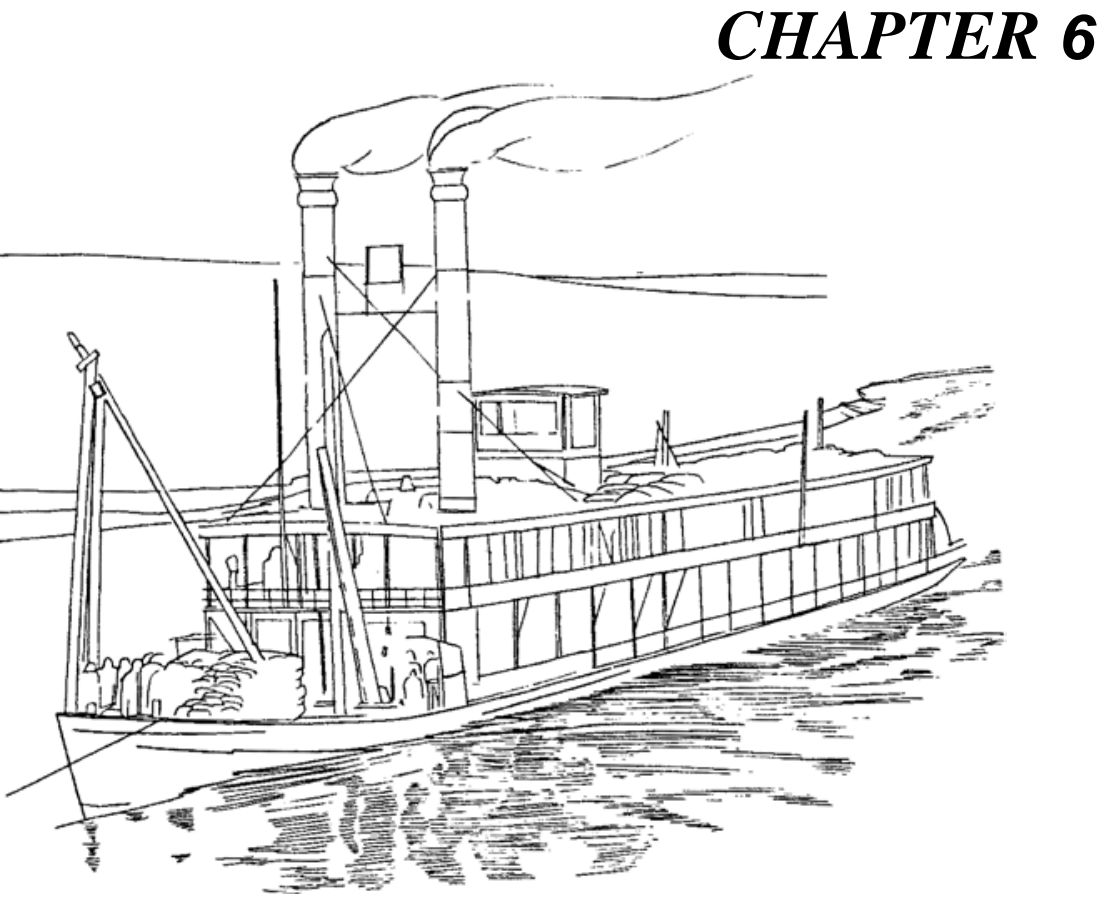

\section{The Beginnings of Settlement}

THE FIRST PORTION OF NORTH DAKOTA to be settled was the valley of the Red River of the North. Except for the Selkirk colonists and the metis about Pembina, agricultural settlement came with the advance of the American frontier. When restless farmers, seeking cheap land, had taken over southern Minnesota, they turned next to the fertile lands of the Red River Valley.

Their coming was stimulated by the opening of a new transportation system. Remoteness was a crucial problem at the Selkirk settlement. Its people, métis and white, wanted easy access to outside markets. At first they were supplied by way of Hudson Bay, but that was costly and the Hudson's Bay Company itself sought a cheaper route. St. Paul, more accessible than the Bay, wanted to make the Selkirk colony its commercial hinterland. When the cheaper route to the Selkirk settlement by way of St. Paul won out over the more costly one by way of the Bay, the valley of the Red River became a trade route. Cart trails, the steamboat line, and then the railroad ran through it. These opened the portion of the valley south of the international boundary and brought in settlers.

The process advanced in three steps. The first as the growth of the metis settlement at Pembina and St. Joseph. There the metis had freer access both to St. Paul and to the buffalo herds on the American side of the boundary. The Pembina-St. Joseph settlement was also an American 
gateway to the Selkirk colony to the north. The second step was the use of the St. Paul route by the Hudson's Bay Company; this brought the steamboat to Red River and a stage and freight line to connect the river with St. Paul. The third step was the creation of the province of Manitoba. In 1869 the Hudson's Bay Company turned its territory over to the Dominion of Canada, which organized the province and opened it to settlement. This stimulated steamboating on the Red River and the beginning of a railroad from St. Paul to Winnipeg. The agricultural settlement of eastern North Dakota followed.

\section{PEMBINA AND ST. JOSEPH}

The movement of the farming frontier into the Red River Valley followed the settlement of southern Minnesota. Congress organized Minnesota Territory in 1849, and in 1851 the Sioux ceded the southern half of the territory to the United States. When steamboats on the Mississippi River connected St. Paul with railroads at Galena and Rock Island in 1854, it was only a thirty-hour trip to Chicago. Settlers came pouring into southern Minnesota, and by 1857 the territory had more than 150,000 people.

The growth of Minnesota was important for Pembina. Norman W. Kittson's trading post was the center of activity, but in 1848, Father George A. Belcourt, a Catholic priest, built a mission nearby. He put up a large, two-story frame house and a log church with a cross, planted a garden, and gave the place an air of comfort.

Father Belcourt had been driven out of the Selkirk settlement for siding with the metis against the Hudson's Bay Company in the struggle over free trade. He wanted to build up a settlement of metis and Chippewas south of the international boundary, and many of the metis attached to the priest, followed him there. After the flood of 1851, Father Belcourt and Kittson chose a new site for the settlement thirty miles to the west, on Pembina Mountain. The new settlement, named St. Joseph for Belcourt's mission and located on the site of present-day Walhalla, became larger than Pembina.

The metis at St. Joseph lived a civilized life. They built one-story houses along the Pembina River, planted fields of barley and potatoes, secured a reaper and thresher, and built a gristmill and a sawmill. Grasshoppers and floods damaged or destroyed the crops, and pemmican ling remained the staple food. The largest house at St. Joseph, twenty-eight by fifty feet, served as a chapel, a school, and the home of the Sisters of the Propagation of the Faith (a religious community of metis organized by Father Belcourt). In 1853 the United States Commissioner of Indian Affairs gave five hundred dollars in support of the school.

Twice a year the metis went to the plains with Red River carts to 
hunt buffalo. They often came into conflict with the Sioux on these hunts, and sometimes the Sissetons harassed St. Joseph itself. The metis also complained about British subjects hunting on American soil. For a time in the 1850's, the United States Army stationed a company of soldiers at St. Joseph. ${ }^{1}$

Minnesotans were much interested in Pembina and St. Joseph. Pembina County, with boundaries reaching west to the Missouri River and east to Lake Itasca, was one of the original counties in Minnesota Territory. IN 1851, Charles Cavileer of St. Paul, an adventurous saddle maker, became customs collector at Pembina. He hindered Norma Kittson's competitors by assessing customs duties on the goods they brought across the line to trade for furs. Presently, he was in business with Kittson. He became identified with the region, spending the remainder of his life there. Cavalier and Cavalier County are named for him.

The people of Minnesota soon saw to it that mail service linked St. Paul and Pembina. At first, letters would go north with a cart train. Then, in 1853, both the government of the United States and that of the Selkirk settlement established official mail service to Pembina. Once a month a lone mail carrier made the trip from St. Paul, on horseback in summer, by dog sled or on snowshoes in winter.

Minnesotans wanted a military post at Pembina and a cession of the Indian lands of the region. Both desires were long frustrated. When Congress finally appropriated funds, the army located Fort Abercrombie on the Upper Red River near present-day Wahpeton, a useless location for the people of Pembina County. It did not establish Fort Pembina until 1870. When Alexander Ramsey, the first territorial governor of Minnesota, made a treaty in 1851 by which the Pembina and Red Lake bands of Chippewas ceded some five million acres, the United States Senate refused to ratify it on grounds that the region was too remote. The treaty would have strengthened the settlement, for the government could then had given the metis fee-simple titles to their farms. The United States did not buy these lands until 1863.

Influential Minnesotans like Henry Hastings Sibley made good use of the Pembina-St. Joseph representatives in the territorial legislature until Minnesota became a state in 1858. Each winter, Norman Kittson and Joseph Rolette traveled by dog sled to the legislative sessions. In 1857, Rolette, by means of an unscrupulous stratagem, blocked the removal of the territorial capital from St. Paul to St. Peter, although both

${ }^{1}$ Vernice M. Aldrich, "Father George Antoine Belcourt, Red River Missionary,” North Dakota Historical Quarterly, II (October 1927), 50-52; Moses K. Armstrong, The Early Empire Builders of the Great West (St. Paul: E. W. Porter, 1901), pp. 179-181; Sister Mary Aquinas Norton, "Catholic Missions and Missionaries among the Indians of Dakota," North Dakota Historical Quarterly, V (April 1931), 155-159. 
houses of the legislature had passed the removal bill.

Minnesotans were also interested in the fur trade of the region. Metis cart trains brought much wealth to early St. Paul, and such men as Kittson and Sibley were heavily involved in the trade at Pembina. But in the 1850's the fur trade was dying. Fur-bearing animals were thinning out, and the Chippewas were decimated by disease, starving, and demoralized. Moreover, land cessions meant cash annuities for the Indians, and this destroyed the Indians' incentive to hunt. Such conditions meant heavy losses. Kittson tried to save himself by stopping credit to the Chippewas and metis. His own creditor, Pierre Chouteau, Jr., and Company of St Louis, had on its books over $\$ 400,000$ in credits to many traders, much of the amount old and of doubtful value. With such gloomy prospects, Chouteau, Sibley, and Kittson withdrew from the fur trade in the early 1850 's. ${ }^{2}$

\section{A NEW TRANSPORTATION SYSTEM}

A new kind of trade began to develop between the Selkirk settlement and St. Paul in the 1850's. Pembina was a gateway for that trade. Before Kittson retired from Pembina in 1854, he began to do business with the Selkirk settlement in a manner which was somewhat different from that of the fur trade. He sold groceries, such as coffee, tea, and sugar, as well as hardware, stoves, reapers, and other agricultural implements. He also did a banking business, cashing checks for English sportsmen and transferring funds for the Catholic clergy.

But it was Sir George Simpson, the governor of the Hudson's Bay Company, who made the Selkirk settlement a hinterland of St. Paul. The route from England by way of the Hudson Bay was long and costly. By one calculation, goods could be brought by way of St. Paul for \$94 to $\$ 110$ a ton, compared to $\$ 155$ by way of the Bay. In winter of 1857 1858, Simpson arranged with the United States Treasury to bring English imports to the Selkirk settlement by way of St. Paul, sealed in bond and paying no duty. The next summer, Red River carts in charge of James McKay carried the company's imports from St. Paul to Fort Garry. Simpson made the Burbank brothers his agents in St. Paul. He gave them and Russell Blakely a five-year contract to carry five hundred tons of merchandise per year from St. Paul to Fort Garry.

\footnotetext{
${ }^{2}$ Alvin C. Gluek, Jr., "The Struggle for the British Northwest: A Study in Canadian-American Relations" (Ph.D. dissertation [later published], University of Minnesota, 1953) pp. 55, 72, 75, 132-139, 142-147; William W. Folwell, $\underline{A}$ History of Minnesota (4 vols.; St. Paul: Minnesota Historical Society, 1921-1930), I, 247; “Address Delivered by Charles Cavileer before a Meeting of Old Settlers at Grand Forks, December 10, 1891," North Dakota History, XII (October 1945), 206 n.; Clarence W. Rife, "Norman Kittson, A Fur-Trader at Pembina," Minnesota History, VI (September 1925), 244-245.
} 
St. Paul, suffering from the Panic of 1857, rejoiced at Simpson's action. Businessmen congratulated each other in the streets; newspapers Blakely recalled, began to talk about how the city should use "this good fortune.” At the same time, the discovery of gold on the Fraser River in British Columbia and the recommendation of a committee of the British Parliament that the valleys of the Red and Saskatchewan rivers be opened to agricultural settlement promised a bright future for St. Paul.

Simpson, who had testified before a committee that the country was unfit for settlement, wanted a steamboat on the Red River to cut freighting costs. In the fall of 1858 the businessmen of St. Paul sent Russell Blakely, who ran steamboats on the Upper Mississippi, to see if the Red River were navigable. When he reported favorably, the St. Paul Chamber of Commerce offered a thousand dollars to the first person who would put a steamboat on the Red River in the spring of 1859. Anson Northrup, who had a boat on the Mississippi at Crow Wing, agreed to do it for two thousand.

In March, Northrup gathered sleighs, thirty-two teams of oxen, and a crew of sixty men. They dismantled Northrup's North Star at Crow Wing, loaded the machinery, cabin, and lumber for a new hull on the sleighs and moved 150 miles through the snow and cold to Lafayette, a townsite opposite the mouth of the Sheyenne River. Six weeks later they launched a new boat, the Anson Northrup, and steamed down to Fort Garry, where they received a wild welcome. "Each turn of the engine," write Bishop Taché of St. Boniface, "appeared to bring us nearer by so much to the civilized world."

The steamboat was to connect with a stage and freight line from St. Cloud to the Red River. In the spring of 1859 the Burbank brothers, Russell Blakely, and Allen \& Chase (who had the mail contract to Fort Abercrombie) organized the Minnesota Stage Company. Blakely took charge of its freight and stage operations to the Red River. The company had a thousand miles of stage lines, the principal ones running from St. Paul to Dubuque, Prairie du Chien, and Superior.

In June, Blakely, cheered by the people of St. Cloud, led a roadbuilding party west to Fort Abercrombie. The fort, a hastily built collection of log cabins put up in 1858, stood on the Red River about twelve miles north of Wahpeton. In three weeks Blakely's men made a passable road with bridges and way stations. It ran up the Sauk Valley, through Sauk Center, Alexandria, and Breckenridge, to Fort Abercrombie, a distance of 152 miles. The new route aroused much interest. Manton Marble, editor of the New York World, Joseph Wheelock, editor of the St. Paul Press, and James W. Taylor traveled over it to Fort Garry that summer.

Northrup, however, having made one trip to Fort Garry and having collected his two thousand dollars, refused to operate the steamboat. Simpson and James McKay came to look it over at Fort Abercrombie. Simpson urged the Burbanks to buy it, and they paid Northrup eight 
thousand dollars, a bad bargain because the boat, built of green pine, was in poor shape with a cracked boiler head. ${ }^{3}$

Simpson, the Burbanks, and Blakeley worked together to make the new transportation system effective. Simpson's man McKay built warehouses at Georgetown (at the mouth or the Buffalo River, so named in honor of Sir George Simpson) for goods awaiting trans-shipment. Above Georgetown the water would often be too low for the steamboat. Simpson had his goods shipped from London to Montreal and from there by a combination of railroad, lake boat, and river steamer to St. Paul.

Blakely organized wagon trails from St. Cloud to the Red River at Georgetown. Each had a captain and crew and traveled some fifteen miles a day. The freight was largely Hudson's Bay goods, but Blakeley also hauled for independent traders. The stagecoach ran regularly, leaving St. Cloud twice a week on the four-day trip to the Red River. The line gave clean accommodations in log cabins along the way.

The Anson Northrup (renamed the Pioneer in 1860) had room for only eighteen cabin passn1gers. In 1862 the Burbanks replaced the Pioneer with a new boat, appropriately named the International. It was 137 feet long and rated at 133 tons. The Burbanks charged more than the Red River carts, but their service was faster and more regular. They charged \$4.80 per hundredweight from St. Paul to Fort Garry. The cost from Liverpool was $\$ 8.50$.

The new transportation system worked well in 1860 and 1861. When the Chippewas protested that the steamboat frightened game and fish, the Burbanks placed Norman Kittson in command of the International. He had known the Chippewas for sixteen years and might conciliate them. Then, in 1862, the Sioux, killing hundreds of settlers in southern Minnesota, stopped the traffic on the Red. They murdered stage drivers, carried off merchandise, burned way stations, and wiped out some of the tiny out posts on the Red River, burning a hotel at Breckenridge. Travelers and settlers sought shelter in Fort Abercrombie, the steamboat stopped running, and for two months no mail was carried to Fort Garry.

In 1863 and 1864 soldiers were stationed at Pembina to watch Sioux refugees who had fled to the Selkirk settlement. In 1863 and again in 1864 the International made only one trip to Fort Garry. Hundreds of Red River carts re-entered the trade; in 1865 a train of 1,200 reached St. Paul.

${ }^{3}$ Russell Blakely, "Opening of the Red River of the North to Commerce and Civilization," Minnesota Historical Society Collections, VIII (1898), 4656; Arthur J. Larsen, "The Northwestern Express and Transportation Company," North Dakota Historical Quarterly, VI (October 1931), 46-49; Fred A. Bill, "Early Steamboating on the Red River," North Dakota Historical Quarterly, IX (January 1942), 69-72. 
The Sioux had wrought the destruction, but the Pembina and Red Lake bands of Chippewas were also sullen. The only Chippewas in Minnesota not receiving annuities, they wanted to sell their lands in the Red River Valley to the United States. When the Sioux uprising prevented a council for a treaty, they plundered a Hudson's Bay Company train led by Norman Kittson and threatened to stop the steamboat. Finally, in September, 1863, Governor Alexander Ramsey in a council at the Old Crossing of the Red Lake River, bought their lands. They agreed to sell ten million acres in northeastern North Dakota and northwestern Minnesota for $\$ 500,000$, to be paid over twenty years. The ceded land extended from the international boundary on the north to the mouth of the Sheyenne River on the south. Its eastern limit was the upper reaches of the Thief and Wild Rice rives, the western limit the Sheyenne River.

The Indian troubles and the consequent stoppage of traffic nearly ruined the Burbank brothers, who were also disappointed because no progress had been made in opening Assiniboia to settlement. In 1864 they sold the International to Norman Kittson, who acted for the Hudson's Bay Company. Thereafter it carried only company goods. In 1867 the Burbanks sold the stage line to Russell Blakely and C. W. Carpenter.

Before the Sioux uprising temporarily closed it, the new transportation system had begun settlement on the Minnesota side of the Red River Valley. The proprietors of earlier townsites began to take a new interest in them. In 1859 the speculators holding Breckenridge (Sibley was one of them) planned a hotel and sawmill. Others staked out townsites along the stage route. The Minnesota Legislature organized counties in the Red River Valley, and federal surveyors ran township and section lines. German settlers pushed up the Sauk Valley.

The new transportation system also stimulated business in St. Paul. By 1859 the Red River settlers were spending \$100,000 a year in that city. Fur sales grew there (\$198,000 in 1861), and customs duties collected at Pembina increased from $\$ 1,748$ for the fiscal year ending July, 1862, to \$6,102 for the year ending July, 1865.

The Selkirk settlement also experienced a boom. The number of independent traders there increased. After the floods of 1861 the traders, many of them Americans, put their stores beside Fort Garry, and Winnipeg, at first called McDermotstown, came into being. Their imports from St. Paul began to include a greater variety of goods-a printing press for the settlement's first newspaper in 1859, stoves, reapers, and other items. ${ }^{4}$

${ }^{4}$ Roy P. Johnson, "The Siege at Fort Abercrombie," North Dakota History, XXIV (January 1957), 11-15; Ella Hawkinson, "The Old Crossing Chippewa Treaty and Its Sequel," Minnesota History, XV (September 1934), 


\section{ST. PAUL'S AMBITIONS FOR A NORTHWEST HINTERLAND}

The trade with Winnipeg nourished St. Paul's ambition to secure a commercial hinterland in the British Northwest. Its chief spokesman was James W. Taylor, the prophet of St. Paul's future. Phi Beta Kappa (Hamilton College), lawyer (reading law with Salmon P. Chase), newspaper writer, Taylor had come to St. Paul from Ohio in 1856. While still the librarian of that state, he had lectured to the Ohio Assembly on the Selkirk colony. He believed that the Saskatchewan Valley would become an agricultural region and that the trade of the region tributary to the Red River-the valleys of the Assiniboine and Saskatchewan-was of the greatest importance to the commerce of Minnesota.

Taylor spread his ideas by means of newspaper articles, speeches, and reports. Indeed, he became so enthusiastic that his friends began to call him Saskatchewan Taylor. For the St. Paul City Council, he outlined a plan for a transcontinental railroad from British Columbia through the Saskatchewan Valley and Pembina to St. Paul. Taylor worked with others to promote the building of railroads from St. Paul to the Red River at Pembina or Breckenridge.

Both Taylor and the businessmen of St. Paul believed in reciprocity with Canada. In 1859, President James Buchanan appointed him as special agent of the United States Treasury to investigate the relations of the United States and the British Northwest. Taylor used his position to defend the reciprocity treaty of 1854, which lowered tariffs between the United States and Canada.

Taylor's plans were aided by the rapid growth of Minnesota after the Civil War. Its population increased nearly 80 percent from 1865 to 1870 , when it reached 439,706. Railroads and settlers pushed toward the Red River Valley. By 1869 the land offices at St. Cloud and Alexandria were the busiest in the state, and farms were scattered along the east side of the Red River as far north as Georgetown.

Customs collections at Pembina increased to \$19,448 in 1868. By 1870 trade with the Selkirk settlement probably amounted to a million dollars a year. Minnesota asked the federal government to improve the road from St. Cloud to Fort Abercrombie and Pembina. The state's leaders worked for the settlement of the American portion of the Red River Valley by creating land offices, conducting surveys, and seeking more aid for the Northern Pacific Railroad.

As traffic down the valley increased, Taylor, editor Joseph Wheelock, and United States Senator Alexander Ramsey began to

282; Gluek, “Struggle for the British Northwest,” pp. 194-244. 
talk about annexation. They felt that trade with St. Paul was Americanizing the Selkirk settlement, which had had no direct intercourse by the old canoe route with eastern Canada since 1821 . They believed that if the United States did not annex the British Northwest, St. Paul would lose her richest hinterland forever. When the reciprocity treaty expired in 1866, Taylor proposed a plan of union with all of the British provinces. In return for admission of the provinces as states and territories, the United States was to pay the Hudson's Bay Company ten million dollars, build canals to improve the St. Lawrence-Great Lakes water-way, and construct a Pacific railroad for the region.

A railroad, Taylor thought, was an absolute necessity for the British Northwest. Canada could not finance it; Britain would not. He felt that the promise of a railroad by the United States would win the people of the Selkirk settlement over to annexation. Taylor's proposal was introduced in the House in 1866, and Senator Ramsey introduced a similar resolution in 1868. The Minnesotans' argument was geographical. Nature had made St. Paul the outlet for the Canadian West, they said, by creating an impassable barrier to railroad construction in the waterlogged country between Lake Superior and the Red River. ${ }^{5}$

\section{THE CREATION OF MANITOBA}

The leaders of eastern Canada resented St. Paul's annexation proposals and entered into a contest for the British Northwest. They feared that by means of annexation the United States would get behind them and cut them off from the Pacific. Early in 1869 the government at Ottawa reached an agreement with the Hudson's Bay Company by which the Northwest would be united with the Dominion of Canada. The Hudson's Bay Company was to be paid $£ 300,000$ and allowed to retain title to two sections in each township and some fifty thousand acres about its fur posts. In turn, it would give up all other proprietary and governmental rights to the Dominion and "all other privileges, franchises, powers, and authorities."

The reign of the great company was at an end; the fur trade was giving way to agricultural settlement. Ottawa, however, did not consult the people of the Selkirk settlement about the transfer, nor did it give them any assurance about their rights or land titles. Late in 1869 the metis, led by Louis Riel, rose in rebellion. They stopped the entry of the lieutenant governor at Pembina, broke up a surveying

${ }^{5}$ Ruth Ellen Sanborn, "The United States and the British Northwest, 1865-1870," North Dakota Historical Quarterly, VI (October 1931), 13-16; Gluek, "Struggle for the British Northwest,” pp. 312-345, 408-430. 
party, and established a provisional government at Fort Garry.

The Minnesota expansionists thought the rebellion offered an opportunity. They believed that the great majority of the metis and other Red River settlers, isolated from eastern Canada and drawn to St. Paul by trade, favored annexation by the United States. Americans Enos Stutsman and Oscar Malmros became Riel's intimate advisers. Stutsman, a prominent leader in Dakota Territory and a man of force and culture, was an agent of the United States Treasury at Pembina. Malmros, a friend of Alexander Ramsey, was United States consul at Winnipeg. Malmro's office became the center of an American annexationist party.

The first issue of Riel's newspaper, The New Nation, spread the ideas and slogans of American annexationists. Stutsman was supposed to have written the bill of rights for Riel's government. On December 30, 1869, James W. Taylor went to Winnipeg as a secret agent of the United States Department of State.

But the annexation drive failed. The Minnesotans grossly exaggerated the desire for annexation among Riel's followers. Riel himself was loyal to the queen, and eastern Canada soon satisfied the demands of the metis. In 1879 the Manitoba Act created a new province, guaranteeing rights and land titles, a representative government, a d a voice in the Dominion. It also made allotments of land to the metis and other old settlers.

Rapid growth followed the creation of Manitoba. A census in 1870 showed a population of nearly 12,000. There were 558 Indians, 5,757 metis, 4,083 English half-breeds, and 1,565 whites. In 1871 a considerable immigration from Ontario began, and by 1881 the population had reached 66,000. The Red River Valley was the sole route by which these new settlers entered Manitoba, by which they imported all their necessities from the outside world, and by which they exported whatever they had to send to an outside market.

The Canadian Pacific Railroad, begun in 1875, did not connect the Red River with Fort William-and hence with eastern Canadauntil 1882. Its first train from Montreal to the Pacific Coast went through in June, 1886. Until 1882, then, St. Paul held Manitoba as a colonial hinterland, and development of the Red River Valley was stimulated by traffic between the two. James W. Taylor, the great advocate of a hinterland for St. Paul in the British Northwest, accepted a post as United States consul in Winnipeg; he would do what he could for the lost cause of annexation. While he was consul, first Jay Cooke of the Northern Pacific Railroad, then Donald A. Smith, Norman W. Kittson, and others representing the Red River Transportation Company, and finally the Canadian Pacific Railroad, paid him an allowance to supplement his modest salary. Taylor, a genial gentleman and popular speaker in the city, was consul at 


\section{STEAMBOATING ON THE RED, 1871-1878}

When the Hudson's Bay Company turned Manitoba over to the Dominion of Canada, a new era began in the Red River Valley south of the international boundary. The opening of Manitoba to settlement placed several steam boats on the Red and hastened the building of railroads from St. Paul to that river. The steamboats and railroads soon brought in settlers.

From 1859 to 1871 there had been only one steamboat on the river. After 1864, Norman Kittson ran the International for the Hudson's Bay Company, carrying only company freight, and the Red River cart trains continued to go to St. Paul. In 1866, at Kittson's suggestion, James J. Hill became the St. Paul purchasing and forwarding agent of the independent merchants at Winnipeg. By 1870, Hill, Griggs \& Company were doing a large flatboat business on the Red River.

Hill, a Canadian immigrant, arrived at St. Paul in 1856 and began to work on the water front as a shipping clerk for steamboat lines. An energetic youth as well as a voracious reader, he gained a knowledge of both business methods and the transportation problems of the region. He also became expert in hustling patronage. Hill saved his money and built up a reputation for integrity and judgment. Always ambitious, he was in business for himself by 1865transferring freight from riverboat to railroad, warehousing, forwarding merchandise, and dealing in fuel. He was soon an agent for the St. Paul and Pacific Railroad and also had a contract to supply it with fuel. All of this was unplanned preparation for relieving the remoteness of North Dakota-Hill's contribution to the history of the state.

It was Hill who began the expansion of steamboating on the Red River. In 1871 he and some partners launched the Selkirk, built at McCauleyville, and began to compete with the International. That spring, the Selkirk's first two trips practically paid for it. Kittson made the International a common carrier, but competition did not last long. Before the 1872 season opened, Hill and Kittson, old friends, placed both boats under Kittson's management, calling the monopoly Kittson's Red River Transportation Line. In the winter of 1871-1872, Kittson built the Dakota, the third boat on the river. In 1874 he added the Alpha and the Cheyenne; in 1875 some outsiders built the Manitoba and the Minnesota.

${ }^{6}$ W. L. Morton, Manitoba: A History (Toronto: University of Toronto Press, 1957), pp. 115-145, 175-177, 216; Gluek, "Struggle for the British Northwest," pp. 275-285, 356-358, 391-397. 
All were stern-wheelers and most of them something over a hundred feet long, with a beam of from twenty to thirty feet. Their carrying capacity ranged from ninety to nearly two hundred tons, and they generally towed a barge or two. In April, 1875, a reporter counted five steamboats, six barges, and eleven flatboats at the Moorhead levee.

They ran from points on the upper river to Winnipeg, carrying freight brought by the Northern Pacific to Moorhead, the usual head of navigation. In low water, however, teamsters had to haul the freight by wagon fifty miles down the river to Frog Point, at the foot of Goose Rapids. The river was generally too shallow for the boats between Breckenridge and Moorhead, but below that point Goose Rapids-twenty-two miles of boulder-strewn water-was the only obstacle to navigation. In the fall of 1872 a branch of the St. Paul and Pacific Railroad reached the Red Lake River at Crookston, and that point replaced Moorhead as the principal place of transshipment. When the railroad was built nine miles down the Red Lake River to Fisher's Landing in 1875, it replaced Crookston as the chief shipping point.

The steamboats improved transportation. They burned wood and apparently ran only in daylight. They could make the downriver trip to Winnipeg in sixty hours and the return to Moorhead in four days, a distance of 410 miles, though only 210 by land. The river dropped 194 feet in that distance. The steamboats and their barges carried much freight and many passengers-a thousand passengers and four thousand tons of freight in 1872 alone. Some of the people were Dukaboor and Mennonite immigrants; freight included rails for the Canadian Pacific Railroad, grain, machinery, and livestock. In May, 1875, the Manitoba arrived at Winnipeg with 102 cabin and 181 deck passengers as well as 365 tons of freight. At times customs collections at Winnipeg amounted to more than \$50,000 a month. In 1877 the Selkirk and its barges took a locomotive (the famous Countess Dufferin, now a museum piece at the Canadian Pacific's Winnipeg station) and several flatcars down the river.

The freight and passenger rates on the river were set by a monopoly. In 1874, Kittson, Hill, and their associates (including the Hudson's Bay Company) organized the Red River Transportation Company with a capital of $\$ 100,000$. It owned all the steamboats on the river and made a profit of 80 percent its first season.

Winnipeg resented its dependence on the monopoly. In 1875 some Winnipeg, St. Paul, and Moorhead merchants, feeling themselves to be exploited, built the Minnesota and Manitoba, the largest boats yet placed on the river. The new concern, the Merchants International Line, cut rates but could not survive. The International sank the Manitoba in a collision (perhaps no accident), a heavy loss, 
although it was raised and put in service again. The new boats were soon sold to the Red River Transportation Company. In 1875 the rate on first-class freight from St. Paul to Winnipeg (railroad and steamboat charges combined) was two dollars per hundredweight; first-class passenger fare (berth and meals) was twenty-four dollars.

Through railroad connections brought about the decline of steam- boating. Late in 1878 a branch of the Canadian Pacific from Winnipeg was completed to the international boundary at Emerson and a branch of the St. Paul and Pacific, building north that year from Crookston to St. Vincent, met it. This ended through steamboat traffic. Some of the boats were sold to a Winnipeg corporation and used on the Assiniboine and Saskatchewan rivers. The International, after eighteen years on Red River, was broken up at Grand Forks in 1880 .

Yet some new boats were built to haul wheat to railroad shipping points-the Grandin in 1878 and the Grand Forks as late as 1895. The last boat disappeared from the river in the spring of 1912 when the Fram broke from its moorings at Grand Forks and sank. Red River steamboats, playing a part in the development of Minnesota and Manitoba, also started the settlement of the Red River Valley. Moreover, they interested James $\mathrm{j}>$ Hill in that new country and laid the foundation for his fortune. He was to become the key figure in the railroads of North Dakota. ${ }^{7}$

\section{THE ST. PAUL AND PACIFIC RAILROAD}

Steamboating expanded when railroads from St. Pail reached the Red River. It was the railroads which really opened North Dakota to the outside world, overcame its remoteness, and made it a hinterland of St. Paul and Minneapolis.

Railroad construction required capital from western Europe or the eastern United States. St. Paul could not supply it, but promoters, using land grants as bait, might talk outsiders into risking their savings. Too often, however, large sums went into the pockets of the promoters or were wasted in mismanagement. When the money was spent, with little railroad construction to show for it, securing more capital became very difficult, and completion of the railroads was long delayed.

The promoters financed construction through the sale of bonds (evidence of the railroad's debt); they divided the stocks (evidence of ownership), among themselves and the bond purchasers as a free bonus. They could sell the bonds, although these bore a high rate of

${ }^{7}$ Fred A. Bill, “Steamboating on the Red River," North Dakota Historical Quarterly, II (April 1928), 201-216; Bill, "Early Steamboating on the Red River,” ibid., IX (January 1942), 69-85. 
interest, only at a large discount. They believed that construction of the railroad would increase the value of the land grant, that the sale of land would pay off the bonds, leaving the promoters with a valuable property that had cost them little more than some persuasive talk. Owning the railroad, they would then be in a position to exploit the settlers whom the road served. Only dishonesty and mismanagement prevented the scheme from working out as the promoters had planned.

Such, in brief, was the history or the early Minnesota railroads. They were to serve three needs: (1) to connect St. Paul with Lake Superior for cheap water transportation to the east; (2) to connect St. Paul with the Red River and Winnipeg-its most promising hinterland; and (3) to connect the rich agricultural region of southern Minnesota-the first portion settled-with the Mississippi.

On March 3, 1857, Congress gave Minnesota about six million acres of land to subsidize railroad construction on routes which Congress itself specified. The grant was six sections for each mile of railroad; in 1865, Congress increased it to ten sections. In May, 1857, Minnesota chartered four companies to build the roads and receive the land grant. By far the largest grant went to the Minnesota and Pacific Railway Company. It was to build two lines to the Red River: the main line through a fertile region to Breckenridge and a branch to St. Vincent through a less fertile region by way of Crow Wing.

No construction, however, took place until 1862, for no bonds could be sold in the depression years after the Panic of 1857. Then the St. Paul and Pacific Railway Company, chartered in 1862 as successor to the routes and grant of the Minnesota and Pacific, laid ten miles of track from St. Paul to St. Anthony. Every year thereafter saw some construction by one of the companies, and by 1865 , Minnesota had 210 miles of railroad.

In a few years the St. Paul and Pacific reached the Red River. Its promoters, led by Edward $\mathrm{H}$. Litchfield of New York, sold $\$ 4,480,000$ worth of 7 percent bonds at an unknown discount to some Dutch investor. In 1866 they built the branch line 76 miles up the Mississippi to St. Cloud (at $\$ 20,000$ per mile, a reasonable cost to build and equip a prairie railroad at that time, the face value of the bonds could have built nearly 240 miles of railroad instead of 76). From 1867 to 1871 the promoters sold \$13,500,000 worth of bonds and built the main line from St. Paul to Breckenridge, a distance of 207 miles. That is, they sold over $\$ 65,000$ worth of bonds for each of the 207 miles of railroad actually built.

Then came a change of ownership. In December, 1870, the Northern Pacific, just getting its own construction underway, bought most of the stock of the St. Paul and Pacific for \$1,500,00 in secondmortgage bonds and \$500,000 in cash. The Northern Pacific could 
use the St. Paul and Pacific's projected branch to St. Vincent as a feeder to its own transcontinental line.

In 1870, Congress allowed the St. Paul and Pacific to change the route of the St. Vincent branch to a more fertile region. The new route, instead of going north to Crow Wing, went west from St. Cloud up the Sauk Valley, through Alexandria and Fergus Falls, and then north to Crookston. In 1871 its promoters sold bonds to Dutch investors for almost nine million dollars to build up the St. Vincent branch and also a branch from St. Cloud up the Mississippi River to Brainerd.

Much of the money was wasted. In 1872 the contractors for the St. Paul and Pacific completed 143.5 miles of track. One section ran 35 miles from St. Cloud to Melrose; another went 4.5 miles north from St. Cloud; and a third, detached from the rest of the St. Paul and Pacific, ran 104 miles from a point 12 miles south of Glyndon to a point north of Crookston. It would serve as a branch of the Northern Pacific, which went through Glyndon. Before the 1872 season was over, the nine million dollars-enough to build and equip more than 350 miles of railroad-had disappeared; the contractors were demanding arrears of half a million, and their workmen, unpaid for two months, were threatening to destroy the bridges. There was a general disappointment and disgust.

The affairs of the St. Paul and Pacific were a complicated maze which led to bankruptcy. In 1866 it had become two separate entities: the First Division, which controlled both the main line from St. Paul to Breckenridge and the branch from St. Paul to St. Cloud, and the St. Paul and Pacific proper, which controlled only the St. Vincent Extension. In 1871 the First Division leased the St. Paul and Pacific proper for ninety-nine years. In the summer of 1873 the St. Vincent Extension could not pay interest on its bonds, and the court placed it in the hands of a receiver, Jesse P. Farley. Likewise, the First Division could not pay interest on its bonds, but the court refused to allow the Dutch bondholders to foreclose on the land grant, the security for the two bonds. To help the railroad, Congress extended the time allowed to earn the land grant by completing construction.

The whole experience was disappointing. By the end of 1872, Minnesota had only 1,906 miles of railroads. Yet in addition to the millions of dollars put up by the purchasers of their bonds, the Minnesota railroads had received 11,250,000 acres of federal lands, $11,250,000$ acres of state lands, and \$1,561,000 worth of municipal bonds. These subsidies, figuring the land at $\$ 2.50$ an acre, were worth about $\$ 34,500,000$. $^{8}$ 


\section{BUILDING THE NORTHERN PACIFIC RAILROAD}

Although the St. Paul and Pacific was the most important of the Minnesota railroads for the Red River Valley, the first railroad to build within North Dakota was the Northern Pacific. As a part of the survey of possible transcontinental railroad routes, Isaac I. Stevens led an. army expedition from St. Paul to Fort Union and on to the Pacific Coast in 1853. He reported that there was no serious obstacle to a northern route. In 1864, Congress chartered the Northern Pacific and gave it a fifty-million-acre land grant to build from Duluth to Puget Sound. The grant was twenty sections per mile, or 12,800 acres, in the states (Minnesota and Oregon) and forty sections per mile, or 25,600 acres, in the territories (Dakota, Montana, Idaho, and Washington).

In spite of the lavish grant, the promoters could get no money for construction until they persuaded Jay Cooke, the famous Philadelphia banker, to sell the bonds. James W. Taylor helped win Cooke over to a faith in the future of the region. On January 1, 1870, Cooke signed a contract to sell $\$ 100,000,000$ worth of Northern Pacific bonds bearing an interest of 7.3 percent. His commission was to be 12 percent, and he was to have about three-fifths of the company's stock. He gave much of it away as bonus to the purchasers of the bonds. He promised to have $\$ 5,000,000$ for the railroad within thirty days in order to finance construction from a point near Duluth to the Red River. Thereafter the Northern Pacific promoters were to build the road only as fast as Cooke was able to sell the bonds.

The undertaking, the largest single business enterprise yet launched in the United States, was to build a two-thousand-mile railroad through an uninhabited wilderness. One estimate placed the cost at $\$ 85,000,000$. The plan called for $\$ 50,000$ worth of bonds for each mile of road, much above the usual bonded debt for railroads.

Cooke put on a huge publicity campaign to sell the bonds. He was an optimistic person who inspired trust and confidence; he was sure of his own powers and liked to do things in a big way. He had financed the Civil War for the North by an imaginative bond-selling campaign, and now he used the same methods to convince investors of the value of the "Fertile Belt" through which the Northern Pacific would run. By May 2, 1872, he had spent $\$ 350,000$ on advertising, stressing the security afforded by the land grant, the value of the Fertile Belt's timber and iron ore, and the importance of future trade with the Orient.

Cooke raised the five million dollars to begin construction. but after that he had great difficulty in selling the bonds. No large banker bought them, and European investors showed no enthusiasm. He could sell them only to small bankers and investors who trusted his 
integrity and judgment (Cooke, who looked like a biblical patriarch with his full beard, was a sincere Christian who tithed).

Unfortunately, the officials of the Northern Pacific were outsiders who did not live in the country to be served by the railroad. They had other concerns which diverted their attention from the Northern Pacific; they themselves had little money invested in it; and their reputations were not at stake in its success. The accounting methods of the Northern Pacific were so poor that no one can even determine the cost per mile to build the road.

Its officials spent money recklessly. They entered into large construction contracts without consulting Cooke and before he had sold the bonds to meet them. Then Cooke had either to advance the money from the resources of his own bank or admit that the Northern Pacific was a failure. As a result, Jay Cooke and Company advanced more than five million dollars to the Northern Pacific and then, its funds exhausted, went bankrupt in September, 1873. Cooke himself lost his personal fortune, and his failure set off the Panic of 1873.

In all, Cooke may have secured \$25,000,000 for the Northern Pacific for the $\$ 30,000,000$ worth of bonds he sold. The company had begun to build westward from Lake Superior in 1870. It reached Moorhead late in 1871, crossed the new bridge over the Red River in June, 1872, and reached Bismarck on June 3, 1873. By that time, it had built 150 miles on the West Coast (from Tacoma to the Columbia River) and 450 miles from Duluth to Bismarck, and had earned ten million acres of the land grant. The mileage was small for the money that had been spent-about $\$ 40,000$ a mile.

The Northern Pacific went bankrupt after Jay Cooke and Company failed. It was later reorganized under a plan by which the bond holders could exchange their thirty million dollars' worth of bonds and unpaid interest for preferred stock. The railroad was thus relieved of a heavy fixed interest charge, and in 1876 its earnings exceeded its expenditures for the first time.

The failures of 1873 left North Dakota with inadequate rail connections. The Northern Pacific gave only a roundabout connection with St. Paul-by was of the Lake Superior and Mississippi Railroad, completed to Duluth in 1870. The St/ Paul and Pacific branch to Crookston had to use the Northern Pacific line from Glyndon to St. Paul. The St. Paul and Pacific mail line to Breckenridge did not help much because shallow water usually kept the steamboats away from that place. During the winter, trains did not run on the lines to Crookston and west from Fargo.

\section{THE BEGINNINGS OF SETTLEMENT}

Townsite speculators initiated the settlement of southern Dakota, beginning at Sioux Falls and Yankton in 1857 and 1858. Captain 
John B. S. Todd, a cousin of Mrs. Abraham (Mary Todd) Lincoln, was the most successful promoter. An army officer, he had come to Dakota with General W. S. Harney's expedition against the Sioux in 1855. Seeing the opportunities offered by the new country soon to be opened to settlement, he resigned his commission, became a sutler at Fort Randall, and formed a trading and land company. Todd put through the cession of land between the Big Sioux and Missouri rivers in 1858; the Indians ceded fifteen million acres for twelve cents an acre. He also had a large part in the creation of Dakota Territory by Congress in 1861 .

Todd himself was a straight-backed, dignified man who carried a silver-headed cane. He had the support of the "Moccasin Democrats" at Pembina and St. Joseph and became Dakota's first territorial delegate to Congress. His town, Yankton, became the territorial capital.

Settlement, though checked by the Minnesota Massacre of 1862, revived after the Civil War. When settlers had filled up Iowa, a boom began in southeastern Dakota. In 1868 a railroad connected Sioux City with eastern points, and a daily stage began to run between Sioux City and Yankton. By 1870 about twelve thousand people were living in a half-dozen counties in the southeastern corner of the territory.

On the Red River of the North, however, townsite boomers were not as important as freighters and soldiers in initiating a settlement. One group of boomers did put up a hotel and sawmill at Breckenridge, and David McCauley, the sutler at Fort Abercrombie, laid out McCauleyville across the river from the fort. But Fort Abercrombie, the river traffic, and the stage line brought in more population by making work for a number of men. In 1862 the fort had a garrison of eighty-two soldiers. Among the civilian population, some men put up hay for the fort and the stage stations. Some worked for the Hudson's Bay Company, which had a hotel and warehouses at Georgetown. Some kept the stage stations, and others drove the coaches and freight wagons. Some ran the steamboat or cut wood for it; others cut timber and built flatboats, A few began to farm on the Minnesota side of the river. In 1862 the Dakota Legislature created four counties in northern Dakota.

Indian troubles delayed settlement. In 1862 the Sioux of southern Minnesota went on the warpath in the bloody Minnesota Massacre. They stopped steamboat and stage traffic, killed settlers, burned their improvements, drove off their stock, and caused many of the survivors to leave the country.

After the Civil War, however, a number of developments prepared the way for the resumption of settlement. In treaties signed by the eastern Sioux in 1867 and by the western Sioux in 1868, those 
Indians accepted reservations and gave up, at least by implication, their claims to lands outside the Devils Lake, Traverse Lake, and Standing Rock reservations. In 1867 the Dakota Legislature again created Pembina County. It had not been represented in the legislature since 1864, a punishment for voting Democratic in the election of 1863. In 1867 surveying of township and section line began in northern Dakota.

In the summer of 1869 the Minnesota immigration board sent Hjelm Hansen to visit the Red River Valley. Hansen, a recent immigrant and well known in Norway for his part in the Thraniter movement to help the laboring classes, began to write letters on the Valley for Norwegian-language newspapers. Describing the opportunities offered by fertile land, free of stumps and stones, Hansen's letters attracted the attention of Norwegians to the Red River country. ${ }^{9}$

There were scattered farms on the Minnesota side of the Red River from Fort Abercrombie to Georgetown when Hansen visited the region in 1869, but the population in northern Dakota was only 2,405 in 1870, most of it in the St. Joseph-Pembina settlement. The first entry on public land in northern Dakota was not made until June 15, 1868, when Joseph Rolette entered the quarter section at the mouth of the Pembina River where Alexander Henry had built his fort in 1801 . By the end of 1870 there had been only twenty-eight entries on public land in northern Dakota, all of them around Pembina.

Settlement really began in 1871 . Five developments that year initiated it: (1) the St. Paul and Pacific Railroad reached the Red River at Breckenridge; (2) the Northern Pacific reached the river at Moorhead; (3) James J. Hill placed a second steamboat on the Red; (4) Russell Blakeley and his partner C. W. Carpenter extended the stage line from Georgetown to Pembina and Winnipeg; and (5) the federal government opened a land office at Pembina and surveyed section lines near Fargo and Wahpeton.

These developments quickly brought into existence a series or settlements. In 1871, Albert Chezik and Matthew Lorenz, young Bohemian immigrants, came from Muscoda, Wisconsin, to start a Bohemian settlement in Richland County. That summer, squatters began to occupy the land along the Red River where the Northern Pacific was to make its crossing. During the winter of 1871-1872, a rough, merry, hard-drinking gang of six hundred lived in tents,

\footnotetext{
9Johnson, “The Siege at Fort Abercrombie,” pp. 11-18, 31, 66-67; Axel Tollefson, "Historical Notes on the Norwegians in the Red River Valley," North Dakota Historical Society Collections, VII (1925), 134-137, 141-147; Luella J. Hall, "History of the Formation of Counties in North Dakota," North Dakota Historical Society Collections, V (1923), 178-179.
} 
dugouts, and log cabins by the river, "Fargo in the Timber," while General Thomas L. Rosser's Northern Pacific engineering crew and their families lived in thirty or forty tents to the west, "Fargo on the Prairie." There were other small settlements along the Red River at Breckenridge, McCauleyville, Georgetown, and other points. At the mouth of the Goose River a Norwegian owned the village of Caledonia and ran a store. a post office, and a hotel. At the foot of Goose Rapids stood Frog Point, with a Hudson's Bay Company warehouse and hotel.

Captain Alexander Griggs founded Grand Forks. Griggs and his flatboat men caught by an early freeze, spent the winter of 1870-1871 there. By 1872, Grand Forks had a boardinghouse, a hotel, a steamboat warehouse, three saloons, a stage station, a sawmill, and seven residences. In 1875, Griggs platted his claim into town lots, and George Walsh started the Plaindealer. By 1872 homesteaders had put up their claim shanties along the Red River all the way from Breckenridge to Grand Forks, but there were few signs of settlement from Grand Forks to Pembina.

When the stage began to run from Fort Abercrombie to Pembina and Winnipeg in September, 1871, a line of stage stations became centers for small settlements. The stage route went up the Minnesota side of the river from Fort Abercrombie to Georgetown, crossed on a ferry, and continued north. The stations, rough log huts with sod roofs and dirt floors, provided changes of horses and accommodations for travelers. The station keepers served pork and beans for fifty cents and charged the same amount for sleeping on the floor. Some had gardens and planted small fields. There were stage stations at Georgetown, Elm River, Kelley's Point, Pembina, and other places.

In the southern part of the Red River Valley, many of the early settlers were Norwegian immigrants. They first came to the Minnesota side but were soon crossing over to the Dakota side, which was less subject to flooding. The first Norwegians reached Cass County in 1869, Richland County in 1870, Traill County in 1871, and Grand Forks County in 1872. They did not come directly from Norway but from Norwegian settlements about St. Ansgar (Iowa), Coon Prairie (Wisconsin), and, especially, Fillmore and Goodhue counties in southern Minnesota.

They arrived in families, with ox teams, milk cows and household goods, choosing lands close to the Red River or on such streams as the Sheyenne and Goose. Such sites gave them timber for building and fuel and water for themselves and their stock. They would pick out their claims, build a sod house and stable, break a few acres with a plow, and put up some hay. Then the men might find work on a steamboat. The first corners planted potatoes and 
vegetables; wheat came a little later. Grasshoppers ravaged their crops, the worst invasions coming in 1872 and 1874. Gristmills at Caledonia and Grand Forks ground their grain. A Hudson's Bay Company store at Caledonia sold groceries on credit and treated its customers to beer. ${ }^{10}$

As the Northern Pacific built westward in 1872 and 1873, small villages sprang up at Valley City on the Sheyenne River, Jamestown on the James, and Bismarck on the Missouri. The first settlers in Valley City-called Worthington until 1881-arrived in 1872. Five or six Northern Pacific engineers and a handful of soldiers had spent the winter of 1871-1872 at Jamestown. The army built Fort Cross (later Fort Seward) there in June, 1872. That summer, businessmen and settlers came in, and on September 13 the first train entered the town.

Squatters, anticipating the coming of the Northern Pacific, spent the winter of 1871-1872 in the vicinity of what was soon to be Bismarck. In 1872 the army located Camp Greeley (later Camp Hancock) there to protect the construction crews. The first train, June 5 , 1873, brought the printing press for the Bismarck Tribune, the first newspaper in North Dakota.

These frontier towns, with a floating population, were rough and violent, but they showed vigorous growth. An army officer wrote his wife in 1876: "I have not fallen in love with Bismarck. It is a bad specimen of a frontier town, nobody incidentally expecting to stay here permanently, but hoping to make some money to get away with.”11

In the 1870's the Northern Pacific Railroad was making a determined effort to attract settlers and to sell its lands. It has set up land and immigration departments in 1871, and these established an agency in London, sent representatives abroad to organize colonies of emigrants, and distributed optimistic literature on Dakota all over Europe and the eastern United States. They offered railroad lands on attractive installment terms: 10 percent down and seven years to pay the balance. They also built large reception houses as temporary homes for land seekers at Duluth, Glyndon, and Brainerd, and offered free transportation to purchasers of Northern Pacific lands.

Dakota Territory also promoted settlement. In January, 1871, the legislature established a bureau of immigration under James S.

${ }^{10}$ William H. Elzinc, “Bohemians in Richland County,” North Dakota Historical Society Collections, IV (1913), 63-65; G. F. Keeney, "Fargo in the Timber,” North Dakota Historical Society Collections, I (1906), 318-321; “Frank Viets," North Dakota Historical Society Collections, VII (1925), 7173, 78; John Lee Coulter, "Industrial History of the Valley of the Red River of the North,” North Dakota Historical Society Collections, III (1910), 562-566.

${ }^{11}$ Robert C. Athearn (ed.), "A Winter Campaign against the Sioux," Mississippi Valley Historical Review, XXXV (September 1948), 275. 
Foster, a land dealer in Yankton. Foster, a hustler, combined his private and official activities. He distributed literature concerning the opportunities of Dakota in English and Swedish, mailed boomer editions of Yankton newspapers, and gave steamboat passage to Norway and Sweden to persons who would promote immigration. Before the legislature stopped appropriations for such work, Foster's successor had put out forty thousand pieces of literature in English, German, and Norwegian. Northern Dakota was given slight attention in all this, but un 1873 the territorial legislature divided all of it east of the Missouri River into twenty-seven counties in order to create an impression of settlement.

The Northern Pacific put forth a greater effort than the territory, but its results were disappointing. In fourteen months (June, 1872, to September, 1873), its land department sold only forty-six thousand acres, all in Minnesota. In the fall of `1872, its land commissioner, James B. Power, traveled the line from Fargo to the Sheyenne Valley. As far are he could see, the burned-over country, with its bleached buffalo bones and hard, dry soil, looked like a "barren desert." To find buyers for such land seemed to be a "hopeless task." "The name, Dakota, had a faraway sound," he recalled later. "It was an untried country, buyers were shy and settlers were timid."

In general, the depression which followed the Panic of 1873 slowed down settlement, but some advances were made before the Great Dakota Boom began in 1878. In 1874-1875, Traill and Mercer counties were created. In the spring of 1874, the federal government moved the Pembina land office to Fargo, and in the fall it opened a second land office at Bismarck. By them it had spent $\$ 100,000$ on surveying public land. That year, Moses K. Armstrong, the territorial delegate to Congress, stated, in proposing a division of the territory, that northern Dakota had much evidence of settlement: a population of ten thousand persons, two newspapers, a telegraph line, two hundred miles of railroad, much steamboat traffic, and United States Courts. ${ }^{12}$ A beginning had been made, but the great transformation to be wrought by settlement was yet to come.

${ }^{12}$ Herbert S. Schell, "Official Immigration Activities of Dakota Territory,” North Dakota Historical Quarterly, VII (October 1932), 8-12, 1920; James B. Power, "Bits of History Connected with the Early Days of the Northern Pacific Railway and the Organization of Its Land Department," North Dakota Historical Society Collections, III (1910), 342-343; Armstrong, The Early Empire Builders, pp. 204, 279, 386, 390. 


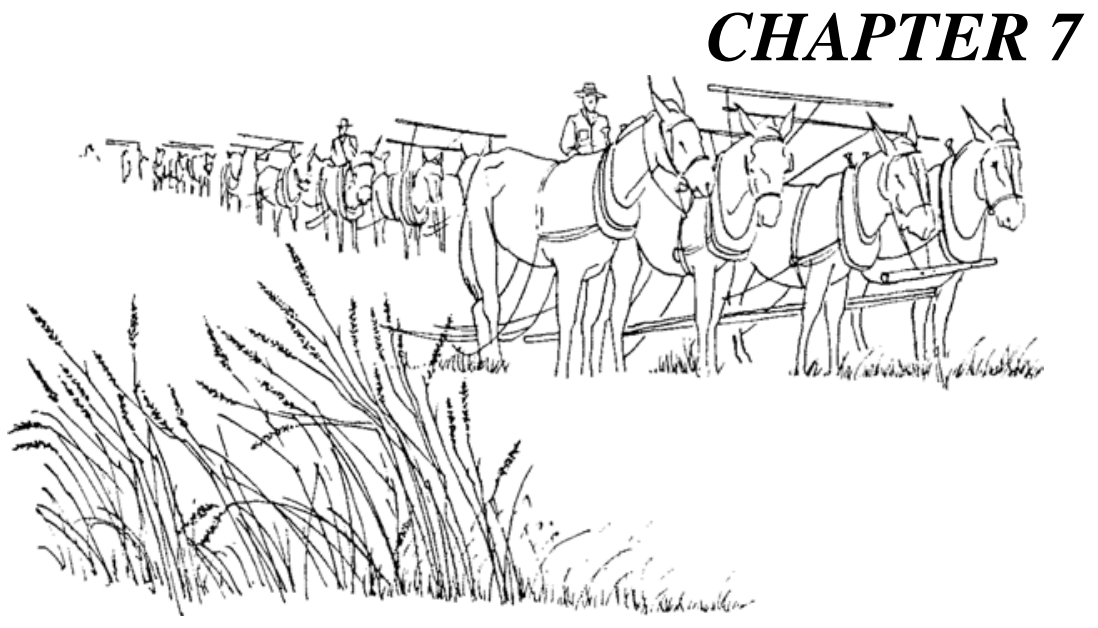

\section{The Great Dakota Boom}

THE HISTORY OF THE UNITED STATES has been to a large extent the history of the westward movement. For centuries Americans sought the opportunities offered by the frontier. "The existence of an area of free land," wrote Frederick Jackson Turner, "its continuous recession, and the advancement of American settlement westward, explain American development." Turner believed that the westward movement shaped American institutions, strengthened nationalism, hastened Americanization, encouraged individualism, and promoted democracy. He wrote: "The true point of view in the history of this nation is not the Atlantic coast, it is the Great West.”

As the nation became more industrialized and more urbanized, railroads enlarged the markets open to producers everywhere and growing cities enlarged the markets for farmers. Such fundamental changes increased both the extent and rate of western settlement, so that it moved forward in a series of booms. It was during the period of rapid industrialization in the 1880's that the Great Dakota Boom took place. In this decade occurred the most extensive railroad construction, the greatest immigration, the most expansion in manufacturing, and the fastest growth of cities that the nation had yet witnessed. All of these things influenced the Great Dakota Boom.

Two developments, however, were especially responsible for the boom: improvements in flour milling and the construction of railroads. New-process milling made Minneapolis the flour-milling center of the United States and created a market. Railroad construction made the Red River Valley the chief supplier of that market. As the hungry mills called 
for more and more hard spring wheat, James J. Hill threw his railroad across the black northern prairies and thousands of pioneers rushed in to take up the land. So it was that the spring-wheat country of northern Dakota was born a hinterland of the Twin Cities of Minneapolis and St. Paul.

Other factors helped to settle the empty grassland. Eastern states were filling up, and land values were rising. Capitalists, acquiring Northern Pacific lands, established bonanza farms. The prairies of the Red River Valley lay ready and waiting, without stone, stump, or tree to hinder the plow. A new wave of emigration came in from Norway. Manufacturers were turning out machines which could cultivate vast areas of level land. The locusts left; the rains came. The whole nation entered a period of economic growth, and with the return of optimism, capitalists were ready to venture their savings and lesser folk their lives in a new country. ${ }^{1}$

The results of this happy combination of circumstances were amazing. From 1878 to 1890 the population of North Dakota increased by more than 1,000 percent-from an estimated 16,000 to 191,000 . In a dozen years the boom, though it slackened in 1886, had brought farms, towns, newspapers, schools, churches, and settled ways of living to an empty grassland. Well before 1890 the new country was producing millions of bushels of wheat for the flour mills of Minneapolis. Wheat production, big farms, and railroads were fundamental adaptations to the nature of the cool, subhumid grassland lying at the center of the continent. Only they could make it productive of much wealth.

Yet there was another side. Much of the boom was a speculative, over rapid, unhealthy growth. North Dakota had too much of too many things too soon. Thousands left soon after they had come, and many of those who remained faced a hard struggle to escape bankruptcy.

\section{THE MINNEAPOLIS MARKET}

In the 1870's, Minneapolis became the largest milling center in the United States. Power from the Falls of St. Anthony, capital from trade and lumbering. the building of railroads to the northwest, a supply of hard spring wheat, the work or ingenious millers, and the use of new milling methods-all contributed to the achievement.

The new milling methods were of prime importance. The bran of spring wheat, unlike that of winter wheat, was brittle and with usual milling methods broke into fine pieces difficult to separate from the 
flour. Such flour was not as white and did not keep as well as flour from winter wheat. It naturally sold for less. By 1870, two country millers in southern Minnesota-Archibald of Dundas and Mowbray of Stocktonhad discovered that slow, loose grinding, separation of the bran, and regrinding prevented difficulties and produced a superior four. Minneapolis millers were eager to learn the secret, but Archibald and Mowbray closed their mills to strangers.

Finally, George C. Christian, the agent of an eastern flour firm, won the friendship of Archibald and learned the new process. Christian began to manufacture flour in the bankrupt Washburn B mill in Minneapolis. He secured the help of Edmund La Croix, who had received a scientific education in France. At Faribault, Minnesota, La Croix and his brother had built a purifier to separate the bran from the flour between grindings. Now he built such a purifier in Christian's mill and improved it with the addition of moving brushes for the underside of the bolting cloth to prevent it from clogging. Another Forward step was the use of rollers instead of millstones. In 1875, Archibald bought one or two sets of porcelain rollers imported from Europe-the first brought to America.

The "Minnesota Patent" flour turned out by the new methods was equal in color to the best winter-wheat flour and superior in strength because of its high gluten content. It sold above winter-wheat flour from the start and found a ready market. Until the middle 1880's, the Minneapolis mills had a virtual monopoly of the new process; their profits were high because the price of spring wheat did not rise as fast as the price of spring-wheat flour. Volume increased rapidly: 193,000 barrels in 1870, 843,000 in 1875, 2,051,840 in 1880, and 5,221,243 in 1885. The flour was marketed in England, Continental Europe, and the southern and southwestern parts of the United States.

Although Minnesota was a leading wheat state, much of its production was in the southern portion and went to Milwaukee and Chicago. There was a shortage of wheat in the region naturally tributary to Minneapolis; sometimes the mills had to shut down for lack of grain. Mills had been built so rapidly that the demand for wheat outran the supply. To eliminate competition in time of shortage and thus enlarge their profits, the millers formed an association which sent out agents to buy wheat for all the mills.

Before 1880, wheat raising in Minnesota began to shift northwest toward the Red River Valley, and the southern portion of the state turned to a more diversified agriculture. In 1877 railroad construction resumed in the northwest. In the 1870's the St. Paul and Pacific brought the Minneapolis mills most of their wheat. The Northern Pacific carried most of its wheat to Duluth, where a large elevator had been built in 
1871.

The wheat traffic grew rapidly. The Northern Pacific carried 144,000 bushels in 1874 and 5,700,000 in 1884. The St. Paul and Pacific and its successor, the St. Paul, Minneapolis and Manitoba, carried 2,300,000 bushels in 1874 and 20,700,000 in 1884. Duluth received a yearly average of $1,700,000$ bushels from 1876 to 1880 and an average of $9,200,000$ bushels from 1881 to 1885 . Minneapolis was the more important market: it received 5,300,000 bushels in 1876 and 32,900,000 bushels in 1885 .

For years the mills used all of the wheat shipped to Minneapolis. Then, in 1881, a few businessmen, against the opposition of the millers, organized the Minneapolis Chamber of Commerce as a grain exchange. The Chamber was an open market, and a small amount of wheat began to be shipped from Minneapolis. ${ }^{2}$ These developments in the marketing and milling of wheat stimulated a boom in northern Dakota by creating a strong demand for its most natural product and thus tying it to outside markets.

\section{BONAZA FARMING}

Bonanza farms focused the nation's attention on northern Dakota. Holders of the bankrupt Northern Pacific's bonds or preferred stock could exchange them at face value for the railroad's lands. Since the securities were selling for $\$ 14.00$ to $\$ 16.00$ per hundred-dollar share, the land, priced from $\$ 2.50$ to $\$ 10.00$ an acre, could be secured for a cash outlay of $37 \$$ to $\$ 1.65$ an acre. James B. Power, the railroad's land commissioner, feared that the land would pass into the hands of speculators and so produce no settlement or traffic for the road. He persuaded George W. Cass, president of the Northern Pacific, to demonstrate the value of the country by putting a large tract into production. He also persuaded Cass to encourage settlement by offering a discount to purchasers who would begin cultivation immediately.

Cass and Benjamin Cheney, a director of the railroad, established the first bonanza farm in the Red River Valley. They bought 13,440 acres of Northern Pacific land near Casselton and hired Oliver Dalrymple to manage it. A graduate of Yale Law School, Dalrymple was a man of ability. He had recently sold his large wheat farm near St. Paul and, full of enthusiasm over the new project, signed a contract to manage the Cass- Cheney purchase for a share of the profits and a title to part of the

${ }^{2}$ Henrietta M. Larson, The Wheat Market and the Farmer in Minnesota, 1858-1900, Columbia University Studies in History, Economics and Public Law, Vol. 122, No. 2 (New York, 1926), pp. 55-137. 
land. He sowed the first wheat in the spring of 1876.

The sale to Cass and Cheney initiated the rapid disposal of the Northern Pacific land grant. From 1873 (but mostly from 1875) to 1878, Power sold 1,700,000 acres in Minnesota and North Dakota to 2,988 purchasers for $\$ 7,900,000$, presumably in securities. By November 30 , 1880 , the sales amounted to $2,900,000$ acres for $\$ 11,600,000$. By the end of 1881 the Northern Pacific had sold most of its land for a hundred miles west of the Red River.

The largest purchasers were the Grandin brothers, bankers of Tidioute, Pennsylvania. They bought 26,000 acres near Mayville in 1875. With later purchases, some of government land and some for a cash outlay of only 41屯 an acre, they eventually owned 63,000 acres. Dalrymple managed 40,000 acres for them. Other large sales of Northern Pacific land were: the Dunlop purchase, 11,000 acres near Casselton; the Amenia and Sharon Land Company, 28,350 acres north of Casselton; the Antelope farm, 17,300 acres in Richland County; the Clarke farm, 9,900 acres in Burleigh County; the Spiritwood farm, 19,700 acres in Stutsman County; the Carrington and Casey purchases, 35,700 acres in Wells and Foster counties; the Steele and Troy farms, 10,000 acres in Kidder County; the Dwight farm in Richland County; and the Cooper farm, 34,000 acres in Barnes County.

Besides these bonanzas on Northern Pacific land, there were the Elk Valley, Emery, Larimore, and McCanna farms in Grand Forks County. In all, there were 91 farms of more than 3,000 acres, a minimum for a bonanza. The big operators bought some government land with military bounty land warrants and half-breed scrip; they also bought some land from homesteaders.

The scale of operation on bonanza farms was spectacular. They were adapted to a wheat country where extensive agriculture was required by scant rainfall and hence relatively low yields per acre. In 1879, Dalrymple was using 400 horses and mules, 100 broadcast seeders, 50 harrows, and 115 self-binding harvesters. He employed 400 men in the harvest rush. By 1880 he had charge of 55,000 acres, though less than half the land was under cultivation. ${ }^{3}$

Such an undertaking attracted much attention. In 1879, two members of the British Parliament visited Dalrymple's farms, and Finlay Dun, a manager of English estates, described them in letters to the London Times. Articles also appeared in national magazines-Harper's, the

\footnotetext{
${ }^{3}$ James B. Power, "Bits of History Connected with the Early Days of the Northern Pacific Railway and the Organization of Its Land Department," North Dakota Historical Society Collections, III (1910), 344-346.
} 
Atlantic, and Scribner's.

Dalrymple's methods were a model for others, He divided the land into huge tracts of five thousand acres. These were connected my telephone, then a new invention, and supervised by a superintendent and two foremen. Each division had two or more sets of buildings-houses, granaries, stables, and machine sheds. The principle homestead of each division had a barracks where fifty men slept in the busy season and a kitchen which could feed one hundred men. The cooks served three hot meals a day: meat, bread, puddings, cakes, tea, and coffee in generous portions. The men worked in gangs of fifteen or twenty under the watchful eye of a foreman on horseback. They were paid $\$ 15.00$ or $\$ 18.00$ a month, plus board, or in rush times from $\$ 1.75$ to $\$ 2.50$ a day.

Work followed the rhythm of the seasons. When winter broke at the end of March or in early April, the men were in the fields seeding. Soon the prairie was "one vast ocean of wheat.” After seeding came plowing of new land, and in July the men put up hay. When harvest began in August, brigades of a dozen or more twine binders would move across the fields in line, accompanied by a foreman on horseback, a wagon with twine and water, and an expert mechanic with spare parts. The day harvesting ended, threshing began. A threshing crew-twenty-three men, ten teams, a separator, and a steam engine-could thresh the grain from a section in a week. When the threshing was finished, the superintendent discharged many of his crew and set the rest to plowing. They turned the stubble and gave the new braking a second plowing called "backsetting."

The big wheat farms were worked by a transient labor force-many for seeding. Then fewer for haying and plowing, many more for the harvest, and even more for the threshing, then fewer for fall plowing, and only a handful to care for the stock during the winter. Some men came from the lumber camps of Minnesota and Wisconsin, where they worked during the winter; some were college students earning next term's expenses; many were Norwegian and German homesteaders getting some cash to carry them through until their own land produced a crop. The big farms, though adapted to the country, could not, with their transient labor, contribute much to the development of community life. There were few women and children on them. ${ }^{4}$

Almost all of the bonanzas had been established by 1885 . They were profitable enterprises. The cost of wheat production was low (around forty cents a bushel) and the selling price was high (about a dollar a

\footnotetext{
${ }^{4}$ Bertha L. Heilbron, “A British Agricultural Expert in the Red River Valley, 1879,” North Dakota Historical Quarterly, VII (January-April 1933), 94-100.
} 
bushel). The big farms could buy lumber, food, and farm implements at wholesale prices; they got rebates from the railroads; they had capital for new machines. They concentrated on wheat, a cash crop, and neglected gardens, orchards, poultry, pigs, and cattle. Eastern North Dakota became the land of No. 1 hard, a new grade created on the Minneapolis grain exchange in 1882. "Tons and tons of hams, shoulders and spiced roll, and pork in many forms and canned meats of every kind," wrote a Fargo editor in 1883, "were shipped in. Tons of cheese, butter, and butter substitutes were sold to the large wheat farms." Wheat became a mania: the doctors, lawyers, merchants, and speculators of the towns were all raising wheat.

Eventually, proprietors broke up many of the bonanza farms. In 1893 the Amenia and Sharon Land Company began to rent its holdings on shares in units ranging from a half-section to a section in size. In 1896, Dalrymple, Cass, Cheney, and the Grandins dissolved their partnership, and Dalrymple came into possession of 30,000 acres, which his heirs sold in 1918. The bonanzas never dominated; the average North Dakota farm in 1890 was only 72 acres. But they did stimulate small farmers to enlarge their holdings, and they did advertise the new country. ${ }^{5}$

\section{RAILROAD EXPANSION}

Although the big farms were spectacular, it was railroad construction that made possible both the rise of Minneapolis as the milling center of the United States and the rapid settlement of eastern North Dakota. When the Panic of 1873 stopped construction, the Red River Valley possessed inadequate connections with the Twin Cities.

The railroads made some extensions near the end of the depression. In 1878, for example, the Northern Pacific built south from Brainerd to Sauk Rapids, where it met the St. Paul and Pacific and acquired a connection with St. Paul. Also in 1878, a change in the control of the St. Paul and Pacific opened the way to great achievements in railroad construction for North Dakota. The Dutch bondholders of that bankrupt line wanted it completed, but they themselves would invest no more money. A group of four ambitious entrepreneurs wanted to get control of the road: Donald A. Smith, governor of the Hudson's Bay Company, who was building a branch of the Canadian Pacific toward Emerson, George Stephen, president of the Bank of Montreal, Norman W. Kittson, and James J. Hill. Hill was the leader of the group; he and Kittson had long been engaged in steamboating on the Red River of the North.

${ }^{5}$ Alva H. Benton, “Large Land Holdings in North Dakota," Journal of Land and Public Utility Economics, I (October 1925), 406-409. 
On March 13, 1878, the four signed an agreement with the Dutch bondholders. Before Hill and his associates could take over the railroad, they had to find money $(\$ 1,016,300$, or about $\$ 8,000$ per mile) for the rapid completion of its lines from Crookston to St. Vincent and from Melrose to Alexandria. This was necessary to save the land grant. On their part, the bondholders agreed to scale down their claims and exchange them for the bonds and stocks of a new company which would take over the railroad and its land grant. The securities of the new company were not to exceed \$12,000 per mile of track. The old St. Paul and Pacific had a bonded debt of more than $\$ 60,000$ per mile.

In that year, Hill, then forty, with a massive, shaggy head and iron determination, accomplished great things. With the railroad still under the legal control of the receiver, he managed, in one way or another, to secure rails and laborers for the necessary construction. Pushing men to the limit and laying a mile of track a day, he drove the road toward St. Vincent. The weather grew cold as fall wore into early winter. Hill himself would get down out of his private car, call the men by their first names, walk a grade, and watch the work, inspiring them with his own zeal. On December 2, 1878, the St. Paul and Pacific met the Canadian Pacific at St. Vincent; the 800,000-acre land grant for that portion was saved, and there was a through line from St. Paul to Winnipeg. The same season, Hill also built the railroad from Melrose through Alexandria to Fergus Falls, a miracle of rapid, economical construction.

On May 23, 1879, Hill and his associates organized the St. Paul, Minneapolis and Manitoba (commonly called the Manitoba) and took over the property of the old St. Paul and Pacific. For a modest sum, but all they could scrape together, Hill, Smith, Stephen, and Kittson had control of a railroad with 657 miles of track, a moderate debt, and nearly two million acres of land in Minnesota (by the end of 1877 the St. Paul and Pacific had sold 458,865 acres of land for \$3,651,641, or an average of $\$ 7.94$ an acre). ${ }^{6}$

Hill, the manager of the new railroad, became a central figure in the opening of North Dakota. His control of the St. Paul, Minneapolis and Manitoba was truly fortunate, for he knew the Red River country and believed in its future. Though a resident of St. Paul, he was not an outsider in the way the earlier promoters had been; Hill was identified with the Red River Valley. The valley and later the northern part of the state were to become "Hill country." Hill himself, with his passion for thoroughness, his iron will, and his farsightedness, was to become a great

${ }^{6}$ William W. Folwell, A History of Minnesota (4 vols.; St. Paul: Minnesota Historical Society, 1921-1930), III, 460-462. 
railroad man.

And railroads were what North Dakota needed more than anything else. Only railroads could tie it to the outside world. So it was that just as the Great Dakota Boom was beginning, the era of easygoing corruption and mismanagement ended on the railroad that was to play the leading role in the history of the state. The very first year showed the promise of the future: in 1879 the Manitoba earned a million dollars over its expenses.

As the boom progressed in the early 1880's, Hill supplied the North Dakota side of the Red River Valley with railroads. He brought the Manitoba from Fisher's Landing to Grand Forks in the spring of 1880 across a bridge built during the winter-and from that year to 1884 he built two lines running north and south through the valley and two lines running west. One extended north from Fargo through Grand Forks, Grafton, and St. Thomas to Neche on the Canadian boundary in 1882. A second line, paralleling it farther west, ran north from · Wahpeton through Casselton, Mayville, and Larimore to Park River in 1884 and Langdon in 1887. A branch of this second line connected Casselton and Hope. A third line ran west from Wahpeton; a fourth, which was to become the main line of the Manitoba, extended west from Grand Forks to Devils Lake by 1883.

Hill continued westward. In the south he built a branch from his line in Minnesota across Richland, Sargent, and Dickey counties to Ellendale. In the north he built from Devils Lake to Minot in 1886 and to Great Falls, Montana, in 1887. That was an exciting year. Determined to reach Great Falls in a single season, Hill gathered men and materials in a huge camp at Minot-8,000 men and 3,300 teams for grading alone, and another 650 men and 225 teams for laying track and building bridges. When they reached Great Falls on October 15, they had averaged three and a quarter miles of track per day.

By then the line west of Devils Lake had two branches reaching north, one to Cando and the other to Bottineau. By 1888 the Manitoba had 998 miles of track in North Dakota. Hill had overtaken the Northern Pacific, which had 814 miles, and his lines, more than the Northern Pacific's, served the most settled portion, the Red River Valley. ${ }^{7}$

Yet the Northern Pacific was important. In 1875 a new president, Frederick Billings, had put through a plan of reorganization by which the railroad was sold under foreclosure and the bondholders turned in thirty million dollars' worth of bonds and received in their stead forty-

${ }^{7}$ A map in Lewis F. Crawford, History of North Dakota (3 vols.; Chicago: American Historical Society, Inc., 1931), I, 256, shows construction by years. 
two million dollars' worth of preferred stock. In 1876 the railroad's earnings exceeded its expenditures for the first time. With the return of good times, it secured capital for its completion. In 1879 it crossed the Missouri River and built west, completing a line to the Pacific in 1883. In 1882 it built a million-dollar bridge across the Missouri at Bismarck.

To avoid competition, the Northern Pacific and the Manitoba divided North Dakota between them. In June, 1882, they reached an agreement on branch lines. The Northern Pacific had built north from Casselton to Mayville and planned to extend the branch to the Canadian boundary parallel to the Manitoba line. It now sold this branch to the Manitoba and bought from the Manitoba the line from Sauk Rapids to St. Paul and the one running west from Wahpeton. The Wahpeton line would extend a Northern Pacific branch then building from Wadena to Breckenridge. Earlier that spring, the two railroads had reached an agreement to divide the traffic between them and had restored rates, which had earlier been cut, to their former level.

In the early 1880's the Northern Pacific built four branches: two north and two south of its main line. In 1882-1883 the Fargo and Southwestern, a subsidiary of the Northern Pacific, ran a line southwest from Fargo through Lisbon to La Moure on the James River. In 1883 the Northern Pacific built a branch north to Cooperstown, and from 1883 to 1885 it built branches north and south from Jamestown along the James River Valley. By 1891 these extended from Oakes to Leeds. The branches served the Drift Prairie, west of the Red River Valley, and also the southeastern section of the state. Except in Cass and Richland counties, they did not compete with the Manitoba. In 1887, however, the Northern Pacific built a branch to Winnipeg which entered North Dakota at Grand Forks and paralleled the Manitoba lines to the Canadian boundary.

Three other railroads entered North Dakota during the territorial period. In 1886 a fourteen-mile branch of the Chicago and North Western was built from southern Dakota to Oakes. The Soo (Minneapolis, St. Paul and Sault Ste Marie) laid ninety-nine miles of track in the southeastern corner of North Dakota. The Chicago, Milwaukee and St. Paul had 118 miles, including a line to Fargo from Ortonville, Minnesota, and another to Edgeley.

The railroads had made great strides by 1890 . When the boom began in 1878, North Dakota had only 200 miles of track-the main line of the Northern Pacific from Fargo to Bismarck. The great building years were the early l880's, but much was done after the boom had died. In 1887, for example, 386 miles of track were laid. By 1890, North Dakota had 2,093 miles of railroad, a tenfold increase, and some parts of the Red 
River Valley were actually oversupplied. This gave the state about 110 miles of railroad for every 10,000 people. In comparison, the United States had about 26 miles of track per 10,000 persons. The railroads of North Dakota represented an investment of twenty-five or thirty million dollars in outside capital, a part of the cost of overcoming the remoteness of the new country. ${ }^{8}$

\section{PROMOTING DAKOTA TERRITORY}

Promotion and advertising stimulated the Great Dakota Boom. Some of the railroads had land to sell, and all of them needed to build up traffic. Both the Manitoba and the Northern Pacific had land grants in Minnesota, and the Northern Pacific had been given nearly a fourth of North Dakota. They offered their lands on easy terms and sought in every way to develop the new country. In his old age Hill recalled with pride that he was "not afraid to open up the country, making it possible for people to live upon the land, cultivate it, and make homes for themselves."

In 1879 the Northern Pacific began a new advertising campaign. It sent agents to the eastern United States and reopened its general European agency in London. It advertised in newspapers and distributed literature in many languages-632,590 pieces from its Liverpool office alone in 1882. That year it had 831 local agents in the British Isles and 124 general agents in Norway, Sweden, Denmark, Holland, Switzerland, and Germany. In 1884 it was advertising in 200 American and Canadian newspapers, 68 German papers, and 32 Scandinavian American papers. James B. Power directed much of the promotional work. He ran the Northern Pacific's land department from 1873 to 1881, then held a similar position with the Manitoba until 1886. In 1880 he fitted out a baggage car as a traveling agricultural exhibit of the products of northern Dakota and took it around to fairs in the East. ${ }^{9}$

The territorial government itself, however, did no promotional work during the boom. It had dropped its bureau of immigration in 1877, and not until 1885 did the legislature again provide for such an agency. That year, O. H. Holt, the private secretary of Governor Gilbert Pierce, put out a booklet entitled Dakota. Some fifty thousand copies were printed.

${ }^{8}$ Dakota Territory Board of Railroad Commissioners, Annual Report, 1889, p. 4; Dakota Territory Commissioner of Immigration, The State of North Dakota, 1889, p. 85.

${ }^{9}$ James B. Hedges, "The Colonization Work of the Northern Pacific Railroad,” Mississippi Valley Historical Review, XIII (December 1926), 329331. 
In the same year, Alexander McKenzie organized an exhibit on the territory at the New Orleans World's Industrial Exposition. After 1885 the commissioner of immigration issued thousands of pieces of literature. The most elaborate was a 500-page book entitled Resources of Dakota; twenty-five thousand copies were printed. In 1890, North Dakota abolished the office to save money.

The Resources of Dakota and other literature pressed home the advantages of the new country: the winters were not too severe, the climate was healthful, the rainfall adequate, the soil fertile, and free land still available. It also boasted of Dakota's railroads, schools, and newspapers-more of each than were possessed by many states. Pioneering in the railroad age had lost some of its hardships.

\section{A FLOOD OF PIONEERS}

Railroads made possible rapid settlement, and during the boom, large numbers of newcomers rushed in. Wrote one pioneer:

Language cannot exaggerate the rapidity with which these communities are built up. You may stand ankle deep in the short grass of the uninhabited wilderness; next month a mixed train will glide over the waste and stop at some point where the railroad has decided to locate a town. Men, women, and children will jump out of the cars and their chattels will be tumbled out after them. From that moment the building begins.

In the spring of 1882 the yards of the Northern Pacific and the Manitoba at St. Paul held hundreds of emigrant cars waiting to be moved to Dakota. The railroads scheduled special trains to handle the rush, but often the new settlers filled all the seats, and many had to stand. Not all rode the trains. Many a pioneer came trudging along over the prairie with his oxen, his wagon laden with tent, plow, a few handy tools, some simple furniture, the whole mounted with wife and children, while a cow or two and perhaps some pigs brought up the rear. In many places the newcomers quickly dotted the empty prairie with their farm homes.

The towns grew amazingly fast. Mandan was laid out early in 1879 around the depot and roundhouse of the Northern Pacific; by May it had a hundred buildings. In eighteen months Devils Lake became a town of a thousand people with a government, a fire department, a United States land office, substantial brick business places, and handsome residences. When the Manitoba reached Minot in the fall of 1886, the new town grew to a population of one thousand within five weeks. The pioneers lived in tents and canvas-covered shacks.

To reduce expenses and lessen privation, many settlers arrived in 
colonies. In an eastern or European community some influential men, often aided by Northern Pacific agents, would organize a colonization society, drawing up articles of association and collecting a membership fee of ten or twenty dollars from friends and neighbors interested in western settlement. After a committee had explored for suitable land, made arrangements for transportation, and secured the help of the railroad, a colony of fifty or a hundred families would travel to the new location. Newspapers mentioned a colony from Lansing, Michigan, in McIntosh County, a German Russian colony of fifty families in Morton County, a colony of seventy-five Dutch families in Emmons County, an Iowa colony in Logan County, a Polish colony of one hundred families at Crystal Springs in Kidder County, and many others. ${ }^{10}$

Of those settlers who were immigrants, most came from Norway and Canada, but there were also some from Germany, England and Ireland, Sweden, and Russia. By 1890 the foreign-born made up 43 percent of the population; they and the children of foreign parentage born in the United States made up 69 percent of the state's population. In 1890, of the 81,461 foreign-born in North Dakota, 25,773 had come from Norway, 23,045 from Canada, 8,943 from Germany, 8,174 from England and Ireland, 5,583 from Sweden, and 4,098 from Russia. Over half of those from Russia (the German Russians) lived in McIntosh County. Because the immigrants came in such large numbers and because they, unlike many settlers of older American stock, came to make permanent homes in the new country, they and their children played the leading role in the settlement of North Dakota.

Many of the immigrants had spent some time in Minnesota, Iowa, or Wisconsin before moving on to North Dakota. The Norwegians came from settlements in Fillmore and Houston counties in southern Minnesota, from St. Ansgar and Decorah, Iowa, and from Rock Prairie, Muskego, and Koshkonong, Wisconsin.

Many of the Canadian immigrants were Scots. They frequently became leaders. Among the fur traders, such Scots as Alexander Henry, Robert Dickson, Norman W. Kittson, and Kenneth McKenzie had distinguished themselves. In the era of settlement, James J. Hill, Alexander Griggs, William Budge, and Alexander McKenzie had wide influence. Later, Frank McVey and John Macnie, distinguished men at the University of North Dakota, and Dr. James Grassick, a Grand Forks physician, were examples of Scottish leadership.

Of the native American population in 1890, nearly 57 percent had 
been born in other states. The largest numbers had come from Minnesota $(13,052)$, Wisconsin $(9,869)$, New York $(6,785)$, Iowa $(4,559)$, Michigan $(3,973)$, Illinois $(3,684)$, and Ohio $(3,192)$, but natives of many other states were living in North Dakota.

By 1890 the pioneers had solidly occupied the Red River Valley and had spread thinly over most of the Drift Prairie. They held, however, only small portions of the Missouri Plateau. Almost half the population lived in the six counties of the Red River Valley. These counties, except for Richland, had a larger population in the countryside, that is, outside places of a thousand or more persons, in 1890 than they were to have in 1960. The pioneers also had a good hold on the counties just to the west of the valley and on the two tiers of counties nearest the southern boundary of the state and east of the Missouri River.

The coming of settlers naturally put pressure upon the Indian lands. The Turtle Mountain band of Chippewas, most of them actually halfbreeds, claimed the country north and west of Devils Lake, and the United States government had at first recognized their claim. When settlers began to move into the area in 1882, the Indians resented their coming and warned them to leave. Thereupon, troops from Fort Totten threatened the Indians, and the Indian Bureau had the General Land Office restore the region to the public domain without consulting the Turtle Mountain band.

The area involved was about nine million acres, or one-fifth of North Dakota. A delegation of Indians went to Washington to protest the loss of the land, and the President, by an executive order of December 21, 1882, set aside most of what was to become Rolette County as a reservation. In 1883, Congress appropriated ten thousand dollars to aid the Indians in establishing themselves on individual farms. On August 24, 1883, the government opened a land office at Devils Lake. Soon many of the half-breeds were living off the reservation and were making good progress in starting farms and build ng houses.

Only about twenty-five families of full-bloods wanted to live on a reservation and not take individual allotments of land. In 1884 the President reduced the reservation to two townships just east of the Turtle Mountains, ample room for the full-bloods.

Although their old hunting life had passed away, the half-breeds resented the coming of the white settlers. There was trouble, but no fighting, in 1889 when county officers took some cattle from the halfbreeds for nonpayment of taxes. The federal government had issued the cattle, but the county taxed them. Trouble came again in 1891 when the Indians refused to pay a poll tax and fortified themselves in an old log house before they gave up to a superior force. 
On October 22, 1892, Porter J. McCumber, later United States senator from North Dakota, signed an important agreement with the Turtle Mountain band. The United States agreed to pay the Indians $\$ 1,000,000$ in annual payments of $\$ 50,000$ for twenty years. The payments were to be made in food, clothing, bedding, houses, cattle, horses, agricultural implements, and seed. The band itself, not individuals who owned farms off the reservation, gave up all claims to land outside the reservation. Members of the band could take up homesteads off the reservation without losing their share of tribal funds. Thus the Turtle Mountain Chippewas formally ceded a large portion of north-central North Dakota ten years after it had actually been taken away from them and opened to settlement. ${ }^{11}$

\section{TAKING UP LAND}

Those who came to North Dakota to acquire land might buy it from the Northern Pacific Railroad or from the federal government, or they might secure it free by making certain improvements under terms of the Homestead and Timber Culture acts.

The Northern Pacific offered its lands on easy terms. At first it asked only a minimum of $\$ 2.50$ an acre, and while it later raised the minimum, it gave a 25 percent discount on land cultivated within two years. In 1889 it was offering its agricultural lands at prices ranging from $\$ 3.00$ to $\$ 6.00$ an acre and its grazing lands at $\$ 1.25$ to $\$ 4.00$. It allowed the purchaser five or ten years to pay, charging 7 percent interest on the unpaid balance.

The United States government sold its lands under the Pre-emption Law. A settler who did not own 320 acres in any state or territory could buy 160 acres for $\$ 1.25$ an acre ( $\$ 2.50$ if it lay with in the Northern Pacific land grant, where the alternate sections had been retained by the government). Before making the purchase, he must have lived on the land for six months and made certain improvements.

The federal government also gave away land for settlement or for the planting of trees. Under the Homestead Act, the settler was given 160 acres for living on the land and cultivating a portion of it for five years. He paid fees of fourteen dollars (eighteen dollars if it was within railroad land grant) when he made the original entry on the land and four dollars (eight with in the land grant) when he made final proof of title. By a law passed in 1880, a homesteader could, after six months' residence, commute the homestead, that is, secure title immediately, by paying cash

${ }^{11}$ John Hesketh, "History of the Turtle Mountain Chippewa," North Dakota Historical Society Collections, V (1923), 112-114. 
at the same rate as under the Pre-emption Law.

Under terms of the Timber Culture Act of 1873, the settler could acquire 160 acres of land by planting 10 acres of it in trees. When making final proof on a tree claim at the end of eight years. he had to have 675 living trees on each of the ten acres. He paid an entry fee of fourteen dollars but did not have to satisfy a residence requirement.

Under the Pre-emption, Homestead, and Timber Culture laws, a settler might file on 480 acres, but not at the same time, for both the Pre-emption and Homestead acts required residence. He would probably file on a pre-emption first and after acquiring title, file on a homestead. Probably many homesteads also filed on tree claims, and probably many had secured pre-emptions before they filed on homesteads.

In the boom years, land passed rapidly from the Northern Pacific and the federal government into the hands of the newcomers pouring into the country. By 1890 the Northern Pacific had sold between 3,000,000 and $4,000,000$ acres of its $10,700,000$-acre land grant within the state. In the year ending June 30, 1884, it sold 268,395 acres for an average of \$4.94 per acre east of the Missouri and $\$ 3.18$ west of the river. That same year, it sold 68 town lots cast of the river for an average of $\$ 51.10$ per lot and 551 lots west of the river for an average of $\$ 7.31 .^{12}$

Many more persons had filed on government land than had purchased land from the railroad. From 1871, when the Pembina land office was opened, to June 30, 1890, about 39,000 persons filed original homestead entries on more than 6,000,000 acres in North Dakota, and about 29,000 persons filed original tree-claim entries on over 4,500,000 acres. Most of them never acquired title to the land they had filed on. By 1895 only about 16,000 homesteaders who had filed original entries before 1890 had made final proof by meeting the residence requirement; they received title to about 2,400,000 acres. Only 8,000 of the settlers who made tree-claim entries ever proved up; they received title to about 1,200,000 acres.

Cash purchase from the federal government was more important than free land for settlement and improvement. From 1871 to 1890 about 19,500 settlers bought 3,000,000 acres under the Pre-emption Law; about 9,500 homesteaders commuted their entries on 1,600,000 acres by paying cash.

Many others abandoned their efforts to secure title to government land. By 1890 some 13,500 homesteaders had abandoned their original

\footnotetext{
${ }^{12}$ Hiram M. Drache, "The Economic Aspects of the Northern Pacific in North Dakota,” (Seminar paper, Department of History, University of North Dakota, 1959), pp. 43-45.
} 
entries on 2,000,000 acres; some 21,000 settlers abandoned their original tree-claim entries on about 3,200,000 acres.

Thus up to 1890 more newcomers had acquired land by purchase than by taking advantage of the government offer of free land. It was a revealing choice. They had bought about 8,000,000 acres (4,600,000 from the government and 3,500,000 from the Northern Pacific). They had earned or had begun to earn by settlement only 3,600,000 acres. But they had also begun to earn by settlement and had then given up, or would soon give up, some 5,300,000 acres. ${ }^{13}$

Two things are clear. One is that many people who came to North Dakota soon gave up and left. The number doubtless included not only those who abandoned their homesteads but many of those who commuted their homesteads by a cash payment or who bought land under the Pre-emption Law. The other conclusion, a sort of corollary to the first, is that many who acquired land in the boom were speculators who had no intention of staying. Not all, of course, who purchased land were speculators or were about to leave the country. Purchase enabled the settler to use the land at once as security for a loan, an advantage denied the homesteader until he had completed five years of residence.

There was a great discrepancy between the amount of land acquired and the amount of land in farms. By 1890 settlers or speculators had acquired, or had begun to acquire on original entries on which they were actually to make final proof, some $11,600,000$ acres. But in that year North Dakota had only 7,700,000 acres in farms. Thus speculators held some 4,000,000 acres not in farms. Moreover, the bonanza farms were often speculative holdings. In 1881, E. P. Wells noted that speculators held 400,000 acres in Stutsman County alone.

During the boom, the value of land increased very rapidly and made speculation profitable. By 1883 farm lands in Cass County within five miles of the railroad were sold at $\$ 15.00$ to $\$ 25.00$ an acre, while unimproved lands within ten miles of the railroad sold for $\$ 8.00$ to $\$ 15.00$. Eight years earlier, these lands could have been purchased from the Northern Pacific, with its depreciated securities, for a cash outlay of $371 / 2$ to $\$ 1.65$ an acre or from the government for $\$ 2.50$.

Speculators also sought profits in town lots. Railroads established townsites when they located their stations. A railroad, or insiders close to it (some directors of the Northern Pacific were land speculators), frequently owned the land on which a town was to be built. James J. Hill, for example, tipped off his friend Budd Reeve about the location of

${ }^{13}$ Compiled from annual reports of the Commissioner of the General Land Office of the United States. 
Buxton, and Reeve bought the land from the government for $\$ 2.50$ an acre.

The prospect of a rapid rise in land values naturally attracted speculators, and the first boom of a townsite often came before the settlement of the surrounding country justified a town. "Real estate is the predominating craze just now," reported the Fargo Argus on September 24, 1881, "and every other man you meet will be found to be an agent for the sale of some property." That fall, promoters sold ten thousand dollars' worth of lots in Steele within two months after it had been surveyed from a wheat field. At an auction on October 27, 1882, the Northern Pacific sold seventy thousand dollars' worth of lots in the new townsite of La Moure. The auction was held in Jamestown, for the railroad did not reach La Moure until the following year. There were few settlers in the region, and the first building in La Moure was not put up until April, 1883. By July 27 there were sixty-nine buildings under construction.

A spirit of optimism infected everyone. "Step off the train at any station," advised one speculator, "shut your eyes, walk to the townsite, stop anywhere and pay the owner his price... and you can't miss it.” As a coat of arms for Dakota, the Minneapolis Morning Call suggested "a real estate agent rampant supporting a corner lot, à la Atlas, on a field verdant dotted with railroad spikes and champagne bottles, alternately, a drove of railroad stock being watered in the distance.” 14

Real estate values skyrocketed in Fargo. In June, 1880, the Northern Pacific auctioned off thirty-four lots for $\$ 30,230$ in an hour's spirited bidding. In 1882 real estate transactions in Fargo amounted to $\$ 2,100,000$, and James Holes was offered \$100,000 for his 210-acre farm on the edge of town. That year in Jamestown, the James River National Bank paid \$2,700 for a lot on which to erect its new building; the same lot had sold for $\$ 25$ in 1878 . The story ran that a dozen men in Jamestown had each made from $\$ 75,000$ to $\$ 150,000$ in town-lot speculation in the last three years.

\section{THE END OF THE BOOM}

Pushed along by the speculative fever, the boom rose gradually to a peak in 1883 and then gently subsided. Settlement had continued at a low rate for some years after 1873 . In 1878 it began to rise rapidly when 1,197 people filed on homesteads as compared with 232 the year before.

${ }^{14}$ Fargo Argus, September 24, 1881, quoted in Drache, "Economic Aspects,” p. 14. Professor Drache found much evidence of land speculation in the Argus. 
The peak of homesteading came in the fiscal year ending June 30, 1882, when 5,579 persons filed original entries on 864,810 acres. Probably some 40,000 persons came to the Red River Valley in 1882.

As the boom neared its peak, many began to purchase government land instead of taking homesteads. In the fiscal year ending June 30, 1884, 3,863 persons bought 603,799 acres under the Pre-emption Law; this was the year of the largest pre-emption purchases. Many also commuted their homestead claims by cash payments. In fiscal 1833 there were 5,094 original homestead entries and 2,506 commuted homesteads. In that same fiscal year, settlers and speculators filed on 


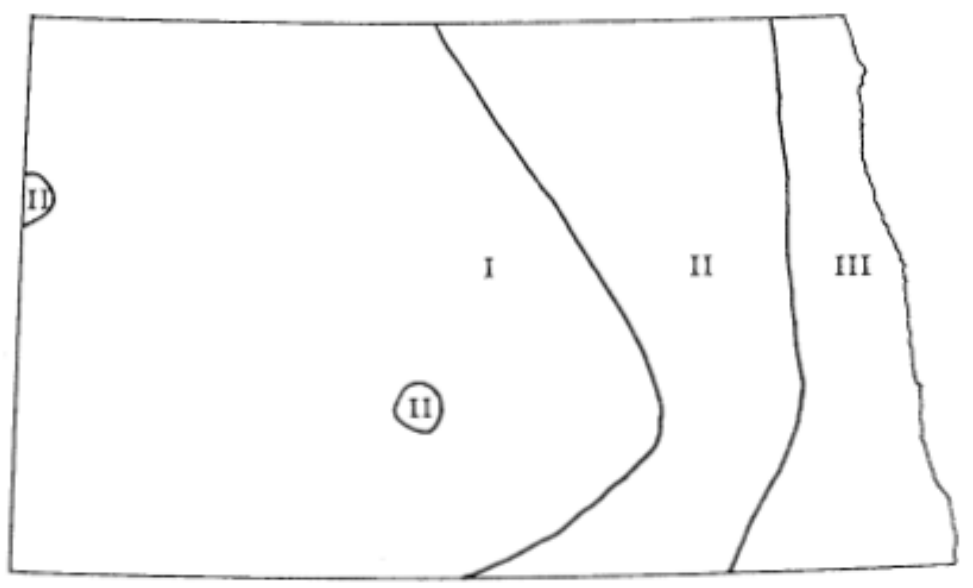

EXTENT OF SETTLEMENT, 1890

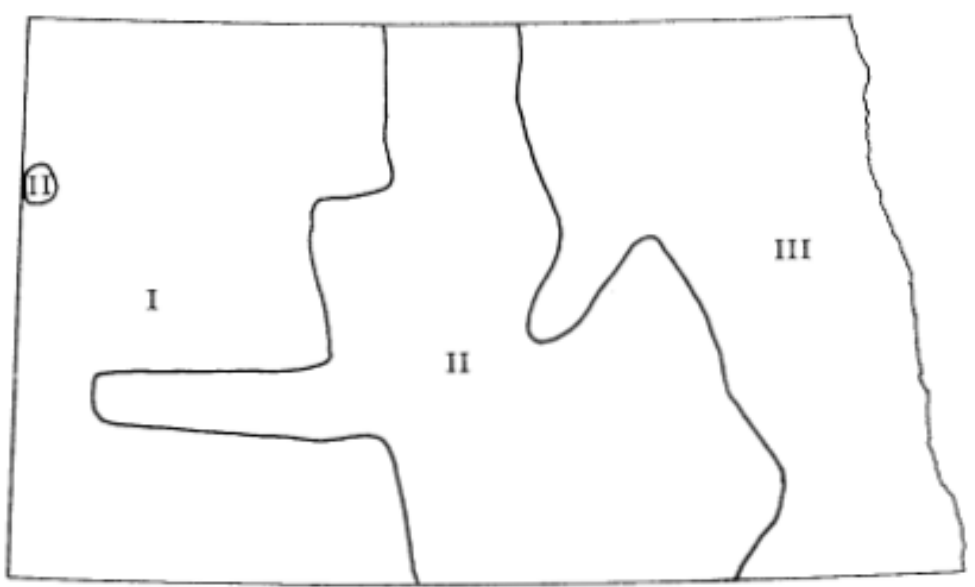

EXTENT OF SETTLEMENT, 1900

I Less than 2 inhabitants per square mile

II From 2 to 6 inhabitants per square mile

III From 6 to 18 inhabitants per square mile 
1,759,601 acres under the Homestead, Timber Culture, and Pre-emption acts, the largest acreage of the boom years but only slightly above the amount filed on in fiscal 1882 and 1834.

When the boom slackened, cash purchases fell off much more rapidly than did original homestead entries. By 1386 the boom was over, but settlement continued as some two thousand newcomers filed original entries on homesteads each year until 1890, when only 981 filed. Many people left North Dakota after the boom. The population, which had risen from 37,000 in 1880 to 152,000 in 1885 , grew to only 191,000 in 1890. If the census taken by the territorial government in 1885 was correct, most of the principal towns and some of the more populous counties lost population between 1885 and 1890. Fargo, for example, was credited with 7,394 in 1885 and with only 5,664 in 1890. Grand Forks declined from 6,516 in 1885 to 4,979 in 1890, Bismarck from 3,167 to 2,186, Jamestown from 2,382 to 2,296, Lisbon from 1,700 to 935, Wahpeton from 1,540 to 1,510, and La Moure from 358 to 309. Billings County declined from 737 in 1885 to 170 in 1890, Burleigh County from 5,354 to 4,247, Cass County from 21,085 to 19,613, Grand Forks County from 20,454 to 18,357, and Stutsman County from 5,632 to $5,266 .{ }^{15}$ However, the territorial census takers, moved by the boom spirit, may have inflated the population figures in 1835.

As hopes collapsed in Bismarck after the boom of 1883, which followed acquisition of the territorial capital, some of the five banks soon liquidated. Real estate values fell, and lots went begging; many houses stood vacant. money was scarce, and merchants fought bitterly for customers.

Some towns died completely. One of them was Mardell in Griggs County. Surveyed in 18i12, it soon acquired a hotel (twenty-four rooms), a blacksmith shop, a dry-goods store, a hard ware store, a post office, a grain elevator, and other enterprises. When the railroad passed Mardell by, the buildings were torn down and moved away. In 1885 the lots were sold for taxes.

Those who stayed on faced many difficulties. Almost half (49 percent) of the farms in North Dakota were mortgaged in 1890. But the boom collapsed because speculative excitement subsided, not because droughts brought crop failures. The driest year or the 1880's was 1881 (fourteen inches or precipitation), just before the peak of the boom. Eastern North Dakota averaged eighteen inches from 1881 to 1890

15“The Dakota Territorial Census of 1885, from the Original Records on File in Bismarck, N.D.," North Dakota Historical Society Collections, IV (1913), 338-448. 
above the state's long-time average. Each year until 1888 saw an increase in the wheat crop, but even the 1887 crop, the largest of the decade, did not stimulate lagging settlement. The year 1889 was dry, but North Dakota raised almost as large a crop as Minnesota, the leading wheat state.

Wheat prices declined, however. The average farm price was 80 cents in 1882, 72 cents in 1883, 46 cents in 1884, 63 cents in 1885, 52 cents in 1886 and 1887, 91 cents in 1888, 60 cents in 1889, and 70 cents in 1890. Low prices in the last years of the boom probably dampened enthusiasm, but the rise in the late 1880's did not revive settlement. The end of the boom was probably as much a psychological phenomenon on as an economic one.

During the boom years, settlers and speculators wrought a great transformation in the prairie wilderness. By 1890 they had created 27,611 farms occupying 7,700,000 acres, or about 17 percent of the nearly 45,000,000 acres in North Dakota. They had established a new wheat-producing region. Production in what was soon to become North Dakota rose from 1,700,000 bushels in 1879 to 36,000,000 in 1887. By the late 1880 's, Dakota Territory as second only to Minnesota in wheat production. ${ }^{16}$

Grain elevators became the distinctive feature of the landscape. By 1884, Dakota Territory had 206 elevators and 54 warehouses; the Northern Pacific Railroad alone had 61 elevators and 19 warehouses with a storage capacity of 2,800,000 bushels along its lines. Later, some stations on the Manitoba in the northern valley were shipping a million bushels a year. In the fall the elevators often overflowed and the grain had to be piled on the ground. As early as the fall of 1881, seventy-five cars of wheat per day were arriving at Fargo from the west and Oliver Dalrymple was daily sending three trains to Duluth. By 1886 freight rates (12.6 to 15 cents a bushel from the Red River Valley to Duluth) were only half of what they had been in 1871 .

By 1890 the new spring-wheat country had acquired many of the essentials of civilization. It had a population of 190,983 as compared with an estimated 16,000 when the boom began in 1878. It had 50 incorporated towns and villages, 8 with more than 1,000 people. The largest were Fargo (5,664), Grand Forks $(4,979)$, Jamestown $(2,296)$, and Bismarck $(2,186)$. It had 35 flour mills, a penitentiary, a university, a hospital for the insane, 125 newspapers, 454 post offices, over 2,044 miles of railroad, some 125 banks (25 with national charters), 1,362 
public schools with 1,741 teachers, and 868 church organizations with 335 church buildings. Fargo and Grand Forks each had 3 daily papers, 5 banks, breweries, flour mills, opera houses, waterworks, electric lights, and gasworks. Fargo had stockyards, a rolling mill, a foundry, and carriage shops; Grand Forks had a street railway. ${ }^{17}$

The pioneers had done well. In a dozen years they had turned an empty wilderness into a civilized society. At the height of the boom, a single year's increase of settlers dwarfed the total population (red, métis, and white) of the pre-boom years. By the later 1880's a single wheat crop dwarfed the wealth gathered in all the pre-boom years. In terms of wealth and people, then, North Dakota had suddenly taken on a new appearance.

Indeed, in the speculative frenzy the pioneers had done too well. Led on by expectations that were not to be realized, they had equipped their new society with more towns, stores, newspapers, churches, and banks than it could support. In the enthusiasm of the Great Dakota Boom, they had inevitably made what can be called "the Too-Much Mistake." Retrenchment and abandonment soon followed. 


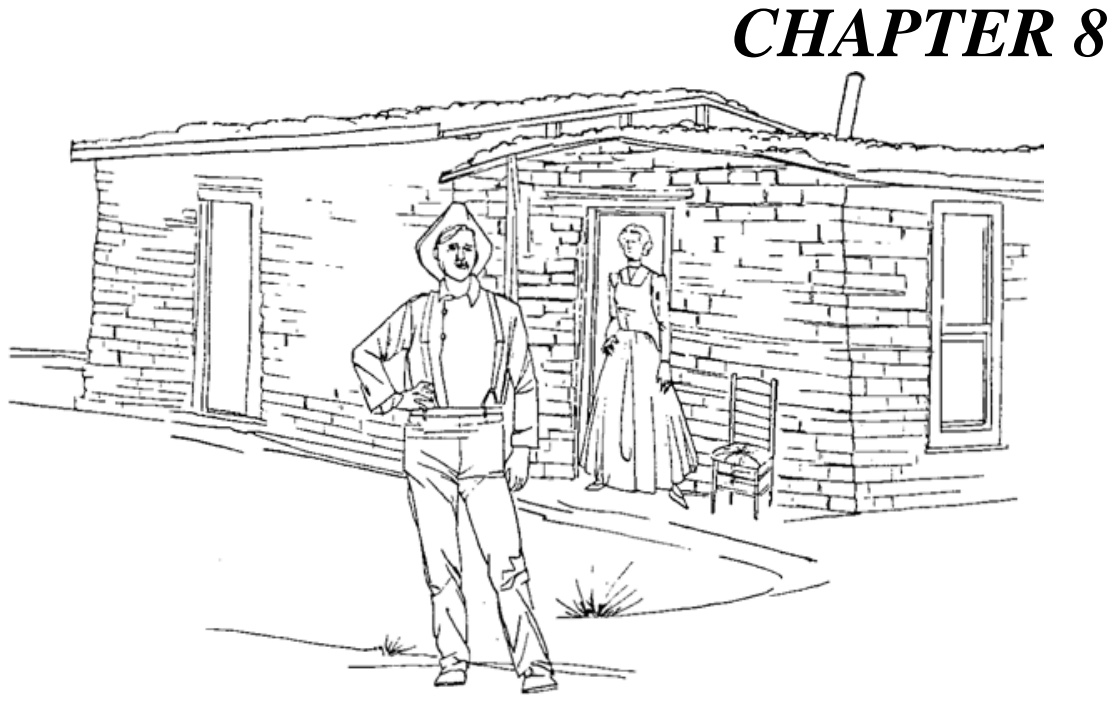

\section{Pioneer Life}

IN SETTLING A NEW COUNTRY, pioneers must often resort to primitive ways-an adaptation to frontier conditions. Later, they can bring in the comforts of civilization. On the North Dakota frontier the railroad made pioneering less primitive and hastened the bringing in of conveniences. But the railroad, by the rapidity with which it brought people to the unsettled country, must have increased the emotional shock of the change. The semiarid climate intensified the feeling of having been uprooted from familiar surroundings and transplanted in a strange land. All of the settlers except the German Russians came from humid regions and were awed by the vast, open, almost barren prairie. It increased their sense of isolation and loneliness. And long winters added to their hardships.

Many of the home seekers soon gave up and left. Others, with more courage and optimism, staved on, met the challenge of the new land, and conquered it. Their victory lay in adapting themselves to the prairie-sod houses and dugouts for shelter, fish and game for food, mutual helpfulness and self-reliance, and a concentration on wheat, the crop suited to the northern grassland.

Pioneering went forward through a large investment of eastern capital in railroads, banks, elevators, and farm equipment. The settlers invested their lives. Money and men together transformed the wilderness, a hard struggle which determined the character of the new· society: its emphasis on frugal living, self-reliance, friendly helpfulness, optimism, energetic 
activity, and courage.

\section{LOCATING IN NORTH DAKOTA}

The settlers came for free or cheap land. That was the great magnet, whether they were Norwegian or German peasants, American farmers or townsmen. Some immigrants came directly from the old country, some after living for a time in Iowa or Minnesota. Often one or two men would come alone, walking from St. Cloud or taking the railroad to some town, such as Fargo, Breckenridge, or Ellendale. They would look about for land, sometimes while working for an earlier settler. Then, having filed on a homestead and a tree claim, they would return to their old homes, sell their land or otherwise settle their affairs, and wait until the following spring, when they would come out to their claims with their families. Often friends came in together and settled near each other. A little Bohemian settlement near Wahpeton started that way in 1871-1872, and some townships in Traill County were more than 90 percent Norwegian. ${ }^{1}$

Even after the railroads had reached North Dakota, immigrants would often stop in some more easterly settlement of their countrymen and work a number of years. Then they would buy a team of horses or oxen, a wagon, a cow, and other gear and move slowly to their new homes, hunting and fishing and taking a month or more on the way. The roads were poor, bridges and settlers few.

Native Americans sometimes traveled in covered wagons, but those with more money filled an emigrant car or two with horses, cattle, farm machinery, blacksmith and carpenter tools, and a barrel of dishes and arrived more quickly and easily. A. G. (Guy) Divet's father and uncle, prosperous farmers near Rochester, Minnesota, filled four emigrant cars with two McCormick wire binders, plows, mowers, harrows, seeders, and sixteen head of horses, as well as four hired men, and came to Richland County. When Usher L. Burdick's father, Ozias W. Burdick, despaired of ever paying for his farm near Owatonna, Minnesota, he loaded his few belongings, stock, and implements into a boxcar and took up a homestead claim northwest of Carrington in 1882. Norwegian sea captain M. C. Falck rode the train to Bismarck and outfitted there before moving north to McLean County.

There was much to see along the way. In 1886, Albert W. Farley of Almont, Michigan, found the hotels and boardinghouses of Ellendale crowded with men, all talking about their expectations as they moved

${ }^{1}$ Jesse A. Tanner, “Foreign Immigration into North Dakota,” North Dakota Historical Society Collections, I (1906), 198. 
into the raw new country. He saw the railroad tracks there lined with piles of boxes and barrels of household goods which the newcomers had unloaded pell-mell.

Newcomers needed the help of established settlers in finding good land. They wanted fertile soil, water for family and stock, and wood for fuel and building. The early arrivals took up the land along the Red River, the Wild Rice, the Goose, the Sheyenne, the James, and other streams. Those who came later had to be satisfied with open prairie.

The land seeker might first visit the county courthouse, become acquainted with county officials, and talk with men who were making it a business to help homesteaders. Then, walking or hiring a rig at a livery stable, he would set out with a compass and a map showing the townships, ranges, and sections. He would travel, if it were June, over a prairie brilliantly colored by carpets of flowers. There were no roads, only some wagon tracks, but the government surveyors had placed mounds of earth with oak stakes at the corners of each section. The stakes were marked with the range, township, and section, so that with his map, the land seeker could tell at each corner just where he was and just where he needed to go to see the land he was interested in.

After riding about the country and talking to earlier settlers, he would make a choice and hurry to the nearest United States land office. He might buy a quarter-section under the Pre-emption Law, secure a homestead for five years' residence, take a tree claim, or buy from the Northern Pacific Railroad or a speculator. In 1881 speculators in Traill County were offering land for the first year's crop or half the first two years' crops. This arrangement was known as the crop-payment plan. ${ }^{2}$ Everyone took a claim, even though he had a business in town.

\section{HOMES}

When the settler arrived with his wagon, stock, and household goods, he had many things to do. He and his family might sleep in or under the wagon the first few nights, or they might have a tent. Water was an immediate necessity; the settler had to find a spring, dig a shallow well, or haul water from a stream. In the Red River Valley, shallow wells, ten feet or so, often supplied water, but many drank river water for a time.

The pioneer hurried to provide a house. If he were near the wooded

${ }^{2}$ R. M. Black (ed.), A History of Dickey County, North Dakota, by the Dickey Historical Society (Ellendale: Dickey County Historical Society, 1930), pp. 8082; Walter E. Spokesfield, History of Wells County, North Dakota [Valley City: The Author, 1929], pp. 42-43; Henry V. Arnold, The Early History of Inkster, North Dakota (Larimore: The Author, 1916), pp. 8-9. 
banks of a river, he generally built a low log cabin of two rooms. The roof consisted of poles resting on a horizontal beam, then a layer of hay and one of earth. The interior was often whitewashed. A typical cabin had two small windows and a single door.

Away from timber, the settler might make himself a one-room dugout in a coulee bank, finishing only the front with logs and building the polehay-earth roof level with the bank. A stovepipe stuck up through the roof. Dugouts made warm but dark homes. When only men spent the first winter in the new country, they sometimes shared a dugout with their horses or oxen.

On the open prairie, the newcomer might build a 14 by 16 -foot sod house, laying up tiers of sod. Windows were small. The walls, sometimes two and one-half feet thick, were often boarded on the inside and whitewashed. Some thought that a sod house was warmer in winter than a log cabin. Both might have only an earth floor, but many had floors of cottonwood slabs or boards. Occasionally, settlers hauled lumber from a railroad station and built a 12 by 14 -foot claim shanty covered with tar paper, often putting sod outside the board walls for greater warmth.

In McIntosh and Emmons counties and elsewhere, German Russians made large, sun-dried bricks and built thick-walled houses of two or three rooms which they plastered inside and out with marl and then whitewashed. These were cheap and durable, warm in winter and cool in summer. Some of them were sheathed inside and out with boards. Roofs might be earth over boards instead of earth over poles and hay. Danish settlers also built houses of sun-dried bricks, whitewashed inside and protected outside with board siding. In Cavalier County, German Mennonites from Russia built long, low buildings, one end of which housed the family and the other the cattle.

The pioneers furnished their first homes simply. They substituted drygoods boxes for tables and dressers and used a small, four-lid stove, homemade beds, chairs, and benches. Often the children had to stand while eating because there were not enough chairs. For bedding, they might use deerskins and buffalo robes. Immigrants generally had a large chest, brought from the old country. in which they stored their linens, bedding, pictures, books, and more valuable possessions.

Settlers found fuel a problem on the treeless prairies. Those close to timbered riverbanks had a handy supply, but others had to haul wood long distances from such rivers as the Red, Sheyenne, and Missouri or from other timbered regions, such as the Sand Hills in Richland County, and Graham's Island, a peninsula in Devils Lake. They helped themselves to timber on school and railroad lands. In winter, some 
homesteaders came fifty miles with ox teams to get wood at Graham's Island, sometimes paying a dollar a load to settlers who held claims there. Wood sold in town for three or four dollars a cord.

There was other fuel. Nina Farley's family bought coal in Ellendale, a round trip of one hundred miles. By 1896-1897 teams were hauling lignite to Bismarck from mines twenty miles north of town. People who settled near rivers or coulees in the lignite region commonly obtained their fuel by digging open pits or tunnels where the seams outcropped along the riverbanks. (In 1884 lignite production was estimated at 35,000 tons and in 1900 at 100,000 tons.) The German Russians burned Mist, manure which had been mixed with straw, trampled by horses, then cut into pieces and dried. Many burned cow chips.

Fuel was a greater problem than food. Fish, ducks, geese, and wild fruits were easily obtained. Aagot Raaen's father put a fish trap in Goose River which supplied his own family as well as the neighbors, and the sons of one Traill County pioneer would scoop a bushel basket of fish out of Buffalo Coulee so that their mother could feed the threshers. Usher L. Burdick recalled that settlers and Indians alike frequently speared pickerel through the ice on Devils Lake. Fish were an important item of food for the residents of Graham's Island and the surrounding prairie country. Other settlers, many of them Norwegians and skilled fishermen, set nets in Big Coulee and salted down or smoked great quantities of their catch.

An abundance of ducks and geese, prairie chickens, and rabbits made welcome provisions for money-short pioneers. They would shoot a supply of ducks and geese in the late fall and hang them on the side of the house, where they froze solid and were available when needed. Some settlers shot deer and antelope for their tables. Their wives preserved wild strawberries, chokecherries, raspberries, and plums.

Pioneer families frequently lacked money, so the womenfolk manufactured many items needed in the home. They made soap and candles, ground wheat in a coffee mill, carded and spun wool into yarn and dyed the yarn, knitted stockings, scarves, and mittens, and even wove cloth for blankets and homemade clothing. The men made rakes and crude carts. ${ }^{3}$

${ }^{3}$ Omon B. Herigstad, "The First Norwegian Settlement in Griggs County, North Dakota," North Dakota Historical Society Collections, I (1906), 137; "Pioneer Experiences," North Dakota Historical Society Collections, VII (1925), 265-269; Waldemar C. Westergaard, "History of the Danish Settlement in Hill Township, Cass County, North Dakota," North Dakota Historical Society 


\section{AGRICULTURE}

The first year he spent on the land, the pioneer often planted only potatoes and earned some money picking up buffalo bones. The prairie was strewn with them, and every railroad station was a market. Piles of bones became a common sight along the railroad tracks. Most merchants dealt in bones, giving receipts which others honored and which were called "buffalo-bone money." At six dollars a ton, a load of two or three tons brought a sizable sum.

But the great thing was breaking the sod. The first day the settler sank his plow into the prairie, laying over a streak of black earth on the green grass, was the beginning of his new life. It was heavy work. The tough sod made it necessary to sharpen the plowshares each night-a blacksmith's job. Some of the pioneers had little equipment, and two might use a single team of oxen and a plow. Others, without tools or stock, had to hire a neighbor to break their land while they worked on a big farm for wages. The Homestead Act required a settler to break ten acres the first year. Probably many did no more than that, but the Divets, coming with many teams, plows, and hired men, broke 250 acres the first year and 500 the second.

Each year, the settlers broke more land. After plowing, they would put up hay and later plow the new breaking a second time. During the first summer, the settler would build a sod stable, perhaps fourteen by thirty feet, or cover a dugout in a coulee bank with branches and straw as a place for his stock. The second season started with seeding; poor settlers had to broadcast wheat by hand. Then followed the breaking of new land, haying, harvesting, threshing, and, finally, plowing the stubble and backsetting the new breaking. On fall nights, burning strawstacks dotted the prairie.

The work was extremely difficult, but the pioneers had plenty of energy and were driven by a consuming ambition to succeed. "The country is alive with seeding and dragging," wrote Mary Dodge Woodward in her diary. At the Divet farm, one or two men would be up at three o'clock to feed the horses. More arose at four, curried and harnessed the teams, ate breakfast, and were in the field ready to start as soon as it was light enough to see. They worked until dark. Young Guy

J. Loynes, "Mennonite Settlements in North Dakota," North Dakota Historical Society Collections, III (1910), 325; J. N. Van Sant and R. C. Ellman, Methods and Costs of Mining Lignite in North Dakota, United States Bureau of Mines Circular 7891 (Washington, 1959), p. 7; L.W. Sperry, Early History of Bismarck (N.d., n.p.), p. 31. 
Divet-doing, like many a boy, a grown man's work at thirteen and sometimes falling asleep as he rode a farm machine-resolved to get away from farming. He was teaching school at seventeen and soon reading law.

There was so much work that women sometimes milked the cows and helped in the field: Aagot Raaen's mother hurt herself with too much hard work. At threshing time the women of the house would be up most of the night preparing to feed twenty-five or thirty hungry men. Mary Dodge Woodward, glorying in the harvest rush, boasted in her diary: "I baked seventeen loaves of bread today, making seventy-four loaves since last Sunday, not to mention twenty-one pies, and puddings, cakes, and doughnuts." 4

When they finished threshing, the men would haul their wheat to town and lay in supplies for the winter. They followed a wagon track across the prairie and sometimes marked the way with piles of sod or with willow sticks set in the ground and bearing pieces of cloth. Many traveled two or three days going to town and as many on the return trip. On the way, they would spend a night or two in the open or with some hospitable settler.

In town, as many as one hundred men with wagons or sleighs might be waiting to sell their loads. Grain buyers were often not too honest, and cheated the farmers in weighing and grading the wheat. The buyer graded by merely looking at a sample and biting a kernel or two, often grading too low and taking off too much for dockage. ${ }^{5}$ In self-defense, the farmers would work off screenings and bin-burned grain on the buyer. He would be so rushed, with many men waiting, that he could not always watch the hopper where the grain was dumped. Sellers might plant a scoop or two of the inferior stuff in the middle of each sack or dump some sacks of it while others diverted the buyer's attention. With his grain sold, the settler would buy large quantities of supplies, for trips to town were dangerous in winter.

\section{TOWNS AND TOWN LIFE}

The towns served the farmers, but townsmen too often looked down upon farmers as "hayseeds" or "country jakes." The farmers, in turn, viewed townsmen with distaste.

\footnotetext{
${ }^{4}$ Mary Dodge Woodward, The Checkered Years (Caldwell, Idaho: The Caxton Printers, Ltd., 1937), p. 90; see also pp. 35-36, 41.

${ }^{5}$ Henrietta M. Larson, The Wheat Market and the Farmer in Minnesota, 18581900, Columbia University Studies in History, Economics and Public Law, Vol, 122, No. 2 (New York, 1926), pp. 97, 155, 163.
} 
In boom times, new towns grew up with amazing rapidity and then, when the boom died, often slowly declined. At the beginning a collection of small, boxlike frame buildings, cheaply built and without architectural pretention, would spring up on the bare, flat prairie. There were usually no trees or shrubs to give any touch of attractiveness. If a town appeared before the railroad entered the region, it often moved to a location on the railroad when the line came through. Some towns away from the railroad were served by stage lines. Daily stages ran from Bismarck to Winona and Fort Yates; another ran north to Washburn.

The new towns, even small ones, quickly acquired many business and professional enterprises. They would have general and hardware stores, drugstores, one to three doctors (often Scots), a lawyer or two, sometimes a dentist, a veterinarian, and a photographer, several hotels and banks, harness shops, blacksmith shops, lumber yards, implement dealers, poolrooms, a school, a newspaper, churches, livery stables, and many grain elevators and saloons.

Banks and newspapers were numerous. Sometimes a bank was the first building in a new town and a saloon the second. One man in Ellendale was said to have started a bank with thirty-five dollars. In the 1880's, Bismarck, with some three thousand people, had five banks; Munich, with only a few hundred, had three banks soon after it came into existence in 1905.

Almost every village had a newspaper. In 1890, North Dakota had about 125 newspapers and only 50 incorporated towns and villages. Grain elevators dominated the landscape, but saloons (or "blind pigs" when and where liquor was illegal) were often as numerous. In 1905, Omemee, a small village in Bottineau County, had seven elevators and seven blind pigs. Drugstores sold much liquor for allegedly medical purposes.

Many of the raw little towns, especially those at the end of the railroad, were rough places with many drifters, prostitutes, sporting houses, and gambling establishments. Usher L. Burdick recalled the Munich "at one time had 13 pigs....Gambling of all sorts was carried on in daylight; sporting houses lined the outskirts of the town to the east of the railroad tracks.” In early years, Bismarck, Grand Forks, and presumably many other towns also had their share of prostitutes and sporting houses. Fights, beatings, and shooting were common. Burdick himself engaged in many fist fights in cleaning up Munich; by 1907 it was a fairly lawabiding place.

Livery stables were an important feature of every town. On Sundays a hundred horses and hacks would be rented out in Grand Forks for 
pleasure driving: the biggest stable had stalls for fifty horses. The streets of early Bismarck were often full of ox- or mule-drawn wagons from the Black Hills, with swearing teamsters cracking long whips. Runaway horses sometimes caused accidents in the streets.

Sanitary conditions were poor. Many towns had stinking slaughter-houses on their outskirts where cattle and hogs were killed for the local meat markets. There was no systematic refuse collection; during the winter, people threw ashes and tin cans in their yards to be hauled away in the spring. Every house had an outside privy, and water came from wells which were easily contaminated.

In early Bismarck, water was peddled from door to door by tank wagons until 1886, when Alexander McKenzie formed a water company. It pumped untreated water, often quite muddy, from the Missouri River to the town's houses through a system of pipes. Grand Forks, taking its drinking water from the Red Lake River, into which Crookston dumped its sewage, suffered a typhoid epidemic in 1892-1893. Fully 10 per cent of the population contracted the disease and more than 150 died.

Many townspeople owned milch cows. At Bismarck, cows were herded outside the city limits by town herders. When some of the residents began to plant lawns about 1890, they had to fence them in to protect them from wandering cows. Until about 1906, some two hundred cows were kept and milked in Bismarck.

Towns were quite naturally centers for diversion and entertainment. Fargo, Grand Forks, and Bismarck had theaters. In 1879 the Fargo theater (called an opera house) presented, according to English visitor Finlay Dun, “dramas, nigger and other songs, and dancing” with good singing and acting and a good orchestra. The performances, Dun reported in the London Times, were seen by large numbers of "dark-visaged farm fellows with slouch hats, many with blue guernseys, some lumberers in red flannel jackets, an occasional Indian, and many half-breeds.”

Grand Forks and other towns had fairs. Many also organized baseball teams. By 1887, Fargo and Grand Forks had semiprofessional teams playing in the Red River League with Minnesota towns. Fourth of July celebrations were popular. As a boy of nine, Usher L. Burdick won two sheep in a foot race at Minnewaukan's celebration of the Fourth. While gaining a great reputation as a football player at the University of Minnesota, Burdick played baseball for Hampden, a tiny hamlet in Ramsey County. In 1905 he gave the address at Munich's celebration of the Fourth and then put on a Wild West show.

Track events, especially the hundred-yard dash, were an important part of Fourth of July celebrations in the northeastern counties. The British 
settlers there had a traditional interest in track and field events-running, "jumping with rocks," and throwing the caber. Sometimes races by professional runners caused betting and excitement; a bitter rivalry grew up between Park River and Grafton from such a contest.

Towns were important centers for the isolated settlers in many ways. They disseminated news and mail. Farmers, picking up news in town, would spread it to neighbors on the way home. Towns on the railroads had telegraphic communication with the rest of the nation. Mail came from the towns to country post offices, often only a box in a settler's cabin, once a week. ${ }^{6}$

\section{RECREATION, SCHOOLS, AND CHURCHES}

Mail and visits to town boosted the settlers' morale. They also drew together to combat the loneliness of the empty prairie. Those who had come with friends and neighbors already had a social circle that was helpful, and on Sundays they would gather in each other's homes to visit. The young people often organized dances and card parties, either in homes or in hotels. A home which had a reed organ would become a social center where neighbors gathered to sing and make taffy. In Emmons County, Braddock supported a lyceum and also staged plays to help civic causes. Many enjoyed fishing and hunting.

When winter came, neighbors sometimes joined in skating and sleighing parties. But cold and storms tended to keep people at home and indoors. Shut up, the men often became restless. To pass the time, they made furniture, repaired tools, or cleaned seed wheat by picking shriveled kernels and weed seeds out by hand. They talked, told stories to their children, and played checkers, chess, and other games.

Often in the long evenings one member of the family would read aloud to the others while the mother knitted. The Scandinavians had a traditional love of literature, and most homes had some books. Nina Farley's father brought a large library from Michigan, including bound

${ }^{6}$ John M. Molberg et. al., Bottineau County Diamond Jubilee (Bottineau: Diamond Anniversary Publication Committee, 1959), entry under 1886; Clement A. Lounsberry, Early History of North Dakota (Washington: Liberty Press, 1919), p. 548; Black, Dickey County, pp. 82-92; Dakota Territory Commissioner of Immigration, The State of North Dakota, 1889, p. 84; Robert S. Anderson, “A Social History of Grand Forks, North Dakota, 1880-1920” (Unpublished M.A. thesis, University of North Dakota, 1951), pp. 30-31; James Grassick, North Dakota Medicine: Sketches and Abstracts (Grand Forks: North Dakota Medical Association, 1926), p. 204; Lowell A. Barsness, "The History of High School Track and Filed in the State of North Dakota" (Unpublished M.S. thesis, University of North Dakota, 1958), pp. 4-16. 
volumes of the Atlantic, Scribner's, and Galaxy. After his death, her mother continued to buy some of the best magazines and recent books in spite of a need for economy.

Reading in the home was the beginning of schooling. A mother would teach her children to read, or an older child would teach a younger one. Next, a group of neighbors would set up a school in one of their homes. In a few years they would build a schoolhouse or convert a claim shanty to school purposes, and a teacher would hold sessions for a few months in spring and fall. In 1874, Ida C. Hall, seventeen, began teaching the first school in Jamestown in a small shed without even a chair for the teacher. She boarded at the railroad section house, and one day she saw the whole Yanktonai tribe go by-several hundred families with their belongings on wagons, carts, and travois, the men riding and the women walking.

Pioneer teachers often performed admirably under difficult conditions. They boarded around from one family to another, without much privacy, walked or rode long distances to poorly equipped schools, built fires and did their own janitor work, and put up with all sorts of inconveniences for a salary of thirty-five dollars a month. Big, unruly pupils sometimes threw an unpopular man teacher out bodily. Usher L. Burdick took over such a school as his first position after graduating from the normal school at Mayville. He soon had not only the pupils-one was well over six feetbut also their parents studying eagerly at night.

Although at first the immigrants' children might not understand the English spoken by the teacher, they soon caught on. Young people were eager to learn, and they were soon crowding into the state university, the state college of agriculture, and the normal schools. Some young Dakotans went to college outside the territory-to Harvard, Beloit, the University of Minnesota, and elsewhere. Curtis D. Wilbur was appointed to the United States Naval Academy at Annapolis in 1884, the first North Dakotan to attend one of the service academics. He became Secretary of the Navy under President Calvin Coolidge.

Like schooling, religious services also began in the home. Parents read from the Bible or a book of sermons and held family prayers, and mothers taught their children hymns. The young studied the catechism to prepare themselves for confirmation. A neighbor might be called in to baptize a dying infant or to read from the hymn book at a burial. Sometimes the settlers gathered in a home for religious services. Itinerant pastors, driving ponies, skiing, or walking from community to community, held services in homes or schoolhouses and later organized the people into congregations. 
One missionary, the Reverend Pall Thorlaksson, was especially outstanding. Born in Iceland in 1849, he graduated from college in Reykjavik, emigrated to Wisconsin in 1872, and entered the ministry after studying at Concordia Theological Seminary in St. Louis. Thorlaksson encouraged the Icelanders to move from their misfortune-ridden settlement on the western shore of Lake Winnipeg to Pembina County and became their pastor at Mountain, Gardar, Thingwalla, and Hallson. When many of his people suffered from a lack of provisions in the winter of 1879-1880, he acted to relieve them. He bought one hundred barrels of flour and forty head of cattle on his own note at Northfield, Minnesota, distributed these necessities among them, and went from house to house with encouraging words. Young Thorlaksson died of consumption in 1882, but a monument in the cemetery at Mountain commemorates his services. ${ }^{7}$

\section{HARDSHIPS}

Pioneering meant hardship. Summer brought dust storms; spring and fall, prairie fires. Wind-blown flames could out run a galloping horse, and sometimes leaped over streams and firebreaks, sweeping over large areas of open country and destroying grain, haystacks, buildings, and stock. Farmers plowed firebreaks and fought the flames with wet sacks and blankets. "At night the whole western horizon would be lighted up for miles," Usher L. Burdick remembered, "and we knew some poor homesteaders would be wiped out."

Winter brought isolation, numbing cold, and blizzards. A blizzard in April, 1873, caused heavy loss of livestock; one in March, 1876, marooned two or three hundred people for three weeks on a Northern Pacific train between Fargo and Bismarck; another in February, 1881, killed many cattle. Perhaps the worst struck on January 12. 1888. It covered haystacks, barns, and houses with snow and brought death to nearly a hundred people.

Many were caught out in a storm and yet survived. Young Guy Divet, returning home from Wahpeton when a blizzard struck, let the horses go, turned over the box of the sleigh, and took refuge underneath-protected by hay, grain sacks, and horse blankets. Sometimes fuel ran short in a storm, and people burned whatever was at hand, even part of the house

\footnotetext{
${ }^{7}$ Pall Thorlaksson, "The Founding of the Icelandic Settlement in Pembina County," North Dakota Historical Quarterly, VI (January 1932), 150-164; Sveinbjorn Johnson, "The Icelandic Settlement of Pembina County," North Dakota Historical Society Collections, I (1906), 109-110.
} 
itself. When the storm had passed, the settlers dug themselves out, found the barn, and cared for their stock, which might have gone three days without being watered and fed. Many of the Farley's Holstein-Friesian cattle, one a prize cow imported from Holland, died in the blizzard of 1888. Aside from storms, it was hard to keep warm in winter. Many suffered frostbite, and Mary Dodge Woodward once noted in her diary that she was preparing breakfast as usual "in hood, shawl, and mittens."

Spring might bring bad floods. The winter of 1896-1897 saw a very heavy snowfall, and some towns were without train service for a week. When the snow melted in the spring, a great flood spread along the Missouri, James, Sheyenne, and Red rivers. It swept away property, drowned many deer, inundated towns, covered twenty-five blocks of paving in Grand Forks, damaged bridges, and made a lake thirty miles wide and a hundred and fifty miles long in the Red River Valley. Families and livestock huddled on the tops of haystacks.

All suffered from such hardships, but the women endured more than the men. They suffered not only from the spectacular hazards of fire, storm, and flood, but also from the whole round of life on the prairie frontier-from living in drab, homely sod houses or log cabins with dirt floors and leaky roofs, from an endless round of pressing tasks in feeding hungry men and caring for ill children when a doctor was beyond reach, from bearing babies with only the aid of a neighbor woman, from listening to the ceaseless wind and the ceaseless talk of crops, and perhaps above all from sheer loneliness. Many times, especially in the first years, the wife and children would be left alone for days and even weeks at a time while the husband was away. He might be working on a railroad construction crew or on a bonanza farm; he might be cutting ties for a railroad or cordwood for a steamboat; or he might be making a trip to town. There were always long trips to be made with slow-moving oxen-to a river for wood, to town for lumber and supplies, to market with grain. It must have seemed to many a woman that she was always waiting for her husband to come home.

Under such pressures many women broke down and became old and stooped before their time. Guy Divet believed that the "crushing burdens of the prairie frontier" contributed to the early death of his mother, "a woman of considerable culture and pride." He wrote that the prairies "devoured" women, that they, like his mother, were "a part of the grist of the frontier's mill, taken for toll in the interest of generations to come." Some even lost their minds.

The burden of hardship was increased by the contrast between life in the old home and the new. Pioneer women were often persons of 
refinement and education from well-to-do homes. Linda Warfel Slaughter, for example, had been an Oberlin College student for a time, and Mrs. M. C. Falck was the wife of a Norwegian sea captain. She was living in an apartment in Oslo with leisure time, pretty clothes, and money to indulge her whims when her husband, tiring of the sea, took up a homestead near Washburn in 1883 and sent for her. When she first saw the low, dirt-roofed cabin with its dry-goods-box furniture which was to be her new home, she was dismayed. Other women undoubtedly shared that emotion when they arrived in North Dakota. Coming from forested, hilly country, many must have been shocked when they first saw the vast, flat, treeless plain.

Although for many North Dakota seemed like a Godforsaken country, part of their dissatisfaction probably stemmed, not from the nature of the place, but from the uprooting involved in their move to a new home. A Norwegian immigrant who settled in Griggs County in 1881 wrote to a friend back home:

On the whole it seems to be a good deal easier to make a living [in Dakota]; but there are many hardships connected with the life of a pioneer, especially at first. I should like to see you and others come over, yet consider the matter twice before you leave the Fatherland and the place where your cradle stood. It is not a small matter. ${ }^{8}$

The hardships of pioneering, both physical and psychological, had important effects. For one thing, many of the pioneers left North Dakota a few years after they had come. The women's inability to adjust to the situation probably played a large part in the exodus. Many stayed, no doubt, who would have liked to get away but were too poor to leave. Immigrants who owned land were more likely to stay than native Americans. Guy Divet believed that about half of the original settlers commuted their homesteads by paying $\$ 1.25$ an acre, sold out to some ambitious neighbor for a few hundred dollars, and left North Dakota.

\section{CONQUEST OF THE FRONTIER}

There was another side to pioneering, as important as hardships and abandonment of the struggle, and that was the conquest of a new country. Many or those who stayed built up their holdings and prospered. For them, pioneering was an adventure, and they quickly developed a feeling

\footnotetext{
${ }^{8}$ Herigstad, "First Norwegian Settlement," p. 138; Frank J. Bavendick, Climate and Weather in North Dakota $\left(2^{\text {nd }}\right.$ ed.; Bismarck: North Dakota State Water Conservation Commission, 1952), pp. 7-8.
} 
of loyalty and affection for the broad, sweeping land ("nothing can excel this endless, enchanting view," wrote Mary Dodge Woodward), where hospitality was a sort of religion, where people gave each other a helping hand when it was needed, and where, by dint of hard work, rising land values, and frugal living, they were getting ahead. Recalling his youth at eighty, Guy Divet harshly divided the early settlers into "workers and stickers" and "shirkers and quitters." Some were natural pioneers, born to conquer the land, and some were not. Surely for the latter the wise course was to leave; Divet himself left North Dakota to practice law in Washington, D.C.

Among the natural pioneers were Nina Farley and the man she married, John H. Wishek. A girl of eighteen, Nina moved to McIntosh County from Michigan with her father, mother. and three brothers in the spring of 1887. Her father, a well-to-do farmer, had selected land east of Ashley, but he died that June, and her mother, though unaccustomed to responsibility, decided to stay on. Nina Farley found McIntosh County a raw, empty country with no protection and no cover, much different from wooded Michigan. Yet she was at once attracted by the vast, open prairie, with its pure air and splendid view. Although she was much alone that first, sad summer, she was never homesick. She helped with the farm work, taught country school in the home of German Russian settlers, and then-a bright, comely, courageous woman-married John H. Wishek in 1891. She came to have a great affection for North Dakota and in her old age wrote of pioneering: "It is hard to draw a clear picture of those days, the isolation, the long distances and slow travel, the crude makeshifts and lack of conveniences, the high hopes and bitter disappointments."9

John H Wishek was born in 1855 to German immigrant parents in Warren, Pennsylvania. He struggled through law school at the University of Michigan, sometimes living for days on corn-meal mush when his funds were low, and then practiced law for five years in Prospect, Ohio. He came to Bismarck in 1884 with slender resources. That April, George W. Lilly and others interested in land speculation set out from Bismarck for McIntosh County, an entirely unsettled region. They selected a site for the business center and county seat near Hoskins Lake, filed on the land, put up claim shanties, and helped the government surveyor to divide the townships into sections. Wishek soon joined the enterprise, became Lilly's partner, and aided the survey party by building mounds at the corners of each section. 
As Lilly, Wishek, and their associates boomed the new country, settlers began to come in. Some of those who arrived in 1885 were German Russians from near Scotland, South Dakota. Wishek, speaking German, won the confidence of these people and helped them to select land and file on their claims. He became a great promoter of settlement and, with his associates, located ten thousand people on lands in McIntosh, Logan, and Emmons counties in North Dakota and McPherson County in South Dakota. By 1890 there were 2,053 German Russian settlers in McIntosh County alone.

Wishek, a tall, heavy man with a black beard, was noted for his strong will, foresight, and frugality. His and Lilly's "land office" early became a social center where Wishek cheered the settlers with his genial ways and humorous stories. He held their confidence and for years served as registrar of deeds and state's attorney, and sat in the legislature as a member of the McKenzie machine.

Wishek also built up large holdings. He developed the townsites of Ashley, Wishek, Danzig, Venturia, Artas, and Pollock. He owned banks, lumber, coal, and implement firms, and grain elevators-in all having had a hand in forming thirty-five corporations. He acquired much of the land for the Soo Line right of way in his part of the state and finally brought the railroad to McIntosh County in 1898, when the town of Wishek was founded. He became known as "Father Wishek," gave sites to churches, built up a large private library, and died at the age of seventy-eight in 1932. In sum, the story of John H. Wishek was the story of McIntosh County.

Gradually, pioneer life passed. The country was settled. Railroads brought markets closer; land values rose. Trees grew about the homesteads, and frame houses replaced log cabins and sod houses. Horses took over the work formerly done by oxen as settlers won the struggle with poverty.

The immigrants took up the language and customs of the New World. Many Anglicized their names: Laverans Fjelstad became Lewis Fisk, postmaster and saloonkeeper of Hatton. Yet they clung to the language and ways of the old country, subscribed to foreign language newspapers, and on holidays (if they were Norwegian) cooked lefse, flat brød, grøt, kjøtboller, and lutefisk.

Both immigrants and native Americans brought much to the new country. In turn, it helped to shape their character. Pioneering in North Dakota, with its hardships, dangers, and isolation, as well as its opportunities, placed a premium on certain traits: courage, optimism, energy and ambition, aggressiveness, and compassion. These were 
prominently displayed in such men as Norman W. Kittson, Alexander McKenzie, William Lemke, James J. Hill, John H. Wishek, Max Bass, Usher L. Burdick, and many another. From Sitting Bull through Charles C. Talbott to William Langer, such qualities have marked North Dakota's principal leaders. Almost by definition, they who transform a wilderness into a civilized society are public-spirited citizens. While those who soon fled the open prairies naturally disparaged North Dakota, those who created the new commonwealth just as naturally developed a strong loyalty to it.

Many North Dakotans like to believe that the long, open view over the prairie has encouraged the long, liberal view intellectually, and that the people of their state, with ample opportunity for reading and reflection during the long winters, are stable, sound, thoughtful, and independent in their ideas and attitudes on public questions. North Dakotans also like to believe that, having so recently conquered the frontier-, they are friendlier toward progress and change than the peoples of older societies. Whether this is true or not-and many would doubt it-North Dakotans still retain some of the pioneer virtues: courage. optimism, self-reliance, aggressiveness, loyalty, and an independent cast of mind and spirit. 


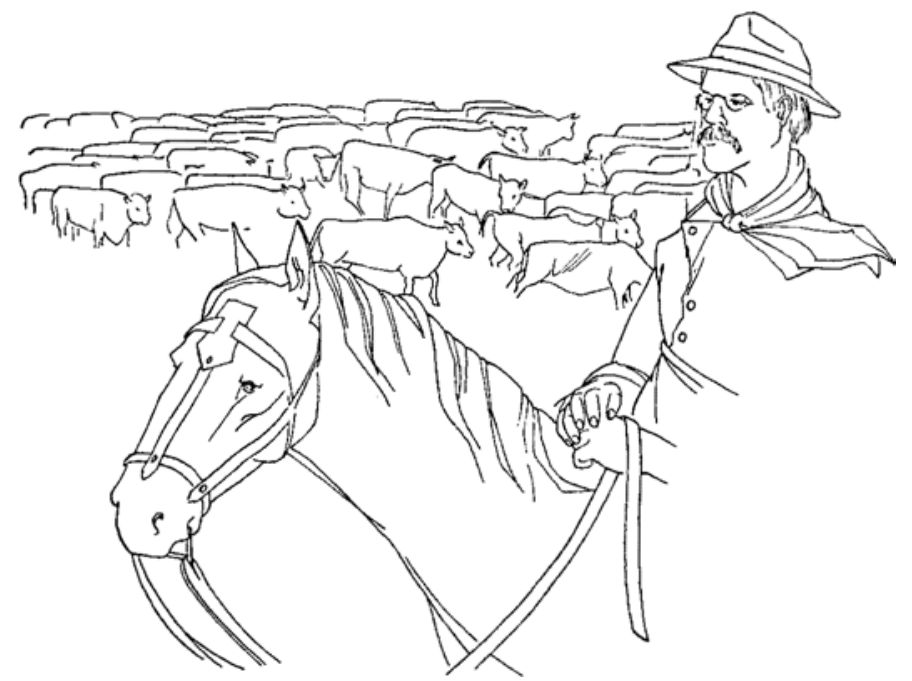

\section{The Opening of the Missouri Plateau}

THE SETTLEMENT OF AMERICA rolled westward across the continent like a series of waves inundating the land. Frederick Jackson Turner, the renowned historian of the American frontier, vividly described the movement in his essay "The Significance of the Frontier in American History” when he wrote: "Stand at Cumberland Gap and watch the procession of civilization, marching single file-the buffalo following the trail to the salt springs, the Indian, the fur-trader and hunter, the cattleraiser, the pioneer farmer-and the frontier has passed by. Stand at South Pass in the Rockies a century later and see the same procession with wider intervals between."

The region of which North Dakota is a part experienced similar waves in human occupation. Long before the coming of the white men, a succession of Indian migrants entered the area. White traders began to arrive late in the eighteenth century. Then the metis and the Scots brought in by Lord Selkirk occupied the Lower Red River Valley with an economy based on farming and the buffalo hunt. The next wave, pushed along by the Great Dakota Boom, carried thousands of farmers, land speculators, railroad construction workers, and townsmen-all mingled together-into the Red River Valley and the Drift Prairie.

The rush and excitement of the Great Dakota Boom did not bring many white men to the Missouri Plateau. The nature of the country made a difference; occupation of the plateau presented more difficult problems of adjustment to a semiarid grassland. The Missouri Plateau, or Northern Great Plains, comprises roughly the western half of North Dakota and 
extends into Montana, South Dakota, and Wyoming. The portion in North Dakota was not all alike. Only about half of the Missouri Slope, the part lying west and south of the Missouri River, was later classified as being suitable for crops; about half was best used for grazing. ${ }^{1}$ A much larger part of the plateau lying east and north of the Missouri was arable.

Throughout the plateau, however, scant rainfall made returns from farming uncertain. Like the Drift Prairie, all of the Missouri Plateau in North Dakota was part of a transition zone between the more humid farming country farther east and the more arid range country farther west. Drought-resistant grasses were its natural wealth. The Indians had long gathered the product of that wealth by hunting the buffalo-their adaptation to the environment. White encroachment broke down this arrangement and called for a new one.

White occupation of the Missouri Plateau advanced in four stages: the military frontier, the transportation frontier, the ranching frontier, and the farming frontier. One followed the other, although to some degree they overlapped and intermingled. The military frontier began when the army established posts along the Missouri River. When the buffalo herds declined, the Indian way of life on the Great Plains vanished. Living beside their agencies, the tribes became dependent upon government rations. They tried to make a living by farming, but drought largely nullified their efforts.

The transportation frontier came with the building of the Northern Pacific Railroad across the Missouri Slope. This brought about some occupation of the country by both ranchmen and farmers. During the ranching frontier, cattle grazed on the free grasses of the open range which had formerly fed the buffalo-the white man's adaptation to the environment. But, like the buffalo hunt, it led to only a sparse population.

The Northern Pacific, key to white settlement, promoted the farming frontier, but its success was limited. By 1900, twenty years after it had first crossed the region, the Missouri Slope had a population of only 22,000. The country north of the Missouri River, served since 1886 by the Great Northern, was even less settled. By 1900 the entire Missouri Plateau in North Dakota-half the state's area-had only about 47,000 people, or 15 percent of the state's population, a sparse 1.3 persons per square mile. As yet the drier half of North Dakota had made little appeal to prospective settlers.

\section{THE MILITARY FRONTIER}


By the early 1870's the United States Army had established a military frontier along the Upper Missouri. Its four Missouri River forts in North Dakota (Rice, Abraham Lincoln, Stevenson, and Buford) were supported by four others in the eastern part of the region: Abercrombie and Pembina on the Red River, Totten on Devils Lake, and Seward on the James River. Each fort had a garrison of from one to three hundred men; it was their presence which brought and kept the Indians under control. In 1873 there were 2,652 troops in North Dakota, better than one soldier for each adult male Indian. ${ }^{2}$

Many of the Indians were living on reservations in the early 1870's. About 3,500 Sioux-Yanktonais, Blackfeet, and Hunkpapa bands of the western Dakotas-drew rations at Standing Rock Agency; thousands of others were attached to agencies in South Dakota. In addition to those at the agencies, many Sioux were living in the country south of the Yellowstone River under the leadership of Sitting Bull. Some 1,300 Arikaras, Mandans, and Hidatsas (the Three Tribes) occupied a village beside Fort Berthold Agency. About 800 Cut Head, Sisseton, and Wahpeton Sioux lived on Fort Totten Reservation south of Devils Lake. The Turtle Mountain band of Chippewas and many of their relatives among the metis made their home in the Turtle Mountain country; they had no reservation or Indian agent and received no assistance from the United States government.

Wild game was becoming scarce, and many of the Sioux were dependent upon the rations issued at the agencies. From 1870 to 1876 the government, believing it was cheaper to feed the Sioux than to fight them, spent more than two million dollars a year for their rations. At Fort Berthold the Three Tribes received food as well as other aid, such as medical care, farm implements, and schools. In the winter of 1869-1870 their agent was feeding the elderly and ill at Fort Berthold, but he had sent the able-bodied Indians by steamboat to Fort Buford and the hunting grounds of the Yellowstone. Suffering from scurvy and hunger, the Three Tribes felt aggrieved that they, who had long been friendly to the whites, were not treated as well as the Sioux, who had made so much trouble. The Indians at Fort Totten, though receiving no free rations except in cases of extreme destitution, were provided with work and paid in provisions and clothing.

The army forts, the agencies and reservations, and the disappearance of wild game confronted the Indians with a problem of readjustment. A

${ }^{2}$ For garrison strength, see Report of the Secretary of War, 1873, pp. 6063. Populations of the reservations are in the annual Report of the 
free people ruling a vast, semiarid grassland, they had developed a way of life centering on the buffalo. But as the herds disappeared, their adaptation to the environment broke down. At the same time, the army was taking away from them both their freedom and their control of the country. The army put them on reservations and they were compelled to submit, for they were now dependent upon the government for subsistence.

So the Indians had to find a new way to live on the Plains. They needed to become self-supporting, to prepare to live in or with white society, and to come to terms with those who now controlled the Plains. The western Sioux, or Teton Dakotas, whose life ways were more completely centered on the buffalo, ha d a more difficult adjustment to make than did the Fort Berthold Indians and the eastern Dakotas, who had long lived in part by agriculture.

The western Sioux, though they could not escape the new conditions pressing upon them, looked reluctantly toward the future. Those who had recently come in to the agencies were restless and insolent; they disliked the white invasions of their country. When in 1871, 1872, and 1873 surveying parties marked out the line of the Northern Pacific in western North Dakota and eastern Montana, the army had to escort the surveyors and ward off Sioux attacks. The Sioux resented it when in 1874 Colonel George A. Custer led twelve hundred troopers from Fort Abraham Lincoln to the Black Hills, a region set aside in 1868 as part of the Great Sioux Reservation.

Custer reported gold in the Hills, touching off a rush of prospectors. The resulting quarrel over the Black Hills brought on an Indian war. Resistance came especially from the Sioux who had not signed the treaty of 1868 and who never came to the agencies. Under leaders like Sitting Bull, Gall, and Crazy Horse, they stayed in the unceded Montana country south of the Yellowstone, where buffalo still grazed. There they clung to the old way of life and were called "hostiles" because they resisted white control.

At first the army tried to keep the whites out of the Black Hills while the government offered to buy the region. When, in the summer of 1875 , the Sioux refused to sell, the army ended its restraint of the gold seekers, who immediately swarmed in by the thousands.

The Sioux naturally believed that they were going to lose their country. Many of the agency Indians, starving on short rations, joined the hostile bands to the west. In December, 1875, the Commissioner of Indian Affairs ordered all Indians to return to their agencies or be considered hostile. Many Sioux on the Powder and Big Horn rivers ignored the order, and in the spring the army set out to punish them. 
The fighting started with the defeat of General George Crook on the Rosebud. Then the Sioux wiped out Custer and 280 troopers of the Seventh Cavalry in the famous Battle of the Little Big Horn. But the army filled the western country with troops and whipped the Sioux in a series of encounters in the summer and fall of 1876. Many of the defeated ones came back to their agencies. Sitting Bull and about two hundred lodges of his followers crossed the international boundary to become unwelcome guests on Canadian soil.

On the reservations, the Sioux gradually submitted to the control of their white masters. In June, 1875, the army had stationed troops beside the agency at Standing Rock in what became Fort Yates. In the fall of 1876, as the defeated bands returned, the army took away their arms and horses, rounding up some 2,200 horses and mules at Standing Rock. These were driven to Bismarck, sold, and shipped east. In the fall of 1876, the Sioux finally gave up the Black Hills for a promise of rations until they could become self-supporting.

They had lost their freedom. Soon the agent deposed chiefs at will and diminished their status by distributing the rations directly to each family. Soon, too, the Indians could not leave their agency without a pass, and they had to live close to the agent's headquarters to be under constant surveillance. The agent could compel obedience by threatening to cut off rations. After authorization by Congress in 1878, the agent organized some of the Indians (called "progressives" because they were in sympathy with the white program) into a police force to discipline the others. At Standing Rock he set up a Court of Indian Offences (authorized in 1883), by which Indian judges helped the agent stamp out polygamy, "heathenish" dances, and the influence of medicine men. They also punished other offenses.

Such controls were meant to bring the Indians to a new way of life, but there were many obstacles. The aim of government policy was for them to become self-supporting by raising crops, but the land and climate at Fort Berthold and Standing Rock were better suited for stock raising. Drought caused many discouraging crop failures. Unfortunately, the government made no effort to establish ranching, an activity suited to both the country and the Indians' love of horses, riding, and group activity; ranching would have been much like buffalo hunting. The government was even slow in sending the needed agricultural implements. Moreover, the Indians suffered from disease, many dying from tuberculosis and scrofula. In 1881 at Standing Rock Agency, deaths (111) exceeded births (105). The certainty of rations from the agent made some Indians indifferent to their own success. Some chiefs opposed the 
new ways, which deprived them of power and influence. ${ }^{3}$

\section{RESERVATION LIFE}

Yet many were eager to work, eager to take up new ways of living, and they made rapid progress, perhaps more in the early years than later. The government supplied tools, oxen, milk cows, seed, and instruction, and at first broke the land for the Indians. Agents and missionaries pushed the Indians along. Both the government and the churches established day and boarding schools, which taught farming and homemaking skills in addition to common school subjects. The first school was opened at Standing Rock in January, 1876.

From 1869 to 1882, the reservations were assigned to religious bodies. In North Dakota the Roman Catholic church received Standing Rock and Fort Totten, the Congregationalists Fort Berthold. Eventually, Catholic orders established boarding schools at Standing Rock, Fort Berthold, Fort Totten, and in the Turtle Mountains. At Standing Rock the Benedictine Fathers, led by the Reverend Abbot Martin Marty, opened a boarding school in 1877; the routine was four hours at studies and four in the garden. The devoted Congregational missionary Charles L. Hall and his wife built a church and a school at Fort Berthold in 1876. Four gentle Grey Nuns won the affection of their charges at Fort Totten. By 1890, when there were 8,174 Indians living on reservations in North Dakota, 1,274 children were enrolled in eighteen schools (eleven day and seven boarding) on the four reservations in the state.

Agriculture was the chief feature of the new life. The Indians gradually moved out to individual claims, planted from one to fifteen acres, and put up log houses heated with stoves furnished by the government. Each year they broke and planted more land, acquired more stock and farm implements, and, at Fort Totten, fenced their field. A few, apprenticed in shops at the agency, became skilled blacksmiths and carpenters. Many changed their habits and outlook. They became peaceable and industrious, attended church, and consulted white doctors when they were ill. They gave up polygamy, cut their hair short, and buried their dead in the ground instead of on scaffolds.

Not all made the same progress. Only a few learned to read and converse in English. By 1880, however, all of the Indians at Fort Totten

${ }^{3}$ Edward A. Milligan, “The Standing Rock Sioux, 1874-1890" (Unpublished M.A. thesis, University of North Dakota, 1948), pp. 17-18, 40-41, 63-69, 88, 91; Darrell De Long, “A History of Fort Yates” (Unpublished M.A. thesis, University of North Dakota, 1956), pp. 12, 20-25, 32; Adrian R. Dunn, "A History of Old Fort Berthold" (M.A. thesis [later published], University of North Dakota, 1951), pp. 84-91. 
were located on individual claims. At Standing Rock by 1881, nearly half the people, 284 families out of 588, had individual claims or allotments. At Fort Berthold in 1885, the Three Tribes began to move to individual allotments, and by the next summer the village was almost deserted. Each head of a family was to have 160 acres of land and each single person 80 acres, although the government held the land in trust for the owner for twenty-five years. In general, the Indian farms were too small for the semiarid climate. In 1900 farms on reservations averaged only 115 acres, with 29 acres of improved land. Again and again drought robbed the Indians at Standing Rock and Fort Berthold of much of the reward for their labor. The agents believed that even white farmers could not have made a living on such land.

The Indians at Fort Totten made better progress toward self-support. They did not receive rations without work, and their land was more fertile and had more rainfall. In 1890 the Fort Totten Indians, except for the aged and destitute, were earning all of their subsistence by civilized pursuits. They wore white man's clothing, and the government was spending only $\$ 20,000$ a year on them.

The Fort Berthold Indians, better corn growers than their white neighbors, earned about 70 percent of their subsistence and pieced it out with a little hunting and with government rations. The government spent $\$ 30,000$ a year to assist them. The Standing Rock Indians earned only 30 percent of their subsistence; their support cost the government \$250,000 a year.

As the Indians began to live by farming and on government rations, it became obvious that some of the reservations were much larger than they needed to be. In August, 1879, the government reduced the size of the Great Sioux Reservation, taking away more than 5,000,000 acres of land east of the Missouri, mostly in South Dakota. And in 1889 the government took about half of the Great Sioux Reservation, or $11,000,000$ acres of what still belonged to the Sioux west of the Missouri, and divided the remainder into six separate reservations. The Standing Rock Reservation had 2,462,000 acres (only 665,000 in North Dakota).

In two cessions, the first in 1880 and the second in 1891, the government took away the greater part of the Fort Berthold Reservation, leaving the Three Tribes about 1,300,000 acres. The cession of 1891, negotiated in 1886, but, to the disappointment of the Indians, long unratified by Congress, gave the Three Tribes $\$ 800,000$ in ten annual payments and opened 1,600,000 acres to white settlement. The Fort Totten Reservation, about 275,000 acres, was not reduced. ${ }^{4}$

${ }^{4}$ Charles G. Royce, “Indian Land Cessions in the United States,” Bureau 
Not all of the Indians were willing to adopt new ways. At Fort Totten some left the reservation to roam over the prairie during the summer. The full-bloods at Turtle Mountain were reluctant to send their children to school. Up the Missouri from Fort Berthold, Crow-Flies-High and his 168 followers still lived in 1890 by hunting, fishing, and gathering buffalo bones. They would come to the agency occasionally to have a horse shod and would accept the gift of a steer and some sugar and flour, but they did not live on government rations and were most reluctant to take up farming.

In 1881, Gall, Sitting Bull, and about 1,300 hostiles who had fled to Canada after the Battle of the Little Big Horn returned to the United States. They eventually settled on the Standing Rock and Cheyenne River reservations. Their coming increased the population at Standing Rock to about 4,700. Some of them were among the irreconcilables who expressed their resistance to white culture by taking part in the Messiah Craze of 1890.

This new religion taught that an Indian Messiah would come from the west with buffalo, horses, and the ghosts of the dead. He would destroy white rule and reunite all Indians, living and dead. The religion's ritual was the Ghost Dance, in which the exhausted dancers fell into a trance and talked with their dead relatives. It encouraged a dangerous recklessness, for the dancers believed that they became immune to bullets from white guns. Sitting Bull, defying Standing Rock Indian Agent James McLaughlin, used the Ghost Dance to reinstate himself as leader of the Sioux; he would turn his people away from the road to self-support through agriculture and education. Gall and John Grass, loyal to the government, opposed the Ghost Dance.

So did James McLaughlin, the tall, honest, dignified Scotch-Irish agent at Standing Rock. Unlike most agents, he was a career man. Before his death in 1923 at the age of eighty-one, he had devoted fifty-two years to the Indian Bureau and the cause of Indian advancement. His autobiography, My Friend the Indian (1910), is an important document. In 1871 he had conducted a bull train of twenty yoke of oxen and ten wagons to Fort Totten to assume his duties as assistant agent on that reservation. In 1881 he took charge at Standing Rock; his wife served as official interpreter.

McLaughlin was convinced that Sitting Bull exercised a demoralizing influence among the Sioux. On December 15, 1890, acting on orders from the military authorities, McLaughlin sent Lieutenant Bull 
Head and forty-three Indian police to arrest the chief in his cabin on Grand River. They made the arrest just before daylight. Though at first submissive, Sitting Bull, gaunt and weak from steam baths and dancing, shouted for help, and his excited followers attacked the police. In the fight, Sitting Bull and seven of his people and Bull Head and five police were killed. After the death of Sitting Bull, soldiers rounded up the Ghost Dancers who had fled from the agencies to the Badlands. In the process, the Seventh Cavalry killed some three hundred of Big Foot's band on Wounded Knee Creek. Ghost Dance resistance to the white man's way was over.

As danger from the Indians diminished, the army gave up its forts in North Dakota. It abandoned Fort Ransom in 1872, Fort Seward and Camp Hancock in 1877, Forts Abercrombie and Rice in 1878, Fort Stevenson and Cantonment Bad Lands in 1883, Fort Totten in 1890, Fort Abraham Lincoln in 1891, Forts Buford and Pembina in 1895, and, last of all, Fort Yates in 1903. The military frontier had passed.

\section{THE TRANSPORTATION FRONTIER}

As the Indians were settling down on their reservations, transportation lines penetrated the Missouri Slope. In 1877 stagecoaches and freight wagons began to travel from Bismarck to Deadwood to accommodate gold seekers rushing into the Black Hills. That February, the Northern Pacific Railroad, the Minnesota Stage Company, N. P. Clark of St. Cloud, and Peter Seims and his associates formed the Northwestern Express and Transportation Company to open the new route. The company invested $\$ 100,000$ in the venture. It brought horses, mules, wagons, and Concord coaches and put up quarters for its men and stock at Bismarck and at ten points along the 210-mile route to the Black Hills. At 75 and 150 miles from Bismarck, these were "home stations," with overnight facilities for passengers. The other stations provided only fresh teams. The Deadwood station had a life-size painting of Custer mounted on a horse to advertise the "Custer Route to the Black Hills." The first stages left Bismarck with 68 passengers on April 11, 1877. The company operated a triweekly schedule, charged a fare of $\$ 23$, and carried mail on a government contract.

The company's business expanded rapidly. For a time the Bismarck route became the most important one to the Black Hills from the east. Stage and freight lines from Cheyenne, Wyoming, and Sidney, Nebraska, were major approaches from the west and south. By June the company had 26 Concord coaches and 200 teams; in January, 1878, it added 100 mules. On October 17, 1879, it brought several carloads of horses to Bismarck and reported that in ten days it had carried 72 passengers and 
nearly 300,000 pounds of freight to the Black Hills. Except for an attack on a stagecoach in the fall of 1877, the Indians did not molest travelers. In 1880 the Chicago and North Western Railroad reached Pierre. That fall, the company began to use a shorter road from Pierre to the Hills, sold its property in Bismarck, and abandoned the old route. ${ }^{5}$

In 1878 the army opened a trail from Bismarck to Fort Keogh. After the disaster on the Little Big Horn, General Nelson A. Miles had constructed Fort Keogh in August, 1876, as headquarters for a winter campaign against the Sioux. The building of Fort Keogh, the site of present-day Miles City, inaugurated regular travel westward from Bismarck. In the summer of 1877, Don Stevenson, an army freighter, made a hay contract for the fort. He took out a party of 125 men, 95 wagons, 20 mowing machines, and 10 horse rakes from Fort Abraham Lincoln. In 64 working days he put up 3,800 tons of hay at \$28 a ton-a gross return of $\$ 106,400$.

To supply Fort Keogh with mail and freight, surveyors marked a trail west from Bismarck in 1878, using mounds of earth, each with a strip of canvas nailed to a cedar post. The trail followed roughly the later route of the Northern Pacific but dipped southward east of present Dickinson. In 1880, John R. Miner received a mail contract to make six trips a week each way for $\$ 70,000$ a year. Light wagons drawn by four or six horses (or mules) carried the mail. The teamsters, often driving on the run, stopped at way stations every seventeen or eighteen miles to change teams. The stations were one-room dugouts in the side of a hill, each with a pole-and-earth roof and a single window and door. Nearby stood a barn and corral. The home station beside the spring at Young Man's Butte had a big log house, a long barn, and a blacksmith shop.

Those who manned the stations lived a lonely, dangerous life. For a time renegade Sioux under Low Dog made things lively by stealing horses and killing hunters, stationkeepers, and mail drivers. In the summer of 1880, however, Captain Bell and troopers from Fort Keogh killed some of the marauders.

Traffic on the trail increased in 1879 when the Northern Pacific began to push west from Bismarck with construction crews, supplies, and equipment. In December the tracks reached a point thirty-five miles east of Young Man's Butte. The workers stayed on during the winter, and supplies were freighted to them, an operation made possible because Gus Plummer, a former government wagonmaster who knew the country, had put up hay along the Northern Pacific route on speculation. By the fall of

${ }^{5}$ Arthur J. Larsen, “The Northwestern Express and Transportation Company," North Dakota Historical Quarterly, VI (October 1931), 58-61. 
1880 track was being laid at the rate of two miles a day, and reached the Little Missouri in September. Grading was nearly finished to the Yellowstone.

In 1883 the Northern Pacific was completed when a golden-spike ceremony linked the eastern and western sections at Gold Creek, Montana. Neither the Northern Pacific nor the Great Northern built any branch lines on the Missouri Plateau before 1900. For many years its only railroads were their main lines, crossing the region on the way to the Pacific Coast.

The building of the Northern Pacific brought white occupation. To protect the construction workers, the army stationed a company of the Sixth Infantry at the crossing of the Little Missouri in November, 1879. The troops built their quarters, Cantonment Bad Lands, about threefourths of a mile northwest of present-day Medora. The post had a storehouse, company barracks, officers' quarters, hospital, bakery, blacksmith shop, stables, and quarters for laundresses.

\section{DESTRUCTION OF THE BUFFALO}

Many eastern sportsmen came to the cantonment to hunt. Frank Moore, full of good humor and windy talk, was post trader; his store was a sort of clubhouse for the post and region. In November, 1880, Moore opened the Pyramid Park Hotel for hunting parties. He was assisted by E. G. (“Gerry”) Paddock, a shifty-eyed guide to Custer and Northern Pacific surveying parties whose questionable operations often got him into trouble with the law. In the fall of 1880, Howard Eaton of Pittsburgh came out to hunt, killing scores of deer, mountain sheep, and antelope. Other sportsmen also came, among them Theodore Roosevelt of New York City and A. C. Huidekoper of Meadville, Pennsylvania. Huidekoper later recalled that Paddock was "the best shot with a rifle I have ever met. He killed a deer running, as a man shoots a bird on the wing."

The railroad made possible the wholesale destruction of game by professional hunters. Large-scale buffalo hunting began on the Little Missouri in the fall of 1881. When the fur became prime for coat robes in October, groups of two or three young men who had caught the "western fever" armed themselves with buffalo rifles, the .45-caliber Sharps single-shot, and set out on the hunt. After the kill, they skinned the buffalo, folded the hides with the hair inside, and stacked them. In cold weather they would cut off the choice meat-hams, shoulders, strips of loin, and tongues, about three hundred pounds per animal. Freighters hauled the meat to Sully Springs, where many carloads were shipped to St. Paul. For months a market in Dickinson sold only wild meat: buffalo, 
elk, deer, and antelope.

With the return of warm weather, hunters or freighters hauled the hides to shipping points, Sully Springs or Dickinson, where they made long ricks of them along the station platform. Great numbers of hides were brought in. Two or three partners would kill up to nine hundred buffalo in a season. The hunters were paid from $\$ 1.50$ for a bull hide up to $\$ 3.25$ for a cow hide, and about a cent a pound for the meat on the range or three cents in Dickinson. In all, they received about $\$ 5.00$ for each buffalo. The best cow hides, taken in October and November, were used to make overcoats-many of them for the army-and also caps and gloves.

Under these conditions the end of the buffalo herds came quickly. The great hunts on the Missouri Slope were in 1881 and 1882, and the last large shipments in the spring of 1883. That fall, Roosevelt had a hard time getting a single buffalo, but other game was still abundant. In December, 1884, Vic Smith, called the champion shot of Dakota, killed sixty-nine deer and antelope in five days. ${ }^{6}$

The destruction of the herds was followed by a harvest of buffalo bones, which were shipped east to make carbon black for refining sugar. In 1884 bone pickers began to bring their wares to Dickinson and Sully Springs, receiving from eight to ten dollars a ton. Freighters, hauling supplies from Dickinson to the Black Hills, increased their profits by picking up bones on the return trip. In 1886 piles of buffalo bones were stacked on every Northern Pacific platform from Jamestown westward, and the next year, when the Great Northern was ready to receive freight shipments at Minot, bones were the chief item. For months at Minot more than a hundred wagons a day unloaded bones along the track. They were often the first income of the pioneer farmer.

\section{THE RANCHING FRONTIER}

The Northern Pacific opened the Missouri Slope, bringing in both ranchers and farmers. The Little Missouri Valley was an ideal cattle country, and the rise of ranching there initiated systematic use of its short grass (the chief natural resource) and permanent occupation of the region.

It was the hunters who first saw the advantages of the country for cattle: nutritious grasses which cured on the stem and which were good for winter grazing, the shelter afforded by ravines and coulees, and water in the streams. All who visited the country were enthusiastic, but none more than Theodore Roosevelt, who wrote perceptively:

${ }^{6}$ Reminiscences of Joe Meyer in Golden Valley News (Beach), January 21, June 24, October 21, 1937. 
The country is covered with a growth of short bunch grass, which cures on the stalk, into excellent cut hey for winter feed; it is very nutritious, and upon it range cattle become as fat as stall fed oxen. Over most of the land there is nothing but this grass and the bitter, grayish stage brush; except for a few weeks in the spring, when the first growth forms a mantle of green, the whole land is covered with a monotonous dull brown, which, joined to the extraordinary shapes and bizarre coloring of the water-worn buttes, gives the landscape a look of grim and forbidding desolation.... This forbidding aspect of the land, however, completely belies its real character; the dull, barren-looking country, clad with withered brown grass, in reality offers as fine grazing as can be found anywhere in the West, while the cliffs and broken valleys offer almost perfect shelter to the animals in winter.... The rainfall is slight, and the snow rarely covers the ground to any depth. The water supply back of the river is scanty, and the country is wholly unfit for agricultural purposes.... The scantiness of the water supply is no harm to the cattle men, as in summer the beasts keep within a few miles of the river, principal creeks or large water holes, and thus loose a great stretch of back country over which they have not grazed, and which can afford them excellent winter feed when ice has closed up all the ponds and streams, and they are obliged to slake their thirst by eating snow. ${ }^{7}$

Obviously, such a country could not be farmed in the same way as regions with plenty of rain, yet its grasses could produce wealth. Ranching was a natural use for much of the Slope-an adaptation to the nature of the land. By 1883 the natural advantages combined with other favorable conditions to bring the ranching frontier to the Little Missouri country. The Northern Pacific provided a way to market; the Indians were docile on their reservations; the buffalo were gone; the cattle kingdom, spreading northward across the Great Plains since the Civil War, was reaching its last virgin range; the nation was prosperous and capital venturesome; and young men like Roosevelt were fascinated by the idea of ranching.

East of the Missouri River the pioneers raised cattle when they lived too far from the railroad to raise grain. Sometimes herders cared for their neighbors' stock during the summer, and in the 1880's there were ranches with from fifty to two hundred head in many places. There were many ranches in Emmons and Burleigh counties, in the country north of Bismarck, and in the Mouse River Loop. There was, however, little or no winter grazing, the pioneers putting up hay for winter feed.

West of the Missouri the first ranches were held by men who had

${ }^{7}$ Ray H. Mattison, "Ranching in the Dakota Badlands: A Study of Roosevelt's Contemporaries," North Dakota History, XIX (April-July 1952), 103-104. 
come to the Slope to hunt, to fill army contracts, to work at stage stations, or to build the Northern Pacific. In 1879, for example, stock tenders at Young Man's Butte had a ranch, and a former railroad section hand was ranching just east of the later site of Hebron. Don Stevenson, the army freighter and contractor, and his employees started ranches near the Bismarck-Deadwood Trail on the Cannonball River and on Cedar Creek, a rough, broken country with badlands and winter shelter that later became important for sheep.

The heart of the cattle country, however, was the Badlands, stretching along the Little Missouri River. Here some ranchers had been hunters, some sportsmen, and some Texas cattlemen. In 1881, Howard Eaton of Pittsburgh, after a hunting trip to the Little Missouri, joined guides Frank Moore and Gerry Paddock in setting up the Custer Trail Ranch five miles south of the Northern Pacific crossing. In 1884, one of Eaton's friends, A. C. Huidekoper of Meadville, Pennsylvania, set up the Little Missouri Horse Company with the HT Ranch near HT, or Black Butte. He bought purebred stallions and some of Sitting Bull's war ponies and raised Percherons.

In the fall of 1883, Theodore Roosevelt, then twenty-five and out in the Badlands on a hunting trip, decided to get into the game. He bought the Maltese Cross Ranch, seven miles south of Medora, and formed a partnership with former hunters Sylvane Ferris and A. W. Merrifield. They ran the ranch for him for half the profits. In the summer of 1884 he brought out Maine guides William Sewall and Wilmot Dow to manage his new ranch, the Elkhorn, on the Little Missouri thirty-five miles north of Medora. Roosevelt was a squatter, not holding title to any land for either of his ranches, but he invested $\$ 82,500$ and at the peak of operations probably had five thousand cattle.

In 1883 and 1884 big Texas outfits also came to the Little Missouri: Towers and Gudgell (the OX brand); the Berry, Boice Cattle Company (the Three Sevens brand); W. E. Hughes and John N. Simpson of the three-million-dollar Continental Land and Cattle Company (the Hashknife outfit); and the Reynolds brothers (the Long X). All of these big outfits handled Texas cattle and brought large herds over the trail each summer from their southern ranges. The OX ran 15,000 head, the Three Sevens 30,000, and the Hashknife 60,000.

But the Marquis de Mores was the most spectacular newcomer. A young French aristocrat, a horseman, a sportsman, and an army officer educated at St. Cyr, he had married Medora Von Hoffman, the daughter of a New York banker, in February, 1882. Fascinated with the idea of a meat-packing plant on the Little Missouri, he founded the town of Medora in April, 1883. His packing plant, built at a cost of $\$ 250,000$, 
began slaughtering in October.

The optimistic entrepreneur poured money into other schemes. He bought 6,000 cattle and 15,000 sheep; he hired 150 cowboys; he began breeding horses and backed a stage and freighting business between Medora and Deadwood which had 150 horses, 4 Concord coaches, and 15 stations. The Marquis also built a church and a school in Medora. In love with the country, he put up a 28-room chateau, filled it with fine furniture, books, pictures, silver, china, and Oriental rugs, and brought his family and guests there during the summer months. ${ }^{8}$

Medora boomed. By January, 1884, it had eighty-four buildings (only four in February, 1883), including three hotels, three groceries, a dry-goods store, and a newspaper, the Bad Lands Cow Boy, edited by Arthur T. Packard, a college athlete from the University of Michigan. In 1883 many men had begun to pick out likely places along the Little Missouri and its tributaries to build their cabins and corrals. At first they were squatters, protected in their rights by the custom of the range. They drove herds from Texas or Colorado, or shipped in eastern cattle ("pilgrims") on the Northern Pacific from Minnesota or Iowa. The herds roamed almost at will and foraged for themselves summer and winter. There were always some winter losses. The smaller ranchers, men like Roosevelt, handled mixed cattle from the East and raised calves.

Roundup time was the high point of the year. The first Little Missouri round up was held in the spring of 1884 . About forty men took part, the ranches sending cowboys, horses, and mess wagons, and the big outfits from Montana and South Dakota representatives, or "reps," to look after their cattle.

The round up brought long hours, hard riding, and dangerous work. Roosevelt loved it; he boasted in a letter to Henry Cabot Lodge: "I have been three weeks on the roundup and have worked as hard as any of the cowboys.... Yesterday I was eighteen hours in the saddle-from 4 A.M. to 10 P.M.-having half an hour each for dinner and tea. I can now do cowboy work pretty well."

Although Roosevelt was attracted by the high spirits of the free life (he felt, he said, “as strong as a bear"), the cowboy's lot was full of hardship. George F. Shafer, who grew up on his father's ranch in McKenzie County and later became governor of North Dakota, recalled that the cowboy on the roundup was "often wet to the skin for days at a time; and, sleeping on a damp bed in the rain, the sleet, and the snow,

${ }^{8}$ George F. Will, "The Marquis de Mores in North Dakota, Translated from the French," North Dakota Historical Quarterly, VIII (October 1940), 323. 
there is little wonder that nearly every cowboy is a victim of rheumatism and a physical wreck at the age of thirty-five years.”

The ranchmen faced problems from rustlers, wolves, and the use of the range. In November, 1884, Roosevelt talked his neighbors into standing together in the Little Missouri Stockmen's Association to give more force to the unwritten laws of the range. By the end of 1885 ranchers had fully occupied the Little Missouri country.

In the summer of 1886, Roosevelt began to worry about over-stocking. The range was already full, but ranchers were still shipping or driving in more cattle. A hot July, grasshoppers, and drought cut down the scanty supply of grass, and in the fall, fire destroyed part of what was left. The winter of 1886-1887 came six weeks early, with blizzards in mid-December, unusual cold, and deep snow that buried the grass. Cattle starved by the tens of thousands, the Texas dogies and eastern pilgrims going first. In April, Roosevelt came out to the Badlands. Sick at heart, he wrote to Lodge: "The losses are crippling. For the first time I have been utterly unable to enjoy a visit to my ranch. I shall be glad to get home." Probably 75 percent of the cattle in the Northwest had died.

The open-range cattle industry had suffered a crippling blow. Many eastern and foreign companies closed out. The big Texas outfits, such as the OX, the Three Sevens, the Hashknife, and the Long X, scaled down their operations but went on bringing in Texas cattle into the 1890's. Roosevelt partly restocked his ranches, but his frequent, happy visits came to an end. After the disastrous winter of 1886-1887, the ranchers avoided overstocking. They used the open prairies in summer, saving the grass in the Badlands, where there was more shelter, for winter grazing. They also made some provision for feeding in a pinch.

Medora, however, died. The Marquis de Mores' enterprises had already failed: the Medora-Deadwood stage gave up in May, 1885, and the packing plant closed in November, 1886. By 1889, Medora was a deserted village, with the brick hotel and the Chateau de Mores shut up.

\section{CONFLICT AND TRANSITION ON THE RANGE}

A way of life-free, exciting, and lawless, but adapted to the semi-arid grassland-was beginning to pass. Lawlessness was a major cause of its demise. The Little Missouri country had a bad reputation: the Dickinson Press concluded in 1884: "If there is any place along the line that needs a criminal court and a jail it is Medora." Men went armed to protect their rights. Roosevelt wrote to his sister that with his "pearl-hilted revolver and beautifully finished Winchester," he felt "able to face anything."

One cause of lawlessness was the tight between large and small 
ranchers over free grass, the wealth of the country. In the fall of 1881 a band of twenty vigilantes, organized by big Montana ranchers, invaded McKenzie County to frighten the small ranchers into leaving. The vigilantes, themselves former convicts and horse thieves, threatened men with hanging, killed a hunter, fired the prairie, and burned a barn and five hundred tons of hay at a sheep ranch. They failed, however, to drive out the small ranchers.

Finally, about 1901-1904, many small ranchers came into McKenzie County, took the public lands for themselves, drove off the range herds, and ended the large-scale operations of the big outfits. Charles Shafer, for example, a hunter-turned-rancher, would shoot a wagon load of deer for winter eating, then take a second load to Dickinson to trade for coffee, shoes, sugar, flour, and other necessities.

The small ranchers in western North Dakota followed a middle course between the methods of handling cattle in the humid East and those used on the open range of the semiarid West. The typical ways of the open range came to the Little Missouri Valley, but no farther cast. On the rest of the Slope, the ranchers raised cattle for beef; branded their stock, handled them on horseback, used the free grass on government or railroad land, and called their places ranches. These were all open-range customs.

But, unlike the typical open-range outfits, the small ranchers did not take part in round ups (there were none in North Dakota outside the Little Missouri country), nor did they have the backing of outside capital. They handled mixed native cattle (bulls, cows, calves, and steers) of eastern origin instead of Texas steers. They held their cattle close to the home ranch, often herding them on horseback during the day (a boy's job) and corralling them at night. Sometimes they herded the stock of their farmer neighbors. They put up hay for winter feed and furnished shelter. Some of them had cow camps, where the cattle were taken during the summer so that grazing land near the home ranch would be in better condition for fall and winter use.

Such transitional ranching methods were adapted to all or the Missouri Plateau in North Dakota, a region covered by a grass community with both long and short grasses. On the Missouri Slope, the portion of the plateau west and south of the Missouri River, half the land was classified as best used for crops and half for grazing. On the rest of the plateau, there was more crop land, less grazing land. Thus with a large part of the land better used for crops, methods of handling cattle had to be arranged accordingly.

The settlement of the Little Missouri country by small ranchers and homesteaders forced the big ranchers to fight for their lives. One issue 
was county organization. The big ranchers naturally opposed organization, for it would bring taxation of their cattle. In 1903 the farmers and small ranchers in McKenzie County wanted to organize a government in order to build roads, bridges, and, especially, schools. Big and small ranchers without families strongly opposed it; they won a hot fight in 1904, only to have the legislature arbitrarily organize the county in $1905 .^{9}$

Another issue was control of the range. When small ranchers and homesteaders began to take over the country, ending the era of free grass, the big ranchers had to acquire title to their range. Owning the range increased not only the burden of taxation but also the burden of interest on capital invested. Many of the big ranchers, anticipating these difficulties, gave up after the bad winter of 1896-1897.

A. C. Huidekoper, however, fought on. Before 1900 he and his associates bought 63,446 acres of railroad land, leased 5,000 acres of school land, and put $\$ 30,000$ in a barbed-wire fence that enclosed 80,000 acres. He fenced not only his own property but also about 21,000 acres of public land. The General Land Office ordered him to remove the fence in July, 1900. Huidekoper refused to do so, and finally, in 1906, he and two associates were fined $\$ 2,300$ and sentenced to twenty-four hours in the county jail.

By this time the building of the Milwaukee Railroad was bringing homesteaders to the region south of his HT Ranch. Huidekoper complained bitterly that the range country was being ruined by homesteaders who were settling on semiarid land unfit for tillage, where they would gradually go bankrupt. In 1905 he disposed of his herd of four thousand horses at St. Louis; he sold his land to Fred Pabst of the Pabst Brewing Company of Milwaukee for \$300,000.

A. C. Huidekoper, Howard Eaton, Theodore Roosevelt, and others who sought out the Badlands and the life of the open range were young men-restless, spirited, seeking adventure and fortune. They had freedom; horses to ride endlessly over the plain; game to hunt (Roosevelt killed a grizzly at ten paces); guns; carved saddles, silver inlaid bits, and other horse gear to play with; and buckskin suits, chaps, and sombreros to wear with a self-conscious swagger. They found a new life seasoned with hardship and danger and excitement. Little wonder, then, that they fell in love with the country. Roosevelt, the most articulate of them, wrote to his sister: "The country is growing on me more and more; it has a curious,

${ }^{9}$ George F. Shafer, “Early History of McKenzie County,” North Dakota Historical Society Collections, IV (1913), 44-61; Luella J. Hall, "History of the Formation of Counties in North Dakota," North Dakota Historical Society Collections, V (1923), 224-236. 
fantastic beauty of its own.” The Marquis de Mores' chateau, today a museum (given by his son to the North Dakota State Historical Society in 1936), is, in a way, a monument to an emotion. And in later life, Roosevelt wrote of his days in the Badlands: "We knew toil and hardship and hunger and thirst... but we felt the beat of the hardy life in our veins, and ours was the glory of work and the joy of living." 10

But the great days were gone. Ranching on a smaller scale, of course, continued, although land hunger and the Homestead Act, feeding an elusive dream of agricultural opportunity on a semiarid grassland, had made it impossible for a few cattlemen to rule a kingdom of free grass.

\section{THE FARMING FRONTIER}

The farming frontier overlapped the ranching frontier. Farming began on the Missouri Plateau in the 1880's in a number of places: in the six counties to the east of the Missouri River; in the fertile Knife River Valley; out along the line of the Northern Pacific across the Missouri Slope; and, to a lesser extent, in the five counties lying to the north of the Missouri River. The Great Dakota Boom brought a considerable number of settlers to the six counties east of the Missouri; by 1890 they had a population of 11,000. North of the river, settlement came later. When the St. Paul, Minneapolis and Manitoba built west from Minot, a few towns sprang up along its line. Williston was a colony of tents and log cabins when the construction workers laid track into the town in 1887. Yet there was very little agricultural settlement until after 1900; that year, the region had a population of only 6,000.

Woodhawks, supplying steamboats with fuel, were commonly the first settlers along the Missouri River. John Nagel was such a one. A restless adventurer, he had taken part in the California and other gold rushes before he came to the Upper Missouri after the Civil War. His woodyard at Knife River Landing employed as many as fifteen woodhawks at one time. Nagel himself had a home between Fort Berthold Reservation and the Fort Stevenson military reserve. He was native, took at one time or another eight Indian wives, and spoke three Indian languages. He dressed in a buckskin coat, fringed leggings, and beaded moccasins. He raised horses and cattle.

The first agricultural settler in the region near the confluence of the knife and Missouri rivers was Edward Heinemeyer, who arrived in 1882. That year, Bob McGahan, a riverman, filed on the first homestead in Mercer County. The territorial legislature laid out the county in 1883, 
and Stanton won the county seat after a fight. The first settlers took up land near the Missouri River, and later arrivals pushed out the Knife. Some ranched; others farmed. Heinemeyer picked up corn from the neighboring Fort Berthold Indians and by careful selection bread an excellent variety, Heinemeyer Flint, which made Mercer County a corn producer.

German immigrants from Russia made it a wheat country. In the last half of the eighteenth century, Catherine the Great had attracted German peasants to southern Russia. A century later, their descendants began to come to America's Great Plains. Some of the first settled near Yankton in 1872, and in 1885 they began to migrate to McIntosh County. The next spring, a party moved north from Scotland, a settlement of German Russians northwest of Yankton. They had loaded thirty covered wagons with bedding, cooking utensils, tools, and plows. Seeking black, level land suitable for raising wheat, they marched up the James River Valley, turned northwest to Bismarck, crossed the Missouri on a ferry, and pushed out the line of the Northern Pacific. At Hebron the land seekers found settlers bringing in loads of buffalo bones worth six to fourteen dollars a load, Short of cash, they themselves camped north of the town to gather bones.

Visitors to the camp told them of good land north of Stanton. After looking it over, they located their claims near present-day Krem. By 1889 some thirty families had settled north of the Knife. Encouraged by Carl Semmler, an immigrant agent for the Northern Pacific, German Russians began to come directly from Russia. By 1910 some 55 percent of the population of Mercer County had either been born in Russia or were the children of parents born there. The German Russians made good settlers, for they knew the soil, the crops it would grow, and how to live frugally. But Mercer County grew very slowly. It had only 1,778 people in 1900, and Oliver County, its neighbor to the south. settled by Germans from both Russia and Germany. had only 990.

Farther south the Northern Pacific had created a string of little settlements across the Slope. Town building rather than farming was the first step, and merchants and land agents were the leaders. When the railroad crossed the Missouri River in 1879, Mandan sprang up. Dickinson began as Pleasant Valley Siding when the railroad reached that point in 1880. The first settlers were railroad men, some of whom married girls who cooked for the construction crews. Cattlemen and former prospectors also drifted in, and the place became a shipping point for buffalo bones and cattle. In 1882, Father Patrick Cassidy began to say Mass once a month in a Dickinson hall, section house, or private home.

Both the Northern Pacific and townsite companies established towns. 
The Richardton Improvement Company laid out a townsite twenty-five miles east of Dickinson in 1883, putting up a large building which served as a store, post office, hotel, and church. In 1890 the firm sold its store to Sebastian Mischel, Sr., the leader of a newly arrived group of German Russians.

The Northern Pacific built Glen Ullin, sending agents into Wisconsin, Illinois, and Ohio to organize prospective settlers into a colonization society. In May, 1883, Northern Pacific trains brought several hundred settlers to a siding on the empty prairie, and the town sprang up overnight. Each winter, E. R. Steinbrueck, the only German and Catholic in the original band, would go east to talk to prospective German settlers. He also wrote letters to German-language papers, seeking, as he remembered it, to "make the Easterners' mouth water for the wealth of the west.” Gradually, Glen Ullin became a Catholic German and German Russian settlement.

The Northern Pacific cooperated with the Deutscher Evangelischer Colonizations Verein (German Evangelical Colonization Society) to found New Salem some twenty miles east of Glen Ullin. In the fall of 1832 some Illinois and Wisconsin pastors of the German Evangelical church organized the society, which sought members by sending out literature to pastors, by publishing reports in Friedensbote (the official paper of the synod), and by writing letters to German-language newspapers. Full of energy and zeal, it placed an agent in New York to talk to German immigrants as they disembarked. It also chose a pastor for New Salem and planned a church, a school, and a "Christian hotel." For- a twenty-dollar fee, the new member was to be given two lots in the projected town and help in getting settled. By the spring of 1883 the society had recruited more than two hundred members, collected $\$ 4,410$ in fees, and sent the first settlers to New Salem. The town prospered. In 1883 the society established a second colony at Hebron, thirty-three miles to the west.

The Hebron and New Salem settlers early turned to dairy farming. In 1883 a Sioux Indian told young John Christiansen that by plowing he was turning the sod "Wrong Side Up." Legend has it that this phrase made Morton County a leading dairy center. ${ }^{11}$ Long before dairying

${ }^{11}$ C. B. Heinemeyer, History of Mercer County, North Dakota, 1882-1932 (Hazen, N. D.: Hazen Star, 1932), pp. 22-25, 28-29, 37-39, 43-45, 53; E. A. Wilson, H. C. Hoffsommer, and Alva H. Benton, Rural Changes in Western North Dakota, North Dakota Agricultural Experiment Station Bulletin 214 (Fargo, 1928), pp. 18-19; Souvenir of Golden Jubilee of St. Patrick's, 

became important, however, the southern Pacific began to mine lignite at Sims, eight miles west of New Salem, bringing in more than a hundred miners, mostly Cornishmen.

Although Dickinson, New Salem, Hebron, and other towns persisted, settlement of the region had scarcely begun. In 1900, some twenty years after the Northern Pacific crossed the Missouri Slope, its population was scattered thinly along the railroad; the back country was vacant except for an occasional ranch. The colonization efforts of the Northern Pacific, the availability of railroad transportation, the conquest of the Sioux, and the attraction of free land had not brought many settlers to the Slope-a semiarid short-grass country.

E. R. Steinbruek, "History of Glen Ullin,” North Dakota Historical Society Collections, I (1906), 297-299; Minutes of the German Evangelical Colonization Society, Hebron Papers, Orin G. Libby Manuscript Collection, Chester Fritz Library, University of North Dakota. 


\section{CHAPTER 10}

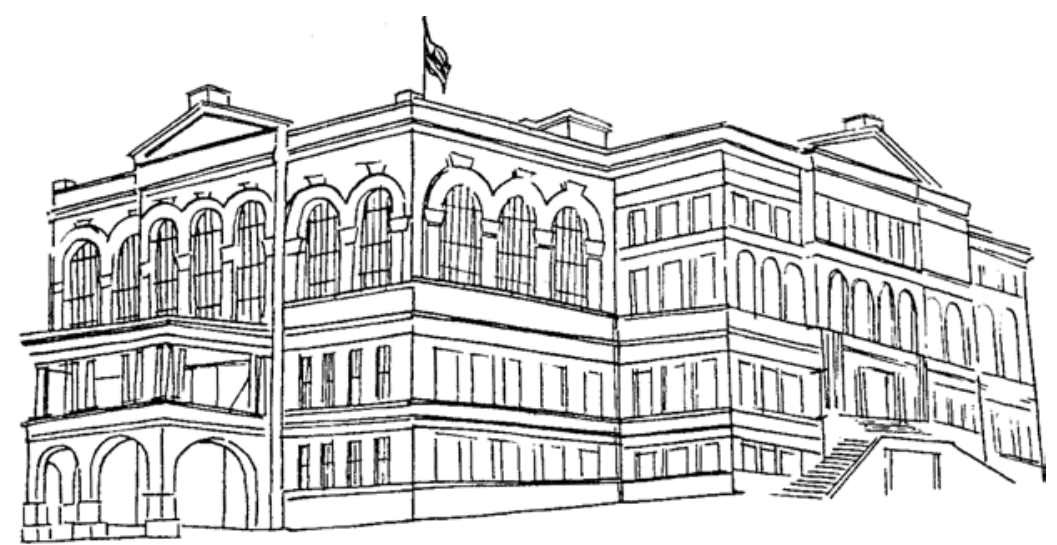

\section{The Making of a State}

THE WESTWARD ADVANCE of the American frontier was accompanied by the establishment of territorial and state governments. In 1787 the Congress of the United States had provided that when the newly settled lands had a sufficient population, they were to be admitted to the Union on a basis of equality with the original states. Until there was sufficient population for statehood, Congress provided territorial governments. As the system evolved, the governor and other officers were to be appointed by the President of the United States, and the legislature was to be elected by the people of the territory. Territorial government, then, was a stage of tutelage in which both local and outside control had a part.

Generally the period of tutelage was a short one. Minnesota, for example, became a territory in 1849 and a state in 1858. But the region organized as Dakota Territory in 1861 was not admitted-and then as two states-until 1889. The long period of tutelage brought about a protracted struggle for statehood: for political equality of status in the nation. While it was in progress, the farmers, organized into the Dakota Farmers' Alliance, revolted against outside exploitation by the railroads, the banks, the grain trade, and the manufacturers of farm machinery: the farmers sought economic equality of status in the nation. Thus at the same time there were two struggles against outside control, one political and the other economic. The political battle culminated in the writing of a constitution for the new state; the economic fight, though less successful, helped to shape the provisions of that constitution.

The statehood movement, the struggles of the Farmers' Alliance, and the writing of the constitution-all revealed the problems with which the people of North Dakota had to contend. Moreover, they helped to channel the psychology of North Dakotans into patterns of revolt against 
outside control, against colonial status. Both the patterns of revolt and the provisions of the constitution, made in the climate of opinion of 1889, would long influence the history of the state.

One of the harsh realities of North Dakota life was the power of the railroads. Albert S. Parsons, a delegate from Morton County and an employee of the Northern Pacific, told the constitutional convention in 1889:

We are largely dependent on corporations. Corporations in North Dakota will always have a stronger influence than they have elsewhere. With all due justice to them-we wish to encourage them-we wish to help them-but we must beware the day when they will shackle us and control our people.

Martin N. Johnson of Petersburg, also speaking to the convention, put it more bluntly: "[The Great Northern] controls everything in our part of the country." The Northern Pacific was also influential. The federal government had given it 10,700,000 acres of land in what was to become North Dakota. The land grant, 24 percent of the state's area, gave the Northern Pacific a huge economic stake in the government. ${ }^{1}$ So for years the railroads and the people struggled for control. Who would dominate the government and economy of North Dakota?

\section{THE STATEHOOD MOVEMENT}

Statehood was a quiet revolution, accomplished by less than two hundred men. The first leaders were Yankton politicians, but all came from southern Dakota and all were Republicans. With few exceptions, they were conservative, middle-class business and professional menbankers, lawyers, ministers, railroad employees, and newspaper editors. They were of the older American stock and came from New England, New York, or the states of the Old Northwest. They were Republicans because Dakota was a one-party region-a result of the long years of territorial status when the Republican party had control of the United States government.

These men wished to throw off outside control. They were tired of the President's appointing the governor and other officials from outside the territory. They aspired to win elective office for themselves. In 1877 the Yankton Press and Dakotaian, the chief newspaper of the territory, wrote:

We are so heartily disgusted with our dependent condition, with being snubbed at every turn in life, with having all our interests subjected to the whims and corrupt acts of persons in power that we feel very much as the

${ }^{1}$ Robert S. Henry, “The Railroad Land Grant Legend in American History Texts," Mississippi Valley Historical Review, XXXII (September 1945), 194. 
thirteen colonies felt when they flung away their dependent condition.

Statehood leaders had nothing but contempt for the graft and corruption of the territorial system. They brought into the movement reformers, prohibitionists, and the best elements in every town: ministers, lawyers, and members of women's clubs. But the Democratsthe workmen of the towns and the Black Hills, the saloon element, and some of the merchants-took little interest in the movement.

From the beginning the Yankton leaders, a small oligarchy with much influence, planned for the division of the territory at the forty-sixth parallel. Division seemed natural. The railroads ran east and west, so that southern and northern Dakota had little contact with each other. The economic ties of the Red River Valley were with St. Paul and Minneapolis. Moreover, the Yankton group feared the influence of the Northern Pacific. In 1877, four of the seven seats allotted to northern Dakota in the territorial council were held by men connected with that railroad.

The oligarchy became hostile to federal control when Secretary of the Interior Carl Schurz tried to break up an Indian ring in 1878. The feeding and clothing of nearly twenty-five thousand Sioux and the troops needed to watch them had turned Yankton and other Missouri River towns into virtual "quartermaster depots." When Schurz arrested some Dakota Indian agents for fraud, there was an outcry against him. Although evidence against them was overwhelming, the defendants were acquitted by sympathetic juries. The Yankton leaders, allied to the Indian agents, felt that they were being persecuted by the federal government.

The demand for statehood also grew because of corruption in the office of the territorial governor, Nehemiah G. Ordway. He had been sergeant at arms for the House of Representatives, but in 1880, when he was appointed governor, he was a member of the state senate of New Hampshire. The appointment was made through the influence of New Hampshire businessmen with investments in Dakota. Ordway was a tall and distinguished-looking leader; his sanctimonious manner hid an able, scheming mind. He brought a number of people with him-his son was to become territorial auditor-and soon built up a powerful political machine, using the patronage of public-land-sales advertising to enlist newspaper editors.

Ordway made an alliance with Alexander McKenzie, the sheriff of Burleigh County who was to become the boss of North Dakota. As a young man McKenzie had worked on Northern Pacific construction crews then pushing the road toward the Missouri River. He settled in Bismarck in 1873, and the next year, at the age of twenty-four, he was elected sheriff, a position he held for twelve years. A natural leader of men, McKenzie was tall, handsome, and courageous, with a friendly handshake and greeting for everybody. 
Although McKenzie could scarcely write his own name, the Northern Pacific chose him as its political agent in northern Dakota, and he came to represent the powerful interests of Minneapolis and St. Paul, which held the region as a colony. McKenzie was to be the Republican national committeeman for North Dakota until 1908; he was to become "Alexander the Great, Boss of North Dakota"; he was to die a millionaire and, even though he had never held a state office, to be given a funeral in the state capitol at Bismarck. ${ }^{2}$

By means of his alliance with Ordway, McKenzie pulled off his first political coup, the removal of the territorial capital from Yankton to Bismarck. In 1882, McKenzie and an associate, perhaps in anticipation of removal, bought a 160-acre tract on the northern edge of Bismarck. Although Yankton was inconveniently located in the southeastern corner of the huge territory, the real reason for removal was the Northern Pacific's desire to have the capital on its main line at Bismarck.

The removal bill set up a commission of nine members to decide upon the location of the new territorial capital. The town chosen must provide 160 acres of land and $\$ 100,000$. Ordway secured some votes for its passage by refusing to sign bills for normal schools and a prison unless the representatives from the towns in which those institutions were to be located would vote for the removal bill and confirm his son's appointment as territorial auditor. For the support of George H. Walsh, a member of the territorial council and the "boss of the number one hard counties” of the Red River Valley, Grand Forks got the University of North Dakota, so named in anticipation of the division of the territory.

Before making its choice, the commission visited many aspiring towns. It was entertained extravagantly at Bismarck. Then, after long balloting, it voted five to four to make that place, although it was located far beyond the area of settlement, the new territorial capital. The Northern Pacific furnished the required 160-acre tract, but Bismarck, a small town, raised the $\$ 100,000$ only after considerable difficulty. There was a short-lived boom in town lots. In September, 1883, Henry Villard, president of the Northern Pacific, laid the cornerstone of the new capitol.

The members of the Yankton oligarchy bitterly resisted the action. They challenged the constitutionality of the removal commission in the courts; they broadcast accounts of Ordway's corrupt dealings (he had, they said, offered positions as county commissioner for sale to the highest bidder); they charged that he had received thirty thousand dollars in cash for his part in moving the capital to Bismarck. President Chester Arthur finally removed Ordway as territorial governor in June, 1884, but the capital remained in Bismarck. The Yankton leaders had advanced the cause of statehood, however, for they had made the territorial government seem hopelessly corrupt. 
To further their cause, the Yankton group had organized the Dakota Citizens League in 1882. It called constitutional conventions which framed a constitution at Sioux Falls in 1883 and revised it in 1885. The most notable feature of the document concerned school lands. At the suggestion of General William Henry Harrison Beadle, territorial superintendent of public instruction, the Sioux Falls constitution pledged the state not to sell its school lands for less than ten dollars an acre. Receipts were to be placed in a perpetual fund for the support of schools. Beadle's "Dakota plan" was inserted in the Omnibus Bill of 1889, authorizing statehood, and in all of the state constitutions written that year.

The people twice approved the Sioux Falls constitution, but the vote was small. There was not really much popular interest in statehood. Ordway, McKenzie, and their newspaper allies opposed the constitution. And so did the Dakota Democrats.

There were also obstacles on the national scene. Through the 1880's the Democrats controlled at least one house of the Congress. No Democrat would think of admitting states which would send Republican senators and representatives to Washington and add Republican votes to the electoral college. Eastern investors likewise opposed statehood. Having put millions into Dakota, they would scarcely want to have the debtors control the loans. For example, after Yankton County deliberately refused to redeem its railroad bonds, in spite of a United States Supreme Court decision, its creditors petitioned that southern Dakota not be admitted to the Union.

The railroads, too, opposed statehood. They preferred the lenient territorial railroad laws, and could influence or control territorial appointments from Washington. After his removal, the Northern Pacific sent Nehemiah G. Ordway to Washington as a lobbyist against statehood, and he may well have prepared the Democrats' bill for the admission of Dakota as a single state. It was strongly resisted by all of the pro-statehood men and so was really a maneuver against statehood. McKenzie and the Bismarck leaders opposed statehood, preferring that Bismarck remain the capital of a large territory.

After the Democratic victory in 1884, President Grover Cleveland appointed Louis Kossuth Church, a New York lawyer and a friend of James J. Hill, as governor and Michael L. McCormack, a member of the Bismarck ring, as secretary of the territory. These men opposed statehood, for the Democrats wanted to enjoy a territorial patronage. They believed that with a few years of Democratic control northern Dakota might enter the Union as a Democratic state. Democratic influence was seen in November, 1887, when northern Dakota voted against division of the territory by a margin of 18,000 to 8,000 .

Finally, the program of division, with southern Dakota becoming a state and northern Dakota a territory, was dropped in favor of a bill to admit two states. Senator Benjamin Harrison of Indiana pushed it hard, 
and the large population of Dakota (in 1890, North Dakota alone had 190,983 inhabitants and South Dakota 348,600) made further denial seem unjust and irresponsible. In the presidential campaign of 1888 the Republican platform called for admission of two states. Ordway and the Dakota Democrats finally dropped their single-state bill. Both Republicans and Democrats voted for the Omnibus Bill of February 22, 1889, authorizing the framing of constitutions in North Dakota, South Dakota, Montana, and Washington. When the bill finally passed the House of Representatives, some of the members threw books and papers into the air in celebration and there was a general handshaking of congratulation. A step toward equality of status had been taken.

\section{THE DAKOTA FARMERS' ALLIANCE}

Like the statehood movement, the organization of the Dakota Farmers' Alliance was a revolt against a dependent, colonial status. But it was directed at exploitation by eastern financial interests and thus was economic rather than political in nature. Many farmers felt that unless they could control the railroads, the market for wheat, and the terms of credit, their dream of a better life on the Dakota prairies would vanish.

By the early 1880's the wheat farmers of northern Dakota harbored a number of real grievances against the grain trade. Minneapolis millers had formed an association to eliminate competition among themselves in the buying of wheat. They and other large dealers controlled both lines of elevators which bought wheat at rural points and the terminal markets. These large shippers formed an alliance with the railroads of the region: the Northern Pacific and the St. Paul, Minneapolis and Manitoba. The railroads aided them by giving the line elevators rebates on freight charges, making rules against track loading by farmers and track buyers, and dictating the size and location of elevators along their rights of way.

These practices drove the independent buyers out of business and gave the line elevators a monopoly. With such rigid control, the latter could and did abuse the farmers with low grading and low prices, with false weights and excessive dockage. The farmers, helpless before the combination of the railroads and the large purchasers of wheat, were the victims of much irregularity and intentional fraud.

Settlement of the Red River Valley was scarcely well under way before protests began. As early as 1881, George B. Winship, editor of the Grand Forks Herald, began to publish vigorous editorials denouncing the abuses of railroad, elevator, and financial interests. By 1884 the Grand Forks Chamber of Commerce thought that the elevator monopoly, by means of undergrading and unfair weighing, threatened the prosperity of the region. In 1884 and 1885 the farmers began to organize, forming such groups as the Ellendale Farmers' Mutual Protective Association. These organizations helped their members to sell their wheat cooperatively and to buy such commodities as coal and twine. Some of them built farmers' elevators. 
In December, 1884, W. F. T. Bushnell, editor of the Dakota Farmer (published at Aberdeen), called at Huron a meeting of delegates from all of the farm organizations. From this and subsequent meetings came a territorial organization, the Dakota Farmers' Alliance. Its purpose, declared its constitution, was to unite the farmers "for their protection against... the encroachments of concentrated capital and the tyranny of monopoly.” Its chief goal was a free market, and it sought to elect farmers and their friends to office.

The Dakota Farmers' Alliance affiliated with the National Farmers' Alliance, founded in 1880 by Milton George, a Chicago farm editor, and commonly called the Northern Alliance. Later the Dakota group affiliated with the National Farmers' Alliance and Industrial Union, popularly known as the Southern Alliance. It adopted the Dakota Farmer as its official paper and created a system of local and county chapters. Rapid growth followed. Henry L. Loucks, a young Canadian immigrant, was elected president in 1886; he gave vigorous leadership as an organizer, speaker, and writer. Drought and low prices convinced the farmers that reform was needed, and by the end of 1886 there were 256 local alliances in Dakota. By 1888 there were 744, with 28,000 members.

The greatest Alliance leader in northern Dakota was Walter Muir, a farmer living near Hunter in Cass County. Born in Scotland, he had taken part in the Pikes Peak gold rush, fought in the Civil War, farmed in southern Minnesota, and served in the Minnesota Legislature. In 1879, at the beginning of the Great Dakota Boom, he came to Cass County to homestead. He was fascinated by politics, read widely, and spoke and wrote on the tariff, the money question, and practical farming. When the North Dakota Alliance · was formed in 1889, Muir was elected president.

Alliance leaders saw that the farmers' battle would have to be fought on many fronts-political, legislative, economic, and social-so the local chapters brought farmers and their wives and children together in friendly neighborhood gatherings. They met in halls or homes, and after supper, the men would go out to the barn or elsewhere to talk Alliance affairs while the women visited. For dues of one dollar or a dollar and a half, the member received a subscription to the official paper, such as the Dakota Farmer, the Jamestown Capital, and, finally, the Normanden (a Norwegian-language paper) and the North Dakota Independent, both printed on the same press in Grand Forks.

The Alliance papers, meetings, and picnics helped to break down isolation on the vast and lonely prairie. But an even more basic need was to increase farm income. From the beginning, local and county organizations had made cooperative purchases of coal and twine, and in 1888 the territorial organization set up the Dakota Farmers' Alliance Company at Aberdeen to centralize such buying. It lacked capital and often found manufacturers and wholesalers reluctant to deal with it, but 
it sent out an illustrated catalog of the items available, pooled the orders of the locals, and signed a four-year contract with a plow manufacturer. Although coal and twine were the basic commodities, the company also sold an "Alliance buggy." By 1889 the Dakota Alliance was doing more business than any of those in the other six northwestern states and territories in the national organization. It also formed the Alliance Hail Association, which saved its members forty to fifty cents an acre on hail insurance.

However helpful, insurance and cooperative buying did not meet the farmers' chief need, a free market for wheat. At the outset some of the local alliances had built elevators, but by 1888 there were only forty-two farmers' elevators and warehouses in Dakota, and they suffered from discrimination. Moreover, control of the terminal market was necessary to correct such abuses as short weights, undergrading, and heavy dockage. In 1887 the leaders of the Dakota and Minnesota alliances planned to build a terminal elevator in Minneapolis and to unite the independent rural elevators.

All efforts to build a terminal elevator ended in failure. Alliance leaders incorporated a series of companies, starting with the Scandinavian Elevator Company. But English investors, though at first interested, failed to put up any money, and the Minneapolis Chamber of Commerce, the master of the wheat market, blackballed Henry Loucks, the president of the company. The necessary capital was not available, especially after the Panic of 1893. The hard fact was that the farmers, in debt for their own farm enterprises, lacked the money to provide themselves with terminal marketing facilities. ${ }^{3}$

\section{THE ALLIANCE PROGRAM IN THE LEGISLATURE}

Before trying these terminal-elevator schemes, Alliance leaders had sought the goal of a free market through government action. The organization's platforms steadily called for laws forcing the railroads to supply cars and grant elevator sites without discrimination, and to refrain from giving passes to government officials. The Alliance also called for an elective board of railroad commissioners that should have the power to set maximum railroad rates, to watch over elevators and warehouses, and to fix grades for wheat. These things would bring about a free market. But as a matter of justice, the farmers also wanted taxation of corporate property on the same basis as other property, taxation of mortgages, and a law setting the maximum interest rate. Later they came to favor such broad reforms as prohibition, the secret ballot, and woman suffrage.

To accomplish these aims, the Alliance would have to enter politics

${ }^{3}$ Glenn L. Brudvig, “The Farmers' Alliance and Populist Movement in North Dakota, 1884-1896" (Unpublished M.A. thesis, University of North Dakota, 1956, pp. 41-100. 
and elect farmers and their friends to office. It began to investigate candidates, endorsing only those who would support the farmers' demands and nominating its own when there were no satisfactory Republicans or Democrats. Such tactics promised success, yet the conservatives, while offering little open opposition, managed to defeat the Alliance. In 1885 the territorial legislative assembly, although it had only seven farmer members, passed a "Free Market Act." The law gave an appointive board of railroad commissioners supervision of the railroads and the grain trade. But it was of little use; the commissioners could neither fix railroad rates nor enforce any of their decisions.

The election of 1886 looked hopeful for the farmers. The Democrats adopted the Alliance platform, and twenty-five farmers were elected to the legislature. In the 1887 assembly a leading Alliance man was elected speaker of the house, and the legislature passed a bill stating that all elevators and warehouses were subject to control by the railroad commissioners, who were to set up "Dakota grades" for wheat. But again the commissioners could not enforce the law: some sections were too vague; the appropriation of five thousand dollars for enforcement had been eliminated; and the elevators threatened any persons who might complain against them.

During that 1887 legislative session, the Alliance failed in other ways. It could not get through its usury law. The one in effect fixed the interest rate at 7 percent, but allowed a higher rate to be set by mutual consent. The Alliance could get no railroad legislation; two important railroad bills disappeared in the closing hours of the session, a dishonest but common conservative tactic. The Grand Forks Herald sadly pointed out that the representatives of the farmers did not have "the experience to cope with the representatives of the corporations."

The Alliance was very active in the election of 1888 . Members were urged to vote only for candidates who would pledge to support Alliance bills without change. These bills had been prepared by Henry Loucks and a committee of four lawyers selected in the fall of 1887. Porter J. McCumber, who was to serve for many years in the United States Senate, prepared the railroad bill. Both the Republican and Democratic parties adopted the Alliance platform, but farmers' conventions endorsed tickets selected from both parties and added some candidates of their own. It was the first campaign in which the Alliance played a large part, and many members resigned in protest against such independent political action. But the Alliance elected a majority in the 1889 assembly; Smith Stimmel, president of its Cass County chapter, was chosen president of the council, the upper house of the assembly, and appointed the committees.

Yet the Alliance legislative program did not get through. The law on fair distribution of cars was ineffective; the usury bill passed both houses but was lost or stolen in the last days of the session; Governor Louis K. Church vetoed a prohibition bill; and other Alliance bills were 
sidetracked or vetoed. This astonishing defeat of the Alliance came not only from conservative scheming but also from a split among Alliance leaders, some more radical than others, on details of the legislation. ${ }^{4}$ For all their struggles, the farmers could not break the grip of the railroads, the elevator monopoly, and their allies upon the government or the economy of Dakota.

\section{THE CONSTITUTIONAL CONVENTION}

The farmers' struggle against the corporations was, of course, reflected in the constitutional convention. Yet the fundamental decisions of the convention had been made before it met; the structure of American state government had already been fixed beyond any real possibility of change. Congress had also decided many things in the Enabling Act of February 22, 1889, the Omnibus Bill, which authorized statehood. The act divided Dakota at the seventh standard parallel. It forbade discrimination in civil or political rights "on account of race or color, except as to Indians not taxed." The law endowed the state with 3,191,770 acres of land, about 7 percent of its area, for educational and other public purposes and forbade it to sell the land grant for less than ten dollars an acre. ${ }^{5}$

The act also provided for a constitutional convention of seventy-five members, with three to be elected from each of twenty-five districts. On May 14, in a late blizzard, the voters went to the polls, many of them in sleighs, and the convention opened at Bismarck on July 4. A big parade celebrated the event; five hundred Sioux from Standing Rock, led by Sitting Bull, who carried a huge American flag, took part.

In general the delegates, some of the best citizens, were young men from the more humid part of the state, and most of them were farmers or lawyers of the older American stock. Fred B. Fancher, Martin N. Johnson, Roger Allin, Alexander Griggs, William Budge, and Burleigh F. Spalding were prominent members of the convention. Thirty-three delegates, or 44 percent, came from the six counties of the Red River Valley. While Cass County alone had nine, the sparsely settled western part of northern Dakota had only six (five of them from Mandan and Bismarck). Only nine delegates were over fifty years of age, and some were even in their twenties. There were fifty-one Republicans, nineteen Democrats, two Prohibitionists, two Populists, and one Independent. A third were lawyers, but the largest group consisted of twenty-nine farmers. Of the seventy-five delegates, fifty-two had been born in the United States, ten in New York and thirteen in Wisconsin. All but five of the foreign-born came from Canada and the British Isles. There were only ten of Scandinavian stock.

${ }^{4}$ Ibid., pp. 102-118.

${ }^{5}$ Harold A. Hagen, “North Dakota Land Grants," North Dakota History, XVIII (January 1951), 24. 
The convention was subjected to many outside influences. The very fact that not a single delegate had been born in Dakota Territory was in itself a pervasive influence. The delegates' experience and background reflected the humid East, but they were writing a constitution for a semiarid state. That document inevitably did little to provide institutions suitable for a semiarid country. ${ }^{6}$ Indeed, the delegates had before them as models the constitutions of many states with much more rainfall than North Dakota. The convention, however, was urged to make adaptations to the semiarid country by Major John Wesley Powell, director of the United States Geological Survey, who argued that the state must retain possession of the waters usable for irrigation. Such a provision was placed in the constitution.

It was appropriate, perhaps almost inevitable, that one important outside influence on making the constitution should come through the Northern Pacific. Henry Villard, then chairman of the railroad's board of directors, asked Professor James Bradley Thayer of the Harvard Law School to prepare a draft constitution for North Dakota. Thayer's draft was a carefully constructed model constitution, not a dishonest effort to create a government favorable to the railroads. It was introduced to the convention by Erastus A. Williams, a delegate from Bismarck. Although it was obviously not Williams' own handiwork, he refused to divulge its origin, causing much speculation. ${ }^{7}$

The constitution finally adopted by the convention followed the phrasing of Thayer's draft in many places. Yet the convention was in fact dominated by reform ideas. It reflected both the radical spirit of the exploited region and the nation-wide concern about the growth of monopolies and corruption in government. Reform influence was seen in the election of Fred B. Fancher as president of the convention; he was vice-president of the Dakota Farmers' Alliance. Many Alliance leaders, such as Martin N. Johnson, also played an active part in the convention. There were, of course, conservatives as well as reformers.

Many reforms were considered. A strong effort was made to adopt a unicameral legislature, considered less subject to corporation corruption, but it failed. Woman suffrage, compulsory arbitration of labor disputes, the prohibition of railroad passes for public officials, and reform of the jury system were also considered but not adopted.

The most important problem was the control of corporations. Above all else, the delegates feared the influence of corporations upon government. Indeed, the very first proposal placed before the convention, introduced by Martin N. Johnson, dealt with common carriers. It was then widely believed, as John D. Hicks has written, that

${ }^{6}$ Carl F. Kraenzel, The Great Plains in Transition (Norman: University of Oklahoma Press, 1955), pp. 165-170.

${ }^{7}$ Clement A. Lounsberry, Early History of North Dakota (Washington: Liberty Press, 1919), pp. 398-399. 
"as the power of capital increased, legislatures grew less trustworthy, or were subject to greater temptations."

This feeling was national, but in Dakota Territory it was strengthened by fresh evidence of danger as seen in the corruption under Ordway and the repeated frustration of the Alliance's efforts toward government correction of abuse. For such reasons it was impossible for the delegates to heed the advice of Judge Thomas M. Cooley. Addressing the convention as a visiting statesman, he told the delegates that they must trust the government: "Don't in your constitution making legislate too much.... You have got to trust somebody in the future and it is right and proper that each department of government should be trusted to perform its legitimate function."

Distrust, however, prevailed, and the convention set out to block corporation influence by limiting the powers of the governor and the legislature. To deal with some functions of government fostering educational institutions, controlling railroads, managing the school lands it set up independent administrative boards. It also usurped the powers of the governor and legislature by placing a huge mass of legislation in the constitution itself The result was a very long document, about six times as long as the federal constitution. The legislation in the constitution placed a heavy responsibility upon the whole body of voters, for changes could be effected only by constitutional amendments, decisions which had to be made by the people themselves. By June, 1960, seventy-three amendments had been adopted and countless others defeated.

The bitterest struggle was over the location of state institutions. These were the spoils. Four were already in existence: the capital and the penitentiary at Bismarck, the hospital for the insane at Jamestown, and the university at Grand Forks. In 1883 the territorial legislature had located an agricultural college at Fargo but had made no appropriation for it. At the convention in 1889, Fargo wanted an agricultural college. and Bismarck, of course, wished to be the capital of the state as it had been of the territory. Fargo, Bismarck, and the Northern Pacific combined to gain these ends.

To secure votes, they devised an article to locate thirteen institutions (one for almost every town) throughout the settled parts of the state. Article XIX of the constitution provided that Bismarck was to have the capital (it also had the penitentiary, but the article tactfully omitted any mention of that fact), Grand Forks the university, Fargo the agricultural college, Jamestown the hospital for the insane, Mayville and Valley City normal schools, Mandan a reform school, Wahpeton a school of science, Ellendale an industrial school, Devils Lake a school for the deaf and dumb, Pembina County a school for the blind, Lisbon an old soldiers' home, and some place in Rolette, Ward, McHenry, or Bottineau counties a school of forestry. Thus, to insure the capital to Bismarck and the agricultural college to Fargo, the new state, with a population of only 
191,000, was to start off with fourteen institutions, ten of them new. This was more than the state needed or could adequately support a mistake in undertaking too much that was to plague it for many years.

Most of the forty-five delegates favoring Article XIX came from counties receiving institutions and from communities served by the Northern Pacific. Thirty delegates led by the Grand Forks men, remembering the McKenzie-Ordway-Northern Pacific steal of the territorial capital in 1883, demanded that Article XIX be submitted to a separate vote of the people. This procedure had already been agreed upon for the prohibition article. Most of the delegates who opposed Article XI X came from Grand Forks, Walsh, and Pembina counties and their neighbors; with few exceptions, they also came from communities served by the Great Northern Railroad. There was apparently a hidden struggle in which Grand Forks and the Great Northern sought to seize the capital from Bismarck and the Northern Pacific. But the opposition to Article XIX failed, and the next day, August 17, the convention ended its 45-day session.

The aftermath or the struggle over institutions was evident in the opposition to ratification. On October 1 the voters ratified the constitution by a vote of 27,441 to 8,107 and approved the prohibition article by a vote of 18,552 to 17,393 . Almost all of the vote against the constitution came from the counties opposed to Article XIX. The majority in Grand Forks, Walsh, Nelson, and Steele counties and large minorities in Pembina and Traill voted against ratification.

\section{THE FRAMEWORK OF STATE GOVERNMENT}

The constitution drafted so painstakingly at Bismarck in the summer of 1889 is still important. Though amended many times, it is still fundamentally the same; it has been added to rather than changed. Both its virtues and its defects have helped to shape the course of events in the state. The convention did four things in the constitution: it constructed a defective framework of government; it amply guaranteed a free and democratic society; it provided wisely for the management of a great landed estate; and it tried unsuccessfully to control corporations in the public interest.

The executive, legislative, and judicial departments are defined in three articles. The governor has the power to call the legislative assembly into special session and the duty to make recommendations to it. He can veto a bill passed by the assembly, and he can also veto individual items in appropriation bills. The legislature, however, can pass bills over the governor's veto by a two-thirds vote.

But the constitution, although it charges the governor to see that the laws are faithfully executed, does not really make him the head of the executive department. Instead, it makes the heads of the separate executive branches elective: the secretary of state, the auditor, the attorney general, the treasurer, the superintendent of public instruction, 
the commissioner of agriculture and labor, and the three railroad commissioners (later changed to the Public Service Commission). They are independent of the governor, a most significant fact.

Moreover, the constitution restricts the governor's powers of leadership. Any governor who seeks to influence the vote of any member of the legislative assembly by threatening or promising to use his veto power, or his appointive or removal power, shall forfeit all rights to hold any office of trust or honor in the state.

This same distrust of government-crippling that body's effectiveness-is seen in some of the provisions for the legislative assembly. The legislature is composed of a senate and a house of representatives. The senate shall have from 30 to 50 members, elected for four-year terms. The state is to be divided into senatorial districts of roughly equal population, each of which is to elect one senator. One-half of the senators are to be elected every two years. The house of representatives is to have not less than 60 nor more than 140 members. The members are to be elected at large from the senatorial districts for two-year terms (in 1960 there were 49 senators and 113 representatives).

The constitution lays down safeguards against trickery in law-making. At the request of one-sixth of the members present, the yeas and nays on any questions are to be entered in the journal. The presiding officer of each house must sign the bills in the presence of the members. Further, the constitution provides that if any member of the legislative assembly offers or uses his influence or vote for or against any measure in return for any other member's using his vote or influence for or against any other measure, the member shall be deemed guilty of soliciting a bribe, or of bribery, and shall be expelled from the assembly.

Distrust of the assembly is also seen in other restrictions. The regular meeting is limited to one biennial session of 60 days, although the first assembly was allowed 120 days. The constitution lists thirty-five subjects on which the assembly is forbidden to pass a special or local law. In addition, the assembly may not pass a special or local law on any subject that can be dealt with by a general law.

The most important limitations, however, are on taxation and debt. The constitution forbids the legislative assembly to levy taxes of more than four mills on the assessed valuation of all taxable property. It limits state debt to $\$ 200,000$ (the constitution assumed North Dakota's share of the territorial debt, $\$ 539,807$ ), except when a vote of the people authorizes additional debts for special purposes.

These limitations, born of hard times and the extravagance of the territorial government, which had contracted a debt of $\$ 1,200,000$ for public institutions, were to force the state government to be economical. The convention felt that the most important objective was to keep from going into debt. The importation of eastern capital-the means by which railroads, banks, farms, and marketing agencies were being established on the prairies of North Dakota-was thus renounced for public purposes. 
The constitution also forbade any governmental subdivision (county, city, town, or school district) to contract debts in excess of 5 percent of the valuation of the taxable property therein, except that by a two thirds vote this limit might be raised to 8 percent.

Drastic limitations could not, in the nature of things, be applied to the powers of the courts. The convention placed the judicial powers of the state in a supreme court, district and county courts, justices of the peace, and police magistrates. The supreme court was to be made up of three judges elected for six-year terms (now there are five elected for ten-year terms). It has mainly an appellate jurisdiction and has supervision of the lower courts. The constitution set up six district courts, their judges to be elected for four-year terms (by 1960 there were sixteen district judges elected for six-year terms). The district courts are given original jurisdiction in all causes in law and equity. To deal largely with probate matters, each county elects a county judge for a two-year term, but counties with over two thousand population may extend the power of the county court to have concurrent jurisdiction with the district court in lesser criminal and civil actions.

In addition to establishing the framework of the state government, the constitution guarantees basic human rights and a democratic society in the American tradition. First come the liberties of the individual: freedom of worship, habeas corpus, jury trial, freedom of speech and publication, the right of assembly, and no imprisonment for debt. The convention granted suffrage to all males twenty-one years of age who were citizens or who, though of alien birth, had declared their intention of becoming citizens not less than one nor more than six years before the election, and also to civilized persons of Indian descent who had severed tribal relations two years before the election. Women might vote in school elections.

Married women could control their own property. Hiring children under twelve to work in mines and factories was prohibited. Corporations were forbidden to exchange black lists. The first legislative assembly was required to establish a system of free public education extending from the primary grades through the collegiate level.

By the Enabling Act, Congress had endowed education in North Dakota with land grants. The grants as they were eventually selected gave 2,523,383 acres to the common schools; 129,999 acres to the Agricultural College; 86,066 acres to the University of North Dakota; 39,997 acres to the Industrial and Normal School at Ellendale; 80,005 acres divided three-eighths to Mayville Normal and five-eighths to Valley City Normal; 40,003 acres to the School of Mines; 39,997 acres to the School of Science; 30,025 acres to the School for the Blind; 39,966 acres to the School for the Deaf; and 40,024 acres to the Training School. The school lands, 3,049,465 acres in all, were worth, at the tendollar minimum, more than $\$ 30,000,000$-a large endowment.

The constitution placed the management of the grants in the hands 
of the Board of University and School Lands, composed of the governor, secretary of state, attorney general, state auditor, and superintendent of public instruction. The board was to appraise the lands and sell them at public auction to the highest bidder, but not for less than ten dollars an acre. It might also lease the lands for five-year terms. Receipts were to be put into a permanent fund, any losses in which were to be made good by the state.

The major problem confronting the constitutional convention, however, was how to control the railroads. Starting with the general proposition that corporations were not to conduct their business in such a manner "as to infringe the equal rights of individuals or the general wellbeing of the state," the constitution went on to declare certain practices illegal: stock watering, consolidation of competing railroads, and combinations to fix the price of any product. It required the railroads to keep books showing their stockholders, assets, and liabilities open for public inspection and to make annual reports to the state auditor. Most important of all, the constitution declared that the railroads were subject to control by the legislative assembly and that the assembly or the Board of Railroad Commissioners (later replaced by the Public Service Commission) could fix railroad rates within the state. The railroads might appeal to the courts to determine the reasonableness of the rates, but the government rates were to hold until the case had been settled.

It is clear, then, that distrust, born of past corruption, placed crippling curbs on the governor and the legislative assembly in the constitution of North Dakota, just as it had in the constitutions of most of the states. Thus much of the burden of government falls upon the people themselves. Because the constitution established a government without adequate powers, not only the major policies but also much of the detailed provisions of government had to be determined in many instances by the people themselves. In the very nature of things, they must lack detailed knowledge of the problems involved, and they are inevitably deprived of the benefit of any full-discussion before they make the decisions. This is a heritage of the fear of corporation influence.

Although the struggles of the 1880's resulted in a modest measure of success for the people, those holding North Dakota as a colony were not really curbed. The state was long to be exploited economically by outsiders who also held much political power. For many years Alexander McKenzie, representing the railroad, elevator, and banking interests of the Twin Cities, was to exercise great political influence in North Dakota. It was to continue to be a colonial hinterland, holding the same unenviable status as other regions producing raw materials for outside markets. 


\section{CHAPTER 11}

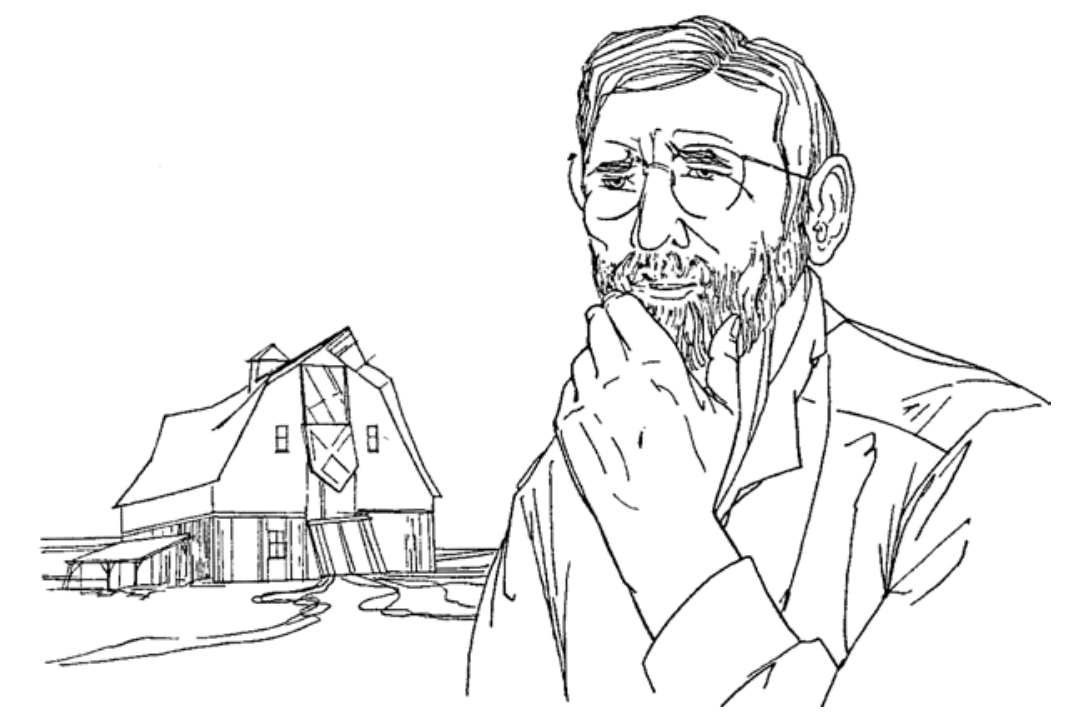

\section{The Depression Nineties}

WHEN NORTH DAKOTA BECAME A STATE, it was a partially settled spring wheat country and a colonial hinterland of Minneapolis and St. Paul. Wheat produced the wealth of North Dakota, and the Twin Cities, the chief market for that product, were inevitably the political and economic nerve center of the state-the headquarters of its railroads, grain elevators, and banks, as well as the residence of its most influential political leader.

Not only these facts but also broad national trends were reflected in the history of the region. In the 1880's, a time of rapid national expansion in industry and urbanization, North Dakota had grown amazingly in population, railroad trackage, and wheat production. But in the latter part of the decade, well before depression hit the nation, the Great Dakota Boom died, the rush of settlers to the new country gave way to an exodus of the disillusioned, and the discontent of the farmers erupted in an agrarian revolt. Not until the middle 1890's was the nation deep in depression and torn by political unrest. Populists gained control of the state in 1892, but when the national depression arrived in 1893, all efforts of the North Dakota Populists ended in failure. Populism declined in North Dakota when it was still rising in the nation; in 1896, William Jennings Bryan fared badly in the state, which James B. Weaver had carried in 1892. The failure of Populism in North Dakota, though caused in part by the Panic of 1893, owed something to strong loyalty to the Republican party and the astuteness of Alexander McKenzie and his 
machine.

The latter 1890's brought revival to North Dakota. Better prices, better crops, lower railroad rates, and renewed promotion of settlement by the Great Northern ushered in a second boom in 1898 . The population increased 67 percent during the decade, mostly in the last two years, and by 1900 much of the Drift Prairie was fairly well settled and well supplied with railroads.

Although Populism had but a brief career in North Dakota, a surprising fact in view of the state's colonial status, it did help to channel the popular psychology into an anti-big business mold. After Populism declined, the state government, while at least nominally controlled by the McKenzie machine, continued to fight the railroads, to raise their taxes, and to force them to reduce their rates.

\section{POPULISM IN THE FIRST LEGISLATIVE ASSEMBLY}

Statehood gave the farmers of North Dakota new hope that they might control their own economy. A market for hard spring wheat at Minneapolis had stimulated the settlement of the region, but soon the cooperation of the millers, the elevator men, and the railroad managers had eliminated competition in the grain trade. The wheat grower wanted a free, competitive market, but the grain buyers felt, as the Weekly Northwestern Miller said on January 11, 1889, that "such words as trust, combine, and monopoly are better than failure, ruin and bankruptcy."

Territorial laws governing the grain trade had been useless, and Judson A. LaMoure, chief lieutenant of Alexander McKenzie, had done little as chairman of the territorial board of railroad commissioners to restore competition. Could the new state break the monopoly? Could it shift the seat of power from the Twin Cities to Bismarck?

At picnics in the summer of 1889, Farmers' Alliance men sang S. A. Fisher's poem “The Farmers Must Rule North Dakota.” That August, the Republican state convention, responding to Alliance demands for a share of the offices, nominated John Miller, an Alliance leader, for governor. Miller was a native of New York State and a large farmer and land speculator in Richland County. In November the Republicans swept the election by a two-to-one majority. Henry C. Hansbrough, Devils Lake newspaper editor and McKenzie man, was sent to the United States House of Representatives.

The first legislative assembly witnessed a series of struggles between the Farmers' Alliance and the McKenzie machine. In the Republican caucus the Alliance men supported Martin N. Johnson and Walter Muir for United States senators. Backing Muir, the Edgeley Mail wrote: "The people of North Dakota are by necessity radical in their 
views, as may be witnessed by the platform of the Farmers' Alliance, and they should be represented in the United States Senate by men who will do justice to those views." Although Johnson had forty-two of the ninety-three votes in the joint session, the assembly elected Gilbert Pierce and Lyman R. Casey to the Senate. Pierce, the choice of the Northern Pacific, was a popular former governor of Dakota Territory and met with little opposition. Casey had come to Carrington in 1882, acquiring a large ranch. He was chosen as a compromise candidate after McKenzie failed to line up enough votes for his friend, former Governor Nehemiah G. Ordway. Casey was a member of the Farmers' Alliance and an honest man, but George B. Winship's Grand Forks Herald considered his selection a victory for the corporations and the "old gang element."

Defeated in the senatorial elections, the reform element won on the moral issues of prohibition and the Louisiana lottery. Prohibition was supported by Charles A. Pollock and Frank Lynch of Fargo, R. B. Griffith of Grand Forks, and Elizabeth Preston Anderson, who was to serve for forty years as president of the North Dakota Woman's Christian Temperance Union. The assembly prohibited the manufacture and sale of intoxicating liquors.

The Louisiana lottery sold tickets throughout the nation and distributed nearly $\$ 15,000,000$ in prizes at each drawing. It was to lose its charter in Louisiana in 1893 and so was seeking a new base for its disreputable operations. It offered North Dakota $\$ 100,000$ for the first year and \$75,000 annually thereafter for a charter. Lottery officials were ready to bribe legislators in order to secure the necessary votes. The McKenzie gang favored the lottery, and the senate passed the charter bill by a two-thirds majority. Governor Miller, however, hired a Pinkerton detective to gather evidence of bribery. The detective, passing himself off as a newspaper correspondent, ingratiated himself with the bribable members of the legislature ("wolves for money," he called them in his racy reports to the governor). After hearing, over drinks, much talk about money for lottery votes, the detective revealed his identity to the astonished legislators. The lottery charter never came to a vote in the house. The university's president, Homer B. Sprague, and faculty openly fought the lottery. When the university appropriation bill came up, the McKenzie gang cut Sprague’s salary from \$3,000 to \$2,500. Sprague resigned in February, 1891. ${ }^{1}$

${ }^{1}$ Lewis F. Crawford, History of North Dakota (3 vols.; Chicago: American Historical Society, Inc., 1931), I, 370-375; Louis G. Geiger, University of the Northern Plains: A History of the University of North 
Much of the work of the first legislative assembly was not controversial. Drawing feely upon the experience of the older states, it defined the duties of state officials, established the structure of county and municipal government, set up a system of free public schools, and authorized the new institutions designated by the constitution. But only the School for the Deaf at Devils Lake received an appropriation. In all, the legislature passed 201 laws in 120 days. Fourteen of them dealt with the railroads and the grain trade. The Board of Railroad Commissioners was granted authority to regulate railroads and grain elevators, to reduce unreasonable railroad rates, and to establish "North Dakota grades" of wheat. The railroads were required to furnish elevator sites and freight cars without discrimination, to build loading platforms, to equalize rates for long and short hauls, and to give no preference in rates or service to any person or company. The assembly forbade elevators to fix prices for grain, to agree on the amount to be purchased by each, or to mix grades. It provided for the licensing of elevators and the bonding of elevator operators; it set elevator rates for grain storage. It also fixed the legal rate of interest at 7 percent but allowed up to 12 percent by mutual consent.

These laws forbade virtually every evil practice that accounted for the exploitation of North Dakota farmers by outside interests. They passed, quite naturally, without any open opposition from the McKenzie machine, the servant and ally of the exploiters. If they had succeeded, North Dakota would no longer have been a colonial hinterland of the Twin Cities. But the laws were so faultily drawn, so complicated, and so contradictory that they were a failure.

Hostile to the regulatory legislation, the elevator companies threatened to close their elevators. To prevent such a calamity, the railroad commissioners and the attorney general went to Minneapolis to talk with the representatives of the elevator firms. To appease them and keep the elevators open, the commissioners agreed to drop the bonding requirement, the storage rates, and a provision for elevator receipts. ${ }^{2}$

\section{THE INDEPENDENT PARTY}

Disappointment over this failure led to talk of a third party. Fred Fancher and other Alliance leaders, loyal to the Republican party, opposed the move, and George B. Winship, who ran the Alliance platform in the Grand Forks Herald for days, urged the Republicans to

pp. 88-89.

${ }^{2}$ Glenn L. Brudvig, “The Farmers' Alliance and Populist Movement in North Dakota, 1884-1896" (Unpublished M.A. thesis, University of North Dakota, 1956), pp 123-134. 
nominate men agreeable to the farmers. The Republican convention did nominate Martin N. Johnson, active in the Alliance, for the House of Representatives, but for governor they nominated Andrew Burke, a Cass County banker satisfactory to the McKenzie machine.

In spite of these concessions, a third party was organized that fall. On September 25-26, 1890, conventions of the Prohibitionists and the Farmers' Alliance met in Grand Forks. When the Prohibitionists voted to form the "Independent Party of North Dakota" and invited the Alliance to join it, Walter Muir agreed. The Independent party nominated Muir for governor, but most of its slate, such men as Martin N. Johnson, had already been nominated by either the Republicans or the Democrats. Its platform contained the usual Alliance and Populist demands: free silver, government loans on real estate and stored crops, woman suffrage, the Australian ballot, and the direct election of United States senators and the President.

Most Alliance members did not follow Muir into the new party, and in November all Republican candidates were elected. Muir himself received only 13 percent of the vote; the Independents elected only eight men to the legislature. Loyalty to the Republican party caused many exploited North Dakota farmers to cast their votes for men like Andrew Burke (elected governor) and George Walsh (elected railroad commissioner), who were identified with the McKenzie machine.

\section{GRAIN-TRADE LEGISLATION}

The second legislative assembly, meeting in 1891, made only limited reforms. It elected Henry C. Hansbrough, the McKenzie candidate, to the United States Senate to replace Gilbert Pierce, although Alliance men and Democrats gave Walter Muir thirty-one votes. It failed to pass a better platform law, much wanted by the farmers. It passed a new law requiring the railroads to grant elevator sites without discrimination, but Governor Burke vetoed it. It passed an Australian-ballot law and made usury a misdemeanor. Finally, it declared that the railroad commissioners had full power to supervise the grain trade and to establish storage rates.

Again the elevators threatened to dose. They challenged the law in the courts on grounds that it deprived them of their property without due process of law in violation of the Fourteenth Amendment. On April 26, 1892, the United States Supreme Court upheld the North Dakota law in Brass v. Stoesser. In the meantime, the railroad commissioners had met with the representatives of the elevators in Grand Forks on July 14, 1891, to work out regulations satisfactory to both the elevators and the farmers. They reported that there was "a profit in wheat over and above handling and freight of thirty cents a bushel, due to short weight, excess dockage, 
low grades and commissions." The commissioners recommended that the farmers build a terminal elevator at West Superior to handle their grain and keep an agent at Liverpool to sell it on the English market. But the Farmers' Protective Association, organized for that purpose in the summer of 1891, soon went bankrupt.

The farmers, too poor to provide their own terminal elevators, had to depend on loading platforms to restore competition. After a special session of the legislature passed an enforceable platform law in June, 1892, the number of loading platforms rose from 38 to 147 in 1893. Now a farmer, dissatisfied with the price offered by the local elevators, could sell his wheat to a track buyer who used a loading platform or could ship it himself to the terminal market.

\section{A VICTORY FOR POPULISM}

In spite of all this, discontent among the farmers increased. Walter Muir and other leaders of the Independent party and the North Dakota Farmers' Alliance took part in the conventions at St. Louis and Omaha which organized the Populist party and nominated James B. Weaver for President in 1892. That June, the Independent convention, meeting in Valley City, accepted the Populist platform and nominated a full slate of candidates, including a congressman and presidential electors. The Democrat convention endorsed the Independent candidates, except for Congress and the state legislature. The Republican convention, controlled by McKenzie, put up Andrew Burke for re-election as governor, but it also nominated some men who had been active in the Farmers' Alliance. Such as Martin Johnson for a second term in Congress and Fred Fancher for insurance commissioner.

Eli C. D. Shortridge, a farmer living near Larimore and recently president of the Alliance, was the Independent candidate for governor. He made a vigorous campaign, going from schoolhouse to schoolhouse across the state, charging that the state government was maintained by and for the corporations, and pointing to Burke's veto of the elevator bill as proof. He promised a state-owned elevator at the head of the lakes.

The Republican national committee sent money to save North Dakota from the Populists. Such newspapers as Alanson Edwards' Fargo Argus had long ridiculed Alliance leaders. Even George B. Winship and the Grand Forks Herald could not accept the Populist platform, and Winship complained that Alliance members should not "assume that all the other classes were against them.” Just because the November election, the railroad commissioners reported: 
toward the prosperity and material advancement of our State.... Persecution of the railway companies by legislative enactment is nothing less than a crime.... For the prosperity of the citizen is the prosperity of the railway company and vice versa. ${ }^{3}$

The Independents took every state office except secretary of state. Christian M. Dahl, the successful Republican candidate, was the only person of Norwegian birth in the campaign. In the presidential contest, James B. Weaver, the Populist candidate, received 17,667 votes to 17,519 for Benjamin Harrison, the Republican candidate. The outcome, however, was so close that two Weaver electors and one for Harrison were chosen. However, one Weaver elector, a staunch Democrat, repudiated his endorsement by the Independents and cast his vote for Grover Cleveland. Martin Johnson was returned to Congress.

\section{THE FAILURE OF GOVERNOR SHORTRIDGE}

Eli C. D. Shortridge, the new governor, had made a success of his farm north of Larimore. A man of sixty-three with receding gray hair, a white beard, and alert eyes behind steel-rimmed spectacles, he inspired confidence. In January, 1893, he told the third legislative assembly that the railroads and elevators had "absolutely put an end to competition" and that they had "practically ignored" the laws for their control. Shortridge and the Populists wanted to force them to play fair with the public. There was some prospect of success, for the assembly, though controlled by the Republicans, was made up largely of farmers (74 percent of the house and 58 percent of the senate), and no one in North Dakota, not even the McKenzie machine, openly opposed sensible reform.

The Populist program, however, was largely defeated by the long struggle over the election of a United States senator. McKenzie wanted to re-elect Lyman R. Casey, but a group of about fifteen Republicans from the eastern end of the state refused to support Casey or any other McKenzie candidate. After forty-eight days and sixty-one ballots, they finally combined with the Independents and Democrats to elect William N. Roach. The first Democrat in Congress from North Dakota, Roach was a leader of his party. He had attended Georgetown University, farmed, dealt in land, and served as mayor of Larimore.

${ }^{3}$ North Dakota Board of Railroad Commissioners, Annual Report, 1892, p. iv; Robert H. Bahmer, "The Economic and Political Background of the Nonpartisan League" (Unpublished Ph.D. dissertation, University of Minnesota, 1911), pp. 124-126, 131; Brudvig, "Farmers' Alliance and the Populist Movement," pp. 135-147, 199. 
In the remaining twelve days, the legislature passed most of the 158 laws that came out of the session; 111 of them reached Shortridge on the last day. On the eve of the Panic of 1893, the assembly, for the first time, made large appropriations for state institutions: the penitentiary, the capitol, the governor's mansion, the old soldiers' home, and the colleges and normal schools. It appropriated $\$ 100,000$ for a state-owned terminal elevator at Duluth or Superior.

Some important railroad and elevator bills passed but were lost or stolen before they reached the governor. It was "a well-known fact," Shortridge asserted acidly, "that every bill brought before the Legislatures of the past, that was not satisfactory to the corporations, and could not be otherwise defeated, was either stolen, mutilated, or destroyed in some way to prevent them from becoming laws of the State.”

The upshot was that Shortridge's administration was a failure. No important reform legislation was enacted; the large appropriations and the depression bankrupted the treasury; and the state-owned elevator was not built. Neither Minnesota nor Wisconsin would give North Dakota exclusive control of an elevator site so that North Dakota grain laws could govern its transactions. It made little difference; the treasury was empty.

In 1894, Walter Muir and the more radical leaders of the North Dakota Independents opposed both the re-nomination of Shortridge and fusion with the Democrats, the basis for success in 1892. Accordingly, the Independents and the Democrats nominated separate tickets; both endorsed free silver. The Independent convention praised Senators Roach and Hansbrough for their free-silver votes in Congress. The Republicans named candidates who had the confidence of the farmers: Roger Allin for governor and the old standbys Martin Johnson for the House and Fred Fancher for insurance commissioner. In November the Republican candidates won every state office, Allin receiving 57 percent of the vote, while the Independent candidate for governor had only 23 percent.

The defeat of the Independents in 1894 marked the permanent decline of Populism in North Dakota. The legislature which met in January, 1895, spent little time on reform legislation, and conditions soon improved. The 1895 crop was bountiful, James J. Hill reduced freight rates on the Great Northern, and the railroads built loading platforms at the request of the railroad commissioners. Consequently, William Jennings Bryan's campaign for free silver in 1896 found little response in North Dakota. That year, the Independents and Democrats fused on a ticket for state offices and came out for free silver. The 
Republican convention, held in Grand Forks on July 22, rejected free silver 164 to 18 and nominated a ticket headed by Frank Briggs for governor. In November, Briggs received 56 percent of the votes cast; Bryan carried only eight counties in North Dakota.

The achievements of Populism in North Dakota were limited. The railroads, in compliance with the law of 1892, did build many loading platforms, but other railroad legislation was ineffective. Yet the Board of Railroad Commissioners, under the leadership of George Walsh, a McKenzie man, did secure the amelioration of many grievances. The project of a state-owned terminal elevator, however, was quickly forgotten. When in 1895-1896 West Superior set up a board of trade and arranged to conform to North Dakota grades for wheat, the state's farmers made such small shipments that the West Superior grain dealers were forced to reinstate Minnesota grades. ${ }^{4}$

\section{THE CRISIS IN PUBLIC EXPEDITURES}

North Dakotans in the 1890's struggled to balance the state's income and expenditures. There were too many institutions, and tax revenues were restricted by depression and poor crops, Moreover, the railroads failed to pay their fair share of the taxes, although they owned, by one estimate, nearly one-fourth of the taxable property in the state. In 1890, for example, the Northern Pacific paid no taxes-neither the percentum of its gross income provided by the constitution nor the regular mill levy on its property. While the constitution gave the railroads their choice between the two imposts, the counties were suing the Northern Pacific for taxes on its lands.

Railroad tax payments, however, increased rapidly. In 1894 railroad property was assessed at nearly $\$ 6,700,000$, in 1898 at nearly $\$ 12,900,000$. In 1900 the railroads in North Dakota paid \$505,940 in state and local taxes. That was $\$ 187$ per mile of track, as compared to $\$ 72$ per mile in South Dakota, and more per mile than in most states west of the Mississippi. ${ }^{5}$

Throughout the 1890's, North Dakota had to fight to meet its obligations. Taxes were often delinquent. By November 1, 1890, the counties owed the state $\$ 210,000$ in back taxes. The legislative assembly generally appropriated more money than taxation was likely to yield.

${ }^{4}$ Paul R. Fossum, The Agrarian Movement in North Dakota, Johns Hopkins University Studies in Historical and Political Science, Vol. XLIII, No. 1 (Baltimore, 1925), pp. 37-49.

${ }^{5}$ North Dakota House Journal, 1891, p. 18; 1897, p. 29; 1899, p. 35; 
The governors, who continually urged the legislature to economize, always vetoed many items in the appropriation bills. Thus Governor Shortridge vetoed items totaling \$108,000 in 1893 and Governor Allin vetoed \$122,640 in 1895. In 1897, Governor Briggs vetoed all appropriation bills, but they were passed over his veto. In 1894 the voters turned down a constitutional amendment to raise the debt limit. Shortridge told the assembly that the state had more institutions than it needed or could support. When Allin vetoed their appropriations, he expected most of the state educational institutions to close, but they secured private funds and remained open.

\section{PROGRESS IN SETTLEMENT}

After the Great Dakota Boom ended in 1886, northern Dakota had entered a period of slow growth. The low point in homesteading came in the fiscal year ending June 30, 1890, when only about 850 persons filed original homestead entries. In 1891, Congress repealed the Timber Culture and Pre-emption acts, leaving the Homestead Act as the only means of acquiring government land. Homesteading picked up during the 1 890's in spite of the depression; in fiscal 1896 about 2,670 persons filed. A new boom began in fiscal 1898, when approximately 7,100 persons filed original entries, almost twice the number of the previous year.

The 1890's saw substantial progress. The population increased 67 percent, from 191,000 to 319,000. The number of acres in farms increased 103 percent. By 1900 some 35 percent of the state was in farms, as compared to only 17 percent in 1890 . By 1900 both the Red River Valley and much of the Drift Prairie were fairly settled, but settlement had barely begun on the more arid Missouri Plateau. That year, the plateau, occupying about 50 percent of the state's area, had less than 15 percent of the population $(47,000)$, while the valley, with about 10 percent of the area, had 38 percent of the population $(122,000)$ and the Drift Prairie, with 40 percent of the area, had 47 percent of the population $(151,000)$.

Settlement moved forward with the investment of outside capital. But whereas debt had increased rapidly during the boom years, it declined during the 1890's. In 1890 nearly 49 percent of the North Dakota farms operated by their owners were mortgaged; in 1900 the figure was down to only 31 percent.

One significant investment during the boom period was railroad construction. By 1890, North Dakota had 2,094 miles of track, representing an investment of about thirty million dollars. In that year the state had 110 miles of track for each 10,000 persons, as compared to 
43 miles per 10,000 in Minnesota. In the early 1890’s the Minneapolis, St. Paul and Sault Ste Marie built diagonally across the state from Hankinson to Portal, the last construction for several years. The eastern half of the state was reasonably well supplied with railroads; probably most settlers lived within 25 miles of a railroad.

In 1889, James J. Hill and his associates organized the Great Northern Railway Company. It leased all the properties of the old St. Paul, Minneapolis and Manitoba; in effect, the Manitoba became the Great Northern. By January, 1893, Hill had completed the Great Northern to Everett, Washington. His line had been built at a lower cost and on a route both shorter and with lower grades than the Northern Pacific. The amount of its stock and debt per mile was less than half that of its rival: in 1890 , about $\$ 66,000$ per mile for the Northern Pacific, compared to some \$26,230 for the Great Northern.

The Panic of 1893 affected North Dakota's railroads in several ways. It pushed the Northern Pacific into bankruptcy for the second time. That line cut its freight rates, and Hill met the cuts. In 1893, Hill's average rate per ton-mile was 1.232 cents, in 1896 only 0.976 cents; in 1880-1881 the rate had been 2.88 cents. Hill worked out a plan with J. P. Morgan to secure control of the Northern Pacific by guaranteeing the interest and principal on $\$ 100,000,000$ of its bonds. In 1896, however, the United States Supreme Court upheld an injunction forbidding an extensive railroad merger in the Northwest, whereupon Hill and his associates, acting as individuals, bought stock in the re-organized Northern Pacific. Thus Hill acquired a strong voice in the management of his competitor. He then controlled 1,921 of the 2,519 miles of railroad in North Dakota. With 870 miles of Northern Pacific and 1,051 of the Great Northern, he had a near monopoly of transportation in a state whose remoteness and sparse settlement made the cost of conquering distance especially important. ${ }^{6}$

It was fortunate for North Dakota that Hill was an efficient, far-sighted railroad manager (a sort of genius in that field) who was interested in earning a large volume of freight at a low unit cost and that he was also much interested in settling North Dakota. In 1892, Hill appointed Max Bass as immigration agent of the Great Northern. Bass, a Bohemian, had grown up in Vienna and had come to the United States

${ }^{6}$ North Dakota Board of Railroad Commissioners, Annual Reports, 18911896; letter written by James J. Hill, 1912, in Clement A. Lounsberry, Early History of North Dakota (Washington: Liberty Press, 1919), pp. 341-349; Joseph G. Pyle, The Life of James J. Hill (2 vols.; Garden City: Doubleday, Page and Company, 1917), 프, 69-70. 
when he was twenty-four. Before joining the Great Northern, he had operated a hotel at Belfield, North Dakota, when it was a jumping-off point for the Black Hills. He then served in Bismarck as deputy commissioner of immigration for Dakota Territory. A friendly, warmhearted man with a mass of black hair and a handle-bar mustache, Bass knew both the immigrant and the new country, and he believed in North Dakota's future.

Bass and others who would promote settlement in the 1890's faced many obstacles. In the eleven years from 1890 through 1900, North Dakota had only four good crops. Hard times, low yields, and a popular picture of North Dakota as a land of impossibly cold winters and unproductive soil discouraged prospective pioneers. The thousands who had come out during the Great Dakota Boom and then abandoned their homesteads to return east had given the state a bad name.

Max Bass needed hard-working settlers who would stick and prosper. His first success was with a colony of Dunkers, a German sect similar to the Quakers, from Walkerton, Indiana. In August, 1893, Bass visited them and persuaded the Reverend A. B. Peters and five others to take a land-prospecting trip to Cando. They were pleased with the country and selected homesteads.

That winter, Peters, employed by the Great Northern, made a personal canvass among the Dunkers and others of north-central Indiana, going from home to home, taking a meal here and staying overnight there, and always talking about the advantages of settling in North Dakota. Because he was, like themselves, a poor man and because he himself was venturing his all in the new country, the people gave him their confidence. Many decided to make the move. In March, 1894, some 350 persons gathered at Walkerton with household goods, farm stock, and tools. With much excitement and also with much discouraging talk from bystanders about terrible winters, they loaded their possessions on a special mixed train of freight and passenger cars and started for North Dakota.

Cando was ready for the newcomers. Barns, livery stables, the town hall, tents, and some railroad cars on a siding provided temporary shelter for stock, goods, and people. Lists of jobs and lands to rent helped. That first summer, most families rented land to put in a crop and then turned to improving their own homesteads. The Dunker colony was a success.

Encouraged by Bass, many people moved to North Dakota. Some 460 colonists came on special trains to the Great Northern country in the spring of 1895, 1,035 in 1896, 1,761 in 1897, 5,342 in 1898, 8,005 in 1899, and 10,056 in 1900. The striking increase in 1898 clearly marks the beginning of the second boom. Thousands also came on the regular 
trains at other seasons. Bass took a warm interest in those he brought to North Dakota; he would revisit their settlements and always felt proud of his part in peopling the vast grassland. He carried on the work until his death in 1909. The Great Northern named a station in Bottineau County Maxbass in his honor. ${ }^{7}$

\section{THE MCKENZIE MACHINE}

The easy defeat of Bryan in 1896 revealed the weakness of Populism in North Dakota. There were three reasons for that weakness: the large foreign-born element in the population, strong loyalty to the Republican party, and the McKenzie machine. The foreign-born, about 43 percent of the population in 1890 , were strangers not yet at home in a new country and a new society. Quite naturally they settled in colonies, knew little of politics, and, if they voted at all, voted in blocs dominated by the native-born leaders of the community-often men (like "Father" John H. -Wishek) who were tied to the McKenzie machine.

Even the native-born settlers, many of them but recently come to new homes, were apt to be more concerned with getting themselves established than with the corporation affiliations of Alexander McKenzie, Judson LaMoure, and company. Foreign- and native-born alike were generally loyal to the Republican party-the party of Abraham Lincoln, the Union, and the Homestead Act. There were 146 Republican newspapers among 163 in North Dakota in 1900.

Although the Republican party was also the party of the railroads, the grain elevators, and the moneylenders, a growing majority voted Republican. The vote going to the fusion candidate for governor put up by the Democrats and Independents declined from 52 percent in 1892 to 40 percent in 1900; the number of Democrats and Independents in the legislature declined from forty-one in 1893 to twelve in 1901.

A one-party state simplified machine control, and the McKenzie machine made Republican loyalty easy. Tall, broad-shouldered, ruddy faced Alexander McKenzie was himself a generous, modest man whose kind deeds soon became legendary. He and his followers never openly opposed reform; if necessary, they were willing to swim with its current. Under McKenzie control, the railroad commissioners secured important concessions from the railroads.

While the McKenzie machine (the "Old Gang," as it was commonly called) regularly controlled the Republican state convention, the slate of nominations was actually made up as a contract among county leaders, 
who divided the offices in a way to satisfy themselves and voted their delegations as units. Judson LaMoure often ran the convention instead of McKenzie, who did not even attend in 1894, 1898, and 1900, though his influence was still felt.

McKenzie personally seemed more interested in controlling the election of United States senators, a source of patronage and power in Washington. By the 1890's he was spending much of his time there, as well as in St. Paul and in New York City, where he was speculating in Wall Street. But he would be in Bismarck, his legal residence, when the legislature chose a new United States senator. He had a hand in the selection of Henry C. Hansbrough (elected in 1891 and re-elected in 1897 and 1903) and Porter J. McCumber (elected in 1899 and regularly re-elected until 1922). They were steadfast McKenzie men.

So were other important officials. Governors Andrew Burke (elected in 1890), Roger Allin (elected in 1894), Frank Briggs (elected in 1896), Fred Fancher (elected in 1898), Frank White (elected in 1900 and 1902), and Elmore Y. Sarles (elected in 1904) were all choices of the McKenzie machine. United States Congressmen Henry C. Hansbrough (elected in 1889), Burleigh F. Spalding (elected in 1898 and 1902), Thomas F. Marshall (elected in 1900, 1902, 1904, and 1906), and Asle J. Gronna (elected in 1904, 1906, and 1908) were all McKenziemachine choices. Martin N. Johnson (elected in 1890, 1892, 1894, and 1896) was accepted, rather than chosen, by the machine because of his large Scandinavian following.

In the state legislature the Old Gang usually won over a large part of the well-meaning but undecided members. Although the men chosen by the McKenzie machine were not McKenzie's puppets (men like McCumber, Allin, and Fancher were selected because of their followings), the machine, led by a boss who no longer lived in the state, dominated North Dakota's political life to a considerable degree. Frequently its political leaders conferred in St. Paul, where McKenzie had a suite in the Merchants Hotel. So, in a sense, the Twin Cities were politically, as they were economically, the capital of North Dakota. ${ }^{8}$

${ }^{8}$ Charles N. Glaab, "John Burke and the North Dakota Progressive Movement, 1906-1912” (Unpublished M.A. thesis, University of North Dakota, 1952), pp. 15-17 ; D. Jerome Tweton, “The Election of 1900 in North Dakota” (Unpublished M.A. thesis, University of North Dakota, 1957), p. 10; David B. Baglien, "The McKenzie Era: A Political History of North Dakota from 1880 to 1920” (Unpublished M.S. thesis, North Dakota Agricultural College, 1955), pp. 9-12, 62-85, 112; letter written by George B. Winship, Grand Forks Herald, June 10, 1916. 


\section{THE RAILROAD RATE FIGHT}

The success of the McKenzie machine did not prevent the people from using the state government to obtain lower railroad rates. In 1897 the legislature, responding to popular dissatisfaction, authorized the Board of Railroad Commissioners to fix maximum rates for passengers and freight carried wholly within the state (such traffic made up only 4 percent of the total). Thereupon the commissioners reduced rates on local traffic about 14 percent. The Great Northern, the Northern Pacific, and the Milwaukee refused to accept the new rates and asked the courts for a permanent injunction against them. They based their action upon the clause of the Fourteenth Amendment forbidding a state to deprive a person of property without due process of law.

The railroads were really alarmed. The new rates, although pertaining only to traffic within North Dakota, threatened their whole rate structure outside the state. The new rates were lower than local rates in Minnesota and Wisconsin and even lower than the railroads' special rates on carload lots moving long distances. Railroad attorneys produced evidence that the cost of carrying local traffic was at least twice as great as that for through freight, that in sparsely settled communities such as North Dakota it was four or five times as great, and that it was greater than the returns from the rates. A vice-president of the Great Northern testified:

[The railroads] have been handling the local business in North Dakota at rates that have put the traffic upon the basis of something done for the accommodation of the neighborhood rather than for the profit that is in it.... The local business in North Dakota has, all the time, really moved at the expense of the through shipper.

On December 30, 1898, the United States Circuit Court, with Judge Charles Fremont Amidon writing the opinion, granted the railroads the injunction they sought.

But it was the railroad commissioners who really won the fight. Their attorney, in presenting their case before the court, showed that the railroads were seeking a return on a much larger capital sum than their actual investment. Experts testified that branch lines (the greater part of the railroad mileage) could be built and equipped in North Dakota for $\$ 12,000$ a mile and that the Northern Pacific could be duplicated for $\$ 16,000$ a mile. The Great Northern itself admitted that its lines, main and branch, were worth only $\$ 28,000$ a mile. But it was paying interest and dividends on $\$ 40,000$ per mile, and the Northern Pacific was paying interest and dividends on $\$ 70,000$ a mile. That is, the rates were fixed to 
make a modestly profitable return on a surprisingly large fictitious investment. The Northern Pacific was paying \$2,040 a mile in interest and dividends, or 12.75 percent on a true value of $\$ 16,000$ per mile.

Such evidence of railroad exploitation aroused considerable resentment. While the case was going through the courts, the state board of equalization raised the assessed value of the railroads in North Dakota almost 50 percent-from $\$ 8,600,000$ to $\$ 12,900,000$. The railroads saw the necessity of conciliating public opinion and therefore reduced rates from points in North Dakota to eastern terminals from 10 to 20 percent. For example, the Northern Pacific cut the rate on grain from Valley City to St. Paul from 17.5 cents per hundred pounds to 15.5 cents per hundred pounds. The railroads also tried to accommodate shippers and to give value for the rates paid. ${ }^{9}$

\section{THE SPANISH-AMERICAN WAR}

In the 1890's the United States became involved in the Cuban crisis and then, pushed along by a sensational press filled with atrocity stories, in a war with Spain. From 1895 on, North Dakota newspapers printed much news on Cuba, scoffed at Spain as a third-rate power, and asked for the recognition of Cuban belligerency. But they dropped the atrocity stories after the murder of General Maceo proved to be a hoax; they remained calm over the De Lôme Letter; and when the Maine went down in Havana Harbor, they refused to call for war. "The United States could gain little honor and less profit by fighting Spain," wrote the Grand Forks Plaindealer on March 2, 1898, two weeks after the sinking. No North Dakota newspaper demanded war with Spain; none criticized President William McKinley's efforts for a peaceful solution. When war came, however, the newspapers tried to outdo each other in patriotic zeal, printing flags at the head of their columns. ${ }^{10}$

With the outbreak of war, the North Dakota National Guard volunteered in a body (the First North Dakota Infantry had been organized in 1883). Only eight infantry companies were accepted. These fought bravely in the Philippine insurrection and were commended by Congress. Their commander, Major Frank White, was elected governor of North Dakota in 1900 on fame won in the Philippines.

During the war, Congress passed a joint resolution for the

${ }^{9}$ North Dakota Board of Railroad Commissioners, Annual Report, 1897, p. 5; 1898, pp. 9, 28-33, 56, 188-200, 213, 342, 357.

${ }^{10}$ Milton W. Reitan, "North Dakota Editors and the Cuban Crisis, 18951898” (Unpublished M.A. thesis, University of North Dakota, 1957), pp. 2269. 
annexation of the Hawaiian Islands. Congressman Martin N. Johnson and Senator Henry C. Hansbrough supported it, but Senator William N. Roach, following the Democratic party's anti-imperialist stand, voted and spoke against it. Recalling the principle of government by consent of the governed, Roach asked: "Whose consent do we have as to Hawaii?” When the treaty with Spain provided for the annexation of the Philippines, the North Dakota Legislature memorialized the Senate for its ratification. Roach, however, remained steadfast. His antiimperialism and the moderation of North Dakota newspapers during the Cuban crisis seem to have foreshadowed the state's later isolationism. 


\section{CHAPTER 12}

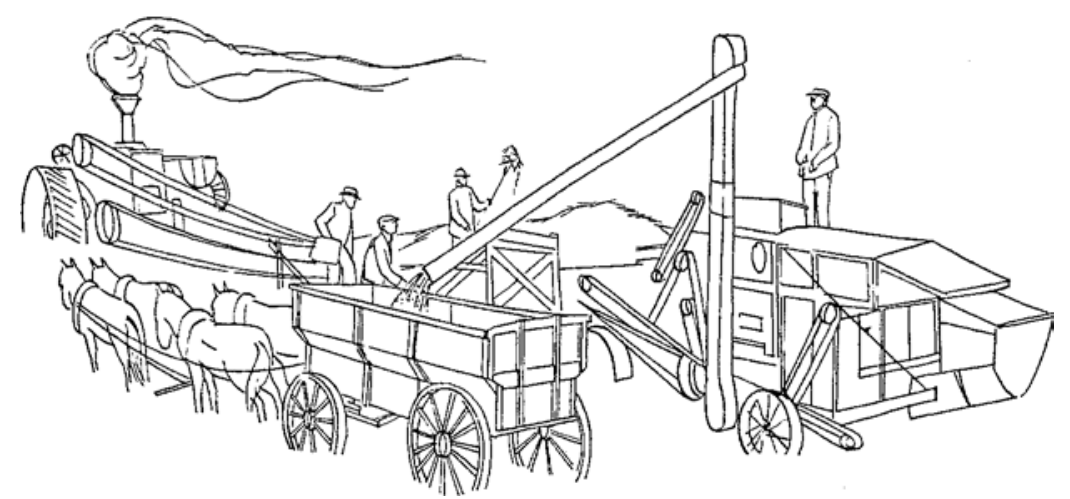

\section{The Second Boom}

THE SETTLEMENT OF NORTH DAKOTA was completed by a second boom which began in 1898 and continued, though with declining exuberance in its later years, to the First World War. The boom was a reflection of national trends. After the depression of the 1890's, the United States entered a period of extraordinary economic growth. Railroads expanded their trackage and equipment at a fast rate, the value added to raw materials by manufacturing doubled, and millions of European immigrants poured into the nation. Urban population increased rapidly. The national wealth more than doubled.

While the second boom in North Dakota was an aspect of this unusual national growth, it also helped to mark the disappearance of the frontier. As the arable, unoccupied lands of the last West began to be taken up, the demand for food rose faster than its production. The prices of both farm produce and farm land went up. Prospects of a food shortage faced the nation and stimulated a westward surge of land seekers.

A flood of new settlers poured into North Dakota, especially onto the Missouri Plateau. From 1898 to 1915, some 250,000 latter-day pioneers entered the state. Then the influx of population, begun in 1871 when the railroads reached the Red River of the North, came to an end. After 1915 the movement was to be outward, away from North Dakota. That would begin a new era in North Dakota history.

But the boom itself had most important consequences for the state. Outsiders gave North Dakota a railroad network which was best suited to a more densely populated region. By 1915 they had invested some $\$ 100,000,000$, but sparse population tended to limit their profits. To their credit, however, the railroads did bring a rush of settlers eager to get a share of the last free or cheap land. By 1910, two-thirds of the population 
had been born outside the state. The country was filled with people who did not understand it very well. They covered western North Dakota with small farms, a pattern of settlement unsuited to the semiarid climate, and so created the problem of slow and painful readjustment to hardships caused by scanty, uncertain rainfall.

The speculative rush increased land values. Their rise made wheat farming, an extensive agriculture requiring cheap land, less profitable, for it raised the cost of capital and hence of production, even though yields were declining. Increasing tenancy, a result of higher land costs, also took some income away from landowners. As a solution to such difficulties, the "Better Farming" movement, promoted by outsiders from more humid and densely populated southern Minnesota, preached a gospel of diversification which emphasized dairy farming. Dairying, however, did not mix well with wheat farming and was not too well suited to the remote, semiarid country. Diversification made only slow progress.

\section{RAILROAD BUILDING}

From 1898 to 1915 the railroad mileage of North Dakota almost doubled, increasing from 2,662 miles to 5,226. Construction stopped with the outbreak of the First World War and was never resumed. In 1898 the state already had over three times as many miles of railroad in proportion to its population as did the United States, but large areas of North Dakota were still without railroads. There were none on the Missouri Plateau except the main lines of the Northern Pacific and the Great Northern.

Construction began with the extension of branches across the Drift Prairie and onto the edge of the Missouri Plateau. In the first years of the boom, from 1898 to 1904, some 550 miles were built. The Northern Pacific added 234 miles of branch lines, reaching Denhoff, McHenry, Marion, Oakes, Esmond, and Linton. The Great Northern added about 125 miles to its branches running toward the Canadian boundary, reaching Walhalla, Hannah, Souris, Munich, and Mohall. The Soo built 110 miles from Kulm to Wishek, then both north to Bismarck and south to the state line. The Chicago, Milwaukee, and St. Paul (commonly called the Milwaukee) built a branch from Roscoe, South Dakota, to Strasburg and Linton.

In addition to the building of branches, two new railroads appeared in the state. William D. Washburn, wealthy Minneapolis miller and promoter of the Soo, organized the Bismarck, Washburn and Fort Buford Railway Company in 1899. His primary aim was to reach the thick lignite beds he owned at Wilton. In July, 1900, the new railroad began to 
run trains to Wilton, where the mine was soon producing one hundred tons of lignite a day. In 1901, Washburn laid track to the town of Washburn, and in 1904 he sold his railroad to the Soo. Meanwhile, in 1902 the farmers or Ramsey County organized the Farmers' Grain and Shipping Company and built a railroad from Devils Lake to Starkweather and then in 1905 to Hansboro.

During the early years of the boom the principal railroads were making substantial improvements. They ballasted roadbeds, straightened curves, lowered grades, replaced wooden bridges with steel ones, laid heavier rails, and added new locomotives and rolling stock. In 1900 the Great Northern built large shops in Minot; the Northern Pacific constructed a large depot in Bismarck; and the Soo bought a very large locomotive, a decapod, considered the second largest in the nation. Passenger fares were reduced from four to three cents a mile, and North Dakotans took some pride in the crack trains, such as the Northern Pacific's North Coast Limited, which crossed the state. Hill of the Great Northern was much interested in the traffic of the Pacific Northwest and the Orient. He organized the Great Northern Steamship Company in 1900 and ordered two large ocean steamers, the Minnesota (launched in 1903) and the Dakota (1904).

There was a lull in railroad building in 1904. Then came three big years: 1905 with 528 miles, 1906 with 144, and 1907 with 273. Much of the new trackage was the result of a raid by the Soo, a project of the Canadian Pacific Railroad and the Minneapolis millers, on territory already served by the Great Northern. Unfortunately, such over-building lessened the chances for low-cost transportation and thus added to the difficulties created by the semiarid climate, the sparse population, and the consequent low volume of freight in proportion to railroad mileage and investment.

In 1905 the Soo built the "Wheat Line” from the Red River at Oslo, Minnesota, to Kenmare, paralleling for nearly 250 miles the main line of the Great Northern. In 1906 it built a 100-mile branch from Drake to Plaza and another reaching westward from Flaxton. Both infringed on Great Northern territory. That railroad extended some of its northern branches and built new ones starting at York, Towner, and Berthold.

Some of the new Great Northern and Soo branches were on the Missouri Plateau. In 1905 the Northern Pacific extended lines to Streeter and Turtle Lake, both on the plateau east of the Missouri River. But when the Milwaukee crossed the southwestern portion of the state in 1907 on its way to the Pacific Coast, it laid the first tracks on the Missouri Slope since the building of the main line of the Northern Pacific in 1879-1880. The railroads continued to make improvements: water reservoirs, heavier 
rails, and more locomotives and freight cars. In 1906 the Northern Pacific began its "Hi-Line" bridge, a mile long and 148 feet above the river, across the Sheyenne Valley at Valley City.

The last spurt of construction occurred between 1910 and 1914, when the railroads laid 1,025 miles of track in North Dakota, 523 miles in 1912 alone. In 1912 the Soo put into operation a line from Fordville to Drake, roughly parallel to the main line of the Great Northern for 130 miles, and during the next two years it extended its branches from Plaza and Ambrose. Also in 1912, the Great Northern inaugurated service on the Surrey Cutoff, 208 miles of track from Fargo to Surrey which runs parallel to much of the Soo's Hankinson-Portal line. The Midland Continental Railroad, an ambitious scheme to connect Winnipeg and Galveston, Texas, was only able to build from Edgeley to Wimbledon.

The railroads built other branches during these years and for the first time put them on the Missouri Slope. In 1911 the Milwaukee laid track from McLaughlin, South Dakota, to New England. The Northern Pacific started lines running north and south from Mandan. The southern branch turned west to Mott; the northern one turned up the Knife River Valley at Stanton and reached Killdeer in 1914. About the same time, another Northern Pacific branch extended south from Beach, and a Great Northern line came to Watford City. A little later, the Great Northern built to Grenora.

The outbreak of the First World War virtually ended railroad construction in both the state and the nation. In North Dakota the Great Northern had 1,872 miles of track, the Northern Pacific 1,496 miles, the Soo 1,269, and the Milwaukee 378. ${ }^{1}$ Including the shorter trackage of other lines, the state had 5,226 miles of railroad. Because of its thinly scattered population, North Dakota had almost three times the railroad mileage in proportion to its population as did the United States-74 miles per 10,000 people for North Dakota, 25 miles per 10,000 for the United States.

\section{CONFLICT WITH THE RAILROADS}

The capitalization of the railroads and the investment in their

\footnotetext{
${ }^{1}$ North Dakota Board of Railroad Commissioners, Annual Reports, 18991914; Joseph G. Pyle, The Life of James J. Hill (2 vols.; Garden City: Doubleday, Page and Company, 1917), I, 51-62; James D. Johnson, “A History of the Midland Continental Railroad, 1906-1950” (Unpublished M.A. thesis, University of North Dakota, 1952), pp. 12-84. A map showing construction by years is in Lewis F. Crawford, History of North Dakota (3 vols.; Chicago: American Historical Society, Inc., 1931), I, 256; mileages built are in the Statistical Abstract, 1900-1922.
} 
transportation systems were vital matters to North Dakota. By 1915 outside capitalists had invested, at an estimated $\$ 20,000$ per mile, some $\$ 100,000,000$ in North Dakota railroads, yet they had issued stocks and bonds for more than three times that amount. For its whole system the Great Northern's capitalization was about $\$ 78,000$ per mile, the Northern Pacific's about $\$ 95,000$. Although a part of these amounts represented costly construction through the mountains and expensive terminals outside the state, it still seems as if the railroads were seeking to earn a return on an investment which was to a considerable extent fictitious.

Aside from the fictitious element in the capitalization of the railroads (practically a universal phenomenon in corporation finance), both mileage and investment in the railroads of North Dakota were inescapably high in proportion to the population. For these reasons, North Dakotans-like other westerners and also southerners, all of whom shared the same predicament-had to pay high freight rates. These charges, which reduced the standard of living, were part of the toll paid for both the remoteness of the state and for the dependence of its people on outside capital.

High freight rates were a serious obstacle to the development of manufacturing and hence of a more diversified economy. As such, they contributed to North Dakota's economic disadvantage, which persisted in spite of the state's great wealth-producing capacity. By discriminatory freight rates the East held the South and West as colonies; North Dakota inevitably shared the bondage of the agricultural sections. ${ }^{2}$

So in North Dakota the railroads and the people were in constant conflict. The railroads sought economical, profitable operation. They built lines cheaply, sometimes laying used rails on an unballasted bed and making improvements later. They converted old boxcars into stations and wished to take off unprofitable trains and to close stations where receipts were small. They entered politics to escape taxation, to block anti-railroad legislation, and to elect their friends to office. For their part, the people kept the railroads under pressure to give better service. They demanded that stations be kept open, that freight cars be supplied promptly, that crack passenger trains stop at nearly every town, that the railroads pay more taxes, and that freight rates be lowered.

The people felt that the railroads failed to meet the transportation needs of the state. The failure was due in part to the concentration of the year's traffic in the fall and early winter with the marketing of grain. But

${ }^{2}$ Capitalization given in Poor's Manual of Railroads, 1915 (New York: Poor's Publishing Company, 1915), pp. 696, 1225, 1448; Wendell Berge, Economic Freedom for the West (Lincoln: University of Nebraska Press, 1946), pp. 97-121. 
it also resulted from poor management, especially the desire of the railroads to move only long trains. In 1905 the railroads failed to move the grain crop effectively, and the following year, although the crop was no larger, they did an even poorer job. The 1,600 elevators in the state could store only a third of the crop. By December the terminal elevators at Duluth, Superior, and the Twin Cities were still almost empty, while in North Dakota the rural elevators were jammed and much wheat, covered with snow, was in open bins along the tracks. The financial loss to the state in insurance, interest, storage charges, and lower prices was serious. And when snow blocked the railroads, an early winter caught coal dealers without fuel.

The fuel shortage sharpened resentment against the railroads. In January, 1907, the legislature said that people were in danger of freezing because of the railroads' negligence or, perhaps, their contempt for state regulatory legislation. A member of the Interstate Commerce Commission, which investigated the situation, condemned the railroads for not following "a policy of operation aimed specifically to meet the needs of the grain raiser."

In the continuing conflict each side had some success. Many state officials, the recipients of free passes, were friends of the railroads, and the railroad commissioners often seemed like their apologists. Yet the legislature compelled them to fence their lines, to build stations, and to operate daily freight and passenger trains. The state board of equalization steadily increased their taxes-from about $\$ 500,000$, or $\$ 187$ per mile, in 1900 to $\$ 1,900,000$, or $\$ 371$ per mile, in 1915 . These sums were much larger than South Dakota collected: \$72 per mile in 1900 and \$312 in 1915.

The comparison suggests that North Dakotans, even before the rise of the Nonpartisan League, were more radical than their neighbors to the south, with whom they had much in common. In the struggle the people of the state, feeling keenly their entire dependence upon the railroads, could hardly be expected to admire the giant corporations, so obviously rich and powerful, which, moving in secret ways, influenced public officials and exploited townsmen and farmers alike, reducing their incomes by freight rates designed to earn a return on fictitious capitalization.

Although railroad agents, conscious of the power of the corporations they represented, were sometimes insolent, the railroad managers usually sought to conciliate a hostile public opinion. Thus the Northern Pacific cheerfully ran a daily passenger train to Streeter for an average of eight passengers and a loss of thirty-five to forty dollars a trip. James J. Hill himself was much concerned for the welfare of the region. "You are now 
our children," he said, "but we are in the same boat with you, and we have got to prosper with you or we have got to be poor with you."3

The railroads resisted legislative efforts to reduce freight rates on lignite, an important expense in a cold country. The legislature set up a schedule of low lignite rates in 1893, again in 1895, and once more in 1903. Each time, the railroads, arguing that the rates were confiscatory, refused to accept them. In 1905 the railroad commissioners themselves called the rates "unjust and confiscatory.” Two years later the legislature, angry with the railroads because of a fuel shortage, again reduced lignite rates and the attorney general secured an injunction from the North Dakota Supreme Court forbidding the railroads to ignore them. After an eight-year legal battle, the United States Supreme Court, reversing the state court's decision in favor of the rates, ruled on March 8, 1915, that a state may not compel a railroad to charge a rate on a particular commodity that does not yield a reasonable return on the investment. ${ }^{4}$

\section{THE COMPLETION OF SETTLEMENT}

The railroad building of the second boom brought to completion the settlement which had begun when the railroads reached the Red River in 1871. As the railroads extended their branches, lines of villages and towns sprang up along the new tracks. From 1900 to 1910, a total of 137 new ones were incorporated; only 75 had been incorporated up to 1900 .

The railroads advertised for settlers. The Great Northern offered special rates to men who wanted to come out to North Dakota to work in the harvest and, while there, look over the country. Pamphlets, filled with the letters of successful pioneers, emphasized the advantages of North Dakota- "Where Wheat is King." After 1909, although the boom was slackening, the Great Northern alone moved 64,000 new settlers into the state.

In 1905 the legislature had appropriated $\$ 20,000$ to advertise the state. The commissioner of agriculture and labor used some of the money to start the North Dakota Magazine, a promotional enterprise, in 1906. From 1905 to 1910 his organization distributed 170,000 copies of the magazine, 265,000 folder-type maps of North Dakota, 10,000 wall maps, and 370,500 folders and circulars.

A mania to secure land seized people. It was stimulated by a rise in the prices of agricultural produce and farm lands which had begun in the

${ }^{3}$ Mary Wilma M. Hargreaves, Dry Farming in the Northern Great Plains, 1900-1925, Harvard Economic Studies, Vol. 101 (Cambridge, 1957), pp. 225226; North Dakota Board of Railroad Commissioners, Annual Report, 1907, pp. 100-110; Statistical Abstract, 1908, p. 267; 1916, pp. 304-305.

${ }^{4}$ Grand Forks Herald, March 9, 1915. 
late 1890's. Moreover, the United States Bureau of the Census had reported that the frontier of unoccupied land was drawing to a close in 1890. In the 1890's public men in Great Britain and the United States began to say that the growth of the population and the end of unoccupied and tillable land meant a shortage of food because food consumption was increasing faster than food production. These trends, they said, would mean scarcity and high prices; they would make the farmers the most prosperous class. Officials of the United States Department of Agriculture held these ideas in 1905; the next year, James J. Hill expounded them in an address at the Minnesota State Fair.

These ideas lay behind the feverish rush to western North Dakota in the days of the second boom. By 1898 farmers and speculators had taken the larger part of the railroad land east of the Missouri River. In the late 1890's the D. S. B. Johnson Land Company of St. Paul bought all of the Northern Pacific land in Foster, Wells, and three other counties. From 1900 to 1904 the Northern Pacific sold 1,569,000 acres west of the Missouri to ten individuals or land companies in tracts ranging from 36,000 to 420,000 acres for an average price of $\$ 1.63$ an acre. In 1902, for example, the Golden Valley Land and Cattle Company bought a strip thirty miles long and nine to fifteen wide.

Sometimes land companies bought large tracts from ranchers to retail in small farms. Speculative funds for this purpose ca me from the Twin Cities. Thus W. D. Washburn bought a large block of land in northern Burleigh and southwestern McLean counties, and in 1909, James C. Young of Minneapolis reportedly held 1,000,000 acres in North Dakota, part of it near Dickinson. The Western Land Securities Company of St. Paul was active in Stark County. In 1904, W. H. Brown and Company of Chicago opened an office in Richardton and began a heavy promotion of the 200,000 acres it held south of that place. There were countless speculators, large and small. In 1906, Alexander McKenzie invested in some 300,000 acres; he was estimated to have made a million dollars from the rise in values by 1909. Speculators advertised in Iowa, Wisconsin, and Minnesota, where land values were rising, brought delegations of bankers, businessmen, and retired farmers out to western North Dakota, and sold them tracts of from one to eighteen sections (the railroad land in one township). Such investors and speculators brought in settlers by the carload. Hugh Connorran Short (father of Don L. Short, United States congressman from 1959 to 1965) was a Northern Pacific land agent in those years. He lived in Iowa and brought parties of land seekers to the Belfield-Sentinel Butte-Beach area before he himself fell 
in love with the country and went into ranching. ${ }^{5}$

Everyone believed that rising values would quickly enrich land-owners, so thousands who had never farmed before and had no idea of what farming was like rushed to get a quarter-section on the old, easy terms before the cheap land of the frontier was all gone. There was, Bishop Cameron Mann wrote about Linton in 1903, "such a rush of business that the stores are open until midnight.... The hotel where there were several beds in each room [had] several people in each bed."

About half the newcomers in western North Dakota had at least some experience in farming, and about half came from other walks of life, many from business but others representing fifty-nine occupationsbanker, jeweler, dock worker, cigar maker, art student, blacksmith, minister, printer, college professor, and so on. Unmarried women also homesteaded; there were stenographers, schoolteachers, widows, daughters of settlers, and elderly spinsters. Both the businessmen of the new towns and railroad employees caught the land fever. They filed on homesteads, built claim shacks, slept in them long enough to comply with the law, and hired others to plow and seed the required acreage. These latter-day pioneers soon dotted the unsettled countryside with their shacks. They filed original homestead entries on 1,100,000 acres in 1898 and then each year took up more and more land until in 1906 they filed on 2,700,000 acres. This was the peak, but in every year from 1898 through 1908, except 1899, they filed on more than 1,000,000 acres. Then filings tapered off, down to less than 600,000 acres in 1914. By that time most of the unappropriated public land in North Dakota had passed into private hands. But some homesteading continued into the early 1920's.

Meanwhile, the federal government had changed the land laws. It repealed the Pre-emption and Timber Culture acts in 1891, and in 1909 it passed the Enlarged Homestead Act, which allowed settlers in certain states to acquire a 320-acre claim for five years' residence and improvement. North Dakota was included in the area to which the law applied in 1912. That year, Congress reduced the period of residence required on all homesteads from five years to three; that is, residence was

${ }^{5}$ Hargreaves, Dry Farming, pp. 73-77, 417-426, 449; story of Don Short by John O. Hjelle, Bismarck Tribune, June 4, 1958, reprinted as an advertisement in the Grand Forks Herald, October 31, 1958; Robert H. Bahmer, "The Economic and Political Background of the Nonpartisan League" (Unpublished Ph.D. dissertation, University of Minnesota, 1941), pp. 22-25; E. A. Willson, H. C. Hoffsommer, and Alva H. Benton, Rural Changes in Western North Dakota, North Dakota Agricultural Experiment Station Bulletin 214 (Fargo, 1928), p. 19. 
required for seven months of each year for three years.

The provisions for acquiring public land by a cash payment were important. Under the homestead laws the settler could commute his claim after fourteen months' residence (it had been six months until 1891) and secure title immediately by paying $\$ 1.25$ an acre or $\$ 2.50$ if the land was within the railroad land grant. Commutation, as the practice was called, enabled either the farmer or the speculator to acquire public land without living on it for five years, or after 1912 for three years. Acquiring title to his homestead allowed the settler to use it as security for a loan.

Many or the newcomers were nonfarming speculators, and the number of commuted homesteads increased. Before 1899 less than 10 percent of the homesteaders commuted their entries. But by 1903 some 60 percent were commuting, and from 1900 to 1910 homesteaders commuted entries on 5,800,000 acres and fulfilled the term of residence to make final proof on 5,600,000 acres. Of course not all who commuted were speculators. Perhaps a third of those who filed on homesteads in the ten years from 1900 to 1910 were speculators who did not stay on the land. An investigating committee reported in 1904 that less than 35 percent of all entries commuted in the previous six years in the Minot and Devils Lake land districts were occupied, and that a large part of the claims had been transferred to other owners within two years after commutation. The committee judged that 55 percent of the commuted entries were made for speculative purposes. By 1904 almost 90 percent of the entries at the Minot land office had been commuted.

Many speculators left without ever having farmed; others farmed a while but soon gave up and sold out to their neighbors. Some had never farmed before; some lived in town, still plying their trades as teachers, carpenters, and businessmen, and did not even try to make a living on their claims. Many homesteaded land unsuitable for farming. Some tired of "batching it"; others discovered that their farming experience in humid regions was not much help on the semiarid Missouri Plateau. Many left because the country had become too thickly settled; there were simply too many small farms.

Gradually the smaller farmers sold out to the larger ones and left the country. From the beginning, farms were larger within the Northern Pacific land grant, where the settler could homestead government land and buy railroad land. The history of Fertile Township, Mountrail County, illustrates how quickly many of the newcomers left and how farms became larger. Part of the Fort Berthold Reservation, Fertile Township was opened to settlement in 1916. That year, there were 123 settlers in the township, almost one for every quarter-section. By 1919, 
however, there were only 73 farms in the township, and by 1924 only 40 . There was practically no abandoned land.

Throughout western North Dakota, those who stayed were usually married men with a farm background who had come to make a home. Although some of the inexperienced made successful farmers, the farmers were better "stayers" than the nonfarmers, the married better than the single, the foreigners better than the natives, the Germans and German Russians better than the Norwegians and older Americans, and the native-born from Nebraska, Ohio, and Wisconsin better stayers than the native-born from Minnesota and eastern North Dakota. ${ }^{6}$ Plainly, those who had traveled the greater distance were more apt to stay. But the foreign-born, especially, were attracted to the land. In 1910 almost 51 percent of the farmers were foreign-born: 10,886 were born in Norway, 7,734 in Russia, 4,825 in Germany, 4,251 in Canada, 3,635 in Sweden, 1,318 in Denmark, 1,304 in Austria, 839 in Ireland, and 627 in England. ${ }^{7}$ For them, North Dakota meant ownership of farms, the satisfaction of an old land hunger.

Although many of the newcomers soon left, the population of North Dakota increased during the second boom. From 1900 to 1910 it grew 81 percent, or from 319,000 people to 577,000, the largest increase in the history of the state. From the beginning of the boom in 1898 to its end about 1915, the population rose from an estimated 270,000 to 637,000 (the number counted in a state census taken in 1915). This was an increase of some 367,000 , or about 135 percent.

The largest increases occurred on the Missouri Plateau, but many counties of the Drift Prairie, and many towns grew substantially. The population of the Missouri Plateau rose from 47,000 in 1900 to 187,000 in 1910, an increase of 296 percent. The population of the Drift Prairie increased from 151,000 in 1900 to 262,000 in 1910, or 74 percent. The population of the Red River Valley grew from 122,000 in 1900 to 128,000 in 1910, an increase of only 5 percent. By 1910 the Missouri Plateau, with 50 percent of the state's area, had 32 percent of the population; the Drift Prairie, with 40 percent of the area, had 45 percent of the population; the Red River Valley, with 10 percent of the area, had 22 percent of the population.

The older towns grew rapidly. Fargo rose from 9,589 to 14,331, Grand Forks from 7,652 to 12,478, Jamestown from 2,853 to 4,358, and

${ }^{6}$ Willson, Hoffasommer, and Benton, Rural Changes in Western North Dakota, pp. 20-68.

${ }^{7}$ United States Bureau of the Census, Abstract of 1910 Census with Supplement for North Dakota, p. 618. 
Bismarck from 3,319 to 5,443. But the really spectacular increases came in the newer places. Devils Lake grew from 1,729 to 5,157, Minot from 1,277 to 6,188 , and Williston from 763 to 3,124 .

At the eastern end of the state, where many were leaving for the Canadian Northwest, three counties actually lost population in the decade: Walsh declined 3.9 percent, Traill 4.3 percent, and Pembina 17.5 percent. ${ }^{8}$ At the western end of the state, Williams County had a population of 1,530 in 1900; it and Divide County (a part of Williams in 1900) had 20,249 in 1910. Billings County had a population of 975 in 1900; it and Bowman County (a part of Billings in 1900) had 14,854 in 1910. Such increases in population were an outstanding example of the Too-Much Mistake. The semiarid Missouri Plateau was acquiring more people than it needed, more people than it would have opportunities for. The stage was being set for a long-continued exodus.

\section{EXPANDING WHEAT PRODUCTION}

Although the rush to western North Dakota proved to be a mistake for many people, the years after 1898 were good ones for American agriculture. The population of the nation was growing more rapidly than farm production; prices were rising; and the farm surplus was disappearing. Plenty of rain fell, and on the Missouri Plateau new settlers reaped good yields in spite of their inexperience with the semiarid country.

The completion of settlement changed the scale of North Dakota agriculture. In 1900, North Dakotans operated 45,000 farms with 15,500,000 acres; in 1910 they had 74,000 farms containing 28,400,000 acres. The average farm size had increased from 343 acres to 382, which compared favorably with the 138-acre average of the United States as a whole. The value of all farm property rose from $\$ 255,000,000$ to nearly $\$ 975,000,000$.

Expansion, however, did not change the character of North Dakota agriculture. Wheat was still king. From 1898 to 1915 the acreage planted to wheat doubled, going from 4,300,000 acres to $9,400,000$, and production rose from $69,000,000$ bushels to $159,000,000$, a record crop rarely approached in subsequent years. In more than half of the years from 1890 to 1919, North Dakota was the leading wheat state, ahead of Kansas, its closest rival. In North Dakota wheat accounted for nearly 60 percent of the value of all farm crops and livestock in 1909 and about 80 percent of the cash income. The other cash crop was flax; North Dakota 
produced more than half the crop in the United States. Flax was a crop for virgin land and also a gamble; the land soon became "flax sick," and production fell off. Large quantities of oats, hay, and barley were also raised, largely for domestic feed. Oats were fed to horses, by far the most valuable livestock. In 1909 the value of the wheat crop (117,000,000 bushels and the largest yet produced) was $\$ 109,000,000$; the value of the oat crop was $\$ 24,000,000$; the value of livestock products was $\$ 16,000,000$; and the value of the flax crop was $\$ 15,000,000$. North Dakota was really a one-crop state.

\section{NEW VARIETIES OF WHEAT}

There was, quite naturally, much interest in new and better kinds of wheat. At the outset, Red Fife, a hard red spring wheat which was also called Scotch Fife, was the variety most commonly grown. Introduced from Canada, it made North Dakota's reputation as "the land of the No. 1 hard.” In the early 1890’s, L. H. Haynes of Fargo took the lead in planting Bluestem, a variety which ripened later than Red Fife. It was very satisfactory when growing conditions were good. Soon after the turn of the century it was grown more extensively than Red Fife. But neither was resistant to stem rust, a destructive disease, and there was much testing of varieties at the North Dakota Agricultural Experiment Station. About 1895, Preston, also known as Velvet Chaff, was introduced from Canada. Preston had a little more tolerance to rust, and while it was grown on about 750,000 acres by 1919, it had a tendency to shatter when ripe, a lower quality gluten, and less market appeal than other wheats.

Durum wheat, introduced from Russia, was first raised in North Dakota in the late 1890's. Encouraged by the United States Department of Agriculture and the North Dakota Agricultural Experiment Station, farmers steadily planted more and more durum. It yielded more bushels per acre than common wheats, grew more vigorously, and was usually more resistant to drought and rust. Durum-wheat flour, however, did not have the strength of gluten that flour from common wheat possessed, and was used only for macaroni products. At first the leading durum was Arnautka, but after the bad rust years of 1916 and 1919, Kubanka replaced it as the leading variety. Minidum, an amber durum, was released by the Minnesota Agricultural Experiment Station about 1917 and soon became the leading variety. Although only moderately resistant to rust, it was an excellent yielder and ranked high in macaroni quality. When durum was first introduced, agricultural experts believed that it might be better suited than hard red spring wheat to the drier conditions of western North Dakota, but durum came to be most successfully grown 
in eastern North Dakota outside the Red River Valley. After 1917, from 20 to 40 percent of North Dakota's wheat acreage was planted to durum, and the state raised from two-thirds to three-fourths of the nation's total output.

After the coming of durum, the next major step was the introduction of Marquis wheat, a new hard red spring variety. It had been developed in Canada in 1903 by Dr. Charles E. Saunders of the Central Experimental Farm at Ottawa. He crossed an early-ripening Indian wheat, Hard Red Calcutta, with common Red Fife and produced a variety then superior to all others for North Dakota. It was not resistant to stem rust, yet its earliness permitted it to escape injury from both heat and rust and so gave it an advantage over Red Fife. Marquis was first grown in North Dakota in 1912. With the serious losses to rust in 1914 and 1916, many farmers discontinued growing the older Red Fife and Bluestem varieties in favor of Marquis. By 1919, Marquis was being grown on four and one-half million acres, about two-thirds of the hard reel spring wheat acreage of the state.

About 1915 the North Dakota Agricultural Experiment Station began a scientific program of crossing wheat varieties to produce new ones-a replacement for the older system of plant selection. By 1918 it had developed and was testing Kota, a hard red spring wheat of Russian origin and the first variety that was resistant to stem rust. Soon other rustresistant wheats were developed; Kota and the others, though not put into extensive farm production, supplied wheat-breeding materials which had rust resistance.

The searchers for better varieties of wheat were true heroes of the land, for Red Fife, Bluestem, the durums, and Marquis were highly important in making North Dakota productive of much wealth. The introduction of a valuable grass adapted to the nature of the country also benefited the state. The seed of brome grass, a native of central Europe and China which was extensively cultivated in Hungary and Russia, was distributed in North Dakota in the early 1890's. It rapidly became one of the most valuable forage grasses in the state-highly palatable as pasture grass and excellent for making hay. Brome grass has a fine and extensive root system, often penetrating to depths of five or six feet, and is well suited to regions with moderate rainfall and low to moderate summer temperatures, such as prevail in eastern North Dakota. It is only moderately drought resistant, however, and did not do well in the western part of the state. ${ }^{9}$ 


\section{THE ECONOMICS OF WHEAT FARMING}

There was a real need for agricultural diversification in North Dakota, for more income from livestock. Average wheat yields were declining in the Red River Valley: the fields were becoming weedy; the seed was often of poor quality; more work was required to produce a crop. The valley was losing its status as "the land of the No. 1 hard" and becoming "the land of No. 2 and 3." People were reluctant to admit it. When Professor Henry L. Bolley of the Agricultural College released the results of a study showing that the land was "wheat sick," he nearly lost his position. Yet many believed that something was wrong. "In 1914, as my sworn statement will show," said Senator Asle J. Gronna before an audience in Grand Forks, “on an investment of between \$350,000 and $\$ 400,000$ in farms, I sustained a loss of over $\$ 4,000$ and the farms were run in a good systematic way.”

For one thing, paradoxical as it may seem, the farmer was really hurt by the increased value of the land and therefore the increased share going to capital invested in land. This was true even though many who made money in North Dakota did so through the rise in land values. The average value of farm land per acre rose from $\$ 11.00$ in 1900 to $\$ 26.00$ in 1910 and to $\$ 35.00$ in 1920 . The increase was welcomed, for virtually all farmers were speculators expecting a rise. Often the increase was spectacular. A farmer bought a section of land in Billings County for $\$ 6.00$ an acre and four years later sold three quarters of it for \$23.00 an acre. The rise was purely speculative; it was based upon the disappearance of free government land and not upon the increased earning capacity. ${ }^{10}$

The price of land went higher than the rate of return justified. The increase hurt the farmer who stayed on when he enlarged his farm; it benefited only the farmer or speculator who was selling out and leaving. Many lost money, for they were enlarging their farms to secure a more suitable size for the semiarid region. Some of them, of course, mortgaged their farms. Fifty-one percent of the farmers had mortgaged their farms by 1910; they owed forty-eight million dollars. The rise in land values increased the cost of raising wheat by increasing the cost of capital. Where the capital was borrowed, the cost was paid in interest on the farm mortgage.

Credit came from a variety of sources. The farmer might borrow

Station, VII, 6 (July-August 1945), 21-26; Warren Whitman et al., Grass, North Dakota Agricultural Experiment Station Bulletin 300 (Fargo, 1941).

${ }^{10}$ Bahmer, "The Economic and Political Background of the Nonpartisan League,” pp. 48, 51, 5S-56, 67-68. 
from a state bank, a life insurance company, or a mortgage or finance company. The state bank would probably use the mortgage as security for a loan from a big bank in Minneapolis or St. Paul. The Union Central Insurance Company of Cincinnati and the Northwestern Mutual Insurance Company of Milwaukee lent much money on farm mortgages in North Dakota. Every community had a moneylender who acted as an agent of outside investors.

Credit was expensive. The average mortgage ran for about five years with 8 percent interest. But the expense of abstracting titles, examining the property, recording the mortgage, and, in the newer sections, a bonus for getting the loan-all these were borne by the farmer. A study in 19141915 revealed that interest and other expenses averaged 8.7 percent for the state. This charge, together with the expense and uncertainty of mortgage renewal (few farms were paid for in five years), made the credit system a heavy burden on the farmers. Moreover, most of them had to buy farm machinery and supplies on credit. They would secure a bank loan for eight or nine months at an average of 10.75 percent interest; more often they obtained credit from a store. Merchants commonly gave a 7 percent discount for cash. ${ }^{11}$

\section{THE BETTER FARMING MOVEMENT}

These and other problems compelled the farmers to think of new ways in which they could make their work more profitable. There had long been much talk about the evils of one-crop farming. James J. Hill had been preaching the importance of more livestock on farms since the 1880's. To promote his ideas, he gave away fifty young registered Shorthorn bulls along the Great Northern line in 1914.

Farmers' institutes worked in the same direction. The Agricultural College held the first one in 1894, after which they became a regular practice. On weekends, faculty members lectured without pay at farmers' meetings; the communities paid their hotel bills, and the railroads furnished transportation. The state soon began to appropriate funds, and by 1911 there were more than one hundred institutes annually. For the same purposes, the Agricultural College began to offer "short courses" for farmers.

\footnotetext{
${ }^{11}$ Mildred L. Hartsough, The Twin Cities as a Metropolitan Market, University of Minnesota Studies in the Social Sciences, No. 18 (Minneapolis, 1925), pp. 125-136; Samuel Torgerson, "Early Banking in North Dakota," Quarterly Journal of the University of North Dakota, XIII (April 1923), 286287; Alvin S. Tostlebe, The Bank of North Dakota: An Experiment in Agrarian Banking, Columbia University Studies in History, Economics and Public Law, •vol. 114, No. 1 (New York, 1924), pp. 32-35.
} 
In 1898 the Agricultural College organized the annual Tri-State Grain and Stock Growers convention at Fargo. Businessmen contributed funds for the meetings; the Northern Pacific and Great Northern gave free transportation to fifty farmers for the first one and charged nominal fares for later ones. Farmers came from North Dakota, South Dakota, and Minnesota. Under the leadership of John H. Worst, president of the college, the Tri-State meetings became an agency to educate the farmers.

There were other educational efforts. Farm papers like the Dakota Farmer helped the cause. In 1906 the Great Northern sent out an agricultural demonstration train with lecturers, and in 1912 it organized a regular department for agricultural research and education. In 1914 the Agricultural College added an extension department.

“Better Farming” became a popular slogan. In Minneapolis and St. Paul, A. R. Rogers, a lumber dealer, collected \$43,000 from business interests to organize and back the work of the North Dakota Better Farming Association. The North Dakota Bankers Association joined in the scheme, and the Great Northern, the Northern Pacific, and the Soo each contributed \$5,000. Thomas Cooper of the Minnesota Agricultural College was hired to direct the association. The whole enterprise was an interesting example of North Dakota's dependence on the Twin Cities and outside interests-in short, of its colonial status.

Soon Cooper was developing the first extensive system of county agents. He hired the first field worker in 1911, and the following year he had eighteen. Cooper employed the first woman agent to advise farmers' wives in 1913. At first, Twin Cities businessmen and North Dakota communities desiring the service shared the expense. The association spent \$43,111 in the fiscal year 1911-1912 and \$62,530 in 1912-1913.

In 1913 the North Dakota Legislature passed a county-agent law. The next year, the work of the association was merged with that of the Agricultural College's experiment station, and the college hired Cooper to direct county-agent operations. In 1913 more than 56,000 farmers attended 747 meetings; some of them organized 180 farmers' clubs. When the Nonpartisan League was organized, Cooper used the county agents as a conservative political machine against it. William Lemke wrote on October 31, 1917: “Cooper is a mighty fine gentleman.... He represents Big Business and not the people.... His County Agents are... in politics. He should be let out.”

The Better Farming Association, however, was unable to change North Dakota's emphasis upon wheat, the natural and most profitable product of its semiarid grassland. Although healthy diversification and a considerable increase in livestock were eventually realized, wheat remained, even in the 1960's, the state's principal crop and chief source 
of farm income. The gospel of diversification preached by the Better Farming movement in the years before the First World War was really the gospel of the dairy cow. It was a gospel for a humid, densely populated country rather than a semiarid, sparsely populated one. Its enthusiasts, men like Hill and Cooper, were from southern Minnesota, a region of relatively small farms close to a large market for dairy products.

Throughout American history wheat had always been a frontier crop, and when the frontier stage ended in an area, that area turned away from wheat. The Better Farming promoters had seen this happen in Wisconsin and Minnesota; they quite logically thought that the same evolution should take place in North Dakota. What North Dakota needed, however, was diversification through beef cattle, like wheat a natural product for grassland. Many things advocated by agricultural experts-summer fallow, better seed, crop rotation-were valuable, but when Better Farming enthusiasts talked of livestock, they meant dairy cattle, not beef herds.

In some places the new system succeeded; in many places it failed. Starting in the 1890's, creameries were established in the Red River Valley, but they often went out of business very quickly. With large farms (essential for wheat) and only a few cows to a farm (an average of about three and one-half), the creameries had to gather cream from a large area, an expensive operation, and they could pay only a poor price. If the farmer's wife made butter for sale, she received just eight cents a pound for it. Dairy products were perishable, and markets were far away. Often there was no profit in dairy cows; the farmers, although abused for their stubbornness by advocates of diversification, sensibly stuck to wheat as their main source of income. ${ }^{12}$

${ }^{12}$ John Lee Coulter, "Industrial History of the Valley of the Red River of the North,” North Dakota Historical Society Collections, III (1910), 650-654; Pyle, James J. Hill, II, 361-362; Edward C. Blackorby, "Prairie Rebel: The Public Career of William Lemke” (Ph.D. dissertation [later published], University of North Dakota, 1958), pp. 211-212. 
CHAPTER 13

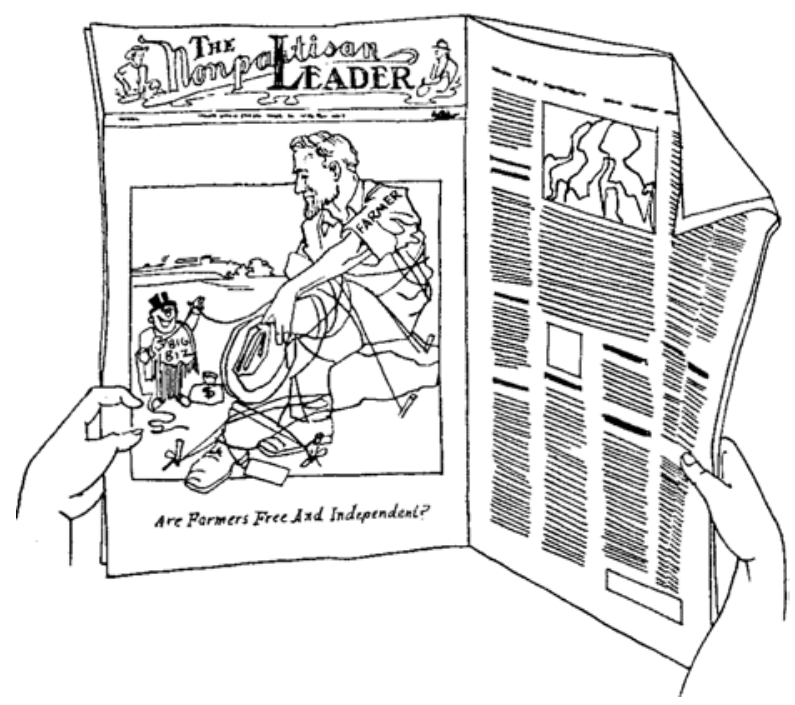

\section{The Progressive Movement}

IN THE FIFTEEN YEARS or so from the turn of the century to the outbreak of the First World War a great reform movement swept over the United States. The progressive reformers, many of their leaders from the urban upper middle class, sought to make democracy work more effectively. To that end they wished to take away the power of political bosses, to curb trusts and railroads, and to cure a multitude of social ills by means of legislation. The progressive movement changed the pattern of American life; it was felt not only on the national level but on the state and municipal levels as well. Progressivism became a vigorous force in North Dakota, just as it did in many other states.

North Dakota had long been struggling against boss-controlled government and the exploitative practices of the railroads, the money-lenders, and the grain trade. After 1900 the fight became both more intense and more successful. Reformers with education, urban professions, and well-to-do backgrounds tended to replace the farm leaders of reform of the 1880's and 1890's and to win strong public support. They were admirers of Robert $\mathrm{M}$ La Follette, the progressive leader in Wisconsin, and also of Theodore Roosevelt and William Jennings Bryan, leaders for reform on the national scene.

The reformers in North Dakota destroyed Alexander McKenzie's control of state government and the Republican party. They secured reform legislation which ensured progress for the state. Some leaders attacked the grain-marketing problem, established many cooperative rural elevators and finally a cooperative terminal marketing agency (the 
Equity Cooperative Exchange), and helped to secure the passage of a federal grain-grading law.

For a time, everyone in North Dakota was a progressive, or at least wore a progressive mask. Conservative Louis B. Hanna, state chairman of the Republican party and closely identified with McKenzie, proposed a constitutional amendment to authorize a state-owned terminal elevator. Conservative Porter J. McCumber put the grain-grading law through the United States Senate. The North Dakota Bankers Association investigated the evils of the grain trade. The Republican party, while still under McKenzie, adopted a platform advocating all of the progressive reforms.

The progressive leaders were frequently lawyers, merchants, editors, and professors. Many of them had conservative records, for they had earlier opposed Populism and had worked with McKenzie. Although they belonged to both the Republican and Democratic parties and cooperated with one another, they were cool to the idea of a third party. Their cooperation did not really impair North Dakota's staunch allegiance to the Republican party, though they elected Democrat John Burke governor three times and Woodrow Wilson carried the state in 1912. The progressives found their strongest support in the eastern portion of the state, the region settled by Norwegians; McKenzie's stronghold was the Missouri Slope and the area of heavy German Russian settlement.

\section{THE REFORMERS AND THEIR OPPONENTS}

North Dakota had a long record of interest in reform. The new country and the open view of the prairies seemed to encourage friendliness to change. There are many early examples: the success of the Farmers' Alliance, the deliberations of the constitutional convention, and the acceptance of prohibition. The dominance of wheat gave the people a common interest; the concentration of control of the terminal grain markets, the railroads, the wholesale dealers, and the banks in the Twin Cities focused the resentments of North Dakotans and thereby strengthened them. Thus in North Dakota even conservatives often adopted liberal, progressive views, and opponents of reform hesitated to act openly against it. From the Earl of Selkirk to Glenn J. Talbott, the region has always had some leaders with a progressive outlook.

So, too, has North Dakota always had conservatives. The railroad corporations were the major conservative force, and genial Alexander McKenzie built a political machine to influence the state government in the interest of the railroads and their natural allies, the grain dealers and bankers of Minneapolis and St. Paul. Many men worked with McKenzie: Judson A. LaMoure (state senator from 1889 to 1912), Henry C. Hansbrough and Porter J. McCumber (United States senators), C. B. Little (a Bismarck banker who was chairman of the judiciary committee in the state senate from 1889 to 1909), E. C. Patterson (proprietor of the 
McKenzie Hotel in Bismarck, now the Patterson), Marshall H. Jewell (editor of the Bismarck Tribune), Alanson W. Edwards (editor of the Fargo Argus and later the Fargo Forum), George H. Walsh (Grand Forks businessman), and many others.

Such men made up the McKenzie machine. Their power was not absolute and they, of course, were not McKenzie's automatons. Yet, led by "Big Alec," they worked together and exerted great influence. McKenzie himself stayed in the background; he never ran for public office, although for many years he was Republican national committee-man for North Dakota. He held much power because of his personal talents, the support of friendly newspapers, and his railroad connections. The railroads contributed campaign funds and free passes. McKenzie, long a land agent for the Northern Pacific, distributed both the railroads' gifts and federal patronage. By such means he could control Republican nominating conventions and legislative committee assignments. Just as in times past Indian chiefs, recipients of white traders' gifts, protected the traders from angry, exploited tribesmen, so did McKenzie, recipient of railroad gifts, protect the railroads as best he could from angry, exploited North Dakota farmers. In this role McKenzie was aided by the saloonkeepers (usually active in politics), the support of the Missouri Slope and the German and German Russian elements, and the general loyalty of North Dakotans to the Republican party. ${ }^{1}$

McKenzie's opponents, the reformers, hailed from the eastern part of the state; they were generally of Scandinavian or older American stock. Some, the earlier ones, were Farmers' Alliance leaders. Others, such as Charles Fremont Amidon and Robert M. and Charles A. Pollock, were Fargo lawyers. In Grand Forks, R. B. Griffith, a successful pioneer merchant, and George B. Winship, editor of the Herald, led the cause. Elizabeth Preston Anderson, a Methodist minister's wife who during the course of her husband's work lived in a series of towns, led the North Dakota Woman's Christian Temperance Union for more than thirty years.

The W.C.T.U. reform-prohibition of the sale of liquor-was one of the first. Saloons were everywhere, and saloonkeepers exerted an evil influence in politics. Farmers did not want their harvest hands to drink. Temperance advocates, mostly Methodists or Scandinavian Lutherans, formed societies and held conventions. They distributed a leaflet entitled The White Ribbon, used county newspapers to reach the public, and held sunrise prayer meetings on election day. The Grand Forks Herald,

${ }^{1}$ Charles N. Glaab, “John Burke and the North Dakota Progressive Movement, 1906-1912” (Unpublished M. A. thesis, University of North Dakota, 1952), p. 20; William W. Phillips, “The Life of Asle J. Gronna: A Self-Made Man of the Prairies" (Unpublished Ph.D. dissertation, University of Missouri, 1958), chap. 3; D. Jerome Tweton, "The Election of 1900 in North Dakota” (Unpublished M. A. thesis, University of North Dakota, 1957), p. 28. 
largest paper in the state in 1890, came to support prohibition; another Grand Forks newspaper, the Norwegian-language Normanden, was started as a temperance sheet. Alanson Edwards' Fargo Argus and Marshall H. Jewell's Bismarck Tribune fought the reform. In 1887 the territorial legislature passed a local-option law allowing any community to forbid the sale of liquor, and in 1889, North Dakota put prohibition in its state constitution.

Enforcement proved difficult. The saloons closed on July 1, 1890, with many liquor dealers moving to Minnesota. The first governor and his attorney general tried to enforce the law, but several state's attorneys did very little and, later, some state officials made no effort at all. In the western part of the state, Germans opposed prohibition, saying that they did not need to obey a law forced upon them by the Scandinavians of the Red River Valley. In many places, "blind pigs," operated by "piggers," sold illegal liquor; bootleggers would invade harvest fields with whiskey bottles in pockets or carts. The prohibitionists formed a state enforcement league and secured many convictions. In the legislature, however, the McKenzie machine used the threat of resubmitting the prohibition article to a vote of the people as a means of blocking railroad regulation. In 1893 resubmission passed the house and failed in the senate by only one vote. In South Dakota resubmission brought repeal in 1895, but North Dakota did not repeal prohibition until 1932.

The prohibitionists were interested in many reforms. They secured repeal of the ninety-day divorce law. In the 1890's Fargo had been a divorce mill, with many eastern society women, Broadway actresses, millionaires, merchant princes, and even British aristocrats living high in Fargo's fine hostelries while establishing the necessary residence. The wife of James J. Corbett, world heavyweight champion prize fighter, was among them. Thousands of divorces were granted. One judge heard 350 cases in a single year.

The Woman's Christian Temperance Union asked for laws restricting the sale of obscene literature, providing for separation of first offenders from recidivists in prisons, limiting child labor, and giving women the right to vote. In 1883, Dakota Territory had granted women the right to vote in school elections. In 1892 the Independent party put woman suffrage in its platform, and the men elected Mrs. Laura J. Eisenhuth, the first woman to hold state office, superintendent of public instruction.

But full suffrage for women met stubborn resistance. In 1914 the voters defeated a woman-suffrage law $(49,348$ to 40,209), and the following year, the legislature killed a state woman-suffrage amendment which had passed the previous legislature. Opposed to woman suffrage were the foreign-born (especially Germans), the liquor interests, the McKenzie machine, and the railroads. Success came after the Nonpartisan League put woman suffrage in its platform. In 1917 the legislature gave women the right to vote in local and presidential 
elections, and in 1919 the legislature ratified the federal woman suffrage amendment. On November 2, 1920, the women of North Dakota had the full right to vote for the first time. ${ }^{2}$

\section{CHARLES F. AMIDON: FIGHTING JUDGE}

The progress of reform owed much to vigorous leaders. Three men were especially outstanding: Charles Fremont Amidon, the federal district judge; Edwin Fremont Ladd, a professor of chemistry at the Agricultural College; and George B. Winship, the editor of the Grand Forks Herald. Highly respected, they influenced the course of public affairs in North Dakota for many years. Winship and Ladd were born in Maine, Amidon in upstate New York. Ladd and Amidon had anti-slavery backgrounds; their parents had named them after the Republican candidate for President in 1856, John C. Frémont, suggesting a family upbringing marked by moral earnestness.

Amidon's father, a Methodist circuit rider, aided fugitive slaves. Young Amidon inherited his father's humanitarian zeal and his mother's eager mind and love of books. After graduating from Hamilton College at Clinton, New York, with Phi Beta Kappa honors, he came out to Fargo in 1882 to organize a high school. He soon began to read law, won admission to the bar in 1886, and became a leading attorney. From 1882 to 1887, Amidon and the Reverend R. A. Beard of the First Congregational Church took political control of Fargo from the hands of a gang led by Alanson Edwards, editor of the Argus and a McKenzie man. When President Grover Cleveland appointed Amidon as federal district judge, Senator Henry C. Hansbrough and the McKenzie machine tried to block Senate ratification of the appointment.

Amidon was a tall, slender man with prematurely white hair. He loved justice, felt a deep sympathy for the exploited farmers of North Dakota, and believed that "the court's decisions must be tested by the way they work in actual application to the national life." He became one of the leading progressive judges of his generation, and formed friendships with great progressives-Louis D. Brandeis, Zechariah J. Chafee, Jr., Robert M. La Follette, and Theodore Roosevelt. In 1906, Roosevelt urged one of Amidon's suggestions for judicial reform upon the Congress. In 1911 he wrote to Amidon: "How I wish you were on the Supreme Court!” Amidon's wife, a widely read and active person, worked for woman suffrage and helped to raise money for the statue of Sakakawea on the capitol grounds at Bismarck. The Amidons entertained

${ }^{2}$ Ruth Stenerson, "Opponents of the Foaming Cup in North Dakota" (Seminar paper, Department of History, University of North Dakota, 1956), pp. 9-28; Jeanne F. Tucker, “The History of the Woman's Suffrage Movement in North Dakota" (Seminar paper, Department of History, University of North Dakota, 1951); Fargo Forum, Diamond Jubilee Edition, June 4, 1950, sec. 6, pp. 6-7. 
distinguished visitors (Gifford Pinchot and Florence Kelley) in their Fargo home. $^{3}$

\section{EDWIN F. LADD: FIGHTING PROFESSOR}

The same courage, energy, and love of fair play which marked Amidon also characterized Professor Edwin Fremont Ladd, another great North Dakotan. Ladd was born on a Maine farm in 1859. After graduating from the University of Maine, he worked as a chemist at the New York Agricultural Experiment Station in Geneva. Then in 1890, when North Dakota Agricultural College opened its doors, he came out to teach chemistry and take charge of the chemical work at the new experiment station. At thirty-one the blond, short, stocky Ladd still had a boyish appearance in spite of his full beard. He was an extremely serious, intense young man, quick to anger, and had a keen sense of justice and an all-consuming passion for work. Although he had only a bachelor's degree, he made up in vitality and ambition for what he lacked in training.

Ladd and the staff of the experiment station, men like Henry L. Bolley and Clare B. Waldron, were very capable; they plunged into experiments designed to advance the state's agriculture. Ladd was soon studying the suitability of sugar beets as a North Dakota crop, the flourmaking qualities of the lower grades of wheat, and the value of screenings as stock feed. The station was a lively place: by 1899 none in the nation exceeded it in number of experiments, and that July, some fifteen hundred farmers came to visit.

Before long, Ladd was an investigator of and a crusader against adulteration in foods, paints, and fertilizer. In the experiment station's Bulletin 53, published in 1902, he issued a wholesale indictment of the food being sold in North Dakota. In his laboratory, Ladd found evidence of shocking adulteration: canned foods preserved and flavored with chemicals, colored with harmful aniline dyes, sweetened with saccharin, mixed with water, and short in measure; coffee mixed with roasted peas; beef embalmed with poisonous preservatives; alum added to flour; paint diluted with water and chalk; formaldehyde too weak to kill the parasites on grain; fertilizer with little plant food.

Such investigations were common in agricultural experiment stations, but Ladd, with his zeal, his courage, and his flair (almost mania) for publicity, became a hero in North Dakota for his work. To capture public opinion, in 1899 he had begun to edit and publish (with "Uncle

${ }^{3}$ Elwyn B. Robinson, “Charles Fremont Amidon,” Dictionary of American Biography (New York: Charles Scribner's Sons, 1928-1958), XXII; Amidon Papers, Chester Fritz Library, University of North Dakota; Grand Forks Herald, February 10, 13, 16, 1897; Fargo Forum, February 10, 17, 1897; Zechariah J. Chafee, Jr., Freedom of Speech (New York: Harcourt, Brace and Howe, 1920), pp. 42, 50, 69, 70, 77. 
Will” Crocker of Lisbon) the North Dakota Farmer and Sanitary Home in order to publicize his findings and to preach sanitation. Soon the legislature was ready to do his bidding. State Senator Louis B. Hanna and others helped to frame Ladd's laws and introduce them. There was no opposition. The people were naturally hostile toward the interests responsible for the frauds; Judge Amidon was read y to render favorable verdicts; there were no commercial interests in the state to fight the reforms.

Ladd secured many important changes. The laws stopped the use of aniline dyes in candy (1897); improved the regulation of dairy products (1899); prohibited adulteration and misbranding of foods and drinks (1901); strengthened that prohibition and provided for a food commissioner (1903); regulated fertilizers, illuminating oils, and gasoline (1903); stopped fraud in paints, formaldehyde, and drugs (1903); set standards for pure liquor, pure seed, and sanitation in food processing establishments (1909); and forbade short weights (1911). In 1903 the basic law, one of the best of its time, made it the duty of the experiment station to analyze foods and beverages suspected of being adulterated and to furnish, twice a year, each county auditor with a list of adulterated foods for publication in the official newspapers. The information published included the adulterant, the brand name, and the manufacturer; the lists attracted much attention. Ladd himself became pure-food commissioner, pure-paint commissioner, oil inspector, hotel inspector, and grain inspector.

Because of Ladd's work, the North Dakota Agricultural Experiment Station probably exerted a more profound influence than did any other such station in the United States. The North Dakota laws were not notably different from those passed in some other states, but Ladd's enforcement of them was more vigorous and successful. He made North Dakota a leader in pure food. When some outside food processors sued him for $\$ 100,000$ for libel in the fall of 1904 , the whole state rallied to his support. The fighting professor (Ladd stood his ground) became known and loved throughout North Dakota as the farmers' champion. Indeed, he gained an international reputation and was showered with honors. In 1916 he became president of the Agricultural College and in 1920 a United States senator. In the Senate he allied himself with Robert $\mathrm{M}$. La Follette and George Norris and opposed legislation favoring what he called "the two percent of the people with their 65 percent of the wealth of the country." The Republican leaders dropped him from the steering committee for his independence. ${ }^{4}$

\section{GEORGE B. WINSHIP: FIGHTING EDITOR}

${ }^{4}$ Ralph J. Kane, “Edwin Fremont Ladd, North Dakota’s Pure-Food Crusader” (Unpublished M.A. thesis, University of North Dakota, 1960), pp. 
A third notable progressive was George B. Winship, editor of the Grand Forks Herald. Amidon, Ladd, and Winship-a humanitarian judge, a crusading professor, and a fighting editor comprised an effective reform triumvirate long before the rise of the Nonpartisan League. Winship was born in Maine in 1847, moved to Wisconsin as a child, and left school at thirteen to work in a printer's shop. For some years he knocked about the Red River frontier-campaigning against the Sioux with the Minnesota cavalry, flatboating on the river, running a stage station near Manvel, and working on newspapers in Winnipeg and the Twin Cities. Then in 1879 he founded the weekly Grand Forks Herald in a tar-paper shack with a hand press and a few fonts of type.

Winship succeeded. In 1881 he made the paper a daily and was printing five hundred copies. In 1890 he moved the Herald into a $\$ 45,000$ stone building, had \$35,000 worth of equipment, and absorbed the old Grand Forks Plaindealer (established in 1875 by George Walsh). Winship then had the largest and best newspaper in North Dakota.

Probably Winship was the chief opponent of the McKenzie machine. He called Alanson Edwards, editor of the pro-McKenzie Fargo Argus, a "blabbering blatherskite and unprincipled hoodlum." He abused Mayor Ed Patterson of Bismarck, McKenzie's ally, when Patterson's gang destroyed the press of a hostile newspaper and drove the editor out of town. He attacked railroad abuses and sneered at James J. Hill: “A certain railroad president and his bulls... are an impertinence.” He stood against the spoils system, the grain trust, gambling, and drinking. He opposed all the machinations of McKenzie: the removal of the territorial capital from Yankton, the parceling out of state institutions in the constitution, the appointment of William Budge and Alexander Griggs (close friends of Hill) as territorial railroad commissioners, and the chartering of the Louisiana lottery. When Winship, a senator in the first legislative assembly, reported that he was offered money to vote for the lottery, the McKenzie machine ended his legislative career by gerrymandering his district. In 1898 and again in 1900, McKenzie, controlling the state convention, frustrated Winship's ambition to be governor.

Yet Winship was loyal to the Republican party. When the Farmers' Alliance formed the Independent party in 1890, he refused to support it. He also opposed free silver. But after 1900, like many another reform leader of the time, he became more progressive. He began to praise La Follette in the Herald and to speak out for direct primaries, the popular election of United States senators, the initiative and referendum, the conservation of resources, and the regulation of monopolies.

The McKenzie machine, however, eventually drove Winship out of the newspaper business. During the bitter campaign of 1906, in which Winship supported Democrat John Burke for governor, Senator Henry C. Hansbrough established the Grand Forks Evening Times. That paper cut down the advertising revenue of the Herald and impaired its profits. On August 15, 1911, Jerry Bacon and a group of businessmen bought 
both the Herald and the Evening Times, and the fighting editor moved to California. Although Winship, then sixty-four, retained a one-third interest in the consolidated enterprise, the crusading days of the Herald were over. ${ }^{5}$ Yet Winship had advanced the progressive cause and prepared the way for the overthrow of McKenzie.

\section{THE REVOLUTION OF 1906}

Progressive sentiment gradually brought about the decline of McKenzie's influence. McKenzie had been entirely successful in 1900, when his lieutenants from the Missouri Slope persuaded the Republican convention to bypass Winship. That fall, the Republican slate, headed by William McKinley for President, Frank White for governor, and Thomas F. Marshall for congressman, won easily. In the campaign the Democrats called themselves "the party of the laborer and the farmer" and said that "McKinleyism is another name for imperialism." Yet William Jennings Bryan secured only 35 percent of the votes, a smaller percentage than he had accrued four years earlier. He did not even do so well as the Democratic candidate for governor, Max Wipperman. Wipperman, though nominated to catch the German vote, carried only one German county. ${ }^{6}$

McKenzie's success continued in the next two elections. In 1902, White and Marshall were re-elected (White was the first governor to have two terms), and Burleigh Spalding became the state's second member of the House of Representatives, an expansion which followed the census of 1900. In 1904, Theodore Roosevelt carried North Dakota for President with 52,595 votes to only 14,273 for Alton B. Parker. That year, McKenzie dropped Spalding for Asle J. Gronna, who had good organizing ability and the support of the Scandinavian Republican League, and elected Elmore Y. Sarles as governor. But the progressives forced a plank for a direct primary into the Republican platform. A primary election would destroy McKenzie's control of nominations and hence the whole structure of his power.

The year 1906 brought the revolution. Late in 1905, McKenzie's opponents had organized the Good Government League, with George B. Winship as president. His editorials calling for an end to McKenzieism were reprinted by papers throughout the state. The progressive Winship shared the insurgent leadership with conservatives Burleigh F. Spalding and Martin N. Johnson, whose ambitions for high office McKenzie had frustrated.

The insurgents were aided by the publication, early in 1906, of Rex Beach's articles on “The Looting of Alaska” in Appleton's Book-lovers

${ }^{5}$ Edward C. Blackorby, “George B. Winship, Journalist of the fiddle Border” (Seminar paper, Department of History, University of North Dakota, 1956), pp. 3-29.

${ }^{6}$ Tweton, “The Election of 1900 in North Dakota,” pp. 23-89. 
Magazine. He also wrote a fictionalized account, The Spoilers. Beach told how, in 1900, McKenzie had secured control of disputed mining claims through Judge Arthur H. Noyes of the Alaskan Second Judicial District. McKenzie boldly worked the claims, taking the gold for himself in defiance of an injunction issued by the federal circuit court of appeals in California. Finally that court sentenced McKenzie to a year in jail and removed Noyes, who had formerly lived in Grand Forks and whose appointment to the Alaskan position McKenzie had secured. At the time, the people of North Dakota were shocked, but when President McKinley pardoned McKenzie soon after he went to jail, his influence in North Dakota did not seem much damaged. James J. Hill and Mark Hanna had asked for McKenzie's pardon.

In 1906, as many newspapers reprinted Beach’s articles, McKenzie fell more and more into disrepute. Yet the Republican convention, ignoring the Republican insurgents of the Good Government League, nominated Sarles for a second term as governor and John Knauf for the North Dakota Supreme Court. Knauf, the boss of Stutsman County because he could deliver the German Russian vote for the machine, was obviously unqualified. The insurgents wanted Charles J. Fisk of Grand Forks, a respected district judge and a Democrat. To attract disgruntled Republicans, the Democratic convention nominated John Burke for governor and Fisk for the court. The Democratic platform called for progressive reforms and concluded: "The political affairs of the state of North Dakota are controlled by the railroads."

John Burke, a son of Irish immigrants, had come to North Dakota in 1888 as a struggling young lawyer of twenty-nine. He had served in the legislature, and after some years at St. John and Rolla, he built up a large law practice at Devils Lake. By 1906 he had an income of perhaps fifteen thousand dollars a year and was widely respected. Thin and angular, he stood over six feet; his rough-hewn features, large ears, and homely gaunt appearance seemed to reveal his integrity. He was fond of reading, especially the poetry of Robert Burns, and he felt a deep sympathy for people. A modest man, he disliked his nickname, "Honest John," with its recollection of "Honest Abe" Lincoln.

Burke campaigned hard, speaking seven or eight times a day. $\mathrm{He}$ attacked McKenzieism, the railroads, and the St. Paul bosses of the state. Winship's Herald and other progressive papers supported Burke, as did the prohibitionists. Elizabeth Preston Anderson denounced Governor Sarles for serving liquor in the executive mansion; some Protestant church groups endorsed Burke, a Roman Catholic. On election day, ten thousand or more Republicans voted for Burke and Fisk. They were elected, but the rest of the Democratic ticket lost. Burke's majority came from the eastern part of the state; the wealthy, urban Sarles, the machine candidate, did better in the west. 
When the legislature met in January, McKenzie and a prominent Democrat had a fist fight in the lobby of the Grand Pacific Hotel. The progressive Republicans and Democrats organized the house, but the McKenzie stalwarts still controlled the senate. Many anti-railroad bills were introduced, and lobbyists were busy against them. Usher L. Burdick, a member of the house, has recalled that railroad lobbyists photographed a progressive legislator with a nude woman and then forced him to vote against the railroad bills or risk exposure. But some of these bills, aa well as other progressive legislation, went through: a direct-primary law with a senatorial-preference provision, a joint resolution for a constitutional amendment for the initiative and referendum, a public library commission law, and laws to enforce prohibition.

The election of 1908 was another progressive victory. McKenzie believed that primary elections (the first in North Dakota was held in 1908) would mean his downfall. Recognizing the strong feeling against him, he voluntarily retired as Republican national committeeman but was able to choose his own successor. The primary disappointed the progressives, however; many McKenzie man won nominations, including Charles A. Johnson for governor. After the primary, the Republican state committee, still in the hands of the machine, drew up an extremely progressive platform: retention of the primary, direct election pf United States senators, and an antipass law.

In the fall, Burke beat Charles Johnson with Republican votes, but the other Republican candidates won. Martin N. Johnson, a conservative now backed by McKenzie, was elected to the Senate over Thomas F. Marshall, now a progressive though formerly a McKenzie man. Louis B. Hanna, a McKenzie man, and Asle J. Gronna, now anti-McKenzie, won seats in the House of Representatives. Hanna was a successful merchant and banker of Fargo who had served in the state legislature and as a chairman of the Republican state committee from 1902 to 1908.

The 1909 legislature, with the conservatives controlling the senate, largely ignored the progressive platforms of both parties. Yet it did pass laws for pure seeds, a game and fish board, a tuberculosis sanitarium, a serum institute for animal vaccines, limitations on child labor, and cooperatives with the one-member-one-vote plan and distribution of patronage dividends. Such legislation, however, received little attention; Democratic and progressive papers called the session a failure.

The progressive triumph finally came in 1910. During the campaign, Burke, nominated by the Democrats for a third term, said at Minot: "This is McKenzie's last stand.” The Grand Forks Herald called it "a contest between the people... and predatory interests." The stalwarts, directed by McKenzie himself at Bismarck and aided by large contributions from out-of-state interests, made an all-out effort to defeat Burke. Willing to bend before the progressive wind, they still held the party machinery and again cynically adopted a more progressive platform than the Democrats. 
They again won some of the Republican nominations in the primary and hence some of the state offices and congressional seats. They re-elected Porter J. McCumber to the Senate and Louis B. Hanna to the House.

But Burke again beat the McKenzie candidate for governor, with the aid of Republican votes, and the progressives and Democrats won control of the legislature. The progressive Republicans elected progressive Asle J. Gronna to the Senate (to fill the unexpired term of Martin N. Johnson, who died in October, 1909) and progressive Henry T. Helgesen to the House. The 1911 legislature put North Dakota in the front rank of progressive states when it passed a whole catalog of reforms without opposition. Laws and constitutional amendments (some passed a second time, as was then required, before being submitted to the people) dealt with corrupt practices in elections, lobbying, a presidential primary, railroad passes, juvenile courts, and workmen's compensation. ${ }^{7}$

\section{THE WILSON CAMPAIGN}

North Dakota again showed its progressive sympathies in 1912. In its presidential-preference primary on March 19, the first ever held in the United States, it favored Robert M. La Follette, giving him 34,123 votes to 23,669 for Theodore Roosevelt and only 1,876 for President William Howard Taft. The McKenzie stalwarts realized that Taft had little appeal. Led by Louis B. Hanna, they supported Roosevelt, but La Follette seemed the better progressive to the majority of North Dakotans. The Minot Daily Reporter said that Roosevelt "had the wrong bunch behind him."

The nominations were decided by the national conventions. Late in June at the Democratic convention, John Burke swung North Dakota's votes, pledged to him as a favorite son, to Woodrow Wilson on the first ballot. After Wilson's nomination, William Jennings Bryan, a good friend of Burke and the leading supporter of Wilson, wanted Burke for Vice-President. Burke, however, was passed over because of a promise made to Indiana for the votes of its delegates.

When the Republican convention nominated Taft, an angry Theodore Roosevelt formed the Progressive party. North Dakota progressives were reluctant to join in this third-party movement, but upon Roosevelt's urging, a Progressive party was organized in the state in September. In the June primary, progressives had captured all Republican nominations except that for governor, which was won by the stalwart Louis B. Hanna. Hanna had led the fight for Roosevelt in the March primary. How could the North Dakota supporters of Roosevelt

${ }^{7}$ William W. Phillips, "The Growth of a Progressive: Asle J. Gronna" (Unpublished M.A. thesis, University of North Dakota, 1952), pp. 36-37; Glaab, “John Burke,” pp. 50-154; David B. Baglien, “The McKenzie Era: A Political History of North Dakota from 1880 to 1920" (Unpublished M.S. thesis, North Dakota Agricultural College, 1955), pp. 96-102, 127-129. 
now ignore him?

The Progressive party of North Dakota did ignore Hanna. After Usher L. Burdick refused its nomination for governor, it nominated Dr. C. C. Creegan, president of Fargo College. When he was found ineligible because he had lived in the state only three and a half years, it chose Mayor W. D. Sweet of Fargo. It also endorsed the previous nominations of the progressives on the Republican ticket. These nominees, however, refused to have their names placed in the Progressive column on the ballot and announced that they would support the men nominated in the Republican primary, including Hanna for governor.

During the campaign, Roosevelt had little support from progressive leaders in North Dakota. Both Hanna and the progressive Gronna supported Taft for President rather than Roosevelt. Few newspapers supported the Progressive party. The Fargo Forum reported that 226 newspapers were for Hanna for governor, 33 for the Progressive party, 19 Democratic, and 62 noncommittal. Burke, of course, campaigned for Wilson, attacking Roosevelt and inviting Republicans to come over to the Democratic party. La Follette, always a hero in North Dakota, also opposed Roosevelt, and Bryan came to the state to speak against him as a come-lately progressive. Many North Dakota progressives distrusted Roosevelt's backer, George W. Perkins of the J. P. Morgan group and International Harvester.

Because of such opposition, Wilson was able to carry North Dakota in November. He had 29,555 votes to 25,726 for Roosevelt, 23,090 for Taft, and 6,966 for Socialist Eugene V. Debs. Hanna won the governorship with 39,811 votes to 31,544 for Frank O. Hellstrom the Democrat (warden of the state penitentiary) and 9,406 for Sweet the Progressive. Wilson had carried the state with fewer votes than were received by the defeated Democratic candidate for governor. After considering Burke for a cabinet post, Wilson appointed him Treasurer of the United States, a lesser position. Burke's Catholicism apparently barred him from the cabinet after Wilson was severely criticized for making Catholic Joseph Tumulty his private secretary. ${ }^{8}$

\section{PROGRESSIVES AND CONSERVATIVES IN CONGRESS}

After the census of 1910, North Dakota was allotted three members in the United States House of Representatives. In 1912 the state elected three progressives to the House. Porter J. McCumber in the Senate and Louis B. Hanna as governor were the only conservatives in important positions. Hanna, who came to northern Dakota in 1881 as a young man of twenty, was born in western Pennsylvania and educated in the common schools. At Page in northwestern Cass County he built up a

${ }^{8}$ Richard M. Norman, "The Election of 1912 and the Progressive Party in North Dakota” (Unpublished M.A. thesis, University of North Dakota, 1950), pp. 31-47, 123-161. 
lumber and mercantile business, prospered, and entered politics. He served three terms in the legislature (two in the senate), worked with McKenzie while chairman of the Republican state central committee from 1902 to 1908, and then went to the national House of Representatives for two terms. In 1899 he moved to Fargo to become vice-president of the First National Bank. Later he built a large brick house in the English Tudor style; with its spacious grounds, it was a show place of the city.

In 1912 and again in 1914, Hanna won the Republican nomination for governor over a progressive opponent through the support of William Lemke and his friends of the Varsity Bachelor Club of the University of North Dakota, the first fraternity on the campus. Although Lemke and his friends were progressives, Hanna had lent money to help build the club's elaborate house (soon to be the Phi Delta Theta fraternity), which Lemke was promoting. In 1914, Usher L. Burdick, a true progressive, opposed Hanna in the primary but lost by less than four thousand votes. So Lemke's support of Hanna may have paved the way for the defeat of the state elevator in 1915 and hence the rise of the Nonpartisan League. Governor Hanna's opposition to the state elevator was significant; his loan to the fraternity apparently changed the course of the state's history. Governor Hanna, who had a clean record, did not end progressivism in North Dakota; the 1913 legislature passed a number of reforms.

Through the progressive years, North Dakota elected both progressive and conservative Republicans to Congress, but not a single Democrat. Oddly enough, some of the progressives were elected as McKenzie men, and some of the conservatives supported progressive measures. To the House the state sent Burleigh F. Spalding (1899-1901, 1903-1905), Thomas F. Marshall (1901-1909), Asle J. Gronna (19051911), Louis B. Hanna (1909-1913), Henry T. Helgesen (1911-1917), Patrick D. Norton (1913-1919), and George M. Young (1913-1924). To the Senate it sent Henry C. Hansbrough (1891-1909), Porter J. McCumber (1899-1923), Martin N. Johnson (1909), and Asle J. Gronna (1911-1921). In the House, Spalding and Hanna were conservatives; Marshall, Gronna, Helgesen, Norton, and Young were progressives. In the Senate, Hansbrough, McCumber, and Johnson were conservatives; Gronna, of course, continued his progressive record. Yet Hansbrough (a silver-mine owner) stood for free silver and introduced a pure-food bill; McCumber was the principal sponsor of the pure-food legislation of 1906 and of the federal grain-grading law of 1916.

The most important men, both for their abilities and their long years in the Congress, were McCumber and Gronna. McCumber was born in Illinois of Scottish parents in 1853. His family soon moved to Rochester, Minnesota; today the Mayo clinic rests on the site of the McCumber farm. Not content to be a farmer, the proud, strong-willed youth studied law at the University of Michigan and began to practice in Lisbon, North Dakota. In 1882 he moved to Wahpeton, combined politics with law, and 
went to the territorial legislature in 1884. There he supported McKenzie's efforts to keep the capital at Bismarck. In 1899, McKenzie helped him win election to the Senate. Then forty-one, McCumber was a good lawyer and an effective speaker, and soon became an outstanding, articulate member of the Senate.

Gronna was born in Iowa on December 10, 1858. His parents, recent Norwegian immigrants, soon moved to a farm at Spring Grove, Minnesota. There they reared their family on religious faith and hard work. Asle, like many a farm boy, was doing a man's work at twelve. But he attended the academy at nearby Caledonia for four years, taught school for two, and came to Fargo in 1880. That summer, he carried grain sacks onto Red River barges and in the fall taught school at Buxton. He soon turned merchant, moved to Lakota, and built up a large enterprise. He had a keen business sense and an engaging personality; he made his store clean, attractive, and up to date. Gronna-quickly grew rich. In the early 1890's he began to acquire land in the settlement of debts. When he lost heavily through bank failures in 1895-1896, he put more of his savings into land. By 1902 he held over ten thousand acres and by 1920 some twenty thousand. He became the publisher of the Lakota American, established banks and lumber yards, and built himself a large house. Gronna was friendly to the Farmers' Alliance, took an active part in church affairs, and served on the board of trustees of the University of North Dakota. He raised $\$ 2,500$ from private sources to found a Scandinavian library at the university. He was also ambitious for public office and worked diligently with and for the McKenzie crowd in the Republican party organization.

When McKenzie wanted to punish Burleigh Spalding a second time, he sent Gronna to the House in 1904. Gronna was the first North Dakota congressman to become a national figure. In Washington he was the close friend of his neighbor George Norris, the famous progressive from Nebraska, and of Robert M. La Follette of Wisconsin. From the beginning he stood with the progressives or Republican insurgents against the Republican Old Guard under Nelson Aldrich. With his boundless energy, Gronna was active in debate and in introducing bills. He voted for all of President Theodore Roosevelt's reforms, including railroad regulation. When the Hepburn railroad bill was under debate in 1906, he mailed McKenzie his free pass on the Great Northern with a sarcastic letter. To gain Gronna's favor, that railroad named a station in Rolette County after him.

Although Gronna cooperated with McKenzie until 1908, he never attacked reform proposals. He always favored direct primaries, the popular election of United States senators, income and inheritance taxes, the regulation of corporations, the initiative, referendum, and recall, the conservation of natural resources, a government guarantee of bank deposits, and, of course, federal inspection and grading of grain. Yet Gronna took no part in the revolt against McKenzie. In 1906 he traveled 
with Elmore Y. Sarles in the last week of campaigning; that is, he worked for John Burke's opponent in the revolution of 1906. In that year and in 1908 he worked for a straight Republican vote and never supported John Burke, although he broke with McKenzie in 1908. In the fall of 1912 he stood by Taft, an unpopular figure in the state, against Roosevelt. ${ }^{9}$

In many ways Gronna was typical of the North Dakotan of his day. He seized the opportunities offered by his state and rose rapidly in the world; he fairly breathed energy, ambition, and drive; he stood loyally by the Republican party and worked willingly with McKenzie. Yet in his independent, courageous way, he fought for a better society with forward-looking zeal.

\section{THE MARKET FOR WHEAT}

Although North Dakotans supported progressive measures, they worried more about the market for wheat. They, of course, had to sell their wheat in outside markets, where they could control neither its grading nor its price. They well realized that their lower income, their position of economic disadvantage, sprang from that situation. They were dependent and exploited, just as the Indians before them had been dependent and exploited. Moreover, their concentration of wheat-the one dominant and universal crop-united North Dakota farmers and intensified their sense of grievance by giving them a common interest and a common foe.

The wheat farmer, hauling his crop to town, might sell it to a line elevator, to an independent elevator, to a cooperative elevator, or to a track buyer who had no storage space. The line elevator would be one of a line of rural elevators owned by a Minneapolis grain firm or flour mill. Most of the rural or local elevators in North Dakota belonged to Minneapolis grain firms. F. H. Peavey, for example, owned 104 elevators in North Dakota. The line elevators and the independents received a daily price card from Minneapolis. To avoid competition, the elevators frequently entered agreements to stay with the card. To keep such agreements firm, the elevator companies held weekly meetings at Minneapolis. In 1905 it was estimated that some 1,400 elevators in the Northwest were in a pooling agreement.

The rural, or country, elevators-line, independent, and cooperativeshipped their wheat to Minneapolis or Duluth, the terminal markets. In Minneapolis some of the grain went directly to the mills, but the larger part was sold by commission merchants in the Minneapolis Chamber of Commerce or the Duluth Board of Trade. The operations of these terminal markets were regulated by the laws of Minnesota; they were beyond the reach of the North Dakota Legislature. This irritating fact was the chief stumbling block to the thousands of North Dakotans who believed that they were being robbed in the terminal markets. 
More than their fellows in other states, North Dakota farmers-an independent, courageous lot-cried out against the crooked practices which reduced their income. Because virtually all of them received the principal part of their income from the same crop and were the victims of the same set of exploiters, they were moved by the same emotions and spoke with one voice. Wheat united the state. Again and again the wheat farmers of North Dakota read the reports of investigations which confirmed their ugly suspicions. Investigations by the legislatures of North Dakota and Minnesota, by the North Dakota Bankers Association, by the Interstate Commerce Commission, by the United States Industrial Commission of 1898-1901, and by the Federal Trade Commission-all told essentially the same story of unfair trading, short weights, and excessive dockage.

In the fall, when the farmers were selling, the inspectors graded rigidly; later, when the grain dealers were selling, the inspectors graded easily. So wheat went into the terminals at low grades, came out at high. The grain buyers knocked off an increasing amount for dockage. The injury was twofold, for such screenings had a cash value of eight dollars a ton, for which the grower received nothing. The suction draft used to remove dust at the terminal elevator also removed grain, so the farmers were cheated in weighing. In ten years the elevators at the head of Lake Superior shipped out 26,868,000 bushels more than they had received. The terminal elevators regularly mixed lower grades with higher; consequently they sold more No. 1 hard than they bought. In 1906, Senator Porter J. McCumber charged that such irregularities were costing wheat farmers from three to five million dollars annually. ${ }^{10}$

\section{REFORMS FOR THE GRAIN TRADE}

Aroused by such reports, thousands of North Dakotans were figuring their losses and demanding reforms; the need for them was never an issue in the state. In their dissatisfaction with Minnesota grades, they repeatedly asked for federal inspection and grading, the basic demand. For a time, Superior, Wisconsin, sought the cooperation of North Dakota in an effort to take part of the grain trade away from Duluth, Minnesota. State Senator George B. Hudnall of Superior persuaded the Wisconsin Legislature in 1905 to establish a grain-inspection commission on which North Dakota growers and Buffalo millers would both be represented. The commission would eliminate abuses in the grain trade. But the Wisconsin law failed. A conspiracy between the railroads (the Great Northern owned elevators in Superior) and the Duluth Board of Trade and then a federal court injunction defeated its purpose.

J. L. Cashel, a North Dakota state senator and prominent banker, had

${ }^{10}$ Robert H. Bahmer, "The Economic and Political Background of the Nonpartisan League” (Unpublished Ph.D. dissertation, University of Minnesota, 1941), pp. 162-260. 
appealed in vain to Louis W. Hill, president of the Great Northern, to stop his efforts to break down Wisconsin inspection. Then Cashel arranged for Hudnall to speak to the North Dakota Bankers Association. After Hudnall had denounced the grain trade, Cashel introduced a resolution for its investigation. The bankers' committee visited Minneapolis, Duluth, and Superior. It, too, appealed to Hill to allow the Great Northern's elevator to come under Wisconsin inspection, and its report listed once more the abuses of the grain trade.

In 1905 and again in 1907 the North Dakota Legislature asked the Minnesota Legislature to reform the trade. It got only an acrid refusal. Banker Cashel thought that North Dakota farmers should own the country and terminal elevators and work for a federal grading law. In 1907, Louis B. Hanna, former president of the North Dakota Bankers Association, did ask that the legislature inquire into the feasibility of a state-owned terminal elevator. When the board of inquiry, reporting in 1909, recommended such an elevator, the legislature proposed a constitutional amendment authorizing one in Minnesota or Wisconsin. In 1911 the legislature approved the amendment a second time, as the constitution-amending process then required. The voters accepted it in 1912. Another amendment for a state-owned elevator within North Dakota went through the legislature in 1911 and 1913 and was accepted by the voters in 1914 .

Discrimination against durum fed the sense of grievance. By 1907 over a third of the state's wheat crop was durum, a higher-yielding type of wheat more resistant to drought and disease. But the millers, having trouble with the flinty grains, would not pay as much for it as for hard red spring wheat. The market for macaroni and other semolina products (the best outlet for durum) was slow to develop, and sometimes durum brought twenty cents a bushel less than No. 1 hard.

The idea of price and grade based upon actual milling value was beginning to take hold. In 1907, George M. Young talked the legislature into appropriating money for an experimental flour mill at the Agricultural College. That year, Professor Edwin F. Ladd began to test the milling value of wheats. His results showed that the price discriminations against both durum and Velvet Chaff, a new variety, were unjustified. By 1914 durum was bringing a premium. ${ }^{11}$

\section{COOPERATIVE ELEVATORS}

Scientific tests of milling value were an important goal, but the farmers themselves also needed to own the elevators. At first they had lacked the capital for even country elevators. Outside capitalists built the elevators and advanced money to buy the crop. In 1892 there were only 11 farmers' elevators in North Dakota and in 1900 only 4. Then the number began to climb, to 40 in 1904 and to 264, with 19,500 members,

${ }^{11}$ Ibid., pp. 221-273. 
in 1915. That year, the state led the nation in grain-selling cooperatives; more than one-fourth of the state's farmers belonged to elevator associations. Although farmers were by nature individualists, those in North Dakota, united by their common interest in wheat, were drawing together to a remarkable degree for common action. The cooperatives had to fight for their lives. They faced price wars by line elevators, pressure against the commission men who sold their grain, railroad discrimination, and sometimes even the hostility of local bankers and businessmen. But they were aided by the Rockwell plan (worked out at Rockwell, Iowa), by which the members pledged themselves to pay a half-cent penalty on each bushel of grain they sold to competitors of their cooperative. The plan assured the cooperative an income even when competitive prices lured away its members.

Thus the cooperatives won the battle at rural points. They lowered the margin between local and terminal markets for all country elevators, and they broke the monopoly of the line elevators. By 1920, 54 percent of the elevators in North Dakota were line, 24 percent were cooperative, 15 percent independent, and 7 percent mill. Each cooperative gave competition to two or more line or independent elevators. While there are no accurate figures, it was estimated that the cooperatives, generally larger than the others, shipped from 30 to 50 percent of the grain which reached Minneapolis.

Some of their members were fiercely loyal. The agent of a line elevator at Regan, North Dakota, wrote that some of the farmers would not leave the cooperative even though he offered them twenty-five cents a bushel more than the cooperative could pay.

\section{THE EQUITY COOPERATIVE EXCHANGE}

Success in the terminal markets was more difficult. The effort of these years grew out of the American Society of Equity, created by J. A. Everitt in 1902. Everitt, an Indianapolis farm editor, wanted farmers to organize, as business and labor had, so that they, too, could set a minimum price for their product. Equity asked its members to withhold their wheat (a sort of farmers' strike) until the price reached a dollar a bushel.

In 1907, Equity made its greatest effort to control the wheat crop. Everitt, touring the wheat states, found the best response in North Dakota: some ten thousand of the state's farmers pledged to withhold a million bushels. That summer, farm-raised Theodore G. Nelson, directing a force of trained organizers, brought thousands of North Dakota farmers into Equity. Their leaders wanted a grain growers' department. Nelson-a progressive, son of a Traill County pioneer, and only twenty-seven years old-became its president and later editor of the official Equity Farm Journal.

Some members wanted to stop withholding crops, an ineffective tactic, and begin cooperative marketing, and in 1908 they organized the 
Equity Cooperative Exchange in Minneapolis as a terminal marketing agency. The organizers set a goal of $\$ 50,000$ for capital stock subscriptions, but in three years they could raise only $\$ 14,000$. The Exchange, however, began to sell grain through commission merchants who were members of the Minneapolis Chamber of Commerce (the Chamber barred cooperatives themselves from membership). In 1911 the Exchange incorporated in North Dakota.

At first the Exchange had little success; it sold only 805 carloads of grain from 1908 to 1912. Its officers encouraged the formation of cooperatives which would consign their wheat to the Exchange. Most members lived in North Dakota, and John M. Anderson, a North Dakota legislator (1909) from Grand Forks, was president. Anderson was a friend of William Lemke, a graduate of the University of North Dakota, and a founder of the Varsity Bachelor Club. For a time the Equity paper, the Cooperators' Herald, was published in Fargo. The Exchange began to grow when George S. Loftus became its sales manager in August, 1912. He was an admirer of La Follette and an aggressive, fiery enemy of the grain trade.

The Exchange and the Minneapolis Chamber of Commerce fought each other. The Chamber, the only market for wheat in the city, forbade its members to sell grain for the Exchange. The Exchange, in turn, instigated state and federal investigations of the Chamber. The war continued with lawsuits, violent words, and proceedings to have the Exchange declared bankrupt. In 1914 the Exchange moved to St. Paul, where business leaders promised it bank credit, a site for a terminal elevator, and a \$30,000 stock subscription. The St. Paul Grain Exchange was then established. It was expected to become a sort of farmercontrolled chamber of commerce.

Although Loftus died in 1916, the Exchange expanded rapidly. That year, it organized a livestock commission company. In 1917 it opened a $\$ 200,000$, half-million-bushel terminal elevator in St. Paul and established a second elevator in 1920. Its stockholders grew from about 7,000 in 1917 to about 17,500 in 1922. In 1918 it handled fifteen million bushels of wheat, built 21 elevators in North Dakota alone, and began to supply its members with carload-lot shipments of flour, feed, salt, potatoes, wire fencing, lumber, shingles, and groceries. It also began to purchase local elevators for use as feeders. By 1921 its capitalization had been increased to nine million dollars. It was financing the grain purchases of more than 100 independent elevators which consigned their grain to the Exchange. By 1922 it owned 80 rural elevators: 52 in North Dakota, 26 in Minnesota, and 2 in South Dakota. That distribution was most significant in revealing the leadership of North Dakota in the cooperative marketing of grain-the unifying effect of North Dakota's concentration on wheat. The Exchange was also managing some elevators for local farmers' associations.

Finally, in 1923, the Federal Trade Commission ordered the 
Minneapolis Chamber of Commerce to cease and desist from interfering with, injuring, or destroying the business or reputation of the Equity Cooperative Exchange or the St. Paul Grain Exchange. But the Exchange was in bad shape. Poor business management had caused heavy losses, and on March 10, 1923, it became bankrupt and went into an operating receivership. In 1926 it was taken over by the Farmers' Union Terminal Association.

The Exchange had gone down because its managers were better fitted for agitation against the Minneapolis Chamber of Commerce than for the direction of a large economic enterprise. Yet the Exchange did influence the inspection, weighing, and grading of grain on both the local and terminal markets. It did carry on the agitation for marketing reform. It did give farm leaders invaluable experience in the problems of grain marketing. Moreover, the Equity Cooperative Exchange actually began the grain-marketing and cooperative-buying enterprises which, with various reorganizations and changes in control and growth, eventually became the powerful Farmers' Union Grain Terminal Association and the Farmers' Union Central Exchange. Myron William Thatcher, who later became director of the vast operations of the Farmers' Union Grain Terminal Association, was a young auditor with the Exchange. 
CHAPTER 14

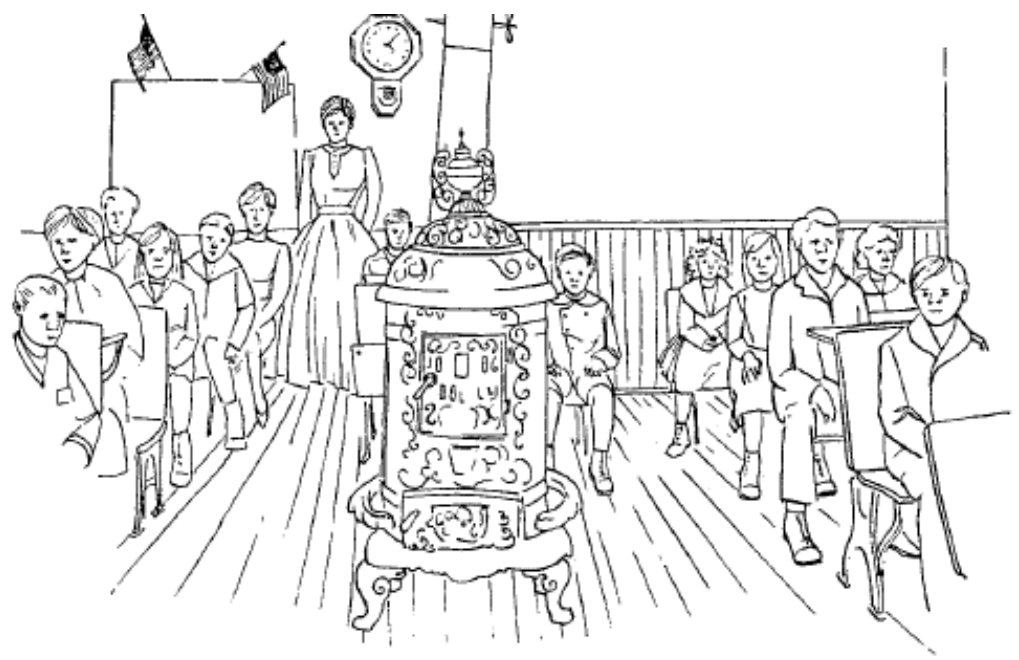

\section{The Life of the Mind and the Spirit}

THE CULTURAL LIFE OF NORTH DAKOTA was tied to its economic base. The base, wheat farming, was laid when railroads, new milling processes, and mobile farm machines opened the northern prairies to outside markets. Attracted by the prospect of quick wealth from wheat and rising land values, settlers and speculators rushed into the new country. In the boom years the pioneers not only opened up farms, built roads and railroads, founded towns, and established governments, but they also started churches, schools, colleges, newspapers, libraries, and most of the institutions necessary for a civilized way of life.

With their eyes optimistically upon the future, the pioneers sought to establish all of the standard institutions and to acquire all of the standard cultural values, not only from a regard for the institutions and values themselves, but also for the contribution which these would make to the rise of property values. So boomers without much religion generously supported new churches; boomers without much education became the patrons of schools and colleges; boomers without much culture sponsored a host of cultural activities.

They succeeded too well. The raw, new country soon had more of the instrumentalities of civilization than its economic base could well support. In their optimism the pioneers disregarded the limitations set by the semiarid nature of the country. They established too many schools, colleges, churches, and newspapers. Because there were too many, all would have a hard, often losing struggle for survival against the difficulties created by distance and the sparseness of the population. The 
steady increase in farm size and the steady decline of farm population sharpened such difficulties. Space itself had a social cost where a meager population scattered over a wide area increased the per capita expenditures for schools, churches, roads, and many other things necessary for a civilized society. North Dakotans paid a high price to learn that the semiarid prairie spread the population thinly.

Yet the pioneers accomplished much. By the outbreak of the First World War, they had given North Dakota a complex and firmly established cultural life. Churches grew stronger, ministering to more people. Schools improved, giving better educational opportunities; normal schools increased their offerings, preparing farm boys and girls more adequately for teaching careers. A university and an agricultural college prospered, opening the professions to the ambitious, giving a sound liberal education, and even expanding the bounds of knowledge through research. A historical society gathered books, newspapers, and artifacts, preserving and publishing the records of the past. Newspapers and magazines increased their circulations, spreading intelligence and breaking down the isolation of the lonely prairie. Here and there men and women cherished books, built up private libraries, and wrote prose and poetry, sometimes producing passable literature. So, for all the difficulties, all the failures, all the crudities, the pioneers brought to the North Dakota frontier much cultural baggage from their old homes. They enriched their new ones with the life of the mind and the spirit.

\section{THE PIONEER STOCK}

Cultural life was affected by the sparsity of the population. Climate caused sparsity: with an average of only seventeen inches of rainfall a year, farms grew steadily larger and the rural population smaller. Moreover, the towns, trading centers for the rural population, could themselves be but small.

Some comparisons will show important differences between North Dakota and more humid parts of the nation. In 1910, with settlement practically completed, North Dakota had 8 persons per square mile, the United States had 31 persons, the Middle Atlantic states 193, and Ohio 117. In North Dakota both rainfall and population fell off to the westward. In 1910 the Red River Valley had 16 persons per square mile, the Drift Prairie 10, and the Missouri Plateau only 5. In North Dakota only 11 percent of the population lived in places of 2,500 or more; in the United States 46 percent lived in such places, in the Middle Atlantic states 71 percent, in Ohio 56 percent. In North Dakota the sparseness of the population, living mostly on farms and in small villages, made more difficult the support of churches and schools and other social institutions; in any given area there were few people to take part and few to pay the cost. North Dakotans needed churches, schools, libraries, and other social institutions, but the scarcity of people increased their per capita cost. In North Dakota, as in all of the semiarid west, space itself became 
a social cost.

The pioneers, of course, did not and could not realize this key fact concerning the society they were forming as they came into the new country. Many, especially those of the older American stock, were restless speculators seeking easy money. A Congregational missionary at Hope described them in 1883:

These newcomers are so eager for the land... that they have little time to give to anything else.... They are found in all these new booming towns! Too many are the fly-speculators, land-jumpers, claim-seekers, and people looking for a profit rather than a home.... The main trouble with this class of people is that they have not come to stay, and, therefore, take little or no interest in our permanent institutions. What we want is the actual settler, with his wife and family. ${ }^{1}$

Yet many of them were interested in their communities. Such a person was Linda Warfel Slaughter, a former student at Oberlin College and the wife of an army surgeon. At rough, frontier Bismarck she organized the first Sunday School in North Dakota in 1872, brought her friends together in a circle to read Shakespeare, acted as postmistress, taught the first school, served as first county superintendent of schools, filed on a homestead, and led the local woman-suffrage movement.

The newcomers long predominated. As late as 1910, two-thirds of the population had been born outside the state. There was a rich diversity in which immigrants played the leading part. In 1910 more than 27 percent of North Dakota's residents were foreign-born; with their children (one or both parents foreign-born), they made up 71 percent of the population. The remainder, except for about six thousand Indians and six hundred Negroes, were native whites of native parentage, or largely persons of the older American stock.

The newer Americans came from many lands. Counting the immigrants and their children, there were in North Dakota in 1910 about 125,000 Norwegians, 117,000 Germans, 73,000 English and Celtic people (many of them from Canada), 29,000 Swedes, 13,000 Danes, and substantial numbers of French, Bohemian, Polish, and Finnish persons as well as smaller numbers of Belgians, Hollanders, Bulgarians, Greeks, Armenians, and Russians. Thus about 21 percent of North Dakota's residents were Norwegians, 20 percent Germans (about half of them from Russia), 12 percent English and Celtic (Irish, Scottish, and Welsh), 5 percent Swedish, 12 percent other newer Americans, and 29 percent older Americans.

By 1920 the make-up of the population had been somewhat changed by a substantial increase in the numbers of Germans and Russians. The census that year showed 143,000 Germans and over 11,000 Russians; the

${ }^{1}$ Earl E. G. Linden, "The History of Congregationalism in North Dakota" (Unpublished M.A. thesis, University of Chicago, 1939), p. 37. 
Germans then made up 22 percent of the population, the Norwegians slightly less than 20 percent, and the English and Celtic elements less than 10 percent. Although the number of immigrants and their children had increased from 407,000 to 432,000, they made up only 67 percent of the population, a smaller percentage than in 1910.

\section{NORWEGIANS AND GERMAN RUSSIANS}

Although an ethnic map would show the immigrant groups widely scattered, the Norwegians and the German Russians tended to hold distinct sections of the state. The Norwegians, coming first, settled principally in the two eastern tiers of counties and westward along the main line of the Great Northern Railroad in the northern part of the state. The German Russians, arriving later, formed a large triangle in the central part of the state. The base of the German Russian triangle ran from Dickey County to Hettinger County along the southern boundary of the state; its apex was in Pierce and McHenry counties. Immigrants from Canada settled in the northeastern corner. There was a Bohemian settlement about Lidgerwood, a Polish settlement in Walsh County, and a settlement of Hollanders in Emmons County.

The Norwegians were for many years the largest group of the newer Americans. They were largely of peasant stock, having been small

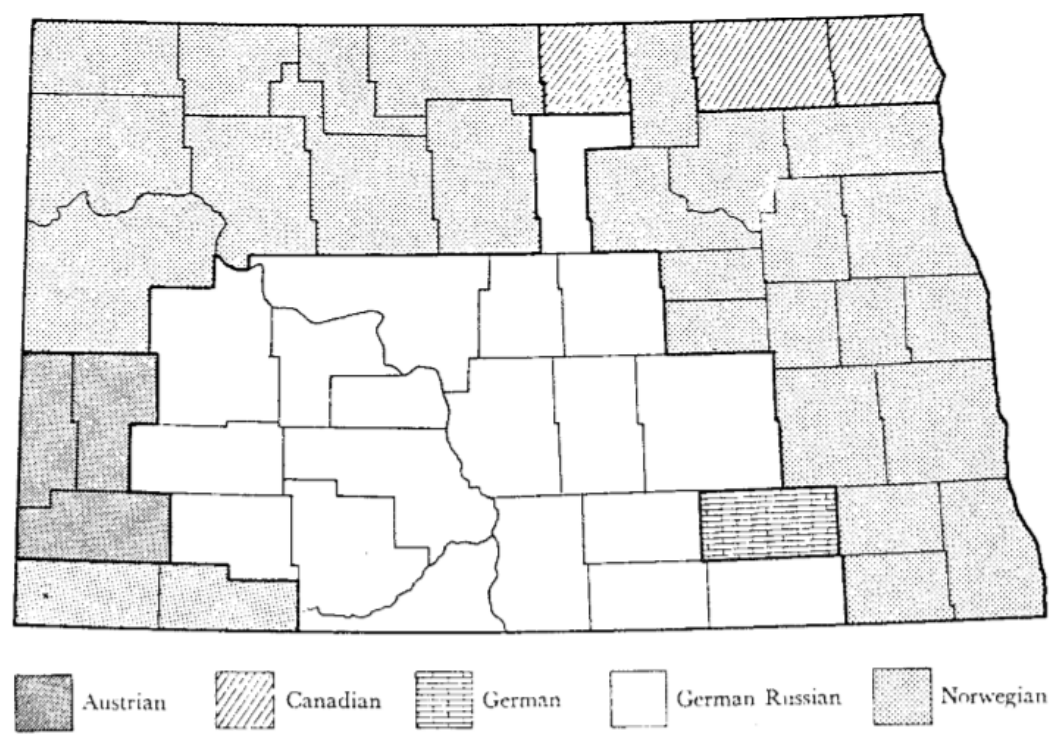

LARGEST FOREIGN WHITE STOCK IN EACH COUNTY, 1910

farmers, small renters, or farm laborers in the old country. But occasionally there was a minister, a schoolmaster, or, more rarely, a doctor or a lawyer among them. Illiteracy was almost unknown. Everyone had learned to read in Norway, for a law of 1736 required all persons to be confirmed, and the state Lutheran church required 
candidates for confirmation to be familiar with Luther's Catechism, the hymnbook, and the Bible. Norway established public schools in 1739.

Not only did Norwegian immigrants read, but they had also developed a bent for politics. The Norwegian constitution of May 17, 1814, had begun abolition of the nobility and had given much power to the common people. Perhaps even more than the other Scandinavians and the Germans, the Norwegians were individualists. They had a strict, puritan moral code, and were a pious, serious-minded, and introspective people; yet they were often excessive in fighting, drinking, and lovemaking.

In 1910 some 125,000 North Dakotans were of Norwegian stock and 117,000 were of German stock. Of the Germans, about 60,000 were German Russians, that is, descendants of Germans who had emigrated to Russia. In the 1 760's, Catherine II of Russia, herself of German birth and training, invited Europeans to settle in Russia, promising them land, religious liberty, and exemption from military service. Germany was suffering from the devastation of the Seven Years' War, and by 1770, Catherine's agents had moved 50,000 Germans to the Lower Volga region. In 1770 there were 140 German colonies in Russia; by 1914 there were 192.

A second migration occurred after Alexander I became czar in 1801. He wished to settle Germans about the Black Sea on land recently taken from the Turks. His recruiting agents, as well as Catherine's earlier ones, secured colonists from all over Germany, but they were especially successful in the southwestern section. Many poor German peasants in Baden, Bavaria, and Württemberg, suffering from the ravages of French armies during the Napoleonic Wars, were ready to move. Taking a pair of beasts, a few farm tools, and what little cash they had, they traveled more than a thousand miles to the Black Sea. Having seen armies destroy all other property, they sought land. Land hunger took them to Russia; it later brought many of their descendants to the Dakotas, Nebraska, and Kansas.

In Russia the German colonists were determined to remain German, to keep their religion and the German language. They succeeded, but the hundred years in Russia had a profound influence upon them. Desiring land, they became and largely remained farmers, living in one- or twostreet villages and going out to their fields of wheat, oats, and barley. Although each village had a herd of cattle, the colonists took little interest in dairying.

They suffered much hardship. Drought on the barren, semiarid steppes brought crop failures. The Russian agents had deceived them about the nature of the country, and the colonists faced a long struggle to adapt to the dry grassland. Grafting Russian officials took advantage of their helplessness; savage, nomadic Tartars plundered their villages. Their early homes were mere clay huts, sometimes without windows and doors. Epidemics of cholera, smallpox, measles, or typhoid would carry 
off a fourth or even a half of the population of a village. Thus the German Russians became a tough, hardy people, accustomed to suffering and adversity.

Moreover, in Russia they were an isolated people, a fact of the greatest significance. They were living in a strange land among a population speaking a strange tongue. No educated Germans-pastors, priests, teachers, professional men, or tradesmen-had joined the migration from Germany. So the Germans in Russia lost all contact with the homeland; they were cut off from all the progress that took place in Germany in the nineteenth century. They could have no stimulating contacts with their Russian neighbors, who were at a lower stage of culture than their own. They had not the time, the ability, nor the money to buy and read books and newspapers. When the Russian government built railroads, these generally bypassed the German villages. The German Russians did not mingle with the Russians; few learned to speak Russian, and there was no intermarriage. Furthermore, each village was all of one faith, Protestant or Catholic.

Isolation and especially the lack of educated people among the illiterate peasants who had migrated from Germany were responsible for the lack of interest in schools and education in the German colonies and hence the backwardness of the people. It persisted because the colonies always had much difficulty in securing priests, pastors, and teachers. When a Catholic colony did secure a priest, he was usually Polish and looked down upon his illiterate parishioners with contempt, calling them dogs and even manhandling them. Such a priest could give no leadership that would arouse respect for education in a village. Sometimes, however, a Protestant colony managed to secure a pastor from Germany and then made rapid progress.

Eventually, every colony established German-language elementary schools. But the peasants, absorbed in farming and despising the white-collar class, such as the Russian officials and shysters who tricked and cheated them, took little interest in education. In the village of Neudorf, for example, the church cost fifteen thousand rubles and the school only fifteen hundred. The German Russians were as devoted to the church as they were indifferent to the school. The few young people who received more than elementary schooling were usually weaklings who did not have the strength to make a living from the land. When the Russian government established secondary schools in the colonies in 1892, with Russian teachers and with the Russian language mandatory, the Germans were hostile. Yet by 1900 some young people were entering other fields besides farming-becoming teachers, writers, church leaders, businessmen, and government officials.

Indifference to education, which was to be such a handicap in America, did not prevent the Germans from prospering in Russia. They were a virile race with a high birth rate. They married early, at fifteen or twenty, and the parents set up the son with horses, farm tools, and, if 
possible, land. The father was a dictator feared by the children; strictness and respect for authority marked family life. Men, women, and children worked hard in the fields. They were thrifty and acquisitive, and they contributed much to the Russian economy by their example of energetic industry. They planted trees, creating orchards and village forests on the treeless steppes. They expanded their land holdings.

When land became scarce and when the Russian government began a program of Russification and took away some of their special privileges, such as exemption from military service, some of the German Russians began to leave for America. The western portions of the Plains states from North Dakota to Kansas, just then being settled, offered them vacant lands. From 1885 to 1905 they came by the thousands, spreading northward from Aberdeen, South Dakota, over twenty-three counties in North Dakota, mostly on the drier, less fertile lands of the Missouri Plateau. They were the only settlers in North Dakota who came from a semiarid country.

In North Dakota the German Russians showed the same characteristics they had displayed in Russia. In Russia they had clung to the German language; in North Dakota, German was heard on the streets of their towns and in their church services fifty years and more after their first coming. As late as the 1930's thousands of their children did not learn the English language until they began school. In Russia they had lived by themselves; in North Dakota they were still clannish, forming the largest single element in all but three of the counties in the German Russian triangle. For years they had little contact with other nationalities. In Russia they had resisted Russification; in North Dakota they long had the reputation of resisting Americanization and were still said in the 1930's to admire everything German.

In Russia they had neglected the schools; in North Dakota they disliked free public education and compulsory-attendance laws. Even in the 1920's few German Russian children were completing the eighth grade, and Joseph B. Voeller, a German Russian educator, wrote in 1940: "To this day the shortest terms, the poorest schools, the lowest teachers' salaries, the most inadequate equipment, and the most irregular attendance, are found in German-Russian communities.”'

The German Russians had been devoted to their church in Russia but had quarreled with its priests; in North Dakota they showed their devotion by attendance and support, but Bishop John Shanley called some of them "ruffians" for their treatment of priests, and the priests though of them as "hard-headed and stubborn.” In Russia every German village had a saloon and drinking was a serious evil; in North Dakota they made a mockery of the prohibition law. In Russia they had been farmers; in North Dakota most of them lived on the land. In Russia they had ignored dairying; in North Dakota they tended to be one-crop wheat farmers, resisting diversification.

Although there were many similarities between life in Russia and 
that in their new home, the German Russians suffered a revolution in status when they came to North Dakota. Joseph B. Voeller wrote in 1940:

In Russia they were the leaders; the upper stratum of people. They were more advanced than the native Russians. They were more successful in making a living than their neighbors. Their leadership was evidenced by their better homes, villages, farm animals and more productive fields. Their prosperity enabled them to buy and rent land around their villages. They were driving out the native Russians in their own land. Here in America they are at the other end of the social and economic scale. Other nationalities look down upon them. They are the underdogs. Most of them have stuck to farming in sections where farming doesn't pay by their methods. Few of them have entered other callings. They are therefore poorer than their neighbors of other nationalities. Their indifference to education they have brought with them to this country. Having neglected education, they are behind other nationalities in culture and refinement. It is not surprising that other nationalities do look down upon them. Reason or no reason, the German-Russians resent being the underdogs. Resentment makes them recall better days in Russia. They recall their situation there and compare it with their present one here, and think Russia was a better land. $^{2}$

The revolution in status, however, was an effective incentive and stimulus to change. In the 1930's, and then even faster in the prosperous years after the Second World War, the clannishness, isolation, backwardness, and neglect of education began to pass away. Joseph Voeller himself, an outspoken critic of his own people, was an example: he became county superintendent of schools in Pierce County and wrote an excellent thesis on the German Russians for his master's degree. The German-speaking priests brought to the Catholics among them by Abbot (later Bishop) Vincent Wehrle stimulated their interest in education, which grew with the establishment of parochial schools. Eighth-grade completions and high-school attendance increased markedly in the 1930 's, and a number of young people were going on to college and into the professions, becoming priests, pastors, teachers, lawyers, and businessmen. By the late 1950's the German Russian counties had about as many eighth-grade and high-school completions as other counties, although they still had a smaller percentage of young people enrolled in college.

Long before such changes, the Old World experiences of the foreignborn supplied a background for radicalism in North Dakota. The German Russians had become accustomed in Russia to government ownership, for the Russian government owned the railroads and the saloons. The German Russians themselves had cooperative granaries for the poor,

${ }^{2}$ Joseph B. Voeller, "The Origin of the German-Russian People and Their Role in North Dakota" (Unpublished M.S. Thesis, University of North Dakota, 1940), pp. 55-56. 
cooperative fire insurance, cooperative herding of livestock, and cooperative tree planting, and they thought the middlemen robbed them, a typical North Dakota attitude.

Norwegian immigrants also brought radicalism to North Dakota. In Norway the shortage of arable land had forced the peasants to eke out a living from their farms with work in forests, fisheries, or mines, so Norwegian crofters and farm workers had a long history of strike activity. They made the first collective wage negotiation as early as 1634 . For many years they took a leading part in strikes and labor disturbances, learned socialistic doctrines, demanded and got the vote and a larger part in government, formed cooperative purchasing groups, and set up sickbenefit funds. Norwegian farm workers, crofters, and industrial workers often lived on a diet of potatoes and salt for dinner, black bread without butter and black coffee at other meals. From 1849 on, they responded to poverty, unemployment, and much child labor with fighting unions, many strikes, and the formation of the Norwegian Labour party. Moreover, they had long opposed Danish and Swedish influence in Norway, a species of outside control, though somewhat different from that which they were to suffer in North Dakota. ${ }^{3}$

\section{THE NORTH DAKOTA CHARACTER}

Besides radicalism, the German Russians, the Norwegians, and all the foreign-born for that matter had other things in common. All had come to North Dakota from afar, across thousands of miles of land and ocean. They were people who had the energy and courage to leave their old homes, to travel great distances, to break the old patterns of their lives. Most of them were poor, suffering psychologically from all that poverty implied in feelings of insecurity and inferiority. In North Dakota they were living in a strange country with strange customs and a strange speech. Even the older Americans, the native-born among the settlers, shared the feeling of strangeness and loneliness on the great open grassland. And all, foreign-born and native alike, shared hope and courage. They had come because of the opportunities which the new country offered: the foreign-born sought land for homes, the older Americans often for speculation.

They soon became North Dakotans. "They feel it, they boast of it," wrote Bishop Cameron Mann of the Episcopal church in 1902. He also noted:

Soil and climate and circumstances are doing their work. The boundless stretch of the prairie from sunrise to sunset, the cloudless sky, the long winter nights and long summer days, the ever-singing wind, the

${ }^{3}$ Edvard Bull, The Norwegian Trade Union Movement, International Confederation of Trade Unions Monographs on National Trade Union Movements, No. 4 (Brussels, 1956), pp. 12-44. 
prodigal wealth of wheat and flax-all these mold and color humanity. So in the North Dakotan one finds a man prompt, generous, speculative, ready to learn each new thing, hard to tie to anything, but, when tied, staunch, sturdy, and loyal. ${ }^{4}$

With the passing years, environment and experience fixed certain traits in the character of the people. Remoteness, with its loneliness and isolation, placed a premium on friendliness and courage, and North Dakotans became brave and friendly, ready to lend a helping hand. The cool, dry climate made them a hustling, energetic people who took pride in withstanding the rigors of hard winters. Exploitation and dependence made many of them radical, suspicious of the interests, aggressive, independent, and loyal members of a self-conscious minority. Sometimes the North Dakotan was optimistic-and for good reason. John Wirch, for example, came from southern Russia in 1891 and started farming in Dickey County with just one yoke of oxen. Twenty years later he owned 1,280 acres of land, 20 horses, 35 head of cattle, and all of the machinery necessary to operate his farm. Often, however, frontier conditions and drought accustomed North Dakotans to hardship and made them cautious, always worrying about the winter.

Early North Dakotans were an alert and intelligent people who had time for reading and social meetings. "The wheat farmer is busy only at seeding time, and at harvest and threshing," wrote Professor James E. Boyle, formerly a member of the faculty at the University of North Dakota, in 1918. Boyle explained:

He belongs to one or two farmers' clubs. He has one or two farm papers-real farm papers, that meet his local needs. He has his church papers and at least one daily paper. His mail is brought to him daily by the rural mail carrier. Every farmer, of course, has his rural phone. [Daily papers and phones were far from universal in 1918.] He makes a weekly visit to the nearby village, or to the more pretentious "county seat" if he owns a Ford, and practically every prosperous farmer has his motor car. The winter season is long, but farm labor is the lightest then and this is the season for public meetings and conventions on every possible subject. This is the season when farmers do most reading. A very considerable number of farmers move into town for the winter or even travel South. ${ }^{5}$

Boyle's idealized picture does not however, show the inner adjustment of the immigrants to the new country. Drawn together by mutual understanding, the Norwegian settlers and others developed compact settlements of people of like origin, even those from a particular valley in Norway. So on every hand the immigrant saw cultural institutions brought over from the homeland. The Norwegians-

${ }^{4}$ North Dakota Sheaf (Fargo), July, 1902, p. 4.

${ }^{5}$ James E. Boyle, “The Agrarian Movement in the Northwest," American Economic Review, VIII (September 1918), 506. 
American, for example, continued to use his native language. He attended a Norwegian-American church; he read Norwegian-American newspapers; he joined Norwegian-American societies; and he even sent his son to a Norwegian-American college. Yet he learned some English, took out citizenship papers, became a voter, often served in some local office, and rubbed shoulders with older Americans in store, land office, and political meeting. This process of adaptation deeply influenced the cultural life of the state-the languages spoken, the books read, the church services held, and the newspapers published.

The language change was fundamental. Most immigrants became bilingual, learning English but also clinging to their native tongue. English was the language of the pocketbook and outer shell of life without warmth; the old language, spoken at home, was the language of the most intimate and valuable experience.

\section{MISSIONARY EFFORTS}

Whenever white men came to the wilderness, they carried with them not only language but much of the baggage of civilization. As soon as they were able, they set up institutions to nourish the life of the mind and the spirit. Churches, schools, newspapers, and colleges would bring religion and enlightenment to a rude new country.

The lawlessness and violence of the fur-trading frontier made religion imperative. After an attack upon his colony by the métis had killed several settlers, the Earl of Selkirk arranged with Bishop Joseph Octave Plessis of Quebec to send Catholic priests to the Red River Valley. In 1818, two young priests, Joseph Norbert Provencher and Sévère Joseph Dumoulin, came as missionaries to the Red River of the North. Father Provencher settled at St. Boniface, Father Dumoulin at Pembina.

Working among the Indians and métis, Father Dumoulin had baptized 394 persons, solemnized 68 marriages, and performed 49 burials by the fall of 1822. He left Pembina in 1823, but priests from St. Boniface and other places often went with the métis in the 1830's and 1840's on their buffalo hunts across the northern Dakota prairies, saying Mass, teaching, and comforting the sick.

In 1843, Father George A. Belcourt accompanied the hunters, and in the spring of 1848 he built a mission at Pembina. A little later he built a second mission at St. Joseph (present-day Walhalla) at the foot of Pembina Mountain. Father Belcourt made long journeys to carry the Gospel to Indian and half-breed camps. He was aided by young Father Albert Lacombe and later by Father Joseph Goiffon. Father Goiffon, caught in an early blizzard, spent two days on the prairie; one of his frozen legs had to be amputated.

While the Catholics enjoyed a good deal of success, early Protestant missionary efforts failed. Baptists (half-breed James Tanner and young Elijah Terry) came to Pembina in 1852, but the Sioux killed Terry that 
June. In 1853 the Reverend Alonzo Barnard, a Presbyterian, and David B. Spencer, a Congregationalist, started a mission at St. Joseph, but they gave up in 1855 after Mrs. Barnard had died of hardship and exposure and Mrs. Spencer had been shot by the Sioux.

The Catholic priests, however, though often in great danger, were never harmed. The most famous of the many to visit the region was Father Pierre Jean DeSmet, a stocky, benign Belgian Jesuit. He was a saintly character who won the love and respect of the Indians. They treated him with much kindness, gave him many a feast, and said that he had not a "forked tongue." He made many voyages to the Upper Missouri country from 1839 to 1868, stopping in northern Dakota to preach to the Indians and traders whom he instructed and baptized. "He never carried a weapon of any kind," wrote Major General D. S. Stanley, "never attempted violence... and never suffered in any way from the aggressiveness of the savages. His only means of defense were love and gentleness." Once, however, Father DeSmet knocked down an Indian who had tried to bully him and gave him a sound thrashing; he had been nicknamed "Samson" as a youth, and on this occasion he certainly lived up to the epithet.

Father DeSmet's visits established no permanent mission in northern Dakota. Soon after his death, however, the Superintendent of Indian Affairs assigned Fort Totten Reservation to the Roman Catholic church. In 11874, four Grey Nuns from Montreal began to conduct a manuallabor school for the Indians at Fort Totten. Father Jerome Hunt, the most notably priest to serve at the fort, prepared a catechism, a prayer book, and a hymnal in the Sioux language.

The first resident priest along the Missouri River in northern Dakota was Abbot Martin Marty, Order of St. Benedict, from St. Meinard's Abbey in Indiana. He started a mission for the Indians at Fort Yates in 1876 and, with his assistants, Father Chrysostom Foffa and Brother Giles Laugel, also cared for Catholics at Bismarck and Forts Rice, Lincoln, Stevenson, Buford, and Seward. In 1879 he was made Vicar Apostolic when Pope Leo XIII designated Dakota Territory as a Vicariate Apostolic. Abbot Marty was consecrated Bishop in 1880; he made his headquarters at Yankton and had thirteen priests with which to care for Dakota.

While Abbot Marty was organizing Catholicism, Protestant missionaries in the 1873's began to come among the farming settlers and townsmen who were entering northern Dakota. Missionaries of three Norwegian Lutheran synods organized congregations in Richland and Cass counties in 1871 and in Traill County in 1872. The Presbyterians began services in a tent hotel in Fargo in December, 1871, and organized a church in Bismarck in 1873. Methodists and Episcopalians held their first services in Fargo in the summer of 1872, the Episcopalians in the dining tent of General Thomas R. Rosser's Northern Pacific construction camp. A missionary of the Lutheran Church-Missouri Synod, preaching 
in German, came to Town Berlin (present-day Great Bend) in 1874. Missionaries of the Evangelical Association (later the Evangelical United Brethren church) began work among Germans in Richland County in 1877. In 1878, one of them, the young pioneer pastor A. C. Schmidt, set up preaching stations in Fargo, Casselton, Grand Forks, Erie, and Grafton, driving a horse and buggy over 250 miles on one missionary journey.

These men and others spread religion through the rough, lawless new country. Holding their first services in tents, sod houses, log cabins, dugouts, schoolhouses, rooms above stores, dance halls, barns, and even saloons, the missionaries were soon organizing congregations and erecting church buildings. At Bismarck, Father J. B. Genin, working in his cassock on the new Catholic church, injured himself in a fall from the scaffold. In Minot two gamblers shot it out ten minutes after attending Mass; one was killed. One of the Minot church trustees ran off to Montana and opened a saloon with the money he had collected to build a Catholic church. Abbot Vincent Wehrle wrote: "Minot had some three or four decent Catholic families in town; the rest were gamblers, saloon keepers, escaped jailbirds, men run away from their wives and wives run away from their husbands."

Like the settlers they sought to serve, the missionaries followed the railroads. The Presbyterians named one division the Northern Pacific Presbytery. All covered large areas, on foot or on skis, with horse and wagon, or by rail. Abbot Wehrle, appointed pastor of Devils Lake in 1888, was soon caring for Catholics at twenty places, from Michigan City to Fort Buford, a distance of 270 miles. He was almost constantly on the road. A Missouri Synod missionary had thirteen preaching stations. The Reverend Hermann F. Buegel, pastor at St. Thomas for twenty years, drove a team of horses more than sixty thousand miles.

Others also performed heroic labors. The Reverend Gotthard Potratz, a Missouri Synod pastor with a salary of \$350 a year, founded twentyfour congregations and preaching stations. The Reverend Bjug Harstada Norwegian Synod Lutheran who preached in English, Norwegian, or German-skied or drove across the prairie and organized sixteen congregations in two years. With little in the way of salary, he took a claim and farmed to support his missionary work. In 1876 the Reverend Richard Wainwright, an Episcopalian, was traveling four hundred miles a month to hold services at Fort Seward, Valley City, Pembina, Bismarck, and other points. Benedictine monks from St. John's Abbey, Collegeville, Minnesota, built many of the Catholic missions in northern Dakota. ${ }^{6}$ 


\section{THE GROWTH OF THE CHURCHES}

At first the churches of northern Dakota were parts of synods, conferences, or dioceses of Minnesota or the Upper Middle West. Later they formed separate organizations. Episcopalians made North Dakota a missionary district with its own bishop in 1883. The Evangelical Association set up the territory as the Dakota Conference in 1884. The German Congregational church also formed its Dakota Conference in 1884; it organized the North Dakota Conference in 1907. Presbyterians established the Synod of North Dakota in 1885. The Methodists set up an annual conference to care for northern Dakota in 1886. Pope Leo XIII created the Diocese of Jamestown for the state of North Dakota in 1889. The Right Reverend John Shanley, its first Bishop, moved his see to Fargo in 1891 and the name was changed to the Diocese of Fargo. In 1910, a year after Bishop Shanley's death, the western part of the state became the Diocese of Bismarck, with Abbot Vincent Wehrle as Bishop.

The churches, stimulated by booming settlement and denominational rivalry, grew rapidly. The Methodists, for example, had forty-seven churches as early as 1886 . By 1890 there were in all about 64,000 church members-48 percent of them Catholics, 26 percent Lutherans, and most of the remaining 26 percent divided among the leading Protestant denominations, of which the Methodists, Presbyterians, and Baptists were the strongest. By 1906, when the second boom was well under way, there were thirty-seven denominations in the state. Dr. C. A. Armstrong, the historian of North Dakota Methodism, has described the rapid growth:

There was a wild scramble to hold the first service in as many towns as possible.... The country was new, people were optimistic and generous in support of new things. Townsite companies gave free lots to all churches. The lumber yards were trusting and willing to sell lumber for a new church on a promise, or less, in many cases. The Mission Boards had funds from eastern donors anxious to convert the Indians, the cowboys, and the outlaws of the New West. The result was that many churches were built on less than a "shoe string," and located where there were few members and no

Dakota Historical Society Collections, VII (1925), 195 283; Lambert J. Mehl, "Missouri Grows to Maturity in North Dakota: A Regional History of the Lutheran Church-Missouri Synod" (Unpublished M.A. thesis, University of North Dakota, 1953); Richard M. Lunde, "History of the Evangelical United Brethren Church in the Dakotas" (Unpublished M.A. thesis, University of North Dakota, 1959); Marian E. McKechnie, "Spiritual Pioneering: A History of the Synod of North Dakota, Presbyterian Church, U.S.A." (Unpublished M.A. thesis, University of North Dakota, 1955); Gerald M. Weber, "John Shanley: First Bishop of Fargo" (Unpublished M.A. thesis, St. Paul Seminary, 1951); C. A. Armstrong, History of the Methodist Church in North Dakota (Fargo: The Author, 1916); W. C. Hunter, Presbyterianism in North Dakota (N.p.: Presbyterian Synod of North Dakota, 1959). 
Many church leaders were notable builders. Bishop John Shanley, son of Irish immigrants and beloved first Catholic Bishop of North Dakota, dedicated 205 churches in eighteen years. From 1893 to 1915 the Reverend Jabez G. Moore, a big man both physically and in his plans for Methodism, had a part in building 70 churches and 72 parsonages. In the boom days everybody expected growth. Bishop Shanley wrote: "We can, the most of us at least, expect to live to see North Dakota as thickly settled as Pennsylvania, to see the country dotted with churches.” With such expectations, churches were built where there were only a handful of members. In 1887, General George W. Cass, former president of the Northern Pacific, gave money to build a beautiful Episcopal church of stone at Casselton as a memorial to his son. When the building was completed, only eight persons attended the meeting to organize the mission.

Such building gave the state more churches than it needed and more than the members could support. Only a third of the population were church members, but the churches of Milnor could seat twice the population, and yet another was planned. Overexpansion meant many churches with few members. By 1916 the state had 2,520 local church organizations with 225,877 members, or an average of only 90 members per church. Only three states had a lower average.

But in North Dakota the averages varied widely from denomination to denomination. In 1916 the Roman Catholics had 352 churches and 95,859 members, or an average of 252 members per congregation. The eight principal Lutheran synods had 1,007 churches and 72,026 members, or an average of 72 members per congregation/ Five older American denomination (Methodist, Presbyterian, Congregational, Baptist, and Episcopal) had 87 churches and 40,410 members, or an average of 48 members per congregation. With averages like these, many congregations had only a few families.

Such small congregations could not support a vigorous church life. They were a result of both the sparsity of the population and the rivalry of many denominations. Small congregations meant that one pastor had to serve several churches. The constant travel, the dissatisfaction of pastors' wives often left alone, the isolation, the cold climate, the poor pay-all these conditions made it difficult for churches to secure or keep pastors. Some used seminary students. The German Congregationalists and the Episcopalians often depended on lay readers; the Catholics turned to Benedictine monks.

Small congregations and the poverty of the population made all churches dependent on outside aid. Bishop Shanley had to raise money by preaching retreats in the East; he often said in later years: "My house came out of my throat.” Bishop Shanley checked the creation of small congregations by forbidding Catholics to build churches on their own 
initiative; when they did, he refused to send them priests. The older American churches, however, were more dependent on outside aid than were the Catholics and Lutherans, the stronger groups in the state. Over the years the Presbyterian church in North Dakota received one million dollars from its national mission board. The Presbyterians, Methodists, Congregationalists, and Episcopalians were hurt more by the moving away of their members than were the Catholics and Lutherans. At Devils Lake the Episcopal church lost forty members in six months; at Fargo it lost half the membership in seven years. A clergyman quipped: "The patron saint is certainly 'Exodus.'” Such heavy losses disheartened those who remained. Even the Catholics suffered losses; one priest encouraged a thousand families to emigrate to Alberta. In 1909, Bishop Shanley forbade any priest who would encourage emigration to say Mass in North Dakota.

The older American churches were also checked in their missionary efforts in North Dakota by the ethnic make-up of the population. By 1910 some 71 percent of the population were immigrants and their children. Most of the Scandinavians belonged to one of the Lutheran synods organized for their particular nationality group. There were five Norwegian Lutheran synods, one Icelandic, one Swedish, two Finnish, two Danish, and four German. The Germans and German Russians were divided among several churches. Many were Lutherans and many were Catholics, some were Mennonites, some members of the Evangelical Association, some Baptists, some Congregationalists, and some members of the Reformed church. Besides the Germans and the German Russians, the Catholic church had the Irish, the French Canadians, the German-Hungarians, the Poles, and some of the Bohemians.

First the lack of German-speaking priests, then conflict between German priests of an authoritarian type and the independent-minded German Russians, threatened to turn many of them away from the Catholic church. To prevent this, Bishop Shanley called on German-speaking Swiss-American Benedictines. They had built St. John's Abbey at Collegeville, Minnesota, and had been doing missionary work in northern Dakota before Bishop Shanley's arrival in 1889. In 1894, one of the Benedictine missionaries, Abbot Vincent Wehrle, built St. Gall's Priory on the shores of Devils Lake. But St. Gall's was far from the German Russian settlements, and Bishop Shanley wrote: "For God's sake and that of our own Faith, my dear Father Vincent, move your monastery to Richardton, where you will be in the midst of these people." In 1899, Abbot Wehrle moved the priory; Assumption Abbey at Richardton became a center of Catholic work. Abbot Wehrle loved the German Russians and with his kindly, tactful ways conciliated them and made them a pillar of strength for his church. Called the "Apostle of the German-Russians and German-Hungarians," he was proud of the salutation. When he retired as Bishop of Bismarck in 1939, he had done more for the church in his fifty-two years as a priest in North Dakota than 
any other churchman.

Churches with immigrant members conducted services in many foreign languages; in 1916 there were services in one of thirteen foreign languages in 1,352 churches with a membership of 141,377. Those with services in English included the Presbyterians, Methodists, Congregationalists, Episcopalians, and Baptists-churches whose members were largely Canadian, English, Scottish, and older Americans. They were in a minority position, unable to make much headway with the Scandinavian and German elements in the population. Their natural constituency was often more scattered than that of the immigrant groups, which gave strength to the Catholic and Lutheran churches. They were, therefore, often in a desperate struggle to survive and frequently had to abandon churches and missions. Their weakness is shown by the percentages of membership. In 1916 the Catholics had about 42 percent of all church members, the Lutherans 32 percent, the smaller immigrant churches (the Evangelical Association, the German Evangelical Synod, the Reformed bodies, the Brethren, and the Mennonites) 8 percent, and the older American churches only 18 percent.

The churches did much for the new society developing in North Dakota. They not only brought together neighbors for spiritual refreshment and affable sociability, no matter on the the lonely prairie, but also raised moral standards and established schools and hospitals. Catholic orders took a leading part. In 1885, Benedictine nuns converted the Lamborn Hotel at Bismarck into a hospital and cared for boatmen for ninety cents a day. They renamed the St. Alexius and built a new 125 bed St. Alexius in 1915. At Fargo the Sisters of St. Joseph converted the Bishop's old residence into a hospital in 1899; five years later they built a new hospital for $\$ 50,000$. At the invitation of the physicians of Grand Forks, they opened St. Michael's Hospital $(\$ 75,000)$ in 1907. Other nuns began to operate hospitals: at Fort Yates in 1889, at Dickinson (40-bed St. Joseph's) in 1911, at Minot in 1911 (a new St. Joseph's with 75 beds in 1917-1918), and at Williston (40-bed Mercy Hospital) in 1920.

Norwegian Lutherans were also active in hospital work. In 1899 they bought Dr. J. E. Engstad's private hospital in Grand Forks; it had started in 1892 with 10 beds. Renaming it Grand Forks Deaconess Hospital, they made additions in 1902, 1910, and 1916. They built a number of other hospitals, among them Northwood Deaconess Hospital in 1902. It was converted into an old people's home when they built a new hospital in 1908.

At the urging of Dr. E. P. Quain and Dr. N. O. Ramstad the Evangelical Association, one of the smaller churches in the state, built a \$200,000 hospital in Bismarck in 1909; it was the largest in the state at that time. The Quain-Ramstad clinic and the new hospital made Bismarck a well-equipped medical center for western North Dakota. The hospitals generally trained nurses, and were often run by persons of extraordinary devotion, such as Sister Boniface Tummins, who was 
administrator of St. Alexius for forty-two years. And of course the church-sponsored hospitals brought incalculable benefits to the state.

Church-established schools were of less significance. The Presbyterians began Jamestown College in 1883, the Congregationalists Fargo College in 1887, and the Methodists Red River Valley University at Wahpeton in 1891. Roman Catholics and Lutherans established elementary and secondary schools. Nuns opened Catholic academies at Fargo (1882), Jamestown (1890), Bismarck (1878), and a number of other places. Lutherans had Bruflat Academy at Portland in 1889 and Grand Forks College (a secondary school) in 1891, as well as a number of others. By 1912 there were some two dozen private schools in the state, about half of them Catholic and a few of them private business enterprises.

\section{THE GROWTH OF THE SCHOOLS}

The early history of North Dakota's schools paralleled that of the churches. Both encountered problems, but the schools had some advantages: unity instead of denominational diversity, taxation instead of voluntary offerings, and compulsory instead of voluntary attendance. Contrariwise, the schools suffered the same difficulties as the churches: too many small units, too little money, and too few trained leaders.

As soon as Dakota Territory was organized, the legislature began to pass school laws. It gradually gave the people a school system: a territorial superintendent of public instruction, county superintendents, a pattern of school districts, and standards for the training and certification of teachers. A law passed in 1883 was especially forward looking. for it required new school districts to be thirty-six square miles, a township, in size. The old districts were nine square miles, four to a township, and in northern Dakota five of the older counties (Barnes, Burleigh, Cass, Grand Forks, and Pembina) retained the smaller districts, a cause of many small, weak schools.

The schools grew rapidly. In 1890, North Dakota had 1,682 schools, 35,543 pupils, and 1,982 teachers; it spent $\$ 658,760$ to support them. Statehood brought a large grant of land to support the common schools. In 1889 the federal government gave North Dakota some 2,500,000 acres, Sections 16 and 36 in each township, for that purpose. The state constitution provided that the lands could not be sold for less than ten dollars per acre and that the money received should be a permanent fund with only the interest spent. The income was to be divided among the school districts in proportion to the number of children of school age. By 1917 the state had sold 1,076,000 acres for an average of \$17.61 an acre; the permanent school fund had grown to more than nineteen million dollars and its annual income amounted to more than a million dollars.

As adopted in 1889, the constitution provided for a system of public schools. They were to be "free from sectarian control" and extend through all grades, including the collegiate level. The constitution 
provided for a state superintendent of public instruction, county superintendents, and a school debt limit of 5 percent of the assessed valuation.

The legislature carried out the constitutional provisions. It established townships as the common-school districts, except for the five counties where the smaller districts were already in existence. Villages and towns with a population of more than three hundred were to be special school districts, but towns which had been independent districts under territorial law could continue as such. Other laws provided for examinations for teachers' certificates, support of institutes for teacher training, school terms of at least seven months, compulsory attendance for children from eight through fourteen years, and free textbooks at the discretion of school boards.

School enrollments grew with settlement. In 1900 there were some 78,000 children enrolled, by 1920 over 168,000; the number of teachers roughly doubled, rising to about 8,000. Although the rapid expansion was a notable achievement, it gave the state more schools than it was either able or willing to support adequately.

The rural one-room schools were often weak. In 1916-1917 there were 4,722 of them, with 51 percent of all the pupils and well over half of all the teachers. Most of the rural teachers were poorly trained. As late as 1911-1912 only 20 percent of them had received as much as four years of education beyond the eighth grade; more than 3,000 teachers had no training beyond the eighth grade. The school term was short; in 1912 the average length was only 140 days (seven months), and 22 percent of the rural schools taught less than the legal minimum set by the legislature.

Attendance was poor. In 1911-1912 the average pupil in a rural one-room school was there only 84 days. Poor attendance meant many retarded pupils. In Sheridan County, which had a large German Russian element, the average age in any grade in 1911 was three years above the normal age for the grade. As a result, less than 30 percent of the farm boys completed the sixth grade, and in 1912 only four hundred of them were enrolled in high school. Only 1 percent of the farm children were completing high school. Counties with large Norwegian populations tended to have stronger schools.

County superintendents, the professional supervisors of the rural schools, were not much help. Holding an elective office and therefore in politics, they were insecure in their positions, subject to pressure for low standards and the nonenforcement of the school-term and compulsoryattendance laws, and often inexperienced. Half of them were new to their positions in 1907.

Rural schools usually had poor teachers. They often taught a term of seven months for $\$ 260$, about 62 percent of the yearly wage of a domestic servant in North Dakota. Most of them were farmers' daughters holding second-grade elementary certificates. In 1916 their average teaching experience was only two years, their average age twenty-three. Each fall, 
half the rural teachers were beginners. With some 1,500 rural positions to be filled each school year and with the normal schools graduating only 450, few normal-school graduates would take a rural school. So most rural teachers received what little training they had from county institutes lasting a week or so, from teachers' reading-circle books, and from three to six weeks of summer school. They took examinations for their certificates and usually received a second-grade elementary certificate good for two years. The certification law of 1911 provided professional certificates for the graduates of colleges and normal schools.

The education offered in most of the rural schools was not only of poor quality but also expensive. Low enrollment in many schools made cost per pupil quite high. In 1912 there were ten or fewer pupils in 40 percent of the one-room schools; the daily cost per pupil often ran from forty to eighty cents, as compared with sixteen cents in the Grand Forks town schools. In 1912-1913, North Dakota was spending \$33.52 per adult male of the population on public education, the second largest amount among all the states.

In North Dakota the town schools did not have to struggle with problems created by sparse population and pressure for boys' help on the farm. The town schools were both less costly and better. They had better teachers (93 percent held college or normal-school diplomas in 1918), better attendance (86 percent completed the sixth grade in 1918), longer terms (nine months was the standard), and better buildings and equipment. In 1912 the state's high school teachers were graduates not only of the University of North Dakota and the Agricultural College but also of such eastern colleges and universities as Adrian, Beloit, Carleton, Chicago, Earlham, Michigan, Minnesota, Northwestern, Oberlin, Ohio State, and St. Olaf. ${ }^{7}$ Teachers at graded town and village schools were graduate of a normal schools.

\section{SCHOOL REFORM}

A number of strong leaders worked steadily for improvement of the schools. Among them were Webster Merrifield, Walter L. Stockwell, Edwin J. Taylor, and Neil C. Macdonald. Their long tenure increased their influence. Short, dark-complexioned Merrifield, a Yale graduate in classical languages, was president of the University of North Dakota

${ }^{7}$ The biennial reports of the Department of Public Instruction are the principal source of information on the schools. The most useful were those for 1906, 1912, and especially, 1918. See also Bertha R. Palmer, A Brief History of the Department of Public Instruction, 1860-1932 (Bismarck: Department of Public Instruction, 1932); Norman H. Hanson, "History of Consolidated Schools in North Dakota” (Unpublished M.S. thesis. University of North Dakota, 1946); United States Bureau of Education, State Higher Educational Institutions of North Dakota, Bulletin (1916) No. 27 (Washington, 1917). The last-named item is referred to as the Craighead Report for its principal author. 
from 1891 to 1909. The enthusiastic, redheaded Stockwell, a graduate of the University of Minnesota, was state superintendent of public instruction from 1903 to 1911. Taylor, who was tall and thin, was a graduate of St. Lawrence University and served as deputy superintendent for Stockwell and then as state superintendent from 1911 to 1917. Darkhaired and heavy-set (five feet nine and over two hundred pounds) Macdonald was a graduate of Mayville Normal who had begun to teach a country school at sixteen. He later earned degrees from the University of North Dakota and Harvard and did graduate work at Chicago and Stanford. He was state inspector of rural and graded schools under Taylor and then state superintendent in 1917 and 1918.

Outspoken about the weaknesses of the schools, these men sought many reforms: larger school districts (the county as the basic unit), a county school board which would choose the county superintendent (taking him out of politics), the consolidation of schools, better-trained teachers, longer school terms, and state aid. Macdonald wrote bluntly:

There are over 15,000 boys on farms in North Dakota, between the ages of 11 and 16 who only see four months' school each year, because those boys... are compelled to do the work of men on the farms.... The country boy, in the average country school has a second-grade teacher-for the well-trained teachers won't go out to the country schools at the wages paid-and a school-room with medieval heating, lighting and ventilation, no library, and a term of seven months. And he is robbed of three months of that.

Merrifield, the greatest hero in the history of the university, used his position as president to bring about improvement or high schools. In 1890 there were only 570 high school students in the state, and nearly all of them were in schools with a curriculum of less than four years. Such schools could not adequately prepare students for college. In the fall of 1891, Merrifield persuaded a conference of high school principals to accept a program which included the classification of high schools, a three-year curriculum as minimum, state subsidies for schools meeting set standards, a high school inspector, and an acceptable course of study. Merrifield became high school inspector. In 1892 he announced that he would send out examination questions to any high school requesting them. Students who passed the examination would be admitted to the freshman class at the university. By 1893 every high school in the state was using the examinations; the university faculty were making out the questions and grading the papers. In 1895 the legislature set up a state high school board, and in 1899 it began to appropriate money for grants to schools which met the standards set by the board. Until his retirement in 1909, Merrifield, the leading member of the board, spent much of his time inspecting high schools. He earned the title "father of the state high school system."

Under Merrifield's watchful eye and encouraged by the state 
subsidies, the high schools advanced steadily. In 1899 only 9 met Merrifield's standards for college entrance; in 1909, a total of 76 did so. The number of high school students increased. By 1906, Bismarck had 106, compared with only 8 in 1895, and was boasting that its graduates had gone on to college not only at the University of North Dakota and the Agricultural College but also at Harvard, Oberlin, Minnesota, Carleton, Princeton, and Dartmouth. By 1917-1918, North Dakota had 9,505 high school students, most of them town boys and girls, enrolled in the 144 classified state high schools. The state was spending $\$ 72,500$ on subsidies for those schools which met the standards. Grand Forks, with 530 enrolled, had the largest high school in the state. Many high schools, however, were very small. Only 60 had more than 50 students, and less than half the students in the state were enrolled in the 63 first-class high schools. The senior classes were quite small: only 1,369 pupils graduated in 1917; only 11 percent of all pupils finished high school; only 3 percent of the farm boys did so.

The high schools, located in towns, were more easily improved than were the rural common schools. One approach to the rural-school problem was consolidation. Small districts lacked the money to hire good teachers; consolidation would allow a larger school with two teachers and a better program. An 1899 law permitted elections on the consolidation of schools within the same district; later laws permitted consolidation of districts and payment for transportation or pupils. The first consolidated school opened in 1901, and by 1909 there were fifty-one consolidated schools in twenty-one counties.

Many townships never had more than one or two schools, and consolidation was easier where the school districts were already of township size. Transportation-the conquest of distance on the vast, semiarid grassland-was the key to consolidation and hence to the improvement of rural education. Superintendent John C. West, later president of the University of North Dakota, reported that Webster School, consolidated in 1901, found a family system without remuneration to be the best way of transporting pupils: "Horses are plentiful and where the children are too small to drive, there is always a large boy who will take care of this for his board.... When a horse is hitched up, one or two miles, more or less, makes little difference.”

The great turning point for the rural schools came in 1911. A commission headed Dean Joseph Kennedy of Teachers College at the University of North Dakota drafted a complete revision of the state school laws. The legislature enacted the commission's work, a part of the flood of progressive legislation which followed the overthrow of McKenzieism. The laws provided for state aid to raise the standards of rural schools and to encourage consolidation. They also provided for county agricultural high schools and for higher qualifications for teachers.

Under the 1911 laws, state aid was to go to standard rural and graded 
schools. Two classes of graded schools, two of rural (one-room) schools, and consolidated schools were eligible for aid. The amount of aid depended upon the preparation of the teachers, the provision of a suitable building and a library, and the length of the school term. For example, graded schools of the first class (four teachers with first-grade elementary certificates and a nine-month term) were to receive $\$ 150$ a year; rural schools of the second class (a teacher with a second-grade elementary certificate and an eight-month term) were to receive \$50. In 1915 the legislature appropriated $\$ 120,000$ to aid rural schools; in 1919, with the Nonpartisan League in control, it appropriated \$425,000.

The laws of 1911 created the position of rural and graded school inspector and made it the inspector's duty to promote consolidation. State Superintendent Edwin J. Taylor appointed Neil C. Macdonald. Aggressive and full of energy, Macdonald was determined to correct the educational injustices against which he himself had struggled as a farm boy near Hannah, where his father had homesteaded. Speaking often and earnestly, writing pamphlets, reports, and articles ("The New Rural School," "The Consolidated School in North Dakota," "The Problem of Rural School Betterment"), traveling about the state, first as inspector and later as state superintendent, inspiring teachers, county superintendents, and school boards to a higher view of their duties, he put on a far-reaching crusade for the consolidation and improvement of rural schools.

The climax came in the fall of 1917 when Macdonald organized a series of "Better Rural School Rallies" in every county of the state. The rallies were a week's institute for rural teachers and then a one-day conference for school-board members. Macdonald brought in ruralschool experts from Boston, Washington, D. C., and Minnesota to aid county superintendents and the state department of education. Governor Lynn J. Frazier, himself a former rural teacher and at one time Macdonald's roommate at the university, spoke at twenty-two of the rallies. More than six thousand teachers and six thousand school-board members attended. The rallies were the most effective campaign for school improvement ever conducted in the state.

Macdonald's zeal, together with state aid and consolidation, brought rapid improvement in the rural schools. In the years from 1911-1912 to 1916-1917, average attendance rose from 84 days to 97; the school term lengthened from 140 days to 156; the percentage of farm children completing the eighth grade increased from 8 percent to 30 percent; the number of farm children in high school increased from 1,115 to 3,920; the number of standard rural schools (those eligible for state aid) increased from 169 to 599; and the number of consolidated schools increased from 114 to 401.

Progress was not uniform. Eastern counties, which had more fertile soil and which had been settled earlier by many Norwegian, Icelandic, Canadian (largely Scotch and Scotch-Irish), and older American settlers, 
had stronger schools. Farther west, counties which had less fertile soil and which had been settled later by many German Russians had weaker schools. Counties like Towner, Ramsey, Foster, Ransom, Nelson, Pembina, and Traill had the strongest schools, measured by such criteria as teachers' qualifications, length of school term, eighth-grade and highschool completions, and progress in consolidation and standardization. Such counties as Oliver, Mercer, Logan, McIntosh, Grant, and Emmons had the weakest schools.

Hopeful progress was cut short by the defeat of Macdonald for reelection as state superintendent in 1918. As part of their campaign against the Nonpartisan League, conservatives, opposed to state aid, charged Macdonald with being a socialist and with corrupting the state's children with socialist books. Their candidate, Minnie J. Nielson, took the lead in a campaign of slander and smear. Macdonald had the support of the Nonpartisan League, whose members were much interested in the improvement of rural schools. Miss Nielson, a tallish, pug-nosed young woman, proud of her Scottish origin and an effective speaker, had the support of the North Dakota Federation of Women's Clubs. A former president of that organization, she defeated Macdonald by some five thousand votes.

The state had replaced a dynamic leader and nationally recognized authority on rural education with a state superintendent who was not even a college graduate and hence could not qualify for the state's highest teacher's certificate. It was a misfortune for both the rural schools and the farm boys, whose welfare was so close to Macdonald's heart.

\section{ACHIEVEMENTS IN HIGHER EDUCATION}

Because boomers established the state's institutions of higher education, these came into being as an anticipation of needs. Like the railroads, towns, churches, schools, and newspapers, they were to help along a speculative boom, to be symbols of the civilization that was to come, a part of the dream of the future.

So it was that George $\mathrm{H}$. Walsh, a land speculator, secured the University of North Dakota for Grand Forks. Walsh, a typical, freewheeling Dakota boomer, had come to Grand Forks in 1875. He founded the Plaindealer, the town's first newspaper, and then, out to make a fortune, went into land and banking. He was a member of the territorial council and a friend of Alexander McKenzie and Governor Nehemiah G. Ordway. As a part of the intrigue by which Bismarck secured the territorial capital, some of the legislators of northern Dakota drew lots for the other institutional plums. "I took the University,” Walsh recalled years later, "Jamestown the insane asylum and Fargo took the agricultural college. The penitentiary went to Bismarck."

When the convention framed the constitution in 1889, it also divided the spoils. The members from Cass County were determined to have the agricultural college, which, though authorized earlier, had not been 
established because of a lack of appropriations. The members from Burleigh County were determined to keep the capital. Cass and Burleigh combined forces and promised institutions to almost every town in eastern North Dakota, the only portion then settled. So the constitution kept the capital at Bismarck, the university at Grand Forks, and the insane asylum at Jamestown; it gave Fargo an agricultural college, Mayville and Valley City normal schools, Mandan a reform school, Wahpeton a school of science, Ellendale an industrial school, Lisbon an old soldiers' home, Pembina County a school for the blind, Devils Lake a school for the deaf and dumb, and some place in Rolette, Ward, McHenry, or Bottineau counties a school of forestry. The young state had more institutions that it needed.

These were established very slowly. The university had opened in 1884. The normal schools at Valley City and Mayville and the Agricultural College got under way in 1890. But not until the more prosperous times of the second boom did other open: the Industrial and Normal School at Ellendale in 1899, the School of Science at Wahpeton in 1904, the School of Forestry at Bottineau in 1907. Authorized by later constitutional amendments, a normal school at Minot opened in 1913, as did another at Dickinson in 1918.

Since there were few high schools in the state, almost all of the early students began with preparatory work or with practical courses at the Agricultural College. At the university there were only 20 college students and 179 enrollees in the preparatory department in 1888-1889. ${ }^{8}$ As the number of high schools increased, so did the number of high school graduates entering state institutions. Except for those at the university, however, the great majority of incoming students were not high school graduates, even in 1914.

Enrollment rose rapidly. In 1884-1885, the first year, there were only 79 students in the state's one institution; in 1917-1918 there were 3,409 students in eight state institutions. There were 278 graduates before 1900, 2,052 from 1900 to 1910, and 2,430 from 1910 to 1915, a spectacular increase. By 1916-1917 the eight institutions had an income of $\$ 800,000$ (some $\$ 200,000$ from the land grants) and the value of their campuses, buildings, and equipment was over $\$ 3,000,000$.

Expansion can from the prosperity of the second boom and the efforts of able leaders. At Fargo, John H. Worst, president from 1895 to 1916, and a remarkable group of teachers and researchers built an excellent college and experiment state. Born in a log cabin on an Ohio farm, Worst had farmed, taught country school, and homesteaded in Emmons County, North Dakota. He also served as county superintendent of schools, sat in the North Dakota Legislature, campaigned for the Republican party, had been a lieutenant governor before becoming 
president of the Agricultural College. Kindly, patient, and a practical farmer himself, Worst could explain scientific developments to farm audiences without talking down to them.

Worst's predecessor, Horace E. Stockbridge, had gathered a young, enthusiastic faculty: Clare B. Waldron, twenty-four, a horticulturist from Michigan; Henry L. Balley, twenty-four, a botanist from Indiana; and Edwin F. Ladd, thirty-one, a chemist from Maine. They and others were to serve the state well.

At the normal school in Mayville, bearded, experienced Joseph Carhart, with his black skullcap, brought a golden age. He was considered one of the ablest normal-school administrators in the nation. Usher L. Burdick, class of 1900, was long to remember Cathcart's warm interest in him. At Valley City, young George A. McFarland from Chagrin Falls, Ohio, taking charge at thirty-four, made that school a success. At the university, two capable presidents and an aggressive member of the board of trustees gave leadership. Webster Merrifield, a small, bearded, almost shy bachelor professor of Greek at Yale, had come to the university when it opened in 1884 . He served as president from 1891 to 1909 and molded the struggling college into a true university.

Merrifield was aided by his close friend William Budge, a member of the board of trustees from 1891 to 1907. Born in the Orkney Islands, Billy Budge had come to Canada as a youth to work for the Hudson's Bay Company but soon drifted across the border into northern Dakota. He ran a stage station in the Red River Valley, fought Indians, freighted to the Black Hills, and then turned to land speculation. With his partner, Jake Eshelman, Budge acquired considerable land in the Grand Forks townsite. When the Great Dakota Boom swelled the population, he found himself, though barely thirty, one of the wealthy men of the region. He was a big, florid, rough self-made man with a reputation for unscrupulous maneuvering, yet he had a fund of hearty good humor and a respect for the education and culture he himself had missed. His sincere interest in the university (for years he visited Merrifield daily), his aggressive energy, and his close connections with the dominant McKenzie machine contributed to Merrifield's success.

When in 1895 Governor Roger Allin's veto of appropriations threatened the existence of the university, Budge led in raising, by private subscription, the $\$ 26,000$ which saved it. On one occasion he paid its fuel bill (\$700) out of his own pocket. When the second boom made expansion possible, he devised unorthodox methods of securing funds for new buildings-borrowing against the land grant and against future appropriations. The courts, however, soon declared such devices unconstitutional. Governor Frank White, who thought the university was receiving larger appropriations than it needed, once said to Merrifield: 
of Trustees of the University he rides rough shod over the laws of the state and even of the constitution. Technically, he ought to be sent to the penitentiary, but he comes down here at the beginning of each new session, throws his arms around the legislators and gives them a big hug, and instead of prosecuting Billy as they ought, they say, "Oh well, Billy is a good fellow, let's give him what he wants," and that's the end of it.

Thus aided by Budge and other friends, the university survived the depression of the 1890's and then expanded in the second boom. From 1899 to 1915 it put up a dozen buildings. Merrifield, and later Frank L. McVey, built up a faculty of Ph.D. specialists trained in the best graduate schools: Orin G. Libby (history, Wisconsin), Arthur G. Leonard (geology, Johns Hopkins), James E. Boyle (economics and political science, Wisconsin), John M. Gillette (sociology, Chicago), Albert Hoyt Taylor (physics, Göttingen), and George Abbott (chemistry, Massachusetts Institute of Technology). Others, too, were outstanding: Harvard-trained dramatist Frederick Koch, ground-water expert Howard Simpson, mathematician Elwyn Chandler, poet Gottfried Hult, lignite researcher Earle J. Babcock. The faculty was young, energetic, and ambitious.

The creation of professional schools transformed the small liberal arts college into a university: the School of Law (1899), the School of Mines (190l), the College of Mechanical and Electrical Engineering (1901), the Normal College (1901), and the School of Medicine (1905). The library grew from 8,000 volumes in 1899 to 56,000 in 1916. When the preparatory department became the model school for practice teaching in 1908, all sub-college work came to an end except that given in the summer for teachers.

After 1909, President Frank McVey continued Merrifield's work. A Yale graduate like Merrifield (he held a Ph.D. in economics), McVey had taught at the University of Minnesota, had published three books and twenty articles, and had served for three years on the Minnesota Tax Commission. Only thirty-nine when he took over the presidency, he was well over six feet in his English tweeds, bursting with vitality, and a polished speaker. Though somewhat standoffish, he had a flair for administration and an insatiable desire to learn.

McVey emphasized faculty writing. Under his leadership the faculty published twenty books in eight years, and in 1909 the university established the Quarterly Journal to stimulate professorial creativity. The university's academic excellence was recognized when Phi Beta Kappa installed a chapter on the campus in 1914. By 1914-1915, twentythree of the eighty-two faculty members held doctor's degrees; there were seven at the Agricultural College and only three others on the faculties of the various state institutions.

The Agricultural College steadily expanded its offerings: mechanica1 engineering (1897), steam engineering (1898), history and 
social science (1899), pharmacy (1902), veterinary medicine, education, and civil engineering (all in 1908), chemical engineering (1910), and architecture (1912).

All of the state institutions trained teachers. The Agricultural College and the university trained high school teachers; the normal schools and the normal department of the university trained elementary teachers. Yet by 1916 the total number of graduates of the normal schools was only about one-sixth of the number of teachers in the state, and the normals were supplying only about one-eighth of the new teachers employed each year.

The institutions, quite naturally and inevitably, did not serve all parts of the state equally. In 1914-1915 almost 54 percent of their North Dakota students came from the eight counties in which the institutions were located, counties which had only 28 percent of the state's population. The university, the Agricultural College, and Valley City Normal, however, drew students from the whole state.

Probably the most important services of the Agricultural College were the research of its experiment station and the short winter courses in practical agriculture. shopwork, power machinery. and homemaking. In 1915-1916, thirty-nine men were engaged in research, and the work of Edwin F. Ladd, Henry L. Bolley, Lawrence R. Waldrom, and others on a flour milling, flax wilt, the eradication fo the Russian thistle, adulteration, and new varieties of wheat was known throughout North Dakota. The college had five substations and twenty-two demonstration farms scattered over the state; county agents were spreading its influence everywhere. In 1914-1915 the college had 518 students in sub-collegiate short courses and 319 taking college work. Only a third of the college students were in agriculture.

The Agricultural College was disturbed by the firing of its president, John H. Worst, in February, 1916. The efforts of conservatives to control the institution had begun at the meeting which organized the Better Farming Association in November, 1911. The bankers present criticized Professor Henry L. Bolley for his bulletins and addresses exposing the diseased condition of the soil and the prevalence of smut, flax wilt, and potato scab. Such publicity was causing eastern capitalists to question investments in farm mortgages in North Dakota. At that time, North Dakota bankers were obtaining eastern money at 6 percent and lending it to farmers at 10 percent. They naturally wanted Bolley fired or shut up, but Worst defended him.

In sympathy with the attack on Bolley, the board of trustees of the college took control of the experiment station and the extension service away from Worst. On July 1, 1914, they made Thomas Cooper director of both branches and independent of Worst. Cooper was the man the bankers and Twin City interests had made director of the Better Farming Association; it was now merged with the college.

Cooper at once set out to harass Bolley, locking him out of his 
laboratories and depriving him of funds specifically granted to support his research. For four years the experiment station published nothing of Bolley's work. But Bolley, who had been active in exposing the methods by which farmers were cheated by the grain trade, did not resign. After talking with Bolley about the experience a few years later, Upton Sinclair described him as "a long, lean, keen old gentleman, a demon for the hunting out of knowledge, and an untamed champion of the people's cause."

As Cooper harassed Bolley, the board of trustees fired Worst while he was away in Washington in November, 1914; that is, they made Worst president emeritus (he had served the college for twenty years as president) and elected Edwin F. Ladd president. But Ladd would not take the presidency unless the change was acceptable to Worst, and Worst refused to resign.

In January, 1915, the legislature passed a bill setting up a board of regents to control all state institutions of higher education. Until then, each one had had its own board of trustees. Governor Louis B. Hanna appointed only conservative Republicans to the new board. All but one were bankers, and Lewis F. Crawford was the chairman.

In January, 1916, Worst expressed open sympathy for the Nonpartisan League in a widely publicized address; in February he proposed a reorganization of the Agricultural College which would make the directors of the experiment station and of the extension service (Cooper in both instances) subordinate to the president of the college. The proposal was a good one, but the board of regents feared that Worst would use his increased authority to dismiss Cooper. On February 28 it discharged Worst and made Ladd president. Ladd was no conservative and no friend of Cooper, but he had much prestige in the state and could not be ignored. A little later, charges of unprofessional conduct were brought against Professor Bolley. He was exonerated and his accusers dismissed. Although Worst's reorganization plan was accepted, Cooper stayed on as director of the experiment station until 1917, when he became dean of the college. Commenting on the turmoil, Ladd said that the college had been "the football of politics" for seven years. ${ }^{9}$ Yet for all the trouble, its services to North Dakota had continued.

The university also served the state well. Redheaded and enthusiastic Earle J. Babcock, coming to the university at twenty-four, soon made his laboratory "a testing room" for the state. He began to investigate lignite and clay deposits as early as 1890. In 1901 his first report as state geologist, elaborately illustrated and summarizing ten years' research, described North Dakota's vast lignite deposits and optimistically discussed their future possibilities. The Bismarck Tribune called it "one of the best public documents ever issued in the state." 
The investigation of lignite, long continued, was supplemented by other services. The university established a public-health laboratory in 1907; it set up a biological laboratory at Devils Lake and a lignite briquetting plant at Hebron in 1909. Professor Arthur G. Leonard mapped the natural resources of North Dakota. As its secretary, Professor Orin G. Libby made the State Historical Society's library and museum at Bismarck a great storehouse of materials dealing with the state's history; he published many valuable documents in the society's Collections. President Webster Merrifield took the lead in establishing the state's high schools. President Frank L. McVey, desiring to make the university an important factor in the life of the state, said in his inaugural address: "It should be the medium through which statistics are gathered, information collected, advice given, problems solved, in fact a real part of the state government."

The university's greatest service, however, was the high-caliber educational opportunity it afforded the state's young men and women, many of them the children of immigrants from isolated farms and small towns. One student wrote in 1898: "The one thing that is done here is to study; here everyone studies; here everyone talks of study; here the days and hours are laid off in regard to study.” The faculty took a deep interest in the students. Merrifield watched their morals and at one time had several thousand dollars lent out to students without interest. One student wrote: "I hereby pledge President Merrifield that I will not taste intoxicating liquor in any form so long as I am a student at the university." In two years, 1916-1918, Frederick Koch's students wrote twenty-eight plays and produced seventeen.

A few years earlier, Koch had taught Maxwell Anderson, the son of an itinerant Baptist minister. Graduating in 1911, Anderson became one of the most gifted playwrights of contemporary America, the writer of such fine plays as What Price Gory? (with Laurence Stallings), Elizabeth the Queen, Mary of Scotland, and Winterset. Anderson, looking back some fifty years to the fall when he had enrolled, wrote a love letter to the university in 1958. He believed that it had been "a retreat for those more interested in the creation of beauty or the discovery of truth than in making a profit." He thanked the university for being there when he had "needed it so badly": "If I hadn't gone to the university I might have been an unhappy and mediocre banker, farmer, or store-keeper. I'd have gone no farther." 10

The opportunities offered by the university meant much to others as well. Many of its graduates became high school teachers, lawyers, and donors throughout the state. From those of the 1890's came two governors, two United States senators, and two state supreme court judges. On the great football team of 1899 were William Lemke, Lynn J. Frazier (captain), and William L. Nuessle-all to become prominent

${ }^{10}$ University of North Dakota Alumni Review, December 5, 1958. 
state leaders. Seven of the eleven governors elected from 1916 to 1960 were graduates of the university: Frazier, Ragnvold A. Nestos, George F. Shafer, William Langer, John Moses, Fred G. Aandahl, and John E. Davis. Many graduates won prominence outside the state, among them Thomas Campbell, the world's largest wheat farmer; John M. Hancock, president of Jewel Tea Company and a partner of Lehman Brothers of New York; Maxwell Upson, president of the Concrete Pile Company of New York; Charles W. Boise, mining engineer with Selection Trust Limited of London; John S. Lundy, head of anesthesia at the Mayo Clinic; and J. F. T. O'Connor, comptroller of the currency under President Franklin D. Roosevelt.

Unfortunately, North Dakota had too many institutions of higher education, more than it needed or could adequately support, an excess which sprang from each large town's desire to have one. Once established, the newer schools sought to expand their programs, to crowd into fields already occupied by older institutions. So they fought among themselves for students and appropriations. There were not enough of either to go around.

When the normal schools opened in 1890, enrollment at the university fell off. Throughout the 1890's the four institutions fought to stay alive. In 1893, Webster Merrifield wrote Governor Eli C. D. Shortridge that the university was "doomed." The Governor replied: "The Agricultural College will do all they can to defeat you." When Governor Roger Allin vetoed most of the appropriations for high education in 1895, he expected all of the schools except the Agricultural College, which had federal funds, to close. When better times came after 1898, four more schools were established to share the available appropriations. The struggle became so intense that a legislative committee in 1915 found "too great a disposition of those in control of our educational institutions to disregard or forget the financial conditions of this state."

But the blame lay with the state for creating schools for which there was little justification. By 1916-1917, three institutions-the university, the Agricultural College, and Valley City Normal School-had 85 percent of the seventeen hundred students doing college work. The normal schools were largely high schools for the counties in which they were located; at Ellendale, the worst example, the Industrial and Normal School was providing the last two years of high school work for the town. At Bottineau the School of Forestry, finding slight demand for its courses, had become a sort of business college; in 1914-1915 all but eleven of its students came from Bottineau County. At Wahpeton the School of Science, with little or no demand for courses to train skilled workmen (its avowed purpose), was largely a commercial school.

Small classes revealed the overexpansion which prevailed. At the eight institutions during a week in April, 1916, there were 662 class meetings with only four or fewer students in attendance; this was 21 
percent of all class meetings. Some 42 percent of the classes had less than ten students. The Agricultural College and the schools at Ellendale, Wahpeton, and Bottineau had the most small classes; the normal schools at Valley City, Mayville, and Minot had the least. The normal schools, however, had many special courses, preparing specialists in such fields as public-school art, with only a few students.

Overexpansion brought much unjustified duplication. Still admitting eighth-grade graduates in the 1920's, the normal schools duplicated the work of the high schools. The former wanted to train high school teachers and thereby duplicate the work of the university and the Agricultural College in that field, an ambition which was satisfied in the 1920's. The university, in turn, duplicated the work of the normals in training elementary teachers. And the Agricultural College and the university duplicated each other's work in the expensive field of engineering, in which both institutions had many very small classes.

The overexpansion of state institutions made survival difficult for church-sponsored colleges. In 1906 the Methodists' Red River Valley University gave up its independent existence at Wahpeton and became affiliated with the University of North Dakota as Wesley College. Fargo College, the Congregational school, gave up in 1919. Jamestown College had closed in 1893, and its lone building became a ruin, the hilltop campus a pasture. Then came a miracle. Dutch-born, dynamic young Barend $\mathrm{H}$. Kroeze, its new Presbyterian pastor-president, reopened the college in 1909 and began a persistent drive for gifts. His dedication to Christian education secured money from atheist Andrew Carnegie as well as from many North Dakotans. By 1913, Kroeze had erected seven buildings (he had been an architect before his ordination) and had secured an enrollment of 249 students.

Although no state institution closed, overexpansion weakened the stronger ones by diverting funds to the others. Requests from the schools always outran appropriations. On short rations, all were handicapped, and the weaker ones had too many young, ill-prepared, inexperienced, and poorly paid teachers. In 1913-1914 North Dakota was ninth among the states in per capita expenditures for higher education, but overexpansion was robbing it of the quality of education its expenditure could have bought.

There was some realization of the problem. To eliminate duplication and competition, the legislature established a single board of regents in 1915 to govern all of the schools, which had been supervised by separate boards before. The legislature also ordered an investigation of all state institutions of higher education and engaged three outside experts to conduct it: Dr. William T. Bawden of the United States Bureau of Education, Dean Lotus D. Coffman of the University of Minnesota College of Education, and Dr. Edwin B. Craighead, former president of the University of Montana. Although their report took cognizance of the many small classes and tried to eliminate duplication, it came to nothing. 


\section{NEWSPAPERS}

Just as settlement quickly brought churches, schools, and colleges to North Dakota, so, too, did it bring newspapers. Walrus-mustached Colonel Clement A. Lounsberry started the first one, the Bismarck Tribune, in July, 1873. A handsome and enterprising young Minnesota newspaperman, he had seen much bloody fighting in the Civil War and had been made a colonel of a Michigan regiment on his twenty-second birthday. The first train to enter Bismarck brought in his printing press.

It was easy to start a paper. A printer with a shirttailful of type and an old Washington handpress was soon in business, often encouraged by a townsite promoter. Thus William G. Fargo of Wells, Fargo and Company offered a bonus of five hundred dollars for the establishment of a paper to be named the Fargo Express. It appeared on January 1, 1874, the second newspaper in northern Dakota. In 1875, George H. Walsh, a printer then working for a Red River steamboat company, started the Grand Forks Plaindealer, bringing in the printing equipment he had formerly used for the defunct West St. Paul News.

The Great Dakota Boom (1878-1886) brought a flood of newspapers. Most of them were weeklies, but the Fargo Argus, founded in 1879 and financed by James J. Hill, who had just organized the St. Paul, Minneapolis and Manitoba Railroad, was a daily, the first in northern Dakota. It was edited by Alanson W. Edwards. By 1880 northern Dakota had ten weeklies and one daily. In 1881 the Grand Forks Herald became the second daily. George B. Winship had founded it as a weekly in 1879, hauling the press and type by wagon from southeastern Minnesota. At the peak of the boom from one to three newspapers were being established every week. By 1884, Bismarck alone had seven, counting both the morning and evening editions of the Tribune. In 1889, North Dakota had 125 newspapers.

There was a lull in the 1890's, although Major Edwards and Horatio C. Plumley started the Fargo Forum in 1891. Then, in the exciting years of the second boom, many newspapers were born. In 1899 the state had 143 newspapers, nine of them dailies; by 1909 it had 333 papers, including twelve dailies. Newspapers were being published at 267 places in the state, although there were only 211 incorporated towns and villages. Many very small places had papers, and Dogden, with a population of eighty, had two.

The booms created the newspapers, and the newspapers, in turn, did all they could to help the booms. They put out special editions and sent them to the East to advertise the new country. In 1885 the North Dakota Siftings (Minnewaukan) printed an "immigration edition" of ten thousand copies, working fourteen days to run it off the hand press.

Just as many papers were established to promote a town or region, so, too, were they started in order to reap a harvest from publication of the legal notices necessary for proving up homestead claims. The 
railroads, as interested as the newspapers in promoting settlement, kept the editors friendly with free passes. They provided free transportation for newspapermen going on the annual junkets arranged by the North Dakota Press Association. In 1890 the association went to Glacier National Park. ${ }^{11}$

Besides the English-language papers, there were a few published in Norwegian and German. The Norwegian papers Tidende and Normanden were published in Grand Forks, the Posten and Fram in Fargo. The Normanden, with a circulation of 9,216 in 1910, was the most influential. By 1918 the circulation was down to 6,790. It had been founded as a weekly in 1887 and was edited by H. A. Foss. Some of the seven German papers were Der Volkfreund (established at Richardton in 1903), the Deutscher Pionier (established at New Salem in 1905), Der Staats-Anzeiger (Rugby, 1905), and the Nord-Dakota Herold (Bismarck, 1907). In addition to the German-language papers, the Harvey Herald, the Ashley Tribune, the Hazen Star, and others had some pages printed in German, and the Wishek News published a German edition called the Nachrichten. Most of the German papers were short lived, and the NordDakota Herold, a Catholic paper, was moved from place to place, finally being published in Dickinson. The strongest one was Der StaatsAnzeiger, an interdenominational paper with a circulation of 2,538 in 1910.

German newspapers flourished during the first decade of the twentieth century. They stressed Americanization, religion, and education and helped Germans to find land and to become citizens. Frank L. Brandt, editor of Der Staats-Anzeiger, moved it from Rugby to Bismarck in 1912. When the First World War came, anti-German feeling made trouble for the German papers. Some died, and the Nord-Dakota Herold was printed for a time in English. But Brandt, though threatened, refused to print in English. The front of Der Staats-Anzeiger plant was twice painted yellow. By 1934 the only German-language newspapers still being published were the Nord-Dakota Harold and Der StaatsAnzeiger.

North Dakota newspapers presented a varied picture. All were heavily political. Most were Republican, although there were a few outspoken Democratic papers. such as the Bathgate Pink Sheet, the Bowman County News, and the Minot Democrat. In the 1890's the

${ }^{11}$ Important sources on newspapers are George B. Winship, "Newspapers of the Red River Valley,” in History of the Red River Valley: Past and Present (2 vols.; Grand Forks: Herald Printing Company, 1909), I, 44l-449; Wendell W. Norris, "The Transient Frontier Weekly as a Stimulus to Homesteading," Journalism Quarterly, XXX (Winter 1953), 44-48; John C. Sim, “The History of the North Dakota Press Association, 1886-1940” (Unpublished M.A. thesis, University of Minnesota, 1940); Fred W. Gross, "Type and Nature of the German Publications in North Dakota” (Unpublished M.A. thesis, University of North Dakota, 1934). 
Jamestown Alert and the Steele Ozone supported William Jennings Bryan and free silver. Newspapers were established, combined, moved from one town to another, and sold with rapidity. Many soon disappeared.

Newspapers reflected the rough society of which they were apart. The early Bismarck Tribune was full of advertisements placed by saloons, dance halls, and sporting houses. Social items in the Grand Forks Herald sometimes implied haste in weddings and spoke frankly and often uncomplimentary of the personal affairs of its readers. Alcoholics were "drunks" and Negroes "coons" in its columns. In all papers, scandal and stories of rape, murder, and divorce were common. All were free speaking and all fiercely loyal to their towns and localities.

The newspapers displayed enterprise in fulfilling their functions. The weeklies, most of them with circulations under one thousand, had patent insides, but they subscribed to a Washington letter and gave some national and world news. The dailies belonged to the Associated Press and other news services. The largest came to have substantial circulations and a considerable investment; the Grand Forks Herald was capitalized at \$100,000 before 1909 and had its own large building. All did job printing. By 1890 there were 207 imprints in North Dakota, books, pamphlets, and broadsides, and 64 places had printing presses.

The largest and most influential papers before the First World War were the Grand Forks Herald, the Fargo Argus, and the Fargo Forum. The Argus, after prospering for a time under Major Alanson W. Edwards, was absorbed by the Fargo Morning Call about 1898. The Herald's circulation declined after the founding of the Grand Forks Evening Times by a pro-McKenzie group headed by Senator Henry C. Hansbrough in 1906. In 1910, the leading dailies in circulation were the Fargo Forum with 12,694, the Grand Forks Herald with 10,427, and the Minot Optic with 4,150. Five places had two daily papers each in 1910: Valley City, Minot, Jamestown, Grand Forks, and Fargo. The circulation of many dailies was quite small. That of the Devils Lake Journal, then a Democratic paper, was only 1,800, and that of the Valley City TimesRecord was estimated at 1,000.

In the years up to about 1910 the leading newspapermen in the state were Alanson W. Edwards, George B. Winship, Horatio C. Plumley, John J. Jordan, and Marshall H. Jewell. All came from states farther east, where they had learned the printer's trade as young men and had worked on a number of papers. All were interested and active in political life. Edwards, born in Ohio, had served in the Civil War, taking part in Sherman's march to the sea and becoming a major at twenty-four. Before he came to Fargo in 1878 to start the Fargo Republican, he had run a newspaper in Illinois, had been a warden of the state penitentiary in Joliet, and had taken part in the Black Hills gold rush. A big, overweight, restless, belligerent editor with the walrus-mustache of the time, he was backed on the Fargo Argus by James J. Hill and was allied with 
Alexander McKenzie. He became an important man in Fargo: mayor, superintendent of the territorial census, and member of the legislature. A companionable fat man, Edwards lived in a big ten-room house, had a large library, drove a spirited race horse, like to read Robert Burn's poems and Dickens' Pickwick Papers aloud to his large family (six boys and one girl), and, proud of having been with Sherman, relished the song Marching Through Georgia. He left Fargo in 1900 to become United States consul at Montreal, but retained an interest in the Forum until his death in 1908.

Edwards' associate of the Argus and later on the Forum was Horatio C. Plumley, a Vermonter who had learned the printer's trade while working as "devil" on paper in New York State. A Republican, Mason, president of the state press association, and holder of state offices, he managed the Forum for many years.

George B. Winship of the Grand Forks Herald, a follower of Robert M. La Follette of Wisconsin, had started the revolution of 1906, which broke McKenzie's power. He retired in 1911 and moved to California.

John J. Jordan was associated with a series of newspapers in Fargo. He purchased the Republican in 1883 and sold it to Edwards in 1895, when it was combined with the Forum. He then served as editor of the Argus until 1898, when he founded the Morning Call. A strong-minded man and a good moral influence, Jordan was born in Canada, the son of a blacksmith, and had worked in the mechanical department of the old Minneapolis Atlas and its successor, the Tribune, for twenty-one years before coming to Fargo.

Another important newspaper editor was Marshall H. Jewell of the Bismarck Tribune. Born in New York State, the son of a newspaperman, he early learned the printer's trade and worked on Chicago papers before coming to Bismarck in 1878 to help Clement A. Lounsberry with the Tribune. Jewell bought the paper from Lounsberry in 1884 and published it until his death in 1911. Edwards wrote of him in 1889: "Jewell is the model newspaperman of North Dakota; modest, pleasant, affable and accommodating, he has no superior in the niche he occupies.” Like Edwards, Jewell was an ally of McKenzie and active in Republican politics; he was secretary of the Republican state committee in 1893 and again in 1896. The Bismarck Tribune did much printing for the state government. In 1903, for example, it had more than thirteen thousand dollars' worth, or almost 60 percent, of the public printing. The Tribune had a circulation of about two thousand in $1910 .{ }^{12}$

\section{WRITERS AND BOOKS}

Most of the writing done in and about North Dakota appeared in the

${ }^{12}$ Biographical sketches of some newspapermen are in Compendium of History and Biography of North Dakota (Chicago: Geo. A. Ogle and Company, 1900). 
newspapers, but actually it all began with the arrival of white men in the region. The first literary effort sprang from curiosity about the strange country and a desire to record adventures there. The Sieur de $\mathrm{La}$ Vérendrye, the first white man to visit the area, came because of his curiosity about rumors of a westward-flowing river. His report, compiled in 1739, is the oldest written record dealing with North Dakota. Thomas Jefferson's curiosity about the western country led to the Lewis and Clark Expedition. Its journals, containing more information about North Dakota than any other portion of the expedition's route, were first published in 1814. They were the first widely circulated and detailed account of the region.

A number of other men matched Lewis and Clark in keeping journals of their travels in North Dakota. Some were naturalists, some fur traders, some sportsmen. In 1811, Henry M. Brackenridge, a young lawyer from St. Louis, accompanied Manuel Lisa to the Knife River villages; his Journal of a Voyage up the Missouri, Performed in 1811 (1814) describes keelboat travel. Romantic artist George Catlin visited Fort Union in 1832; his book North American Indians (1841) is profusely illustrated with reproductions of his paintings. Many others kept records which were later published, preserving myriad details: John Bradbury. a Scottish botanist, came in 1811; Thomas Say, geologist and zoologist, in 1823; John James Audubon, world-famous ornithologist, in 1813; John Palliser, an English sportsman, in 1818-1849; and Henry Boller, an adventurer, from 1858 to 1866.

The most valuable description was written by Maximilian, Prince of Wied. A German scientist, he had dreamed on the battlefields of the Napoleonic Wars of discovering new species of plants and animals in the New World. Making up a very important part of his book Travels in the Interior of North America in the Years 1832 to 1834 (German edition, 1839-1841; English translation, 1843) is an account of a winter spent at the Knife River villages. Maximilian's companion was a young Swiss artist, Karl Bodmer, who made an outstanding series of paintings and drawings of' the Indians. D during the winter, he and Maximilian lived in a cabin within the stockade of Fort Clark. Before spring, Maximilian, a slender man with some of his teeth missing (he wore a black velvet coat and extremely greasy trousers), nearly died of scurvy, but he had recorded his observations of the Indians, a significant contribution to science.

Men like Audubon and Maximilian were only visitors, but the fur traders, more or less permanent residents, were also moved to record the adventurous life of which they were a part. David Thompson, Charles Chaboillez, Alexander Henry, Charles MacKenzie, John C. Luttig, and Francis A. Chardon kept journals. These were not, of course, published until many years later. One trader even wrote his reminiscences in his old age: Forty Years a Fur Trader on the Upper Missouri: The Personal Narrative of Charles Larpenteur, 1833-1872 (1898), a two-volume work 
edited by Elliott Coues. And Father George A. Belcourt produced a Chippewa grammar which was published in 1839.

The establishment of military posts in the North Dakota region brought in a new group, some of whom wrote accounts of what they saw. At Fort Stevenson, General Philippe Régis de Trobriand, a French-born officer in the United States Army, kept a diary and made sketches. At Fort Abraham Lincoln, while his fellow officers drank and played cards, Colonel George A. Custer (he was brevet major general of volunteers), the hard-riding and abstemious commander of the Seventh Cavalry, wrote articles for Galaxy, a popular monthly. They appeared later in book form as My Life on the Plains (1874). After Custer's death at the Little Big Horn, his widow, Elizabeth Bacon Custer, wrote Boots and Saddles; or, Life in Dakota with General Custer (1885). It became a classic.

Stationed at Fort Buford for six years, Dr. Washington Matthews, an army surgeon of genuine scientific bent, compiled Grammar and Dictionary of the Hidatsa (1873) and Ethnology and Philology of the Hidatsa (1877). A friend of Matthews and also an army doctor, Elliott Coues did much research on the bird life of the state. He was secretary and naturalist of the United States Northern Boundary Commission, 1873-1876. Later he edited and arranged for the publication of many early journals, such as those of Alexander Henry and David Thompson.

Each phase of North Dakota life produced a literary counterpart. Thus Theodore Roosevelt turned his adventures in the Badlands into a book entitled Ranch Life and the Hunting Trail (1888). But Joseph Henry Taylor's record was more unusual. After a stint as a soldier in the Civil War, young Taylor, a Quaker printer from eastern Pennsylvania, published a Democratic newspaper for a short time at Yankton. Then, in 1869, he took up a career as a hunter and trapper in the Painted Woods region north of Bismarck. Twenty years later, though a shy, retiring man, he began to put his experiences into a series of books, composing them as he set the type by hand, then printing and binding them. In this way he published Sketches of Frontier and Indian Life (1889), Twenty Years on the Trap Line (1891), Kaleidoscopic Lives (1902), and Beaver: Their Ways and Other Sketches (1902). Taylor died in 1908 in his small printing shop at Washburn.

North Dakota writing was largely a description of experiences, but as the period of frontier adventure passed, some men began to produce works of fiction and other types of literature. H. A. Foss, editor of the Norwegian Normanden, wrote romantic novels. Farmer-poet Jon Norstog wrote long biblical dramas in Norwegian-Moses, Israel, and Saul-setting them in type by his own hand and printing them on his own press in a shanty on the prairie. ${ }^{13}$

${ }^{13}$ Lincoln Colcord, Introduction to Giants in the Earth, by O. E. Rölvaag (New York: Harper and Brothers, 1927), p. xxxiv. 
In the years before the First World War, North Dakota's one professional literary man was James W. Foley, the poet laureate of the state. A slender, friendly, precocious youngster, he grew up at Bismarck and Medora and began to punch cattle on the range. Foley was more interested in writing poetry, however, and when the Bad Lands Cow Boy published some of his verses, other publications reprinted them. The New York Times sent him his first literary check in 1889 when he was only fifteen. In few years he was working for Marshall $\mathrm{H}$. Jewell on the Bismarck Tribune and selling his poems to the Youth's Companion, the Saturday Evening Post, and other national magazines. The Bismarck Tribune published the first volume of his poetry soon after 1900. Foley became a greatly beloved person. His most famous poem, "A Letter Home," was written in 1906 for a special immigration edition of the Fargo Forum and celebrated the wholesomeness and freedom of the state. Foley himself, however, moved to California about 1915 to become poet-columnist for the Pasadena Star-News; he became one of the most popular speakers in that state. In 1924, North Dakota began to celebrate his birthday as "Foley Day," to be observed annually; in 1926, Foley wrote "North Dakota," later adopted as the state song. Before he died in 1939, he had turned out thirteen volumes of folksy, optimistic poetry.

\section{READINGS AND LIBRARIES}

Reading matter came to the northern Dakota country with the first white men. At the Knife River villages in 1796, John Evans borrowed European magazines from the British traders then crossing the prairies from the Assiniboine forts. Alexander Henry had a library of sorts at his Pembina post soon after 1801, and the keelboats and steamboats ascending the Missouri carried newspapers, books, and magazines. The military posts had books; Generals George A. Custer and Philippe de Trobriand, as well as many another officer and enlisted man, liked to read. Farming settlers brought books with them, sometimes substantial libraries. The Norwegians, a reading people, packed books in their trunks before setting out for the New World. In some of their settlements in North Dakota, the books in the public libraries were mostly in Norwegian. Others also loved books; R. B. Griffith, pioneer Grand Forks merchant, built up a large private library. And Bismarck had a bookstore in the 1870's.

Reading was a habit in early North Dakota. It was long the custom in Icelandic families to sit around the fireplace during the long winter evenings, the mother knitting, the father reading aloud from some saga or modern Icelandic poet. Every community had some well-educated men and women who were eager to re-create the cultural fabric of the older parts of the country. They soon set up theaters, lecture circuits, music groups, literary societies, and study clubs.

Libraries grew out of such activities. Women's clubs provided their 
members with books and magazines. In Grand Forks and Fargo the Young Men's Christian Association had reading rooms. Sometimes local chapters of the Farmers' Alliance maintained small libraries. By 1882, Fargo had two library associations, and in 1893 the Masonic Library was established there.

The public-library movement, however, came to North Dakota with the expansive, optimistic days of the second boom (1898-1915). Grafton, inspired by Almon L. Woods, county superintendent of schools and copublisher of the Walsh County Record, established the first public library in North Dakota in 1897 when the town took over the library of a private association and agreed to support it. At Grand Forks the federation of women's clubs promoted a library which opened in 1900 in two rented rooms. That same year, both Fargo and Valley City voted for one-mill tax levies to support libraries. Other towns followed, and by the end of the First World War every large town in the state had a public library.

Philanthropy provided an effective stimulus to the founding of such libraries. In 1898, Andrew Carnegie, the steel multimillionaire of Pittsburgh, announced that he would donate a library building to any town which would agree to support a public library. As the boom expanded in North Dakota, many towns made applications to Carnegie. He gave both Fargo and Grand Forks library buildings costing \$20,000 in 1901, and in the years which followed he gave smaller libraries to Valley City, Grafton, Dickinson, Devils Lake, and Minot. His last gift in North Dakota was a \$25,000 building in Bismarck in 1916. By that time he had given over \$190,000 for eleven library buildings in North Dakota: eight to towns for public libraries and three to colleges (the University of North Dakota, the Agricultural College, and Fargo College). Carnegie donated twenty-five library buildings to South Dakota, fifty-five to Minnesota, and seventeen to Montana, but in those states the gifts were usually smaller.

Other financial contributions also aided the founding of public libraries, generally on the same terms as the Carnegie grants. The Grandin brothers, wealthy bonanza farmers, gave Mayville \$8,000 for a library building in 1899. Alfred E. Dickey donated \$20,000 for a library at Jamestown in 1918, and D. Willis James gave Williston the same amount. In 1919, Orrin A. Leach contributed \$25,000 toward a library building in Wahpeton.

By 1920 all of the larger towns had public libraries. The provision of library service in rural areas, however, was much more difficult. In such cases library associations frequently made collections of books and opened reading rooms. Fifty-eight small libraries of that sort were in existence by 1920. Some had financial support from towns, usually less than five hundred dollars, and sometimes free quarters and heat. Such libraries, often short lived, with their small collections and circulation, gave only a poor reading fare to the rural population. Towns with less that twenty-five hundred people lacked the population and tax base to 
support and adequate public library.

One solution was a centralized library to serve the rural population of the whole state. In 1907 the leaders of the North Dakota Library Association persuaded the legislature to establish the Public Library Commission (renamed the State Library Commission in 1920). Since 1897 the superintendent of public instruction, Walter L. Stockwell, had been sending out traveling collections of forty to sixty volumes to each county superintendent for use in the rural schools. He now turned the three thousand volumes of his office's educational reference library and also the traveling libraries over to the Public Library Commission. The commission organized a legislative reference bureau, aided the town libraries, and set up a system of traveling libraries, sending out sixtyvolume wooden cases of books. These would be kept in some central place-a school, a home, a store, a post office, or a bank-for a period of six months.

The demand for books was highest in the winter months, when farmers had time to read. The Public Library Commission supplied many people with free reading matter, but appropriations for its work were modest and the demands upon it were more than it could meet. The introduction of parcel post in 1912 was a great boom to books by mail. By 1918 the Public Library Commission had 324 traveling libraries in circulation. In 1922, however, the libraries of towns with more than twenty-five hundred people had 80 percent of the library circulation in the state, although such places had only 14 percent of the population. What North Dakota needed was a system of public libraries supported by larger governmental units than towns. A county-library bill was introduced in the legislature in 1921, but it failed to pass. ${ }^{14}$

${ }^{14}$ Glenn L. Brudvig, "Public Libraries in North Dakota: The Formative Years, 1880-1920” (Unpublished M.A. thesis, University of Minnesota, 1962), pp. 3-119. 


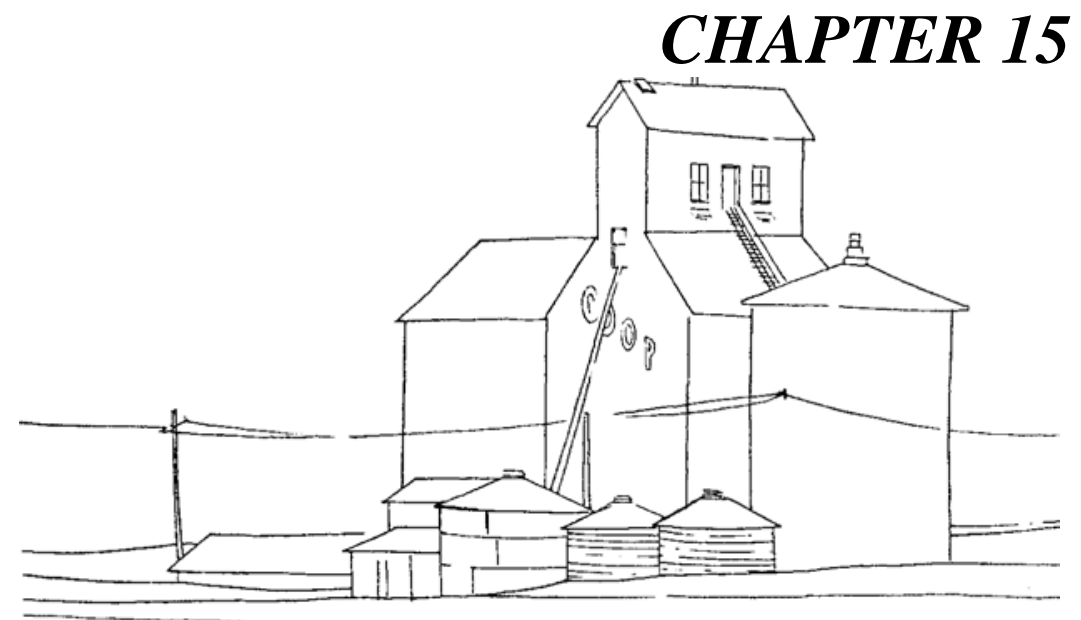

\section{The Great Socialist Experiment}

THE RISE OF THE NONPARTISAN LEAGUE was but another chapter in North Dakota's revolt against its dependent, exploited status. First the Farmers' Alliance and then the Populist, progressive, and Equity movements had won wide support and some success. McKenzieism had been overthrown, a multitude of reforms had been enacted, and cooperative rural elevators and a cooperative terminal marketing agency had been built. All of this was accomplished before the birth of the Nonpartisan League. Thus when Arthur C. Townley organized the League in 1915, he was aided by a long history of revolt against exploitation by outside interests. Townley won a great victory: the League gained control of the state government and enacted its program.

But Townley's far-reaching schemes for socialistic enterprises, the host of Socialists and other extremists about him, his preaching of hatred against local businessmen, and, finally, doubts about the integrity of some of the league leaders-all of these things turned thousands of early supporters away from the Nonpartisan League. To many, Townley and his socialist experiment came to mean, not a sound program against outside domination, but class war within the state and a new kind of alien control. So, for all their talents as agitators and for all their devotion to the farmers' cause, Townley and William Lemke, his chief lieutenant, became, ironically, the principal obstacles to public approval of the League. Mismanagement of state industries and the boycott of their bonds by eastern capitalists also contributed to its downfall.

In the end, the League gave the state a number of reform laws in the progressive tradition, the Bank of North Dakota, and, though it was not completed under League control, the State Mill and Elevator at Grand 
Forks. These were significant achievements, lessening somewhat the state's exploitation, but they were by no means the system of state enterprises planned by the League and authorized by the laws of 1919 . Nor did they greatly alter wheat-producing North Dakota's fundamental problem of dependence on outside interests. Measured by its larger goals, North Dakota's great socialist experiment, like other agrarian revolts, was a failure. History seems to show that all producers of raw materials everywhere, in spite of all their struggles, have always been dependent upon and exploited by the producers of finished products.

\section{TOWNLEY AND THE SOCIALIST PARTY}

Although the Nonpartisan League was born of long-standing grievances, it was also the creation of one man-Arthur C. Townley. He was born and raised on a farm in Brown's Valley, Minnesota, graduated from high school at Alexandria, read voraciously on politics and economics under the tutelage of a radical tailor, and taught country school. In 1907, at the age of twenty-seven, he began to farm in the Golden Valley country near Beach, North Dakota. He soon plunged in flax, borrowing heavily for power machinery. When in 1912 an early frost and a break in flax prices wiped out his returns, he went bankrupt with debts of eighty thousand dollars. An embittered Townley turned to socialism. In November, 1913, the Socialist party of North Dakota, recognizing his talent, hired him as an organizer in the western counties.

Socialist activity had begun in North Dakota in 1900 when Arthur Basset organized a socialist club in Fargo. Many Norwegian immigrants had leftist sympathies and were socialists when they came to the Red River Valley; in Norway, socialism was a rural phenomenon. In 1902, Basset, Arthur LeSueur, and others organized the Socialist party in North Dakota. LeSueur, a dynamic young lawyer, became the bestknown Socialist in the state when he was elected president of the Minot City Commission in 1911. The Socialists ran candidates for state and local offices, polling some seven thousand votes (about 8 percent of the total) at their peak in 1912. Minot was the center of Socialist activity; Ward, Bottineau, Rolette, and Williams counties cast the most Socialist votes. The party was weakest in German Russian counties, such as McIntosh and Emmons.

The Socialists had considerable success. They brought in many outside speakers; Eugene V. Debs spoke at a large antiwar rally ("red to the core," he called it) at Garrison in 1915. By 1912 there were 175 Socialist locals in the state. Many Republican weekly newspapers had "Socialist departments"; Rugby and Hillsboro elected Socialist mayors. In 1912 the party established a weekly paper, the Iconoclast, at Minot. It attacked and ridiculed the National Guard, the Reserve Officers' Training Corps at the University of North Dakota, the Boy Scouts ("hired hessians of capitalism"), and a deity which presided unfeelingly over capitalist injustice. It upheld the violent Industrial Workers of the 
World.

The right wing, however, generally controlled the party, and it was interested in a moderate reform program that would attract popular support among farmers. In North Dakota the party dropped collective ownership of land and adopted a platform, the work of LeSueur, of immediate demands: state-owned flour mills and terminal elevators, rural-credit banks, and state-financed hail insurance. ${ }^{1}$ Such proposals, of course, were not pure socialism; they represented a Socialist shift, in both the state and nation, to the right to meet the challenge of progressive reform. Henry G. Teigan, a clever and ambitious man, led the shift in North Dakota; he became secretary of the party in 1913 and editor of the Iconoclast in 1914.

Under Teigan, Townley began organizing in the western counties late in 1913. He soon saw that the farmers liked the platform but not the party, and he also noted that the organizer needed to get to the individual. More money, more organizers, and more Fords; less emphasis on the party, more on reforms-these were the needs. So, in 1914, Townley created the "organization department." He persuaded some friends to put up the money for a Ford, and set to work in Bowman County. He talked to the farmers individually. He did not tell them that he was a socialist organizer, but charged each a dollar a month to become a member of the organization department, accepting postdated checks. At a certain stage he would move on to another county, find money for another Ford, and send another organizer with a Ford back to finish the work in the county he had opened up.

Townley had phenomenal success; in a few months he had covered nine counties and bought four automobiles. Although he distributed Socialist literature, the Socialist party denied his organization department any official recognition. On December 15, 1914, the party fired Townley and three organizers for having worked in Renville and Bottineau counties after they had been ordered to stop. ${ }^{2}$

\section{THE BIRTH IF THE NONPARTISAN LEAGUE}

Disgusted and at loose ends, Townley went to Bismarck and watched the legislative session of 1915, which killed the proposal for a stateowned terminal elevator. Amendments to the constitution authorizing such an elevator had already been passed by the legislature and approved by the voters. The 1913 legislature had levied a special one-eight mill tax for it and had asked the state board of control to report plans and recommendations for its construction. In 1915, however, the board's report sensibly pointed out that an elevator built in Minnesota or

${ }^{1}$ Theodore Saloutos, “The Rise of the Nonpartisan League in North Dakota, 1915-1917,” Agricultural History, XX (January 1946), 47.

2Jackson K. Putnam, "The Socialist Party of North Dakota, 1902-1918" (Unpublished M.A. thesis, University of North Dakota, 1956), pp. 23-143. 
Wisconsin would be controlled by the grading standards of those states. It recommended leasing a terminal elevator instead of building one. Leasing would permit an immediate start and save expense. Moreover, the one terminal elevator proposed could not end the dominance of the Minneapolis Chamber of Commerce. Governor Louis B. Hanna, though he had originally proposed the constitutional amendment to authorize a state-owned elevator, now opposed it.

As the 1915 legislature considered the bill for the elevator, the North Dakota Union of the American Society of Equity held its annual convention in Bismarck. The convention endorsed the bill and marched to the capital to present its demands. At an Equity rally the night before the vote on the bill, hotheaded George S. Loftus, the sales manager of the Equity Cooperative Exchange, bitterly denounced the report of the state board of control and named the legislators whom he expected to vote against the elevator bill. His ugly, passionate abuse may have turned some undecided legislators against it, and the next day it was decisively beaten.

The Equity convention quickly became a protest meeting; angry farmers argued long and bitterly with legislators. During one such argument late at night, Treadwell Twichell, a house member, was reported to have told the farmers that the running of the state was none of their business and to have jocularly advised them to "go home and slop the hogs." Twichell denied ever having said it, but the phrase became a fighting slogan of the Nonpartisan League.

As Townley saw the anger at the defeat of the proposal, he decided to form a new farmers' organization. From his experience with the Socialist party, he would take the platform of state ownership, his own organizing techniques (individual solicitation, paid organizers, Ford cars, high dues, and the postdated check), and hatred for the business classes. He would keep the League within the Republican party, using party loyalty to give the League control of state government after his well-organized minority had won in the primary election.

While at Bismarck, Townley discussed his plan with his friend A. E. Bowen, a former schoolteacher and one-time Socialist candidate for governor, and also with Fred B. Wood. Genial and respected, Wood was a Socialist, a director on the board of Equity, and a successful farmer near Deering but in Ward County. He told Townley to come out to his place in the spring and they would get the new organization started. Unable to wait, Townley showed up at the Wood farm late in February. Talking late into the night, he sold his plan to the Woods-Fred, about fifty, and his two grown sons, Howard and Edwin.

They scribbled a brief platform on a scrap of paper: state ownership of terminal elevators, flour mills, packing houses, and cold-storage plants; state inspection of grain and grain dockage; exemption of farm improvements from taxation; state bail insurance on an acreage-tax basis; and rural-credit banks for low-interest loans. Early next morning, 
Howard Wood and Townley started out in a bobsled to talk to the neighbors. Wood did the introducing; Townley gave the sales talk. This became the standard technique: a "convert" in the township went along with an organizer as a "booster" to break the ice with his neighbors. It was very successful.

The Nonpartisan League grew rapidly. With the help of the Woods, Townley bought a Ford. Then, as the League mushroomed, he recruited a staff of Socialist organizers (old friends and men brought in by advertisements in Socialist and labor papers) and bought dozens of Fords. He trained them in applied psychology-how to get the farmers' interest, how to put ideas across, how to arouse emotions, and how to secure payment of dues. The organizers swarmed out over the state, avoiding the towns and going from farm to farm. They preached hatred of "Big Biz," and painted local businessmen-the grain buyer, the cream buyer, the merchant, the banker, and the stock buyer-as the minions of eastern interests. And they took the farmers' money: dues of six dollars a year and eventually eighteen dollars for two years. High clues paid the heavy expense of person-to-person organization and gave the members an economic stake in the League. If the farmer could not pay cash, the organizer accepted a postdated check.

The Nonpartisan League was a blend of socialism and high-pressure salesmanship. It stirred up and used the old hatreds and feelings of exploitation, but it also succeeded because Townley was an un usually talented agitator. Thirty-five in 1915, he was a slender, intense man with dark hair and a large nose. He was frequently profane, and although no polished orator, he spoke the farmers' language fluently; his strong, resonant voice moved his listeners with his own emotions. In 1915 and 1916 he was speaking everywhere crowds could be gathered. A man of imagination and courage, he aimed at a solid organization which would trust its leaders, enter the Republican primary, gain control of the state government, and enact its program. The farmers did not organize themselves, but, as Townley recalled years later, "they woke up one morning and found themselves organized.”

The League was strengthened by having its own newspaper, the Nonpartisan Leader, published weekly in Fargo. Charles Edward Russell, a well-known Socialist writer, helped put it out, and the Leader carried many cartoons by John M. Baer ridiculing Big Biz. Through the Leader, Russell and the others kept the members sold on the organization. "Do not believe anything you read about it," warned Russell in an early issue, "unless you read it in your own journal or in journals that you know are absolutely with you.” By the winter of 19151916, the Leader had a circulation of nearly thirty thousand, about double that of the largest newspaper in the state.

Not all hailed Townley as a savior, though none denied that the farmers had long-standing grievances. The Grand Forks Herald and the Fargo Courier News (until it was purchased by the League in 
November, 1916) were the leading newspapers against it. Such papers liked to call the League leaders "a lot of soreheads" or "bellyachers." Opponents were always saying that the farmers, "six-dollar suckers," were being "gypped"; they suggested that there must be mishandling of the large sums which the farmers were pouring into the League treasury. They also called the League undemocratic because all authority rested with a self-elected executive committee of three: Townley, Fred Wood, and William Lemke.

As the League grew, Townley came to depend more and more upon the talents of Lemke. Born of German stock in Minnesota in 1878, Lemke had grown up on his father's farm in the Big Coulee country of Towner County. Although the family knew pioneering struggles, his land-hungry father had acquired 2,700 acres before dying of apoplexy when he was outbid for another piece of land. One of nine children, William, a shy boy on the lonely prairie, longed for an education. He attended the University of North Dakota, graduating in 1903, and gained the confidence of his professors and especially of President Webster Merrifield. As a serious, ambitious undergraduate, he took part in the debates of the literary societies; he also won a reputation for grit on the football field, although he was only five feet eight and weighed only 149 pounds. Many of his teammates-William L. Nuessle, Olger B. Burtness, Lynn J. Frazier-were to become leaders in the state; they were also members of the Varsity Bachelor Club, which was to aid Lemke in his later career. Lemke then studied law at Georgetown University and at Yale. He began to practice in Fargo in 1906.

Lemke became an intense, bitter, tenacious fighter for the plain people against the hated interests; he was a natural extremist, in Edward C. Blackorby's phrase a "prairie rebel." His hard, tough appearance was unprepossessing; he had lost an eye in a boyhood accident. His face was rough, his big jaw determined, his clothes rumpled. Versatile and emphatic in speech, the language of the threshing crews as well as that of the courtroom came naturally to him. He neither smoked nor drank. When the occasion demanded, he could drive himself unsparingly with a terrible concentration. He was brilliant, a good organizer, ambitious and aggressive, eager for power, a natural promoter and dreamer, an ultranationalist, and an Anglophobe. Until America became involved in the First World War, his friends called him "the Dutchman."

He began in politics, like so many of his university classmates, as a La Follette progressive. Growing up where everyone belonged to the Farmers' Alliance, he came naturally to hold the attitudes of debtor farmers: a hostility to bankers and the moneyed interests. About 1911 he found employment as an attorney for the Equity Cooperative Exchange through its president, John M. Anderson, Lemke's friend from university days. He soon made friends among agrarian leaders (the fiery Loftus impressed Lemke) and acquired a reputation as the farmers' friend. While working for Equity, Lemke became acquainted with Fred 
Wood, and Wood suggested him to Townley. Early in 1916, Lemke, then virtually bankrupt, became a salaried employee of the Nonpartisan League and soon a member of the executive committee. The League became a religion to Lemke.

By the winter of 1915-1916 the League was riding the crest of a wave of almost fanatic enthusiasm; when snow flew, it had some twenty-six thousand members. Its headquarters at Fargo was sending out top-notch speakers to dozens of meetings all over the state; farmers were driving miles over the prairies to hear them. They were shouting the League slogan, "We'll Stick," and meaning it. Farmer solidarity was Townley's great achievement and the key to League success.

As the League grew, the Socialist party in North Dakota declined; its members were dropping out to join the League. In February, 1916, Henry G. Teigan resigned as secretary of the party and editor of the Iconoclast to become secretary of the Nonpartisan League, a position he held until the League's collapse in 1923. In July the Iconoclast stopped publication. By 1917 almost all of Townley's “ace organizers” were former Socialists, and all of the Socialist leaders in North Dakota were active and influential in the League. The Socialist party was dead in the state; in the spring of 1918 its last secretary, H. R. Martinson, sent the books and records to the national Socialist headquarters and joined Townley.

\section{THE FIRST LEAGUE VICTORY}

The League's first success came in the primary election of June, 1916, when it sought Republican nominations for its candidates. Like the McKenzie machine, it wished to benefit from the solid loyalty of North Dakotans to the Republican party. A state convention, meeting in Fargo, nominated a slate for the state offices. Townley opposed selecting either office seekers or League officials. The convention, however, endorsed three avowed candidates: William Langer for attorney general, Thomas Hall for secretary of state, and Carl R. Kositzky for state auditor. These men were all progressives and all had expressed their agreement with the League program, but they were to turn against it in 1919. The other candidates, excluding those for the North Dakota Supreme Court, were all farmers and all Republicans except P. M. Casey, a Democrat, who was endorsed for state treasurer. Most of the candidates were friends of William Lemke.

Lemke had known Langer when they were students at the University of North Dakota. By 1911, Langer and his father had invested and lost $\$ 50,000$ in Lemke's scheme for land speculation in Mexico. Lemke’s Land Finance Company, organized in 1906, invested $\$ 400,000$ in 550,000 acres in the state of Sinaloa, Mexico, but the Mexican Revolution wrecked Lemke's hopes of settling American colonists on the land.

Lemke and Langer were much alike in background, outlook, and 
ambitions. Langer was born on a farm near Casselton on September 30, 1886. His parents were of German stock, and his father, Frank, served in the first state legislature. Frank Langer prospered. His son-a keen, energetic lad with a knack, even at fifteen, for handling men-graduated from law school at the University of North Dakota in 1906, passed the bar examination, and then, too young to practice, enrolled in Columbia University. Four years later he had won the Roelker Medal as the outstanding student, received a B.A. degree, and was president and valedictorian of his class. He was chosen by his classmates as "the biggest politician, noisiest student, most popular man, and the most likely to succeed." 3

After fruitful years in New York City (one evening he met Lydia Cady, his future wife, at a concert; her father was the architect who designed the Metropolitan Opera House), Langer returned to North Dakota and began to practice law in Mandan in 1911. He was a brilliant, ambitious young attorney: six feet tall and weighing some two hundred pounds, aggressive, handsome, and self-confident. With his powerful frame, his high forehead and searching eyes, his determined jaw, he was a picture of easy, confident strength. With a genial, warmhearted spirit, he had a talent for friendship and apparently a sort of instinct for the popular medium of human emotions and loyalties in which a politician works.

In 1914 and only twenty-eight, Langer campaigned for state's attorney of Morton County, beating the bootleggers in the wide-open county by means of a person-to-person canvass. On his first day in office he swore out 167 warrants for the arrest of liquor dealers and vice operators. After cleaning up the county, Langer sued the Northern Pacific Railway Company to compel payment of taxes on the sites it leased for grain elevators, lumber yards, and oil-tank stations on the right of way. The decision of the state supreme court in Northern Pacific Railway Company v. Morton County (December 13, 1915) upheld Langer. It established a principle which affected the taxation of 2,038 grainelevator sites, some 1,000 lumber-yard sites, and 260 oil-tank-station sites in the state. The back taxes amounted to about $\$ 1,250,000$. Langer had won a reputation throughout North Dakota as an enemy of the corporations; he was on his way to a public career.

Besides choosing Langer, the Nonpartisan League convention endorsed Lynn J. Frazier, an unknown farmer of Hoople, for governor.

Then forty-one, Frazier had graduated from the University of North Dakota in 1901. At the university he was football captain, an honor student, and a close friend of William Lemke. "Frazier is a ruddy cheeked, broad-shouldered, quiet, plain-spoken man," wrote one

\footnotetext{
${ }^{3}$ Current Biography, 1952 (New York: H. W. Wilson Company, 1953), pp. 326-328; John M. Holzworth, The Fighting Governor: The Story of William Langer and the State of North Dakota (Chicago: The Pointer Press, 1938), pp. $1-2$.
} 
observer, "a purely American product who came up from the sod house and the pioneer's hardships, and you can tell by looking at him that he is as clean as a hound's tooth."

After the convention, the primary election demonstrated the solidarity of the League. Its opponents stressed the threat of socialism: "State farms will follow state flour mills and creameries." The League put on a series of picnics; Townley painted Big Biz in a red suit with tail and horns; the Frazier "Victory Special" train toured the state, stopping at every town while Frazier spoke to the crowds. "He looked like a bishop," one Leaguer recalled. "He stood before them sunburned and baldheaded. His voice was firm and persuasive. He spoke briefly and the tired farmers loved him." On election day, June 28, all candidates for state office endorsed by the League won Republican nomination except P. M. Casey, who won a Democratic nomination. For the senate 17 out of 22 Leaguers and for the house 87 out of 98 Leaguers were nominated on the Republican ticket. Frazier carried 46 of the 53 counties; he received 39,246 votes to 23,362 for Usher L. Burdick and 9,780 for John H. Fraine.

The League then had widespread support among all elements in the population. Burdick, the progressive candidate, had made no attack upon Frazier or most of the League program: he did, however, take issue with state-owned elevators and flour mills. Many small business and professional men supported the League. In New Rockford, Bottineau, Valley City, Minot, Devils Lake, and Jamestown, the League had a relatively favorable press. In March, 1916, Fargo had welcomed the League convention with bands, special displays, and free use of the municipal auditorium. After the primary, many standpat Republicans supported Frazier. In September the Democratic state committee adopted the League platform. The majority of the progressive leaders, however, did not join the League; Burdick, Asle J. Gronna, and Patrick D. Norton were typical examples. That fall, Professor Edwin F. Ladd's experimental mill showed that the milling value of wheat damaged by rust and bad weather in the 1916 growing season was only slightly below that of No. 1 Northern, yet the grain trade was paying only a fraction of the price. No North Dakotan doubted the reality of the grievances attacked by the League. What opposition there was came for other reasons.

In the fall election the League was chiefly concerned with its three candidates for the state supreme court; the enactment of its program would require amendment of the state constitution. On September 11, 1916, however, the court had ruled, in the New Rockford case, against the new and faster method of amending the constitution which had been provided by a 1914 amendment. The new method consisted of an initiated petition approved by the voters and then accepted by the state legislature. The court decided it was inoperative until the legislature provided laws to put it into effect. New judges could reverse the 
decision; the election of League candidates would remove both judicial and constitutional obstacles to the League program. The Nonpartisan Leader said: "We've got to have a Supreme Court that will hold constitutional the laws we pass in the legislature."

The League won an easy victory in November. Frazier carried every county, receiving 79 percent of the vote. All League candidates for state office won except P. M. Casey, who ran on the Democratic ticket. The League elected 81 of the 113 members of the house, but only 18 of the 49 members of the senate ( 24 senators were holdovers and did not stand for election).

\section{CONFLICT IN THE LEGISLATURE}

Lack of control in the senate checked the Nonpartisan League program in the 1917 legislature. The house elected Howard Wood speaker and A. E. Bowen chief clerk. The important decisions of the legislature were made in the League caucus. The League members lived by themselves in the old Northwest Hotel, leased for the session. Each night they met in secret caucus in a large hall of the hotel.

The caucus was an excellent training school for inexperienced farmer legislators; Townley and other League leaders, of course, managed it. The caucus adopted the unit rule, binding the members to follow its decisions in their votes in legislature. William Lemke and other League lawyers drafted the bills. Frazier, trusting his old friend from university days, constantly looked to Lemke for counsel. Lemke's willingness to work, his dynamic energy, his fiery presentations in the caucus, and his closeness to Frazier and Townley gave him extraordinary influence.

To secure its full program, the League would have to amend the constitution, although this was not necessary with regard to a stateowned elevator. The standard amendment procedure seemed too slow, the initiative procedure too uncertain. Therefore, League leaders boldly decided to have the legislature frame an entirely new state constitution in order to authorize a full-scale experiment in state socialism. They reasoned that its approval by the voters would make it legitimate. The proposed constitution, the well-known House Bill 44, allowed the state to engage in any business or industry; it entirely removed the debt limit for state bonds secured by mortgages on real estate or by the property of state industries. These were the controversial points. It also exempted farm improvements from taxation, permitted taxation for hail insurance, established four-year terms for state and county officials, and provided for many other reforms in state government. House Bill 44 raised a storm of protest. Jerry Bacon, owner of the Grand Forks Herald, sent out thousands of copies of a pamphlet entitled A Socialist Constitution for North Dakota. The bill, after passing the house, was defeated in the senate.

Yet the legislature enacted many reforms. The opposition members of the senate not only voted for them but even wrote some of the bills. The 
new laws set up a grain-grading system, guaranteed state bank deposits, established a nine-hour day for women, forbade discrimination by railroads (charging separate rates for long hauls and short hauls, furnishing cars, granting elevator sites), authorized negotiable warehouse receipts, established a state highway commission, and trebled state aid for rural education. The legislature also proposed constitutional amendments for woman suffrage and the exemption of farm improvements from taxation.

The opposition introduced and passed, with the aid of League votes, a proposal to build a state-owned terminal elevator and to appropriate \$300,000 for it. But Governor Frazier, after consulting with League leaders, vetoed it. He believed that a single small elevator could have little effect-one of the reasons for the defeat of a similar bill in the 1915 legislature. He also believed that it would give enemies of the League a chance to discredit state ownership. The Equity people, however, disapproved of the veto; Theodore G. Nelson began to doubt League leadership.

\section{EXPANSION OF LEAGUE ACTIVITIES}

Although the Nonpartisan League had not been able to put its basic program through the 1917 legislature, it had become a large, powerful organization with many activities. By November, 1916, it claimed forty thousand members and an income of $\$ 270,000$. It had spent $\$ 50,000$ on Fords for organizers, $\$ 40,000$ on printed propaganda, and much of the rest on office rent and salaries for lecturers and organizers. At first most people were friendly to the League, but as time passed, much bitter feeling arose between Leaguers and anti-Leaguers. In many a country school, League and anti-League children did not play together; even members of the state supreme court were not all on speaking terms with each other.

The League went into merchandising, banking, and newspaper publishing. Early in 1917 it organized the Consumers' United Stores Company to distribute goods (groceries, clothing, hardware, and farm implements) directly from the manufacturers to the consumers. By 1919 it had some thirty stores in Kenmare, Crosby, Minot, and other towns. The enterprise was carelessly managed by an inside clique which diverted the farmers' funds to political activity. By shady manipulations, League insiders (operating as the League Exchange) gained control of the Scandinavian-American Bank of Fargo, then a chain of banks across the state. Loyal farmers put up capital for the banks, but insiders who had contributed nothing controlled them.

The League also acquired control of newspapers. After beginning the weekly Leader, it bought the Fargo Courier-News, a daily, in the fall of 1916. The next spring, it organized the Northwest Publishers' Service. Without investing a dollar of its own, the Northwest Publishers' Service acquired control of some forty-five rural weeklies in North Dakota and 
thirty in other states. This was possible because farmers bought preferred stock, which had no voting rights. The Service was also publishing the daily Grand Forks American.

The League, hoping to form a national party, spread into other states. It started organizing in Minnesota in the fall of 1916, and by the end of 1917 it was working in thirteen western states. Townley had changed its name from the Farmers' Nonpartisan Political League of North Dakota to the National Nonpartisan League and had moved its headquarters from Fargo to St. Paul early in 1917 (anti-League newspapers soon quipped that the "throne room" of North Dakota, which the League had so righteously returned to the state, had gone back to the Twin Cities). When the 1918 elections were held, the League had 188,365 paid-up members, the greater part of them in Minnesota, North Dakota, South Dakota, and Montana, and a staff of more than five hundred speakers and organizers and twelve state offices. Control still rested in the hands of the executive committee, composed of Townley, Wood, and Lemke.

As the League expanded, its platform broadened. It was friendly to organized labor; Townley addressed the convention of the American Federation of Labor at Buffalo, New York. on November 16, 1917. The national platform of the League, adopted by a delegate convention in December, 1918, called for a democratic world government, the end of monopoly, full employment, public works for the unemployed, national ownership of public transportation and communication, steeply graduated income and inheritance taxes to pay off the public debt, the repeal of wartime laws limiting civil rights, and the enfranchisement of women.

A national organization had not been part of Townley's original plan. The League had stayed out of the national election of 1916, but when Congressman Henry T. Helgesen of the eastern district died in the spring of 1917, the League ran John M. Baer, the cartoonist of the Leader, in the special election in July. Baer defeated Olger B. Burtness, a progressive Republican, and George A. Bangs, a Democrat.

\section{THE ELECTION OF 1918}

The election of 1918 was also a Nonpartisan League victory. Its opponents charged it with disloyalty. Actually, the League's war aims, similar to the Socialist Stockholm Manifesto of the Second International in 1916, anticipated Wilson's Fourteen Points. The League endorsed three men for the House of Representatives: John M. Baer, George M. Young, and James H. Sinclair. For the state offices it again backed Lynn J. Frazier and most of the men it had elected in 1916; Howard Wood became the candidate for lieutenant governor. The main concern, however, was with amending the constitution to legalize the League's program. Its members initiated seven amendments. These raised the debt limit, simplified the amending process, and authorized the state to engage in business. 
The opposition, very much greater than in 1916, tried to turn the prevailing war hysteria against the League. Twin City papers gave the impression that a victory for Frazier would be a victory for Germany. "Vote as You Would Shoot!" admonished the Bismarck Tribune. "The Tribune is unalterably opposed to the itinerant preachers of a destructive Socialism, and a damnable pacifism, but it believes the time has come in North Dakota for a complete readjustment of sentiment toward the economic demands of the farmers.” But League leaders, making an allout effort, won a sweeping victory in the June primary. League candidates won every Republican nomination for state and congressional office; Frazier carried forty-five of the fifty-three counties; enough legislative candidates were nominated on the Republican ticket to insure League control of both houses. In Minnesota, however, the disloyalty charge defeated the League.

Before the fall election, the opposition set up the Independent Voters Association (I.V.A.) to defeat the proposed constitutional amendments. The I.V.A. sold ten-dollar memberships, published the Independent, and provided speakers and publicity. Its secretary was Theodore G. ("TwoBit”) Nelson; its chief strength was in the cities and towns. Nelson was a former Equity leader who had joined the League, although he doubted the wisdom of state ownership; he had voted for Frazier in 1916. He believed in producer cooperatives. ${ }^{4}$ In the fall, a joint committee of antiLeague Republicans and Democrats directed a campaign for the Democratic candidates. In November, Frazier received thirty-three thousand less votes than he got in 1916, yet the League elected him and its whole state ticket except the superintendent of public instruction. It also held large majorities in both houses of the legislature and four out of five of the judgeships of the state supreme court.

Soon after the election, the court ruled that all of the constitutional amendments had passed. This was a questionable point, for some of the amendments had not received a majority of the votes cast in the election, a plain constitutional requirement, but only a majority of the votes cast on the amendment.

\section{THE TRIUMPH OF THE LEAGUE}

The court's ruling enabled the 1919 legislature to enact the League program. Most of the real lawmaking of the session took place in the nightly League caucus. Lemke, especially, but also Townley, Walter Thomas Mills, and other League officials, worked out drafts of legislation and brought them before the caucus. There they were discussed freely and thoroughly, yet Lemke, Townley, and others of the inner circle were extremely influential, and each member was bound to vote in the legislature for the bill as it was accepted by the majority of

${ }^{4}$ Theodore G. Nelson, Scrapbook Memoirs (Salem, Oreg.: Your Town Press, 1957), pp. 70-75. 
the caucus. Lemke, an old Leaguer recalled, was "a bit dictatorial”; Myron W. Thatcher remembered that League leaders "threw themselves around" and called "the shots just a little bit too roughly." After the 1918 victory at the polls, Lemke and the others were in no mood for moderation, and they lost touch with public sentiment.

Five laws created the legal framework for a system of state socialism. One set up the Industrial Commission, composed of the governor, attorney general, and commissioner of agriculture and labor. The Industrial Commission was empowered to manage all business enterprises of the state.

A second law created the Bank of North Dakota, with a capital of two million dollars. The law required that all state and local government funds be deposited in the bank. It was to provide low-cost rural credits, to finance state departments and enterprises, and to serve as a clearinghouse and rediscount agency for banks throughout the state. It might redeposit funds in any bank and make loans on real estate and warehouse receipts.

A third law formed the North Dakota Mill and Elevator Association, which was to engage in the manufacture and marketing of farm products and to establish "a system of warehouses, elevators, flour mills, factories.” A fourth law set up the Home Building Association, through which the state would build houses for a down payment of 20 percent and installments running from ten to twenty years. A fifth law amended the state hail-insurance system already in operation; a flat tax of three cents an acre was to pay part of the cost.

Besides these laws, the legislature passed a number of reforms. At Professor Edwin F. Ladd's suggestion, it strengthened the 1917 grain-grading law requiring grain buyers to pay the market value of dockage. It enacted a graduated income tax and an inheritance tax. It authorized a state printing commission, made up of League-elected officials, to select the one official newspaper for each county until the next election, when the voters would select it. (The law would subsidize League newspapers with a monopoly on legal printing and so force out of existence many small weeklies hostile to the League. In 1919, sixtyone weekly newspapers stopped publication.) It proposed a constitutional amendment for the recall of public officials. It enacted a workmen's compensation law and also an eight-hour-day and minimumwage law for women. It limited the use of injunctions in labor disputes. (Such labor laws would help the League bid for labor support in more industrialized states.)

A new spirit also animated the administration of old laws. The assessed valuation of railroad property rose from \$51,000,000 in 1916 to $\$ 219,000,000$ in 1919 . When the legislature adjourned, the Grand Forks Herald said: "The state is now the socialistic laboratory of the country." The League published a booklet of the laws it passed called The New Day in North Dakota. What the North Dakota Bankers 
Association had begun in 1907 as a proposal for a state-owned terminal elevator had become a broad experiment in state socialism.

\section{LAUNCHING THE EXPERIMENT}

Two principal obstacles faced the experiment: the talent for mismanagement on the part of some of the persons placed in charge and the natural reluctance of eastern investors to furnish the essential capital. Yet the Industrial Commission set about its work with dispatch. It appointed James R. Waters manager of the Bank of North Dakota in April, 1919, and he soon made F. W. Cathro director-general. Waters had served as state bank examiner for three years; Cathro was connected with the First National Bank of Bottineau for twenty-six years and had served as the first president or the state bankers' association. Waters and Cathro could not, however, find purchasers for the \$2,000,000 worth of bonds which were to furnish the bank's capital. Nevertheless, the Bank of North Dakota opened for business on July 28, 1919. Treasurers of the state, county, township, municipal, and school-district funds began to deposit them as the law required. By September the deposits amounted to $\$ 8,700,000$; at the peak in April, 1920 , they totaled $\$ 28,700,000$. Banks also began to make deposits; 396 banks in the state had \$1,400,000 in the Bank of North Dakota by August 15, 1919.

Thus it began to do a large clearinghouse business. It also acted as a rediscount bank, lending to banks throughout the state. The bank's policy was to redeposit public fund, in the banks of the communities in which they originated; it did, however, help out poor communities by redepositing more money in their banks. But for political reasons, the state bank violated its own policy by giving very large deposits $(\$ 229,883)$ and loans $(\$ 175,189)$ to the Scandinavian-American Bank of Fargo, which was controlled by the Nonpartisan League. These redeposits gave Cass County, the wealthiest in the state, more money than its public treasurers had deposited in the Bank of North Dakota. In the last months of 1919, the state bank began to make loans on farm lands. These ran for thirty years and bore 6 percent interest when the average in the state was 8.7 percent. By November 15, 1920, the bank had made \$2,900,000 worth of farm loans, an insignificant amount, for that year the total farm-mortgage debt in the state on owner-operated farms was $\$ 108,000,000$.

The North Dakota Mill and Elevator Association had much trouble in getting its operations under way. In August, 1919, it bought a small flour mill at Drake in order to demonstrate what state ownership could do. The manager, opening the mill with fanfare, bought wheat for twelve cents a bushel above the market price and sold flour for fifty cents a barrel under the market. He pretended to be making a profit, but was actually losing \$1.58 on every barrel. The Drake mill closed down on 
March 27, 1924, with a loss of $\$ 98,158 .^{5}$

The Mill and Elevator Association could not sell the bonds necessary to build a large enterprise. In October, 1919, Townley announced that the State Mill and Elevator would be built at Grand Forks. This was a poor location because it could serve only the northern portion of the state, but Grand Forks businessmen had agreed to furnish a site and to buy $\$ 1,000,000$ worth of bonds, and Townley wanted revenge on Fargo. On April 7, 1920, the Industrial Commission let a contract for the building of a 1,600,000-bushel elevator and a flour mill with a daily capacity of 3,000 barrels. The cost was to be $\$ 922,850$, exclusive of power and machinery; the money was advanced as a loan by the Bank of North Dakota. Construction stopped in the fall of 1920 for lack of funds and was not resumed until after the recall election of October, 1921. The first unit was completed in October, 1922, the last in February, 1923; the total cost was $\$ 3,044,391$. Thus the chief objective of the League program-a system of state-owned warehouses, elevators, flour mills, and factories-was a complete failure, entirely nonexistent, until after the League was driven from power.

The Home Building Association also failed. It plunged into home building in reckless disregard of the law creating it. Within a few months it began fifty-seven houses, fifty-one simply on oral contracts and with few clients who had made the required 20 percent down payment. William Lemke, although his wife questioned the move, borrowed $\$ 4,000$ to start a house estimated to cost $\$ 7,000$. It eventually cost more than $\$ 20,000$, a great burden on Lemke for many years.

There were, however, some minor successes. The hail-insurance program functioned efficiently. Professor Edwin F. Ladd made the elevators pay for dockage. His inspectors soon condemned a wagonload of false scales, and his report of October, 1919, was an astonishing recital of commercial malpractices.

\section{THE CAMPAIGN AGAINST THE LEAGUE}

As the Industrial Commission struggled to launch its program, the Nonpartisan League suffered a disastrous defection. During the 1919 legislative session, three League-elected state officials began to attack the League leadership, though not the original program, and to expose League misdeeds. The trio consisted of William Langer (attorney general), Carl Kositzky (state auditor), and Thomas Hall (secretary of state). Langer revealed that the League Exchange was gaining control of 51 percent of the stock in banks it organized, without investing any money. He also noted that the League-controlled ScandinavianAmerican Bank had lent \$170,000 to the League-controlled Consumers' United Stores Company and had made other excessive loans, totaling

${ }^{5}$ Gilbert W. Cooke, “The North Dakota State Mill and Elevator," Journal of Political Economy, XLVI (February 1938), 26-27. 
$\$ 734,000$, to the League and its various agencies. The bank's capital and surplus was only $\$ 60,000$; by law it was limited to loans of not more than $\$ 9,000$ to any one individual or corporation. The excessive loans were secured by postdated checks, worthless as collateral.

Earlier, Townley had called Langer a "traitor." Langer replied: "You and your hirelings have lied to and are deceiving the farmers of North Dakota." In November, 1919, Langer and Kositzky began to publish The Red Flame ("The Red Flame is Socialism"), a monthly magazine which was distributed free by the thousands. It was entirely devoted to attacks on League leaders and state officials, referring to them as "Comrade" Townley and "Comrade" Frazier and playing on the theme of "Bolshevism."

Other tactics were used against the League program. Opponents circulated petitions referring seven of the laws to the voters, those creating the Industrial Commission and the Bank of North Dakota among others. But in a special election on June 26, 1919, all of the referred laws were approved by the voters.

Opponents at tacked the League program in the courts. In April, 1919, forty-two taxpayers from forty-two counties filed a suit in the federal district court at Fargo asking that the League laws be declared unconstitutional. The forty-two taxpayers were represented by able lawyers-Judge M. C. Young (counsel for the Northern Pacific), Tracy Bangs (counsel for the Red River Power Company), and C. J. Murphy (counsel for the Great Northern); they were backed by large banking and business interests of Minneapolis. In this case, Scott v Frazier, the attorneys argued that the laws required taxation for other than a public purpose and so would deprive the taxpayers of their property without due process of law, a violation of the Fourteenth Amendment. On June 14, Judge Charles F. Amidon dismissed the suit. He said that state elevator, mills, and packing houses were the only effective means by which the farmers could escape the economic injustices at the hands of the great combinations of the terminal cities. He ruled that the court had no jurisdiction, for none of the plaintiffs had shown injury to the extent of nine thousand dollars, and that the taxation involved was clearly for a public purpose. The state supreme court decided a similar case, Green $v$ Frazier, in the same way. Both cases were carried to the United States Supreme Court. On June 1, 1920, the federal court likewise upheld the constitutionality of the laws.

In the 1920 elections, Republican and Democratic opponents again combined against the League. Before the primary an Independent Voters Association convention, called by a committee of Republicans and Democrats, endorsed Langer for governor and declared that "the real issue in the campaign in the state is between Americanism and socialism." Large corporations supplied the I.V.A. with funds. With I.V.A. leaders prominent, the Democratic convention endorsed J. F. T. O'Connor for governor. The League convention endorsed Frazier for 
governor, most of the League officeholders, William Lemke for attorney general, and Edwin F. Ladd for United States senator. Ladd was to oppose Asle J. Gronna, a progressive Republican.

In the pre-primary campaigning, Townley toured the state in an airplane, but the old enthusiasm for the League was dying. Langer upheld the state industries and attacked only the "corrupt leadership" of the League; he promised to throw the Socialists out of the government. The Grand Forks Herald asked: "Shall A. C. Townley continue to rule North Dakota?"

It is clear that many opponents of the League were men much concerned with the exploited status of the state. Some of them were progressive in spirit and ready to use the state government and even state ownership to bring about a better deal for the wheat farmer in the terminal markets. They were not enemies of the farmer (all were bound to his welfare) or the minions of selfish outsiders. They were not, however, ready for state socialism on a broad front, nor were they willing to turn the state over to Townley and a group of Socialists. And they had good reason to doubt the integrity of some League leaders.

League candidates were not as successful in the primary as in earlier years. Frazier beat Langer by a narrow margin, and Ladd defeated Gronna. But League opponents took the Republican nominations for four state offices, and James Sinclair was the only Leaguer to win a nomination for the House of Representatives. John M. Baer, defeated by Olger Burtness, began a career of more than forty years as cartoonist for Labor, the official publication of the Railroad Brotherhoods. After the primary, the League endorsed men to run as Independents for offices where I.V.A. candidates had Republican nominations.

The fall election showed a marked decline of confidence in the League leadership. The I.V.A. supported O'Connor and Democratic candidates when Leaguers won Republican nominations. It also initiated five measures to check the League. The most important would make optional the deposit of local government funds in the Bank of North Dakota and would provide for an audit of the state enterprises. Frazier won over O'Connor by 117,118 votes to 112,488 , receiving 51 percent of the vote. Leaguers won all of the state offices for which they had Republican nominations. For the others, the I.V.A. candidates with Republican nominations beat the Leaguers running as Independents. This outcome showed that, as a third party, the League could never have controlled the state. Only by operating in the Republican primary, where fewer voters took part, did it succeed. ${ }^{6}$ The I.V.A. gained control of the lower house of the legislature by a four-vote margin. The League kept a majority in the senate by one vote, but it had lost control of the state government. All of the anti-League-initiated measures passed. The outcome of the 
election brought the state industries to a standstill: construction on the mill at Grand Forks stopped; the Bank of North Dakota ceased making farm loans and honoring its checks; the Home Building Association started no more houses.

The 1921 legislature was one of bitter quarrels and investigations of the state industries. The audit, authorized by the initiated measure, found plenty of mismanagement but no dishonesty. A senate investigation commended the Industrial Commission; a house investigation showed that "political considerations" had entered into the state industries. On the last night of the session, anti-League crowds surged through the corridors of the capitol. Fist fights were common. Carl Kositzky came out of one brawl with a cut check and a black eye.

\section{THE FAILURE OF THE LEAGUE}

The state industries were handicapped by the inability of the Industrial Commission to sell bonds to provide them with capital. The investment bankers of the nation felt no enthusiasm for financing socialistic enterprises and were in sympathy with the conservative business interests of the state and their natural allies of the Twin Cities. They were boycotting the bonds. The bitter political strife, doubt about the legality of the enterprises, and the depression of 1921 were additional reasons for the boycott. In January, 1921, the North Dakota Bankers Association offered to try to sell the bonds to eastern financiers. The conditions were that the Bank of North Dakota confine its business to the state institutions and departments and that the socialistic enterprises be limited to the bank, the Drake mill, and the Grand Forks State Mill and Elevator. (Events were to prove that the bankers' conditions reflected majority opinion in the state. Since 1921 the socialistic enterprises have neither expanded nor contracted.)

But the Industrial Commission refused the offer. Townley, more realistic, thought the refusal was unwise. A little later, a similar proposition from some Minneapolis bankers came to nothing. The commission, however, did sell five or six million dollars' worth of bonds to labor organizations and individuals after Governor Frazier proclaimed July 23, 1921, as "North Dakota Bond Selling Day.” Then in October, 1921, the Industrial Commission sold $\$ 6,100,000$ of bonds to Spitzer, Rorick and Company of Toledo.

The long delay in selling the bonds hurt the Bank of North Dakota. It was both deprived of capital for itself and forced to advance funds for the State Mill and Elevator and for home-building activities. The bank was also hurt by the price recession which began in the spring of 1920 . As the price of wheat fell, farmers could not repay their loans. Banks began to fail, especially in the western part of the state, where crops had been poor for four years and the farmers were heavily in debt. To help out, the Bank of North Dakota redeposited a million dollars more in the banks of western North Dakota than it had received from that area. 
The initiated measure passed in November removed the requirement that local governmental funds be deposited in the state bank, and large sums were soon withdrawn. The bank was forced to call in some of its redeposits; eighteen banks closed in the first three weeks after passage of the measure. But many banks were unable to meet the demands of the Bank of North Dakota for redeposit money, and on December 20, 1920, it stopped paying checks drawn by county and other treasurers who had stopped making deposits. Public deposits continued to drop. Not until September, 1921, was the bank able to pay all checks and other obligations.

By that time a recall election was approaching. In 1920 the voters had approved a League-sponsored constitutional amendment by which petitions could bring about an election to recall a state official. In 1921 the I.Y.A. circulated petitions to recall the three members of the Industrial Commission: Governor Lynn J. Frazier, Attorney General William Lemke, and Commissioner of Agriculture and Labor John N. Hagan. The petitions nominated three men to take their positions: Ragnvold A. Nestos for governor, Sveinbjorn Johnson for attorney general, and Joseph A. Kitchen for commissioner of agriculture and labor. Nestos was a progressive Republican and an earnest attorney from Minot who had attended the university with Frazier and Lemke. Johnson was chairman of the Democratic state committee and a law partner of J. F. T. O'Connor in Grand Forks. Kitchen was a state legislator from Sentinel Butte. The I.V.A. also initiated by petition a constitutional amendment and six laws to limit or end the slate industries; these proposals were also to be voted on at a recall election on October 28, 192l. Nestos, Johnson, and Kitchen said, however, that they supported the original League program or at least were willing to give it "a fair trial." There were therefore two issues in the special election: the membership of the Industrial Commission, which directed the state industries, and the continuation of the industries themselves.

Former Senator Asle J. Gronna, a respected progressive, campaigned against the League, as did such former League leaders as Arthur LeSueur. The League state committee, believing that Townley was now a liability, did not ask him to campaign. Lemke also hurt the League, for the I.V.A. made effective use of the fact that the Home Building Association had lent him $\$ 4,000$ to help build his expensive house. By law the maximum cost of houses built by the association was to be $\$ 5,000$, but the Lemke house had cost over $\$ 20,000$. That fall, crowds surged about the house, burning Lemke in effigy.

On election day the three I.V.A. candidates defeated the three League officeholders. It was the first recall of state officials in the United States. But the margin was narrow; Nestos received 111,434 votes to 107,332 for Frazier; Johnson and Kitchen won by similar majorities. All of the initiated measures were defeated. The League had majorities in the western two-thirds of the state, but the vote went heavily against it in the 
eastern portion. A slim majority of the voters had lost confidence in the League officeholders, but not in the League program. Mismanagement of the state industries and distrust of Townley and Lemke played an important part in the League's defeat. After the I.V.A. victory, conservatives, such as N. C. Young, attorney for the Northern Pacific, put much pressure on Nestos to end the state industries, but he stubbornly stood by his promise to give them a fair trial.

The League organization, however, was rapidly falling to pieces. In March, 1921, the telephones in the Fargo headquarters were disconnected for unpaid bills; some employees were laid off; others went for months without pay. A membership drive in August failed; revenues dwindled; the number of organizers and lecturers declined.

In November, 1921, Arthur C. Townley finally began to serve a ninety-day jail sentence in Jackson, Minnesota, for conspiring to discourage enlistments. He had been convicted in July, 1919, after a most unfair trial. The charge was based on the distribution of a pamphlet stating the League's war aims. These were quite similar to President Woodrow Wilson's famous Fourteen Points, and Townley had a letter from the President thanking him for his patriotism. But the presiding judge refused to allow such evidence of loyalty to be introduced. In 1922, Townley resigned as president of the National Nonpartisan League. The next year, the executive committee sold the Fargo CourierNews, the victim of an advertising boycott, and the Leader ceased publication. Members were no longer paying dues, the foundation of the whole operation. The League as it had been was dead.

The State Mill and Elevator was completed by the opponents of the League and eventually became a successful enterprise. The Bank of North Dakota lowered interest rates for the farmers and served the state government effectively. These enterprises, however, were not the system of socialistic undertakings called for in the League platform. Moreover, they did not greatly alter the dependent, exploited status of North Dakota. In a broad view, the great socialist experiment was a failure. 


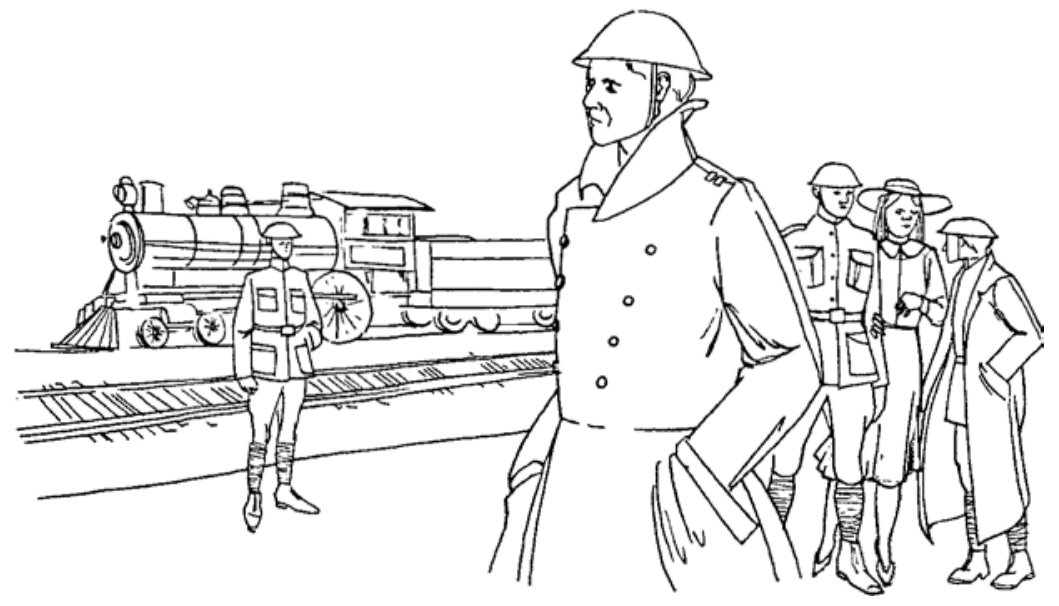

CHAPTER 16

\section{A Socialistic State in the First}

\section{World War}

THE RISE AND FALL of the Nonpartisan League was a part of the agrarian discontent of all the western states, a part of colonial revolt wherever colonial status prevailed. In a similar vein, North Dakota's response to the First World War was part of a world-wide development. The war was a turning point in the history of all nations and all peoples. Its impact upon government, taxation, agriculture, and industry was everywhere profound. The tremendous efforts, the millions of dead, the violence and destruction, the overturning of social systems, and the rise of Communism and Fascism brought a deepening disillusionment which eroded old values and ways of thinking, weakened democratic and Christian ideologies, and brought a revolution in manners and morals. The titanic struggle profoundly altered every aspect of life throughout the world.

What was North Dakota's response to the war, and how did the war affect the state? As with its agrarian revolt, North Dakota, a land of extremes, made a strong response, stronger than that of many other places. Its response was affected by the state's colonial status and the attitudes springing from that status. The war, in turn, reacted upon the fundamentally agricultural character of the state, bringing near disaster by inflation to the semiarid grassland. There was continuity as well as change in the war years.

The Nonpartisan League and North Dakotans generally did not want the United States to enter the First World War. They regarded President Woodrow Wilson's rigid position on neutral rights as unjustifiable; they believed that powerful financial and industrial interests, more concerned with profits than democracy, were pushing the nation toward war. Their 
hostility toward these interests, which was making them socialistic, also made them antiwar; North Dakota's socialism and pacifism were related.

Once the United States had declared war, however, the state patriotically supported the war effort. Accepting the Nonpartisan League's war aims, North Dakotans favored conscription of wealth, as well as of men, and a just peace without secret treaties, annexations, or indemnities. They stood for the extension of federal controls over prices and transportation to curb profiteering. Thus North Dakota's wartime patriotism, like its prewar pacifism, had a socialistic coloring. Both attitudes were reflections of its status as a dependent and exploited colonial hinterland.

The state's conservatives quite naturally sought to discredit both the Nonpartisan League and its socialistic program by depicting its leaders as disloyal and by excluding the League from all patriotic projects. The conservatives would use the powerful wartime emotions of patriotism to destroy socialism in North Dakota. Their efforts gave North Dakota a reputation, entirely unjustified, as a disloyal state. Moreover, North Dakota did not share the prevailing war prosperity of the nation. Although its farmers expanded their wheat acreage, crops were poor. Wartime inflation and the end of free land increased the cost of farm land and laid the foundation for the hardships of the 1920's.

The seven years from 1915 to 1921 brought a traumatic emotional experience to North Dakotans. The rise of the Nonpartisan League generated extremely intense emotions among both its friends and its enemies, and the events of the First World War raised them to a high pitch: the opposition to America's entry into the war, the experiences of the draft, the sacrifices of the war effort, the deaths of many young men, and the charges of disloyalty. About one-fifth of the people were of German stock; war against Germany must have aroused a conflict of loyalties in thousands.

At almost the same time, pioneering came to an end as the last free land was taken up. As the dreams of the pioneers faded, as the exciting and hopeful experiences of opening up a new country ended, thousands of settlers on the Missouri Plateau struggled with the problems of adjustment to a strange, flat, semiarid land. Many were recent immigrants with the additional problem of adjusting to a new society.

Then came the great turning point in North Dakota history: the tide of population which had flowed into the state for so long began to ebb. The process of uprooting and leaving often must have been accompanied by deep emotions of fear, frustration, and regret. All of these experiencesthe Nonpartisan League struggle, the wartime sacrifice, the end of the pioneer dream, adjustment to semiaridity and a new society, and uprooting and leaving-came together, and they undoubtedly intensified one another. At the same time, the war prosperity sweeping over the nation passed North Dakota by, a keen disappointment. 


\section{OPPOSITION TO INTERVENTION}

When war came to Europe in early August, 1914, North Dakotans rejected it as "needless and foolish"; they believed that trade rivalries and the alliance system had caused the war. They were skeptical of propaganda about German atrocities. "Don't believe all the wild stories," warned the Fargo Courier-News. The Fargo Forum felt that Germany's offense lay in making "more rapid advance in commerce than any of her rivals."

North Dakota newspapers presented an impartial picture of the war. They warned their readers that European dispatches were censored, and after wireless communication with Germany was established in November, 1914, they printed news stories from Berlin. At Bismarck, Der Staats-Anzeiger dealt exultingly with German victories; the Jamestown Alert and Valley City Times-Record defended Germany. The Grand Forks Herald, Germany's severest critic in North Dakota, published articles by German officers. The Bismarck Tribune said that it was futile to justify one nation in the war against another. Many newspapers printed the German defense of the execution of Edith Cavell, an English nurse.

North Dakota wanted to be entirely neutral, to stay out of the war. In the congressional elections of 1914 the North Dakota Democrats used a statement by Robert M La Follette concerning President Woodrow Wilson: "He is keeping us out of war." In 1915 and 1916 the people of the state generally opposed preparedness: their congressmen voted against Wilson's program for a larger army and navy. Frequently opinions were expressed in anticapitalistic terms. Most North Dakotans believed that munitions makers were behind the preparedness movement. In January, 1916, the Tri-State Grain and Stock Growers Association passed a resolution favoring government manufacture of munitions and warships as a means of taking the profit out of war. On May 12 the Germans of Hebron sent a telegram to the state's congressmen: "T. R. may roar his head off-but take a straight tip-the big bunch are behind Ford, Bryan, and Benson.... N. D. is keeping her shirt on. Play the people's game, not Morgan's.” Significantly, the Grand Forks Herald, the chief opponent of the Nonpartisan League, was also the chief advocate of preparedness in the state and the chief defender of American neutral rights.

Many in North Dakota, however, were ready to surrender the nation's rights on the seas rather than run the risk of war. Representative Henry T. Helgesen though Wilson should take a strong stand against the British blockade in order to avoid any possibility of trouble with Germany. Although many editors denounced the sinking of the Lusitania, they did not want to go to war about it. The Bismarck Tribune urged the people to remember that "England offended against international law first." Many newspapers were critical of Wilson's stiff stand against 
Germany's unrestricted use of the submarine. The state's delegation in Congress voted for the Gore-McLemore resolutions to give up the right of Americans to travel in war zones on the merchant ships of belligerents. Senator Porter J. McCumber believed in "being so everlastingly neutral in this war that not one of the nations engaged in the conflict can make any complaint against us.” Governor Louis R. Hanna was the only American political leader to be a member of Henry Ford's Peace Ship party, which went to Europe on the Oscar II in a vain effort to restore peace. The press of the nation ridiculed the Peace Ship; most North Dakota newspapers had only kind words for it.

The presidential election of 1916 revealed the socialistic state's strong desire for peace. The Democrats put a two-page anticapitalistic advertisement in the Nonpartisan Leader: "Is Wall Street and Big Biz putting up the money for the Hughes campaign because Hughes would be a good President for you?... If you want peace, elect Wilson." Although, paradoxically, most of the counties with large German populations voted for Hughes, Wilson carried thirty counties and received 55,206 votes to 53,471 for Hughes. Editor Gerald P. Nye wrote in the Fryburg Pioneer that the clear thinking of "a sane people" gave Wilson the victory.

As the crisis deepened, however, many North Dakotans gave up hope for peace. The dailies of the larger towns supported the diplomatic break with Germany on February 3, 1917, but Representative Henry T. Helgesen and Senator Asle J. Gronna voted against the resolution to back the President. Gronna said: "Many want war, for they hold British bonds." Helgesen and Gronna opposed giving Wilson authority to arm merchant vessels; they had many supported in the state. When German submarines sank several American merchantmen in March, the Grand Forks Herald, the Bismarck Tribune, and the Fargo Forum-all opponents of the socialistic Nonpartisan League-called for war.

But telegrams for peace poured into the offices of North Dakota congressmen. Governor Lynn J. Frazier and Arthur C. Townley telegraphed senators McCumber and Gronna that while the people of the state were "patriotic and loyal," they were still for peace. In the debate on the war resolution, Gronna, a stolid North Dakotan with a massive walrus mustache, asked, in his unpolished and deliberate manner, why the hundreds of thousands of petitions against war were being ignored. La Follette, making the principle speech against war, began by reading a letter from Mrs. H. A. Wood of Flasher, North Dakota: "Is the sinking of a few merchant ships worth even on life?" On the roll call in the Senate, Gronna courageously cast the first of six nay votes. McCumber, however, voted for war, and in the House, Patrick D. Norton and George M, Young also did so. But Helgesen, who was to die shortly, was in a hospital and did not vote.

Why did North Dakota so staunchly oppose entry into the war? Although about one-fifth of its people were of German stock, the ethnic 
factor should not be overemphasized. North Dakotans, always hostile to outside interests, believed that the wat was being fomented by eastern financiers and industrialists for their own selfish advantage. They believed that the war would destroy progressive reform, that it was not really a just one for democratic ends. And finally they believed that war was not necessary to vindicate national honor. They remembered that European neutrals, such as Norway and Sweden, had lost 667 vessels through German submarines, as compared to only 19 lost by the United States. "Deeply rooted ideological distrust of the financial and industrial capitalist classes by the German and Norwegian elements of the population," wrote Professor Robert P. Wilkins, "which was greatly intensified by the exploitation of North Dakota producers, may be said chiefly to account for the persistent opposition to policies that appeared to lead to war."

\section{HELPING TO WIN THE WAR: MILITARY SERVICE}

After the United States entered the war, North Dakota performed its full share of patriotic service. The first men from the state to go overseas were those of the two National Guard regiments. One regiment, the First North Dakota, had served on the Mexican border. Soon after it was discharged from such service on February 14, 1917, part of the regiment was put to work guarding the bridges and yards of the Northern Pacific. In May, other companies began to drill in their armories, and the regiment was recruited up to full strength. Many of its former members were eager for service, so, late in June, Governor Frazier authorized the organization of the Second North Dakota under Colonel Frank White, Valley City banker and former governor, who had commanded the First North Dakota in the Philippine insurrection. In two weeks the new regiment had 47 officers and 1,622 men.

On July 3, President Wilson called the National Guard into federal service. On August 16, Field Hospital No. 1 of North Dakota (six officers and seventy men) entrained at Lisbon for Camp Cody, Deming, New Mexico; there it became Field Hospital No. 136 of the Thirty-fourth Division. On September 29 the First North Dakota, 51 officers and 2,057 men under Colonel John H. Fraine of Grafton, entrained for Camp Greene, North Carolina. Fraine, an English immigrant and attorney, had been a member of the regiment since 1885. On October 1 the Second North Dakota also left for Camp Greene.

Both regiments, except for the field-hospital company at Camp Cody, became part of the Forty-first, or Sunset, Division, which was composed of Guard units from several western states. It was a replacement division; its men became widely scattered, serving with many Regular Army

\footnotetext{
${ }^{1}$ Robert P. Wilkins, "North Dakota and the European War, 1914-1917: A Study of Public Opinion” (Unpublished Ph.D. dissertation, West Virginia University, 1954), p. 334; see also pp. 19-319.
} 
units. On December 15 the Forty-first Division, after a few weeks' training interrupted by epidemics, sailed for Liverpool on the Leviathan, the reconverted German ship Vaterland. These men fought at Cantigny and Soissons, held the defensive Toul sector, helped to stop the German offensive at Château-Thierry, and then took part at Saint-Mihiel and in the Argonne Forest in the Allied offensives which ended the war.

One of them was Wesley R. Johnson, a tall, 126-pound university student who had enlisted in the Guard at seventeen. That was in August, 1917. By March 2, 1918, young Johnson was in the front lines. For much of the next nine months he marched through rain and mud, stumbled about in dark woods, dug trenches, stretched barbed wire, listened to deafening artillery fire, slept in barns, went over the top, and saw his comrades die.

National Guardsmen like Johnson numbered 4,195 officers and men; a few of these were in the state quartermaster detachment and the rest went overseas. In all, 31,269 officers and men from North Dakota served in the various branches of the armed forces during the First World War. Of this total, 19,772 volunteered, 11,481 entered through the Selective Service System, and 16 were civilians attached to the armed forces. The first draft call, 1,582 men, came on September 5, 1917; the peak of the draft was in May, June, and July of 1918. Of those called, 78 percent were physically fit, compared to 70 percent in the nation.

In all, 160,292 men from 18 to 45 years of age registered for the draft in North Dakota. The county draft boards placed 44,134 men in Class I as liable to military service; 24,382 of these were in the 21-30 age group and none were over 36. Most draftees filed claims for exemption or deferment. In 1918 the state draft board considered 35,815 claims. No able-bodied Sioux from Standing Rock sought exemption; all were eager to do their part in preserving civilization. ${ }^{2}$

Before the draft was under way, many eager patriots rushed into war service. College students and alumni flocked to officers' training camps and earned commissions. Early in April, 1917, Dr. Eric P. Quain, Swedish-born surgeon and founder of a clinic in Bismarck, organized a Red Cross hospital unit with doctors and nurses from Bismarck. It became a base hospital at Bazeilles-sur-Meuse, and Quain himself served as chief of surgical services and director of operating teams in military hospitals in France. At the Armistice, 148 North Dakota nurses

\footnotetext{
${ }^{2}$ North Dakota Adjutant General, Official Roster of North Dakota Soldiers, Sailors, and Marines, 1917-1918 (4 vols.; Bismarck, 1931), II, 968-969, III, 2491-2492, IV, 3349; Luther E. Birdzell, “North Dakota's Contribution of Men,” Quarterly Journal of the University of North Dakota, X (October 1919), 4-14; Leonard P. Ayres, The War with Germany: A Statistical Summary (Washington: Government Printing Office, 1919), pp. 19, 28; Wesley R. Johnson, "War Experiences of a University Student as a Doughboy," Quarterly Journal of the University of North Dakota, X (October 1919), 93-120.
} 
and about 200 physicians were serving with the United States Army Medical Corps. ${ }^{3}$ Eight men (including former Governor Louis B. Hanna) and seven women went overseas with the Red Cross; others worked in army libraries. More than 100 men entered the war work of the Young Men's Christian Association.

Some North Dakota women used their talents to entertain the troops. Young Ethel Halcrow (later to be Mrs. John B. Cooley and long the national Republican committeewoman for North Dakota) was a dramatic entertainer in army hospitals and camps. After the Armistice, Helen J. Sullivan, a member of the university faculty, managed the Étoile Service Club in Paris. Hazel B. Nielson, a young high school teacher in Fargo, and Delia Linwell, talented in dramatics, worked in army recreation centers in southern France. They and several hundred other American girls-all tremendously proud to be doing their bit-talked, walked, picnicked, sang, and danced with battle-weary veterans; they put on vaudeville acts, drove mobile canteens, and served chocolate and doughnuts. Everywhere she went, Hazel Nielson heard nothing but praise for North Dakota soldiers. A little later, while "fighting the battle of Paris," she met a number of them and had gay, exciting reunions with the girls from the University of North Dakota.

Many North Dakota women went to Washington to take government jobs. The state's institutions of higher education were, of course, affected by the war. In March, 1917, students at the university began to drill under volunteer faculty instructors. Some soon enlisted; many others went to work on farms, but in the fall the enrollment was down only 11 percent. The university and the Agricultural College gave courses in radio, telephony, auto mechanics, blacksmithing, carpentry, and other practical subjects to prepare men for the armed services. In the fall of 1918 the federal government established units of the Student Army Training Corps at some five hundred colleges and universities throughout the nation to combine military training and college courses and to train officers and technical experts. In North Dakota, S.A.T.C. units were placed at the university, the Agricultural College, Fargo College, and Jamestown College. An influenza epidemic stopped the program when it had been under way a week. At the university the epidemic forced the suspension of classes and a quarantine of the campus. A week later, most of the students were ill. Dormitories became hospitals, and the well fled to their homes; the physicians and women of Grand Forks helped nurses and an army doctor care for the stricken. At the Agricultural College, 12 of the 735 students enrolled there died; 29 of the university's 473 students died in three weeks. It had been a tragic experience.

During the war, there were 1,305 deaths among the men from North Dakota: 514 were killed in action; 149 died from wounds; and 642 died 
from disease. North Dakotans won 133 decorations: 2 Medals of Honor, 26 Distinguished Service Crosses, 4 Distinguished Service Medals, 4 Navy Crosses, and 97 decorations by Allied governments. ${ }^{4}$

North Dakota appreciated the service rendered by its fighting men. The legislature declared a moratorium on their debts, and when the war was over, it gave them a bonus of \$25 a month for each month of service. North Dakota was the first state to give veterans a substantial bonus; in May, 1921, Senator Edwin F. Ladd boasted that no other state had equaled it. By the end of 1928 the state had paid out $\$ 8,800,000$ to 26,475 veterans.

\section{HELPING TO WIN THE WAR: CIVILIAN EFFORTS}

Besides supplying men, North Dakota mobilized its material and emotional resources. On May 28, 1917, Governor Frazier appointed a state council of defense; each county set up a subsidiary committee. In July, John P. Hardy of Fargo began to organize a corps of "Four- Minute Men" to give patriotic speeches. Soon the 130 towns with motion-picture theaters had their Four-Minute Men; eventually, 588 speakers enrolled. Each week some of them gave patriotic talks in movie houses, schools, churches, and poolrooms. They talked to threshing crews and at lodge meetings and auction sales, asking for binoculars for the navy, preaching conservation, whipping up support for the war, and aiding bond sales.

There were five bond drives, Liberty Loans, to raise money for the war. Federal Reserve officials assigned each state and each county a quota. North Dakota's quota was $\$ 1,500,000$ in the first loan, $\$ 6,000,000$ in the second, $\$ 6,500,000$ in the third, $\$ 19,000,000$ in the fourth, and $\$ 18,500,000$ in the fifth, which came after the war was over. A system of state, county, and local committees organized the drives, put on nightly appeals at movies, and personally called on every prospective subscriber. Louis B. Hanna was state chairman for the first two loans.

The response was tremendous. North Dakota oversubscribed every loan, the third by 87 percent, and bought $\$ 65,500,000$ worth of bonds. This was 24 percent more than its quota; the nation oversubscribed by only 16 percent. On one occasion a threshing hand subscribed for $\$ 5,000$ worth of bonds, pulling out his bankbook to prove he had the money. The poverty-stricken Sioux of Standing Rock, throwing prudence to the winds, bought some $\$ 100,000$ worth of bonds. Bond buying seemed to stimulate other saving. Although the war years, except for 1915, produced poor crops, per capita bank deposits rose from \$35 in 1914 to $\$ 132$ in $1918 .^{5}$

In addition to buying bonds, North Dakotans gave generously to the

${ }^{4}$ Letters to Elwyn B. Robinson from H. A. Brocopp, Office of North Dakota Adjutant General, July 10, 11, 1957.

${ }^{5}$ Samuel Torgerson, "North Dakota's Contribution Thru the Liberty Loan," Quarterly Journal of the University of North Dakota, X (October 1919), 17-22. 
Red Cross, the Young Men's Christian Association, and other agencies working for the troops. The Sioux alone gave more than two thousand dollars to the Red Cross. "The Red Cross," wrote Aaron McGaffey Beede, an Episcopal missionary at Standing Rock, "is the center of Indian eager emotion and firm resolve in all war work... because of the association of the Red Cross with the Sundance, or at least with the basic Sundance ideas.” The Sioux associated both the Red Cross and the Sun Dance with the recovery of sick or wounded persons, with a cross symbol, and with the color red. During the war, Sun Dance vows were sometimes paid by giving horses to the Red Cross, and a red cross would be worn as a substitute for the old-time cutting of the breast.

Many white women joined the Red Cross (the state was near the top in membership) and spent long hours making surgical dressings, socks, and sweaters. In the Junior Red Cross, school children also turned out large quantities of such items. There were many other ways to help the war effort. In every village and town, vacant lots became war gardens; housewives canned vegetables as never before and cheerfully accepted restrictions on the consumption of meat, sugar, and wheat flour. It became fashionable to be frugal. Dean E. J. Babcock of the university's School of Mines, in charge of fuel conservation for the state council of defense, preached the gospel of lignite to cut down the consumption of eastern coal. As state fuel administrator, Captain I. P. Baker, an old-time steamboat captain, continued Babcock's work, publishing pamphlets on the uses and advantages of lignite. The use of lignite increased, the state had ample fuel, and the lignite industry was permanently benefited.

When the Armistice of November 11, 1918, ended the fighting, North Dakota rejoiced with the rest of the nation. The Sioux at Standing Rock held victory dances, the first since the Little Big Horn. At Cannonball they counted coups (touching with war club or lance in imitation of an ancient battle custom) on an effigy of Kaiser Wilhelm II. At Fort Yates, however, missionary Beede heard some old Indians decide that the most appropriate punishment for Kaiser Wilhelm, the object of intense hatred throughout America as the instigator of the war, would be to give him an allotment of land like an Indian's, some trees for a log cabin, a team of horses, harness, a wagon, a few cattle, and some agricultural implements such as were given to the Indians. Then the Indian agent should say to the Kaiser:

Now you lazy bad man, you farm and make your living by farming, rain or no rain; and if you do not make your own living, don't come to the Agency whining when you have no food in your stomach and no money, but stay here on your farm and grow fat till you starve. ${ }^{6}$ 
The number of Indian farms in North Dakota declined from 721 in 1910 to 517 in 1920.

\section{WAR AIMS IN NORTH DAKOTA}

The cost of the war, the terrible sacrifices demanded of the participants, made the goals for which the nations were fighting a matter of great importance. Early in the war some socialist groups in Europe began to talk of a peace based on no annexations and no indemnities. Before the United States entered the war, President Wilson spoke of the need for a peace without victory: a peace dictated by the victors would only plant the seeds for future wars. As a radical organization, the Nonpartisan League naturally sympathized with such views and opposed war profits. Its conservative opponents sought to identify such a stand with disloyalty and thereby destroy the League and its socialistic schemes by turning the powerful emotions of patriotism against it.

The League wanted to pay for the war with taxes on war profits and the conscription of wealth-methods which would promote the socialistic goal of equality. In 1917, before the declaration of war, the Leaguecontrolled lower house of the legislature passed a resolution calling on Congress, in the event of war, to make the first levy upon the "swollen fortunes" created by war profits. When Congress began to finance the war by means of bond sales instead of drastic taxation, Arthur C. Townley spoke throughout the state in favor of the conscription of wealth as a war policy. He favored conscription of men but also demanded that the government take the profits of the "rotten rich" to pay for the war. "Is this treason?" he would ask. "It is right!" the farmers would shout.

Late in the spring of 1917 the League drew up a statement of war aims. These resolutions pledged League members to defend the nation. They opposed the annexation of territory or the exaction of indemnities because these would deepen hatreds and cause future wars. They asked that the United States and its allies immediately make a common public declaration of peace terms "without annexations of territory, indemnities, contributions, or interference with the right of any nation to live and manage its own internal affairs.” The resolutions called for the conscription of wealth: "Patriotism demands service from all according to their capacity. To conscript men and exempt the blood-stained wealth coined from the sufferings of humanity is repugnant to the spirit of America and contrary to the ideals of democracy.” The League leaders denounced the evils of secret diplomacy; they feared that secret treaties instead of generous principles of humanity and democracy would govern the making of the peace.

The Nonpartisan League also favored federal control of the economy during the war. It urged food and price controls and the taking over of 
the railroads, the communications system, the major utilities, and resources of coal and oil. Such controls, it believed, would protect the well-being of all citizens. Leaguers liked President Wilson's strictures on profiteering; they loved Assistant Secretary of Agriculture Carl Vrooman, who spoke in Fargo, praising the patriotism of the farmers and blasting the "food pirates": "We have the best blood of the nation; we must draft also the wealth of the nation." They cheered when Herbert Hoover told a congressional committee that the people were being robbed of fifty million dollars a month by profiteering on flour alone.

There were obviously many similarities between the policies advocated by the League and those of the Wilson Administration. Wilson's Fourteen Points, announced in January, 1918, contained many of the League war resolutions drawn up in the spring of 1917: a just peace, no indemnities, no annexations, and an end to secret diplomacy.

Although he was not a member of the Nonpartisan League, Senator Porter J. McCumber supported Wilson's war aims, especially the proposal for a League of Nations. As early as January 13, 1916, he introduced a resolution in the Senate asking that the United States take the lead in forming such an organization. In 1919 he fought hard for the acceptance of the League Covenant. which Wilson had framed in Paris, and sharply criticized the isolationists and the selfish partisan opposition of Senator Henry Cabot Lodge and most of the Republican senators. McCumber was the only Republican senator to vote for joining the League of Nations both with and without reservations. Senator Asle J. Gronna, however, joined its most extreme opponents: "I for one will die before I will vote for the League of Nations in its present form.” There was considerable support for Wilson's plan in North Dakota. One newspaper wrote that the League of Nations was a "scheme to boost and not to knock.” Twice in 1919 (in March and again at a special session in December) the state legislature passed resolutions favoring participation by the United States.

Woodrow Wilson's liberal philosophy had long appealed to the Nonpartisan League. Before America's entry in to the First World War, the Nonpartisan Leader had often printed paragraphs from Wilson's published speeches, The New Freedom, and League speakers constantly quoted the book. The League was soon selling it at a special price to members, commending it as a "textbook of League principles." Late in 1917, George Creel, head of the federal war propaganda agency, arranged an interview between Townley and Wilson. Creel himself wrote: "North Dakota... has as fine a record of war support as any other commonwealth in the Union."7

${ }^{7}$ Herbert E. Gaston, The Nonpartisan League (New York: Harcourt, Brace and Howe, 1920), pp. 177-195; Robert L. Morlan, Political Prairie Fire: The Nonpartisan League, 1915-1922 (Minneapolis: University of Minnesota Press, 1955), pp. 111-112, 136-138, 149-182; Paul W. Morrison, “The Position of 


\section{THE LOYALTY ISSUE}

In spite of that record, loyalty became an issue in North Dakota. Wartime patriotism, the presence of many recent immigrants, and the struggle against the Nonpartisan League raised the issue. The last-named cause was especially important. Conservatives, seeking to destroy the League, seem to have entered in to a conspiracy to picture North Dakota as a disloyal state. To attack the patriotism of League officeholders was, in reality, to attack the patriotism of the overwhelming majority who had elected them and who still supported them. Yet for most of the war, Jerry Bacon filled the Grand Forks Herald with statements questioning the loyalty of Lynn J. Frazier, Arthur C. Townley, and other League leaders. It frequently attacked Senators La Follette and Gronna for their alleged pro-German feelings and represented the election of League-backed John M. Baer to Congress in 1917 as a defeat for Americanism. Other conservative newspapers and speakers at patriotic meetings repeated the same themes. The opposition press freely misquoted Townley's speeches-in order to give them a pro-German cast-until he began to have a stenographic transcription made for his own protection.

Opponents of the League-community leaders: bankers, lawyers, and members of commercial clubs-took the lead in all patriotic activities, such as Liberty Loan, Red Cross, and war-charity drives, and excluded the League. When collections for the Red Cross were taken up at League meetings, Red Cross officials refused to accept the money. The state Red Cross chairman's secretary sent out a letter on official stationery: "Here in North Dakota we consider the League thoroughly disloyal." Statements like this were falsehoods. There was never a federal indictment for sedition or discouraging enlistment returned against a League official or against a League-elected state officeholder. Under such men, North Dakota compiled an outstanding record in patriotic service. After a year· and a half of vilification, North Dakotans re-elected Governor Frazier by a large majority.

There were, however, some trials involving League speakers, although they did not prove disloyalty. In December, 1917, Kate Richards O’Hare was sentenced at Bismarck to five years in a federal penitentiary after a trial before Judge Martin J. Wade of Iowa. She was a well-known Socialist and an earnest pacifist. While a guest of prominent Leaguers Mr. and Mrs. George A. Totten of Bowman, she made an antiwar speech, not sponsored by the League, and was charged with sedition. Many believed that she was convicted on false testimony.

The most important case involving the Nonpartisan League was that of Walter Thomas Mills. A veteran Socialist and agitator from California and nearly eighty, Mills made a fiery speech in Fargo before the June, 
1918, primary:

Who are the men who are fighting for us in France? They are not the sons of members of chambers of commerce; they are not the sons of commercial travelers; they are not bankers' or merchants' sons; but they are your boys. For every thousand soldiers killed in France there is one additional millionaire in America.

Boiling with anger, a group of Fargo businessmen demanded that Mills be indicted. At the conclusion of his trial, Judge Charles F. Amidon seeing that aroused emotions made a fair judgment unlikely, directed the jury to return a verdict of not guilty. He said that although the sons of the rich were serving in France, "unfair speech does not constitute a violation of the espionage act."

The Fargo business community turned on Amidon, one of the leading men of the city for over a third of a century. For days he was scarcely spoken to; businessmen crossed the street to avoid meeting him; at church, people moved out of the pew in which he sat. Amidon, a courageous judge, was sympathetic with the Nonpartisan League; for a time, his daughter worked for it. ${ }^{8}$

There were, of course, espionage and sedition trials which did not involve the League. In the 1880's, John H. Wishek had promoted the settlement of McIntosh County, winning the affectionate title "Father Wishek," and had become wealthy. Although born in Pennsylvania, he was proud of his German ancestry, and gave away five or six copies of a booklet entitled German Achievements in America. Enemies, jealous of his business success, secured his indictment under the Espionage Act and gathered at Bismarck to gloat over his downfall.

The trial dragged on for three weeks. Wishek's attorneys showed that he had bought more Liberty bonds than all of his business rivals combined. At the end, Judge Amidon pointed out that the prosecution witnesses bore a "private grudge" against Wishek. He told the jury that three things were forbidden by the Espionage Act: false reports to interfere with the success of the armed forces, incitement to mutiny, and obstruction of recruiting. The jury must decide whether Wishek's act would naturally tend to accomplish any of these things and whether he gave away the booklets with that "deliberate purpose" in view. The jury, standing nine to three for acquittal, disagreed. The charges were dropped, but the incident darkened Wishek's later years. ${ }^{9}$

As the trial revealed, Judge Amidon tended to interpret the Espionage

${ }^{8}$ United States Department of Justice, Interpretation of War Statutes, Bulletins 148, 153, 164, 204 [1918]; Beulah Amidon Ratliff, "Charles Fremont Amidon," North Dakota Historical Quarterly, VIII (January 1941), 98-99; Gaston, Nonpartisan Leaque, pp. 188-192.

${ }^{9}$ Nina Farley Wishek, Along the Trails of Yesterday: A Story of McIntosh County (Ashley, N.D.: Ashley Tribune, 1941), pp. 422-424. 
Act narrowly. He excluded as valid evidence acts and speech which showed that a defendant lacked patriotism, if these things did not interfere with the success of the armed forces or obstruct recruiting. Amidon's fair handling or such cases won him the praise of Zechariah J. Chafee, Jr., a Harvard law professor, his book Freedom of Speech (1920). The two became friends. Amidon gave North Dakota a good record on civil liberties during the First World War, probably the period of their greatest restriction. Edwin F. Ladd, making his first speech in the United States Senate in 1921, boasted that during the war the state had been "an oasis of sanity in a desert of hysteria."

There were, however, some convictions in North Dakota under the Espionage and Sedition acts. Farmer Henry von Bank, a naturalized citizen from Luxembourg, was president of a d strict school board in Cass County. When the board was criticized for refusing to buy a flag, he visited the school. Miffed by the fuss, he told the teacher (the originator or the criticism) that he would just as soon see a pair of old trousers flying over the schoolhouse as the flag of the United States. Von Bank was convicted, but the circuit court ordered a new trial because Judge Amidon had not directed a verdict of not guilty.

The conviction of the Reverend John Fontana was also revered. A German Evangelical pastor at New Salem, he had become a naturalized citizen in 1898. Fontana blamed President Wilson for the declaration of war. Moreover, he refused to buy Liberty bonds, to put up a flag in his church, or to give to the Red Cross. Judge Amidon told the jury that these deeds were not crimes, but when Fontana was found guilty, Amidon sentenced him to three years in the penitentiary. After his conviction, Fontana's congregation refused to dismiss him, and his synod chose him as chief speaker at the dedication of the new church in Hebron.

\section{THE ECONOMIC IMPACT OF THE WAR}

The war, of course, influenced North Dakota agriculture, always subject to outside forces. The war's inflationary impact was intensified by the almost simultaneous end of free land. The war did not make the state prosperous, as it did the nation; rather, the wartime inflation of land values wrought permanent injury to the North Dakota economy.

North Dakota's role was to supply wheat for the United States and the Allies. The war increased the price of wheat, but the state did not benefit very much because in half of the six years from 1914 through 1919 it had poor crops. The wheat crop was poor $(50,000,000$ to $60,000,000$ bushels) in 1916, 1917, and 1919; it was average (about 100,000,000 bushels) in 1914 and 1918; only in 1915 was it large-a record-breaking 159,000,000 bushels. That year, however, the price fell off sharply (about twenty-five cents a bushel) when the farmers sold the crop.

When the United States entered the war, farmers were urged to increase their production of food. The day after the declaration of war, Governor Lynn J. Frazier urged farmers to plant every available acre to 
meet the need. In 1918, Frazier, Edwin F. Ladd, then president of the Agricultural College and state food administrator, and Thomas Cooper, director of the North Dakota Agricultural Experiment Station, asked North Dakota farmers to grow more wheat and rye. They increased their plantings and in 1918 harvested about half a million more acre of wheat than they had the year before.

The federal government, however, moved against the wheat farmer. In August, 1917, a commission appointed by Food Administrator Herbert Hoover set the price of No. 1 Northern at \$2.20 at Chicago. The cash price at that time was $\$ 3.06$. In 1918 the government raised the price to $\$ 2.26$. It did not, however, regulate the price of flour. It hardly seemed fair that the farmer should be singled out for control while others were allowed to make all they could from the war boom. The Nonpartisan Leader called it virtually "commandeering the crop."

Drought also hurt farm income. The western two-thirds of the state had less than normal precipitation for four straight years, from 1917 through 1920. The year 1917 was the driest since statehood, with only 10.75 inches; only 1934 and 1936 have been drier. By the fall of 1918, hay was fifteen dollars a ton and scarce. Stockmen were culling their herds and selling the cattle they could not feed. After three dry years, cattle went in to the winter of 1919-1920 in poor condition; many starved. Ranchers, operating on borrowed capital, had to sell their herds in a declining market, and some of the older men never recovered from their losses. The price of good beef steers fell 48 percent from the fall of 1920 to the fall of 1921. ${ }^{10}$

Earlier the war had created a shortage of farm labor. Thousands of men entered the armed services; many others left the state for jobs in war industries. In the summer of 1917 a committee of the Nonpartisan League worked out an agreement with representatives of the Agricultural Workers' Union (affiliated with the radical Industrial Workers of the World), but Arthur C. Townley thought the four-dollar minimum daily wage was too high and refused to accept it. Governor Frazier then issued an order for strict protection of employers and crops against worker violence but forbidding police action against workers seeking higher wages. By 1918 farm hands were getting an average wage of seventy dollars a month. School terms were shifted, allowing high school boys to work in the fields. In most towns, groups of businessmen helped to bring in the crops. Six-foot-four John Moses, then a lawyer at Hazen and later to be governor of the state, organized such a harvest brigade and excelled the others as a bundle pitcher. Labor shortages and high farm wages were a part of the national inflationary trend.

The decade from 1910 to 1920 saw some expansion in agriculture. The number of cattle on farms more than doubled, but farms were still not 
well stocked in 1920 and wheat still dominated the economy. There was a small increase in the number of farms, from 74,000 to 78,000 , but there were large increases in the amount on land in farms (from 28,000,000 acres to 36,000,000) and in their average size (from 382 acres to 466). The really big increase, however, came in the value of all farm propertyfrom $\$ 975,000,000$ to $\$ 1,760,000,000$, a peak which would not be reached again until the inflationary spiral of the 1950's.

Land was, of course, the basic wealth of North Dakota. Its value had been rising since the beginning of settlement, and the end of free land, followed shortly by wartime inflation, drove land values even higher. Farm land averaged \$11 an acre in 1900, \$26 in 1910, and \$35 in 1920. As the value of the land went up, so did the number of mortgaged farms, the mortgage debt, and tenancy. Half of the farms operated by their owners were mortgaged in 1910, 71 percent in 1920. The mortgage debt increased from $\$ 48,000,000$ to $\$ 108,000,000$. The percentage of farms operated by tenants increased from 14 percent to 26 percent.

Inflation nearly ruined the state. Many farmers, dazzled by high prices for farm produce, borrowed money from banks and bought land for more than it was worth. When the bubble burst, land values and produce prices began a disastrous decline. In the deflation, North Dakota suffered severely. Many farmers lost their land in the 1920's; many banks failed; tenancy increased rapidly. The optimistic time of rapid settlement was over, and the state now entered a period of relative stagnation.

The turning point had actually come about 1915 . For the first time in North Dakota's history the population began to grow at a rate less than that of natural increase. The rate of natural increase (the excess of births over deaths) was about 15 percent per decade. The population of the area which became North Dakota in 1889 had risen 1,435 percent from 1870 to 1880 and 417 percent from 1880 to 1890 . The state's population had grown 67 percent from 1890 to 1900, and 81 percent from 1900 to 1910. From 1910 to 1920, its population increased by only 12 percent.l

North Dakotans were moving from the countryside to the towns and cities. From 1910 to 1920 the population of urban places (over 2,500) grew 39 percent; the population of the smaller towns and villages rose 29 percent; the population of the countryside increased by only 4 percent. Ten counties actually declined in population.

According to the federal census, North Dakota had a population of 577,000 in 1910 and 647,000 in 1920, an increase of 70,000 persons during the decade. This number was some 22,000 less than the rate of natural increase. A state census in 1915 put the population at 637,000. Thus almost all of the growth had come in the first half of the decade. Then, large numbers of people began to leave the state, more than matching the number still coming in. This is shown by the increase in the number of persons born in North Dakota but living in other states; in 1910 the number was 48,000; in 1920 it was 101,000. People had been leaving North Dakota since the beginning of settlement, but now, for the 
first time, more were leaving than were coming in.

It was a turning point in the state's history. Up to 1915 the major problems had been connected with the taking up of the land, the creation of farms and towns and railroads and the whole mechanism of a civilized society-the mighty influx of people and capital from the outside. Now, in 1915, the free lands were gone; the new frontiers of opportunity were the cities. After 1915 the most serious problems (although, of course, they had appeared before) were to be connected with adjustments to the semiarid nature of the country, to North Dakota's status as a dependent hinterland producing wheat and cattle for outside markets and lacking opportunities for all of its people. That North Dakota's greatest export was people was to become almost a folk saying in the state. Could the state diversify its economy or must it remain fundamentally a springwheat country? After the First World War, North Dakota began its long struggle to answer that question. 


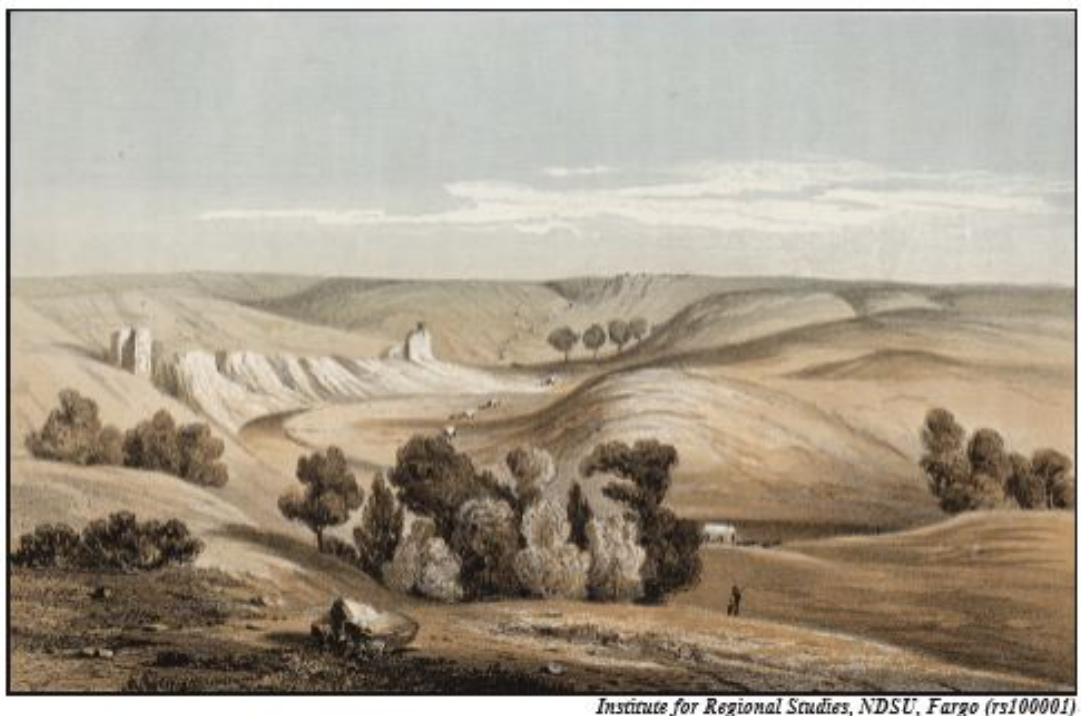

Dakota Landscape near Mouse River, engraving from railroad exploration and survey report, published 1860 .

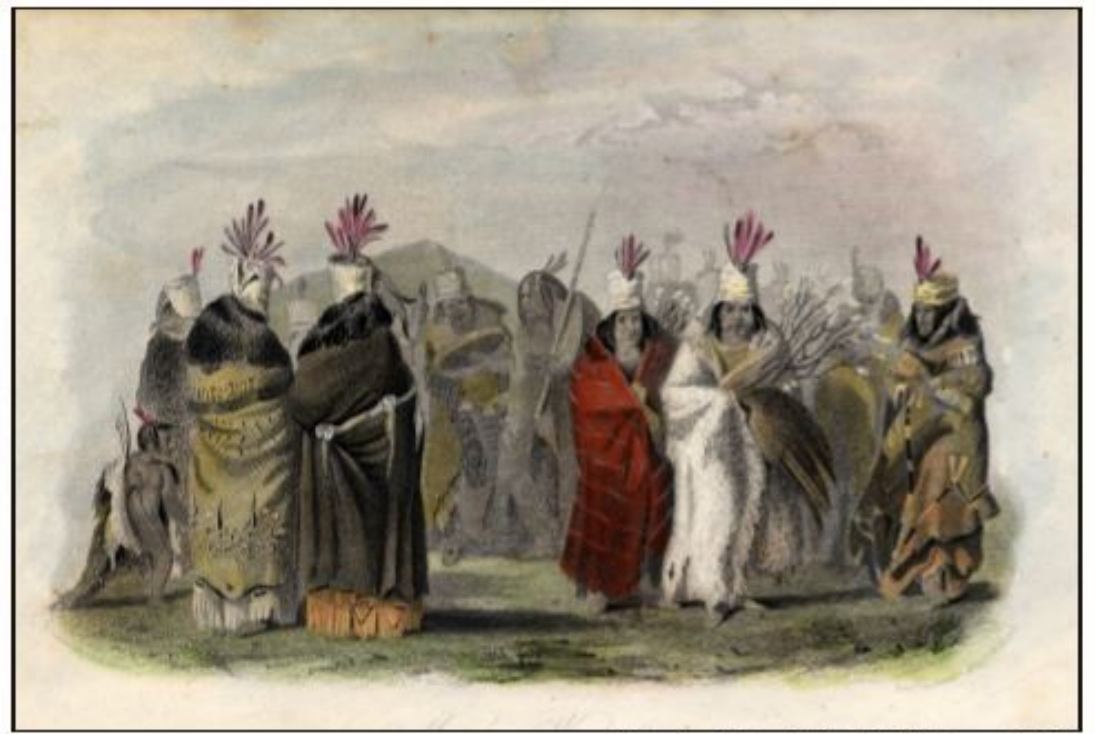

Institute for Regional Studies, NDSU, Fargo (rs100004)

Mandan Indian women, c. 1860. 


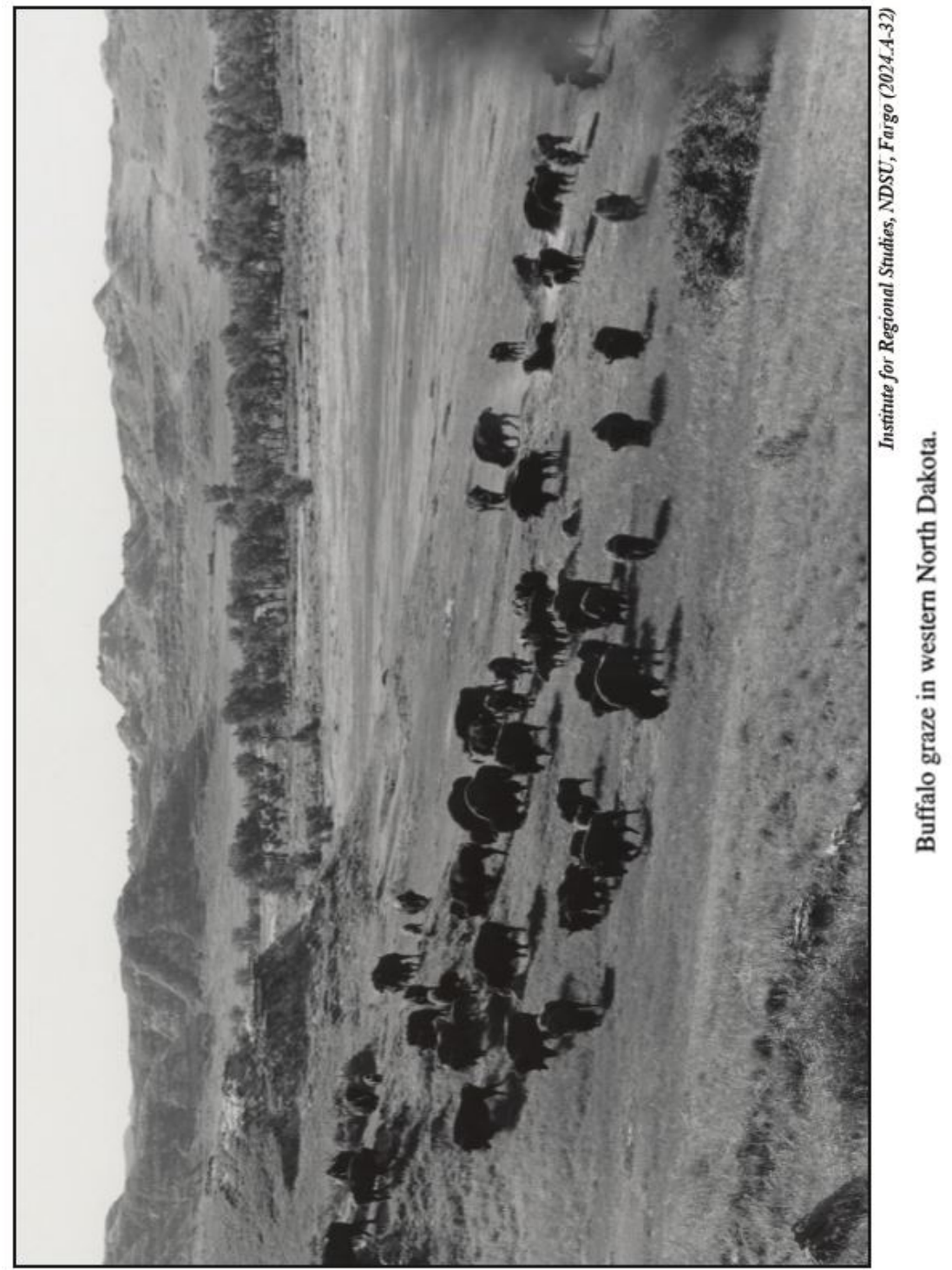




\section{FRONTIER SCOUT}

Winegar \& Goodwin, Publishers

LIRERT AXD USTOX.

Ca. I 30th Wis Vols, Proprioton

Vol. 2

FORT UNION, D. T, JULY 14, 1864.

No 2

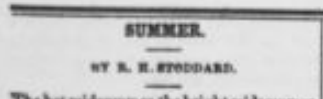

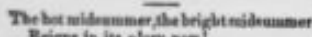
Reigne is ite glory sow ?

The with je nocmbed with a goldes firs,

Tare sre berries dead ripe eserery brier,

Aad fraies es every beuth.

Bot the antenes drys, so wober and ealm, wheped is a dreats lane;

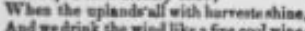
And wernisk the pied hive a five cool wise, Als, thene are the bees of days?

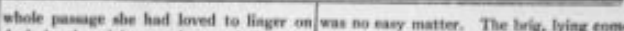

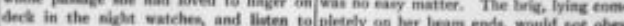
the narvellows tales of the and hisen to pieicly on her hieam ends, woulit sot obey

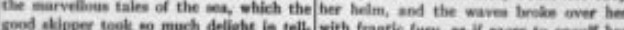
good stipper teek to much delight in tell- with frantic fury, an if eager to engulf her laer; sad she had atready learned to boek with all her wealth of property asod lile. opres Mim almoet in the light of a brotber, "Save $\mathrm{m}$ save is, Captain Mainer?" so kind and considerate was he upon ali ghrieked the Count Gensales, in a taue of ocrasines, and soch pleasure disd he feet is the wildent alarm sed terroc, while the

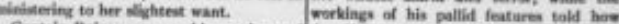
Captain lainer was a noble opecinen of dreadful was the anguish be endures:

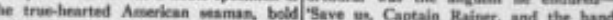

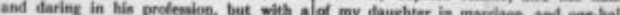

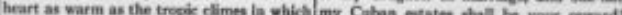

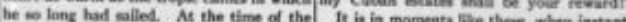

Tine asscued ramex.

or sts. masace.
opening if eur tale, Captain kainer was desth is staring the proud mas in dhe face. abowt twenty-eight yearn of age, with as ab- that he forgets his rank, his titles, and hi. bie form and manly cast of leatures, and dignities, and becoenes imtiund with the altbough without the advantages of mbolas- opirit of humanity. On the firm, Ary lant.

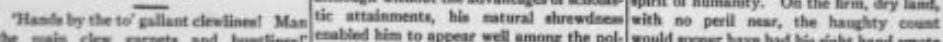

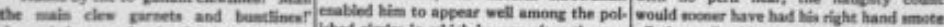

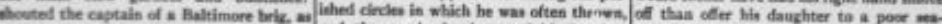

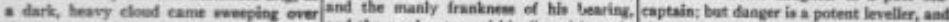

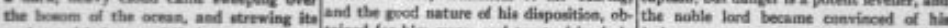
the biace sirh loas ocean, aed strining ito

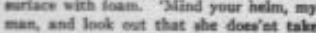
the whet out ef your hand

"Ay, ay, alr? tained for his warm and truety friende in forlorsmens

the the

T should be happy to ave both you and

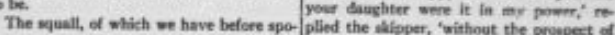
to captain, captainf' wald a fair, light- ken, was now close upos the trik, and ev. the rich reward you promined, but fear the

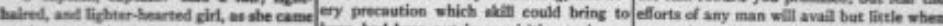
up the companibe ladder to the apper deck, bear, had been put in requinition to inaure opposed to the atrong arn of the finrta

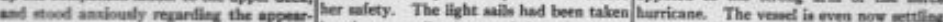
once of the havens, Thope we are not in is, the top salle close reeled, and coursen by the head.'

any danger, are ver?

'No, no- ho danger, Elen,' asmered de shipger, in an gentle tose. 'Hut go be. bow, child: you will enly te in the way here.

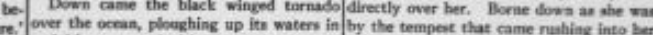

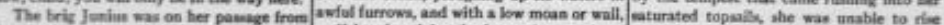

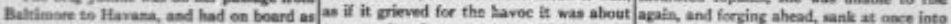

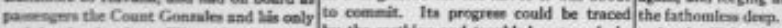

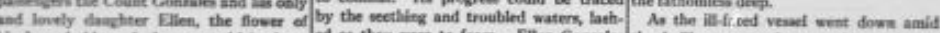

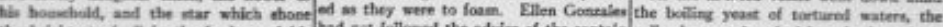

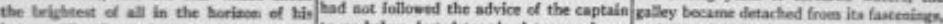
hopes. The Count had bees upee a viati to $\mathrm{go}$ below, beat determines to remain on and flosted clear of the derk. To this frail

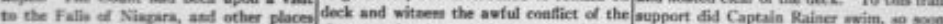

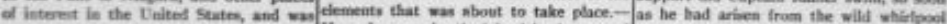

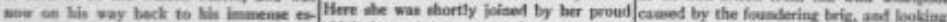

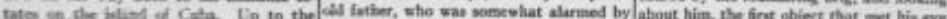

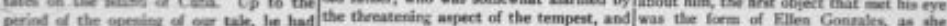

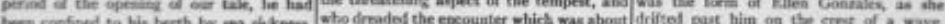

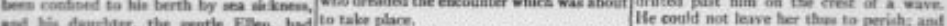

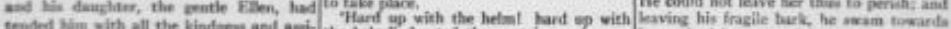

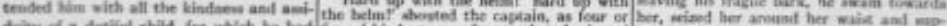

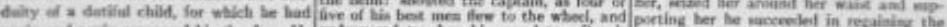

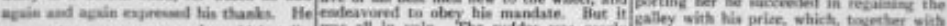

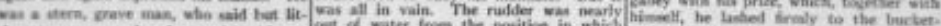

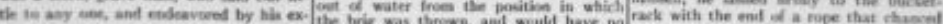

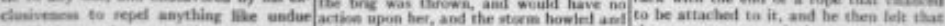

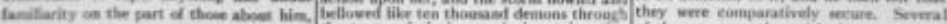

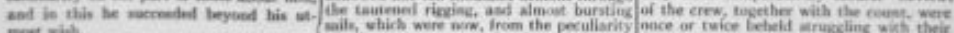
mos wish.

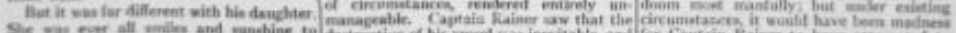

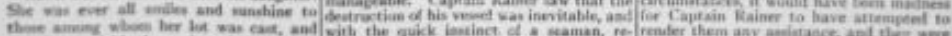

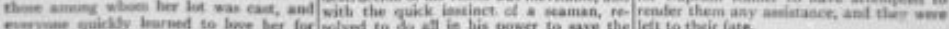

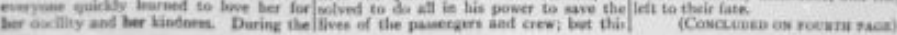

Instimute for Regional Studies, NDSU, Fargo

Frontier Scout, North Dakota's first newspaper, issue of July 14, 1864. 


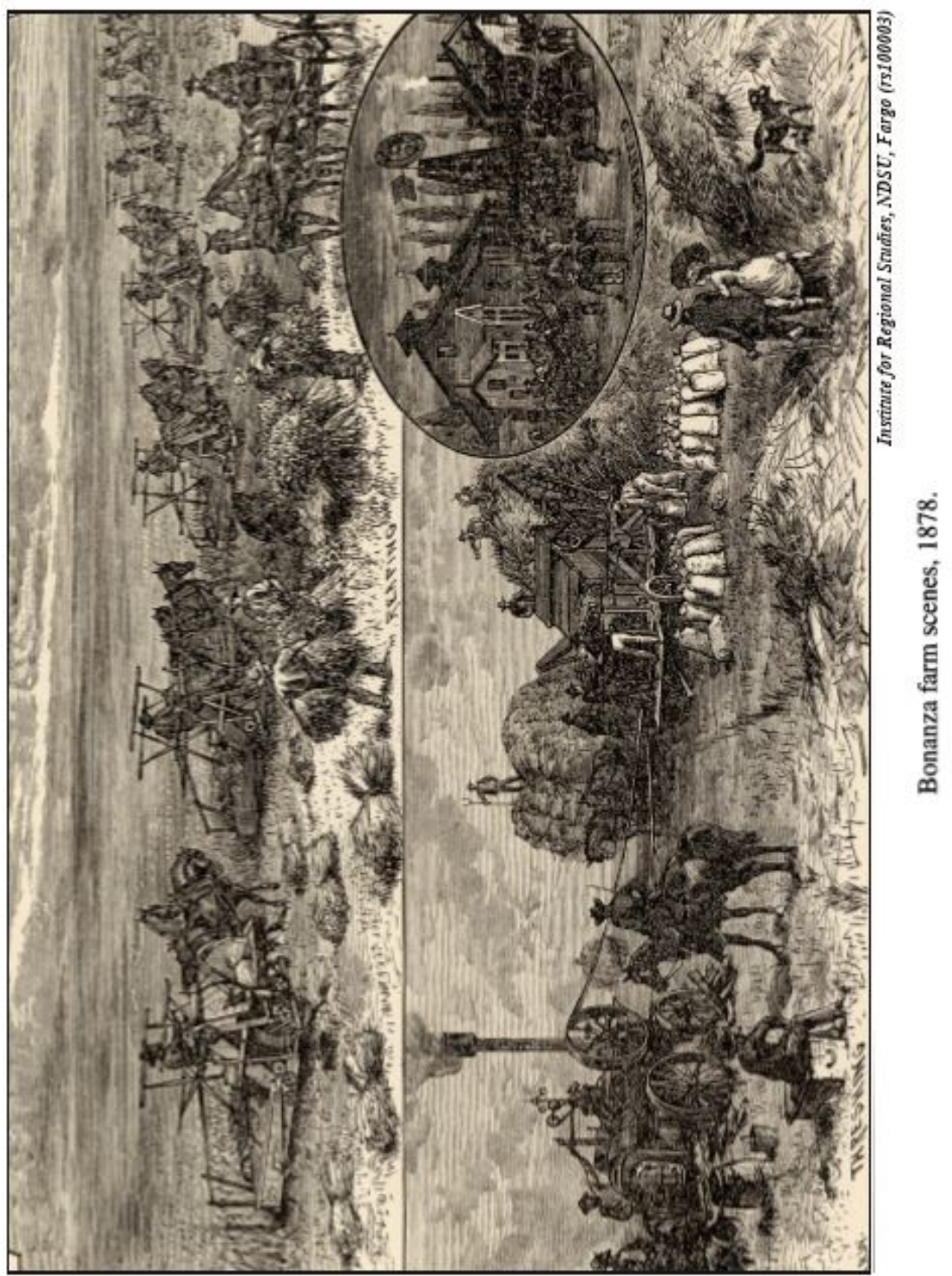




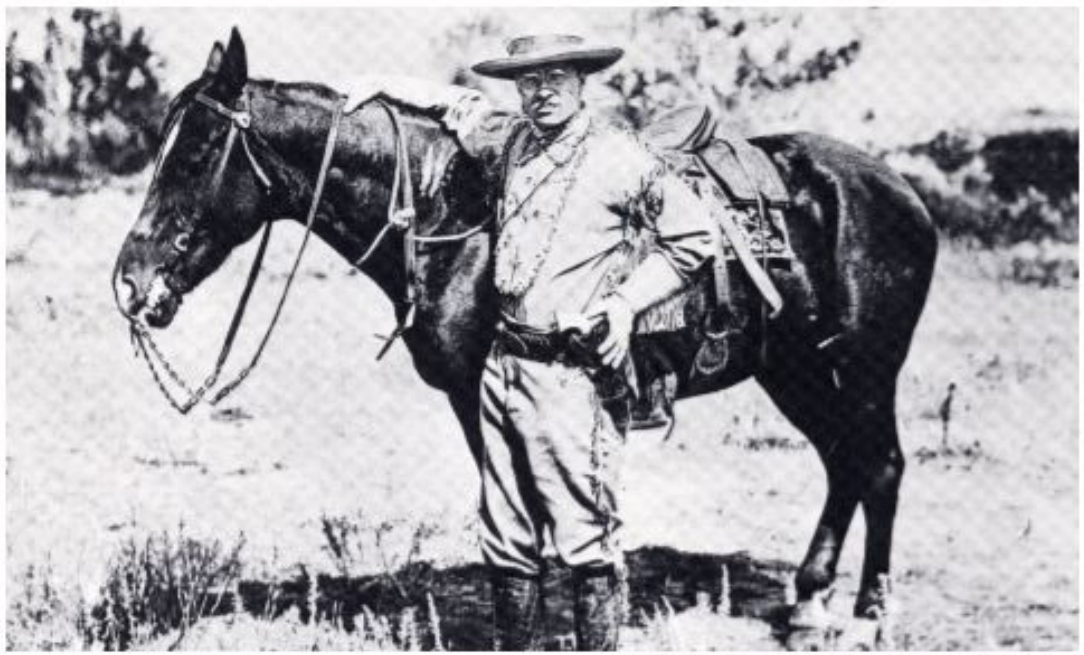

Institute for Regional Studies, NDSU, Fargo (P190.1)

Theodore Roosevelt in Medora, early 1880 s.

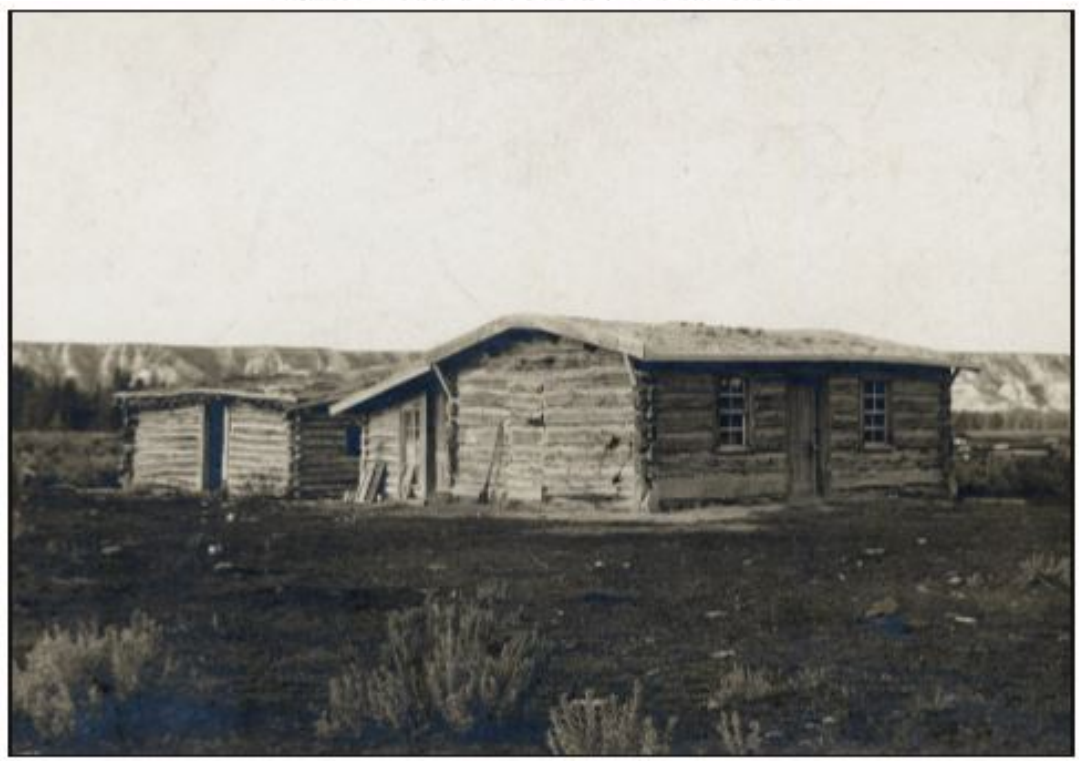

Institute for Regional Studies, NDSU, Fargo (9.3.2)

Theodore Roosevelt's log cabin on Chimney Butte Ranch, Badlands, c. 1904. 


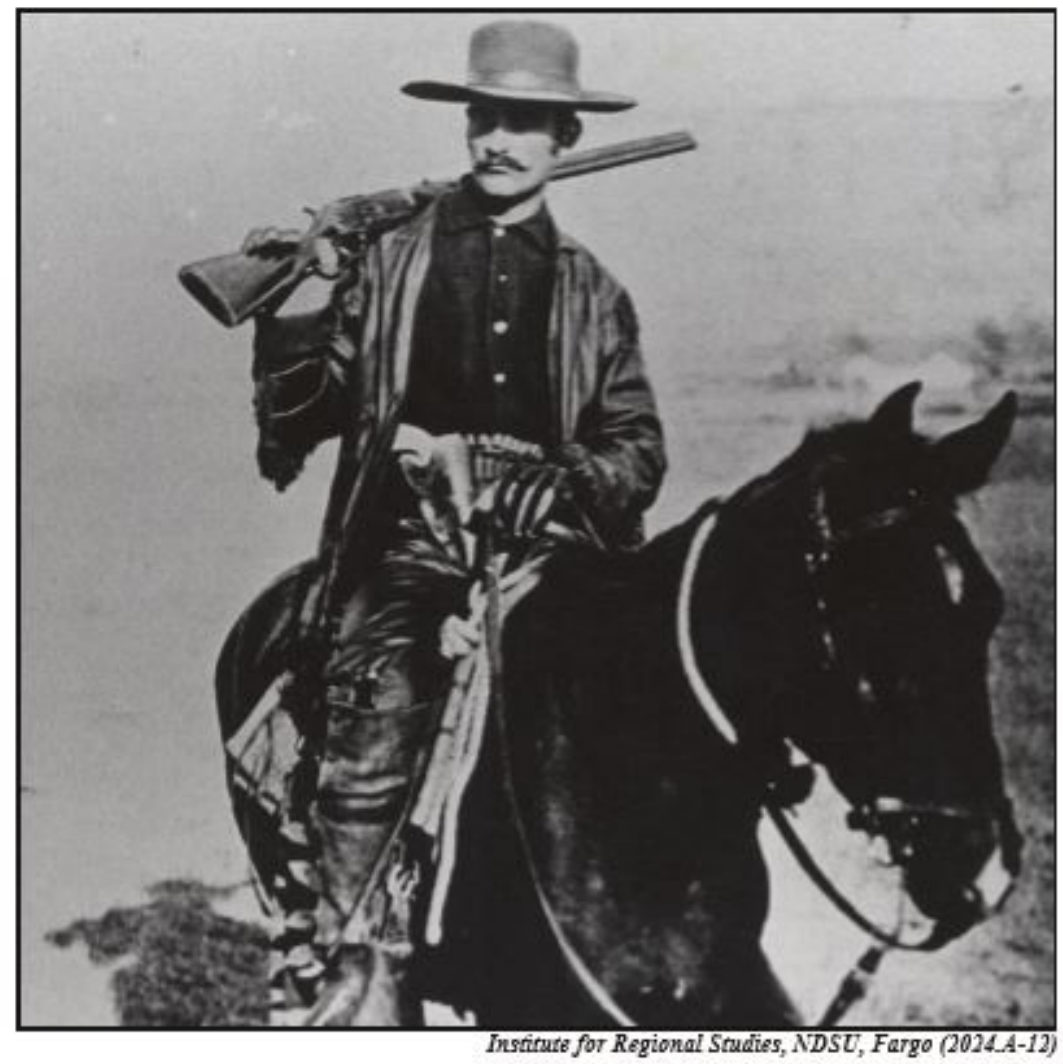

Marquis de Morés, 1886.

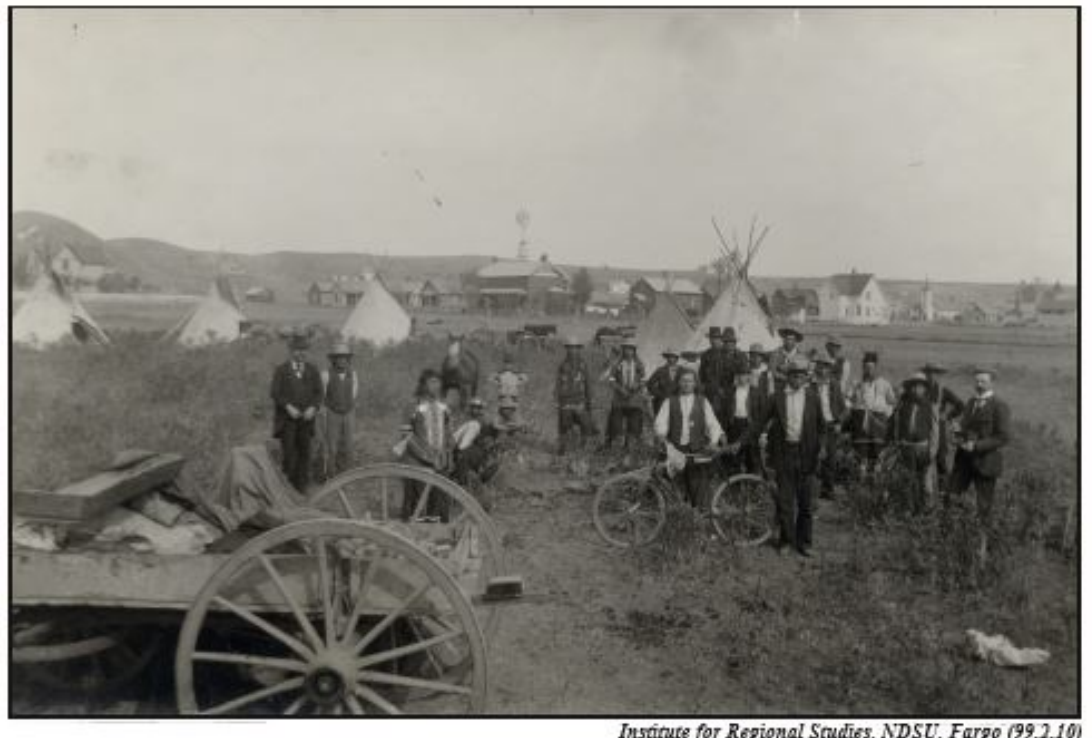

Mandan Indians attend state fair at Mandan. 


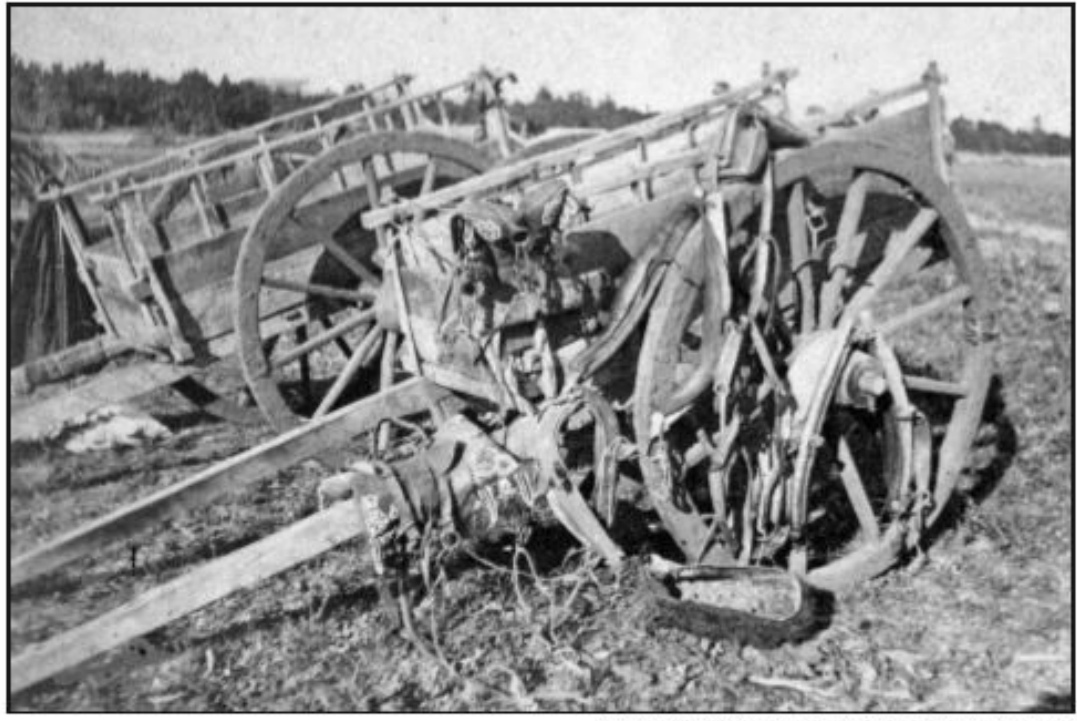

Institute for Regional Studies, NDSU, Fargo (rs005085)

Red River carts in North Dakota.

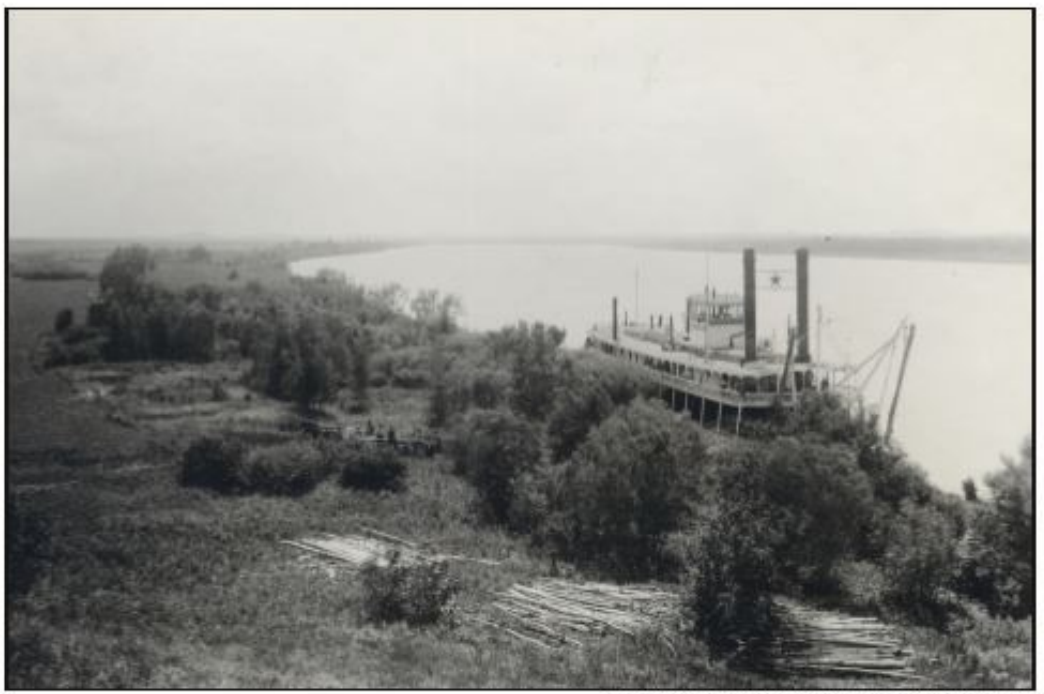

Institute for Regional Studies, NDSU, Fargo (59.1.9)

Steamboat on the Missouri River at Fort Yates. 


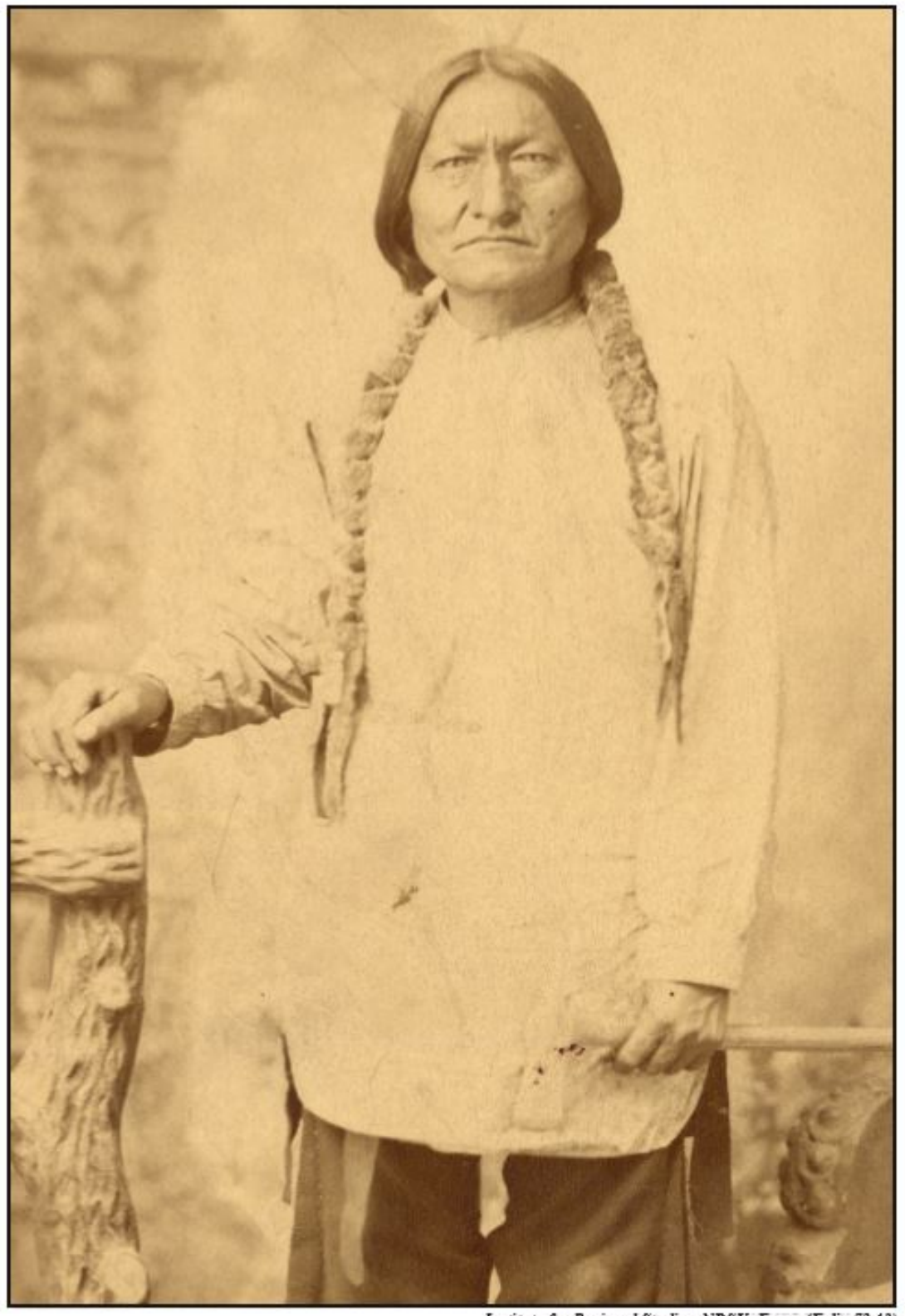

Institute for Regional Studies, NDSU, Fargo (Folio 72.12)

Sitting Bull, c.1880s. 


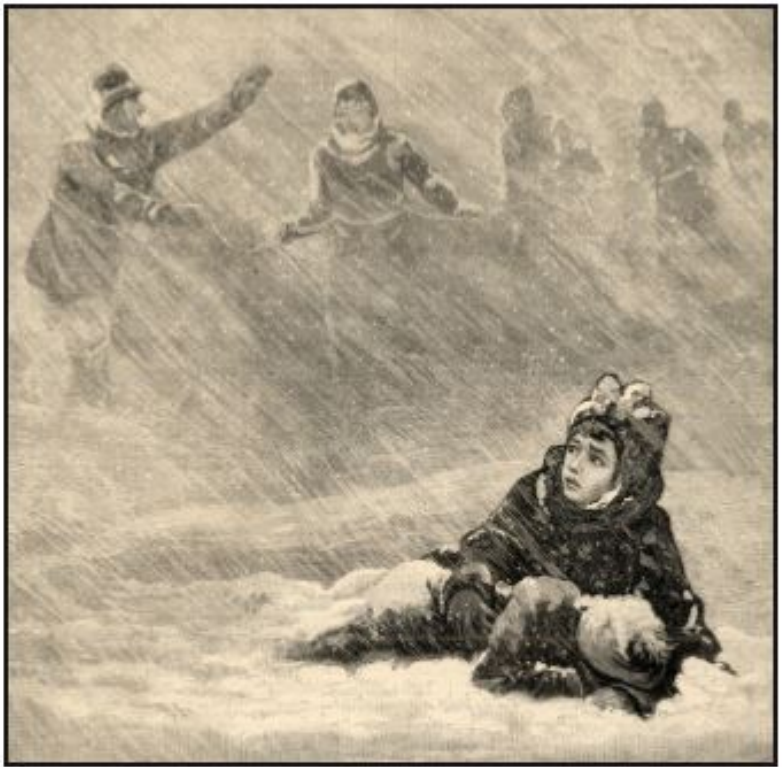

Instimte for Regional Stuties, NDSU, Fargo (rs100005)

Dakota rescue party, roped together, searches for missing children. Engraving from "Scenes and Incidents of the Recent Terrible Blizzard in Dakota," Frank Leslie's Illustrated Newspaper, January 28, 1888.

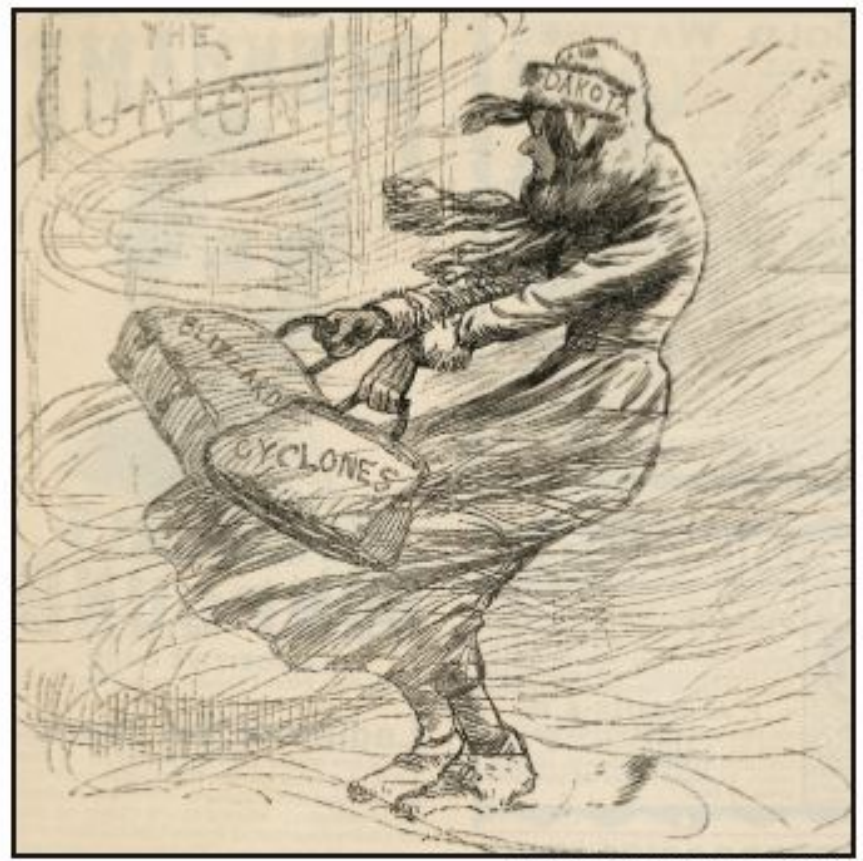

Institute for Regional Studies, NDSU, Fargo (rs100002)

Editorial cartoon depicting Dakota Territory applying for statehood, Frank Leslie's Illustrated Newspaper, March 3, 1888. 


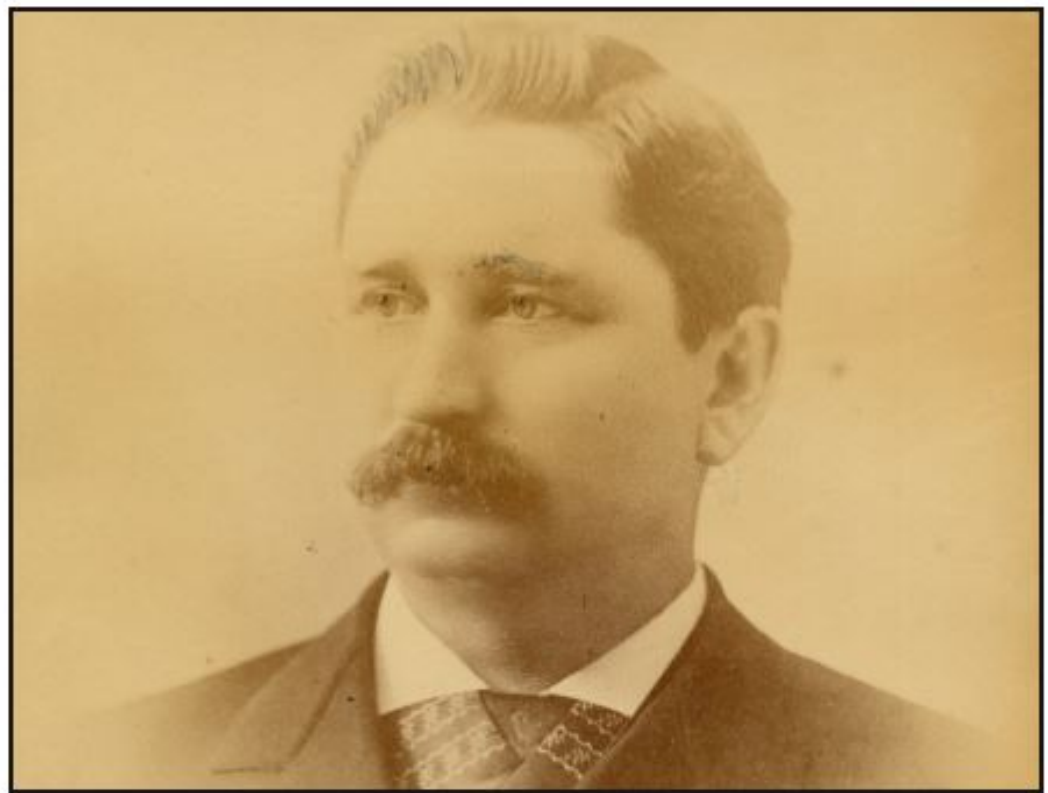

Institute for Regional Studies, NDSU, Fargo (2041.33.1)

Alexander McKenzie, 1890s.

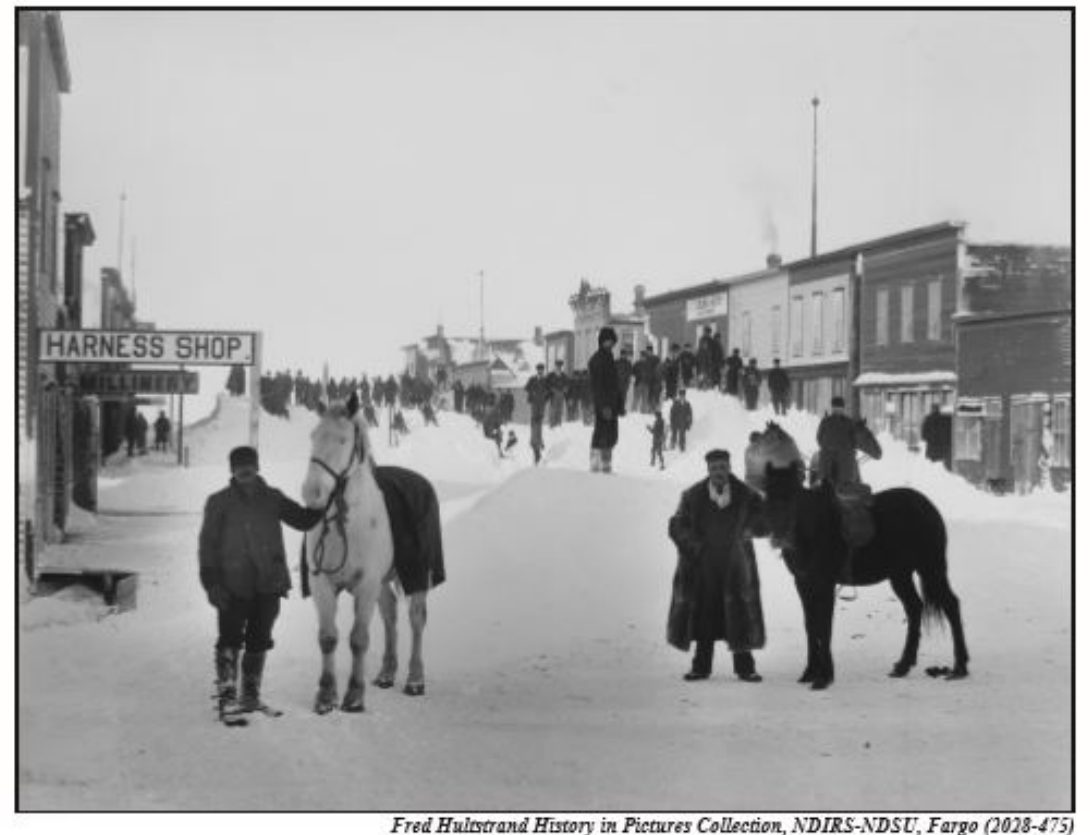

After the blizzard, Main Street, Milton, c.1893. 


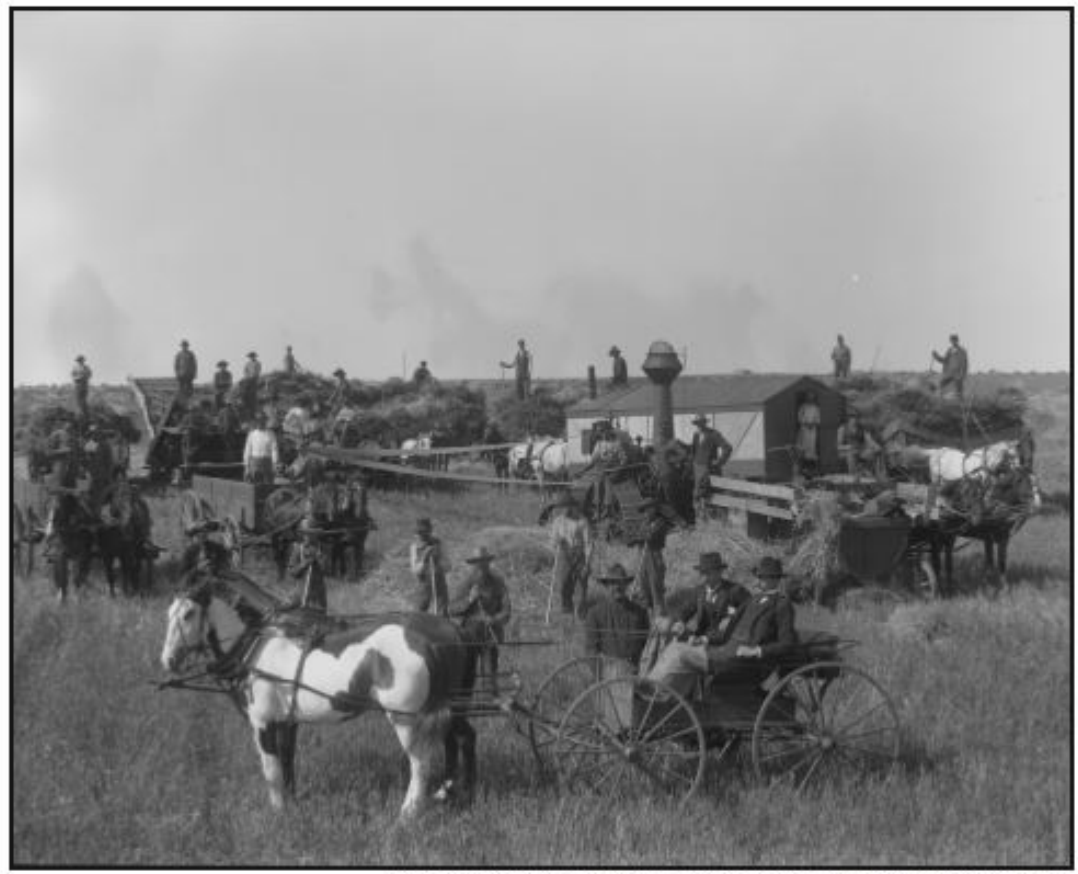

Fred Hultetrand History in Pictures Collection, NDIRS-NDSU, Fargo (2028-173)

John McKay threshing outfit, Milton, c. 1900.

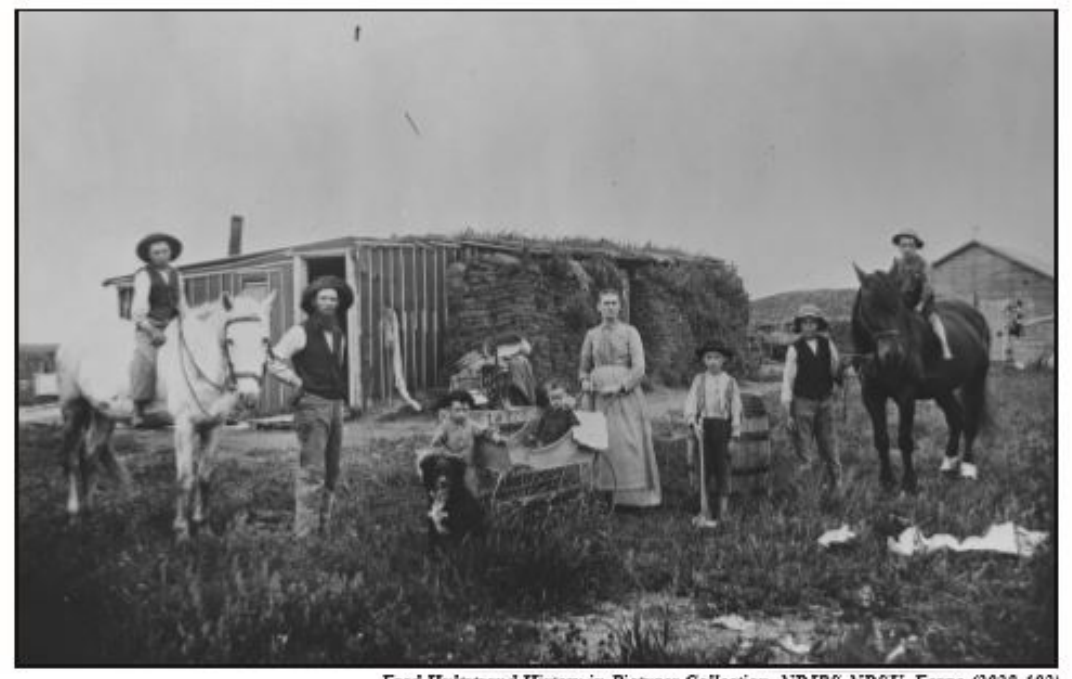

Fred Hultstrand Hustory in Pictures Collection, NDIRS-NDSU, Fargo (2028-102)

Joseph and Annie Burkholder family, Towner County, 1901. 


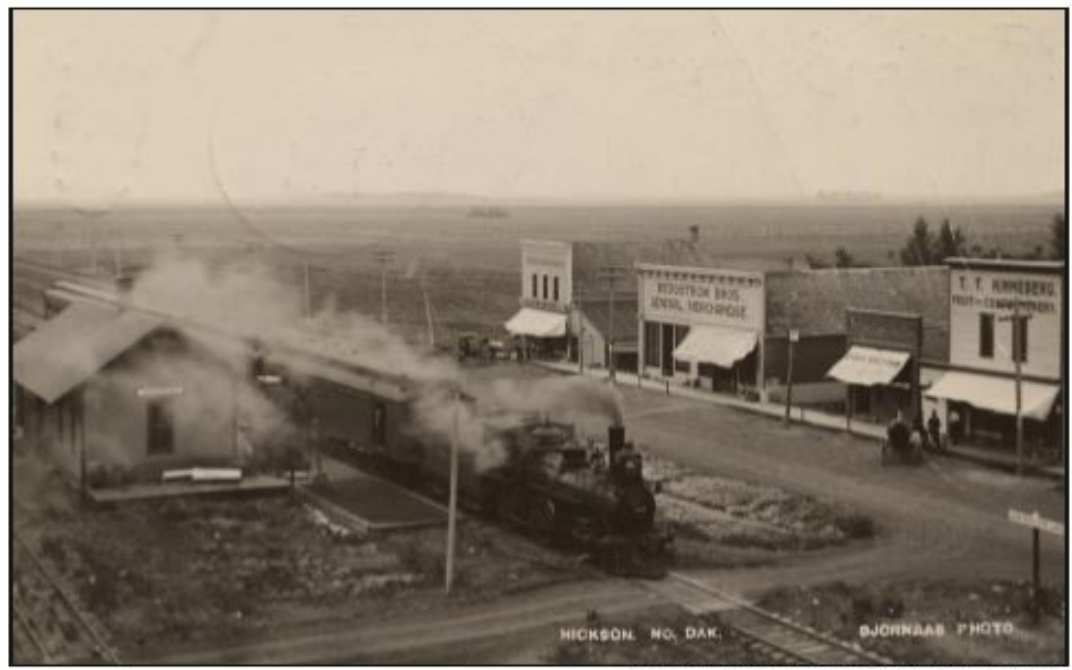

Instituce for Regional Studies, NDSU, Fargo (80.1.1)

Hickson, around 1910.

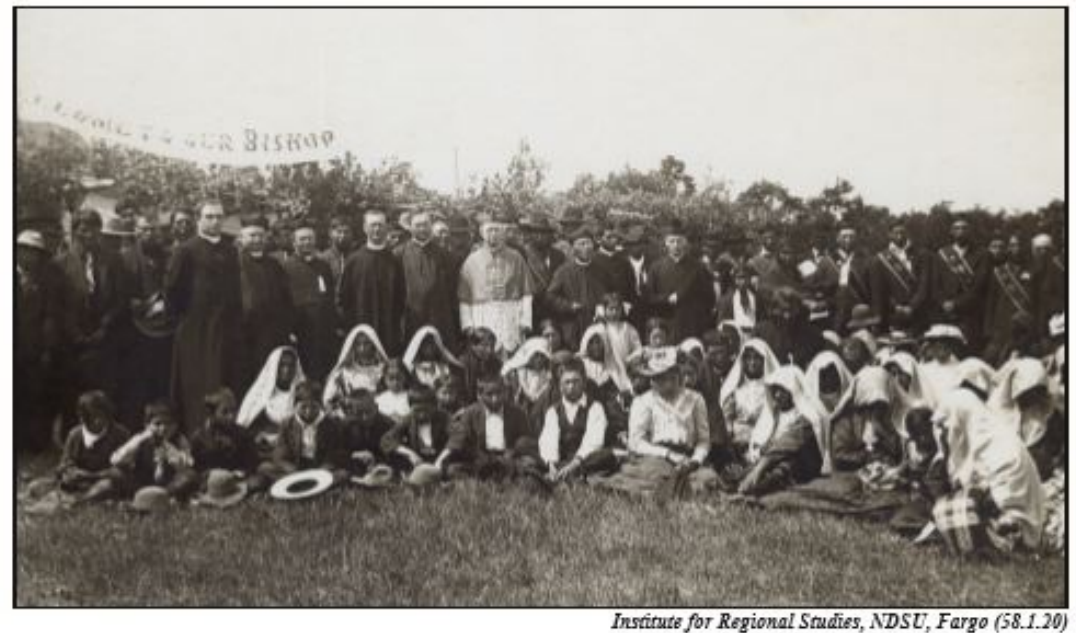

Bishop Shanley with Indians at Fort Totten, 1909. 


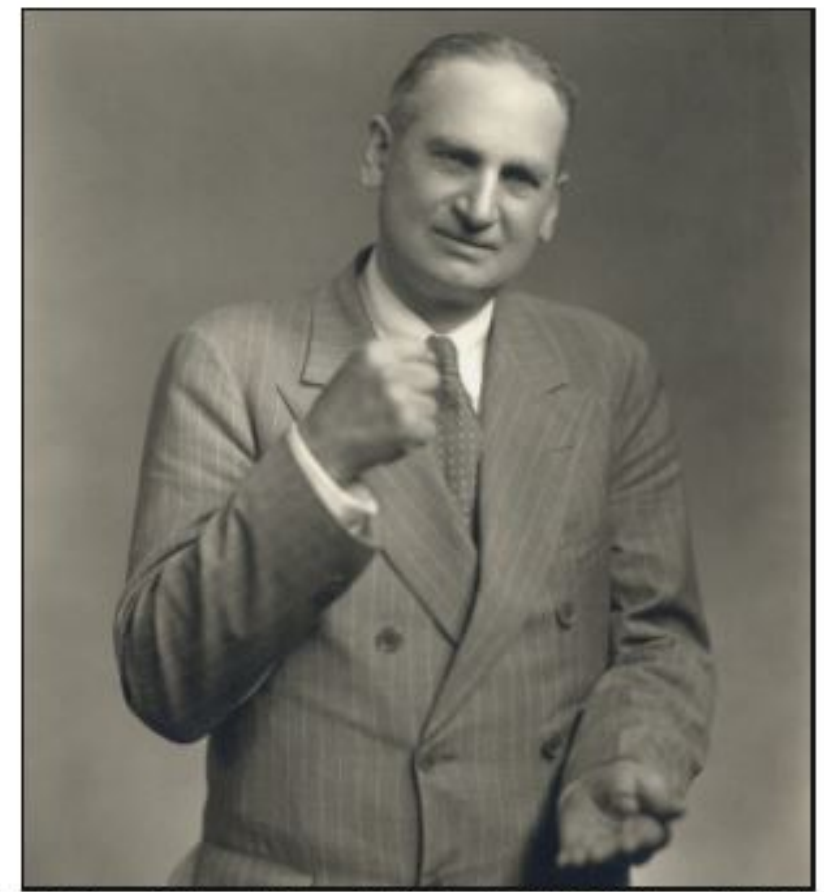

Fred Hultstrand History in Pictures Colloction, NDIRS-NDSU, Fargo (2028-266)

William Langer.

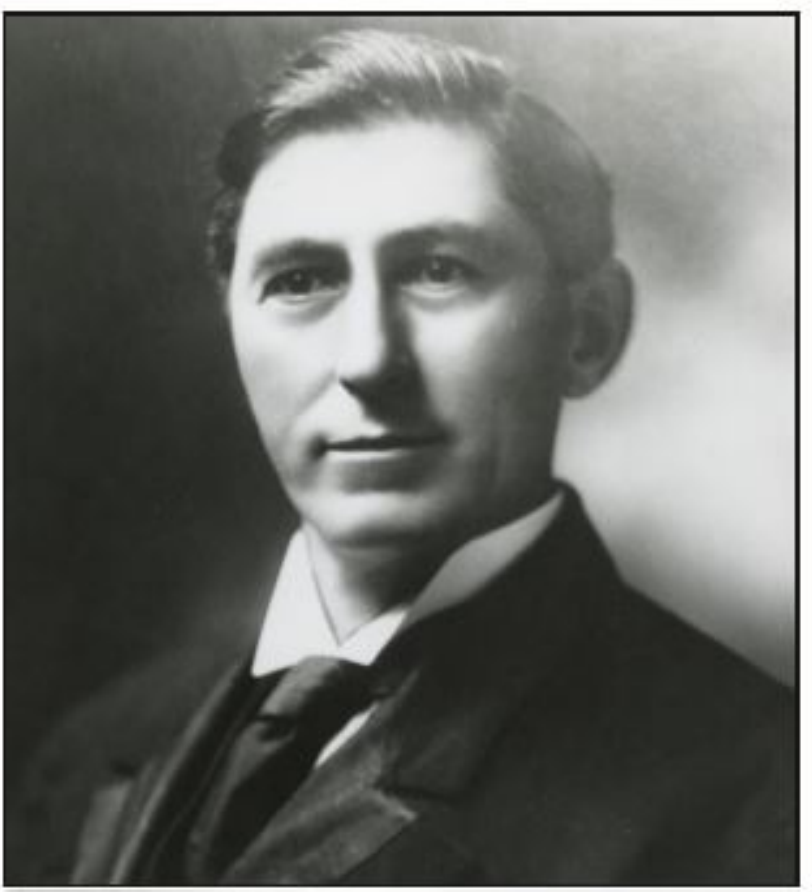

Instimute for Regional Studies, NDSU, Fargo (mss 631.1.6) John Burke, c. 1908. 


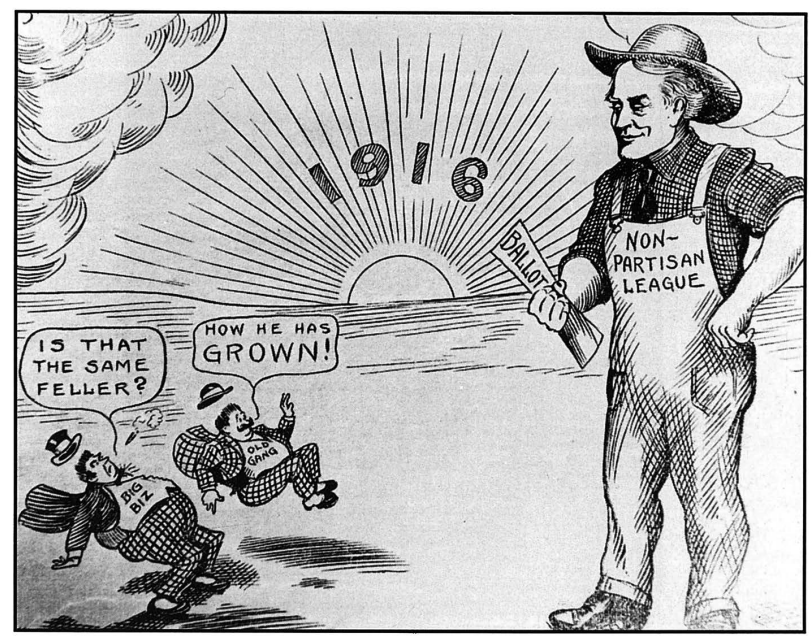

Nonpartisan League editorial cartoon, 1916

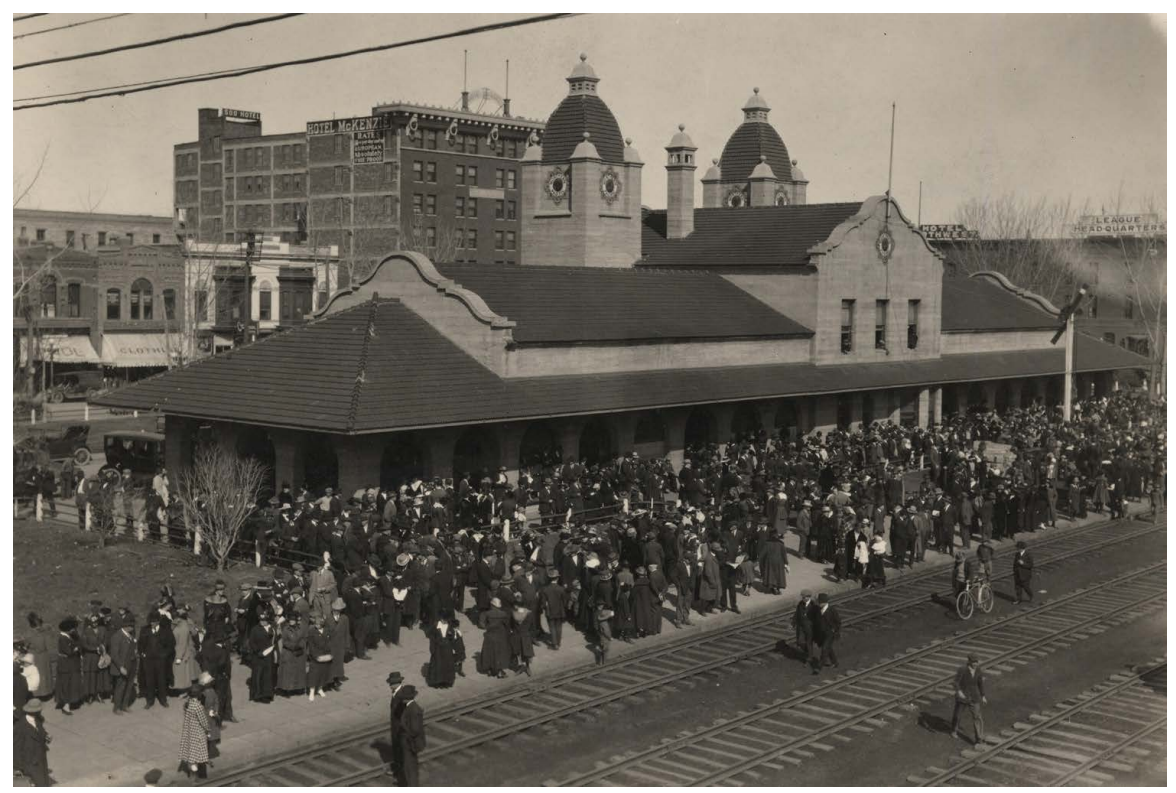

Crowd waiting to see World War I soldiers leave for the draft, Bismarck, c. 1917-18. 


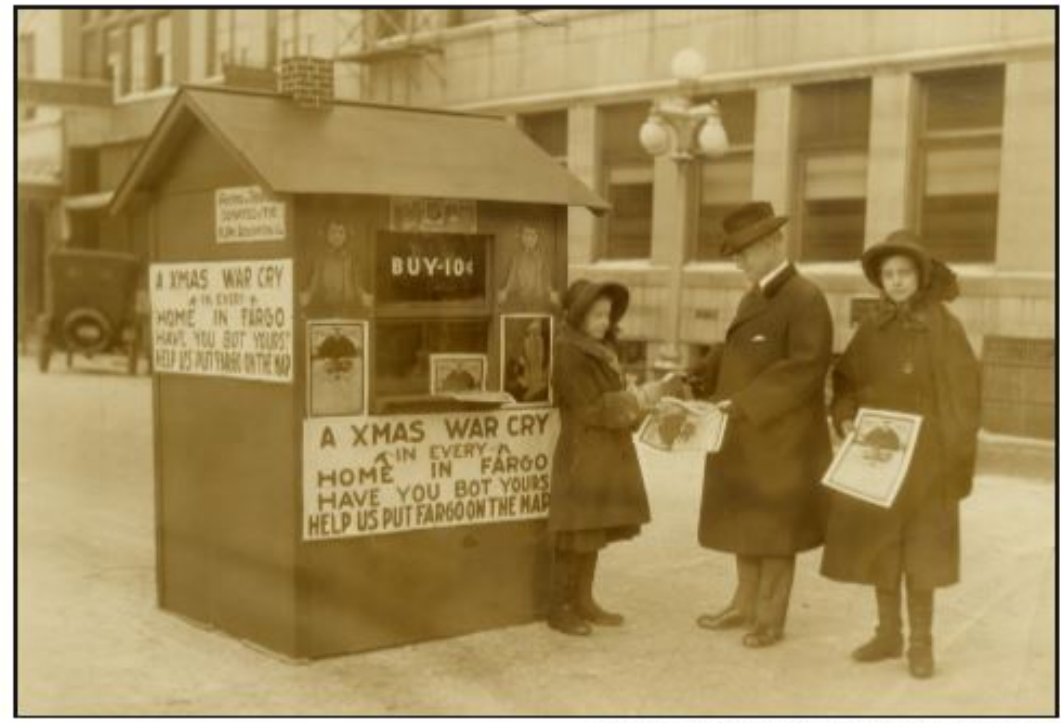

Instimute for Regional Studies, NDSU, Fargo (51.176.1)

Salvation Army booth, Fargo, c. 1917.

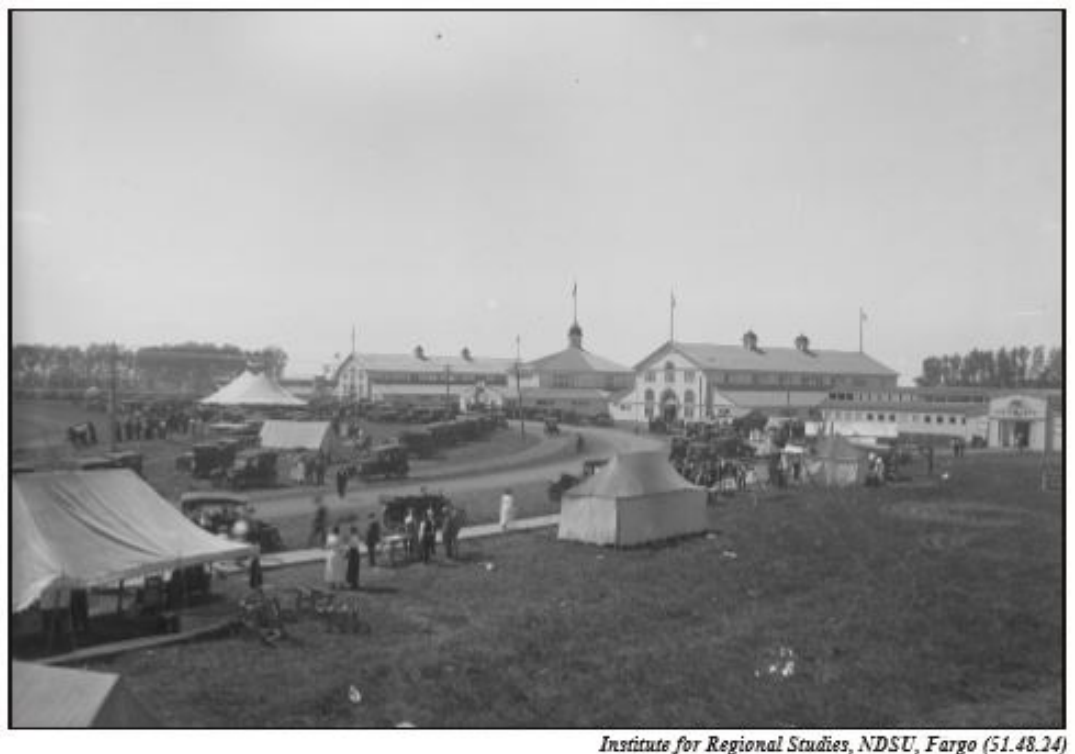

Red River Valley Fairgrounds, Fargo, July 1918. Fargo North High School currently occupies the site. 


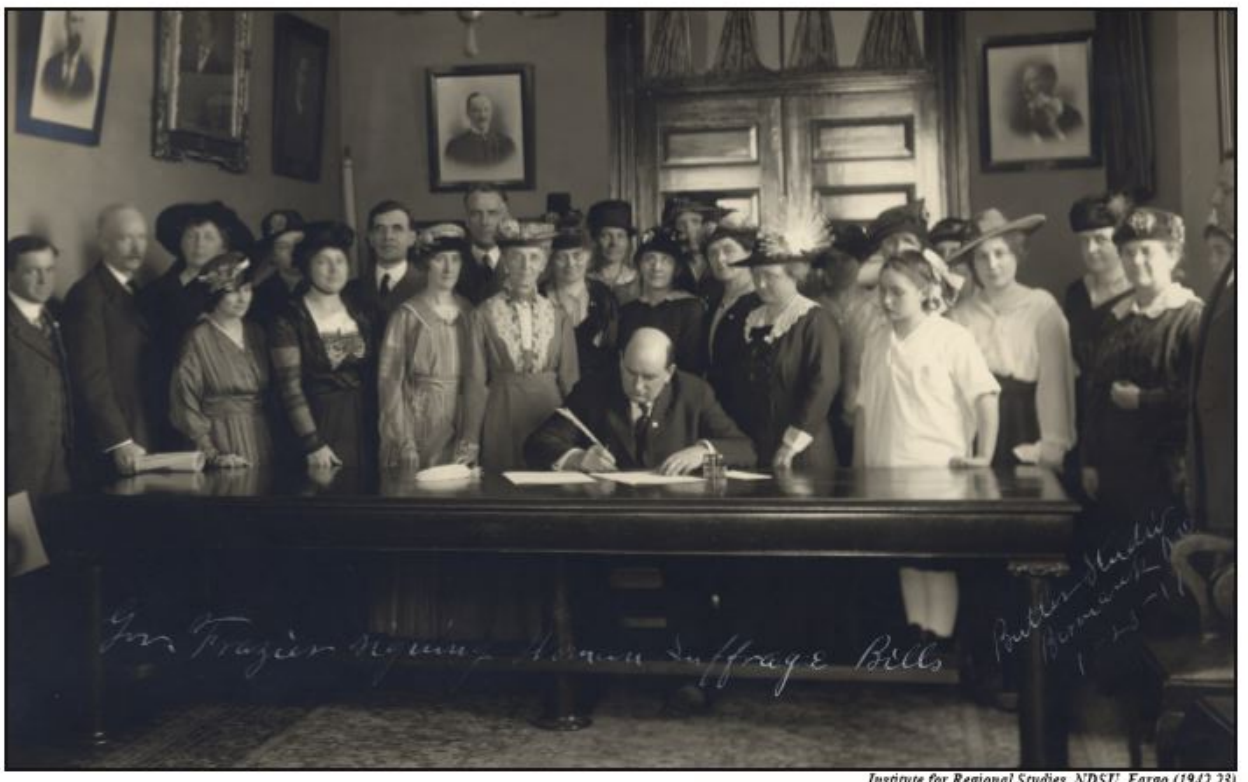

Governor Lynn G. Frazier signs women's suffrage bills, 1917.

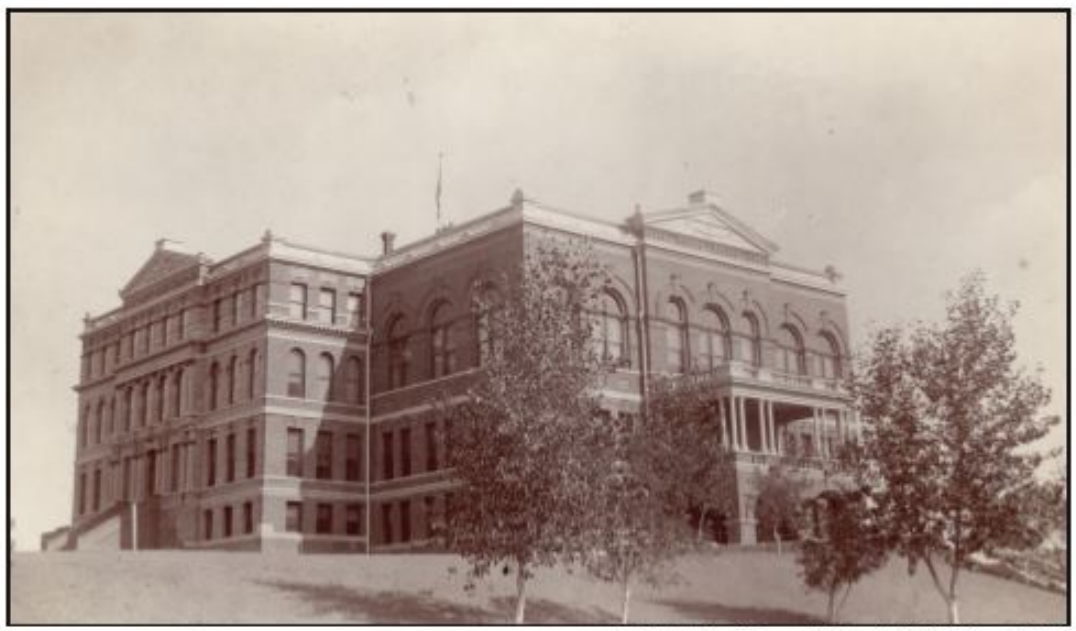

Institute for Regional Studies, NDSU, Fargo (13.6.1)

Old North Dakota capitol, Southwest view, c. 1910. 


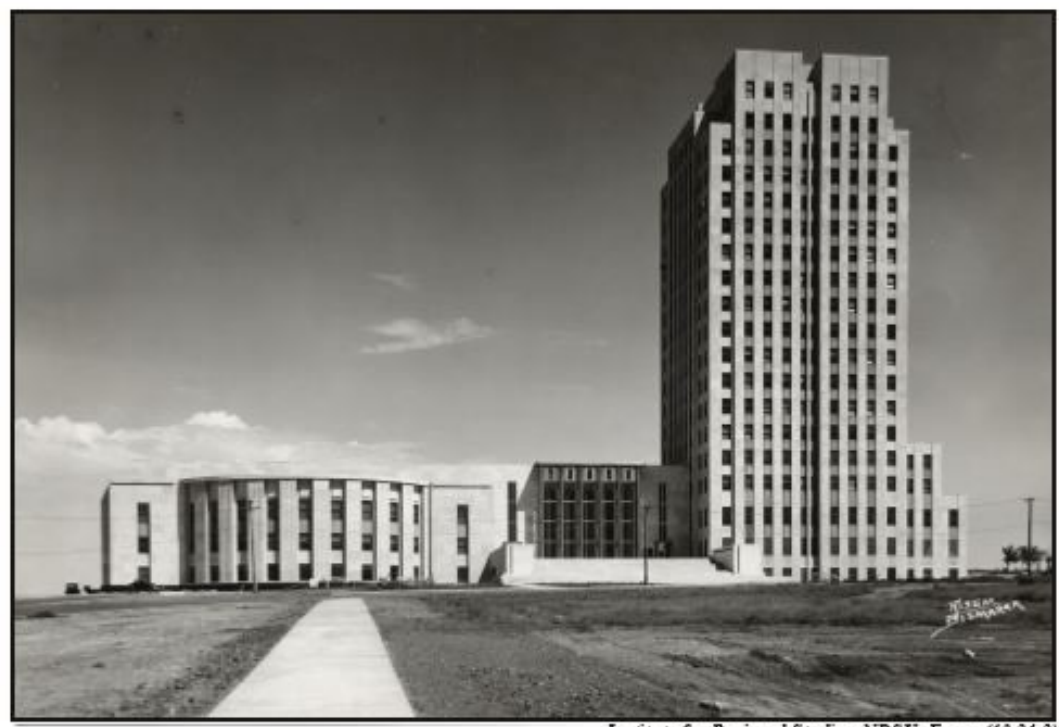

Instirute for Regional Studies, NDSU, Fargo (13.21.2)

New state capitol, completed in 1934.

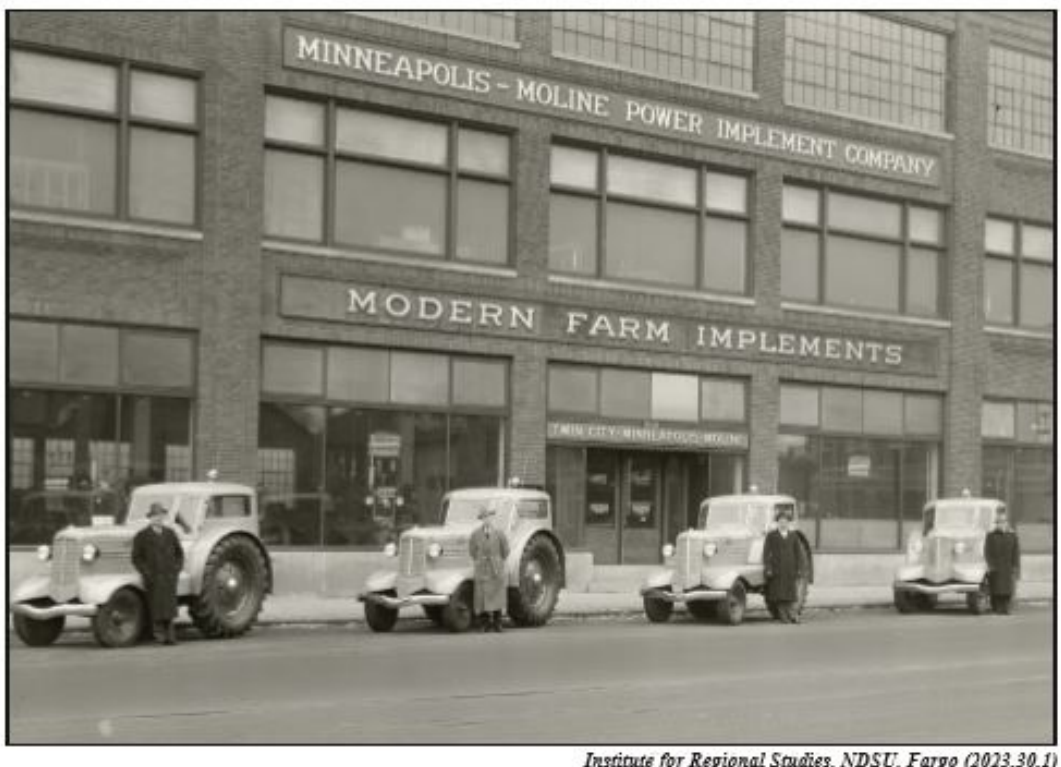

Minneapolis-Moline Power Implement Co. building, 1930s. 


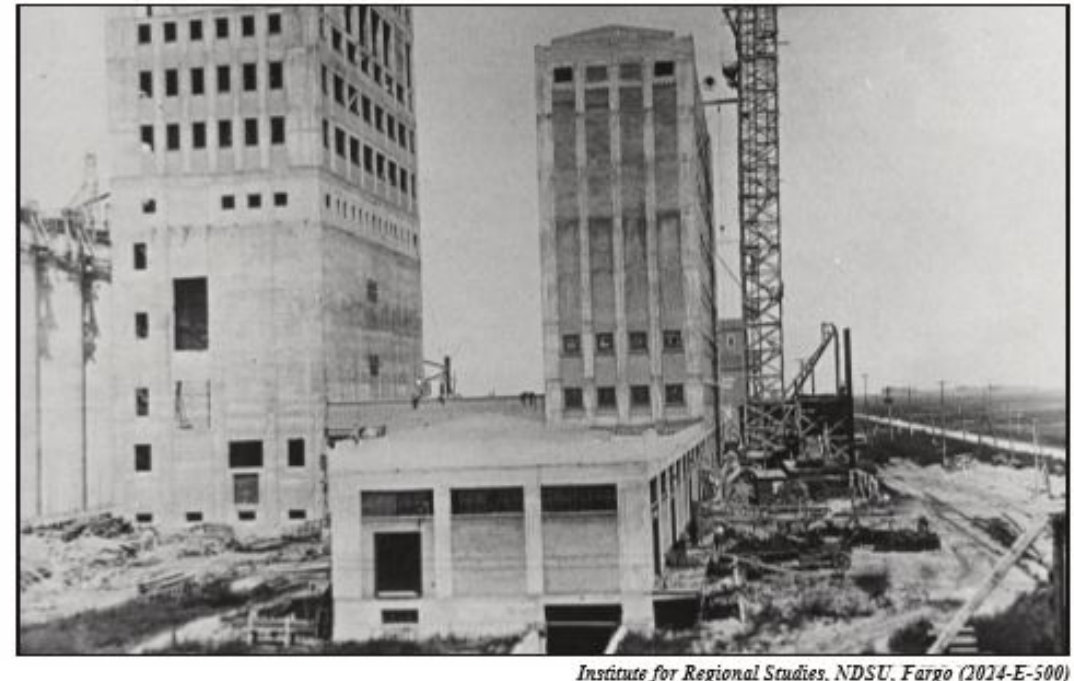

Building North Dakota Mill and Elevator, Grand Forks, 1922.

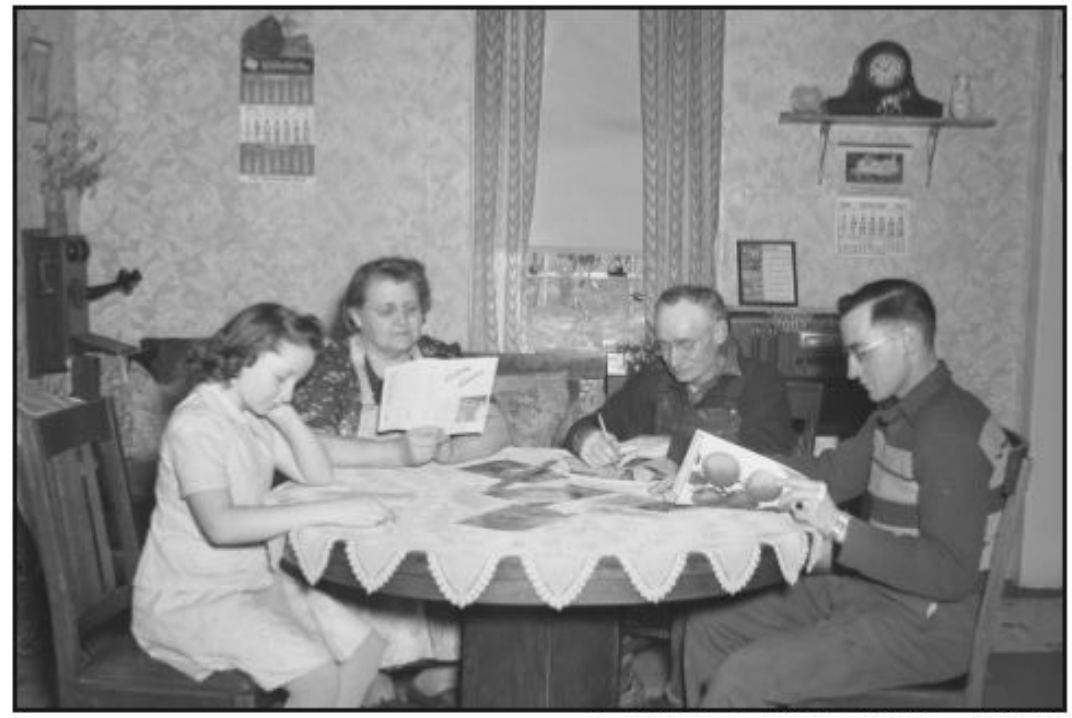

Institute for Regional Studies, NDSU, Fargo (2023.51.5)

Home life, 1944. 


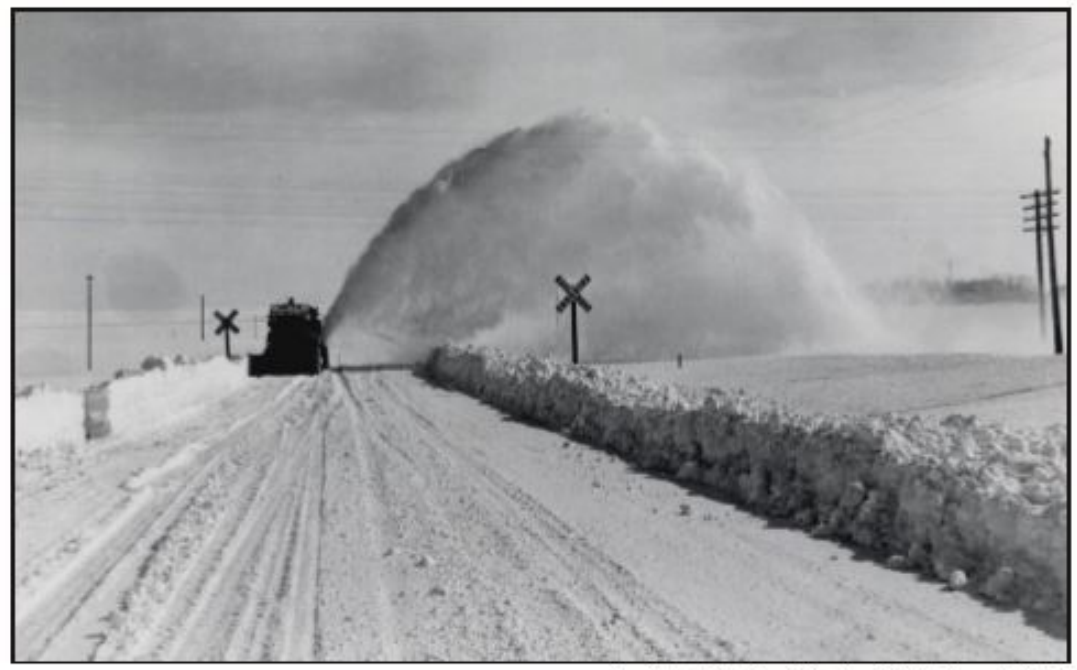

Instirute for Regional Studies, NDSU, Fargo (439.1.1)

Snow removal in rural North Dakota. 


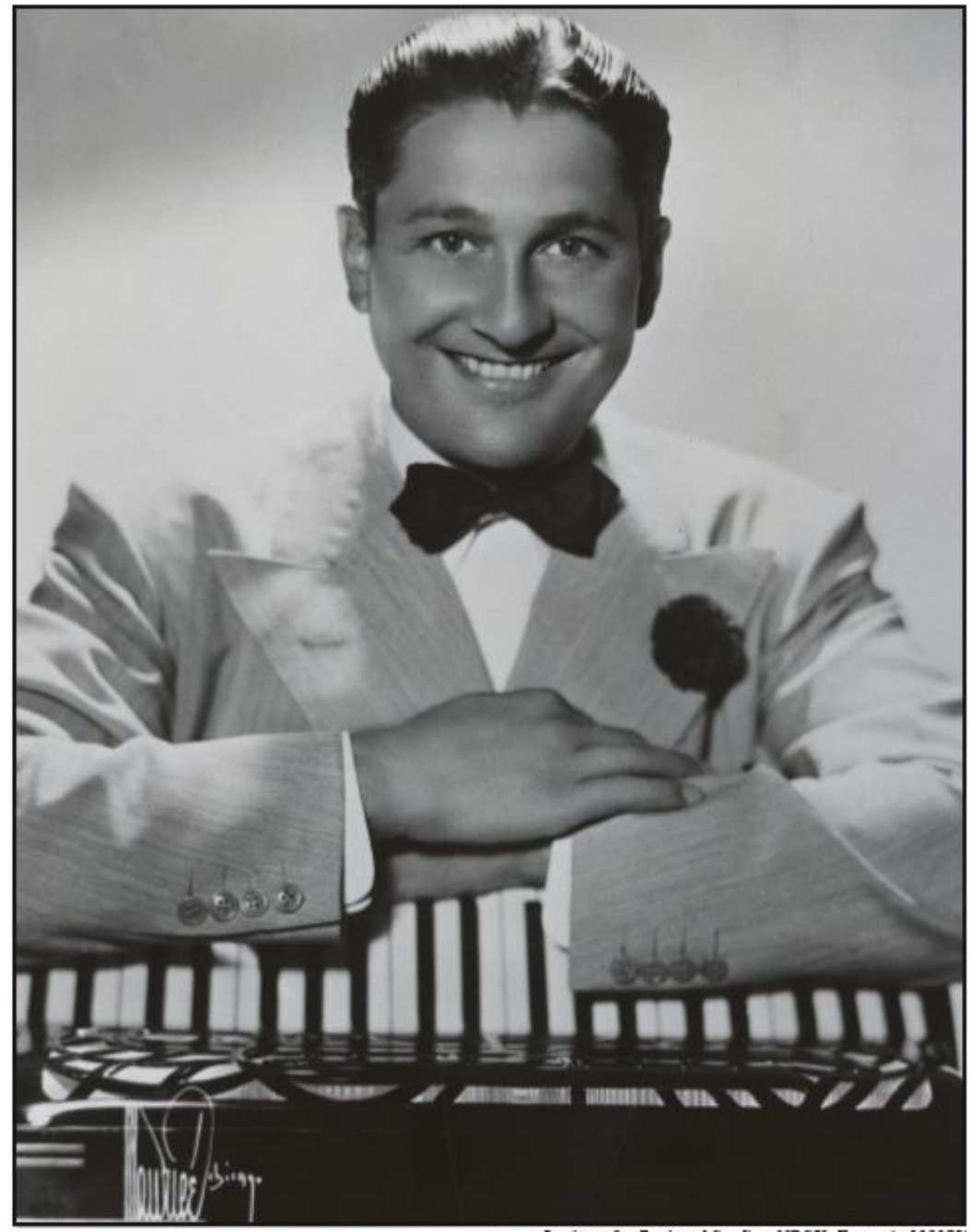

Institute for Regional Studies, NDSU, Fargo (rs005078)

Lawrence Welk, 1940s. 


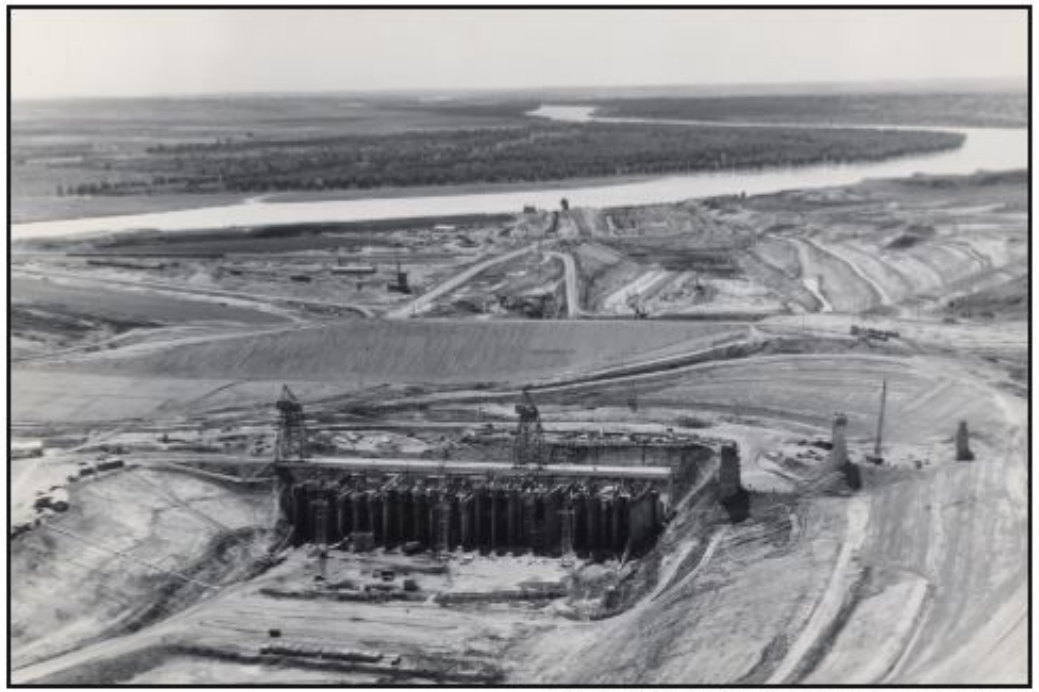

Institute for Regional Studies, NDSU, Fargo (Folio 69.9.1)

Garrison Dam Construction near Riverdale, 1950 s.

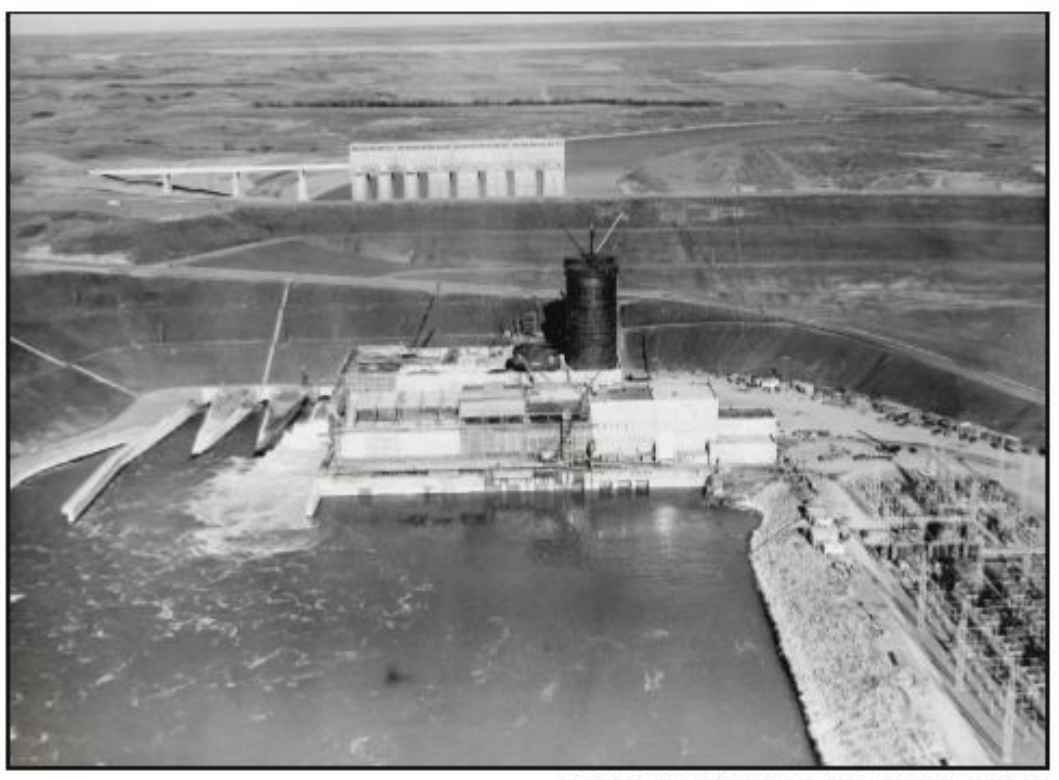

Institute for Regional Studies, NDSU, Fargo (Folio 69.2.1)

Garrison Dam Spillway, 1950s. 


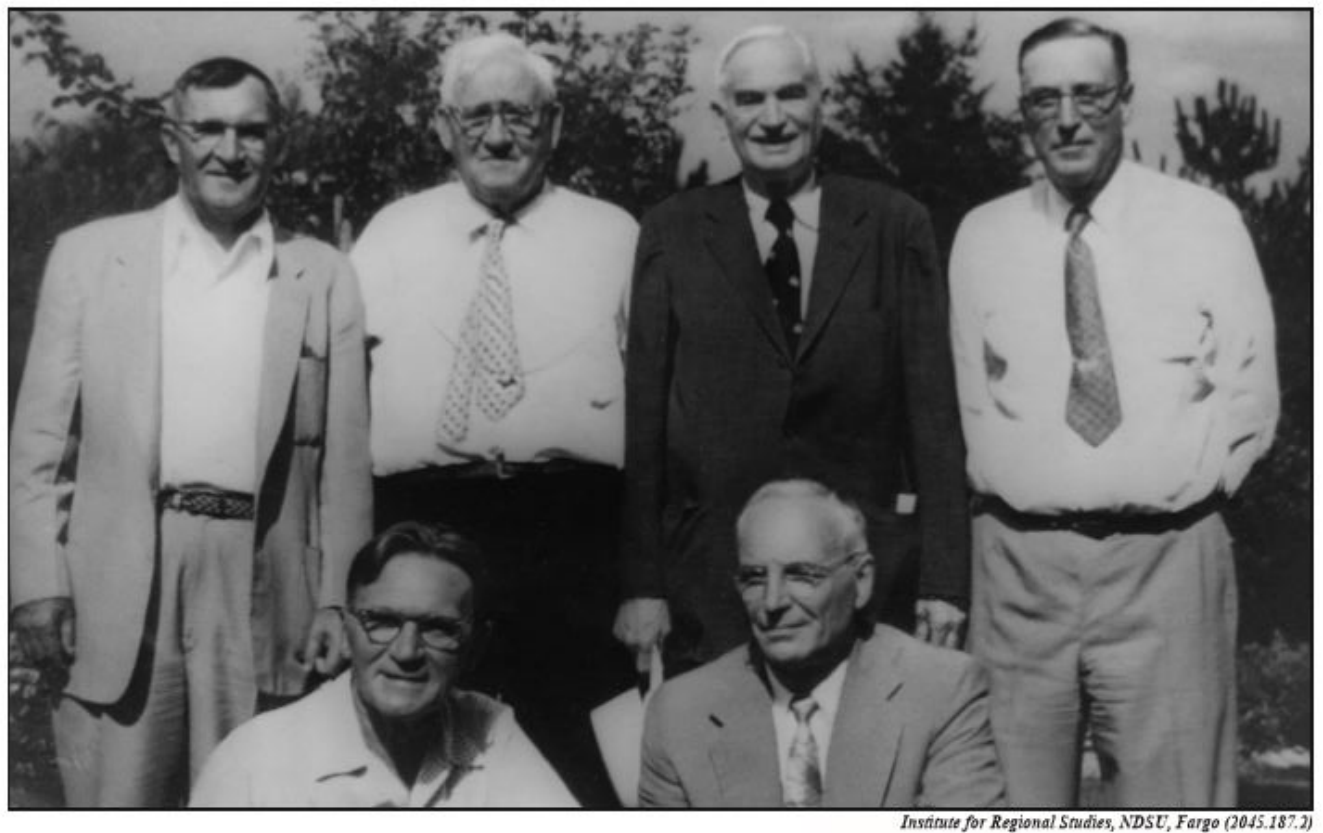

North Dakota politicians, from left to right, front: Gerald P. Nye, Fred G. Aandahl; back: Otto Krueger, Usher L. Burdick, William Langer, Milton R. Young.

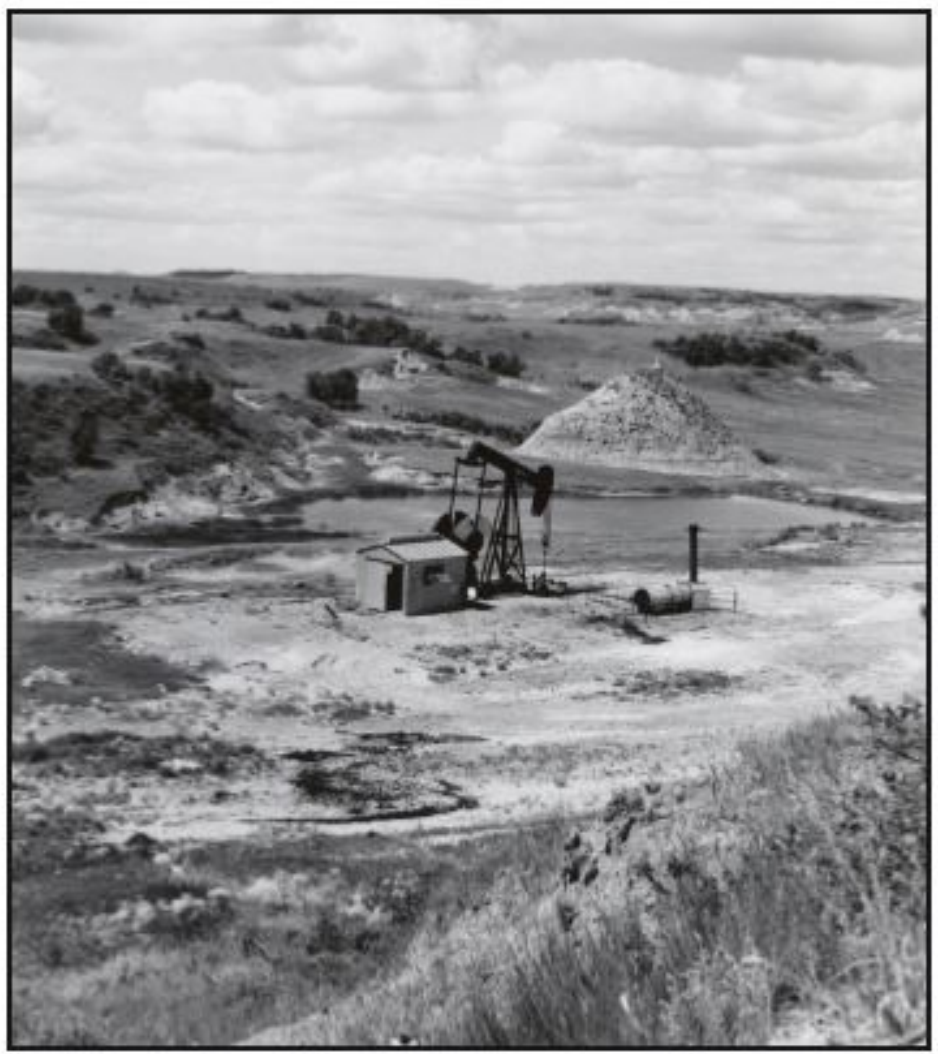

Institute for Regional Studies, NDSU, Fargo (409.1.7) 


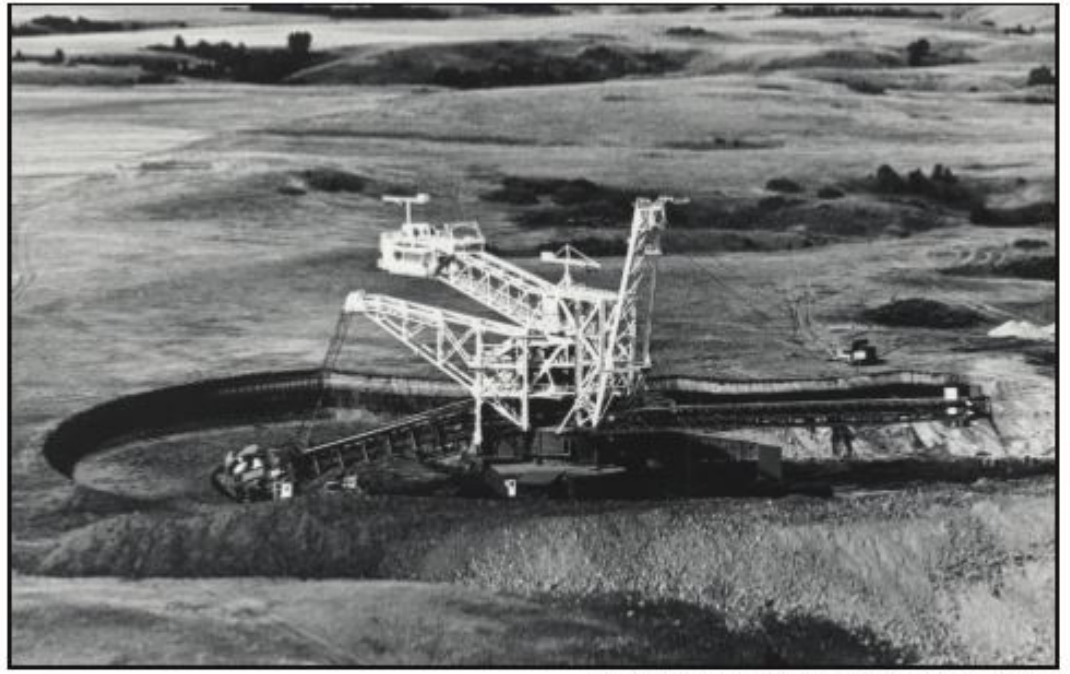

Institute for Regional Studies, NDSU, Fargo (410.1.12)

Mining lignite coal near Beulah, $1960 \mathrm{~s}$.

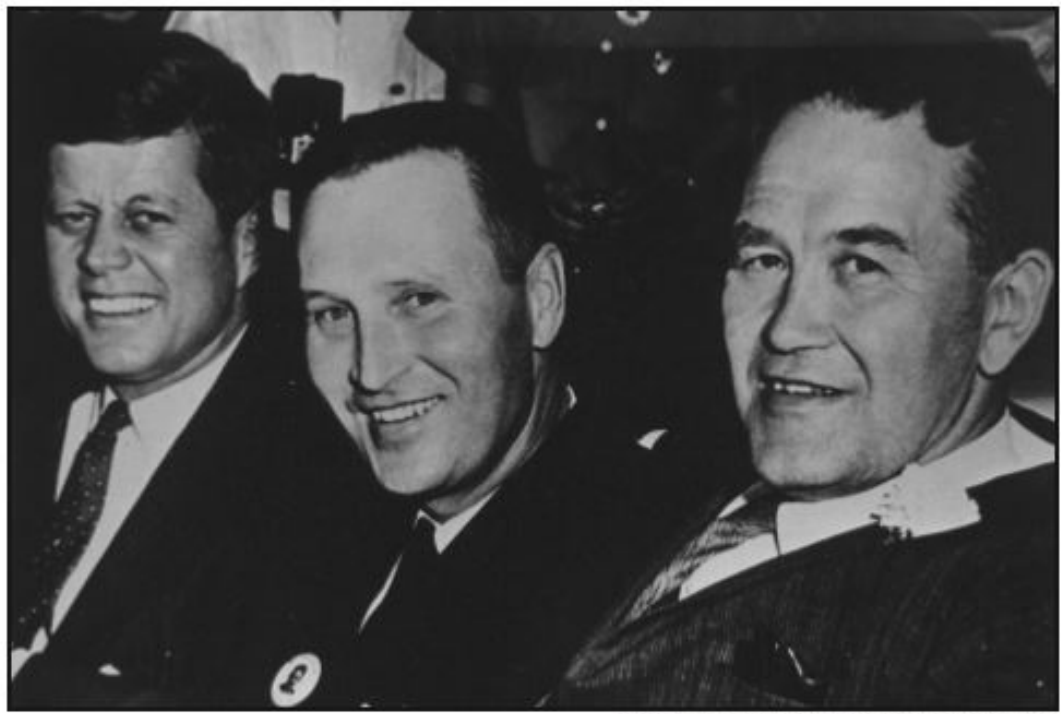

Institute for Regional Studies, NDSU, Fargo (P35.9)

John F. Kennedy, William L. Guy and Quentin N. Burdick, 1960. 


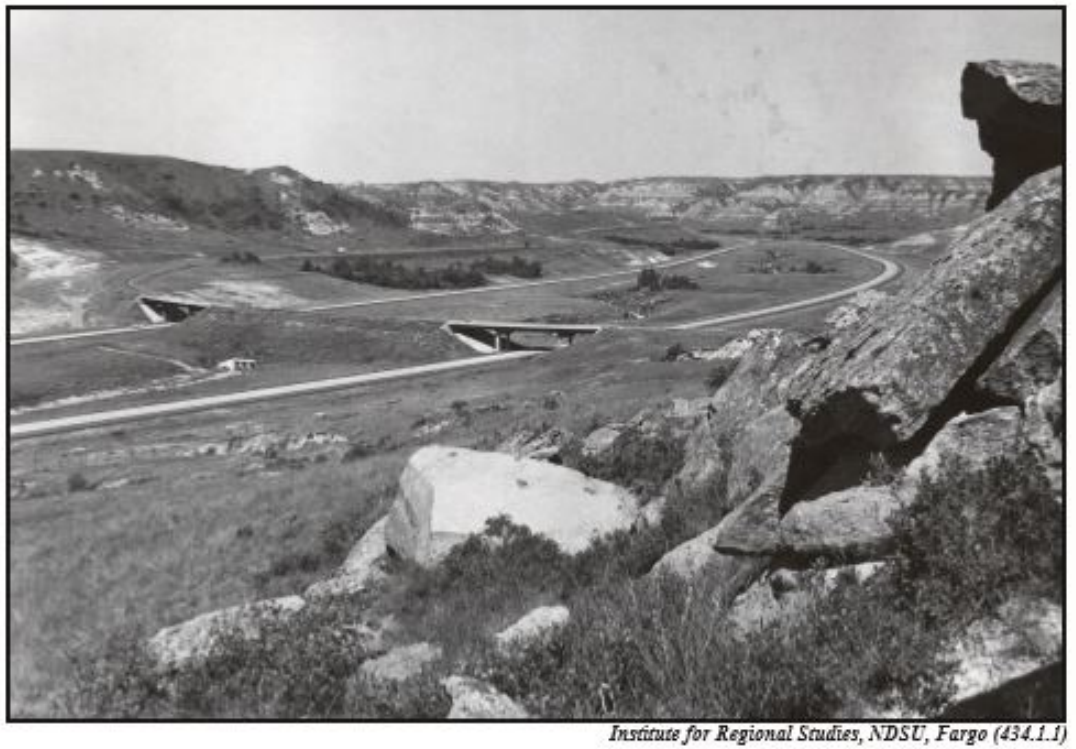

Interstate 94 in western North Dakota. 


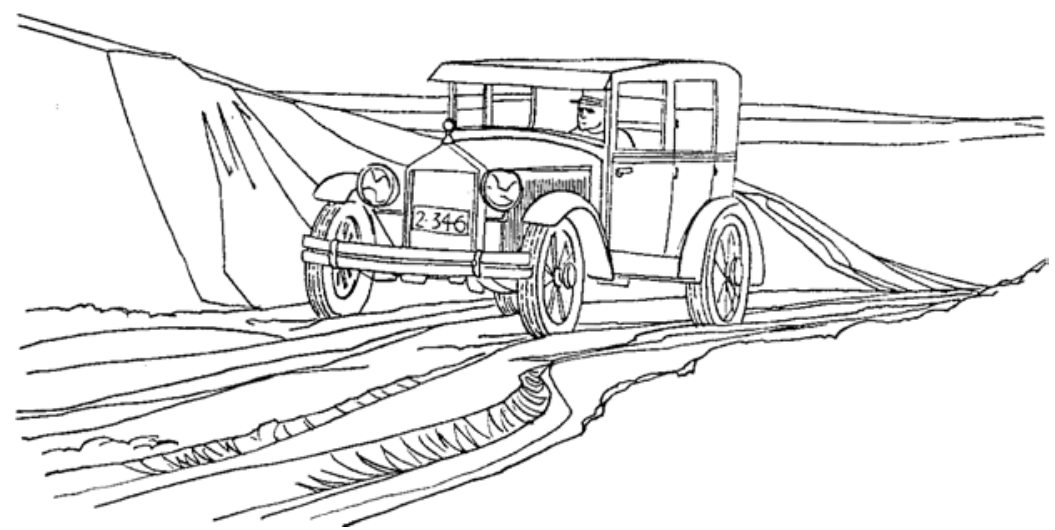

\section{The Twenties: Beginnings of Readjustment}

AS IN OTHER PERIODS, the history of North Dakota in the 1920's was marked with both continuity and change. Continuity was revealed in a number of ways: the state's old problems, such as colonial status and scant rainfall, continued; national trends, such as the swing to conservatism, the impact of the automobile, and disillusionment, were also reflected in the state's history. Change, or contrast with the nation, was highlighted in a number of ways: North Dakota's conservatism was quite liberal; the automobile meant adaptation to the sparsity of population on the treeless plains-a somewhat different meaning than it had for the nation; and North Dakota's disillusionment sprang more from agricultural depression than from disappointment with the outcome of the First World War. The greatest contrast, however, was that North Dakota, like other agricultural areas, suffered from depression in the 1920's while the urbanized, industrialized segments of America enjoyed prosperity.

Moreover, the 1920's in North Dakota were a time of readjustment. The stimulus of pioneering had vanished. Settlement of the semiarid state by people from humid regions had left a heritage of maladjustment, of institutions unsuited to the nature of the country. Because they had anticipated a denser population and a greater production of wealth than the state has yet attained, the pioneers created too many farms, too many towns, too many schools, churches, and colleges, too many counties and too much government, too much railroad mileage, too many banks, and too much debt. This was the Too-Much Mistake, a central theme of North Dakota's history. The 1920's saw the beginnings of a slow and painful readjustment to inescapable realities grounded in the nature of the country.

The First World War and the end of free land had pushed land values up too high for the farmers to make a profit on the capital invested. Through the 
1920's they struggled with heavy debts, high costs, and low prices. Land values fell. Many lost their savings in the wave of bank failures, and thousands left the state to seek opportunities elsewhere. Such problems were not, of course, peculiar to North Dakota; they involved many of the farmers of the nation. In North Dakota, however, farmers turned more and more to cooperatives as a way out.

In politics, the Nonpartisan League, with Arthur C. Townley and his Socialist agitators out of the picture, came back under moderate leadership. Its opponents made a success of the Bank of North Dakota and the State Mill and Elevator. Gradually, much of the bitterness died, and many League leaders supported Herbert Hoover for President in 1928.

\section{FARM DEPRESSION}

During the 1920's, the important changes in North Dakota agriculture were increased mechanization and the introduction of a superior wheat and a superior grass. Farmers bought thousands of tractors and trucks. In 1920, one farmer in six owned a tractor and one in a hundred owned a truck, but by 1930 , more than two in every five owned tractors and one in five owned trucks. The number of horses on the farms fell by one-fourth.

Logically, mechanization should have cut down both the farm labor force and the number of farms, yet such changes could come only slowly. The number of farms did not decline in the 1920's, but the average farm size rose from 466 acres to 496 acres as the amount of land in farms increased by two and one-half million acres in the last years of the decade.

Small increases in numbers of sheep, swine, and dairy cattle meant little advance in diversification, but the introduction of an improved wheat and a better grass meant much. Ceres, the new wheat, was first distributed in 1925. Developed by Lawrence R. Waldron from a cross between Kota and Marquis. it was only moderately resistant to rust, but it gave good yields under drought and other severe conditions and so was a notable adaptation to the semiarid country. By 1934 it was planted on 45 percent of the state's wheat acreage.

The new grass was crested wheat grass, a hardy perennial bunch grass which had been brought to the United States about 1900 from the steppes of Russia and Siberia. Crested wheat grass has a wide spreading and deeply penetrating root system which contributes to its ability to survive cold, drought, and grazing and to protect the soil from wind and water erosion. The first planting in North Dakota was at the United States Northern Great Plains Field Station at Mandan in 1915; the station began seed production in 192l. By 1929 crested wheat grass was listed in the catalog of Oscar H. Will and Company, Bismarck seedsmen. Well adapted to the cool growing conditions of the Northern Great Plains, more resistant to drought than other grasses, and highly palatable, it became the leading grass for pasture, hay production, and erosion control in western North Dakota. It had two or three times the grazing capacity of the native range, so its introduction was a 
notable landmark in the history of the state. ${ }^{1}$

Ordinarily, more than two-thirds of North Dakota's farm income came from crops (mostly small grains) and less than one-third from livestock (mostly cattle). Wheat was still king, producing more than half the state's cash farm income in 1925. "So far as Velva was concerned," recalled Eric Sevareid, "wheat was the sole source and meaning of our lives.... We were never its masters, but too frequently its victims.... It was rarely long outside a conversation."

The farm income of the 1920's, divided between 395,000 farm people and almost 78,000 farms, was simply not large enough. There was no spectacular failure, but crops were neither very good nor prices very high. Rainfall was below average for six of the twelve years from 1919 through 1930, and six of the twelve wheat crops were rather poor-under 100,000,000 bushels. The poorest crop was a scanty $61,000,000$ bushels in 1919, the best a near record 155,000,000 in 1928. Wheat fell from $\$ 2.35$ a bushel in 1919 to $\$ 1.01$ in 1921, rallied in the middle 1920's, and sank to 60\$ in 1930. Beef cattle brought \$8.10 per hundred pounds in 1919, \$4.45 in 1921, and \$8.30 in 1929. Selling their stock and grain at such levels, North Dakota farmers generally pocketed a cash income of $\$ 200,000,000$ to $\$ 250,000,000$, ranging from a high of $\$ 278,000,000$ in 1925 to a low of $\$ 149,000,000$ in 1930 . These figures, representing an average gross income per farm of $\$ 2,500$ to $\$ 3,200$, spelled an unspectacular but real farm depression throughout the decade.

A study of the cost-of-living records of 139 North Dakota farm families showed that, in spite of the agricultural depression, the quantity of familyliving goods and services purchased actually rose 30 percent from 1923 to 1928 and then declined 9 percent from 1928 to 1931. In 1923 the average cost of family living (food, housing, clothing, medical care, recreation, and other items) in this group of above-average farm families was $\$ 1,471$, of which $\$ 882$ consisted of cash expenditures. It rose to $\$ 1,721$ (with a cash expenditure of $\$ 1,158$ ) in 1928 and fell to $\$ 1,305$ (\$842 in cash) in 1931 . $^{2}$ In 1929 the per capita (not per family) personal income was \$375 in North Dakota and \$703 in the United States. Low farm income increased other difficulties.

In the postwar deflation, the value of all farm property in the state fell by one-third, from $\$ 1,760,000,000$ in 1920 to $\$ 1,191,000,000$ in 1925 . This was a shattering loss in values-over half a billion dollars. But the total or all taxes paid-largely the general property tax and excluding taxes levied by towns and villages-rose nearly two and one-half times, from $\$ 11,000,000$

\footnotetext{
${ }^{1}$ Theodore E. Stoa, “A Brief History of Wheat Variety Changes on Farms in North Dakota,” Bimonthly Bulletin, North Dakota Agricultural Experiment Station, VII, 6 (July-August 1945), 24; Warren Whitman et al., Grass, North Dakota Agricultural Experiment Station Bulletin 300 (Fargo, 1941), pp. 23-25.

${ }^{2}$ E. A. Willson, Incomes and Cost of Living of Farm Families in North Dakota, 1973-1931, North Dakota Agricultural Experiment Station Bulletin 271 (Fargo, 1933), pp. 6-18.
} 
in 1912 to $\$ 27,000,000$ in 1922 . Taxes on farm real estate scarcely declined at all in the deflation of the 1920's. ${ }^{3}$

Heavy taxes and the decline in value of farm property further burdened men already deeply in debt. In 1920, seven-tenths of the men working their own farms owed mortgage debts; the total farm-mortgage debt was $\$ 286,000,000$. Many could not bear the burden and lost title to their land. In 1920, one in every four North Dakota farmers was a tenant; in 1930, one in every three. William Lemke wrote a friend in 1927:

The farmers have never been as hard up as at present. I have more work than I can do trying to save their homes in a legal way and in defending them in many unfortunate lawsuits, due to poverty or rather deflation. It used to be that they were able to pay my carfare and expenses, but it is getting so now they offer me post-dated checks for even actual expenses.

\section{THE COLLAPSE OF THE BANKS}

The misfortunes of the grain farmer affected the small rural banks, and their wholesale collapse in the 1920's revealed the instability of the state's agricultural economy. Fraught as it was with risk in a one-crop, semiarid country, the economy needed sound banks. But the imperative demand for credit had led to a rapid but unsound development of banking. In some new towns, banks were the first business establishments. North Dakota had 102 banks by 1895, 671 by 1910, and an astounding 898 in 1920. It had three banks for every incorporated place and more banks in proportion to its population than any other state. The most rapid increase had come in the decade of fastest growth in population, but the number of banks had grown four times as fast as the population.

The smaller banks generally had state charters and were opened in the smaller towns; the larger banks had national charters and located in the larger towns. Charters were easily secured. The capital required for a state bank was low, only $\$ 10,000$ in the years from 1900 to 1915, and the state bank examiner seldom refused an application. Some state banks even opened on entirely borrowed capital. Charters for national banks were also easily secured, and their capital requirements were low-only $\$ 25,000$ in a town under 3,000 population. North Dakotans tolerated laxity because they were more interested in credit for the debtor (a great need in a new country without capital) than security for the depositor. Moreover, everyone was optimistic about the future: the growing economy would soon be able to support all of the new banks.

With good wheat prices and rising land values, banks rarely failed before 1920. Deposits climbed spectacularly, nearly doubling from 1915 to 1917. To attract outside money, the legislature passed a deposit guarantee law in Farmers, North Dakota Agricultural Experiment Station Bulletin 203 (Fargo, 1926), pp. 11-12. 
1917. The guarantee fund, however, was entirely inadequate (each bank paid in annually only one-twentieth of one percent of its deposits), and the most recklessly managed bank could not be shut out of the system. Country banks used the law in misleading advertisements in which the state itself was represented as guaranteeing deposits on which 6 percent interest was offered. Thus they secured large deposits from the residents of other states.

With their vaults full of cash and with almost unlimited confidence in the state's future, North Dakota banks expanded their loans to farmers far beyond the bounds of prudence. Sound principles required that a bank's loans should not exceed 60 percent of its deposits, but in 1922 the loans of state banks averaged 120 percent of deposits, with many higher. The national banks had lent from 47 to 285 percent of their deposits. The banks then had very small cash reserves, an average of only 6.8 percent of deposits for the national banks in 1922. Three fourths of their assets were loans, mostly to farmers and often of doubtful value and on inadequate security. The situation was fraught with danger. The banks, especially the hundreds of state banks in the smaller towns, were dangerously overcommitted to an unstable, local agricultural economy. If deposits declined, the banks would have to collect their loans to farmers, and if many of the loans should prove uncollectable, the banks would fail.

The collapse of North Dakota agriculture in the early 1920's brought the banks to ruin and wiped out fifty million dollars in hard-earned savings. North Dakota suffered from a nation-wide deflation of agricultural prices. Agricultural exports declined; production was over expanded; Europe could not buy American farm commodities; purchases by the federal government fell off; large carry-overs from 1919 and 1920 glutted the market. The Federal Reserve Board, alarmed by the continuation of inflated prices and credit in 1919, adopted a deflationary tight-money policy. Late in 1919 it began to raise the rediscount rate in order to restrict credit and reduce prices. In June, 1920, the rediscount rate of the Minneapolis Federal Reserve Bank stood at 7 percent.

These deflationary forces, the collapse of farm prices in the fall of 1920, the hard winter of 1919-1920 on the western ranges, and then drought-all cut down sharply the flow of money into North Dakota. The outward flow of money. however, for the necessities of living and for interest, taxes, farm machinery, coal, and transportation, remained high. The balance of payments went heavily against the state, a universal experience in a falling market for regions specializing in the production of raw materials.

Farmers had to draw on their savings, and by the end of 1921, bank deposits had fallen one-third in two years. To meet withdrawals, the banks, short of cash themselves, borrowed heavily from Minneapolis and St. Paul banks, pledging their best securities as collateral. They also began desperately to call in loans. But large loans from Twin Cities banks, from the Federal Reserve Bank of Minneapolis, and from the federal War Finance Corporation enabled North Dakota banks to renew many of their loans to 
state farmers and to make new loans where necessary. During the first two years of deflation, the mortgage debt on farms actually increased as desperate farmers refinanced short-term loans into mortgages. The mortgage debt reached a peak of $\$ 320,000,000$ in 1922, a staggering sum yet only a fourth or fifth of the value of farm property in the state.

When the agricultural economy failed to revive, many of the farmers and bankers went down together. Each year, hundreds of farmers lost their land in forced sales. The banks, losing their deposits and cash reserves, could neither collect their loans nor repay the Twin Cities banks. In 1923, the first bad year, 99 failed; dozens more went under each year until 573 of the 898 bank, in business in 1920 had closed by 1933. In all, 94 national and 479 state banks failed. Victims of their own overconfidence in the future of a semiarid spring-wheat country, all of the closed banks had made loans in excess of 100 percent of their deposits.

The depositors of the closed state banks lost almost $\$ 40,000,000$, receiving about one-fourth of their claims, while depositors of closed national banks lost about $\$ 10,000,000$, receiving about half their claims. Bank failures had lost approximately one-third of the $\$ 150,000,000$ on deposit in North Dakota banks in 1922, half the loss being borne by out-of-state depositors deceived by the 1917 deposit guarantee law. The fifty-million-dollar loss, though small compared to the half-billion-dollar decline in farm property, was serious; it undermined confidence in banks and dissipated reserves needed for productive purposes. It was a part of the excessive price paid for the rapid development of the new country. ${ }^{4}$ Some bankers committed suicide; Eric Sevareid wrote of his father, a banker at Velva: "Years of drought ruined his wheatlands and broke his bank."

The great deflation had other sides. The assets of all North Dakota banks fell from $\$ 223,000,000$ in 1922 to $\$ 68,000,000$ in 1933 , and bank loans from $\$ 171,000,000$ to $\$ 26,000,000$. The day of too many banks and too much easy credit had passed. Indeed, with the great deflation the pioneer dream of plenty on the prairie frontier was fading. "Everyone agrees," wrote Mandus E. Bridston in 1924, "that something must be done if we are going to save our homes; if we are going to spare our wives and children from a life of drudgery and want.... Is farming a failure?”

\section{POPULATION CHANGES: RURAL EXODUS}

Such disillusionment with farming set off a rural exodus. Certainly farming in North Dakota, as elsewhere, was no longer offering opportunities for more people. There were already too many people on farms. The population of the state grew slowly and then just in the towns. It increased only 5.3 percent during the 1920 's —-from 647,000 in 1920 to 681,000 in

\footnotetext{
${ }^{4}$ William E. Koenker, "Banking Trends in North Dakota, 1922-1947”

(Unpublished Ph.D. dissertation, Ohio State university, 1949), pp. 39-311; Arthur S. Link, "The Federal Reserve Policy and the Agricultural Depression of 19201921,” Agricultural History, XX (July 1946), 167-173.
} 
1930. The urban population (places over 2,500) grew 28 percent; the population of the smaller towns (all incorporated places below 2,500) grew 9 percent; the population of the countryside declined 0.5 percent. Some of the larger places grew very rapidly: Minot from 10,475 to 16,099, Bismarck from 7,122 to 11,090, and Fargo from 21,961 to 28,619.

As a whole, however, the state's 5.3 percent increase (34,000 persons) amount to only one-third of the natural increase, the excess of births over deaths. Thus the state lost about 65,000 people during the decade. In 1920 there were 101,000 persons born in North Dakota but living in other states; in 1930 there were 176,000. Some 75,000 native-born North Dakotans had left, but a part of the loss had been balanced by a modest movement into the state. Many North Dakotans had moved to Minnesota, California, Washington, and Montana. Eighteen of the fifty-three counties and 44 percent of the 295 towns actually declined in population.

In particular, the more semiarid and newly settled sections lost. By the early 1920's some farmers and ranchers were leaving almost every county north and west of the Missouri River. There the number of farms was declining as the more prosperous took over the holdings of those who were leaving. In the northwest corner of the state, defeated farmers were abandoning the poorer land, often owned by absentee speculators. In the typical range counties on the Little Missouri, ranchers were giving up much of their leased range. ${ }^{5}$

The smaller trading centers suffered. When the railroad companies built their lines, they established a station every five or six miles, and often a small settlement would spring up. But the semiarid nature of the country restricted the growth of the surrounding farm population. The sparse rural population hurt the small trading centers, and even before the 1920's the automobile began to rob them of their meager business.

\section{THE AUTOMOBILE REVOLUTION}

The automobile was changing North Dakota life in the 1920's. In 1913, North Dakotans owned only 13,075 automobiles, but by 1920 they owned 92,000 , and 57 percent of the state's farmers had them. The number doubled during the next decade. By 1930, North Dakotans owned 183,000 automobiles, one for every 3.7 persons, and 87 percent of the farmers were car owners. In the United States as a whole, there was only one automobile for every 5.3 persons.

North Dakota fell in love with the automobile. It provided an excellent means of traveling long distances over the prairies; it reduced isolation; it helped to overcome remoteness; it freed North Dakotans and gave them

\footnotetext{
${ }^{5}$ E. A. Willson, H. C. Hoffsommer, and Alva H. Benton, Rural Changes in Western North Dakota, North Dakota Agricultural Experiment Station Bulletin 214 (Fargo, 1928), pp. 26-28, 41-42; Jesse C. Korthal, "The Growth and Decline of Incorporated Farm Trade Centers in North Dakota, 1900-1920” (Unpublished M.S. thesis, University of North Dakota, 1935), p. 52.
} 
mobility, just as a century and a half earlier the acquisition of horses had freed the Plains Indians.

Automobiles quickly brought better rural roads. In 1917, North Dakota had no surfaced roads and only a few well-graded ones. Most of them were impassable for automobiles a considerable portion of each year. By 1928, however, there was a state highway system of 7,200 miles; about 4,000 miles of it had been graded and 2,400 miles given a gravel surface. By 1930 the state, in spite of hard times, had spent nearly eight million dollars on highway construction.

Improved roads expanded the potential trading area of villages and towns. They furnished farmers with better transportation to shipping centers and made easier the sometimes long trips to town for necessities. They played a part in knitting together the farm and town elements in North Dakota communities and made social contacts easier and more frequent. Good roads aided the consolidation—and hence the improvement—of schools and churches. E. A. Willson, a rural sociologist at the North Dakota Agricultural Experiment Station, wrote in 1928:

Improved highways are causing many changes in rural social life. Good roads improve rural mail service, make better educational facilities available to farm children, bring medical assistance to the farm home quickly, and make possible a broader social life. The automobile and improved highways are causing a readjustment in rural social organizations and agencies. They enable the farmer to do his trading, seek recreation and attend church at more distant cities and villages where more and better services are available than the smaller villages furnish. ${ }^{6}$

So farmers began to trade in the larger towns. Such places had many attractions, including larger stores, movies, and banks. By locating in the bigger trade centers, chain stores increased their profits. The J. C. Penney Company, the first chain in the state, opened a store in 1912 and had thirtythree by 1935. Others came in the 1920's; by 1935, Montgomery Ward had eight stores in North Dakota, Gamble Stores fourteen, and Red Owl Grocery forty-six. The automobile and improved rural roads had brought a revolution to North Dakota life.

\section{THE STATE BANK AND THE STATE MILL AND ELEVATOR}

During the depression of the 1920's, North Dakota farmers received aid from the socialistic enterprises originally sponsored by the Nonpartisan League. After the defeat of the League, its opponents continued the Bank of North Dakota and completed the construction of the State Mill and Elevator. Soon after the recall election of October, 1921, Governor Ragnvold A. Nestos began, as he had promised, to give the League enterprises a fair trial. 
He pushed the rural-credit program of the Bank of North Dakota. Its farmloan department made loans on farm land; the state treasurer sold real estate bonds, secured by farm mortgages, to raise the money for the loans. The department had begun to make loans before the recall election ousted the League-controlled Industrial Commission, but most of the loans were made under a conservative commission controlled by the Independent Voters Association.

Each year the state sold several million dollars' worth of real estate bonds; each year the farm-loan department made one to two thousand loans. From August, 1919, to October, 1933, it lent 16,486 farmers nearly \$41,000,000. The loans bore 6 and 6.5 percent interest and were amortized to be repaid in annual installments running 26 to 30 years. They averaged from $\$ 3,600$ per loan in 1921 to $\$ 1,500$ in 1933 . The average loan declined from $\$ 14.07$ per acre in the former year to $\$ 5.95$ in the latter. Most of the loans were made in the western portion of the state. While the Bank of North Dakota was making its farm loans, the average interest rate on all farm mortgages declined from a peak of 7.3 percent in 1915 to 6.6 percent in 1925 and to 6.0 percent in 1933.

With drought (one year in three was dry in the western part of the state) and depressed prices, payments on a large part of the loans became delinquent. By 1929 the Bank of North Dakota had foreclosed mortgages on 8.3 percent of the loans, by 1934 on 17.3 percent. By 1934 only 12.2 percent of the loans were in good standing. By 1936 an agency of the federal government had taken over 46 percent of the loans, the state bank had foreclosed on 21 percent, and the state had lost $\$ 8,800,000$ on the rural-credit program. To meet interest payments on the real estate bonds, nearly $\$ 8,000,000$ had been transferred from the motor vehicle tax, the beer tax, and the general tax levy. By.1940 the Bank of North Dakota had acquired 6,277 tracts of land by foreclosure. ${ }^{7}$

A determined effort had been made to solve the credit problems of North Dakota farmers. Its failure demonstrated the unsuitability of the prevailing adaptations to the nature of the country. But the problems were broader than those created by drought, small farms, and high land values.

The state vigorously attacked the wheat-market problem. In 1922, Governor Nestos sold three million dollars' worth of State Mill and Elevator bonds, and that spring, construction was resumed on the skeleton standing on the northern edge of Grand Forks. He hurried the work with round-theclock shifts, and on October 30, before a large crowd in downtown Grand Forks, he pushed a button to start the mill machinery. The workmen did not

${ }^{7}$ H. L. Waister, "Farm Mortgage Loans and the Interest Rates in North Dakota," Bimonthly Bulletin, North Dakota Agricultural Experiment Station, V, 1

(September 1942), 22-23; Gilbert W. Cooke, “The North Dakota Rural Credit System,” Journal of Land and Public Utility Economics, XIV (August 1938), 273283; Kenneth C. Johnson, “The Bank of North Dakota: An Analysis of Its Value” (Unpublished M.A. thesis, University of North Dakota, 1957), p. 16. 
actually finish construction until February, 1923, but the ceremonial opening a week before election day demonstrated the Governor's good faith and helped to secure his re-election.

The people of North Dakota had acquired a large grain-handling facility. Costing \$3,044,391, it could store 1,700,000 bushels, manufacture 3,750 barrels of flour a day, and wash, clean, and dry grain. The State Mill and Elevator paid as high a price as possible for wheat, allowing a premium for protein; it sold flour for substantially less than private mills. But it purchased only 1 to 3 percent of the state's wheat crop. It seems doubtful that such small purchases could have had any influence on the price received by most North Dakota wheat farmers.

The State Mill and Elevator consistently lost money in the 1920's. Buying more than half its wheat from the line elevators of commission houses, the old enemies of North Dakota farmers, it was paying them a middleman's profit of \$117 per carload in 1927 when under the control of Nonpartisan League Governor Arthur G. Sorlie. Poor sales of mill products, a poor location to serve the southern half of the state, political interference, the lack of low through railroad rates on grain which stopped in Grand Fork-all contributed to the losses. But the principal reason was that during its first ten years the mill operated at much less than its full capacity, generally at a third in the spring and at a half in the fall. ${ }^{8}$ Each barrel of flour, therefore, had to carry a heavy interest and depreciation charge. The losses of the mill were much less important than the fact that it was playing an insignificant role in the marketing of the state's wheat crop.

\section{THE GROWTH OF FARMERS' COOPERATIVES}

In the 1920's cooperative marketing of wheat proved more helpful to the farmers than did the operations of the State Mill and Elevator. During the first years of the decade, the Equity Cooperative Exchange was expanding its operations, and other cooperatives were established. In the summer of 1920 the American Farm Bureau Federation organized to unite all farmers' cooperatives. In 1921 it set up a national sales agency, called U.S. Grain Growers, Inc., to provide terminal sales agencies, terminal elevators, a finance corporation, and an export corporation. At the end of 1920, Usher L. Burdick, John Lee Coulter, Hans Georgesen, and some county extension agents organized the Farm Bureau in North Dakota. Edwin F. Ladd and Burdick drew up the constitution. Burdick became president and also a director of U.S. Grain Growers. The resolutions of the first two meetings recommended cooperatives, farm legislation, more adequate credit, and county extension work as promising ways of helping the farmers. By the end

\footnotetext{
${ }^{8}$ Gilbert W. Cooke, “The North Dakota State Mill and Elevator," Journal of Political Economy, XLVI (February 1938), 27-29; E. Bruce Hagen, “The North Dakota State Mill and Elevator Association: History, Organization, Administration, and Operation” (Unpublished M.A. thesis, University of North Dakota, 1955), pp. 142-172, 184-185, 325-329.
} 
of 1921, thirty-five counties in North Dakota had Farm Bureau chapters. Many cooperatives were started-for marketing horses and turkeys, for buying binder twine, and for insurance-but all failed, and Grain Growers was undermined by attacks from the grain trade. By 1924 the Farm Bureau had disappeared from North Dakota.

The early 1920's, however, saw a peak in the organization of marketing cooperatives in the Middle West. Secretary of Commerce Herbert Hoover and other national figures were advocating them as the answer to low farm prices. Many North Dakotans were convinced that cooperatives could eliminate the excessive profits of middlemen and throw off the burden of outside exploitation. Cooperatives were a natural expression of the radicalism and hostility to the interests that pervaded much of the thought and emotions of many North Dakotans.

Encouraged by the Equity Cooperative Exchange, cooperatives grew rapidly, especially in the form of farmers' elevators, in the years from 1913 to 1922. Many were organized in the newly settled western portion of the state; in eastern North Dakota, they had come earlier. In 1915 there were 446 farmers' elevators, in 1921 a total of 621, or about a third of all rural elevators. Every farmer was within easy hauling distance of one; the earlier abuses of the grain trade were passing away. ${ }^{9}$

In 1921 the North Dakota Legislature, as did those of many other states, passed the Standard Marketing Act, devised by Aaron Sapiro, a brilliant citybred Jew, from his experience in aiding the farmers of California and Oregon with their marketing problems. It legalized a marketing agreement to give farmers' organizations the advantages of monopoly control in the market. In 1922, Congress passed the Capper-Volstead Act, which exempted agricultural cooperatives from the antitrust laws.

\section{THE NORTH DAKOTA WHEAT GROWERS ASSOCIATION}

The most ambitious cooperative in the state was the North Dakota Wheat Growers Association, the creation of George E. Duis, A. J. Scott, and R. L. Taft. A big, aggressive man, Duis had served as a Democratic mayor of Grand Forks, farmed, and made money in a variety of enterprises-farm implements, an auto agency, and the Mutual Implement Dealers Insurance Company. Scott was a friendly, quick-witted entrepreneur who had come out to North Dakota from New York State as a young man to teach school at Rolla and to play semipro baseball. While teaching at Arvilla, he had begun to learn the grain business as secretary of the local farmers' elevator association. Taft was a Montana banker who had served as cashier of the Washington Wheat Growers Association.

Duis, Scott, and their associates wished to create a huge farmers'

\footnotetext{
${ }^{9}$ W. L. Ettesvold, Farmers' Cooperative Marketing and Purchasing Associations in North Dakota, North Dakota Agricultural Experiment Station Bulletin 294
} (Fargo, 1940), pp. 19-20. 
cooperative that could gain a monopoly in marketing hard spring wheat and thereby raise its price. Most farmers, pressed for cash, sold their wheat at a depressed price in a glutted market as soon as the harvest was over. Such dumping, Duis argued, meant that although the United States raised less of the high-protein hard red spring wheat than it used, North Dakota farmers received neither any benefit from the tariff on imported wheat nor any premium for protein. To replace dumping with orderly marketing, Duis and nineteen others organized the North Dakota Wheat Growers Association, a nonprofit corporation with no capital stock, at Grand Forks on January 23, 1922.

The association's plan was simple. It had already been worked out by Aaron Sapiro and tried by California fruit growers, by some tobacco raisers, and in some wheat areas. Borrowing the money from a government agency, the association would advance its members 70 percent of the market value when they delivered their wheat. The wheat pool, as the association was commonly called, would sell the wheat throughout the year to millers and exporters, avoiding the depressed prices of the fall glut. Then, after deducting its own expenses, it would divide the returns among the members. The member was to sign a five-year contract to put all his wheat into the pool; he would receive the average price for the year.

If the association could bring most of the North Dakota wheat growers into its membership, the users of hard red spring wheat would have to buy at the association's price. Since North Dakota farmers produced the bulk of the hard spring wheat raised in the United States, monopoly control and monopoly prices were a real and exciting possibility. That was the goal, or, as Duis wrote in 1924, "better times in North Dakota, better homes for our families, better schools for our children, and a more prosperous and contented commonwealth.”

But nothing close to monopoly control was ever attained. In 1922 organizers signed up three thousand members. The association borrowed from the War Finance Corporation and sold the wheat in the pool for $\$ 13,300,000$, deducting 13.7 cents a bushel for its expenses. After 1922 the association borrowed from the Federal Intermediate Credit Bank of St. Paul. It sold its wheat by protein content, not on grade, and (a matter of pride for its leaders) paid the first protein premium ever received by North Dakota growers. The State Mill and Elevator was not yet in operation, and country elevators, even cooperatives, could not pay a protein premium because they had no laboratories for testing.

Duis drove hard for the indispensable large membership. In 1923 the association had 9,200 signed up and began publishing the Wheat Grower, an official bimonthly newspaper, to carry the gospel to all members. A strong drive in 1924 brought the membership total to 15,300 , but that was only a fifth of the growers in the state. And the $\$ 6,300,000$ worth of wheat handled that year by the pool, while large in itself, was only a minor part of the wheat grown, even by its members, and an insignificant fraction of the 
$\$ 125,000,000$ crop. Monopoly control was unattainable.

After 1924 the membership grew, but the amount of wheat put into the pool fell off. There were several reasons for failure. Many members refused to deliver all of their wheat to the pool as the contract required. When the harvest came, most North Dakota farmers, in financial straits, had to have the full price for their wheat, not the 70 percent the pool advanced. Moreover, most country elevators were hostile to the pool, either because they were the line houses of Minneapolis firms or because they depended on Minneapolis commission houses to finance their own purchases of grain.

To combat these difficulties, the association expanded its operations. In 1926 it began to seek members in Montana. It set up the North Dakota Wheat Growers Credit Corporation to lend money to its members, freeing them from antipool pressure by the holders of crop mortgages. It set up the North Dakota Wheat Growers Warehouse Company to buy or lease rural elevators, giving the pool a direct contact with its members. In 1927 it owned thirtyfour elevators and in 1930 bought forty-four elevators of the Powers line. In 1928 it set up the North Dakota Wheat Growers Cooperative Terminal Association, which bought a 150,000-bushel-terminal elevator in Minneapolis. By July, 1928, the association had 22,500 members, 4,500 of them in Montana.

In the fall of 1929 the Federal Farm Board raised wheat prices by offering a guaranteed price through marketing cooperatives. Because the association was the only wheat cooperative in North Dakota organized under the Capper-Volstead Act, growers had to join it in order to secure the government price. New members poured in, and many country elevators contracted to handle wheat for the pool. But in the spring of 1930 the price of wheat fell, and the United States Grain Stabilization Corporation took the stored wheat off the association's hands. It did not, however, pay the storage costs. The heavy losses on storage and falling prices upset the orderly marketing program of the association, and it went out of business after the small 1930 pool. Its claims against the Federal Farm Board for heavy damages were denied. ${ }^{10} \mathrm{~A}$ valiant effort to apply the methods of business trusts to the central problem of the hard-spring-wheat country had failed.

\section{THE NORTH DAKOTA FARMERS’ UNION}

The North Dakota Farmers' Union, organized in the late 1920's, was another expression of the farmers' persistent efforts to improve their status. The Farmers' Educational and Cooperative Union was established in Texas in 1902 and came to North Dakota in 1912, first forming locals and then a state organization in 1915. Another national farm organization, the Grange,

\footnotetext{
${ }^{10}$ Pamphlets of the North Dakota Wheat Growers Association (Merchandise Your Wheat, North Dakota Wheat Growers Association, Pooling for Profits, Articles of Incorporation) and the file of the Wheat Grower (Grand Forks), the newspaper published by the association-all in Wheat Growers Association Papers, Orin G. Libby Manuscript Collection, Chester Fritz Library, University of North Dakota.
} 
came to North Dakota in 1914, largely in the counties west of the Missouri River. It sought to relieve the isolation and remoteness, to bring a spirit of friendliness to rural communities. But the rise of the Nonpartisan League sapped the strength of both the Grange and the Farmers' Union, and they soon died out in the state.

'When the Nonpartisan League failed, Arthur C. Townley started the Northwest Producers Alliance in 1924. It was a price-fixing venture designed to withhold wheat from the market, but had little success. In January, 1926, Northwest Producers Alliance members and Equity Cooperative Exchange stockholders decided, upon the urging of Myron William (Bill) Thatcher, to merge with the Farmers' Union on condition that it organize the farmers of the northwestern states. That year, the Farmers' Union Terminal Association took over Equity Cooperative Exchange terminal operations in St. Paul. ${ }^{11}$

The Farmers' Union set up the Northwest Organizing Committee, composed of Bill Thatcher, A. W. Ricker, and Charles C. Talbott, to recruit members in Wisconsin, Minnesota, North Dakota, and Montana. Thatcher had been with the Equity Cooperative Exchange and later was to be the manager of the Farmers' Union Grain Terminal Association. A. W. Ricker was manager of the Northwest Producers Alliance, editor of the Farmers' Union Herald (the official paper of the northwestern states, published in St. Paul), and also a former Populist, former Socialist, and former Nonpartisan League member. Charles C. Talbott, a massive, square-jawed farmer from Dickey County, had been active in the Nonpartisan League, the Northwest Producers Alliance, and his own local farmers' elevator company. A natural leader and an organizing dynamo, Talbott was to become an outstanding farm spokesman and the first president of the North Dakota Farmers' Union.

In 1927 the committee concentrated on North Dakota, sending out crews of organizers to make a farm-to-farm canvass in each county. They played upon the farmers' sense of grievance and exploitation, condemning the existing order in strong language. The Farmers' Union terminal livestockand grain-marketing firms at St. Paul financed the work, withholding patronage dividends for that purpose.

Membership offered substantial advantages. Members could ship their grain to the Farmers' Union Terminal Association and their livestock to the Farmers' Union Livestock Commission. They could buy coal, lumber, and twine from the Farmers' Union Exchange, and life and property insurance from Farmers' Union insurance companies. These advantages and the arguments of the paid organizers were effective. In November, 1927, the North Dakota Farmers' Union was organized with thirteen thousand members; Jamestown became the state headquarters and Talbott the first

\footnotetext{
${ }^{11}$ William P. Tucker, “Populism Up-to-date: The Story of the Farmers' Union," Agricultural History, XXI (October 1947), 204; Ross B. Talbot, “The Politics of Farm Organizations in North Dakota” (Unpublished Ph.D. dissertation, University of Chicago, 1953), pp. 20-40.
} 
president.

The new organization was an immediate success. In 1928, with twenty thousand members, North Dakota shared with Nebraska the distinction of being the largest state unit in the national Farmers' Union. In 1929 the state legislature passed the first law sponsored by the North Dakota Farmers' Union; it permitted the issuance of warehouse receipts on farm-stored grain. By 1930, Farmers' Union locals had been organized in all but eight counties-Grant; Hettinger, Sioux, Adams, McIntosh, Logan, Sheridan, and Cass.

The success of the Farmers' Union stimulated the growth of cooperatives. By 1929 it owned twenty oil companies in North Dakota. The following year, the Farmers' Union Terminal Association was handling more than fifteen million bushels of grain annually and claimed to be the largest cooperative grain-marketing association in the United States. It paid a premium based on the protein content of wheat. In 1931 it sold out to the government-controlled Farmers' National Grain Corporation. The Farmers' Union Exchange, reorganized in 1930 as the Farmers' Union Central Exchange under the cooperative laws of Minnesota, was supplying local Farmers' Union cooperatives with gasoline, oil, feed, fertilizer, twine, coal, fencing, tires, seed, and groceries. By the middle 1930's it was doing almost five million dollars' worth of business annually and had its own compounding plant for lubricating oils. Thus the organization of the North Dakota Farmers' Union brought a new force into the life of the state. With dynamic leadership, radical ideas, and funds for widespread activity, it was to play a powerful role in the future of North Dakota.

\section{THE CONGRESSIONAL DELEGATION}

In the 1920's, North Dakota politics reflected both the farm depression and the conservative swing of the nation. A few generalizations characterize the political scene. The state, of course, remained Republican during a Republican decade, with the primaries being the significant elections in oneparty North Dakota. The cooperation of conservative Democrats and conservative Republicans, forged in the fight against the Nonpartisan League, tended to persist. After the defeat of the League in 1921 and 1922, the voters became apathetic - barely more than half of them bothered to vote in 1930. The Herbert Hoover-Al Smith campaign, however, with its religious bigotry and prohibition issue, was an exception, bringing out more than 72 percent of the voters.

Although after 1922 the Nonpartisan League was dead as an organization with a large dues-paying membership, an official newspaper, and a salaried headquarters staff, it continued to be a factor in elections. It represented economic discontent and the progressive tradition in North Dakota, and its support came from the more western counties, except that Stark, Morton, Sioux, and Golden Valley were not League counties. Since the League's opponents had adopted the heart of its program-rural credit and the State 
Mill and Elevator-the elections were often decided by factional strife and personalities rather than issues.

The results were mixed. The League elected the governor, Arthur G. Sorlie, in 1924 and 1926; the Independent Voters Association elected the governor, George F. Shafer, in 1928and 1930. After 1922, no leader, no issue, and no faction dominated either the political scene or the state government.

The state's congressional delegation was also divided. Anti-League Republicans held two of the three seats in the House of Representatives; after the defeat of Porter J. McCumber in 1922, League Republicans held the two seats in the Senate. In 1920, tall, able, moderate Olger B. Burtness, a Grand Forks attorney, defeated sharp-witted League cartoonist John M. Baer (creator of "Big Biz") for representative from the eastern First District. The only native-born North Dakotan in Congress, Burtness was regularly reelected until the Democratic landslide of 1932.

The central Second District was represented by attorney George M. Young from 1913 to 1924. Young was a Canadian who had graduated from the University of Minnesota and had begun to practice law in Valley City in 1884. Secretary of State Thomas Hall, onetime Fargo newspaper reporter and secretary of the Progressive Republican Committee of North Dakota from 1906 to 1912, was then elected and re-elected in the Second District until 1932. Burtness, Young, and Hall were anti-League Republicans, but they were or had been progressives.

A League Republican, James H. Sinclair of Kenmare, represented the western Third District in the House from 1919 to 1935. A Canadian immigrant, he had graduated from Mayville Normal and, versatile and enterprising, served as superintendent of schools in Cooperstown and later as Griggs County registrar of deeds. He then started a bank in Binford, but moved to Kenmare, where he farmed and dealt in land. After serving in the state legislature for three terms, he went to Congress for eight terms.

Sinclair was the only Leaguer in the House, but the League held both North Dakota seats in the Senate. President Edwin F. Ladd of the Agricultural College replaced Asle J. Gronna in 1920, and Lynn J. Frazier replaced Porter J. McCumber in 1922. Although McCumber was a conservative Republican, the Independent Voters Association refused to support him against Frazier because he had never been an active opponent of the League. Frazier and Ladd lost their membership in the Republican party and their seniority in the Senate when they supported Robert M. La Follette for President in 1924.

Ladd died in June, 1925. Governor Arthur G. Sorlie, after considerable delay, appointed young political unknown, Gerald P. Nye, then thirty-three, to Ladd's seat on November 14. Nye was a Leaguer, a left-wing supporter of La Follette, and the editor of the Griggs County Sentinel-Courier (Cooperstown). After a fight which made Nye's name a household word in North Dakota, a combination of Democratic and insurgent Republican 
senators seated him by a vote of forty-one to thirty-nine. The long contest over the seating insured Nye's election in 1926. Nye was above average height, slender, and rather handsome in a boyish way. In Washington he lived simply, but he became an effective, popular speaker and also a skilled conductor of senatorial investigations. Though modest and unassuming, he had a flair for self-advertisement. ${ }^{12}$

The North Dakota congressional delegation, both League and anti-League, were men of progressive outlook, as were the voters of the state generally. North Dakotans naturally supported federal action in aid of agriculture: the Federal Intermediate Credit Bank, the McNary- Haugen bill, and the Federal Farm Board. Though Republicans, they opposed President Calvin Coolidge and later President Herbert Hoover and were critical of big business. But the North Dakota senators and representatives were not the leaders of the farm bloc in Congress.

\section{THE PRESIDENTIAL ELECTIONS}

North Dakota's votes in the presidential elections of the 1920's revealed both isolationist and progressive attitudes. In 1920, with the League of Nations an issue, Warren G. Harding received 78 percent of the votes cast for President in North Dakota. In 1924, Calvin Coolidge, opposed by Robert M. La Follette on a third-party Progressive ticket, received only 48 percent of the North Dakota vote, with 45 percent going to La Follette and 7 percent to Democrat John W. Davis.

Although the state's daily papers attacked La Follette as a radical, he had the support of the Nonpartisan League. Only the votes of conservative Democrats gave Coolidge a victory in North Dakota. La Follette had a larger percentage of the vote than in any other state except Wisconsin, which he carried. La Follette ran strongly in the western counties (71 percent of the vote in Mercer); Coolidge gathered the bulk of his votes in the two tiers of counties just west of the Red River, where he lost only Sargent.

In 1928 the Herbert Hoover-Al Smith campaign aroused much interest. Fargo Methodists and Grand Forks Baptists condemned Smith, a Roman Catholic, for his Tammany Hall connections and his support of the saloon. Such League leaders as Frazier, Nye, and Sinclair supported Hoover, but the Republican state central committee, though controlled by the League, refused to endorse him. William Langer, running for attorney general on the Republican ticket, and William Lemke both supported Smith, but Walter Maddock, a Leaguer running for governor on the Democratic ticket, refused to do so. Two German-language papers, Der Staats-Anzeiger (Bismarck)

\footnotetext{
${ }^{12}$ Edward C. Blackorby, "Political Factional Strife in North Dakota from 1920 to 1932” (Unpublished M.S. thesis, University of North Dakota, 1938), pp. 85-90; Robert L. St. Clair, "Progressivism in North Dakota, 1924” (Unpublished M.A. thesis, University of North Dakota, 1960), p. 167; Ordean G. Ness, "Gerald Prentice Nye: An Illustrative Analysis of Persuasive Technique” (Unpublished M.A. thesis, University of Wisconsin, 1947), pp. 4-9.
} 
and the Nord-Dakota Herold (Dickinson), supported Smith.

The vote was very heavy. Smith received some twelve thousand more votes than Coolidge got in 1924, carrying fifteen counties, many of them with large German Russian populations. Excluding McIntosh and Mercer, the population of the remaining Smith counties was 51 percent Roman Catholic. Smith carried several counties lost by Maddock, Democratic candidate for governor; Maddock, in turn, carried several counties lost by Smith. But Hoover took the state easily with 55 percent of the vote, winning the cities and the heavily populated counties. ${ }^{13}$ For many North Dakotans, the election had turned on moral and religious issues-Tammany Hall, liquor, and Catholicism.

\section{STATE POLITICS: LEAGUERS VERSUS INDEPENDENTS}

The 1920's saw a running fight between Leaguers and Independents for control of the Republican party and the state government. In 1922 the Independents (both conservative Democrats and Republicans were active in the Independent Voters Association) renominated Ragnvold Nestos for governor. A heavy, dark-complexioned man of commanding presence and obvious integrity, he had never been a rabid opponent of the League program. Norwegian-born, he was a churchgoing Lutheran, spoke with an accent, and promised to complete the State Mill and Elevator and to provide rural credits through the Bank of North Dakota. Just before the primaries, the Independents secured the indictment of League leaders William Lemke and Arthur C. Townley for wrongdoing in the failure of the ScandinavianAmerican Bank in Fargo. The court dismissed the charges after the election, but the damage had been done. Lemke wrote that he had been "doublecrossed, deceived, tricked.” The Independents again raised such a hullabaloo about Lemke's Fargo house, built by the state-owned Home Builders Association, that they made Lemke, a man of sterling integrity, seem like a shabby trickster. The daily press and outside corporations worked to "get Lemke.” Nestos defeated Bert F. Baker in the primary and Lemke, running as an Independent, in the fall election. The Independents won both houses of the legislature for the first time; the League took only three state offices.

Lemke, the chief figure of the Nonpartisan League in North Dakota, was then a powerless, discredited leader, and the League itself appeared to be dead. It was bankrupt; it sold the Fargo Courier-News in April, 1923; it dissolved the national organization. The League did publish a small weekly, The Nonpartisan, at Bismarck; its editor was John Blum until his death in 1925, when Gerald P. Nye became editor. As the League collapsed, its opponents abandoned the Independent Voters Association. Secretary and founder Theodore G. Nelson resigned, and in July, 1924, its newspaper, the Rural Independent, ceased publication.

\footnotetext{
${ }^{13}$ Eugene O. Holen, “The Election of 1928 in North Dakota” (Unpublished M.A. thesis, University of North Dakota, 1959), pp. 120-150.
} 
Both Leaguers and Independents, however, long continued to shape the course of North Dakota politics. The League was divided between a radical faction, headed by Lemke, and a group of moderates. The motto of the radicals was "No retreat"; Lemke called the moderates "trimmers." At the League convention in October, 1923, a delegate from Sheridan County said: “We can't go back [to power] unless we not only bury Townley and Lemke but plant grass on their graves." The moderates were willing to work with William Langer, the bitter enemy of the League in 1919-1920, and for a while used the Fargo Courier-News to undermine Lemke with Leaguers.

The moderates, in tune with the more conservative temper of the time, were able to control the organization. In the 1924 League convention, with Lemke absent, they chose Arthur G. Sorlie as their candidate for governor in the Republican primary. Sorlie, a large, friendly person of fine appearance and democratic manners, was a wealthy Grand Forks businessman. He was not a member of the League, but he was sympathetic with its program, believed in the State Mill and Elevator, and could win over middle-ground voters. His son later described him as "a conservative Liberal.” Moreover, Leaguers believed that he would finance their campaign.

The Independents again endorsed Nestos, but he was hurt by some of his courageous acts as governor. He had vetoed appropriations for the Bottineau School of Forestry and for a bridge over the Missouri at Williston; he had also refused to deposit state funds in weak banks during the great wave of bank failures in 1923. Many voters were. indifferent to the campaign. Though Sorlie spoke against the "common enemy in the East" and wanted the Bank of North Dakota and the State Mill and Elevator to succeed, he opposed the expansion of state ownership and toned down the radical aspects of the League platform. He endorsed La Follette for President with obvious reluctance.

Few expected the League to win. Independents, who wished the League industrial program liquidated, could see little difference between Sorlie and Nestos, yet Sorlie defeated Nestos in the primary by the narrow margin of 2,200 votes. In the fall he was elected over Halvor L. Halvorson, the Democrat, who had I.V.A. support. The League divided the other state offices with the Independents, but won control of the lower house of the state legislature and failed by one vote to take over the senate. The League had made a surprising recovery. Although it was no longer a militant crusader for state socialism, it was still an important expression of farmer class consciousness.

Governor Sorlie had returned the League to power. He was opposed, however, throughout his two terms by left-wing Leaguers led by Lemke and Lieutenant Governor Walter Maddock. The left-wingers disliked Sorlie because he was a conservative businessman, because he was reluctant to support La Follette for President in 1924, because of his campaign promise not to expand the state industries, because he did not finance the League campaign, and because he appointed Gerald P. Nye to the United States 
Senate. In the 1925 legislature they tried to have the state compensate the depositors of closed banks. In 1926 they set up a small Farmer-Labor party to oppose Sorlie's re-election. Sorlie, however, was easily re-elected when the Independents adopted a platform calling for the liquidation and sale of the state industries. The more progressive Independents voted for Sorlie, but the League lost both houses of the legislature.

In the 1927 legislature the League left-wingers joined with the Independents to embarrass Governor Sorlie with an investigation of the State Mill and Elevator. The investigating committee (two Leaguers and one Independent) recommended that the mill be taken out of his hands because of inefficient management. Incredulous at this repudiation, the Governor called a special session in January, 1928. Then O. L. Spencer, the mill manager appointed by Sorlie, sustained the committee's criticisms; not a Leaguer rose in the legislature to defend the Governor. In 1924, Sorlie had promised to make the mill pay, but in the second fiscal year of his governorship it had its first operating loss. Losses after deductions for interest and depreciation had been the usual thing, but not before such deductions. Sorlie's political future was destroyed ("a dead one," wrote Lemke), and he himself died of heart disease in the summer of 1928. His enemy, Walter Maddock, became governor.

In 1928 the left-wingers secured a League platform calling for the extension of the state industries and the establishment of branches of the Bank of North Dakota. The radical League platform embarrassed the moderate League candidate for governor, T. H. H. Thoresen, a Grand Forks attorney. The convention, through the efforts of Roy Frazier, endorsed William Langer for attorney general; thus Langer re-entered the League after long ostracism because of his 1919 defection. The Independents endorsed George F. Shafer for governor; he had served as attorney general since 1923. Shafer defeated Thoresen in the primary and Walter Maddock, running on the Democratic ticket, in the fall election. Langer ran well and was soon contending with Lemke for control of the League organization.

Shafer had two successful terms as governor. He was thoroughly familiar with the problems of North Dakota government, and under his guidance the State Mill and Elevator yielded its largest operating profit up to that time. In 1930 he was easily re-elected, and the Independents won both houses of the legislature. Only three Leaguers, the incumbents, were elected to state offices.

In December, 1930, the old state capitol, built in territorial days, burned. The legislature provided for a capitol commission and a vote on a capitol bond issue. In 1932 the voters turned down Jamestown's bid for the removal of the capital to that city, and the construction of the modern capitol began.

After the 1930 census, North Dakota's representation in the House of Representatives was reduced from three to two. The 1931 legislature failed to redistrict the state, and until 1960 the two congressmen were elected at 

large. ${ }^{14}$ By 1932 a new era was beginning in North Dakota. Compared to its trials, the depressed 1920's were to seem like a time of serene prosperity. 


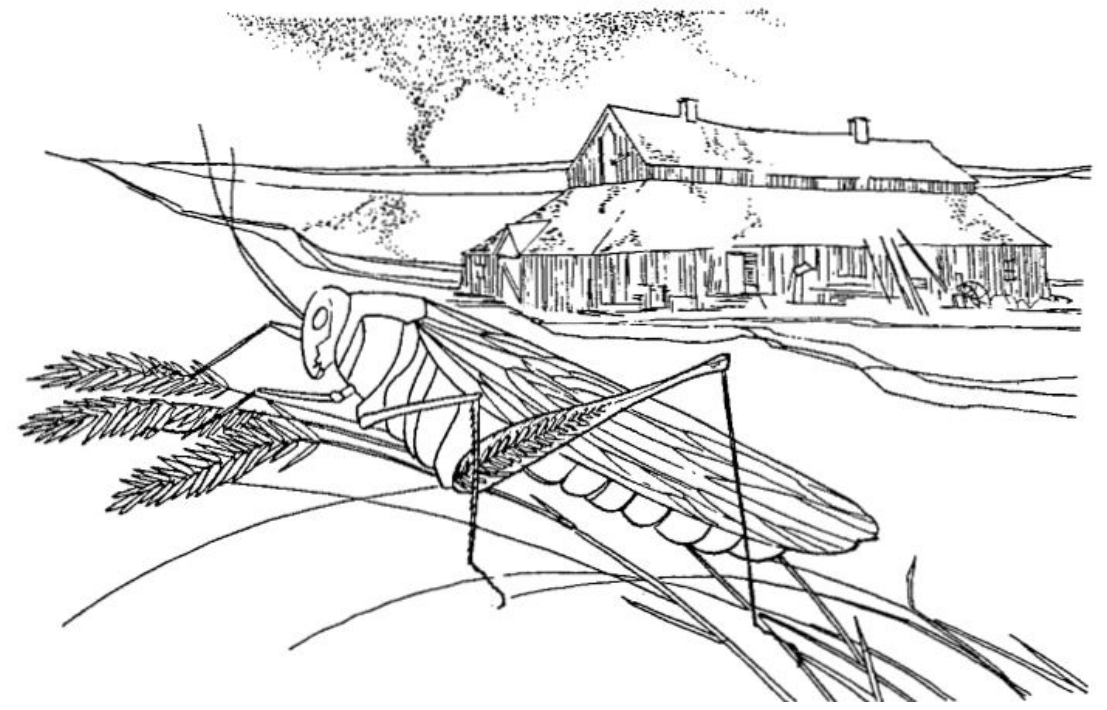

\section{The Thirties: Drought and Depression}

AFTER THE STOCK-MARKET CRASH of 1929, the economic system of the United States and much of the world began to break down as economic activity declined and mass unemployment appeared. During this crisis, threatening the very fabric of society, the administration of President Herbert Hoover and then that of President Franklin D. Roosevelt took the responsibility for the economy of the nation. Both the Great Depression of the 1930's and the principle of government responsibility for the economy were of momentous consequence for the United States and the world. They were no less so for North Dakota.

The state underwent a traumatic experience in the 1930's. Because drought added to the difficulties caused by the depression, North Dakota suffered more than much of the rest of the nation. Moreover, in North Dakota drought and depression accentuated long-standing difficulties created by its status as a producer of raw materials which had little or no control over the markets in which it bought and sold. Thousands lost their farms; more than one-third of the population lived on relief; many people left the state.

During the crisis, the principle of government responsibility for the economy placed the strength of the United States government, and to some degree the resources of the nation, behind efforts to improve the economic well-being of the people of North Dakota. Massive federal expenditures for relief and farm programs saved North Dakota. President Franklin D. Roosevelt's Great Plains Committee pointed out the 
adjustments needed for a better life in that vast semiarid region, and his administration began to work toward such adjustments. Moreover, the Roosevelt Administration was committed to the liberal and progressive outlook which had long found a congenial climate in liberal, progressive North Dakota.

Yet there was conflict. Farmers, even in North Dakota, where farm cooperatives had long flourished, were individualists, each running his own enterprise. Aid and direction from the federal government inevitably meant some loss of freedom. Then, too, aid and direction from the federal government accentuated North Dakota's dependent status, an unhappy outcome for many touchy North Dakotans. So, while federal relief and farm programs devised by a Democratic administration in Washington were vital to their very survival, North Dakotans remained staunchly Republican. Scarcely a single popular leader in the state, Democratic or Republican, was a consistent supporter of the New Deal. More significant, in spite of or possibly because of their suffering, North Dakotans were reluctant to change their ways. Progress toward adjustment to the semiarid country was painfully slow in the 1930's.

The crisis did produce a bold leader in North Dakota-William Langer. Using his authority as governor to stop foreclosures on farms and to raise the price of wheat, he gave a distressed people not only some economic aid but also some measure of emotional security. His daring, aggressive course brought him the hatred of both the conservatives and some segments of the Nonpartisan League. The political history of the decade revolved, to a remarkable degree, about Langer; it ended with his triumphant election to the United States Senate.

\section{THE GREAT DROUGHT}

Drought struck down North Dakota in the 1930's. Nine of the eleven years from 1929 through 1939 had less than average rainfall. June, 1929, was one of the driest Junes on record; in 1930 hot winds cut down the crops; spring rains were light in 1931, and in July searing heat withered the vegetation. By fall more than half the farmers in the hardest-hit northwestern counties needed relief. The next year, 1932, had normal moisture, but 1933, with only 13.5 inches, was the fourth-driest year yet recorded. The state was drying up. In the spring of 1934, dust storms occasionally made travel by plane and auto hazardous; here and there drifting soil covered fences, ditches, and farm machinery. With only 9.5 inches of rainfall, 1934 was the driest year yet on record. On the western ranges, new grass made no growth that spring, and hungry cattle lost weight. The federal government began buying stock, paying four dollars a head for calves and twenty dollars for cows. Ranchers culled their breeding herds and in some counties sold half or more of their cattle. Many cattle died from lack of feed and from dust in their lungs and stomachs.

In the late winter and spring of 1935, dust storms brought anxious 
foreboding, but good rains gave the growing season above-average moisture, though still producing a small wheat crop. The year 1936 was the coldest $\left(-60^{\circ} \mathrm{F}\right.$. at Parshall on February 15$)$, the hottest $\left(121^{\circ} \mathrm{F}\right.$. at Steele on July 6), and the driest (8.8 inches) ever reported. Summer was a disaster. By the end of a hot June, stock feed was short; from July 5 to 18 , temperatures reached $100^{\circ} \mathrm{F}$. nearly every day; no prairie grass grew outside the Reel River Valley. Again the federal government bought cattle. Ranchers, unable to raise any winter feed, sold a large part of their herds, keeping only their best breeding stock and feeding them on cottonseed cake, brush, old straw, and whatever roughage was available. ${ }^{1}$

Throughout the 1930's, grasshoppers, menacing the whole Northern Plains, added their ravages to the damage of drought. In the spring of 1931 they began to destroy crops in Pembina and Adams counties, cutting binder twine on sheafs of grain, chewing up clothing, and even roughening shovel and pitchfork handles with their powerful mandibles. They soon spread over large parts of the state. Led by county agents, farmers spread poison bait (molasses, bran, arsenic, and water) and plowed under unhatched eggs. The state government had no funds for the work. The counties spent $\$ 25,000$ in $1931, \$ 110,000$ in 1932, $\$ 90,000$ in 1933, \$764,000 in 1934, and \$24,000 in 1935. From 1936 to 1947 the North Dakota State Grasshopper Control Committee spent \$3,600,000, the largest sum expended by any state. In 1936, Works Progress Administration crews were mixing poison bait, sometimes working day and night to keep up with the demand.

County control was ineffective: farmers in counties which checked the hoppers saw their fields reinfested from counties without money for poison bait. The problem was really a national and international one. The Greater North Dakota Association called a regional grasshopper conference in Fargo, November 21-22, 1933, with delegates from seven states and three Canadian provinces. The conference finally secured funds from Congress for the control program. ${ }^{2}$

\section{THE IMPACT OF THE GREAT DEPRESSION}

The battle against the hoppers was won. Although precipitation remained below normal in 1937, 1938, and 1939, the disastrous droughts of 1934 and 1936 were not repeated. But the drought years were also depression years, and depression prices for meager crops brought double hardship. At the bottom in 1932, North Dakota farmers sold wheat for 36థ a bushel, oats for $9 \$$, barley for $14 \$$, potatoes for $23 \$$, flaxseed for $87 \$$, and beef cattle for $\$ 3.30$ per hundredweight. Prices recovered somewhat,

${ }^{1}$ Frank J. Bavendick, Climate and Weather in North Dakota (2nd ed.; Bismarck: North Dakota State Water Conservation Commission, 1952), pp. 1317, 53.

${ }^{2}$ J. A. Munro, “Grasshopper Outbreaks in North Dakota, 1808-1948,” North Dakota History, XVI (July 1949), 150-157. 
but were never good in the 1930's: wheat sold for only 53థ a bushel in 1938.

Yields were scanty and income small. From 1929 to 1941, North Dakota farmers produced only two wheat crops of more than 100,000,000 bushels - a minimum for a satisfactory yield. In 1936 the crop was a pitiful 19,000,000 bushels. Even in the depressed 1920's, annual cash farm income had always exceeded $\$ 200,000,000$, but in the 1930's it was quite often less than $\$ 100,000,000$, and a sizable portion (24 percent in 1934) came from government payments. The low was $\$ 61,000,000$ in 1932 , or about $\$ 760$ per farm. Basing the calculation upon the average cash farm income in North Dakota from 1924 to 1928 (not very good years in the state), drought and depression deprived the state's farmers of the staggering sum of $\$ 1,340,000,000$ from 1929 to $1933 .^{3}$

In 1933, the low year, the per capita personal income in the United States was \$375, but in North Dakota it was only \$145. By 1933 the figures were \$527 in the United States and \$278 in North Dakota. From 1932 through 1937 the per capita personal income in North Dakota was only 47 percent of the national average. Plainly, the 1930's brought much greater hardship to North Dakota than they did to the nation as a whole.

Low income caused a multitude of misfortunes: a decline in land values, delinquent loans and foreclosures on mortgages, unpaid taxes, increasing tenancy, growing public - ownership of land, large numbers of people on relief, and a great movement of people out of the state. The average value of farm land per acre fell from $\$ 22$ in 1930 to $\$ 12$ in 1940, the average farm from $\$ 12,200$ to $\$ 6,600$. Most of the farm mortgage loans became delinquent (78 percent of the Federal Land Bank loans in 1933), and the number of forced sales increased. From 1921 to 1934 there were 43,000 forced sales of farm land in the state. From 1930 to 1944 probably onethird of North Dakota's families lost their farms by foreclosure. The number of forced sales was larger, but not all were for entire farms, and some debtors later recovered their land. ${ }^{4}$

Many people were unable to pay their taxes. By the end of 1936 about three-fourths of the taxes in the southwestern counties were delinquent. In 1933 the total tax burden of the state, over $\$ 31,000,000$, was one-third of the farm income. From 1932 to 1937 the unpaid general property taxes amounted to more than $\$ 34,000,000$.

\footnotetext{
${ }^{3}$ North Dakota Public Welfare Board, "Special Report to Honorable John Moses on Relief and Economic Situation in North Dakota, April 22, 1939," prepared by L. A. Baker (Mimeographed; [Bismarck], n.d.), p. 18 (cited hereafter as "Special Report to Moses").

${ }^{4}$ Rainer Schickele and Reuben Engelking, Land Values and the Land Market in North Dakota, North Dakota Agricultural Experiment Station Bulletin 353 (Fargo, 1949), pp. 13-16; William E. Koenker, “The Rural Land Tax Problem in North Dakota with an Appraisal of the Income Value of Land as a Measure of Taxation” (Unpublished M.A. thesis, University of North Dakota, 1938), pp. $15-16$.
} 
Farm tenancy increased from 35 percent in 1929 to 45 percent in 1939. Because farmers could not pay their debts, a considerable amount of farm land passed from individual to corporate and public ownership. The Bank of North Dakota, the Federal Land Bank of St. Paul, the state land department, county governments, and the United States Soil Conservation Service acquired title to about six million acres. ${ }^{5}$ After 1934 from onethird to nearly one-half of the people were on relief; 75 percent of the people in Billings County were receiving government assistance in February, 1939.

Thousands fled the stricken state. By 1940 the population was down to less than 642,000, a loss of 5.7 percent, or nearly 39,000 persons, in a decade. The loss was really much greater. The excess of births over deaths in the 1930's was more than 82,000. That is, if no one had left the state, its population would have increased by 82,000 from 1930 to 1940. North Dakota lost not only that number, however, but also 39,000 more, a loss by out-migration of over 121,000, or about double the loss of the 1920's.

The loss was spread fairly evenly through the decade. For the years from 1935 to 1940, a special census on internal migration showed that 86,699 persons left North Dakota, moving principally to Minnesota, Washington, and California. During the same years, 20,218 persons moved into the state. The loss was chiefly from the farms, although the small towns also lost many people. The urban population (persons living in towns of 2,500 and more) increased by 16 percent, or approximately the rate of natural increase; the small towns increased by only 7 percent; the farm population declined by 17 percent. Forty-three of the fifty-three counties lost population; the western ones lost most heavily-Slope County 29 percent.

Many defeated people drifted from the farms into the towns. Professor John M. Gillette, a stocky, white-haired rural sociologist at the University of North Dakota, described their condition after he had made a sixthousand-mile tour of the state in 1939:

Stoves are giving out; bedding is wearing out; curtains, carpets, and furniture becoming unusable; clothes have become shabby and indecent.... Along with these changes has come a decided loss of morale. Ambition... has been killed; and there is little hope of ever being anything but a WPAer. The children born into and being reared in this situation are decidedly underprivileged. They are cut off from association with middle class children, feel themselves to be outcasts and inferiors, have little or no recreational privileges, and come to absorb an atmosphere of defeatism and parasitism.... Itis a most serious situation for the young men and women on farms who are

${ }^{5}$ Lyman W. Wallin and Reuben Engelking, Land Ownership Trends in North Dakota, Selected Years, 1929-1944, North Dakota Agricultural Experiment Station Bulletin 337 (Fargo, 1945), pp. 3-8; Morris H. Taylor and Raymond J. Penn, Management of Public Land in North Dakota, North Dakota Agricultural Experiment Station Bulletin 312 (Fargo, 1942), pp. 7-11. 
just coming to maturity. Farming no longer has power to absorb them; and after remaining idle parasites on the farmstead for a time they float into towns and villages, marry, and join the WPA forces. For them and the stranded agricultural laborers and farmers there is no longer a retreat in great cities to join the armies of manual and white-collar workers, for those are filled with unemployed millions and new recruits generally soon apply for relief and are then sent back to the North Dakota counties from which they derived arid where their legal residence is. ${ }^{6}$

\section{LEMKE AND THE ELECTION OF ROOSEVELT}

As a farm state, North Dakota thought of relief chiefly in terms of scaling down farm debts, increasing the supply of money, and guaranteeing the farmers prices which covered the cost of production. In 1929, William Lemke began to work out a program. He devised a bankruptcy law to scale down farm debts in proportion to the decline of land values, a refinance law to pay off farm debts with three billion dollars' worth of newly printed money, and a government-owned United States Bank to take over the issue of paper money from the privately owned Federal Reserve banks. Under the refinance plan, the farmers would repay the government credit agency at a rate of 3 percent annually (half as interest and half on the principal). Lemke also adopted a cost-ofproduction plan by which the government would guarantee farmers prices which covered the cost of production without any restriction on the size of the crops grown.

Lemke was a fighter who believed there was a devil behind every difficulty. He was a man of extravagant dreams; he simplified reality for the farmers and gave them hope. He promoted his simple cures with energy and determination. In 1931 the North Dakota Legislature endorsed Lemke's proposals, and he sent out copies of the resolution to every state legislator in the nation. Under Farmers' Union auspices, he spoke for them in many middle western states.

Senator Lynn J. Frazier introduced the bankruptcy and refinance bills in Congress. When the Hoover Administration refused to support them, Lemke began to believe that Democratic Governor Franklin D. Roosevelt of New York would be the best candidate for President. Late in 1931 or in January, 1932, Lemke went to see the Governor at Albany. Roosevelt received him graciously, listened carefully, and assured Lemke of his support in general terms: "Yes, yes, I am for all that.” Lemke was pleased with his reception and went home to work for Roosevelt in the Farmers' Union and the Nonpartisan League in North Dakota and neighboring states. As a result, Roosevelt made the first formal announcement of his candidacy for the North Dakota presidential primary to be held on March 15.

${ }^{6}$ John M. Gillette, “Social-Economic Submergence in a Plains State,” Rural Sociology, V (March 1940), 64-63. 
Lemke worked effectively for Roosevelt among League county leaders, and thousands of Republicans voted in the Democratic primary and gave Roosevelt an easy victory over William H. “Alfalfa Bill” Murray, whose inflationary ideas and picturesque personality had a strong appeal in North Dakota. Lemke always believed that the early victory in North Dakota helped Roosevelt in the other farm states of the Northwest and that he himself played an important part in starting Roosevelt on the way to the White House.

\section{THE LANGER REVOLUTION}

Just as the election of Franklin D. Roosevelt as President in 1932 brought a new era to the nation, so, too, did the election of William Langer as governor in the same year bring a new era to North Dakota. Before the June primary the Nonpartisan League had endorsed Langer for governor, Gerald P. Nye for the Senate, and William Lemke and James H. Sinclair for the House of Representatives (after the 1930 census, North Dakota's representation in the House was cut from three to two). From 1928 to 1932, Langer had spent twenty-one thousand dollars of his own money to finance the resurrection of the League. He was endorsed for governor over opposition from the Lemke-Nye faction.

The 1932 primary campaign was a runaway for the League candidates. Langer, a rough and boisterous campaigner, was a great vote getter. He was especially appealing to the German Russians, many of whom could not read English and distrusted well-groomed candidates. They became Langer's loyal supporters. ${ }^{7}$ He emphasized the need to reduce taxes and to end nepotism - telling issues in the depression. Senator Nye's national prominence, a result of his investigation of the corrupt election to the Senate of Ruth Hanna McCormick from Illinois, helped the entire League ticket. His opponent, Governor George F. Shafer, lost votes by defending President Hoover and opposing government action against the depression. Lemke promised that his debt-reduction and refinance proposals had Roosevelt's support.

Every League candidate won Republican nomination. Lemke and Sinclair defeated Independent incumbents Olger B. Burtness and Thomas Hall and also Usher L. Burdick, who ran without endorsement. In the fall campaign the Republican nominees opposed Hoover's re-election. Nye and Sinclair criticized Hoover bitterly, and although Langer spoke only of state issues, Lemke campaigned openly for Roosevelt, making ninetynine speeches in October alone. The outcome was a rout for Roosevelt, who received 69 percent of the votes. Although League candidates all received fewer votes, the League won a complete victory: the House seats, all state offices, and control of the legislature. For the first time since

${ }^{7}$ Joseph B. Voeller, "The Origin of the German-Russian People and Their Role in North Dakota” (Unpublished M.S. thesis, University of North Dakota, 1940), pp. 99-105. 
1919, it controlled the state government.

Before Franklin D. Roosevelt took office in Washington, Governor Langer and the League began a bold operation to meet the crisis in North Dakota. Angry crowds were surging into Bismarck; a spirit of desperation was seizing many; the state treasury was empty; state bonds were far below par. Langer believed that it was imperative to raise farm prices, to save farm property from foreclosure, and to reduce public expenditures. Although seriously ill at the beginning of his term, he acted with daring and imagination. Under his urging and aided by his many vetoes, the legislature cut the biennial appropriations from ten million dollars to five million. Salaries were reduced, and funds for the state's multitudinous departments, its penal and charitable institutions, and the colleges and the university were cut drastically.

The reduction in appropriations did not mean a similar reduction in expenditures, for the legislature controlled only a fraction of the moneys paid out by the state treasurer. Although the legislature appropriated only five million dollars for the 1933-1935 biennium, the state treasurer actually paid out forty-nine million. There were many special funds, such as the six million dollars for highways, that were beyond the authority of the legislature or the governor.

Langer improved the state's credit by transferring money from other funds, such as the gasoline tax, to the bond-retirement fund. He persuaded the legislature to pass a 2 percent sales tax; it was, however, referred to and disapproved by the voters on September 22, 1933, by a large majority. The Public Service Commission secured reductions in electric rates.

In the fall of 1933, Langer made a dramatic move to raise the price of wheat. Using the authority granted by a new law, he placed an embargo on all wheat shipments from the state. The price of wheat rose five cents in Minneapolis on the first day of the embargo and twenty-three cents before he withdrew it on December 5. Late in December the federal district court issued an injunction against the embargo, but Langer had already accomplished his purpose. All farm prices, however, were moving upward in the last half of 1933.

An even more significant action was Langer's moratorium on foreclosures. The voters had twice defeated initiated measures for a moratorium on farm-mortgage debts in 1932. On March 4, 1933, however, Langer proclaimed both a state bank holiday (President Roosevelt was proclaiming one for the nation) and a moratorium on all debts. The state banks reopened on March 14, but Langer retained the moratorium, soon restricting it to forbid foreclosures only on real property being farmed by the owner. On April 17 he exempted from the moratorium foreclosures by the federal government and its agencies.

The daily newspapers and the Democratic party opposed the moratorium, but the League, the Farmers' Union, and the Farm Holiday Association supported it. The Leader, started by Langer in July, 1933, liked to say that "human rights are more sacred than property rights." 
When sheriff's sales continued in spite of the moratorium, angry crowds of farmers abused officials, making them slop the hogs, scrub the barn floor, and walk home. At the eviction sale of Martin Oyloe near Williston, members of the Farm Holiday Association bid in Oyloe's farming equipment for a few cents and returned it to him. Governor Langer finally used the National Guard to stop the sheriff's sales.

The moratorium helped morale in a time of great anxiety. North Dakotans were encouraged because they felt that the state government was doing everything in its power to help them. Most states tried some form of moratorium in the 1930's, but none took as broad or as effective action as North Dakota. South Dakota, for example, had about 12,000 more foreclosures on farms than North Dakota. The moratorium was continued by Langer's successors, and then in 1937 the legislature passed a moratorium law, which it re-enacted in 1939 and 1941 and finally dropped in $1943 .^{8}$

As the depression and the moratorium largely destroyed the value of farm land as security for private lenders, the farm-mortgage business passed into the hands of public agencies. In the 1930's bankers persuaded their farmer debtors to refinance their loans with federal agencies. By 1945 the commercial banks of North Dakota held only 1.3 percent of the farm-mortgage debt; the Federal Land Bank and the Federal Farm Mortgage Corporation held 50.9 percent and insurance companies 16.7 percent.

The moratorium did not prevent foreclosure by the federal agencies, which therefore acquired title to much land. In 1939, with the end of the moratorium on tax foreclosures, the counties took over some 2,000,000 acres. Taxes had not been paid on some of it for ten or twelve years. The state land department had lent nearly seventeen million dollars on farms and had foreclosed on more than 821,000 acres when the loans became delinquent. By 1942 the Bank of North Dakota owned nearly 1,600,000 acres of land, the Federal Land Bank an estimated 1,000,000, and the United States Department of Agriculture over 1,000,000-both original public domain and submarginal land recently purchased. ${ }^{9}$

\section{FEDERAL RELIEF}

The depression emphasized North Dakota's dependence on outside resources in a new way. Significant as Langer's wheat embargo, debt moratorium, and budget cuts undoubtedly were, a flood of money sent in by the federal government from the rest of the nation did the chief work in relieving the suffering of the terrible 1930's.

\footnotetext{
${ }^{8}$ William W. Phillips, “The North Dakota Moratorium” (Seminar paper, Department of History, University of North Dakota, 1951), pp. 12-47.

${ }^{9}$ Taylor and Penn, Management of Public Land in North Dakota, pp. 8, 11; William E. Koenker, "Banking Trends in North Dakota, 1922-1947" (Unpublished Ph.D. dissertation, Ohio State University, 1949). pp. 25-55.
} 
By the end of 1932 the counties and private charity could no longer carry the relief burden. In January, 1933, Governor Langer appointed a state emergency relief committee with Supreme Court Judge A. M. Christianson as chairman. The 1933 legislature appropriated no money for relief, but Christianson's committee, working feverishly in the crisis, borrowed \$492,000 from the Reconstruction Finance Corporation and organized county relief committees to distribute the funds. On June 1, 1933, the committee began to receive its money from the Federal Emergency Relief Administration (F.E.R.A.), headed by Harry L. Hopkins.

Relief soon became the biggest business in the state. The committee furnished groceries on relief orders, started a state-wide garden program, gave medical aid, and set relief clients to mining their own lignite on school lands. A large part of early relief was stock feed, in return for which farmers built roads. After the Civil Works Administration (C.W.A.), supervised by the Christianson committee in North Dakota, began an employment program on November 15, 1933, most of the needy performed useful work for wages. The C.W.A. built and repaired roads, constructed skating rinks, swimming pools, and tennis courts, bound and catalogued library books, rendered nursing service, and served school lunches. At the peak of its program it employed about thirty-seven thousand persons in North Dakota.

When the C.W.A. was discontinued on March 15, 1934, its work projects were taken over by the F.E.R.A., which employed about 21,000 workers at a minimum wage of thirty cents an hour and had a weekly payroll of some $\$ 250,000$. In April, 148,000 persons, or more than a fifth of North Dakota's population, were receiving relief. By the time the F.E.R.A. was discontinued on December 15, 1935, it had built 114 dams, 34 wells, 60 bridges, 2,300 miles of streets and highways, 986 sanitary privies, 70 public buildings, 14 swimming pools, 11 playgrounds, 88 tennis courts, 32 golf courses, 108 skating rinks, 40 baseball diamonds, 36 airports, and 23 parks.

Many F.E.R.A. projects did not deal with construction. The F.E.R.A. hired teachers (1,985 in 1934) to keep schools open; it gave part-time employment to needy college students; it ran camps for transients; it trained social workers; it mixed grasshopper bait; it organized recreational programs; it sponsored the arts and historical research. By December 15, 1935, it had enrolled some 12,000 North Dakota boys in 28 companies of the Civilian Conservation Corps. They planted trees, made parks, and earned \$30 a month, \$25 of which was sent home to their families.

Such activities maintained the morale and the economy of a stricken people. From February, 1933, to the end of December, 1935, relief in North Dakota cost over $\$ 36,000,000$. The federal government furnished more than $\$ 32,000,000$, the counties $\$ 3,500,000$, and the state only $\$ 139,000$ (all of it in December, 1935). In March, 1935, after the terrible drought of 1934, some 37 percent of the state's people were on relief, 
ranging from 72 percent in Divide County in the parched northwestern corner to none in Traill in the Red River Valley, which received its first federal help in November, 1935.

On March 1, 1934, by long-distance telephone, Harry Hopkins took control of federal relief in North Dakota away from the state emergency relief committee. Early in 1935 the legislature created the Public Welfare Board and passed a sales tax to provide money for its work. The relief program was then reorganized. In December a new division of responsibilities went into effect. The Public Welfare Board, using state and federal money, would care for the aged, mothers and dependent children, the unemployable needy, and needy employables not on work relief. The federal government would care for the others through new agencies. The Resettlement Administration (later renamed the Farm Security Administration) would care for rural relief cases. The new Works Progress Administration (W.P.A.) would give work relief to a specified number of "employables other than farmers." 10

Relief activities expanded after the drought of 1936. By October nearly 61,000 persons were employed on W.P.A. projects, emergency conservation work, and the projects of other agencies. The peak relief expenditure was nearly $\$ 18,000,000$ in the last half of 1936 . Late that year, about 330,000 persons (half the population) were on relief. Expenditures continued to be large. In May, 1938, for example, over 13,000 people were working on W.P.A. projects, nearly 4,000 were with the Civilian Conservation Corps, and more than 25,000 farm families were receiving grants from the Farm Security Administration. That year, nearly $\$ 23,000,000$, largely federal funds, was spent on relief programs in North Dakota. In 1939 the legislature appropriated nearly \$6,000,000 for relief and welfare. In January of that year, over 242,000 persons (about 37 percent of the population) were receiving assistance from a state or federal agency. About half of them were members of the nearly 31,000 farm families on relief.

In North Dakota the W.P.A. alone, between July 1, 1935, and June 30, 1942, built 20,373 miles of highways and streets, 721 new bridges and viaducts, 166 miles of sidewalks, 15,012 culverts, 503 new public buildings, 61 additions to public buildings, 680 outdoor recreational facilities (stadia, grandstands, fairgrounds, parks, playgrounds, athletic fields, swimming pools, and golf courses), 809 water wells, 2 irrigation projects, 39 sewage treatment plants, and 9 water treatment plants. It reconstructed 1,002 bridges and viaducts, 2,180 public buildings, and 1,721 culverts. It repaired 646,206 books, served 3,653,392 school lunches, and sewed 2,078,451 garments.

The W.P.A. also distributed surplus commodities, conducted literacy classes, and operated salvage programs. Directed by brilliant young Ethel

\footnotetext{
${ }^{10}$ Federal Emergency Relief Administration for North Dakota, Relief in Review in North Dakota (Bismarck, 1936), pp. 15-124.
} 
Schlasinger, it wrote one of the best books on the state ever produced: Federal Writers' Project, North Dakota: A Guide to the Northern Prairie State (1938). Aided by the National Park Service and a series of Civilian Conservation Corps camps and other work projects, the North Dakota State Historical Society developed sixteen newly acquired park areas (4,511 acres) and enlarged five older parks. The work on the North and South Roosevelt, Fort Abraham Lincoln, Lake Metigoshe, Turtle River, and Peace Garden parks and on the De Mores, Fort Abercrombie, Fort Rice, and White Stone Hill historic sites was especially important. ${ }^{11}$

In all, including both relief programs and payments made to farmers under farm programs $(\$ 142,000,000$ from 1934 through 1940), the federal government spent about \$266,000,000 in North Dakota from 1933 through 1940. This massive outpouring of federal funds by the Democratic administration in Washington was of the utmost importance to the state, contributing much to its survival and wellbeing. But such federal assistance did not make North Dakota a Democratic state, nor did it win more than temporary support for President Roosevelt's New Deal among a people long attached to liberal and progressive programs. Basically, North Dakotans were not very happy about their dependent position. This situation had obtained ever since the Indians of the region had first shown resentment at their dependence on the traders.

\section{THE BATTLE AGAINST LANGER}

North Dakota politics in the 1930's was largely the story of determined attacks upon William Langer and his triumph over his adversaries. They were first made on Langer's political tactics. Soon after taking office as governor, he cleaned out the executive departments and appointed persons loyal to himself. He started a party newspaper, the Leader, and openly solicited his appointees to buy subscriptions equal to 5 percent of their annual salaries, a political tithe for the faithful. Langer defended this as an honest campaign-fund solicitation: the job-holders could recoup by reselling the subscriptions, and those who refused to subscribe were not fired. Young Harold McDonald solicited subscriptions for the Leader, not only in state offices, but also in the relief office, where the clerks were paid from federal funds. State employees pledged \$58,282 and relief employees only $\$ 469 .{ }^{12}$

${ }^{11}$ North Dakota Public Welfare Board, Report, 1940-1942, pp. 7, 96-101; “Special Report to Moses,” pp. 5, 14; Works Progress Administration, $\underline{\text { Report }}$ on Progress of the Works Program, December 15, 1936, pp. 55, 67-68, June 30, 1938, p. 114; Russell Reid, "Report of the North Dakota State Park Committee... December 31, 1940,” North Dakota Historical Quarterly, VIII (January 1941), 138-141.

${ }^{12}$ United States Senate Committee on Privileges and Elections, Senator from North Dakota, Report... on the Protest of Various Citizens... to the Seating of William Langer, Senate Report No. 1010, 77 Cong., 2d Sess., p. 26 (cited hereafter as Langer Investigation). 
For such solicitation the Roosevelt Administration, cheered on by conservatives in the state, set out with considerable hypocrisy (it was then said to be levying assessments on postmasters in North Dakota) to destroy Langer. On March 1, 1934, Harry Hopkins removed the administration of relief from the state committee appointed by Langer. That spring, a federal grand jury indicted Langer and eight associates on charges of soliciting and collecting money for political purposes from federal employees and of conspiring, to obstruct the orderly operation of an act of Congress. After a long trial (May 22-June 17) at Bismarck before Judge Andrew A. Miller, an old enemy, Langer and his co-defendants were found guilty. Judge Miller, saying that he was "delighted and pleased" at the verdict, sentenced Langer to serve eighteen months in a federal penitentiary and to pay a $\$ 10,000$ fine. The Postmaster General took away the Leader's second-class mailing privileges.

In spite of his conviction and a split in the Nonpartisan League, Langer and the Langer League candidates (including Lynn J. Frazier, William Lemke, and Usher L. Burdick) easily defeated the slates of both the antiLanger Leaguers (headed by T. H. H. Thoresen) and the Independents for the Republican nominations in the primary. Langer campaigned vigorously after his conviction. Many people considered him a martyr being legally tarred and feathered. At rallies they would stand reverently when he entered and then cheer mightily. Speakers would mention the crucifixion of Christ and the assassination of Abraham Lincoln.

Langer was eventually cleared after a long legal battle. On May 7, 1935, nearly a year after the first trial, a federal circuit court of appeals reversed the original conviction. After a new conspiracy trial, November 1-15, the jury disagreed. After a perjury trial, December 3-6, Langer was found not guilty. After a third conspiracy trial, December 10-19, he was finally found innocent of the original charges.

Long before his vindication, the state supreme court had removed Langer from office. On July 17, 1934, it had ruled that because he had been convicted of a felony, the duties of governor had devolved upon the lieutenant governor, Ole $\mathrm{H}$. Olson. Although crowds in the Bismarck streets shouted "We want Langer," Olson moved into the governor's office on July 19. After Langer's disqualification, the Republican state central committee chose his wife, Lydia, to take his place as Republican candidate for governor. During the campaign, old Leaguers, such as Gerald P. Nye, James H. Sinclair, and Olson, spoke for Democratic candidate Thomas H. Moodie, and he defeated Mrs. Langer. The other state offices, however, went to Langer supporters.

The election was scarcely over when Langer discovered that Moodie had voted in Minneapolis in 1930. The state constitution requires that the governor shall have resided in the state for the five years next preceding the election. Moodie had lived in North Dakota since 1898, but he had been an editorial writer on the Minneapolis Tribune from August, 1929, when he sold his newspaper in Mohall, to April, 1931, when he bought a 
paper at Williston. On February 2, 1935, the state supreme court disqualified Moodie, and Lieutenant Governor Walter Welford became governor. North Dakota had had four governors in seven months.

Langer came back in 1936. When the Nonpartisan League convention endorsed Langer for governor, some delegates withdrew and endorsed Welford. In the June primary, Welford, supported by the conservatives, won the Republican nomination by a margin of only 695 votes. John Moses won the Democratic nomination for governor. When Langer filed as an Independent candidate in the fall election, it became a tight threecornered race. Lemke, running for President of the United States as the candidate of the Union party as well as for re-election to the House, did not oppose Langer. Senators Frazier and Nye supported Welford, but Representative Burdick worked for Langer.

Moses, born in Norway, was a good vote getter. He campaigned tirelessly, speaking three or four times a day in English, Norwegian, and German. He appealed both to the immigrants and to the conservative Republicans, who had little use for Langer. Yet Langer's opponents could not unite on one candidate, and Langer was elected governor in November with only 36 percent of the votes. That year, President Roosevelt carried every county in North Dakota, getting 163,000 votes to less than 73,000 for Alfred M. Landon, the Republican candidate. Lemke, though reelected to the House of Representatives, had only 13 percent of the state's vote for President $(36,708)$ and only 891,886 votes in the nation.

In his second term, Langer was again the champion of the common man and the wheat farmer. Pointing out that many were "desperately hard up and... suffering for the lack of the necessities of life," he asked the legislature to appropriate nearly six million dollars for general relief, pensions for the aged, and child welfare-a sum equal to all appropriations for the 1933-1935 biennium. He coerced the legislature into passing an income tax to balance its renewal of the 1935 sales tax. When on the night of July 23, 1937, the grain trade reduced the price of lightweight 37-pound wheat from 89 cents per bushel to 37, Langer had the State Mill and Elevator offer 35 cents a bushel over the market price. The grain trade met the advanced price. Langer estimated that his bold maneuver had saved the farmers twelve million dollars. In 1938, with durum at 48 cents a bushel, Langer had the State Mill and Elevator offer 65 cents. Overnight the millers paid the higher price. ${ }^{13}$ Such daring and imaginative acts won Langer the loyalty of thousands.

Other acts, however, won him the hostility and distrust of many. In 1937 and 1938, V. W. Brewer, a bond broker from Minneapolis, and Gregory Brunk, a lawyer from Des Moines, made profits of \$297,236 by buying the bonds of North Dakota counties at a discount and selling them to the Bank of North Dakota at par. Brewer, Brunk, and Frank A. Vogel, 
manager of the bank, were all friends of Langer. Although the hank could legally have bought the bonds directly from the counties, it apparently refused to do so. While making the bond transactions, Brunk bought land said to be worth only $\$ 5,718$ from Langer, paying him $\$ 56,800$. Brunk never saw the land. The Great Northern Railroad was then fighting in the federal courts against taxes levied on its property in 1935 and 1936 by the state board of equalization, of which Governor Welford was chairman. In 1937 the board, with Langer as chairman, raised the assessment of the Great Northern's property by $\$ 700,000$ but reduced it in 1938 by $\$ 3,000,000$. The Great Northern employed Thomas Sullivan of Chicago as a special attorney at $\$ 20,000$ a year. Sullivan bought from Langer worthless stock in William Lemke's defunct Mexican Land Finance Company, paying $\$ 25,000$. Sullivan never asked for delivery of the stock. ${ }^{14}$ These matters were first clearly disclosed by the testimony of the participants before the Senate Committee on Privileges and Elections in 1941.

Rumors of them entered into the 1938 campaign. That spring, the League convention endorsed Langer for Nye's seat in the Senate; it also endorsed Burdick and Lemke for re-election to the House. Lemke had as yet taken no part in the opposition to Langer, but in 1938 he broke with him and supported Nye. In the Republican primary, Nye defeated Langer by 5,151 votes, but Lemke and Burdick and the rest of the League slate, many of them Langer men, won Republican nominations.

Langer filed as an Independent candidate for the Senate in the fall election. Langer sponsored an initiated measure to raise old-age pensions from thirty dollars a month to forty. To help Nye, Lemke and Nye agreed to support John Moses, the Democratic nominee for governor; in return, Moses was to have Jess J. Nygaard, the Democratic nominee for the Senate, fail to campaign. Nye was a national figure, but he was able to defeat Langer largely because the anti-Langer vote was not divided. Nygaard received only 19,244 votes; if he had campaigned, Langer, with 112,007 votes to 131,907 for Nye, would probably have gone to the Senate in 1938. Thus a coalition of conservative Republicans, Democrats, and Lemke-Frazier-Nye Leaguers were able to make Moses governor and to send Nye back to the Senate.

\section{JOHN MOSES AS GOVERNOR}

The new governor was to compile a notable record. A six-foot-four giant, John Moses had come to the United States from Norway in 1905 at the age of twenty. After various jobs, he enrolled at the University of North Dakota, graduating from the arts college in 1914 and from the law school in 1915. After 1917 he practiced law in Hazen, farmed on the side, married, and raised a family of four. He was elected state's attorney of Mercer County five times and in 1934 was nominated by the Democrats

${ }^{14}$ Langer Investigation, pp. 63-68, 72-75. 
for attorney general.

Moses' first term as governor was largely an attack upon Langer. One issue was old-age pensions. Langer's initiated measure to raise pensions had passed overwhelmingly in November, carrying every county, but the 1939 legislature, backed by Moses, refused to appropriate money for the larger pensions. The League-controlled house passed a gross-transactions tax, but the anti-League senate defeated it. Langer then initiated three measures to finance the higher pensions: a gross-transactions tax, a prohibition of highway construction with diversion of highway funds to pensions, and the establishment of municipal liquor stores, whose profits would go for pensions. Langer campaigned tirelessly for his measures, but in the special election on July 11, 1939, they were defeated by more than four to one. Governor Moses, business and civic leaders, the North Dakota Taxpayers Association, and many members of the Nonpartisan League fought Langer's proposals.

Their defeat revealed Langer's declining influence. Moses had already moved to expose Langer's administration as governor. In January, 1939, he had appointed Clyde Duffy to investigate the State Hospital for the Insane and the Motor Vehicle Registration Department. Duffy reported irregularities in the department and the political assessment of employees at the hospital. Moses appointed Robert M. Stangler manager of the State Mill and Elevator, and the mill began to make a profit. In December, 1938, under Langer's manager, the mill had manufactured 22,142 barrels of flour with 267 employees; in December, 1939, under Stangler, it manufactured 42,087 barrels with 179 employees.

On July 29, 1937, the Langer-appointed Board of Administration had dismissed seven staff members, some with thirty-three years of service, from the Agriculture College. The college was promptly dropped from the North Central Association's accredited list. An initiated measure approved in June, 1938, created the Board of Higher Education to replace the Board of Administration as the governing body for the state's institutions of higher education. Before the new board took over on July 1, 1939, Moses had secured the reinstatement of the dismissed men and the restoration of the college to the accredited list. He said: "We have come to an end of forced contributions and 'political racketeering."”15

Moses was also able to cut government expenditures. In January, 1939, many counties were bankrupt; 37 percent of the population was still on relief; three-fourths of the farm loans were delinquent; a third of the school districts were dependent on state aid. The state government was facing a deficit of two and one-half million dollars. Governor Moses ordered officials whom he had appointed to reduce expenditures by 18 percent and asked the elective heads of departments to cooperate in the economy plan. Public opinion supported him, and most department heads

${ }^{15}$ Adam J. Schweitzer, "John Moses and the New Deal in North Dakota” (Unpublished M.A. thesis, University of North Dakota, 1954), pp. 100-121. 
complied with his request

The economy move made Moses popular and helped to secure his reelection in 1940. He defeated Jack Patterson, lieutenant governor and League candidate, who had secured the Republican nomination. Roosevelt was running for a third term as President, but Moses, anxious not to offend his conservative Republican supporters, ignored the national campaign. Many newspapers supported Moses the Democrat for governor and Wendell Willkie the Republican for President. Moses won by a large majority: 173,000 votes to 101,000 for Patterson.

President Roosevelt, however, failed to carry North Dakota in 1940. Isolationist feelings aroused by the war crisis turned many voters against him; no important leader in the state urged his re-election. Senator Nye, who had supported Roosevelt in 1936, told North Dakotans to vote for Willkie and stay out of war. Willkie received nearly 155,000 votes to 124,000 for Roosevelt. Willkie ran best in the counties with a large German Russian population; Roosevelt ran best in strong Farmers' Union counties. ${ }^{16}$

In 1940, Langer sought Frazier's seat in the Senate. The loose anti-Langer coalition fell apart. Conservative Republicans turned against Lemke and Frazier, who had helped them defeat Langer in 1938. The conservatives believed that Langer was through in politics; they disliked Lemke's and Frazier's hostility to banks and insurance companies and also their isolationism. So the Republican convention refused to endorse Frazier; it withdrew its endorsement of Lemke, running for re-election to the House, when he supported Usher L. Burdick, endorsed by the League for the House. The Republican convention endorsed Thomas E. Whelan for Frazier's seat. Whelan was a prominent member of the American Legion and no isolationist; his potato partnership at St. Thomas labeled each sack: "To Hell with Hitler."

The Nonpartisan League convention endorsed Langer for the Senate. In the primary he defeated Frazier and Whelan, winning the Republican nomination with only 40 percent of the vote. Burdick and Lemke won the Republican nominations for the House.

After the primary, many conservatives urged Lemke to run against Langer in the fall. So Lemke, giving up his nomination for the House, filed as an Independent candidate for the Senate. Ambitious to be a senator, he thought that Moses could have Charles Vogel, the Democratic candidate for the Senate, hold back from campaigning as Jess J. Nygaard had done in 1938. But Vogel, an able Fargo attorney and Democratic national committeeman from North Dakota, campaigned vigorously. He believed in President Roosevelt's domestic and foreign policies; he thought that Moses, by aiding Lemke, was weakening Roosevelt's

\footnotetext{
${ }^{16}$ Map on Farmers’ Union strength in Harold V. Knight, Grass Roots: The
} Story of the North Dakota Farmers' Union (Jamestown: North Dakota Farmers' Union, 1947), p. 70. 
chances in North Dakota in order to secure his own re-election. Moses helped Lemke, however, while Lemke was attacking Roosevelt bitterly. In November, Langer was elected with 38 percent of the votes. He had 100,847 to 92,593 for Lemke and 69,847 for Vogel.

Langer's enemies made a determined effort to prevent the Senate from seating him. In 1941 the Senate Committee on Privileges and Elections listened to much damaging testimony. Langer himself admitted having paid some $\$ 525$ to Gale B. Wyman, son of the federal judge who presided at his second and third trials in 1935. Although the committee decided that Langer was not entitled to be the senator from North Dakota, the Senate voted 52 to 30 to seat him. The political warfare of the 1930's had ended with Langer's triumph.

\section{MOVING TOWARD ADJUSTMENT}

Yet the political struggle, revolving about one man, was essentially a side show. It was unrelated to solving the people's problems of adjustment to the demands of a semiarid spring-wheat country. North Dakota's settlers came mostly from more humid regions. In the wet years before the First World War, they plowed up much land better left for grazing and planted wheat, creating an economy with a narrow reserve. The misuse of the land lowered its productivity: the scant water supply was wasted, the range overgrazed, the light, dry soil exposed to the wind. Even after the price collapse that followed the First World War, the settlers still planted large acreages to wheat in a desperate endeavor to stay on the land and pay their debts and taxes. The quality of living went down; tenancy increased; the population became unstable; improvement was neglected. In the 1930's drought and depression merely accentuated trends long in the making.

The people needed to adjust their ways of life to the Great Plains environment, to learn to live on the land on its own terms, as the Indians had done centuries before. On September 30, 1936, President Roosevelt appointed the Great Plains Committee to report on a long-term program for "the efficient utilization of the resources of the Great Plains." Roosevelt himself wrote: "Perhaps in this area of relatively little rain, practices brought from the more humid portion of the country are not most suitable under the prevailing natural conditions."

In its report, The Future of the Great Plains (1936), the committee recommended many things - a summing up of current thinking — as part of an "intelligent adjustment to the ways of Nature." The federal and state governments, as well as communities and individuals, the committee insisted, must all respond to imperatives really dictated by the Great Plains themselves. These were, the committee said, the commands of the Plains. Conserve water-in the soil itself, in stock-watering facilities, and in small irrigation projects. Enlarge farms and ranches so that they are large enough to support families. Prevent the unwise expansion of cultivated areas in times of high rainfall and high prices. Let the 
government hold the range land and set up cooperative grazing associations to prevent overgrazing. Make possible the use of large ranges for grazing in connection with dry farming and irrigation. Give tenants a stake in conservation and improvements by means of long-term standard leases. Help people stay on the land by taxing its income, thus cutting down tax delinquency. Consolidate local governments and change the pattern of settlement to reduce the cost of schools, roads, and other public services. Prevent the inflation of land values. Form soil-conservation districts and plant windbreaks to control erosion. Stop single-cash-crop agriculture. ${ }^{17}$

North Dakota moved very slowly to obey these imperatives. Institutional inertia, the natural attraction of inflationary schemes for those burdened with debt, the struggle for power between Langer and his opponents, and the attitude of the state's most popular leaders-all held back progress in adjustment. Langer himself, sometimes contemptuous of ideas (he hated the Roosevelt brain trusters who had tried to take his scalp) and preoccupied with maneuvers for his own personal power, tended to look upon life as struggle between the wicked exploiting interests and the virtuous common people.

Such an outlook, of course, had long been the prevailing one in the state. Actually, in a society like North Dakota's, where all worked hard and where the differences in wealth were not too great, all prospered or all suffered together. More important, this class-conflict philosophy sometimes seemed to blind its believers to the adjustments which the state needed to make to the semiarid Great Plains environment.

No important or influential leaders of the state worked nearly so hard to implement long-run adjustments, such as those recommended by the President's Great Plains Committee, as they did for less-significant shortrun objectives. In Congress, for example, hard-working William Lemke put all his energy behind his bankruptcy and refinance proposals. He believed that his simple idea-reducing the burden of farm debts and inflating the money supply-would largely solve the problems of the farmers. After a quite heroic struggle, Lemke persuaded Congress to pass the bankruptcy proposal as the Frazier-Lemke Bankruptcy Act in June, 1934. Throughout the 1930's the North Dakota Legislature regularly passed resolutions in favor of the refinance proposal, the inflationary Townsend old-age-pension plan, and the cost-of-production scheme, by which the federal government would guarantee the farmers their cost of production without any controls. In 1935 it asked Congress to give the Bank of North Dakota authority to issue money backed by the securities of the state.

Along with this support for inflation, however, the legislature did provide some means for the adjustment of the state's economy. In 1935 it 
created a state planning board (abolished in 1939) to help the people "realize the greatest possible benefit from the land, water, mineral, recreational and economic resources of the state." The board-ten persons, including the state geologist, the dean of the Agricultural College, the head of the School of Forestry, the director of mining engineering at the university, and six others appointed by the governor was especially charged with making investigations and recommendations on land utilization. In the scramble for a living, too much land had been placed under cultivation and too many cattle had been put on the range. Also in 1935 the legislature passed the Cooperative Grazing Associations Act to conserve forage resources. Under its terms, ranchers could form associations to lease government-owned land and control grazing thereon.

A more comprehensive step was taken in 1937. In order to take advantage of the Federal Soil Conservation and Domestic Allotment Act, the legislature passed the Agricultural Conservation and Adjustment Act to protect the land and to cooperate with federal agencies in conserving it. Under the law, the Agricultural College Extension Service was to make an "agricultural plan" for the state each year; farmers would make adjustments in their use of the land and production for the market in return for money payments. By the Soil Conservation Districts Law, passed in 1937, farmers could form soil-conservation districts, which became governmental subdivisions of the state. The districts, by a two-thirds vote, could adopt land-use regulations, including the construction of dams and terraces, the adoption of contour furrowing and strip cropping, the planting of trees and grasses, and even the removal from cultivation of areas where erosion could not be controlled. Land-use regulations were enforceable in the courts.

The drought years made North Dakotans even more conscious of their water problem. In 1933 and again in 1935 the legislature revised the state's irrigation laws and in 1935 passed the Water Conservation Districts Law, by which a water-conservation district could build dams and reservoirs and make regulations for the use of water. A law passed by the 1937 legislature created the State Water Conservation Commission, giving it broad powers to develop the state's water resources. Many towns had to secure water by means of railroad shipment; in some towns the people had been purchasing drinking water from "water peddlers" for years. ${ }^{18}$

In the 1930's it was widely believed that many counties had too small a population to justify a county government with a courthouse, county commissioners, and seven elected officials. By 1940 there were eleven counties with populations under 6,000; Billings County, the smallest, had only 2,531 people. The consolidation of some of the smaller counties seemed like a sensible way of reducing the cost of government. In the

${ }^{18}$ North Dakota State Planning Board, Trade Centers in North Dakota (Bismarck, 1939), p. 83. 
1930's the legislature passed a series of laws and constitutional amendments providing methods by which counties could consolidate and by which the number of county officials could be reduced by combining the duties of the county judge, the clerk of the district court, and the registrar of deeds, or by adopting an optional county-manager plan of government. No county was consolidated with a neighbor; none adopted a county-manager government.

Although adjustment to the harsh realities of North Dakota life came but slowly, some progress had been made. Federal payments to farmers for soil conservation and laws dealing with grazing and soil and water conservation were important steps. For the first time, North Dakota was planning a more intelligent use of its resources, a natural consequence of the principle that the government was responsible for the economy. The acts of the 1930's held promise for the future. 


\section{CHAPTER 19}

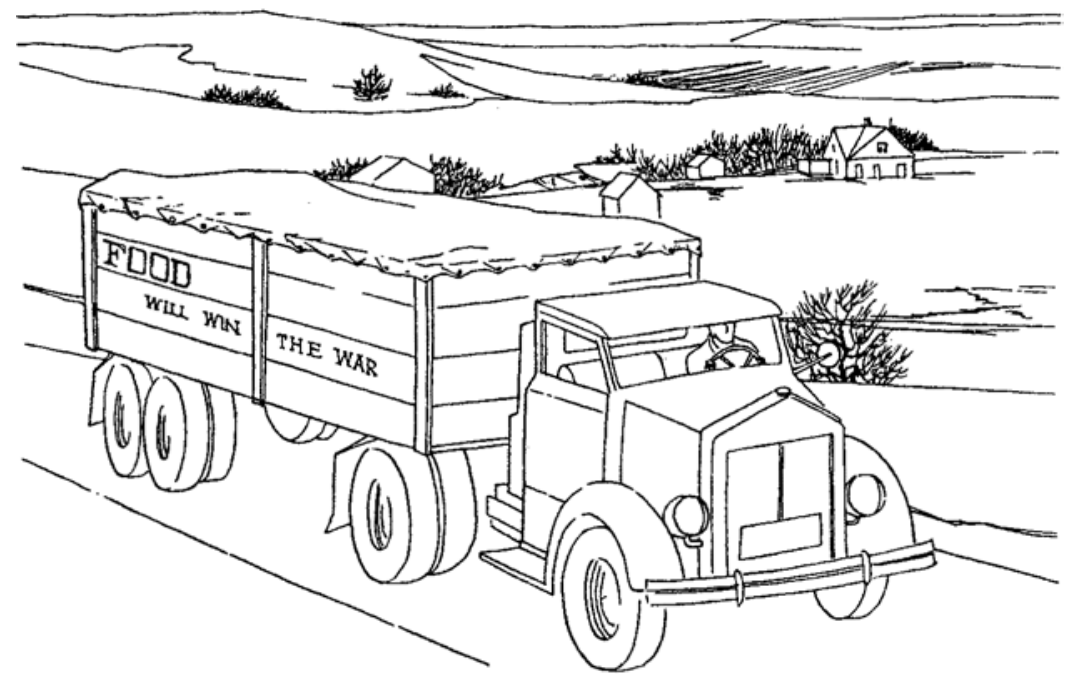

\section{Impact of the Second World War}

THROUGHOUT MUCH OF THE 1930's the United States lived under the shadow of approaching war. In this time of great anxiety, North Dakota influenced national policy through Gerald P. Nye, its junior senator. The state held most of the same isolationist views it had held during the years before America's entry into the First World War. Senator Nye played a leading part in making North Dakota isolationism the policy of the nation; he became a national and even world figure.

After war began in Europe in the fall of 1939, North Dakota gave no support to the policy of aid to Britain. But when the United States entered the war after Pearl Harbor, North Dakotans did their part. They bought $\$ 397,000,000$ worth of government bonds, an extraordinary record, and some sixty thousand North Dakotans served in the armed forces.

The war brought many changes to North Dakota, just as it did to the nation and to the world. With plenty of rain and with good prices for farm produce, the state enjoyed greater prosperity than it had ever known. Sober in good fortune, the farmers paid off their debts, bought land at low prices, and put aside savings for future hard times. The state government reduced its debt and built up reserves.

In prosperity the people became more conservative. The Republican Organizing Committee gave conservatives some success over the Nonpartisan League. Participation in the war weakened isolationist sentiment, and Nye, the best-known North Dakotan in the nation, failed in his bid for re-election to the Senate in 1944. North Dakota seemed to be 
repudiating isolationism.

While these changes were marking the war years, continuity with the past remained strong. The conflict between conservative and liberal dragged on as the Greater North Dakota Association and the North Dakota Farmers' Union fought over the Anticorporation Farming Law and the graduated land tax. Governor John Moses' drive to reform the state government failed. The exodus of population to other states proceeded. Wheat farming continued to dominate the economy when wartime efforts to bring industry to North Dakota ended in almost complete failure.

\section{NYE AND ISOLATIONISM}

In 1934 the United States Senate created a committee to investigate the manufacture and sale of arms and ammunition. Gerald P. Nye, the leading Republican isolationist, became its chairman. Seizing his opportunity boldly, Nye set about to prove the isolationist thesis concerning American entry into the First World War. For two years he tirelessly probed the activities and attitudes of leading bankers and munitions makers. Nye proved to the satisfaction of most Americans that the First World War was the result of the mad imperial ambitions of the European belligerents and that America had been sucked into it by insidious propaganda and the evil machinations of munitions makers. ${ }^{1}$ The committee supplied evidence to support the arguments of such isolationist historians as Harry Elmer Barnes and Charles A. Beard and such exposés as Helmuth C. Engelbrecht's and Frank C. Hanighen's Merchants of Death.

Thus Nye helped to fix the isolationist beliefs, really the North Dakota doctrine of pre-April 6, 1917, in the popular thought of the people. Distance and its own strength, the isolationist faith held, made the United States immune to the effects of any European war; no European victor could threaten America's security. Neutrality in such conflicts was therefore preferable to war. American security had not been at stake in the First World War; it was inconceivable that it would be in any future conflict. So effectively did Nye and his associates work that by April, 1937, some 70 percent of the American people believed that entry into the First World War had been an error.

As a result of the Nye committee's work, Congress passed a series of neutrality laws from 1935 to 1937 which provided for an arms embargo, a prohibition of loans or credits to belligerents or trade with them in

\footnotetext{
${ }^{1}$ William L. Langer and S. Everett Gleason, The Challenge to Isolationism, 1937-1940 (New York: Harper for Council on Foreign Relations, 1952), p. 14; Donald F. Drummond, The Passing of American Neutrality, 1937-1941 (Ann Arbor: University of Michigan Press, 1955), pp. 40-48.
} 
American ships, and a prohibition of travel by Americans on the ships of warring nations. This growing list of restrictions was mandatory in case of war; the law allowed no discrimination between belligerents, between the aggressors and their victims. President Franklin D. Roosevelt rightly complained that the neutrality laws interfered with his conduct of foreign relations. What the country editors of North Dakota had written in their weeklies from 1914 to 1917 was the law of the land from 1937 to 1939.

The real test came when the Second World War broke out in September, 1939. When Roosevelt asked Congress to repeal the arms embargo portion of the neutrality law, Senator Nye was a "dynamo" of opposition. "We deny," he told the Senate, "that the British Navy and the French Army are America's first line of defense.... We deny that the United States can make the world safe from Hitlerism by becoming the silent partner of the British Empire.” There was, however, some support for repeal in North Dakota, but when Congress repealed the arms embargo on November 3, the whole North Dakota delegation-Nye, Lynn J. Frazier, William Lemke, and Usher L. Burdick—voted nay.

In April, 1940, Scandinavian North Dakota's isolationist faith was shocked by the German invasion of Norway, soon followed by that of the Low Countries and France. Anxiety for relatives in Norway mingled with hatred for the invaders. Indignantly, many North Dakotans began to raise money for Norwegian relief. Inkster had a benefit dance. Norway-born Governor John Moses appointed Henry Holt, a Grand Forks printer, as state chairman for the Norwegian relief drive. Holt planned a drive to begin May 17, Norwegian Independence Day. Large quantities of clothing were collected, and eventually the people of North Dakota also contributed $\$ 46,025$ in cash.

Though shaken by the invasion of Norway and Denmark and plainly sympathetic with the French, Dutch, and Belgian victims of Hitler's aggression, North Dakotans still wanted to stay out of the war. On May 24, 1940, the Grand Forks Herald advocated the granting of private credits to Britain and France as the best means of keeping out of war. A Bismarck Tribune poll, however, showed that war veterans and others opposed loans or any direct or indirect participation. At the end of May, students at the Agricultural College were organizing a keep-out-of-war movement. That summer, the North Dakota Farmers' Union opposed conscription. Before the June primary, no candidate, not even the Democrat Moses, supported the President's policy of helping Britain and France. Speaking as Paris surrendered, Frazier and Lemke warned the people not to be swept off their feet by war fever. Frazier scoffed at "war 
propaganda": "There is no immediate danger of any nation attacking us." ${ }^{2}$

Thomas E. Whelan, seeking the Republican nomination for Frazier's Senate seat, attacked Frazier's long antimilitary record, itemizing Frazier's many votes against defense appropriations and concluding that he had "sold America short." William Langer, also seeking the Republican nomination for Frazier's post, argued that Frazier opposed "any army or navy whatsoever." Langer's own position was that the United States must defend the Western Hemisphere. Moreover, Langer, who had been vigorously antiwar in the 1930 's, wanted conscription of wealth as well as of men-no war-created millionaires.

During the summer of 1940, Nye opposed the conscription bill and the trade by which the Roosevelt Administration sent fifty over-age destroyers to the hard-pressed British for a number of bases on British soil in the Western Hemisphere. The trade, Nye declared, was "a belligerent act making us a party to the war." Speaking in Iowa, he advised people to vote for Wendell Willkie for "leadership that will keep us out of war." Lemke denied that the security of the nation was at stake: "There is no nation or combination of nations that are a threat to the United States." "Hitler will not get us," he wrote to a friend. Roosevelt's policy of aid to the Allies probably lost North Dakota for him in 1940; he had carried every county four years before.

After the election, Nye became one of the principal speakers for the America First Committee. He fought the Lend-Lease Act bitterly, saying that Roosevelt was "planning for war" and that soon the United States would be "lending and leasing American sons to the British purpose in Europe.” On February 8, 1941, Burdick and Charles R. Robertson, North Dakota's members in the House, voted against it. In April the Grand Forks Herald denied that Nye represented the thinking of North Dakotans. They believed, the Herald thought, that "Hitler must be stopped" and were ready to spend billions arming his enemies, but the North Dakota legislative assembly passed a concurrent resolution rather ambiguously endorsing opposition to Lend-Lease. Time magazine called Nye "the U.S. Senate's most rabid isolationist.” In 1941, Lemke, then out of Congress, joined in the work of the America First Committee and made a lecture tour in the Middle West.

When the Japanese attack on Pearl Harbor came on December 7, Nye said: "Just what the British had planned for us.... We have been maneuvered into this by the President." The next day, however, Nye and all of the North Dakota delegation voted for the declaration of war. 


\section{A WAR PROSPERITY}

North Dakota, having suffered more than the rest of the nation in the depression, now prospered more exuberantly. From 1940 to 1945, total personal income rose 145 percent in North Dakota, only 109 percent in the nation. Per capita personal income rose from \$350 in 1940 (59 percent of the national average) to $\$ 1,009$ in 1945 (82 percent of the national average).

Everything seemed to work for the benefit of the state. Rainfall was ample, market demand strong, crop prices high, and land values low. Every year from 1940 to 1944 had above-average precipitation, and 1941 was the wettest on record. From 1940 to 1945, wheat prices went from $67 \$$ a bushel to $\$ 1.53$, beef cattle from $\$ 6.80$ per hundredweight to $\$ 10.10$.

The 1941 crop was the first big one: $140,000,000$ bushels of wheat (the largest yield since 1928) and \$233,000,000 cash farm income (the highest since 1927). North Dakota farmers were starting on the greatest run of crops and income they had yet experienced. From 1933 to 1940, North Dakota had not grown a 100,000,000-bushel wheat crop; the crops of the war years were the largest the state ever produced-generally over 150,000,000 bushels.

Farm production increased even though thousands left the state to work in defense industries or to serve in the armed forces. The state lost people more rapidly than ever before; by 1945 the population was down to an estimated 521,000, compared with 642,000 in 1940. When the expected gain by natural increase is included, about 165,000 persons had left the state in five years. The farm population declined from 325,000 in 1940 to an estimated 285,000 in 1945, or a loss of about 18,000 farm workers. To make up the loss, farmers worked longer hours and bought more tractors; school children, college students, and townspeople worked in the harvest fields.

In spite of prosperity, many farmers gave up farming. The number of farms declined from some 74,000 in 1940 to about 69,500 in 1945, and the average size rose from 513 acres to 590 acres. By 1945 a third of the state's farm land was in farms of more than one thousand acres. Farm size was moving toward an acreage more suitable to the semiarid nature of the country.

War prosperity ended work relief and subsistence grants to farm families. In June, 1942, only 11 farm families received subsistence grants, but federal work projects still employed 3,452. The W.P.A. came to an end in North Dakota on February 1, 1943.

Bank deposits rose from $\$ 151,000,000$ in 1941 to $\$ 446,000,000$ in 1945 , and by the end of that year, North Dakotans had bought some 
$\$ 397,000,000$ worth of war bonds. The banks were bulging with bonds and cash; their loans were only 10 percent of deposits, and the farmers were operating on a cash basis as they never had before. ${ }^{3}$

With prosperity, many farmers bought farms; tenants were becoming owners. The Anticorporation Farming Law of 1932 required corporations owning farms in 1932 to sell them by 1942. Thus the law forced many farms onto the market and held down prices in spite of prosperity. In February, 1941, B. E. Groom estimated that corporations had to sell fifteen thousand farms by July 1, 1942, at what he called “confiscatory” prices.

In 1940 and 1941 many corporations and also public agencies not covered by the law, such as the Federal Land Bank of St. Paul, the Federal Farm Mortgage Corporation, the Bank of North Dakota, and county governments, began to sell large numbers of farms, principally to farm operators. In 1940 they sold 7,000 and in 1941 some 9,000 more. The counties sold 1,724 tracts in 1941, and the Bank of North Dakota sold 1,107. July, 1942, was a record-breaking month as corporations made a special effort to sell their holdings before the deadline. In 1942 the Bank of North Dakota sold 1,180 of its 5,334 farms at an average price of \$9.57 per acre. By February, 1945, it still owned 2,387 farms; that year, it sold 546 of them at an average of \$11.14 per acre. The school and university land department also sold much land. Some sales were for cash, and on others the purchasers often paid up long before the contract matured. ${ }^{4}$

In general, the price of land rose very slowly in comparison with farm income: from twelve dollars per acre in 1940 to only eighteen dollars in 1945 , the smallest increase in any state. The farmers were well aware of the dangers of a land boom. In March, 1944, the legislature suspended the sale of state and county lands so that land would be available for returning servicemen.

The sale of corporation and government-owned land decreased farm tenancy. For a long time in North Dakota the majority of the farmers had owned some land and rented some. Seventeen percent of the farm land in 1940 was farmed by full owners, 38 percent by tenants, and 44 percent by part owners (those who owned some land and rented some). Twenty-two percent of the farm land by 1945 was being operated by full owners, 22 percent by tenants, and 55 percent by part owners - an important shift of land ownership to the farmers themselves. Almost half of the farm land,

${ }^{3}$ Fargo Forum, December 30. 1945; William E. Koenker, "Banking Trends in North Dakota, 1922-1947” (Unpublished Ph.D. dissertation, Ohio State University, 1949), pp. 219, 222.

${ }^{4}$ There is much on land sales in the North Dakotan (Greater North Dakota Association, Fargo), 1941-1945. 
however, was still owned by nonfarmers, for the part owners held title to only slightly more than half of the land they farmed, and all land farmed by tenants was owned by nonfarmers.

Yet in the prosperous years many lost their farms by foreclosure. The forced sales of farms were high-higher in North Dakota than in neighboring states or in the United States as a whole, and higher than in North Dakota in the mid-1930's, when the farm debtor was protected by the Langer moratorium. From 1940 through 1945 there were over 14,500 forced sales of farm land, a fifth of the number of farms. Forced sales declined sharply in 1945 and then virtually stopped. In 1943 almost half (47 percent) of the Federal Land Bank Loans in North Dakota were delinquent or had been extended.

In spite of many transfers of farms, farm debt declined. Total farm debt had declined in the depression thirties, a normal thing; it continued to go down in the prosperous forties-from $\$ 141,000,000$ in 1940 to only $\$ 70,000,000$ in 1948 - a movement against the general tendency for debts to grow in prosperous times. By 1948 probably more farmers held their farms free of debt than at any time since the state had been settled.

Depression-scarred North Dakota farmers reacted slowly to their new prosperity. They needed many things. In 1940 most of their homes lacked electricity, running water, indoor bathrooms, mechanical refrigeration, and central heating; a third of their homes needed major repairs. But they spent cautiously, buying mostly farm machinery, automobiles, and trucks.

\section{WAR INDUSTRIES AND POSTWAR PLANNING}

In North Dakota, war prosperity came entirely from farm production. The people hoped that the war would stimulate a broad industrial development. State leaders-Governor John Moses, the North Dakota War Resources Committee, and the Greater North Dakota Associationworked diligently to secure war industries. As early as December, 1940, Governor Moses and Dr. Irvin Lavine presented the first brief to authorities in Washington for defense plants in North Dakota. In March, 1942, Berlin Boyd, W. P. Chesnut, and Joseph B. Bridston, representing the War Resources Committee, had twenty-six hearings in two weeks with officials in Washington. That summer, Fred J. Frederickson, mayor of Valley City, became the executive director and permanent Washington lobbyist of the committee.

The results were most disappointing. By March, 1945, the state had received only $\$ 9,600,000$ in war contracts, a miniscule portion of the $\$ 225,000,000,000$ awarded and apparently the least of any state. Thus the war failed to increase manufacturing and a wider use of resources in North Dakota. Some new plants for processing dehydrated potatoes, meat, eggs, 
and milk were built. But the state actually became more agricultural in terms of the proportions of its income derived from agricultural and nonagricultural sources.

By 1943 the state's leaders were turning to planning for full employment after the war. They were worried about the state's loss of population. Since agriculture could not use many of the returning servicemen and war workers, an expansion of other economic activities was imperative. The goal, Governor Moses said, was "greater agricultural, economic and financial stability for North Dakota”; research and public planning were to be the means. Upon his recommendation, the 1943 legislature set up the North Dakota Research Foundation and the North Dakota Postwar Planning Board. The legislature charged the foundation with research on economic uses of the state's resources and the board with making "a postwar rehabilitation plan for the benefit of returning veterans, war industry workers, farmers, businessmen.” The board sought to coordinate the plans of many organizations and departments of government for full employment.

By the beginning of 1945, sixty-seven towns were developing such plans. They needed new business structures, sidewalk and street improvements, water and sewage facilities, and new schools and hospitals. Counties planned new courthouses and road and bridge improvements. In the state as a whole, Missouri River development, highway construction, and rural electrification promised many jobs. Housing construction and repair were urgent, for 75 percent of North Dakota's houses had been built before 1920. The state needed, in the opinion of the planning board, to conserve its human resources by improving its educational, health, and recreational programs. Moreover, planning "to secure the best use of the land" could eliminate "futile and unnecessary waste of human effort and financial resources" and raise the standard of living of the population. ${ }^{5}$

\section{MEN AND MONEY FOR THE WAR}

North Dakota's men and money did their part in the war effort. On October 16, 1940, more than a year before Pearl Harbor, the state's fiftyfive local draft boards (one for each county and one each for Fargo and Grand Forks) began to register men under the Selective Service Act. By July 31, 1945, they had registered nearly 145,000 men from eighteen through forty-four, the age brackets liable for military service. By December 30, 1941, some 4,185 men from North Dakota were in the armed forces, and by March, 1944, there were about 46,000. 
The conflict over the draft concerned agricultural deferments. North Dakota farms were short of help. By November 30, 1942, local draft boards had given agricultural deferments to nearly 50,000 men. Because of such heavy deferments, North Dakota had only 34 percent of its men from eighteen through thirty-seven in the armed forces by March, 1944, compared with 41 percent for the nation. Except for South Carolina, North Dakota had the smallest percentage of its man-power in the armed services of any state in the nation; New Jersey, with 48 percent, had the highest. A comparison of urban and rural areas shows the varying deferments within the state. In March, 1944, Fargo had 49 percent of its registrants in the armed forces and 11 percent deferred for necessary work; Oliver County, a rural area, had 20 percent in the armed forces and 62 percent-the highest percentage in the state-deferred for agriculture. ${ }^{6}$

On March 14, 1944, Selective Service authorities in Washington prohibited occupational deferments for men eighteen through twenty-five except by state draft directors, a policy already in effect for ages eighteen through twenty-two. In North Dakota, occupational deferments for men from eighteen through thirty-seven declined from 46,527 on August 31, 1943 , to 27,335 on July 1 , 1945, or less than a fourth of those registered. Some 16,345 were deferred for physical disability. The rate of rejection for disability per 100 registrants was 25 for North Dakota and 33 for the United States.

In all North Dakota sent 58,509 men and 1,570 women to the armed forces. Of the men, 37,913 were drafted (8 percent of them fathers) and 20,596 enlisted. Eighty percent of the men saw overseas duty, spending an average of fourteen months outside the nation. The men served an average of thirty-five months, the women twenty-four.

A total of 1,939 North Dakotans died in the armed forces: 313 in the navy and 1,626 in the army. This was 4.14 percent of those in the armed forces from the state, a much higher death rate than the 2.98 percent of all men in the armed forces from the nation. ${ }^{7}$ North Dakotans fought and died in all major theaters of the war. The 164th Infantry, the state's National Guard regiment, landed at Guadalcanal on October 13, 1942; it suffered heavy casualties in the fighting that drove the Japanese off the island.

As the young men of North Dakota entered the armed forces or were deferred for agricultural work, enrollment at the state's institutions of higher education fell off sharply-from 7,138 in the fall of 1939 to 1,891 (mostly women and a few men rejected by the armed forces) in the fall of 1943. Although regular instruction continued, the college faculties and 
facilities were used more and more for the war effort. In 1939 and 1940 some of the colleges began to train civilian pilots; next they taught welding and similar skills to defense workers.

After Pearl Harbor, training programs multiplied. In May, 1942, the Wahpeton School of Science began turning out machinist's mates for the navy; in June the university started to train glider pilots for the Army Signal Corps; in September the Agricultural College opened the first Army Administration School in the nation and by June, 1943, had graduated 2,400 second lieutenants. In 1943-1944 the university and Jamestown College gave instruction for the Army Air Corps, and the university also conducted programs in nursing, medicine, and radio for the armed forces. On July 1, 1943, the teachers colleges at Dickinson, Minot, and Valley City began to train selected high school graduates as officers (the Navy V-12 Program) for the United States Navy, Marine Corps, and Coast Guard.

The various training programs helped schools financially and contributed to victory, but the greatest contribution of the colleges was, of course, their regular educational work before the war. Thousands of their former students entered the armed forces and served all over the world; 172 former University of North Dakota students, for example, died in the conflict.

While their sons fought, North Dakotans at home compiled an extraordinary record in the purchase of war bonds. The state easily oversubscribed its quota in every loan, buying 181 percent of its quota in the fourth loan early in 1944. That year, North Dakotans put 11 percent of their income, the largest percentage of any state, into Series E bonds, the series sold only to individuals. North Dakota was first in the nation in percentage of E bond quotas in the third, fourth, and victory loans; it was the first to reach its quota in the fifth war loan and the victory loan; it was first in per capita sales of E bonds in the sixth war loan. Altogether, by December, 1945, the people of North Dakota had bought \$397,000,000 worth of war bonds. Although a fifth of them were of German stock, North Dakotans had compiled a magnificent record of patriotic support for the war effort.

At the same time, they were learning to live with the uncertainties of their semiarid state. They were building up financial reserves against the lean years which they knew must lie ahead. When prosperity came, they saved more of their income than did the rest of the nation.

\section{GOVERNMENT FINANCE AND REFORM}

The war greatly influenced the government of North Dakota. War prosperity allowed the state to pay off much of its debt and to build up 
large financial reserves. Revenues from sales and income taxes increased rapidly. Delinquent property taxes were paid. The Bank of North Dakota sold large amounts of land and put nearly \$7,000,000 into the real estate bond sinking fund. The State Mill and Elevator began to show a net profit, which went into the sinking fund for its construction bonds. The state's net debt dropped from $\$ 23,000,000$ in December, 1938 , to $\$ 6,000,000$ on June 30, 1945. By that date the state treasury had reserves of $\$ 54,000,000$. The county governments were also much better off, many of them without any indebtedness.

Yet North Dakota was slow to increase government expenditures. Still suffering from the shock of drought and depression, the people believed that in prosperous times they must hold down spending and build up reserves. Governor Moses repeatedly urged caution in appropriations. He believed that in a state with an unstable income ("Good years may be followed by bad," he told the legislature), the building of reserves was imperative. Even in 1945 when the new governor, Fred G. Aandahl, spoke up for needed renovations and replacements in the state institutions, he urged caution. He also stressed the importance of large reserves against future declines of income.

The elimination of excessive government would have made tax dollars go farther, but such retrenchment was psychologically difficult to accept. Efforts at government reform in the 1930's, even under the direst economic necessity, had been unsuccessful. Now Governor Moses, showing typical conservative interest in efficient and economical government, pushed for a thorough reorganization. In 1941 he asked the legislature to establish a governmental survey commission. He also made his own far-reaching proposals for change: a merit system for state employees, a smaller legislature, the election of state and county officials on a no-party ballot for four-year terms, the elimination of all treasurers for school districts, villages, and townships (their duties to go to the county treasurers), a uniform accounting system for all state departments and institutions, and, finally, a 10 percent contingency fund for all institutional and departmental heads. "In state government," Moses told the legislature, "we have much overlapping authority. In many departments we are doing business today as we did it fifty years ago."

Although the legislature believed that there was "duplication of functions and services” among institutions and departments and "wasteful and extravagant practices in government," it refused to adopt any of Moses' reforms. It did, however, create a governmental survey commission and authorized the commission to study the state government

${ }^{8}$ Message to the Legislature, 1941, pp. 29, 33-34. 
and bring in recommendations for the elimination of unnecessary offices and departments, the consolidation of their functions, and the simplification of the state's governmental structure.

The commission employed the Public Administration Service of Chicago to survey the state government. After a six-month study, the Public Administration Service gave the commission its report in 1942. That document analyzed the organization and administration of state functions and made sweeping recommendations for their improvement. It condemned the state administration in strong language. For more than fifty years, the report stated, almost every session of the legislature had added new state functions and agencies. By 1942 there were more than sixty state agencies-departments, boards, bureaus, commissions—with related functions divided among them.

By and large, this tangled, overlapping maze of government did not have improved management practices, such as strong centralized financial control and centralized purchasing. It did not have centralized personnel management for the recruitment of employees, the standardization of positions and salaries, and job security. The turnover of state employees was rapid, and there was little relationship between salaries and responsibilities. The state tax commissioner, for example, was paid less than a minor foreman at the State Mill and Elevator.

The principal defect, however, was the lack of authority, and hence of responsibility, for the governor. "The state administration is not a single, well-coordinated unit but a series of separate, independent units," said the report. "Related functions are, in many cases, divided among different agencies without regard for the similarity of work being performed; it is therefore difficult or impossible to assign responsibility for their performance."

To remedy the defects, the report recommended changes by which the state government would (1) utilize staff agencies serving all departments for fiscal control, personnel management, and purchasing; (2) organize all administrative activities by function into a small number of departments; and (3) concentrate administrative authority and responsibility in the governor-abolishing the election of administrative officials and giving the governor power to appoint them.

'In 1943, Moses urged the legislature to adopt the recommendations. He believed they gave a choice between "the present archaic form of government" and "a modern form of government in which the people will be able to fix responsibility for every policy adopted and every public action taken.” In his retiring message in January, 1945, he again insisted on the absolute necessity of reform, calling the state government "a hodge- 
podge.” But there was no popular support for thoroughgoing reform; Moses' efforts were a complete failure.

The only reform during the war years was the establishment of the Legislative Research Committee by the 1945 legislature-a result of the persistent efforts of Albert R. Bergesen, a Cass County banker. The law, passed over Nonpartisan League opposition, provided for a committee of the legislature to study public problems between sessions. The committee was of the greatest importance, for it brought about a more informed approach to the state's problems, a step toward better adjustment to the imperatives of the semiarid grassland. ${ }^{9}$

\section{THE CONSERVATIVE-LIBERAL CONFLICT}

North Dakota witnessed a continuing struggle between conservative and liberal, between the creditor businessman and the debtor farmer. They fought over ownership of the land (the great wealth of the state) and over competition between the free-enterprise ventures of the middleman (after farming the chief source of income) and the cooperatives of the North Dakota Farmers' Union.

The conflict was one of attitudes, loyalties, and thought patterns. The conservatives were concerned with the promotion of economic development and security for property rights. They tended to be tied to the large property interests - the railroads, the banks, and the manufacturers - from outside the state. The liberals, largely farmers with a few allies in organized labor and an occasional intellectual in the towns, were concerned with human rights and debtor interests. They thought in terms of class conflict and the exploitation of the producers by "the interests." The conservatives were represented by the Greater North Dakota Association, the North Dakota Farm Bureau, and one wing of the Republican party. The liberals were represented by the North Dakota Farmers' Union, the Nonpartisan League, and the New Deal Democrats.

The Greater North Dakota Association (G.N.D.A.) united the businessmen of the state. It had been organized in 1924 with Herman Stern as president; later it absorbed several state associations: the Good Roads Association, the Automobile Association, the Roosevelt Memorial Park Association. and the Northwestern North Dakota Development Association. A Banker of Grand Forks served a year as president, but for

${ }^{9}$ Public Administration Service, Organization and Administration of the State Government of North Dakota (2 vols.; Chicago: Public Administration Service, 1942), I, 1-5, 59-60; Earl S. Strinden, "The North Dakota Legislative Research Committee” (Unpublished M.A. thesis, University of North Dakota, 1958), pp. 
many years the two most important leaders of the G.N.D.A. were Herman Stern, who retired as president in 1941, and B. E. Groom, long-time secretary. Stern, a short, alert person with generous purposes and an appealing personality, was president of the Straus Clothing Company stores in Fargo and Valley City. The G.N.D.A. was a member of the United States Chamber of Commerce, and interlocking officers and members tied it to local chambers of commerce throughout the state and to other state-wide organizations, especially the North Dakota Bankers Association.

The long-range goal of the Greater North Dakota Association was to diversify the economy of the state and thus improve the well-being of the people. It sought new industries and a wider use of the state's resources. It tried to attract tourists; it promoted irrigation; it encouraged diversified farm production; it worked for highway improvement. The G.N.D.A. sought to develop loyalty to the state, to "sell North Dakota to North Dakotans.”

The conservative businessmen active in the organization were keenly interested in better farming. For many years after 1930 the North Dakota Bankers Association won an annual award from the American Bankers Association for outstanding work in agriculture. In 1939, for example, 171 North Dakota banks spent an average of \$12,136 each in promoting agricultural development, and an average of 1.9 bankers attended 667 farm meetings. They supplied the credits for farm production; 123 banks made 48,265 loans to farmers for a total of $\$ 50,500,000$ in 1943 , while the Production Credit Administration, a federal agency, was making only 1,549 loans in the state. Obviously, the bankers were the farmers' friends, and the G.N.D.A. used such facts to win farmers from the North Dakota Farmers' Union.

The Farmers' Union had become the chief liberal force in the state during the 1930's when the Nonpartisan League had split into Langer and anti-Langer groups. The organization grew through the aid of the New Deal, the vigor of its own leadership, and the long-standing liberal outlook of the state. In 1939 the Farm Security Administration lent money to farmers on relief to buy stock in Farmers' Union cooperatives, thereby assisting in the organization of ninety new ones in North Dakota. Some $\$ 1,500,000$ was lent to buy stock in locals and $\$ 350,000$ for stock in the Grain Terminal Association (G.T.A.). Indignant at such use of public funds, the Greater North Dakota Association was able to persuade Congress to forbid such loans in 1940.

When Ben C. McCabe of Minneapolis organized the National Tax Equality Association in 1943 to require cooperatives to pay the same taxes 
as private enterprise, the G.N.D.A. was interested. In 1947 the North Dakota Tax Equality Association was formed, with B. E. Groom as executive secretary.

In 1942 a drive raised Farmers' Union membership more than 50 percent - to 21,318. By 1944 it was up to 25,674, or more than a third of the number of farmers in the state. Such numbers meant real power. Although wartime travel restrictions hampered the work of the state office, the organization of the Farm Bureau in North Dakota in 1940-1941 created a stimulating rivalry.

The Farmers' Union was dedicated to the ideal of the family-size farm. It was alarmed at the trend toward large holdings and corporate ownership. By 1940 corporations and government agencies, such as the Bank of North Dakota, owned nearly 20,000 farms, more than one fourth of the farms in the state. The Federal Land Bank of St. Paul alone owned some 8,000, the Bank of North Dakota 6,000, and thirty-nine insurance companies 2,700. Many other farms were mortgaged. While the Farm Credit Administration held the bulk of the mortgages, private lenders held a substantial number, and further concentration of ownership seemed likely.

To penalize large holdings and check their growth, the Farmers' Union initiated a proposal for a graduated land tax. It was defeated in November, 1940, and again in June, 1942. Although the Greater North Dakota Association was successful against it, other efforts to help the creditor class failed. In 1940-1941 and in 1944-1945 the G.N.D.A. tried to secure repeal of both the Antideficiency Judgment Law and the law making hailinsurance premiums a prior lien over first mortgages. The Antideficiency Judgment Law protected the debtor whose property was sold for less than the amount of the debt, as frequently happened in forced sales. Before the law's enactment in 1937, the creditor could bid less than the value of the property and obtain a deficiency judgment for the difference between the bid price and the debt. North Dakota gave the debtor no guarantee that the fair value of his property would be credited against his debt. By the deficiency judgment, the creditor victimized the debtor.

The G.N.D.A. campaigns were aided by the boycotts of the Federal Land Bank of St. Paul and the insurance companies, which had stopped making loans in North Dakota because of these laws, clearly an attempt by outsiders to control public policy in North Dakota. In 1941, Governor Moses asked for legislation to bring the "re-entry" of the Federal Land Bank into North Dakota, but Moses' request, the bank's boycott, and the G.N.D.A.'s efforts were all ineffective. In 1944 the G.N.D.A. began to circulate petitions against the laws on the patriotic ground that their repeal was essential to enable veterans to buy farms on credit. The argument was 
refuted by the rapid sale of farms, and on July 31 the petitions were stopped.

The G.N.D.A. campaign against the Anticorporation Farming Law also failed. Passed in 1932, the law required corporations to sell farm lands within ten years of the passage of the law or their acquisition of the lands by foreclosure. In February, 1941, the association, urging the repeal of the law, estimated that corporations would have to sell 15,000 farms before July, 1942. It argued that by forcing the sale of such a large number of farms, the law would virtually confiscate the property of farm-owning corporations. Governor Moses also feared that the sale of many corporation-owned farms would drive the price of farm land down; he asked the legislature to repeal the law.

But three or four thousand Farmers' Union members crowded into Bismarck and, in the words of the association, by "unprecedented pressure, threats and intimidation,” prevented its repeal. The association sadly commented that the Federal Land Bank would lose millions on the sale of its farms. On January 2, 1943, the North Dakota Supreme Court upheld the constitutionality of the Anticorporation Farming Law: all corporations (no exceptions for colleges or hospitals) must dispose of their farm lands within ten years of acquisition.

Business corporations had made vigorous efforts to sell their farm lands for the past three years. Land values had sunk to an all-time low of twelve dollars per acre in 1940. They began to rise in 1942, but the spurt upward did not come until 1944. By 1947 they were at twenty-two dollars per acre, the predepression level of 1930. Land values did not rise nearly as much in North Dakota from 1940 to 1947 as they did in the nation as a whole.

\section{WARTIME POLITICS: A CONSERVATIVE TREND}

A conservative trend was the principal development in politics during the war years. Prosperity played a part, and so did the coalition against William Langer. The trend had really begun in 1938 when a coalition defeated Langer's first bid for the United States Senate and elected John Moses as governor. A Democrat but no New Dealer, Moses was re-elected twice; his three terms as governor brought some degree of conservative control to the state government.

The strength of conservatism derived from the coalition of Langer's enemies: conservative Republicans, conservative Democrats, and some old members of the Nonpartisan League. William Lemke and Gerald P. Nye were the chief anti-Langer Leaguers; their virulent opposition to both Langer and President Franklin D. Roosevelt's foreign policy brought them into cooperation with conservatives who opposed the President's liberal domestic policies nationally and Langer's leadership in the state. 
The Langer faction, however, was successful in 1942. In spite of the revelation about Langer before the Senate investigating committee, Langer's friends won most of the Republican nominations in the primary against a coalition slate calling themselves "Progressive" Republicans. But Lemke defeated Langer-endorsed Charles R. Robertson for nomination to the House of Representatives. Robertson, a Bismarck businessman and the Republican state chairman, had been elected to the House in 1940 when Lemke was making an unsuccessful bid for the Senate.

After the primary, the defeated anti-Langer Republicans formed a coalition with the Democrats. Their ticket was headed by Moses, who was seeking a third term as governor. Five Democrats nominated for state offices in the primary withdrew and were replaced by "Progressive" Republicans. The coalition slate had five Republicans and four Democrats for state offices. In the fall the Langer ticket was largely successful against the candidates in the Democratic column. But for the coalition, Moses was re-elected governor, Henry Holt became lieutenant governor, and Thomas Hall was chosen secretary of state. Langer's Nonpartisan League took the remaining six state offices and a majority of the legislature; it re-elected Usher L. Burdick to the House. The outcome was more a victory for the incumbents than for liberalism.

Conservatism gained strength in 1943 with the formation of the Republican Organizing Committee (R.O.C.), a pivotal event in the postdepression period. With the R.O.C., a group of state senators-Rilie R. Morgan of Grafton, Milton R. Young of Berlin, Fred G. Aandahl of Litchville, and Joseph B. Bridston of Grand Forks — succeeded for the first time in creating a solid, permanent organization of all Republicans opposed to Langer. By the end of 1943 they had an organization in most counties, a state committee, a permanent headquarters at Bismarck in charge of Ruth Smith, and a seven-point statement of principles. The statement included acceptance of both the socialistic state industries already set up by the Nonpartisan League and the conservative principle that "the prosperity of agriculture, labor and business enterprises must go hand in hand"-an explicit denial of the class-conflict philosophy of North Dakota radicalism. Morgan was chairman of the R.O.C., Young its campaign manager, and Aandahl gave the keynote address at its first convention, held at Bismarck in March, 1944.

Chief interest in the 1944 campaign lay in the contest over Gerald P. Nye's seat in the Senate. Nye was seeking a fourth term. The Nonpartisan League endorsed Usher L. Burdick, its best vote getter. Lynn U. Stambaugh also announced his candidacy. Some Republicans liked 
Stambaugh's internationalism, but the success of the Republican Organizing Committee as an anti-Langer coalition demanded the endorsement of Nye and Lemke, the anti-Langer Nonpartisan leaders, for re-election. The satisfaction of their followers, about half the delegates to the R.O.C. convention at Bismarck in March, would pave the way for the endorsement of non-Leaguers for state offices.

Nye's isolationist record was the issue. Some R.O.C. members thought him "un-American and a joy to Hitler," yet others were attracted by his anti-New Deal stand and defended him. After a fight the convention endorsed Nye, with eighty-eight delegates not voting. When the convention accepted a platform plank for United States participation in a postwar international organization, State Representative K. A. Fitch of Cass County asked: "How are you going to support that and Nye, too?" The convention endorsed Aandahl for governor, Lemke and Young for the House, and a complete slate for the state offices.

The Democratic opponent of Nye was Governor John Moses. President Roosevelt believed that with Moses, a three-time winner, on the ticket, his own chances of carrying North Dakota would be improved. Moses would have preferred to run against Langer in 1946, when he could again benefit from Republican votes. In January he consented to run in 1944, but only after the national party promised campaign funds, "an able pen” to handle Nye's record, and a good federal appointment in case he should lose. "Get the money on the line,” Moses wrote to D. G. (Dave) Kelly, Democratic national committee-man for North Dakota. ${ }^{10}$

In June the Republican primary was largely a victory for the Republican Organizing Committee. Nye won in a close race with 38,191 votes to 37,219 for Stambaugh and 35,687 for Burdick. A heavy rain, cutting the vote by half in the strongly Nonpartisan northwestern counties, probably cheated Burdick out of the nomination. Aandahl (R.O.C.) was nominated for governor and Lemke (R.O.C.) for the House of Representatives; Robertson (Nonpartisan) barely defeated Young (R.O.C.) for the other congressional nomination. Of the eleven persons endorsed by the Nonpartisan League, only four secured nominations. They were all incumbents, and one, John Gray, had also been endorsed by the R.O.C.

The fall campaign again centered on the senatorial race, for it seemed certain that Republican Thomas E. Dewey, supported by all North Dakota Republican leaders, would easily carry the state over Roosevelt in the presidential contest. The once-defeated Stambaugh filed as an Independent for the Senate, and the Grand Forks Herald ardently 
supported him, asking for the defeat of Nye as a barrier to international cooperation. The R.O.C., Aandahl, and Lemke campaigned hard for Nye, whose fight for his political life was attracting national attention.

Some Nye supporters whispered that Stambaugh was Langer's stooge and that Moses, if elected, would not live to take office. Moses spent most of the fall months at the Mayo Clinic. He underwent an abdominal operation on September 12 and then prolonged X-ray treatments, but just before the election he was well enough to make some radio addresses and to assure his friends of his recovery: "My doctors tell me I am completely cured.” He supported Roosevelt's re-election (he had not done so in 1940) and United States participation in an international organization.

On election day, Moses was the only successful Democratic candidate on either the state or national tickets in North Dakota. He had 95,102 votes to 69,530 for Nye and 44,596 for Stambaugh. Roosevelt received 100,144 votes to 118,535 for Dewey. Moses won, although he received 5,000 fewer votes than Roosevelt, because 44,596 Republican voters repudiated Nye's isolationism by voting for Stambaugh. A vote for Stambaugh proved to be a vote for Moses. Nye carried only eleven counties, all but one (Billings) with large German Russian populations.

In the presidential election the origin of the population and the strength of the Farmers' Union influenced the pattern of voting. Dewey did best in the German Russian counties, such as McIntosh, Mercer, Emmons, and Morton. Roosevelt did best in the Norwegian and Canadian counties, such as Ward, Williams, Nelson, Traill, Pembina, and Walsh. The Dewey counties were only weakly organized by the Farmers' Union; the Roosevelt counties were strongly Farmers' Union. Apparently, the German Russians furnished the Republican margin in the presidential contest.

Moses re-entered the hospital at Rochester, Minnesota, fifteen days after taking the oath of office as United States senator. He died on March 3, 1945. On March 12, Governor Aandahl appointed Milton R. Young to the vacant seat. 


\section{CHAPTER 20}

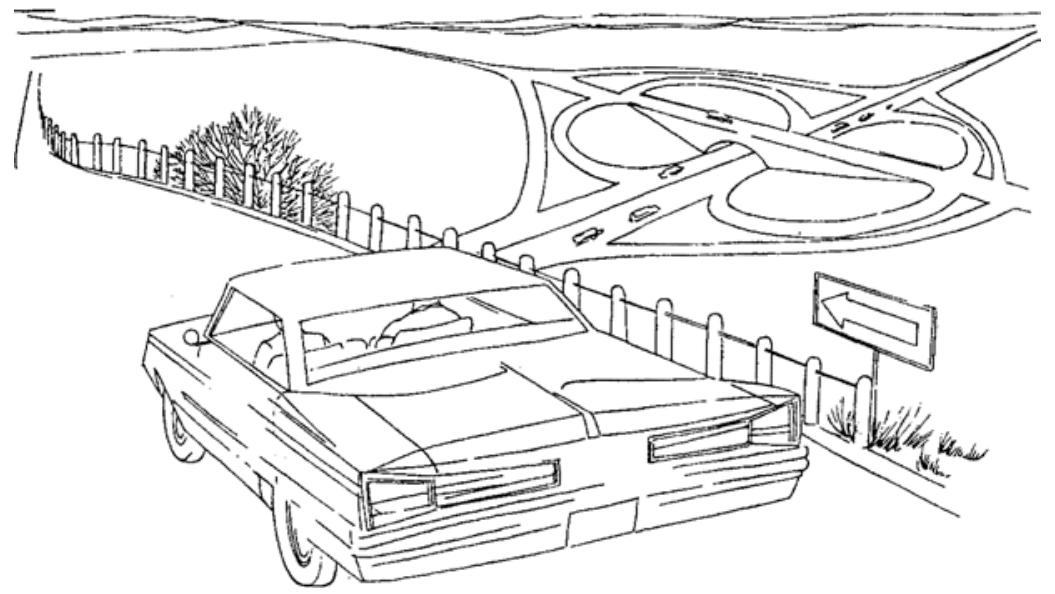

\section{Revolutionary Change in the Postwar Years}

THE SECOND WORLD WAR, like the Great Depression and the First World War, was a cataclysm in human history. The world entered a new era - the age of the atomic bomb and the cold war, of space exploration and the population explosion. Life and thought in North Dakota were affected by these things, for even though the state was far from the main stream of action, it was still part of a world locked in deadly struggle between Communism and capitalism, a world threatened by nuclear destruction.

Continuity tied the state not only to such world trends but also to its own past. At the end of the war, North Dakota still was, as it had long been, a sparsely settled spring-wheat country dependent on outside markets. In spite of wartime prosperity, it still occupied a position of economic disadvantage because of its agricultural economy; it still suffered from isolation and the heavy transportation costs which isolation imposed.

The prosperous and optimistic postwar years, however, brought revolutionary changes to the state. North Dakotans made much progress in the age-long process of adaptation to the semiarid plains and prairie country. Many of them left the state, creating a more favorable ratio between population and land. Farms became larger. More tractors, trucks, and automobiles, as well as a gigantic highway-construction program, increased mobility and aided in the conquest of distance. Hardsurfaced roads made possible a beginning in school district 
reorganization. Farming shifted to more beef cattle, more flax and barley; rural electrification made farm life easier. Rapid progress in soil conservation checked wind erosion and increased productivity. A great boom in construction-schools, churches, hospitals, and homes-raised living standards. These capital expenditures, along with massive federal spending for highways, rural electrification, Garrison Dam, and United States Air Force bases at Minot and Grand Forks (a consequence of the cold war), stimulated the economy of the state. Farmers' Union cooperatives grew amazingly, but conservative North Dakotans looked to economic diversification as the principal way of raising the state's relatively low income.

North Dakota's persistent efforts to attract industry met with little success. The oil industry, a strong stimulus to both the economy and the morale of the people, was a good start, but the market for North Dakota oil was limited. Cheap power from Garrison Dam's dynamos failed to bring factories to the Northern Great Plains, and Garrison diversion for extensive irrigation was still only talk in the early 1960's. However, the opening of the St. Lawrence Seaway in 1959, which brought ocean transportation nearer, seemed to modify the state's isolated position and to promise important changes in future years.

If economic diversification were slow in coming, the state did change in important ways. Even while the North Dakota Farmers' Union grew stronger, the state, like the nation, became more conservative. Yet prosperity and a strong desire for the standard American values made possible greatly increased public expenditures for highways, education, health, and welfare. And North Dakota, so long a one-party state, had two strong parties after the Nonpartisan League went over to the Democratic party in 1956.

\section{POPULATION CHANGES}

There was much that was old in postwar North Dakota. The long-time trends of out-migration and rural loss and urban gain continued. Thousands of people left the state and thousands more moved from the country and the small villages into the larger towns. North Dakota's population was 642,000 in 1940, 620,000 in 1950, and 632,000 in 1960. It declined 3.5 percent in the 1940's, grew only 2.1 percent in the 1950's. The natural increase would have been about 15 percent. By 1950 some 360,000 persons born in North Dakota were living in other states; by 1960 the figure had risen to more than 450,000, or 48.9 percent of all persons born in North Dakota and still living. Only Wyoming and Arkansas had larger percentages. The people who left North Dakota, seeking opportunities it could not offer, were often the better educated 
and those in their most productive years. Thus by raising and educating those who left, North Dakota was actually subsidizing the richer states. Not all of the migrants were young. Congressman Otto Krueger, retiring to Lodi, California, found it "just like home" because so many North Dakotans lived there.

Population movements within North Dakota brought rural losses and urban gains. In each decade after 1930 the rural population (villages and farms) declined by about 10 percent, but the urban population (places of 2,500 or more) increased by 16 percent in the 1930's, by 25 percent in the 1940's, and by 34 percent in the 1950's. In 1960 some 35 percent of the population was urban, and 47 percent lived in places of 1,000 or more. Throughout the state only those counties with large towns or oil wells grew. In the 1950's, thirty-eight of the fifty-three counties and 66 percent of the towns and villages declined in population.

The distribution of population was slowly beginning to fit the resources of the physiographic: divisions of the state. By 1960 the Red River Valley (about 10 percent of the state's area) had roughly 27 percent of the population, the Drift Prairie (40 percent of the area) approximately 39 percent, and the Missouri Plateau (50 percent of the area) about 34 percent. Although such percentages can only be approximations, they do show that in population, just as in climate, soil, grass communities, and economic activity, the Drift Prairie was a transition zone between the more humid Red River Valley on the east and the more semiarid Missouri Plateau on the west.

The continuing loss of population in the rural areas and the state as a whole was, of course, an adjustment to the environment and its attending economy. But fewer people meant increased per capita costs for community services. Those who remained simply had to pay more for schools, roads, churches, hospitals, and government. In the sparsely settled state, with only six persons per square mile (excluding the urban population), space itself created an additional cost which society had to pay. Thus it was more expensive for a thinly scattered population to provide what it needed. The same items of government, for example, cost twenty-two dollars per person in Billings County (population 1,777, or 1.6 per square mile) but only four dollars per person in Walsh County (population 18,859 , or 14.7 per square mile). ${ }^{1}$

\section{AGRICULTURAL ADAPTATIONS}

The loss of village and farm population was a result of the growing

\footnotetext{
${ }^{1}$ William E. Koenker and Glenn W. Fisher, Tax Equity in North Dakota, Bureau of Business and Economic Research, University of North Dakota, North Dakota Economic Studies No. 4 (Grand Forks, 1960), p. 12.
} 
mechanization of farming and the increased use of automobiles. After the war, the number of tractors, combines, and trucks increased rapidly. In 1945, North Dakota had 1.05 tractors, 0.33 combines, and 0.52 trucks per farm; by 1959 it had 2.05 tractors, 0.98 combines, and 1.25 trucks per farm. Although mechanization was a national trend, North Dakota had more tractors and trucks per farm than any other state. From 1945 to 1960 the number of automobiles registered in the state increased 90 percent. By 1960, North Dakota had one car for each 1.8 persons, compared to one for each 2.5 persons in the United States. Automobiles, of course, increased the advantages of larger trading centers over smaller ones and so contributed to the decline of village populations.

Automobiles, tractors, and combines increased the farmer's productivity by giving him more mobility. The results were larger farms, higher output, and more income. These changes, though long in progress, came more rapidly in the 1950's than ever before.

Many small farms disappeared. From 1945 to 1959 the number of farms fell from 70,000 to 55,000, and the average size increased from 590 acres to 755 acres. The number of farm workers also declined. There were about 124,000 in 1940, about 111,000 in 1950, and about 99,000 in 1959. Mechanization made hired help less important. In 1950 family workers supplied more than half the labor on 93 percent of the farms. The percentage of tenancy among farm operators also declined, from 28 percent in 1945 to only 19 percent in $1959 .^{2}$

The elimination of small farms was wise, for it tended to make more of the farms large enough to give a farm family a decent living. Yet in 1959 there were still far too many small farms, both in North Dakota and throughout much of the United States. In the states of the Upper Middle West, probably two-thirds of all farms earned net incomes too low to give an adequate return for the labor and capital invested. In North Dakota over two-fifths had less than 500 acres in 1959. For much of the state, however, a father-and-son partnership, a typical arrangement, could handle from 640 to 1,280 acres in a grain-and-livestock operation, and some family farms had 2,000 to 4,000 acres. Such farms were much more profitable because they could make fuller use of expensive agricultural machinery.

Nearly three-fourths of the farms in the small grain-livestock region from the Red River Valley to the Missouri River were too small. Some figures on investment and income prove the point. In the middle 1950's

\footnotetext{
${ }^{2}$ Baldur H. Kristjanson, What about Our Large Farms in North Dakota? North Dakota Agricultural Experiment Station Bulletin 360 (Fargo, 1950), p. 21.
} 


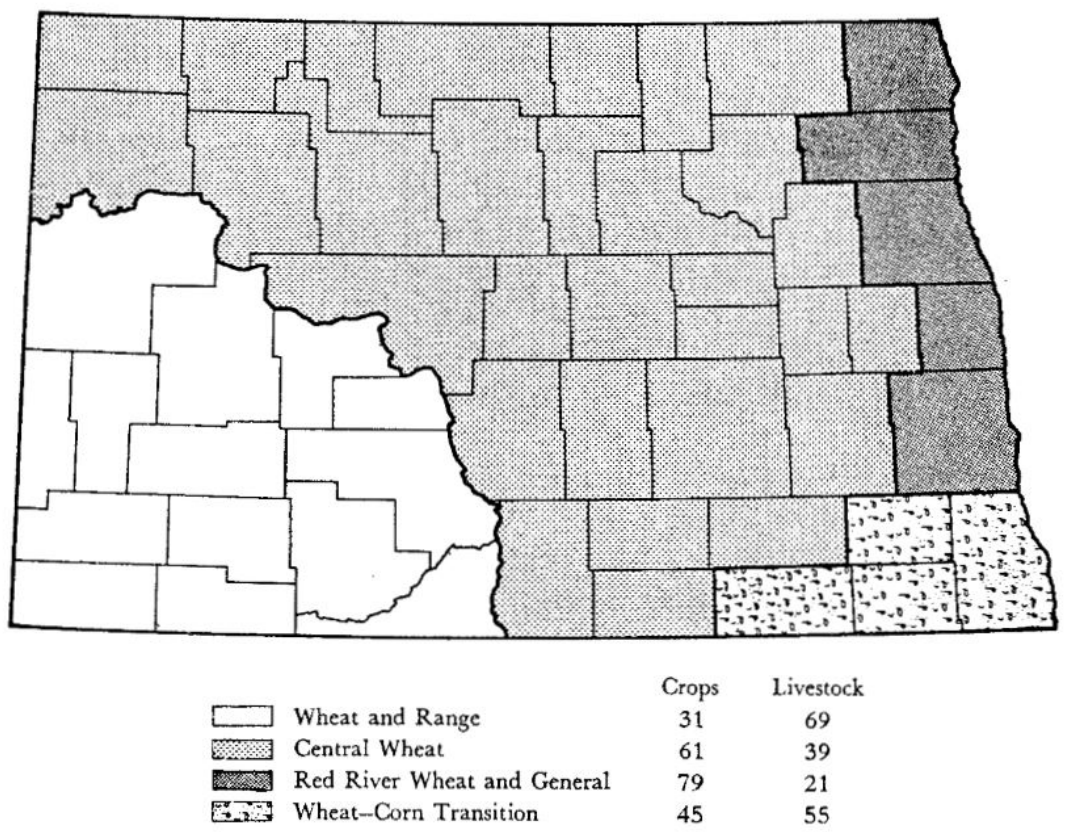

FARMING AREAS OF NORTH DAKOTA

that region had about 34,000 farms, divided into three classes. The 8,000 farms of the first class had annual cash marketings of $\$ 10,000$ or more, an average investment of $\$ 68,000$, and an annual average net income of $\$ 12,000$. They were much more profitable enterprises than the other two classes of farms in the region. The 20,000 farms of the second class had annual cash marketings of $\$ 2,500$ to $\$ 9,999$, an average investment of about $\$ 34,000$, and an annual average net income of only $\$ 3,500$. The 5,600 farms of the third class had annual cash marketings of less than $\$ 2,500$, a capital investment of about $\$ 18,000$, and an annual average net income of less than $\$ 500$. Operators in the third class would have been much better off financially if they could have invested their capital in other ways and hired themselves out as farm laborers.

That possibility was not open to many of them. The readjustment which followed elimination of some of the small farms often caused hardship. The men forced off the land often lacked the education or vocational training necessary for other employment; the small towns, in turn, lacked employment opportunities. As farm families moved away, retail sales in the villages declined, and the villages themselves decayed. The reorganization of North Dakota agriculture-which would make possible full utilization of modern machinery and available labor and which would give each farm a gross cash income of $\$ 10,000$ or morewould bring about a revolutionary change in the state. Such a drastic revision in farm population would mean the disorganization of 
community life and the death of many villages, as well as much suffering for those who had to take up new occupations in new places. Yet the steady growth of farm size, forced by the need to use expensive machines more fully, was moving in that direction. ${ }^{3}$

There were other changes. From 1950 to 1959, North Dakota farmers increased their use of commercial fertilizer sevenfold and doubled their use of commercial feed. They raised fewer chickens, turkeys, sheep, hogs, and dairy cattle. (The amount of milk and cream sold actually increased as artificial-breeding associations began to serve dairy farmers in forty-eight of the fifty-three counties by 1953.) They raised more barley, flax, and beef cattle. In general they depended more on crops and less on livestock than in earlier years, but by 1960 the fattening of beef cattle on rolled barley was increasing rapidly, bringing a more diversified agriculture. Probably a fifth of the farms had no livestock; wheat alone usually brought in about 40 percent of the cash farm income. Although federal restrictions reduced North Dakota's wheat acreage by more than a million acres from 1940 to 1960, the state planted 13.6 percent of the nation's wheat in 1940 and 13.4 percent in 1960. By the early 1960's, wheat yields had doubled since the 1930's, but national consumption remained almost exactly the same.

The great change, however, was rural electrification. In 1935 only 2.3 percent of North Dakota's farms had electricity from central power stations, the lowest percentage in the nation. Rural electric cooperatives received their first loan in 1936 and put their first line into operation in 1937 at Cando. Expansion came after the war. Rural Electrification Administration loans reached their peak in 1949, and by 1954 some 90 percent of North Dakota's farms had electricity. By 1960, twenty-four North Dakota cooperatives had borrowed $\$ 119,000,000$, built 53,000 miles of power lines, and brought electricity to 65,000 customers, including an estimated 52,000 farms. In 1954 the R.E.A. began to make loans for rural telephone systems in North Dakota. By 1960 it had lent $\$ 23,000,000$, and 36,000 farms had telephones. With electricity, the whole aspect of farm life changed; television sets, home freezers, electric milk coolers, and many other appliances lightened the work load and began to wipe out the differences between rural and town living.

At the same time, soil conservation was making rapid progress. It had begun in the 1930's with federal payments for planting shelter belts and following other soil-conserving practices. Then, under terms of a state

\footnotetext{
${ }^{3}$ Arvid C. Knudtson and Rex W. Cox, Upper Midwest Agriculture: Structure and Problems, Upper Midwest Research and Development Council and the University of Minnesota, Upper Midwest Economic Study, Study Paper No. 3 (Minneapolis, 1962), pp. iii-v, 1-4, 20-25, 38.
} 
law passed in 1937, interested farmers began to organize soil conservation districts. By 1947 there were sixty-six districts, and by 1957, seventy-eight districts covered 98 percent of the state. Soon the more progressive farmers were planting trees in shelter belts, stripcropping, cultivating their land on the contour, building dams and dugouts for livestock water, planting grass and using grass rotation, controlling grazing, and stubble-mulching their fields.

The United States Soil Conservation Service supplied plans and advice and lent heavy equipment. The North Dakota Association of Soil Conservation Districts established a tree nursery at Oakes in 1947 and another at Fort Lincoln in 1953. Every year, the Greater North Dakota Association honored the outstanding conservation farmer of each district. By 1960 some 35,000 farmers were cooperating with the districts, nearly 23,000 had complete conservation plans for their farms, and some 15,000 had applied essential treatments to eleven million acres, more than a fourth of the farm land in the state. Although much remained to be done, a revolution in the use of the state's greatest resource was well under way. ${ }^{4}$

Better use of the land paid off. A comparison of two periods of roughly equal rainfall shows that the average yield of wheat per acre rose from 10.9 bushels for the years 1919-1928 to 12.5 bushels for the years 19461955. Summer fallow often increased wheat yields by 50 percent or more, and new varieties of wheat, barley, flax, and hybrid corn also helped.

New varieties of hard red spring wheat and durum were especially important. In 1945, Thatcher and Pilot were the most commonly grown hard red spring wheats in the northwestern and western parts of the state, Rival and Regent in the more central and eastern counties. Mindum was the most commonly grown durum. By the late 1940's, however, Mida, a superior wheat released by the North Dakota Agricultural Experiment Station in 1944, occupied about 40 percent of the wheat acreage. But varieties once resistant to leaf rust were showing more and more leaf rust, and in 1950, Race 15B of black stem rust, not previously present in the area, caused much damage. In the early 1950's, Lee became the leading variety because it was resistant to leaf rust and had some tolerance to Race 15B. Then Selkirk, bred at the Dominion Laboratory of Plant Breeding at Winnipeg and released in 1955, became the leading variety because of its capacity for high yields and its resistance to Race

\footnotetext{
${ }^{4}$ North Dakota State Soil Conservation Committee, North Dakota: Twenty Years of Progress in Soil and Water Conservation (Bismarck, [1957]), pp. 2, 7-10.
} 
15B. Since 1957 it has been grown on 65 to 70 percent of the wheat acreage. By 1959 new durums resistant to Race 15B-Langdon, Yuma, Ramsey, and Towner-occupied more than 90 percent of the durum acreage. $^{5}$

Varieties of grain and farming methods were undergoing rapid change. Don L. Short, thinking about his father's failure in the 1930's and his own later success, said in 1958: "We know a lot more about farming and ranching than we did then. For example, we’ve learned a lot about how to use the country.... If you believe in this country, and treat it right and work hard with it, it will be good to you.” On his ranch twenty miles north of Medora, Short practiced conservation by storing extra hay in good years and by taking care not to overgraze the range.

In Benson County, young John R. Beckstrand, also a believer in conservation, followed different practices. Receiving a medical discharge from the navy in 1944, Beckstrand, then twenty-three, began to farm near Warwick with 200 acres of rented land and a loan of $\$ 500$. Inventive and believing in hard work, he was soon getting high yields from land considered unproductive. By 1956 he was farming 2,400 acres and was worth $\$ 131,000$. That year, the United States Junior Chamber of Commerce honored him as one of the four outstanding young farmers in the nation. In 1964, 36-year-old Steve Reimers of Bordulac, Foster County, was similarly honored. After starting from scratch on rented land in 1950, he was farming 6,080 acres. The success of Beckstrand and Reimers was unusual, but many farmers were making big money.

\section{THE FARMERS’ UNION AND THE FARM BUREAU}

Farmers strengthened their position by means of organizations. Many joined cooperatives to obtain greater bargaining power. By 1958 there were some six hundred cooperatives in North Dakota, not many more than in the 1930's. Their business, however, had grown enormously in the postwar years. From 1942 to 1958 the number of the stockholders increased from 70,000 to 216,000 , assets from $\$ 19,000,000$ to $\$ 136,000,000$, and annual business from $\$ 57,000,000$ to $\$ 273,000,000$. The cooperatives, mostly elevators and oil companies, were strongest where the Farmers' Union was strongest (Ward and Williams counties), weakest where it was weakest (Oliver, McIntosh, and Kidder). Williston was the most cooperative town in the state; it even had a cooperative funeral home. The counties with weak cooperatives cast few votes for the Democratic candidates for President, and they also seem to have been

\footnotetext{
${ }^{5}$ Theodore E. Stoa, "History of Wheat Variety Changes on North Dakota Farms for Years 1945 to 1960,” North Dakota Farm Research, XXI, 8 (November-December 1960), 17-21.
} 
slow to form soil-conservation districts and to adopt summer-fallow practices.

Growth of North Dakota cooperatives was enhanced by the amazing success of the two large regional cooperatives of the Farmers' Union: the Grain Terminal Association (G.T.A.) and the Central Exchange. The G.T.A. began operations in 1938 with capital stock of only $\$ 30,000$ and handled 17,000,000 bushels of grain the first season. Soon it bought 138 rural elevators and 38 lumber yards from the long-established St. Anthony and Dakota Elevator Company and built huge terminal elevators at Superior, Minneapolis, and St. Paul. By 1947 it was handling $125,000,000$ bushels of grain a year. Buying more country elevators from old line companies, it sold many of them to local Farmers' Union groups but also operated some itself. By the late 1950's its subsidiary, Great Plains Supply, owned 118 lumber yards, 45 of them in North Dakota. In 1957 the G.T.A. handled more than 150,000,000 bushels of grain, about one-fourth of the amount sold in the Minneapolis and Duluth markets. It had a capital of over \$33,000,000, 903 employees, 148 rural elevators (62 in North Dakota), and a total storage capacity in terminal and subterminal elevators or more than 20,000,000 bushels. Besides its own country elevators, 440 locally owned ones (186 in North Dakota) shipped grain to the G.T.A.

Through the G.T.A., members of cooperatives had some voice in the marketing of their grain; through the Farmers' Union Central Exchange, they secured supplies distributed by locally owned Farmers' Union oil companies. Organized at St. Paul in 1931, the Central Exchange had come to own oil wells, pipelines, refineries, oil-blending plants, fertilizer factories, and machinery warehouses by the 1950's. It was supplying 122 oil companies in North Dakota in 1956, as well as many others in the region. By 1960 it was doing an annual business of $\$ 90,000,000$. Other Farmers' Union cooperatives were concerned with livestock marketing and insurance.

Cooperative growth was largely the result of educational work by the Farmers' Union. In North Dakota the Farmers' Union itself grew steadily stronger-from 26,000 members in 1945 to 44,000 in 1959. It carried on a vigorous program: conferences on health and rural education; tours of Tennessee Valley Authority projects, regional cooperatives, and Washington, D.C.; publication of the North Dakota Union Farmer; and radio and television programs ("Focus on the News" began in 1957). In 1959 its receipts amounted to more than $\$ 422,000$. Its cooperatives deducted membership dues from the patronage dividends, making all of their patrons Farmers' Union members automatically. Moreover, the large regional cooperatives, and many local ones as well, paid a share of 
their profits into the treasury of the North Dakota Farmers' Union.

The Farmers' Union platform summed up the thinking of the farmer liberals of the state. Its two principal planks were protection of the family-type farm and 100 percent parity income for family-farm production. The North Dakota Farmers' Union was friendly to organized labor. It favored a graduated land tax, progressive taxes on personal income, repeal of the sales tax, federal health insurance, and a Missouri Valley Authority. Yet many of its members did not support either the liberal platform or the cooperatives. In 1956, for example, President Glenn J. Talbott said that the business of the Farmers' Union insurance companies and the Central Exchange was only a fraction of the potential from the membership. He also noted that if all members patronized the cooperatives, the G.T.A. would market 75 percent of North Dakota's grain, not 25 to 30 percent.

Another farm organization, the North Dakota Farm Bureau, also grew rapidly in the postwar years. Its membership rose from about 3,000 in 1945 to over 15,000 in 1960. It was strongest in the Red River Valley and the northeastern counties, where about half the farmers were members. With headquarters in Fargo, it offered its members insurance, the North Dakota Farm Bureau News, a national newsletter, and a voice in agricultural policy. Where the Farmers' Union was Democratic and called for increased federal activity in many spheres, the Farm Bureau was Republican and talked of free enterprise and the individual. By 1959 it was asking for termination of marketing quotas and acreage allotments, stronger control of organized labor, and less federal spending. It also wanted taxation of the undistributed earnings of cooperatives. Farm Bureau leaders considered Glenn J. Talbott a socialist; Talbott and Farmers' Union leaders considered the Farm Bureau an ally of the United States Chamber of Commerce.

Thus North Dakota had two vigorous farm organizations. One stressed cooperatives and government price supports, the other better farming and free enterprise. The more liberal was stronger in the western portion of the state, the more conservative in the eastern portion. Probably the majority of the state's farmers were less liberal than the leadership of the Farmers' Union, less conservative than the leadership of the Farm Bureau. Although tension between the two groups permeated North Dakota life, liberal and conservative continually rubbed shoulders in the give and take of rural living.

\section{THE ECONOMY}

In the postwar years, farming produced most of the new wealth in North Dakota. There, more income came from agriculture and less from 
manufacturing than in any other state. In 1946, for example, 46 percent of North Dakota's personal income derived from farming. The best crops and the best prices came just after the war. Wheat production averaged about 140,000,000 bushels, and gross cash farm income was over $\$ 700,000,000$ in 1947 and 1948. Beginning in 1949, however, the state had modest crops as drought and Race 15B of black stem rust cut down yields. During the 1950's, farm income generally fluctuated between $\$ 500,000,000$ and $\$ 600,000,000$.

Farmers were squeezed when farm prices went down and the cost of farm supplies went up. In 1947, the peak of farm prosperity, prices received by farmers stood at the index figure $301(1910-1914=100)$, while prices paid by farmers stood at 230 . But in 1956 prices received stood at 227, prices paid at 264. Thus net farm income had suffered a disastrous decline. In 1960, an average year, only 22 percent of the state's personal income came from farming.

Rising farm debt reflected the change. In the very prosperous years during and immediately after the war, farmers had paid off their debts. By 1949 the farm-mortgage debt was down to $\$ 67,000,000$, but by 1959 it was up to $\$ 149,000,000$. Although farming was becoming less profitable, the value of farm land rose steadily, from an average of about \$19 an acre in 1945 to nearly \$44 in 1958.

Farming was not very profitable in either North Dakota or the nation. In the nation in the mid-fifties, the median money income of farm families was only $\$ 2,117$, of other families $\$ 4,705$. In North Dakota the average net income per farm was only $\$ 2,683$. One study showed that the return for the labor of the farmer and his family might be as low as forty-nine cents an hour, the return on capital invested as small as 1.4 percent. Yet the income of North Dakota farms and farm families was much above the national average, ranking sixth in the nation in 1958. North Dakota farmers suffered in part because the consumption of their principal crop, wheat, was declining. In the United States the per capita consumption of wheat flour was 158 pounds in 1945, only 119 pounds in 1959. In the 1950's, North Dakota farmers put nearly three million acres in the Soil Bank, a larger percentage of farm land than any other state. Over 7,800 whole farms in North Dakota were in the Soil Bank.

The relatively low income of farmers, the dominant group in the state, made the wages and salaries paid in nonagricultural occupations, except mining, lower in North Dakota than in the nation. In 1958 the average in North Dakota was $\$ 3,873$, in the nation $\$ 4,531$. Inevitably, low farm income and lower-than-average incomes in nonagricultural occupations gave North Dakotans a lower per capita personal income than the national average, lower, in fact, than all but the southern states. In 1945 
the per capita personal income in North Dakota was $\$ 1,009$, or 82 percent of the national average of $\$ 1,234$. In 1960 it was $\$ 1,741$, or 78 percent of the national average of $\$ 2,223$. Only in 1947 did per capita personal income in North Dakota, $\$ 1,446$, exceed the national average, $\$ 1,316$.

Many persons, however, believed that the government figures understated the net farm income and hence the per capita personal income of the state. If North Dakotans' incomes were actually below the national average, there was nevertheless much evidence of increasing economic well-being in the postwar years. The total personal income for North Dakota increased from \$549,000,000 in 1945 to $\$ 1,104,000,000$ in 1960. The United States Department of Agriculture's index number measuring the level of farm-family living rose for North Dakota from 111 in 1945 to 146 in 1954. All towns of more than five hundred people acquired sewage-disposal systems. By 1960, Blue Cross hospital insurance covered a third of the population. The production of electricity increased from 313,000,000 kilowatt hours in 1945 to 2,011,000,000 kilowatt hours in 1959. Electricity, tractors, trucks, combines, and other machines transformed farming. The greatest building boom in the history of the state brought new schools, hospitals, clinics, churches, swimming pools, business structures, college buildings, and homes, as well as thousands of miles of hard-surfaced highways. In some years the construction industry was second only to agriculture, and from 1950 to 1960, building permits in Fargo alone totaled more than \$73,000,000. In 1959 the National Municipal League and Look magazine named Fargo an All-America City. In 1959-1960 the Fargo-Moorhead metropolitan area led the United States in retail sales per household.

Progress like this, of course, sprang from the energy of an optimistic people. But it was also made possible by the economic stimuli of the oil boom and federal spending on rural electrification, Garrison Dam, highways, and the air force bases at Minot and Grand Forks. A large part of these expenditures went out of the state for turbines, electrical cable, cement, and supplies of all sorts, yet the gross sums are suggestive of the massive boost to the North Dakota economy: $\$ 119,000,000$ for rural electrification, $\$ 294,000,000$ for Garrison Dam, $\$ 77,000,000$ for interstate highways, possibly as much as $\$ 650,000,000$ in the oil industry, and probably some $\$ 200,000,000$ each for the air force bases. By 1960 the oil industry's annual payroll was some $\$ 19,000,000$, and the payroll at the Grand Forks air base was about $\$ 1,000,000$ a month.

Such expenditures helped to modify the state's economy. North Dakota remained, of course, primarily an agricultural state, but an ever larger part of its population went into nonagricultural employment, an 
ever larger part of its personal income came from nonagricultural sources. Although the population remained virtually stationary, nonfarm employment rose from 83,000 in 1945 to 124,000 in 1960, an increase of more than 50 percent. During the same years, farm employment declined about 40 percent. Thus by the later 1950's, except in the summer rush season, there were more people working off the farms than on. Personal income from nonfarm sources increased rapidly, from $\$ 320,000,000$ in 1946 to $\$ 759,000,000$ in 1958 , while personal income from farming increased from $\$ 276,000,000$ to $\$ 344,000,000$ during the same years. Manufacturing, however, supplied only 3 percent of the state's personal income. ${ }^{6}$

Lack of manufacturing, dependence on wheat, loss of population, and relatively low income worried North Dakota. The state's leaders felt that a more diversified economy was essential in order to provide more jobs and a more stable income, so North Dakota sought to attract new industries. The North Dakota Research Foundation, a government agency established in 1943 and headed throughout its existence by Alex C. Burr, worked to increase the use of lignite and other resources. Thousands of North Dakotans hoped that cheap power from lignite (reserves were estimated at a staggering 350,000,000,000 tons) would bring industry to the state. In 1951 the federal government's Bureau of Mines built the Charles R. Robertson Lignite Laboratory for lignite research on the campus of the University of North Dakota. Yet by 1960 only about 100,000,000 tons of lignite had been mined since operations began in 1884, and in the 1950's, when three-fourths of it was being used to generate electricity, production was actually declining.

North Dakotans made good progress toward economic diversification in the late 1950's. In 1957 the legislature created the North Dakota Economic Development Commission to replace the North Dakota Research Foundation, and emphasis shifted from research to promotion. The commission director, dynamic Lawrence Schneider, prepared much literature on industrial opportunities in the state and worked to aid businesses and communities in developing their potentials. Governor John E. Davis, creator of the new program, and the Greater North Dakota Association sponsored a "business climate" resolution which the legislature passed in 1959. "We need a political climate that will encourage the development of our state,” Davis said. In June, 1959, Schneider and some members of the commission went to New York City to inform the nation's business leaders of industrial opportunities in 
North Dakota.

Although no large industry located in North Dakota, the commission did have some success in helping to establish small enterprises geared to local markets. By 1959, ninety-two towns had community development committees with funds of $\$ 2,000,000$. Potato-flaking and starch plants, poultry-and-egg enterprises, straw and cheese processing, and barleypelletizing operations got under way. In 1960 the Dakota Salt and Chemical Company opened a plant near Williston. The Melroe Manufacturing Company of Gwinner (population 400), marketing its little Bobcat tractor-loader in every state as well as in Canada, England, Australia, and South Africa, sold over \$6,000,000 worth of farm machines in 1964. But plans for a \$15,000,000 fertilizer plant at Garrison Dam fell through, and Armour and Company closed its packing plants at Grand Forks and Fargo in 1958-1959.

North Dakota failed to attract industry largely because of its location at the center of the continent, far from markets and centers of population. To help the state compete in such distant markets, the railroads in several instances gave lower rates. "The railroads of North Dakota," said Vincent P. Brown, general freight manager of the Great Northern, "are quick to cooperate with new industry.” Moreover, the St. Lawrence Seaway, opened in 1959, brought cheap water transportation to ports 2,400 miles inland, less than 300 miles from eastern North Dakota. Still, as the Grand Forks Herald said, "freight rates... stood out like an iron curtain to any inquiring industry."

\section{THE HIGHWAY REVOLUTION}

The shortage of industries contributed to the sparsity of population, which, in turn, increased the per capita cost of government services. So North Dakotans, although their incomes were relatively low, had to pay a larger proportion of them for such services than did the people of other states. By 1957, for example, North Dakotans were paying \$117 in state and local taxes for each $\$ 1,000$ of personal income, a larger sum than that paid by the people of any other state.

In the postwar years, public expenditures increased rapidly. Disbursements from the state treasury rose from about $\$ 34,000,000$ in the fiscal year 1945-1946 to about \$135,000,000 in the fiscal year 19601961, an increase of well over 200 percent, although personal income had increased less than 100 percent. The principal expenditures were for highways, higher education, welfare, and aid to the public schools. But two other large sums were paid out: $\$ 28,000,000$ as adjusted compensation to veterans of the Second World War and \$7,000,000 to Korean War veterans. 
Highways got the most money. North Dakota had excessive mileage of rural roads and relatively few people to use and pay for them. In 1951 it had 73,000 miles, not counting 43,000 miles of prairie trails. Some 25,000 miles, however, carried 85 percent of all traffic. About 6,500 miles were in the state highway system, about 18,000 miles were county roads, and the remaining mileage consisted of lightly used township roads.

Obviously, many of the township roads were unnecessary. Even without the prairie trails, North Dakota had more than a mile of road for each square mile of area and by the 1950's more than a mile for each farm family. As farms became larger, some farm residences needed to be relocated so that a considerable number of the rural roads could be eliminated. "North Dakota must face the facts," Governor John Moses had said in 1941. "We are maintaining the largest highway system in point of mileage per car of any state in the Union."

The result was bad roads and the waste of millions of dollars. Federal grants, starting in 1916, could be used only for construction, but in the 1930's the state highway department had difficulty in securing money to match the federal grants and was in danger of losing them. In 1939 the federal Public Roads Administration termed half of the state's highway system "unsatisfactory.” By the end of 1940, although nearly ninety million dollars had been spent on construction and maintenance, only seventeen hundred miles of roads in the state system had a hard surface.

The war slowed down construction; there was not even enough money for maintenance. Most of the state highways were gravel roads which needed much attention; poor design increased the cost of snow removal to as much as two hundred dollars per mile for a winter. When frost left the ground in the spring, the light bituminous pavement often broke up. With the capital investment being lost, the Public Roads Administration cut off federal funds late in 1946 until the state would provide for adequate maintenance.

North Dakota exerted a strong effort to raise the necessary money. In 1945 it sold some $\$ 12,000,000$ worth of highway revenue anticipation certificates; it repeatedly raised gasoline taxes and tried to check the widespread evasion of them; from 1943 to 1957 it transferred some $\$ 23,000,000$ from other state funds to the highway fund; it raised automobile registration fees; it even turned down half the requests from institutions of higher education for capital outlays, spending less than $\$ 10,000,000$ for such purposes from 1947 to 1957. By 1957, North Dakota and South Dakota ranked first among all the states in the amount spent on highways in proportion to personal income (\$51 for each $\$ 1,000$ of personal income). By the same measure, North Dakota ranked seventh 
among the states in the amount spent on higher education.

The money thus raised speeded up construction. By 1951 the state had spent $\$ 48,000,000$ on construction since the war and had 2,329 miles of hard-surfaced roads. They were expensive, costing about $\$ 30,000$ per mile in 1950. Much progress had been made, but only a small part of the 25,000 miles of state and county highways were hard surfaced and 59 percent of them were judged "intolerable" by the Bureau of Public Roads.

Unfortunately, much of the new construction had been gravel or lowquality bituminous; such roads would soon have to be rebuilt. There was much dissatisfaction. Many legislators believed that the work had been done "without sufficient factual information or planning." In 1951 the legislature authorized an investigation, and the Legislative Research Committee hired the Automotive Safety Foundation of Washington, D.C., and Professor James C. Nelson of Washington State College to make a study. These experts concluded that the state system was too large. "To bring it within the financial limits of what the people are willing and able to purchase," they recommended that the system be cut to 4,121 miles by turning 2,472 miles of the less-traveled roads over to the counties. The proposed 4,121 miles of state highways, the study stated, would carry 60 percent of all rural traffic, reach all county seats, connect all major population centers, and serve every section of the state. Most of it should be given a hard surface, but a staggering $\$ 134,000,000$ was needed. The legislature, however, was unwilling to reduce the state system drastically. ${ }^{7}$

Much progress was made in the 1950's, however. The highway department, abandoning the low-quality bituminous surface, built a more durable, high-quality bituminous road. Each year, from twelve to fourteen million dollars went for construction. The main arteries, first paved in the 1930's, were rebuilt; many miles of gravel roads were given a hard surface. Each year, the mileage of gravel declined, the mileage of hard surface increased. In 1945 scarcely. 25 percent of the state system had been hard surface; by the end of 1960 almost 80 percent of it was. At the end of the war, the state had two hard-surfaced east-west routes (U.S. Highways 2 and 10) and four partially completed hard-surfaced north-south routes (U.S. Highways 81, 83, 85, and 281). By the end of

${ }^{7}$ Automotive Safety Foundation, Better Roads for North Dakota (Bismarck: North Dakota Legislative Research Committee, 1952); Automotive Safety Foundation, An Engineering Study of North Dakota's Roads and Streets (Bismarck: North Dakota Legislative Research Committee, 1952); James C. Nelson, Financing North Dakota's Highways, Roads and Streets (Bismarck: North Dakota Legislative Research Committee, 1952). 
1960 the state was covered with a grid of hard-surfaced routes, only twenty to thirty miles apart and running east and west, north and south. Except for the Badlands region, few parts of the state were many miles from a hard-surfaced highway.

The counties also improved the roads under their jurisdiction. They spent \$83,000,000 for construction from 1945 to 1959, most of it on gravel roads. From 1947 through 1959 the state highway department spent $\$ 220,000,000$ on construction, over half of it federal money. Together, the state and the counties invested approximately $\$ 303,000,000$. That sum, about $\$ 479$ per capita, was little more than the cost of Garrison Dam, yet it relieved the isolation which had always hindered the sparsely settled state. Postwar highway construction had brought a revolution to North Dakota.

Construction took a new turn in 1956 after Congress authorized an interstate system of divided, limited-access highways for which the federal government would pay 90 percent of the cost. By July 1, 1964, North Dakota had completed 242 miles of its allotted 570 miles in the interstate system, spending nearly $\$ 102,000,000$.

\section{THE OIL BOOM}

The discovery of oil on April 4, 1951, brought another revolution in North Dakota life. It came after many years of exploration. In 1916 the Pioneer Oil and Gas Company had begun drilling the first wildcat well three miles southeast of Williston. The next year, A. J. Collier of the United States Geological Survey discovered the Nesson Anticline along the eastern edge of Williams and McKenzie counties. In 1927 some Williston businessmen formed the Big Viking Oil Company and began drilling on the anticline; the firm ran out of money at 4,680 feet in the mid-1930's. The California Company, with ample backing and a capable technical staff, spudded in a well in 1937 about a quarter of a mile from the abandoned Big Viking hole. The following summer it gave up at 10,281 feet, having missed the productive Beaver Lodge Field by only three and a half miles. Soon a dozen major oil companies were assembling properties for exploration. They drilled eleven dry holes before the Amerada Petroleum Corporation discovered oil in April, 1951. In the first seventeen hours, the Clarence Iverson No. 1, the discovery well, produced over three hundred barrels of oil.

The discovery set off an exciting boom. Wildcat drilling mushroomed, and by the end of the year nearly two-thirds of the state was under lease. Crowds of strangers - oil operators and scouts, promoters, geologists, drillers, lease buyers and brokers, as well as unskilled labor-invaded the oil region. The newcomers turned granaries, sheds, and garages into 
living and business quarters. They and their families jammed community services, crowded schools, wore out roads, and brought on a boom which meant dozens of new enterprises, ranging from lunch counters to oilfield equipment houses. Steel derricks dotted the plains; drillers and geophysical crews searched for the limits of pools; storage tanks went up beside the wells; gas flares lit up the night. Tioga, the new oil capital near the Clarence Iverson No. 1, grew some 250 percent in three years, and Williston had eight hundred persons living in trailers by the fall of 1953.

Oilmen and speculators sought drilling leases and mineral rights all over the Williston Basin. The basin, a saucer-like depression in the granite of the earth's crust, contained sedimentary strata which under-lay western North Dakota and parts of Manitoba, Saskatchewan, Montana, and South Dakota. In 1948 leases had gone for ten cents an acre, but even before discovery some were bringing as much as a dollar; after discovery most were sold for a dollar per acre plus large bonuses. In addition to the drilling-lease business, there was brisk traffic in the sale of mineral rights. Although some ill-informed land-owners sold their rights for as little as sixty-two cents an acre, others received from one hundred to seven hundred dollars, with a few tracts going for two thousand dollars an acre. Outside the oil fields, however, most mineral rights brought less than thirty dollars an acre.

Seismograph crews fanned out over the Williston Basin in search of oil. Some 150 companies, many of them one-shot combinations, drilled wildcat wells to find new pools, but Amerada Petroleum Corporation performed most of the exploration. Each year, a few of the wildcats struck oil (6 out of 58 in 1955, for example), and by 1959 they had found 77 oil pools in North Dakota. Because the oil lay so deep, sometimes at 14,000 feet, drilling was unusually expensive. The Clarence Iverson No. 1 cost Amerada \$721,000, and other wildcats cost half a million. Even after drillers found a pool, development wells cost some \$200,000 each. They found most of the pools on the Nesson Anticline, stretching northsouth in a narrow, 73-mile-long belt from a point north of Tioga to northern Dunn County. But wildcatters also found oil off the anticline: near Westhope in Bottineau County, in northern Burke and Divide counties, and in less-productive pools in Stark and Billings.

The oil companies put much money into exploration and development, and oil production steadily increased. By the end of 1960 the oil industry had invested an estimated \$650,000,000 in North Dakota. By April, 1961, ten years after discovery, 2,806 wells had been drilled and $110,000,000$ barrels of oil produced, worth, with the gas which accompanied it, some $\$ 280,000,000$. Oil production was then $2,000,000$ 
barrels a month, and the state had an estimated 2,000,000,000 barrels in reserves. It stood tenth among the oil states. ${ }^{8}$

The obstacle was markets. North Dakota's remoteness, the lack of refineries, and the world surplus of crude ("We have oil running out of our ears,” said C. E. Boone, vice-president of Amerada) posed serious problems. Important steps to solve them were soon taken. In the summer of 1953, Standard Oil of Indiana was building a 30,000-barrel, $\$ 25,000,000$ refinery at Mandan, a 157-mile crude-oil pipeline from Tioga to Mandan, and a 207-mile products pipeline from Mandan to Moorhead. The Signal Oil and Gas Company was building a $\$ 17,000,000$ natural-gasoline and sulphur plant at Tioga. Other firms built small refineries at Williston and Dickinson. The facilities at Mandan and Tioga soon furnished a market for North Dakota crude and also for the gas which came out of the wells.

Oil from the Nesson Anticline went largely to the refinery at Mandan, but companies with wells in Bottineau, Burke, Divide, and Renville counties had to send their oil by tank car to refineries in Minnesota and Wisconsin. There it competed with Canadian oil moving to the same refineries through pipelines, a much cheaper method of transportation. Marketing was difficult. Because of the world-wide surplus of crude oil, North Dakota wells could produce much more than their markets would take. The North Dakota Industrial Commission estimated the demand each month and gave each well a quota. At the end of 1959, for example, the quota was only twenty-eight barrels a day, although some wells could have produced four hundred.

The market, however, gradually expanded. The Soo and Great Northern railroads helped by reducing rates on tank-car shipments. By the end of 1959 the capacity of the Mandan refinery was up to forty-five thousand barrels a day, and the Minnesota and Wisconsin refineries were taking larger amounts of North Dakota oil. But the profits seemed modest. Oil from the northern pools was then bringing only \$2.09 a barrel at the wellhead, from the Nesson Anticline only \$2.95.

In spite of it all, the oil industry moved North Dakota toward a more diversified economy in the 1950's. In 1951, during debate over a 4.25 percent gross-production tax in lieu of other taxes on the new industry, one state legislator said that a higher tax would be "poor psychology, when we're trying to attract industry to our state."

\section{GARRISON DAM AND DIVERSION PLANS}


The outcome of long-maturing plans to harness the waters of the Missouri River for electrical power and irrigation was a distinct disappointment. Irrigation had long seemed a natural adaptation to the needs of the semiarid North Dakota country. Talk of diverting the waters of the Missouri eastward began as early as 1889. The first irrigation in the state was from works built in 1905 and 1906 by the United States Bureau of Reclamation on the Lower Yellowstone and on the Missouri near Williston.

Farmer interest in these projects lagged, and they were operated only intermittently. In the 1930's, however, drought stimulated new interest. The North Dakota State Planning Board believed that irrigation in the western sections of the state could check the loss of population, help local business, and bring greater stability but that it would not remove all of the hazards of dry-land farming. Work-relief projects created 312,000 acre-feet of water storage in western North Dakota, but it was more useful for livestock, recreational, municipal, and wildlife purposes than for irrigation. In the late 1930's the North Dakota Water Conservation Commission built three irrigation works to water some 15,000 acres.

The great hope for irrigation, however, lay in the diversion of water from the Missouri River. A number of people had taken up the idea in the 1920's, and in 1924, Sivert W. Thompson and the people of Devils Lake formed the Missouri River Diversion Association. By 1935 the Corps of Army Engineers was talking about a great earth dam across the Missouri near Garrison. In 1942, W. G. Sloan of the Bureau of Reclamation presented a plan to divert water from below Fort Peck Dam, in Montana, to irrigate more than a million acres, mostly in the CrosbyMohall region in the northwestern corner of North Dakota.

After damaging floods on the Lower Missouri in 1942 and 1943, Colonel Lewis A. Pick of the Army Engineers drew up a plan for six giant dams on the main stream of the Missouri and ninety-nine or more on its tributaries. Pick's plan aimed at flood control and navigation, Sloan's at irrigation and hydroelectric power. Pick's plan appealed to the states of the lower river, Sloan's to the states of the upper river. The Farmers' Union, the St. Louis Post-Dispatch, organized labor, and President Franklin D. Roosevelt wanted a Missouri Valley Authority patterned after the Tennessee Valley Authority. When the M.V.A. bills appeared in Congress, the Army Engineers and the Bureau of Reclamation compromised their differences to form the Pick-Sloan Plan. Accepted by Congress in the Flood Control Act of December 22, 1944, it included both Garrison Dam for flood control and power and the Missouri-Souris Diversion Unit for irrigation. 
By October, 1947, giant earth-moving machines were piling up the embankment of Garrison Dam. As the years passed, some 2,300 men (peak employment in September, 1952) shaped what was at that time the largest rolled-earth dam in the world-12,000 feet long, 210 feet high, 2,600 feet wide at the base and 60 feet at the top-in all, 70,000,000 yards of earth and 1,500,000 yards of concrete. In some years, 300,000 visitors came to see the great dam taking shape. In the spring of 1953, round-the-clock shifts of workmen dropped load after load of boulders into the channel, closed the dam, and diverted the river into the giant tunnels. In January, 1956, they put the first three of the five 80,000kilowatt generators into service. By 1960, with $\$ 294,000,000$ spent, the great dam was virtually complete, and above it the muddy Missouri was turning into a blue lake which reached 200 miles upstream to Williston.

As work on the great dam went forward, the Bureau of Reclamation built three multiple-purpose dams (municipal water, flood control, irrigation, and recreation) at Dickinson, Heart Butte, and Jamestown at a cost of eleven million dollars. It also revived the Buford-Trenton irrigation project near Williston and began irrigation at Fort Clark. But benefits from these projects were small. Not all of the land in them was being irrigated, suggesting that irrigation was a marginal practice in a region in which the rainfall was adequate or nearly so much of the time. By 1959 some 48,000 acres were being irrigated in North Dakota, only two-tenths of one percent of the crop land of the state. Half the irrigated land was in private projects which pumped water from rivers and lakes.

The scheme for irrigation by diversion of the Missouri River, though authorized by the Flood Control Act of 1944, met frustrating delays. Sloan's original plan, called the Missouri-Souris Diversion Unit, provided for a canal which would carry water from below Fort Peck Dam to irrigate a million acres in the Crosby-Mohall region. In 1947, however, surveys began to reveal that drainage problems, caused by the unusual density of the glacial subsoil, made virtually all of the one million acres unfit for irrigation. Seeking suitable land, the Bureau of Reclamation found a million acres in the drainage of the James and Sheyenne rivers south and southwest of Devils Lake. The chosen areas, once covered by glacial lakes or glacial outwash, were small and intermingled with nonirrigable land. Moreover, this land had more rainfall and hence much less need for irrigation than did the CrosbyMohall region.

In January, 1957, the Bureau of Reclamation finally reported its new plan, renaming it the Garrison Diversion Unit. Huge pumps were to lift water from Garrison Reservoir to Snake Creek Reservoir, from which the 73-mile McClusky Canal would carry it to Lonetree Reservoir on the 
headwaters of the Sheyenne River. From Lonetree, canals would carry the water to the lands to be irrigated and also to Devils Lake. The plan called for 6,773 miles of main and lateral canals (a mileage in excess of the state highway system), 8 reservoirs, water supplies for 41 towns, 656 pumping stations, and 9,300 miles of drains. To be built over a period of sixty years, the project would cost an estimated \$529,000,000 at 1956 prices. (By way of comparison, in 1954 the value of all farm land and buildings in North Dakota was only $\$ 1,500,000,000$.)

The obstacle to the plan was, of course, the enormous cost. It was so great that the irrigators themselves, who usually paid for the whole cost of Bureau of Reclamation projects, could be expected to pay only 15 percent, even with payments spread over fifty years and bearing no interest charge on the capital invested. The towns receiving water supplies would pay something, and some millions could be charged to flood control and recreation and so come from federal taxes, but the Bureau proposed that more than 80 percent of the cost come from the surplus revenues of the Missouri Basin hydroelectric power plants. This meant that users of power from government dams throughout the Missouri Basin would be taxed to pay for the Garrison Diversion Unit. The power plants, the Bureau calculated, would have paid for themselves by the year 1994; their revenues could then be applied to the diversion unit and pay for it by A.D. 2015. The Bureau justified the colossal undertaking by an analysis of the indirect benefits which would, it argued, stabilize the economy of North Dakota. It predicted that completion of the diversion plan would increase the population of North Dakota by 95,000 , increase farm income by $\$ 55,000,000$ a year, increase trade by $\$ 144,000,000$ a year, and create 1,699 new business establishments. $^{9}$

Would the benefits justify an investment in irrigation works of more than five hundred dollars an acre in order to treble the production on a million acres? The cost of the Buford-Trenton works near Williston had been only thirty-eight dollars an acre, yet that was considered excessive by irrigators. North Dakota farmers had taken nearly three million acres out of production in the 1950's by putting them in the Soil Bank. Clearly,

\footnotetext{
${ }^{9}$ United States Bureau of Reclamation, Garrison Diversion Unit, 1960, 86 Cong., 2 Sess., House Document 325, pp. 84-85. Other sources on irrigation are North Dakota State Water Conservation Commission, North Dakota Water Resource Development Projects (Bismarck, 1955); North Dakota State Planning Board, Irrigation in North Dakota, prepared by Oscar Becker (Grand Forks, 1937); and North Dakota State Water Conservation Commission, Development of Irrigation, Municipal Water Supplies, Electric Power, Flood Control in North Dakota (Bismarck, 1948).
} 
additional farm production was not very urgent. The one million acres to be irrigated made up only 5 percent of the crop land in the state. Since the irrigable land was scattered in small tracts, it would probably work out that about 15 percent of the state's farmers would each have from 120 to 160 acres of irrigated land on farms which would average more than a section in size. So, for the state, the question might be asked: would trebling production (the result of irrigation) on one-fifth of the land of 15 percent of the farmers make very much difference to the remaining 85 percent and the trading centers which served them?

It is obvious that the adoption of only slightly better farming methods or a small increase in farm-produce prices would bring a much greater benefit to the state as a whole than the completion of the Garrison Diversion Unit. For example, an increase of only 10 percent in productivity or a price rise of only 10 percent would mean an additional farm income of from fifty to sixty million dollars annually, the estimated increase in farm income which would result from the Garrison Diversion Unit. And such an increase in productivity or prices would benefit all farmers and their trading centers, not just 15 percent of them.

What about the individual farmer who might have a portion of his farm irrigated? Would he be better off by irrigating, or by using the capital irrigation would require to enlarge his dry-land farm to a size which would use both modern farm machinery and labor more economically? Each of the eight thousand or more farmers who would have some irrigated land would face a number of problems. Each would have to make a large investment, about $\$ 77$ an acre, to level the land and otherwise prepare it for irrigation. This would be in addition to paying, over a span of fifty years, 15 percent of the $\$ 529$ an acre (about $\$ 80$ an acre) which the irrigation works themselves would cost. Moreover, each farmer would need new managerial skills if he were to irrigate and dryfarm at the same time. An economic analysis by L. W. Schaffner of the North Dakota Agricultural Experiment Station showed that each farmer would need to find $\$ 16,000$ of new capital (largely for leveling the land and adding livestock) in order to benefit from completion of the Garrison Diversion Unit. Schaffner noted, however, that if the farmer invested the $\$ 16,000$ in expanding his dry-land farm, his return would be much larger than if he irrigated a portion of his original farm.

Although Schaffner's analysis raised serious questions about irrigation in a region which received adequate rainfall in at least three years out of every four, it was given little attention. No one in North Dakota publicly questioned the benefits of diversion, any more than he would motherhood, virtue, or patriotism. Any doubters remained silent. North Dakota's leaders seemed to see the plan as the solution to the state's 
problems, the cherished dream of escape from pressing difficulties. Moreover, they felt that "in equity" Congress owed North Dakota the Garrison Diversion Unit, for the state had sacrificed some 550,000 acres to the Garrison and Oahe reservoirs. Few benefits other than recreation had come to the state from Garrison Dam. Flood control aided mostly the down-river states. Cheap electricity had not brought industry to North Dakota, although in 1960 three-fourths of the power from Garrison generators was sold to North Dakota companies or cooperatives.

In spite of all the support for diversion, its huge cost. delayed congressional approval of the plan. The Bureau of Reclamation reported the plan in January, 1957; Secretary of the Interior Fred A. Seaton adopted it in June, but he did not send it to the President and the Bureau of the Budget until October, 1959. To meet the objections voiced in Washington, the Bureau of Reclamation worked out a revised plan to irrigate only 250,000 acres at a cost of $\$ 183,000,000$. The acting director of the Bureau of the Budget, Elmer B. Staats, thought the economic justification of the plan was "at best marginal" because it depended too heavily upon secondary or indirect benefits. He pointed out that the direct benefits were much less than the cost and that too much of the cost was assigned to the enhancement of wildlife and fish values. ${ }^{10}$ The project finally reached Congress in 1960, and committee hearings were held. But in 1962 the Bureau of Reclamation raised the estimated cost of the reduced plan from $\$ 183,000,000$ to $\$ 218,000,000$. It had found the irrigable land to be more scattered than it had first thought. North Dakota Senator Quentin N. Burdick called the increased cost "a severe blow to this project.” Finally, in July, 1965, Congress accepted the plan, although it did not appropriate any funds for construction.

\section{THE REPUBLICAN ORGANIZING COMMITTEE}

When the war ended in 1945, North Dakota was both Republican and conservative. Republicans of the two factions, the Republican Organizing Committee and the Nonpartisan League, held all of the state offices and the congressional positions. There were only 7 Democrats among the 162 members of the state legislature. The more conservative Republican Organizing Committee dominated the political scene.

The election of 1946 revealed the weakness of both the Nonpartisan League and the Democratic party. In the primary, Governor Fred G. Aandahl (R.O.C.) won the Republican nomination for re-election over

${ }^{10}$ Garrison Diversion Unit, Missouri River Basin Project, Hearing before the House Sub-committee on Irrigation and Reclamation, 86 Cong., 2 Sess., June 10, 1960, on H.R. 1891 and H.R. 1963, pp. 1, 49. 
his Nonpartisan League opponent by a three-to-one margin. The fall election was a Republican sweep. Against Aandahl the Democratic candidate for governor, Quentin N. Burdick, could carry only two counties, and the R.O.C. took control of both houses of the legislature. There was more interest in the two senatorial contests. In a June special election, Milton R. Young easily retained the Senate seat to which Aandahl had appointed him after John Moses' death. In the primary, Joseph B. Bridston, endorsed by the R.O.C., attacked Senator William Langer for his vote against the United Nations, and Life magazine asked North Dakota voters to take Langer out of the Senate. But Langer beat Bridston by a narrow margin and in the fall election won over the Democratic candidate by better than two to one.

Conservative success led to attacks upon the Farmers' Union cooperatives in the 1947 legislature. Two of the anti-Farmers' Union bills authorized the state insurance commissioner to terminate fraternal insurance company licenses annually and to require all mutual insurance companies to maintain a 100 percent reserve on premiums. (In 1944 the state insurance commissioner, an old Leaguer, revoked the license of the Farmers' Union insurance agency, the National Union Security Association, but the revocation was rescinded in 1945 after the death of the commissioner.) A third bill applied the state corporation income tax to all surplus earnings of cooperatives not distributed to patrons in cash.

During the fight which followed, Senator Carroll Day, a Grand Forks attorney for several insurance companies, threatened Glenn J. Talbott with an investigation of Farmers' Union insurance activities which he said would give the organization a million dollars' worth of bad publicity. But Milton R. Young, himself a farmer, warned the Republican Organizing Committee against becoming "purely a businessman's party.” Some R.O.C. legislators voted against the bills, and they were all defeated by narrow margins. ${ }^{11}$

The 1947 attack upon the Farmers' Union brought that organization into politics. President Talbott asked Farmers' Union leaders: “Do we dare any longer to remain inactive in the selection and election of candidates for political office?” In June the leaders decided to form the Farmers' Union Progressive Alliance and to unite with like-minded groups. Early in 1948 the Farmers' Union, the Nonpartisan League, and organized labor formed the Committee for Progressive Unity, and the League convention endorsed a ticket representing the three groups.

\footnotetext{
${ }^{11}$ Ross B. Talbot, "The Politics of Farm Organizations in North Dakota" (Unpublished Ph.D. dissertation, University of Chicago, 1953), pp. 167-170; Grand Forks Herald, February 28, 1947. The Herald has been used as the chief source for recent political developments.
} 
Although the Farmers' Union-Nonpartisan League coalition could not prevent the re-election of Governor Aandahl for a third term, it did elect some state officials, a majority of the lower house of the legislature, and Usher L. Burdick to the House of Representatives. Burdick had not been in the House since 1945.

The Farmers' Union soon found its venture into politics disappointing. The North Dakota Union Farmer criticized some Nonpartisan League leaders for a lack of liberalism, saying that such men as Math Dahl had "divorced themselves from the true liberals" who made up the League. On the other hand, it complained that some R.O.C. legislators were trying "to appear” liberal. The 1949 legislature did defeat a bill which would prevent cooperatives from paying Farmers' Union dues for their patrons out of patronage dividends, like labor unions' check-off system.

Farmers' Union leaders decided to get out of politics, for their followers belonged to all political factions. Still, they wanted a union of liberals in the state and believed that the existing division of liberal strength was unrealistic. They favored the Democratic party as the "more progressive and liberal” on such issues as cooperatives, parity for farmers, national health insurance, and public power. The result was a new proposal. In January, 1950, a meeting of Farmers' Union county officers adopted a resolution urging the Nonpartisan League to file its candidates in the Democratic column for the coming election. ${ }^{12}$ This proposal was eventually to change the character of politics in North Dakota and to make it really a two-party state. But in 1950 the Nonpartisan League emphatically rejected the idea. The convention voted it down, 220 to 48, and endorsed a slate of candidates most of whom opposed the Farmers' Union. The 1950 League platform did not support one Farmers' Union policy.

The Democratic party warmly welcomed the Farmers' Union, inviting all county presidents to attend the convention as delegates. It endorsed a slate of liberal candidates and adopted a platform close to the Farmers' Union 1949 statement of principles - the Brannon Plan, a Missouri Valley Authority, and repeal of the Taft-Hartley Act and the North Dakota antilabor laws. The Democratic candidate for governor was Obed A. Wyum, a Sargent County farmer active in the Farmers' Union; a candidate for Congress was Ervin Schumacher, a director of the Farmers' Union Grain Terminal Association.

The 1950 election, however, was a conservative victory. Wyum did not even win the Democratic nomination in the primary, and although a number of Nonpartisan League incumbents won Republican 

nominations, they did not represent a liberal trend. In the fall election, all Republican candidates won by wide margins, and the election of Norman Brunsdale as governor, Milton R. Young as United States senator, and Fred G. Aandahl as United States representative, as well as R.O.C. control of both houses of the state legislature, made the outcome a solid conservative success. The re-election of Usher L. Burdick to the House of Representatives was the only liberal victory. Aandahl took the House seat held by William Lemke, the Prairie Rebel, who had died on May 30.

The election of 1952, except for the re-election of Langer to the Senate and Burdick to the House, was another conservative victory. Aided by Democratic votes, Langer easily defeated Aandahl in the primary for the senatorial nomination. Russian-born Otto Krueger took over Aandahl's seat in the House; Krueger was the first North Dakota German Russian to attain that distinction. Brunsdale won a second term as governor, but the Nonpartisan League took control of both houses of the legislature away from the Republican Organizing Committee.

\section{AN ISOLATIONIST TREND}

The election of 1952 in North Dakota showed that the state was moving back toward its earlier isolationist position. Immediately after the Second World War, both the state's leading newspapers and the North Dakota Farmers' Union had supported a bipartisan internationalist foreign policy. A poll in 1948 revealed that North Dakotans favored the Marshall Plan for aid to Europe.

There was, however, a continuation of isolationism. Senator Langer voted against the United Nations and both Langer and Representative Burdick voted against the Marshall Plan. Although Senator Young, the most internationalist member of the state's congressional delegation, at first supported foreign aid, both he and Langer voted against the North Atlantic Treaty. Lemke and Burdick voted against appropriations to arm the North Atlantic Treaty Organization. The state's opposition to universal military training had some of the earlier anticapitalist, anti-Wall Street overtones.

The Korean War, beginning in 1950, strengthened the isolationist trend in North Dakota as it did in the nation. During the war, the state legislature called for the evacuation of American troops from Korea; a senate resolution asked for the conscription of wealth, and Governor Brunsdale even wanted the withdrawal of army recruiters from North Dakota. When in the 1952 campaign Dwight D. Eisenhower promised to go to Korea to end the fighting, Adlai E. Stevenson failed to carry a single county in the state. It was clear that North Dakotans persistently 
opposed war, whether it was against Imperial Germany in 1917, against Nazi Germany in 1939-1941, or against Communist Russia and China in the postwar years. Thus one antiwar citizen wrote the Nonpartisan League Leader on March 27, 1952: "Mud throwers of today... link us with 'commie fronts.' Yesterday we were pro-Nazi and before that proHuns.”

Langer, when alarmed at the danger of war over Formosa, voted against the alliance with Chiang Kai-shek. A poll showed that by January, 1956, the state was overwhelmingly opposed to foreign aid. In the campaign of that year, the Republican state convention called the Democrats the war party, and Usher L. Burdick promised that there would be no more killing if Eisenhower were re-elected. Langer said: "The issue is: Shall we have more carloads of coffins?” Milton Young said that he opposed sending "our sons to the slaughter fields of Europe and Asia." In November, in spite of dissatisfaction with his farm program, Eisenhower carried the state easily. ${ }^{13}$

\section{MOVING TOWARD A TWO-PARTY SYSTEM}

The state, of course, was not entirely isolationist, just as it was neither entirely liberal nor entirely conservative. And by 1952 the traditionally liberal Nonpartisan League was itself divided into the "insurgents" and the "old guard." The insurgents were the more liberal, pro-Farmers' Union, pro-organized labor, and pro-Democratic party group. They looked upon the old guard as reactionary and wanted to take the League into the Democratic party. Gorman King, Wallace E. Warner, Anson J. Anderson, Ray Thompson, and Donnell Haugen were insurgent leaders; in 1952 they formed a Volunteers for Stevenson Committee.

The old guard, or "crowd," were the more conservative, anti-Farmers' Union, antilabor, and pro-Republican party group. They wanted to keep the Nonpartisan League in the Republican party; they supported Eisenhower for President. Ray Schnell, Albert Jacobson, Math Dahl, and Orris G. Nordhougen were old-guard leaders. William Langer, Usher L. Burdick, and Ralph Beede did not line up with either faction.

Both the Nonpartisan League insurgents and the Republican Organizing Committee wanted a two-party system. Working toward Republican unity, R.O.C. leaders held out overtures to the old guard, and in the 1953 legislature some of the old guard, deserting the League caucus, began to cooperate with the R.O.C. In April, 1954, the R.O.C. convention invited the old-guard Leaguers to join in a unity move. The

\footnotetext{
${ }^{13}$ Robert P. Wilkins, "Middle Western Isolationism: A Re-examination," North Dakota Quarterly, XXV (Summer 1957), 72-74.
} 
convention did not endorse candidates to oppose old-guard incumbents seeking re-election. Brunsdale, running for a third term as governor, appealed for the support of Leaguers who were "Republicans at heart."

For their part, the insurgent Leaguers and the Democrats drew closer together. The Democratic convention supported the constitutional amendment for a graduated land tax and adopted a thoroughly liberal platform for the 1954 campaign. Insurgent Leaguers and the Brotherhood of Railroad Trainmen supported Democratic candidates for offices where R.O.C. and old-guard candidates had the Republican nominations. But on election day the Republicans overwhelmed the Democrats by margins of nearly two to one. The following winter, a group of old-guard legislators worked with the R.O.C. in the house.

The fundamental realignment of North Dakota politics came in 1956. That year, the Nonpartisan League finally moved into the Democratic party, and all Republicans joined in one organization. In March the state Nonpartisan League convention, with the old guard absent, voted 173 to 3 to file its candidates in the Democratic column. It endorsed a full slate, including Wallace E. Warner for governor and Quentin N. Burdick for the United States Senate; it adopted a liberal platform-repeal of the Taft-Hartley Act, a minimum wage of $\$ 1.25$ an hour, 100 percent parity for family farms, and a graduated land tax on holdings worth $\$ 20,000$ or more. In May the Democratic convention accepted the Nonpartisan League's candidates and adopted its platform. The Republican unity convention, R.O.C. and old-guard Leaguers, endorsed a ticket headed by John E. Davis for governor and Milton R. Young for the Senate. The ticket also included old-guard incumbents and Leaguers, such as Usher L. Burdick, who had decided to stay with the Republican party.

In spite of party realignment, the Republicans won the 1956 election. In the primary, 58,000 Democratic votes were cast, the largest Democratic primary vote in the history of the state. Yet in the fall the Republicans won easily. The Suez crisis, Langer's bitter attack upon the Democrats as the war party, bad weather on election day (which cut down the farm vote), and Soil Bank payments of more than thirteen million dollars in 1956 - all these helped the Republican candidates.

Even so, the move of the Nonpartisan League into the Democratic party added many votes to those usually cast for Democratic candidates. Before the move, Democratic candidates for the lesser state offices generally received fewer than 50,000 votes, although they had done better than that in 1954. Since the move, they have generally received some 90,000 votes. The Nonpartisan League apparently brought 40,000 votes to the Democratic ticket.

Both before and after the move, however, the candidates at the head 
of the Democratic ticket always picked up a considerable number of what seemed to have been Independent or Republican votes, but which may have been Democrats who were not voting for the whole ticket. Thus in 1948, when most of the state Democratic candidates received about 50,000 votes, President Harry Truman received nearly 96,000 votes in North Dakota.

Many Nonpartisan Leaguers stayed with the Republican party after 1956. The example of William Langer and Usher L. Burdick, as well as that of old-guard leaders and years of loyalty to the Republican party, must have exerted a strong influence. Many of those who remained Republican were Leaguers of German Russian stock and lived in the strong League counties in the southwestern portion of the state. But elsewhere, many farm voters, strongly issue-oriented, moved into the Democratic party. Small-town voters tended to remain Republican. ${ }^{14}$

The result was that the union of liberals in the Democratic party still left that party a minority in North Dakota. The conservative leanings of the state were demonstrated by the outcome of the presidential elections, though isolationism and the threat of war complicated some of the contests. In 1948, both Republican factions, League and R.O.C., supported conservative Thomas E. Dewey. With the old radical William Lemke campaigning tirelessly for him, Dewey defeated Truman by 115,000 votes to 96,000 , but received some 16,000 fewer votes than did the popular conservative Fred G. Aandahl for governor.

In 1952 the old-guard Leaguers supported conservative Dwight D. Eisenhower, the insurgent Leaguers the more liberal Adlai E. Stevenson. Although Langer did not openly declare for Stevenson, he rode through the state on Truman's train as he campaigned for Stevenson. Eisenhower defeated Stevenson in North Dakota by 192,000 votes to 77,000. In 1956, when all Republicans, including Langer and Burdick, supported Eisenhower, he defeated Stevenson by 157,000 votes to 97,000. In 1960, Richard M. Nixon defeated John F. Kennedy in North Dakota by a vote of 154,000 to 124,000 . The percentages show the persistent but fluctuating Republican margin. Dewey had 52 percent of the North Dakota vote in 1948; Eisenhower had 71 percent in 1952 and 62 percent in 1956; Nixon had 55 percent in 1960.

Although the Democratic party was still the minority, the number of Democrats in the state legislature increased greatly. In 1955, before the Nonpartisan move into the Democratic party, there were only 5 Democrats among the 162 members of the two houses of the legislature.

${ }^{14}$ Ross B. Talbot, “North Dakota-A Two-Party State?” North Dakota Quarterly, XXV (Fall 1957), 99-102. 
After the move, there were 28 Democrats in the 1957 legislature, 67 in 1959, and 62 in 1961. For the first time in its history, North Dakota was actually becoming a two-party state.

Moreover, the strengthened Democratic party began to have some success. Each fall election became a close contest instead of a two-toone Republican landslide. Whenever an attractive Democratic candidate could add from 10,000 to 20,000 Independent or Republican votes to the some 90,000 votes cast for the rest of the Democratic ticket, he would win. Thus in 1958, Quentin N. Burdick became the first Democrat from North Dakota ever elected to the United States House of Representatives. His father, Usher L. Burdick then seventy-nine, did not seek re-election but campaigned for Quentin, saying bluntly: "North Dakota could not be worse off than they are under Republican administrations.” The younger Burdick, a Fargo attorney close to the Farmers' Union, had the support of the A.F.L.-C.I.O. Committee on Political Education and the many Indians whom his father had befriended throughout a long public career. Miss Mary Louise Defender of Fort Yates, one of the first Indian girls to be named "Miss Indian America," was soon working in Burdick's Washington office.

In 1960, Burdick won William Langer's post in the Senate. Langer, haggard and underweight from diabetes, had been re-elected in 1958, beating the Democratic candidate without making a single speech or even an appearance in the state. After Langer died late in 1959, Burdick defeated John E. Davis, 104,593 votes to 103,475 , in a special election held in June, 1960.

That fall, another Democratic victory came when William L. Guy won the governorship, polling more votes (over 136,000) than any Democratic candidate since John Moses received 173,000 votes for governor in 1940. Although the Democratic victories of Burdick and Guy were the only important ones, the other Democratic candidates lost by only narrow margins. North Dakota had become a two-party state. 
CHAPTER 21

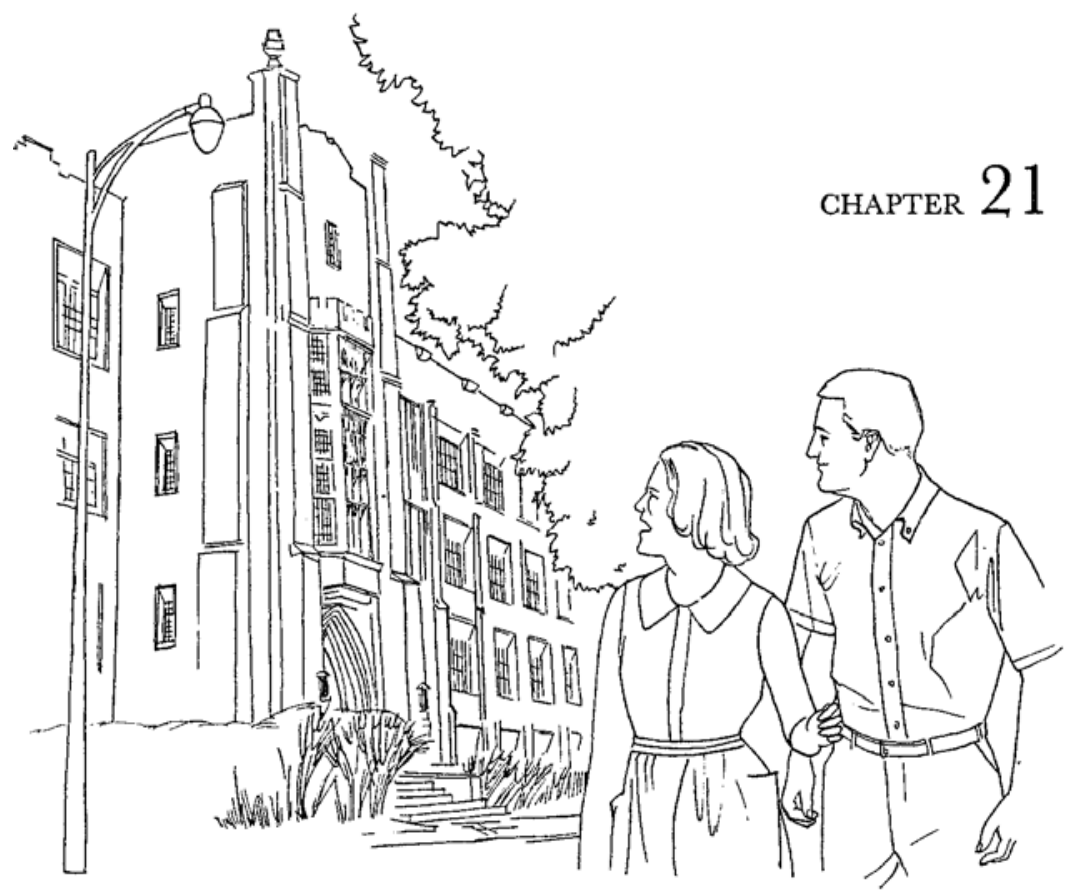

\section{Cultural Growth and Adaptation: Education, Research, Writing, and Medicine, 1920-1960}

IN A BROAD PERSPECTIVE the cultural development of the United States was an extension of that of Europe. American culture expanded European beginnings in a new setting. In turn, the new setting-the wilderness, free political institutions, relative isolation from Europe, the wealth produced by resources and human energies-influenced American cultural development by shaping the entire complement of social and cultural institutions: churches, schools, colleges, libraries, the search for new knowledge, the production of books and newspapers, and the provision of medical care.

Just as the cultural development of America sprang from that of Europe, so, too, did the cultural development of North Dakota derive from that of the United States. North Dakota was influenced by all of the national cultural currents of the 1920's, the Great Depression, and the postwar years. In the nation, schools improved, high school and college enrollments and 
expenditures grew, research and the dissemination of new knowledge expanded, and medicine and the fields of hospital care and public health were revolutionized. North Dakota shared in all of these trends; it looked to the nation for standards, and the national standards stimulated the state's own achievements.

And just as the development of European cultural beginnings in America was shaped by the new setting, so also was the development of American cultural institutions in North Dakota influenced by the North Dakota environment. The sparsely settled country, the rural agricultural economy, the remoteness of the state, the ethnic make-up of the population-these influenced the establishment of schools and colleges, the support for research and the subjects which concerned it, the provision of medical care, and all other cultural activities.

In 1920, North Dakota had a population of 647,000 scattered throughout an area of 70,000 square miles. Most of the people were living on farms or in small villages; only 14 percent lived in the twelve urban centers with populations over 2,500. Outside such places, the population was only eight persons per square mile. Rapidly growing Fargo, the largest town, had a population of only 22,000 in 1920.

These factors determined the relative failure or success of all social and cultural institutions. Because there were only a few persons per square mile, schools and colleges, churches, libraries, newspapers, hospitals, and doctors had to serve large areas, an expensive and difficult business, or suffer from the lack of both people to serve and financial support. Yet in spite of these and other obstacles, their story is one of substantial cultural achievement.

\section{THE RURAL SCHOOLS IN THE TWENTIES}

Two things were true of the public schools of North Dakota. First, they were deeply influenced by the nature of the country, the sparseness and rural character of the population, and the uncertainties of the agricultural economy. Such conditions made it difficult for the state to meet the rising educational standards of the nation. Second, by every measure-mass participation, large expenditures, and vital goals - the schools were the state's most important cultural activity. Thus in 1920-1921 they enrolled 169,000 pupils, more than one-fourth of the population; they paid eight million dollars in salaries to 8,179 teachers; they sought to transmit the state's cultural heritage and to undergird both democracy and the freeenterprise system. Both the conditions confronting the schools and their importance demanded that North Dakota adapt the system to the environment in order to overcome the difficulties it imposed. Only by such adaptation could the state attain the standard values of American life.

Yet in the 1920's, though pioneering days were over, many of the rural 
schools were weak. Almost half the pupils were enrolled in 4,335 one-room schools. The school term averaged only eight months; average daily attendance was only two-thirds of the enrollment; rural teachers were poorly trained and poorly paid. Many high schools were also weak. In 1921-1922 there were 630 high schools, but only 80 were rated as first class and only 146 were accredited. Of the 4,522 rural teachers in 1920-1921, only 2,876 were even high-school graduates and only 120 were normal-school graduates. Their average pay, soon to decline, was \$102 a month. In northwestern North Dakota, rural teachers were the lowest paid class of employees, below cooks and farm laborers, making only $\$ 400$ a year. Rural teaching, said an instructor at Mayville Normal, was "a last resort"; few normal-school graduates would take such positions. "It is tragic," wrote Professor W. E. Peik in his survey of the state's schools in 1930, "that almost two of three North Dakota rural schools have a new teacher each year, when the job is so difficult because it covers all grades, when supervision has to be inadequate at best, and when the teacher herself is so young." 1

Such weaknesses, however, were not found in the town schools, which had longer terms, good attendance, more adequate programs, and better trained and paid teachers. The school problem was a rural one. Everywhere in the nation difficulties sprang from sparseness in rural population and inadequate school systems; throughout the nation the rural child did not enjoy equality of educational opportunity. But in North Dakota and the other Great Plains states, the semiarid climate and the steadily increasing size of farms further diminished the farm population and made the problem more acute. Moreover, the inherited school system, created for common schools, could not provide adequate high school education in the countryside and the small villages.

In North Dakota the constitution made public education a state responsibility, but the legislature shirked it. After establishing school districts too small for high schools (not common in 1889) and setting up inadequate standards on the length of the school term, the certification of teachers, and the quality of equipment and instruction, the state turned its

${ }^{1}$ W. E. Peik, The Training of Teachers in North Dakota: A Survey Report (Bismarck: North Dakota Department of Public Instruction, 1930), p. 10. The principal sources on the schools are the files of the North Dakota Teacher (first published as The Associated Teacher); the biennial reports of the Department of Public Instruction; the North Dakota Educational Directory; the session laws and also compiled schools laws; North Dakota Tax Survey Commission, A Report of North Dakota's Tax System and Its Administration, Report No. 7 (Bismarck, 1936); and minutes and reports of the North Dakota Legislative Research Committee. There is much in the federal census reports and the Statistical Abstract. 
responsibility over to the 2,250 local school districts. These rural districts, generally a township in size, were too small as tax units, too small as administrative units, and, with the coming of the high school, too small as attendance units. If the rural children were not to be cheated, the system would have to be adapted to existing conditions.

In the struggle to adapt, schoolmen took the lead. In 1921 the North Dakota Education Association (that name was not adopted until 1922) employed a full-time executive secretary, started a monthly, The Associated Teacher, and began to work for school legislation. It called for many reforms to give equality of opportunity to rural children: larger school districts with the county as the unit for management of the rural schools; a county board of education which would appoint the county superintendent, taking the schools out of politics; a state board of education which would appoint the state superintendent, removing him from the "field of political football"; better teachers by at first requiring one year and later two years of normal training for certification; and the equalization of school taxes by having the state pay a larger share.

In the 1920's the association's program met with no success. Rural North Dakotans, though hardy, ambitious, and hospitable, were also conservative, individualistic, and isolated from stimulating contacts. Bred in a materialistic society which only asked how many acres were farmed, how much profit was made, many of them thought little of schooling and were content to follow the ruts of tradition.

Moreover, many farmers, not very prosperous, were reluctant to pay school taxes. In 1922 in one Red River Valley county, 55 percent of the school districts levied less than 5 mills, but the town districts levied 20.5 mills. Tax valuations, school levies, and per-pupil expenditures varied widely from district to district. For example, in 1922 the school districts in Williams County had an assessed valuation of $\$ 5,277$ per pupil, levied average school taxes of 17.7 mills, and spent an average of \$10.53 per pupil per month. The districts in Walsh County had an average assessed valuation of $\$ 10,906$ per pupil, levied an average tax of 4.1 mills, and spent an average of $\$ 10.71$ per pupil. The county averages, of course, concealed large differences between districts, many of which could easily have afforded more than they were spending.

Yet there was constant pressure to reduce spending for schools. The North Dakota Taxpayers Association secured repeal of the teachers' minimum salary law in 1922 and in 1923 persuaded the legislature to reduce the valuation of property for taxation from 100 to 75 percent of its value. That fall, the president of the association told the state teachers' convention that farmers and businessmen must have relief from extravagant expenditures for schools. 
North Dakota did spend more on schools proportionately than most of the states in the nation. In 1928 it ranked eighth in per capita spending and second in percentage of income spent on public education. But it ranked thirty-fourth in average teacher's salary, itself an indication of poor quality. The low rank was caused by many schools with small enrollments; only a few pupils per teacher meant expensive education, even though the teacher was poorly paid. Thus sparseness of population, small school districts, and schools with few pupils brought a poor quality of education. Larger school districts and schools and larger units for taxation, equalizing the burden, would soon have brought about better paid and trained teachers. But such a reorganization of the system would require transportation of pupils for considerable distances. In the 1920's, although North Dakota had no hard-surfaced roads, it was making rapid progress in grading and graveling the rural roads and had 183,000 automobiles by 1930, one for every 3.7 persons. Transportation was available for school reorganization.

There was, however, no reorganization, although some changes came in the 1920's. Public-school enrollment grew to an all-time high of 176,000 in 1923. Then, as the number of children from five to nine fell off, it declined to 169,000 in 1930. Enrollment in parochial schools, which had risen from 1,000 in 1910 to 8,900 in 1920, declined to about 8,500 in 1928. Public high schools grew rapidly. In 1920, 144 classified high schools enrolled 11,600 students; in 1930, 191 classified high schools enrolled over 20,000, and others were attending some 400 unclassified high schools. While teachers' salaries increased rapidly in a prosperous United States, they remained low in a not-so-prosperous North Dakota. In 1920 the average in North Dakota was \$728, in the United States \$871; in 1928 the average in North Dakota was $\$ 837$, in the United States $\$ 1,364$.

The state also lagged behind the nation in the preparation of its teachers. In 1920-1921 some 1,400 teachers were not even high school graduates; in 1921, however, a law required teachers to be high school graduates. But through the 1920's (in fact, until 1949, when, surprisingly, the requirement was reduced) the state gave teachers' certificates upon the completion of a meager twelve-week summer normal course. By the end of the 1920's only one percent of the teachers were not high school graduates, yet two-thirds of the rural teachers had less than a year's normal training.

The school term did not increase, averaging 167 days (less than eight and one-half months) in both 1920 and 1930, but children stayed in school longer. In the 1920's the number of eighth-grade graduates increased by 33 percent, the number graduating from high school by 132 percent. In 1929, 36 percent of those who had enrolled in the first grade eight years earlier finished the eighth grade; 57 percent of those completing the eighth grade four years before graduated from high school. By 1930 about one-fourth of 
the students graduating from high school were going on to college, and another one-sixth to normal school.

\section{THE SCHOOL CRISIS OF THE THIRTIES}

After the modest progress of the 1920's, the plight of the schools became desperate in the 1930's. Years of drought, depression, and tax delinquency brought many school districts to insolvency. In 1932 an initiated measure, sponsored by the North Dakota Taxpayers Association, reduced the valuation of property for taxation from 75 to 50 percent of its value. As assessed valuation and hence returns from local school taxes fell off, some 1,800 rural schools could levy less than one thousand dollars annually, the estimated cost of a standard school.

The crisis forced state-equalization payments to the schools. In 1935 the legislature passed a 2 percent sales tax to raise money for welfare and education and created a state-equalization fund, appropriating nearly four million dollars for it. It ordered that the fund be distributed, first, on a basis of need to school districts which could not pay for a minimum program; second, to pay tuition for nonresident high school students; and third, to all schools on a teacher-unit basis. The law also set up a high school correspondence division by which students living too far from a high school could do high school work by correspondence, attending a one-room school and receiving some supervision from the teacher.

Later legislatures changed details in the law and appropriated about three and one-half million dollars for each biennium. In 1940, initiated measures made it a settled policy that all sales-tax money should go for welfare and education, divided five-twelfths for welfare and seven-twelfths for education. The emphasis was upon aid to rural districts which did not maintain high schools. It helped them pay their teachers and keep their schools open. At first, most of the money went to the western counties, the ones hardest hit by the drought. In 1940, twelve western counties received 52 percent of that part of the appropriation to be distributed on the basis of need. State Superintendent Arthur E. Thompson called the equalization law "the most important school law ever passed in our state." By 1937 the state was paying 27 percent of the cost of the public schools, compared to 8 percent in 1929.

But the equalization fund did not solve the schools' problems, even the problem of support. The legislature refused to tie equalization payments to higher standards, as Thompson urged, or to equalize differences in taxable property between districts. In the late 1930's more and more school districts became insolvent; school boards cut salaries and hired uncertified teachers.

During the crisis, the teachers bore the brunt of hardship. Some went unpaid for months; others received warrants which they had to sell at a 
discount. In 1937, two-thirds of the rural teachers had salaries under \$500 a year. Some 60 percent of the rural teachers-disgusted with poor salaries, heavy teaching loads, and inferior professional status-changed schools every year. Yet in 1937 the people of North Dakota, who spent only $\$ 10,500,000$ on schools, were spending $\$ 23,300,000$ on cigarettes, snuff, hard liquor, beer, and amusement parks.

While the state faced a crisis in its school system, it could not or would not make the changes that were needed. Calling a conference of county superintendents and school officers in 1938, Governor William Langer asked: "Why should the school children in the one-room school house on the prairie not enjoy the same privileges of education as those that are more fortunate by living in the larger cities in the state?” The answer, though Langer apparently did not realize it, was found in an unsuitable system of taxation, administration, and attendance for the schools. The system inevitably produced many one-room schools and many small high schools with a low teacher-pupil ratio. The inescapable result was wretched salaries and poor schools, although even in 1935-1936, a time of disaster from drought and depression, North Dakota was still spending more per pupil than the national average.

There was little support for the reorganization so badly needed. In 1937 the legislature turned down significant reforms proposed by the North Dakota Education Association. The association asked for a four mill county equalization fund, the county as the school district with a board of education and an appointive superintendent, and decent salaries for teachers. Equalization was badly needed, for one district had an assessable valuation of only \$73l per pupil, while another a short distance away but with railroad property had an assessable valuation of $\$ 7,000$ per pupil.

In semiarid North Dakota, with its widely scattered population, distance was a major problem. The elimination of small schools, implied in the county-wide district, would require the transportation of pupils. The North Dakota Teacher declared in September, 1939: “The problem simply resolves itself into a question of maintaining rural and small high schools in every nook and corner of the state on a starvation basis for both teacher and pupil, thus giving each child at least a meager opportunity, or through certain combinations make better supported and better schools.”

In many rural schools, poor teaching, poor attendance, bad roads, absences for farm work, and a short school term took a toll. In 1929, Stanford standardized achievement tests showed that rural pupils in grades 6,7 , and 8 were three-quarters of a year behind the national norms and that rural pupils were a year behind city pupils in the same grade. ${ }^{2}$ In 1940 the

\footnotetext{
${ }^{2}$ Robert D. Cole, Educational Achievement in North Dakota City. Town, and
} 
average urban dweller over twenty-four in North Dakota had completed 9.8 years of school, the average farm dweller 7.9 years.

There were at least some changes, if few improvements, in the schools during the 1930's. As the population grew older, enrollment fell from 169,000 pupils in 1930 to 140,000 in 1940 . During the same years the number of high school graduates increased 38 percent. The average school term declined by a day. The average of all teachers' salaries, including superintendents, fell from \$956 in 1929 to \$569 in 1935, then rose to \$719 in 1939, about half the national average. As the countryside lost population, the number of one-teacher schools declined from 4,336 in 1929 to 3,655 in 1939, but the number of school districts increased slightly. The total annual cost of the public schools fell from $\$ 15,800,000$ in 1929 to $\$ 10,300,000$ in 1939.

\section{POSTWAR SCHOOL PROBLEMS AND REFORMS}

Some of these trends continued into the Second World War and the postwar years. Public-school enrollment fell steadily until 1948, when it reached 113,000 . It then began a steady rise, reaching nearly 136,000 in 1960. Enrollment in parochial schools, after remaining nearly stationary at about 8,000 for twenty-five years, grew rapidly after the war, reaching some 20,000 by 1960 . As farms became larger and the farm population smaller, the number of one-room schools continued to decline. There were 3,043 in 1945 and 1,143 in 1960. With wartime prosperity, teachers' salaries rose to an average of \$1,303 in 1945 and continued upward after the war, reaching $\$ 2,018$ in 1949 and \$4,121 in 1960. In 1958 salaries ranged from less than $\$ 2,500$ to $\$ 8,950$; many janitors, working twelve months, had a higher yearly income than the teachers, working nine months. Total expenditures for the public schools rose spectacularly, especially in the 1950's: from $\$ 13,900,000$ in 1945 to $\$ 21,400,000$ in 1949 and to $\$ 51,500,000$ in 1960 . From 1949 to 1960, school expenditures increased some 140 percent, but the personal income of North Dakotans increased only 63 percent.

Larger expenditures and better salaries, helpful as they were, did not in themselves solve the problems of the schools. Many reforms were needed. The teachers and superintendents, acting through the North Dakota Education Association, pressed them upon the legislature. Before each legislative session, the N.D.E.A. policies commission prepared a program. It was ably aided, of course, by the superintendent of public instruction, the Parent-Teacher Association, and the investigations of the Legislative Research Committee, many of whose members were stalwart supporters of 

reform.

The education lobby was the strongest at the capitol. Often meeting much opposition in the legislature (its proposals, if enacted, frequently would have aroused the hostility of many voters), it was never entirely successful. Yet the schoolmen managed to secure notable reforms: in 1947 a schooldistrict reorganization law, a better minimum-salary law, a continuingcontract law, and improvements in the teacher-retirement system; in 1949 a county equalization fund; in 1953 and 1957 higher teacher-certification requirements; in 1959 a minimum high school curriculum and a foundation program of state and county support.

One persistent weakness was poorly trained teachers. For many years persons with only twelve weeks' training beyond high school were entitled to a second-grade elementary certificate. In 1949 the legislature, alleging a shortage of teachers, took a step backward by permitting a second-grade elementary certificate to be given to a person who earned twelve quartercredits in an eight-week summer session. To the disgust of the professional teachers, the law made it legal for the ill-trained to compete with the welltrained. Indeed, many teachers had no certificates at all; for years some boards had made it a practice to hire such persons, paying them poor salaries. In 1951-1952, out of 2,697 rural teachers, 399 had no training beyond high school, 1,062 had less than a year of college, and 724 had only one year of college; 1,287 held second-grade elementary certificates, and 545 had no certification of any kind. The number of uncertified teachers was actually increasing (651 in 1952-1953) in spite of the low requirements and the $\$ 300$ rural-teacher-training scholarships which the legislature began to offer in 1949. Paul Dalager, executive secretary of the North Dakota Education Association, said that the state's teaching standards were among the lowest in the nation.

Under pressure from Dalager and his fellow lobbyists, the legislature finally made the long-called-for reform. In 1953 it abolished the secondgrade elementary certificate; in 1957 it abolished the first-grade elementary certificate (one year of college training), making two years of college training, the requirement for the second-grade professional certificate, the legal minimum beginning in September, 1960.

The preparation of teachers improved rapidly. By 1959-1960 there were only 3 teachers without certificates, but 629 rural teachers, more than half the total, had one year or less of college training. The level of training improved greatly the next year, but there were still 245 teachers with as little as one year of college training.

The county superintendents, leaders of the rural schools, were themselves not too well prepared. In 1957 the legislature required them to have had a four-year college course, but did not make the law retroactive. In 1960 only 
sixteen of the fifty-three county superintendents met the requirement; the remainder were serving under the grandfather clause.

North Dakota had trouble keeping well-trained teachers, especially in the small high schools. Superintendents in other states, offering much higher salaries, sought teachers in North Dakota, where the small high school, with many diverse preparations for the teacher, old and limited equipment, and the isolation of village life, was unattractive to many. In 1958 the placement bureau at the University of North Dakota had requests for 3,133 high school teachers from 770 superintendents in 26 states. By the late 1950's, from one-half to two-thirds of the current college graduates prepared for teaching were taking positions outside the state. As a result, almost half the teachers in North Dakota were married women who had left teaching and later returned to it.

Teachers, of course, influenced the quality of schooling, but so did size. Most of the high schools were small and unable to offer much of a program-little in science and mathematics and almost no foreign languages. Gradually, many of the smaller ones were closing. In 1946 there were 433 high schools (compared to about 600 in 1930), but only 261 were accredited, although accrediting standards were low. Two teachers instructing in their majors and minors and a minimum of twenty-five pupils allowed minor accrediting. In 1960 there were 352 high schools, of which only 199 were accredited. By then a minor accredited high school had to have a minimum of three teachers instructing in their majors and minors and twenty-five pupils; a fully accredited high school needed only four teachers in majors and minors and forty-five pupils. Only 137 high schools were fully accredited.

The accrediting standards were much too low. Dr. Clair Blikre, superintendent at Stanley, thought that in order to offer a good program a high school should have a minimum of two hundred students and a dozen teachers. But in 1958-1959 only 42 high schools enrolled two hundred or more students; only 117 had more than one hundred students, and 157 had fewer than fifty. About 45 percent of the students attended high schools of two hundred or more; about 66 percent attended high schools of one hundred or more. That is, from one-third to one-half of the students were attending high schools too small to have a satisfactory program. State Superintendent M. F. Peterson called the small high schools "a weaker link in North Dakota's educational chain than the little elementary school." What, he asked, can such schools "offer in terms of the needs of our boys and girls in their preparation for life?"

Moreover, the smaller high schools generally cost more per pupil. Paying the best salaries and offering the best program, Fargo Central High School, the largest in the state, had a per-pupil cost of \$316 in 1958-1959; high 
schools with enrollments under one hundred pupils generally had per-pupil costs running over $\$ 400$ and sometimes from $\$ 500$ to $\$ 700$. Dean Martelle L. Cushman of the College of Education at the University of North Dakota, an expert on school reorganization, told an assembly of state legislators: "You must recognize that the smaller the school the more meager its offerings and the higher its cost." He added: "The easiest way to improve the quality in a small school is to increase its size." ${ }^{3}$

\section{THE EQUALIZATION REVOLUTION IN SCHOOL SUPPORT}

The condition of the small high schools pointed up the need for reform. The basic trouble was the small school districts-about twenty-five hundred of them at the end of the Second World War. They could give neither the needed financial support nor adequate educational opportunities; many had fewer than two dozen children of school age. Inequalities between districts with regard to assessable property, caused largely by differences in the amount of railroad property, required that financial support be equalized by levying school taxes over a larger area, such as the county or state.

From the early years of statehood, taxes levied by the local districts had not provided all of the school funds. Income from the school land grant of two sections in each township was substantial. In 1960 it paid \$2,600,000, or nearly 5 percent, of the cost of the schools. From the 1890's to 1948 a county levy, sometimes a mill and sometimes a half mill, was made for the schools. From 1899 to 1933 the legislature granted state aid to schools which attained certain standards, appropriating some $\$ 600,000$ per biennium for this purpose through the 1920's. After the war the state equalization fund, using sales-tax money, was paying some 19 percent of the cost of the schools.

The cost of high school education was most unfairly distributed. Beginning in 1935, the state equalization fund paid tuition for high school students attending classes outside the districts in which they lived, but these payments did not nearly equal the cost to the high school district. Since only about a fifth of the districts operated high schools in 1946, a large part of the people were not paying taxes to support high schools.

Such conditions finally produced equalization of school financing-the equalization revolution in the school system. The first step came in 1949 when the legislature created a county equalization fund based on a ten-mill levy on all property. The fund, aided by money from the state equalization fund, was to make large payments to all elementary schools in the county

\footnotetext{
${ }^{3}$ M. L. Cushman, "Some Factual Bases for Improving Elementary and Secondary Education in North Dakota" (Hectographed copy of an address to the North Dakota Legislators School, Grand Forks, November 26, 1960), pp. 20, 2324.
} 
on a teacher-pupil basis; the state fund was also to pay each high school ninety dollars per student. In 1949, before the law went into effect, state and county aid paid 27 percent of school costs; in 1950 such aid paid 41 percent.

The second step in the equalization revolution was a county-wide tax for high schools; for the first time, all property would bear taxes for high schools. The legislature established a county high school equalization fund with a one-mill levy in 1951, raised it to three mills in 1955, and to four mills in 1957.

The third and final step in the equalization revolution came in 1959 when the legislature established the Foundation Program. For it the legislature created a new county equalization fund based on a 21-mill levy. Aided by moneys from the state equalization fund, the new county fund was to pay each school 60 percent of the average cost per pupil, exclusive of the cost of physical facilities, transportation, and indebtedness. The basic payments were to be \$198 for each high school student and \$187 for each of the first twenty elementary pupils per teacher. One-room schools were to be paid more (\$225 per pupil), larger elementary schools less (\$150 per pupil). The law also provided half a cent per pupil-mile for transportation. The Foundation Program taxed all property for schools and equalized the burden between districts. But the legislature did not find new revenues, urgently needed, for the state equalization fund, and it did not use the Foundation Program to raise the standards of the high schools or to force school-district reorganization.

These failures were significant. The Foundation Program cost the state equalization fund $\$ 9,200,000$ in its first year and $\$ 10,400,000$ the second. The state fund supplied an average of 42 percent of the amounts paid the districts from the county equalization funds-10 percent in Slope County, 65 percent in Sioux County. The range showed that uniform assessments, a reform long debated but not yet enacted, were imperative. In 1961 the state equalization fund had money for only 80 percent of the payments to county funds required by the law.

\section{THE SCHOOL-REORGANIZATION REVOLUTION}

The equalization revolution in financing the schools was accompanied by a reorganization revolution in their administration. The latter came about through revisions which eliminated many of the small school districts. Involving sweeping change, it was more difficult than the equalization revolution and hence less successful.

Both revolutions stemmed from a growing realization of the inadequacy of the state's small yet costly schools. In 1951 1952, North Dakota was spending 3.2 percent of its people's income on schools, ranking third among all the states in this measure of school support and eighth among the states 
in per capita expenditures for schools. Yet in the percentage of its elementary teachers who had four years of college, it was forty-seventh among the states, and in the Korean War, 13 percent of North Dakota draftees failed the armed-forces qualifications tests, as compared with only 2.2 percent of Minnesota draftees.

A number of investigations of the schools from 1945 to 1960, many articles in the North Dakota Teacher, and statements by the state superintendent of public instruction emphasized the need for school reorganization. They also generated a desire for reform among many citizens. Thus a state committee reported:

Large numbers of boys and girls, men and women in rural sections all over the state are being robbed of opportunity for suitable education. Citizens are getting a low quality of education for their tax dollars in many places. Why? Because the school districts through which they buy education are too undersized and anemic to deliver a full measure of modern educational goods. ${ }^{4}$

Such conditions were common throughout the nation, and a national movement for school-district reorganization developed in the postwar years. Joining the movement, the North Dakota Legislature passed the state's first reorganization law in 1947. It provided for county committees to make plans for school-district reorganization, for a state committee to approve the plans, and, finally, for the submission of the plans to the voters of the districts concerned. Incorporated villages voted as a unit, as did rural territory; approval required a majority in both incorporated and rural territory.

The legislature, beginning the reorganization revolution with caution, provided neither reward for reorganization nor penalty for failure to reorganize. The 1947 law gave no aid for the transportation of pupils, set no minimum standards for the new districts, withheld no state equalization money from districts which failed to reorganize. Such deficiencies, reflecting the legislature's reluctance to force the issue, were understandable. Reorganization would generally mean not only increased expense for the transportation of pupils but also the closing of some schools. Economic interest opposed the first, community pride the second.

Yet there was immediate progress. From the spring of 1949 to June, 1951, there were 42 elections reorganizing more than 220 districts. One of the notable successes was the merging of 42 rural districts in Williams County

${ }^{4}$ Clair Blikre, "The Positive and Negative Factors Involved in Successful and Unsuccessful School District Reorganization Proposals in North Dakota"

(Unpublished Ed.D. dissertation, University of North Dakota, 1960), pp. 152-153. 
into New School District No. 8, with a taxable valuation of $\$ 4,800,000$. The new district continued the one-room schools, but painted the buildings, bought new equipment, and hired better teachers, paying them the best salaries in North Dakota and giving them free teacherages. Twenty-seven reorganization plans were defeated, generally by the rural vote.

In 1951 the legislature, responding to rural opposition, virtually stopped reorganization by an amendment to the 1947 law which required a majority in each district for any reorganization plan. From 1951 to 1957 only twenty plans were approved and forty-four were rejected, although 60 percent of the voters favored them. In Emerado, for example, reorganization lost through a tie vote in two districts, yet 75 percent of the voters favored reorganization.

Then in 1957 the legislature began to remove some of the obstacles to reorganization. That year, it required districts not maintaining high schools to pay nonresident tuition to the schools its students attended, removing an economic penalty for reorganization. It reinstated the provision that in voting on reorganization plans, incorporated areas should vote as a unit and rural areas as a unit; a majority in each brought approval, not a majority in each district. In 1959 it provided state aid for transportation of pupils, a definite encouragement to reorganization.

But the legislature steadily refused to force reorganization by tying it to either standards or equalization payments. It apparently judged the temper of the state correctly, for in November, 1958, the voters defeated an initiated measure requiring any district not operating a high school to become part of such a district within three years. The measure carried only four counties.

The legislature did show a growing concern for the small high school. In 1959 the Legislative Research Committee reported: "Some high schools have such limited course offerings and poor quality of instruction that they are high schools in name only, which in effect cheats the students who believe they are obtaining a high school education.” After hearing that report, the legislature established, for the first time, a minimum program for an accredited high school. After July 1, 1961, an accredited high school had to offer a minimum of twenty-two units in four years: four of English, three of mathematics, four of physical science, five of other required units, and six of electives.

Although there was no penalty for failure to establish the minimum curriculum other than loss of accreditation, reorganization did make much progress under the changed method of voting and the aid for transportation. From July 1, 1957, to June 30, 1961, voters approved 151 plans, rejected only 29; the number of school districts was reduced from 2,271 in 1947 to 
about 1,000 in $1961 .{ }^{5}$ And rapid highway construction in the postwar years made reorganization more feasible. In 1945, North Dakota had only about 1,600 miles of hard-surfaced roads; by 1960 it had more than 5,000 miles.

Still, reorganization often brought a bitter struggle between people favoring change and those willing to allow things to remain as they were. Persons favoring reorganization felt the urgent need for better schools; their opponents acted from a variety of motives. In some places, strong parochial schools seemed to be an obstacle; in others, such nationality groups as the German Russians seemed to favor the status quo. Some feared tax increases, for many districts levied nothing or almost nothing for schools. In Walsh County, for example, thirty-seven districts were not maintaining schools in 1960-1961. Reorganization would mean taxes and bond issues.

Antagonism between rural and town residents was also a knotty problem, for almost all plans meant the merging of rural districts with a town district. Many feared the deterioration of the community if the local school closed. Very few plans called for the combining of two or three villages into one district with the elimination of some small high schools. Indeed, some plans were defensive, designed to forestall just such an elimination through the formation of a still larger district. Some thought the small high school was adequate; others disliked the long distances the children would have to travel to school.

Where reorganization was successful, it was usually a result of the vigorous, courageous leadership of a county superintendent. Thus Miss Florence Rasmussen of Grand Forks County and Mrs. Luba E. Johnson of Rolette County compiled notable records. Stepping on the toes of objectors and ignoring the loss of votes, Miss Rasmusson, aided by many schoolmen and school officers, led Grand Forks County from 111 districts in 1947 to 34 in 1961 and was planning an early reduction to 5 districts in the county. Two of the victories were Larimore and Midway. Larimore united 24 old districts and had a high school of 275 students. Midway Special School District No. 128, a veritable model of reorganization, combined the high schools of Gilby, Inkster, and Forest River. It had a guidance counselor, a speech therapist, and a band-and-chorus instructor, as well as several teachers in science, mathematics, business education, and other subjects. Cass County, lacking such vigorous leadership, had twenty small high schools in 1961, many of them within a few miles of each other.

Many other counties made little progress, but even where changes were made, the results were often unsatisfactory. When a subcommittee of the Legislative Research Committee held hearings on reorganization in the

${ }^{5}$ Department of Public Instruction, "School Reorganization in North Dakota" (Mimeographed; [Bismarck], n.d.). 
summer of 1961, it heard much blunt criticism from schoolmen and school officers. The state had three or four times as many high schools as it needed and eight or ten times as many school districts, for the schoolmen told the committee that a reorganized district should have a minimum taxable valuation of two or three million dollars and a minimum of 150 to 200 high school students.

Most reorganizations did not even come close to such minimums. They did not substantially increase the size of the high school; that is, they did nothing to eliminate the some two hundred high schools which would have to be closed before every student had an opportunity for a good high school education. Thus the schoolmen criticized the State Board of Public School Education (established by the legislature in 1955) for approving inadequate reorganization plans. Such approval, they said, was generally followed by the construction of new buildings, which would make further reorganization very difficult. The board felt, however, that if it disapproved plans acceptable to the people involved, it would block any progress.

Many schoolmen felt that the state should assume a more active role in matters of education and tie state aid to accreditation. They believed that it should formulate a state-wide plan for school-district reorganization based on an unbiased study and should then force acceptance of that plan. But such a revolution, taking high schools away from a large number of the 249 incorporated towns with less than 500 population (a population in that range would have less than three dozen high school students), would clearly mean political suicide for the legislators and other elected officials who attempted it.

By 1961 the reorganization revolution begun by the law of 1947 was under way but far from completed. The goal of an opportunity for a good high school education for every student was yet to be achieved. Adaptation of the educational institutions to the conditions imposed by North Dakota's physical and political environment, painful and difficult as that would be, would have to be made if the state were to give its young people the education they needed.

\section{HIGHER EDUCATION IN THE TWENTIES}

Like the public schools, higher education in North Dakota was profoundly affected by the fluctuating fortunes of the state. In providing higher education, the state struggled with the problems of too many institutions, inadequate support, and poor quality. Such difficulties, of course, were not peculiar to North Dakota. Many states had too many small schools, inadequate funds, and low standards, and even at the largest, richest universities of the nation there were serious deficiencies. Whatever the problems, the colleges and universities in North Dakota and in the nation 
did grant opportunities and perform services which were of the utmost importance, not only to the young people who attended them but also to the state and nation. In North Dakota the 1920's were a time of rapid growth in enrollment and considerable expansion. The depression of the 1930's seriously handicapped higher education, but then in the postwar years, prosperity brought more students and money, enlarged programs and facilities, and higher standards.

When the 1920's began, North Dakota had ten institutions of higher education. One was a private, church-affiliated liberal arts school, Jamestown College, sponsored by the Presbyterian church and headed by dynamic idealist Barend H. Kroeze. A Netherlands-born graduate of the University of Michigan and McCormack Theological Seminary, Kroeze had taken over the abandoned institution in 1909 (it had been closed since 1893). He ran it until his resignation in 1946 at the age of seventy-eight. Winning support with his confidence and enthusiasm, Kroeze secured gifts, gathered a faculty, and constructed buildings. He won accreditation from the North Central Association of Colleges and Secondary Schools in 1924, when the college enrolled 378 students.

Of the nine state institutions, only the University of North Dakota at Grand Forks and the Agricultural College at Fargo offered four years of college work in 1920. The other seven offered only two years, as well as much high school instruction. Five of them were normal schools (Mayville, Valley City, Minot, Dickinson, and Ellendale) which trained rural and elementary teachers. The School of Forestry at Bottineau was really little more than a business college, although it had a tree nursery, and the School of Science at Wahpeton was largely a trade school offering work of less than college grade. In the 1920's the total enrollment of the ten institutions doubled, rising from some three thousand to about six thousand. Throughout the decade, the university and the Agricultural College, by far the largest institutions, had about half the state's college students.

The university, growing from some one thousand to sixteen hundred students in the ten years, was headed by Dr. Thomas F. Kane, a tall and dignified yet ingratiating classical scholar who had built up the University of Washington before coming to Grand Forks in 1913. Under Kane, the legislature provided money for Merrifield Hall and the law-school building. Fraternities and sororities built houses which still grace University Avenue, and students and alumni raised the funds for Memorial Stadium. Kane, however, was soon involved in a bitter feud with some of the best men on his faculty: energetic and respected William G. Bek; rotund, florid John M. Gillette, often called the "father of rural sociology"; tall, scholarly Orin G. Libby, an authority on North Dakota history; and others. The university did not advance as rapidly as the Agricultural College in the 1920's. 
The Agricultural College grew from some six hundred students in 1920 to over fourteen hundred by 1929, the largest increase enjoyed by any of the institutions. This was a tribute to the able leadership of Dr. John Lee Coulter, who served as president from 1921 to 1929. After growing up on a Minnesota farm, Coulter had graduated from the University of North Dakota, took a Ph.D. at the University of Wisconsin, and followed a varied career in education and government service. He was dean of the School of Agriculture at West Virginia University and director of its experiment station when, at forty, he accepted the presidency of the Fargo institution. There he not only increased the enrollment but also built up the staff, added two major buildings (Morrill Hall and the field house), broadened the programs offered, and raised academic standards. Coulter brought the world's leading scientists to the campus as guest lecturers. Speaking everywhere, he built up good will throughout North Dakota and made "Our State is Our Campus" the slogan of the college. He was effective, for, a farm boy himself, he spoke the farmer's language and could do the farmer's chores, a fact he liked to demonstrate as he traveled over the state.

Coulter's speaking activities were a part of the sharp competition for students among the state institutions. All needed to grow, for even the largest were small for their class, and increases in enrollment would mean increases in appropriations. To attract more students, all of the institutions lived under a strong compulsion to expand their offerings. In the 1920's the university established the School of Commerce, separated the School of Education more distinctly from the arts college, and organized a graduate program. Offering a Ph.D. as it did was then a questionable step, for the university had only a limited library (seventy-five thousand volumes), a heavy teaching load for its faculty, and few distinguished professors.

The biggest expansion of the decade, however, was the transformation of the two-year normal schools into four-year teachers colleges. The legislature authorized the move in 1921, and one after another, starting with Valley City in 1923 and ending with Dickinson in 1931, they made the transition and began to grant the bachelor's degree in education. With the change, they stopped admitting eighth-grade graduates and dropped much of their high school work. As they started training high school teachers, they also began to give college work to students not preparing for teaching. In both programs they were competing with the university, the Agricultural College, and Jamestown College, which were already meeting these needs and were much better equipped to give such work.

The competition for students and the accompanying expansion helped some institutions more than others. In 1929 the teachers college at Minot, serving a large area in the northwestern portion of the state, outstripped Valley City, until then always the third institution in enrollment. In 1931, 
Dickinson, the smallest of the institutions in 1920 except for Bottineau, outstripped Mayville by growing nearly 500 percent in a dozen years. ${ }^{6}$ Minot and Dickinson grew rapidly because they served large areas and populations without competition from nearby institutions.

Expansion in enrollment and the number of courses offered was not, however, accompanied by an increase in appropriations. The legislature appropriated some three million dollars for the state institutions for the 1921-1923 biennium and only four million dollars for the 1929-1931 biennium, although enrollment had doubled. As appropriations lagged behind, the institutions were unable to secure or retain faculty members with the proper training. Even at the university, salaries in the 1920's were below those in similar institutions in the nation, and there was a large turnover, averaging thirty resignations a year. As the normal schools became teachers colleges, they needed to upgrade their faculties, but they found that nearby states were paying salaries from 10 to 50 percent greater than they could offer. So they often had to tolerate inadequately trained instructors.

Part of the problem was that too many small institutions offering too many types of courses meant too many small classes, especially in advanced - work, where there were only a few students majoring in each department. In 1929, for example, some 26 percent of the classes had fewer than ten students. When Professor W. E. Peik of the University of Minnesota made a thorough study of the state institutions for the Board of Administration in 1930, he pointed out that only Maine had more teachers colleges and normal schools in proportion to its population than North Dakota. He concluded that the excessive number of small institutions doomed them to mediocrity. North Dakota was suffering from the Too-Much Mistake in higher education, just as it was in the public schools.

\section{A CRISIS IN HIGHER EDUCATION}

In the depression of the 1930's, the colleges and the university suffered even more severely. The legislature cut appropriations for all institutions, and the problem of faculty training and salaries, with its influence on the quality of instruction, became more acute.

New leaders at both the university and the Agricultural College took charge in the crisis. At the latter, Professor John H. Shepperd succeeded John Lee Coulter as president in 1929. After training at Iowa State College and the University of Wisconsin, Shepperd had joined the faculty in 1893.

\footnotetext{
${ }^{6}$ See table on enrollment in North Dakota Legislative Research Committee,

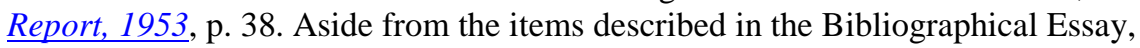
the sources on higher education are the session laws, the reports of the Board of Administration and later the Board of Higher Education, and reports of the Legislative Research Committee.
} 
A specialist in animal husbandry, he was in 1929 an honest, sociable man of sixty with a gray Vandyke beard who entered happily into the social activities of the students and faculty. He was not as successful as the new president of the university in wrestling with the problems of the hard years.

At the university, Thomas F. Kane's opponents forced his resignation in 1933, and John C. West became president. Then forty-seven, West had grown up on a Minnesota farm, taught rural school, graduated from St. Cloud Normal and Fargo College, served as superintendent of schools at Sauk Center and Bemidji, Minnesota, and earned a doctorate at the University of North Dakota. He was superintendent of the Grand Forks schools when he became the choice of university faculty leaders, such as Dean Bek and Professor Gillette. Gillette wired Governor William Langer: "West absolutely straight. You can trust him implicitly. Best prospect." West accepted the presidency at a reduction of nearly 50 percent in salary, a sacrifice which revealed his interest and loyalty. A sandy-haired man with homespun humor and pride in his craft as an administrator, he had a talent for storytelling and a readiness to conciliate and harmonize. He liked to call himself "a politician." He made friends with students, parents, and legislators, explained the university to the state, and in some way brought the school through the dark days of the depression.

It was a difficult task. In 1933 the legislature cut the appropriations for all institutions of higher education for the biennium to $\$ 1,600,000$ (they were $\$ 4,000,000$ in 1931). The university took a 55 percent cut, the Agricultural College a 59 percent cut. At the university the salaries of professors were reduced from $\$ 3,650$ to $\$ 1,914$, instructors from $\$ 1,943$ to $\$ 1,322$. Yet the state, as the North Dakota Teacher pointed out bitterly, paid poolroom and hotel inspectors $\$ 2,400$ a year. Although salaries were raised 7.5 percent in 1935, North Dakota paid its college faculties the poorest wage of any state in the nation. Many, of course, left; the Agricultural College lost fifty-seven from 1930 to 1936. Many of those who remained became embittered, and so the faculties deteriorated, falling behind in academic training and scholarly production. By 1936-1937 only 30 percent of the faculty at the university held doctorates, compared to 49 percent for public universities in the North Central Association of Colleges and Secondary Schools.

The depression convinced many people that North Dakota had more colleges than it could support. In 1933 the legislature ordered the Board of Administration to "eliminate all unnecessary duplication of courses"; in 1935 it called for "a thorough study of the feasibility of either consolidation or closing of some of these institutions." In 1936 the Tax Survey Commission found fault with the colleges' tendency to expand their programs and pointed out that North Dakota had more state-supported colleges than thirty-three other states. It concluded, however, that 
duplication was like the weather: everybody talked about it, nobody did anything. Although the distribution of many small institutions over the state had disadvantages, it did bring more young people into college classrooms. In 1937-1938, North Dakota had 105 college students for each 10,000 of population; it ranked a respectable twenty-fourth among the states in this matter. The counties with institutions had by far the most students in college. ${ }^{7}$

The depression hurt accreditation. In the 1920's the American Association of Teachers Colleges had warned the schools at Minot and Valley City that they must make improvements or lose their membership. In the 1930's, accrediting associations dropped several departments at the Agricultural College, and the Council on Medical Education and Hospitals of the American Medical Association announced that the University of North Dakota no longer had “an acceptable medical school”; it was allowed to continue, however, on a year-to-year probation. Then in 1937 the North Central Association took away the accreditation of the Agricultural College because of political interference in its administration. The action came after the Board of Administration, dominated by Governor William Langer, fired President Shepperd and seven veteran faculty members, four of them deans, without making any formal charges or giving them a hearing. Many people believed that the firings were an effort by Langer to build up a political machine by securing control of the extension service and the experiment station. These branches of the college employed some 3,200 persons and had a payroll of a million dollars a year. They also distributed some twenty million dollars annually to North Dakota farmers for compliance with the federal agricultural program.

Repercussions were immediate and significant. Angry students burned four members of the Board of Administration in effigy. Dr. A. F. Yeager, the famous plant breeder, resigned in disgust, lashing the board for wrecking the college. The alumni association started a petition for a constitutional amendment to remove control of the colleges from the Board of Administration and place it in the hands of a nonpolitical board of higher education. The amendment passed in 1938, and the new board, appointed by Governor John Moses, took over on July 1, 1939. Before that time, Moses had secured the reinstatement of both the Agricultural College's accreditation and the fired faculty members.

After this crisis, conditions improved. The North Central Association investigated the university but gave it a clean bill of health as free from political interference, and Phi Beta Kappa decided to leave its chapter on 
the university campus. Dr. Frank L. Eversull became president of the Agricultural College in the summer of 1938. A native of Ohio and an ordained Presbyterian minister, he was the head of church-affiliated Huron College in South Dakota and a vice-president of the North Central Association when appointed president of the Agricultural College. Under Eversull, a hard-working idealist, the school took on new life. Enrollment rose, and even athletics improved when in the fall of 19313 Ernie Wheeler led the Bison to a football victory over the university and its great Negro star Fritz Pollard. One long-standing problem persisted, however. In 1940 the Board of Higher Education reported: "The most serious problem... is the trying one of securing qualified members for the faculties. Young and inexperienced instructors can be found willing to serve for a year or two to gain experience.” But they were not what the institutions needed.

\section{POSTWAR EXPANSION IN HIGHER EDUCATION}

Enrollment in the state institutions increased to more than 7,000 by 19391940 , only slightly more than it had been at the end of the 1920's. It fell off sharply during the Second World War, down to less than 1,900 in 19431944. After the war, however, the colleges enjoyed their greatest boom. Enrollment rose to a peak of 7,800 in 1949-1950, fell off a couple of thousand in the early 1950's, and then rose steadily to more than 14,000 in the fall of 1961. Appropriations shot up, from \$3,600,000 for the 1945-1947 biennium to $\$ 24,000,000$ for the 1959-1961 biennium.

New leaders took charge. Dr. Fred S. Hultz, a 55-year-old Iowan with a doctor's degree in animal husbandry, became president of the Agricultural College in 1948. Eager for more ample funds, the new president bluntly told the legislature that "of the land-grant colleges in the United States, he didn't know of one as ill-equipped and so run-down as that of North Dakota." Aided by postwar prosperity and greatly increased appropriations, Hultz launched a ten-year plan for expansion. Though skillful in handling the budget and dealing with the legislature, he gradually began to make important decisions, such as establishing a graduate division, without consulting the faculty. The result was a bitter quarrel, the firing of four faculty members in 1955, and the blacklisting of the college administration by the American Association of University Professors. Hultz's greatest triumph was changing the name of the school to North Dakota State University of Agriculture and Applied Science by means of a constitutional amendment approved by the voters in 1960. That year, four land-grant colleges in other states made similar changes.

At the university, Dr. John C. West retired in 1954 after serving as president for twenty-one years (longer than any other president of the university and longer than any other state-university president then in 
office). In his later years, when new buildings were transforming the campus, he liked to call himself a "brick-and-mortar president." His successor was Dr. George W. Starcher, a farsighted, 48-year-old mathematician who had been dean of the arts college at Ohio University Athens. "The mission of the University," Starcher said in his inaugural address, "is to prepare men and women for life in a changing dynamic society."

Under West, Hultz, and Starcher, as well as the heads of the other colleges (O. A. DeLong at Mayville, Charles E. Scott at Dickinson, R. L. Lokken at Valley City, George W. Haverty at Wahpeton, and Casper Lura at Minot), the institutions of higher education moved forward in many ways. From 1947 to 1957 the legislature appropriated money for twenty major college buildings. In addition to these funds, bonds issued in anticipation of revenues built dormitories and student unions.

Stocky, white-haired, philanthropic Chester Fritz, a former Buxton boy who had prospered in the China trade, went into investment banking, and was living in Switzerland, gave a million dollars for a library building at the university, the largest contribution ever made to a North Dakota institution up to that time (in 1962, Edmond A. Hughes made a bequest of a million dollars for a fine-arts building at the university). Choking a bit with emotion at the dedication of the new library, Fritz said: "It means more to me to give with a warm hand.” A former university student, Fritz got idealism and his interest in the university in part from his aunt (now Katherine B. Tiffany) and her husband, Neil C. Macdonald, the crusading schoolman who died in 1923 after being pilloried as a socialist. By 1957, with much of the building still to come, the physical plants of the state colleges were valued at more than thirty-three million dollars; their value had been only five million dollars in 1932.

More colleges were established. Bismarck Junior College opened in 1939 and Devils Lake Junior College in 1941. Assumption Abbey at Richardton expanded the junior college and theological school it had begun in 1900. In 1956, Benedictine nuns began to hold the classes of Mary College at St. Alexius Hospital (Bismarck) and moved into the new priory at Apple Creek in 1959.

Bismarck Junior College prospered. After 1959 it benefited from a legislative subsidy of two hundred dollars per student. By the early 1960's it had a one-million-dollar building overlooking the Missouri River, plus six hundred students.

All of the institutions gradually expanded their offerings. Soon after the war the teachers colleges at Minot and Valley City began to give liberal arts as well as education degrees. At the university the one-mill levy for a medical center, passed in 1948 with a campaign slogan "Vote Yes for More 
Doctors," provided funds for a better medical school, a division of nursing, a program in medical technology, and a rehabilitation center. After the discovery of oil at Tioga, the university's geology department expanded rapidly, and in 1958 the university resumed the training of elementary teachers.

There was also much expansion of graduate work, both at the university and the Agricultural College. The university granted 15 master's degrees and a single doctor's degree in 1945, the last year of the war; in 1961 it granted 153 master's and 12 doctor's degrees. For all years before 1954 the Agricultural College had given only 18 master's degrees; it gave 69 in 1958 alone and had 310 graduate students enrolled in the fall of 1960.

The struggle for quality continued. Higher appropriations and higher salaries helped. Professional associations accredited departments at Fargo and Grand Forks, and by 1960 the North Central Association had accredited four of the teachers colleges. New libraries at the Agricultural College in 1950 and at the university in 1961 provided opportunities for a more active intellectual life. Many research grants (\$800,000 for the 1958-1960 biennium alone at the university) stimulated scholarly activity and publication. More scholarships (especially the Maxwell Upson and Chester Fritz scholarships at the university) and vigorous recruitment attracted better-qualified students. There was a general tightening of academic standards and a steady effort to improve the faculties. At the university, President Starcher stressed honors work for the most promising students. At the teachers colleges, the number of juniors and seniors increased greatly.

Yet the old deficiencies and difficulties held on stubbornly. Faculty salaries and hence the level of staff members' training remained below the averages for institutions of the same class in the nation. At the university, for example, 36 percent of the faculty held doctorates in 1958, while the national average for universities was 48 percent. That year, a study by the United States Office of Education criticized the state's institutions for employing unqualified instructors, having an excessive number of small classes, and giving high school courses.

For all the deficiencies, the institutions did much for the state. They gave the young people an opportunity for a higher education at a lower cost than in most of the states. Many have taken that opportunity. By 1960 the Agricultural College had granted more than 10,000 degrees, half of them in the 1950's. By 1961 the university had enrolled over 50,000 students since its opening and had granted more than 18,000 degrees. The graduates served the state in many ways - as farmers, doctors, lawyers, teachers, legislators, judges, congressmen, senators, and governors. Many of them left the state to pursue distinguished careers in many fields. Moreover, the institutions themselves were stimulating centers of intellectual life, communities of 
scholars and ambitious young people, in which the state's cultural heritage was transmitted, the skills and professions of the modern world were learned, and the bounds of knowledge, especially knowledge of the state itself, were extended.

\section{RESEARCH AND WRITING}

The value of the institutions of higher education centered on the teaching, research, and writing of their faculties. That was their vital part and leading role in the intellectual life of the state. Many at the university made notable contributions in the 1920's. Dean Joseph Kennedy, retiring in 1932, was remembered by the North Dakota Teacher as "the greatest and best loved teacher in North Dakota." Upon his death in 1937, it wrote: "For fifty years he served as counselor and guide... and his influence moulded the lives of thousands of teachers who have in turn had a definite part in making the history of this state."

There were many others. Orin G. Libby, editor of the State Historical Society's Collections and later the North Dakota Historical Quarterly, performed an outstanding task in preserving the records of the state's early years. Arthur G. Leonard, head of the university's geology department, wrote more than fifty articles and long reports. He made a significant contribution to knowledge of the geology of the state by mapping lignite and gravel fields and possible oil resources. John M. Gillette, called the "father of rural sociology," was president of the American Sociological Society in 1928. Other stars of the university faculty were warmhearted, sharp-eyed William G. Bek, dean of the arts college and professor of German; sentimental, hotheaded Vernon P. Squires, a dean of the arts college and an inspiring teacher of English literature; the capable lignite researchers Earle J. Babcock, Alfred W. Gauger, and Irvin Lavine; Germantrained economist Ezra T. Towne, first dean of the School of Commerce; and industrious Howard Simpson, the expert on ground water who awakened the state to the need of conserving its artesian waters.

The 1920's saw some decline in the scholarly output of the university faculty from what it had been in the days or President Frank L. McVey, when it had averaged two and a half books a year against a book a year under President Thomas F. Kane. The 1930's saw a further decline; some of the old faculty members retired or were past their productive years, and the stoppage of the Quarterly Journal of the University of North Dakota, the Law Review, and the North Dakota Historical Quarterly cut down opportunities for publication.

The depression brought in federal money for a mineral-resources survey and more research on lignite, and the United States Bureau of Mines established a gasification pilot plant on the university campus in 1944 . 
Nearly every department benefited from federal research or survey projects as a part of the relief and recovery program. There were some thirty approved between 1935 and 1938 alone.

The postwar years saw many able members of the university faculty engaged in a variety of research enterprises. Indeed, the expansion of research at both the university and the Agricultural College was one of the notable aspects of the postwar years. At the university the completion of the Charles R. Robertson Lignite Laboratory by the United States Bureau of Mines in 1951 added to research facilities. With the discovery of oil, the work of the North Dakota Geological Survey under Dr. Wilson Laird became of major importance in the state at large, with an appropriation of \$330,000 in 1957 and a staff of twenty full- time employees.

Dr. William E. Koenker, head of the university's Department of Economics, and Arlyn J. Larson made a study of Equitable Highway Cost Allocation in North Dakota (1956) for the Legislative Research Committee. Dr. Koenker and Dr. Glenn W. Fisher, associate professor of economics at the Agricultural College, prepared a study of Tax Equity in North Dakota (1960), also for the Legislative Research Committee. Both were published by the Bureau of Business and Economic Research of the university's College of Business and Public Administration. Born in Regent on the Missouri Slope, Koenker was a graduate of Dickinson State Teachers College and held a Ph.D. from Ohio State University. He was one of the most productive scholars at the University of North Dakota, and his ability as a teacher was recognized by an Alumni Award for Distinguished Teaching in 1958. In 1962 he became vice-president in charge of academic affairs at the university. Another outstanding teacher and recipient of the Alumni Award was Dr. Erich Selke, a professor of education widely known and respected by schoolmen.

Most research, however, was in science and technology and was supported by funds both from within and without the state. From 1950 to 1957 the medical school, which had done nothing in research before 1948, received \$650,000 in research grants. Between 1948 and 1957 the students and faculty in medicine published 170 articles in professional journals. Dr. William E. Cornatzer, head of the biochemistry department and a specialist in liver disease, published more than forty. His work was aided by gifts of $\$ 85,000$ from Mrs. Guy L. Ireland for a cancer-research laboratory. This was matched by $\$ 96,000$ from the United States Department of Health, Education, and Welfare and the American Cancer Society.

There was much other activity. Albert M. Cooley and Arthur Koth worked on lignite; George C. and Jeanette Wheeler published The Ants of North Dakota (1963); and Dr. Louis G. Geiger established the Orin G. Libby Historical Manuscripts Collection in the university library in 1951. The 
papers of William Lemke were the first significant contribution to the collection. Geiger himself wrote University of the Northern Plains: A History of the University of North Dakota, 1883-1958 (1958) as a part of the 1958 celebration of the seventy-fifth anniversary of the founding of the university.

A number of other faculty members produced books: Richard Beck, $A$ History of Icelandic Poets, 1800-1940 (1950); Robert P. and Wynona H. Wilkins, God Giveth the Increase: The History of the Episcopal Church in North Dakota (1959); Melvin E. Kazeck, North Dakota: A Human and Economic Geography (1956); Bernt L. Wills, North Dakota: The Northern Prairie State (1963). In 1954-1956 the university received more than $\$ 230,000$ in outside research funds, in 1958-1960 over $\$ 800,000$ in such funds. Graduate students at the University of North Dakota wrote many excellent theses and dissertations. Notable examples in history were Charles N. Glaab on John Burke, Jackson K. Putnam on the Socialist party in North Dakota, and Hiram M. Drache on the Amenia and Sharon Land Company, published as The Day of the Bonanza: A History of Bonanza Farming in the Red River Valley of the North (1964). Edward C. Blackorby's dissertation, Prairie Rebel: The Public Lift of William Lemke, was published by the University of Nebraska Press in 1963.

The activity at the university was matched by that at the Agricultural College. There, research had an even more direct bearing upon the wellbeing of the state. The Agricultural College was really three interrelated institutions: the college proper, which instructed students; the experiment station, which conducted research; and the extension service (established under the federal Smith-Lever Act of 1914), which disseminated knowledge through county and home-demonstration agents and leaders of boys' and girls' clubs. Dean Harlow L. Walster, one of the college's dynamic leaders, was dean of the School of Agriculture from 1924 to 1954, director of the experiment station from 1934 to 1954, and director of the extension service from 1933 to 1937 . The research conducted by the experiment station contributed mightily to the welfare of the state. Indeed, until after the Second World War, it conducted the bulk of the research done in the state. The legislature gave it $\$ 323,000$ for the 1921-1923 biennium and about $\$ 2,000,000$ for the 1957-1959 biennium. By that time it had a professional staff of more than one hundred. From 1891 to 1960 the experiment station published 430 bulletins and 73 circulars reporting the results of its research.

The outcome was impressive, being, as the Fargo Forum wrote in 1948, "so intimately enmeshed with the economics and social welfare of the people of North Dakota." As early as 1920 the Fargo Courier-News estimated that the services of the Agricultural College had meant a saving of seven million dollars to the farmers of the state. Working in laboratories, 
greenhouses, and test plots, Lawrence R. Waldron developed new varieties of wheat-Ceres, Komar, Rival, Vesta, Mida, and Premier-in the years after 1916. By 1949 these Waldron wheats, resistant to rust, were grown on eleven million acres, or 62 percent of the acreage in the United States planted to hard red spring wheat. They contributed greatly to the huge crops of the war years and added millions of dollars to the income of North Dakota farmers. In the 1950's, Waldron's successor, Dr. Glenn S. Smith, a graduate of the Agricultural College, produced durums resistant to stem rust. Before 1916, Henry L. Bolley, the “conqueror of flax wilt," had developed varieties of flax resistant to both wilt and rust. Such varieties as Sheyenne, Victory, Norland, and Bolley made flax a surer crop. Dean Walster, appraising Bolley's services, called him "a fearless trail blazer who cut deep and lasting 'blazes' $m$ the forest of ignorance about plant diseases."

Bolley's colleague, Orin A. Stevens, a botanist and distinguished teacher who had come to the college in 1909, wrote two books after the Second World War: Handbook of North Dakota Plants (1950) and Wild Flowers for Your Garden (1952). A. F. Yeager, called "the plant wizard of the north," was a horticulturist who acquired an inter- national reputation while at the experiment station. Before he left in 1937, he had developed Sunshine and Golden Gem sweet corn; Bison and Red River tomatoes; Buttercup squash; Pixwell, Perry, and Abundance gooseberries; Dryweather Everbearing strawberry; Zephyr cantaloupe; and Red River crab apple.

After the Second World War a new generation began to take over in agricultural research. They developed a malting barley (Traill), corn hybrids, new durums, potatoes (Norland, Nodak, Snowflake, and others), the pelleting of barley for better feeding of pigs, a vaccine for listerellosis in sheep, a drench for the control of worms in sheep, a method to control sugar-beet root maggots, soil tests for phosphorus availability, and new varieties of soybeans, grass, and sweet clover.

The results of the experiment station's work were carried to North Dakota farmers by the extension service. Its county and home-demonstration agents helped to evolve a more productive agriculture and a more satisfying farm life. In the 1930's they aided in combating grasshoppers by developing and supervising the use of poison bait. They ameliorated the ravage of drought, preventing a great deal of suffering, and helped to administer the federal wheat program. After the war they helped farmers to make adjustments to new conditions. The 71 extension agents and assistant agents, located in every county of the state, gave assistance to 9,966 farmers and 20,359 farm families. Livestock feeding, sponsored by the extension service, increased farm income. As a result, in five years North Dakota farmers raised their average net income by 16 percent over the 1949 and 1950 levels, and did it on 10 to 12 percent fewer harvested acres. 
The Agricultural College contributed to intellectual life in other ways. In the years after the war, Rainer E. Schickele wrote on agricultural economics, Glenn W. Fisher on income and taxation, and Courtney B. Cleland on rural sociology. William C. Hunter produced a scholarly history of the college-Beacon Across the Prairie: North Dakota's Land-Grant College (1961). In 1950, Dean G. Ernst Giesecke, aided by H. Dean Stallings, Leonard Sackett, Rudolf Ottersen, and others in the School of Applied Arts and Sciences, established the Institute for Regional Studies to encourage research and writing on North Dakota. The institute gathered books, maps, and manuscripts (its most notable catch was the records of the Chaffee bonanza farm) and published books and pamphlets; by 1961 it had eight books to its credit. The institute also sponsored exhibitions of regional art. An earlier cultural contribution was made by Professor Alfred G. Arvold, who had come to the college as professor of speech in 1907. In 1914 he established the Little Country Theater on the campus as a laboratory to show what people in small towns might accomplish in dramatics. He wanted to make the theater a means of enjoyment and enlightenment for the masses.

A number of contributions to North Dakota culture were made by persons who had no connections with the university or the Agricultural College. Some forty-two novels had North Dakota settings. Mostly written after 1920, they dealt with frontier adventure or farm life. Many were historical, treating such popular subjects as Lewis and Clark or Custer, but the pioneering-spirit theme ran through even those concerned with the contemporary scene.

A successful North Dakota novelist was Zděna Trinka of Lidgerwood. Of Czech stock and educated at Valley City State Teachers College, she first won international recognition with Jenik and Marenka of Czechoslovakia (1938), which became a juvenile classic. The book brought her an invitation to visit Czechoslovakia as a guest of the government. President Eduard Beneš gave a garden party in her honor at Hradcany Palace; then, as the Nazis seized the country, she fled on the last train which left Prague. Miss Trinka had a warm feeling for the Badlands (she had been a librarian at Dickinson) and in 1940 published Medora, a novel about the Marquis de Mores. After the war, A Little Village Called Lidice (1947), concerning the Czech village destroyed by the Nazis, brought her acclaim. Her books were translated and published abroad. ${ }^{8}$

The best novel on North Dakota farm life is The Bones of Plenty (1962), by Lois Phillips Hudson. Mrs. Hudson was born in Jamestown; her book deals with a wheat-farming family in the 1930's.

\footnotetext{
${ }^{8}$ Harvey K. Jacobson, “A Study of Novels About North Dakota” (Unpublished M.A. thesis, University of North Dakota, 1956), pp. 13-23.
} 
Closely akin to the novels were the half-fictionalized accounts of growing up in North Dakota. Two examples were Dorothy de St. Clement's White Gumbo (1951), recounting her childhood on a sheep ranch near Dickinson, and Margarethe E. Shank's The Coffee Train (1953), describing her life as a young girl in Fessenden during the 1920's. Probably the best of this kind of book was Aagot Raaen's Grass of the Earth (1950), telling of the struggles of a pioneer Norwegian family on the Goose River. More unusual was American Daughter (1946), in which dark-skinned, athletic Era Bell Thompson told what it was like to be a Negro girl on a North Dakota farm, in the town of Bismarck, and at the University of North Dakota. From such beginnings Miss Thompson became managing editor of Ebony magazine in the 1950's.

Such books add an emotional, human touch to the understanding of North Dakota life. Of a different sort entirely were the studies made at universities outside the state. There, graduate students, often from North Dakota, sometimes worked on North Dakota subjects. For example, at Columbia, Alvin S. Tostlebe wrote The Bank of North Dakota (1924); at Johns Hopkins, Paul R. Fossum wrote The Agrarian Movement in North Dakota (1925); at Chicago, Alfred W. Bowers wrote Mandan Social and Ceremonial Organization (1950); at Minnesota, Robert Morlan wrote Political Prairie Fire: The Nonpartisan League, 1915-1922 (1955) and Alvin C. Gluek, Jr., wrote Minnesota and the Manifest Destiny of the Canadian Northwest (1965); at Yale, Howard R. Lamar wrote Dakota Territory, 1861-1889 (1956).

By far the most important book on the region, however, was the work of Carl F. Kraenzel, a mature scholar and rural sociologist at Montana State College. Kraenzel had grown up at Hebron, North Dakota, and had graduated from the University of North Dakota before doing graduate work at Minnesota, Harvard, and Wisconsin. His book The Great Plains in Transition (1955), a seminal work, looked at the problems of the region in a new way.

Much of the new knowledge of the state worked out by scholars was not generally available, for many of the doctoral dissertations were not published. Thus at·Wisconsin, Gilbert W. Cooke wrote on the North Dakota state industries and Stanley N. Murray on the economic development of the Red River Valley; at Minnesota, John Harnsberger wrote on the Northern Pacific Railroad and Robert H. Bahmer on the economic background of the Nonpartisan League; at Ohio State, William E. Koenker wrote on North Dakota banks; at Colorado, Paul W. Morrison wrote on North Dakota senators and foreign affairs; at Missouri, William W. Phillips wrote on Asle J. Gronna; at West Virginia, Robert P. Wilkins wrote on North Dakota opinion and the First World War; at Chicago, Ross B. Talbot wrote on North 
Dakota farm organizations. Such works, based as they were on thorough research, made significant contributions to knowledge about the state.

They did not, however, reach the wide audience that Bruce Nelson's Land of the Dacotahs (1946) did. A tubercular young newspaperman in his thirties, Nelson had set type as a boy for the Flaxton Times, worked as a harvest hand, and wrote editorials for William Langer's Leader. He wrote the book on a regional writing fellowship from the University of Minnesota. An interesting, colorful account, it was widely read, but Nelson himself died after a long illness at the age of thirty-eight.

Although none had Nelson's narrative skill, many persons wrote worthwhile books. Courtly, genial, enterprising Colonel Clement A. Lounsberry drew upon his third of a century in the state to put a wealth of information into his Early History of North Dakota (1919). Though weak on organization, it was the first substantial history of the state. A better book is Lewis F. Crawford's History of North Dakota (1931). A Missourian from the Ozarks, Crawford had earned B.A. and M.A. degrees from Harvard and came out to Dickinson as superintendent of schools in 1899, just as a new boom in settlement was getting under way. Before long he was a spare, square-jawed rancher and banker at Sentinel Butte and later, as his reputation grew, a member of the board of regents of the institutions of higher education and superintendent of the State Historical Society. (One of his sons went to Oxford on a Rhodes Scholarship and joined the faculty of Harvard.) Drawing upon his own experience, Crawford made a real contribution to knowledge in his chapter on ranching.

After Crawford, those who wrote on North Dakota did not attempt a complete history. Big, burly, outspoken Usher L. Burdick added historical writing to his career in law, politics, and ranching. Out of his love for the adventurous old days and the Indians (he spoke a Sioux dialect) he gathered a personal library of some twelve thousand volumes on the West and wrote many articles, pamphlets, and books, including his own reminiscences and such items as The Life and Exploits of James Goodall (1931) and The Last Days of Sitting Bull (1941).

More research went into Roy P. Johnson's writing for the Fargo Forum. Quiet, thoughtful, and unassuming, Johnson was a reporter with the instincts of a scholar. His many articles - those on the siege of Fort Abercrombie and on Jacob Horner of the Seventh Cavalry, which were reprinted in North Dakota History, are good examples-added new historical lore. With the large circulation of the Forum, Johnson reached a much wider audience than any other writer on the history of the state.

Other professional writers did well. Vera Kelsey, graduate of the University of North Dakota and writer of travel books and mystery stories, put solid research into Red River Runs North! (1951). Slender, idealistic 
Erling N. Rolfsrud, a graduate of Concordia College who had taught rural school in McKenzie County, increased appreciation of the state with his readable Lanterns over the Prairies (1949-1950), biographical sketches of heroic North Dakotans. He also wrote The Story of North Dakota (1963), a history for young readers. Marion J. Piper, an enthusiastic North Dakotan and the director of the Dakota Territory Centennial Commission, published an outstanding collection of photographs in her Dakota Portraits: A Sentimental Journal of Pictorial History (1964). Sturdy, painstaking Ray H. Mattison, a historian with the National Park Service, was stationed at the Theodore Roosevelt National Memorial Park in the early 1950's. His articles on Roosevelt's ranching days and on the military posts and Indian reservations of the Upper Missouri contributed much to knowledge of the region. Some of Mattison's articles and many others as well-those by staunch Dana M. Wright, the authority on early North Dakota trails, and the young Benedictine Louis Pfaller at Assumption Abbey were exampleswere published in North Dakota History, the quarterly of the State Historical Society.

Dr. Orin G. Libby of the university reorganized the North Dakota State Historical Society in 1903; in 1905 he persuaded the legislature to make it a trustee of the state. Federal Judge Charles F. Amidon was its first president, and Libby served as its secretary until his retirement in 1944. The society secured some small rooms in the basement of the old capitol, and Herbert C. Fish took charge as the first curator of its growing collection. Soon Libby and Fish were gathering stone hammers, Mandan pottery, Chippewa pipes, books, and papers and were doing field work on Indian village sites. The collection was enhanced by a law of 1905 which required each newspaper in the state to file two copies of each issue with the society. Its newspaper files thus became a storehouse of information on North Dakota history. In 1906, Libby edited the first volume of the society's Collections, more than five hundred pages of articles and documents dealing with the history of the state.

Although Libby himself was fascinated by the Indians, he and his friends were interested not only in collecting and preserving historical documents and museum specimens but also in acquiring historic sites. By 1919 the society had six such places as state parks, including Fort Rice and Fort Abraham Lincoln. Meanwhile, in 1916, Dr. Melvin R. Gilmore had succeeded Fish as curator. A trained botanist, he became an authority on Indian uses of native plants, and built up the museum's natural-history collection. It was a mark of honor that Gilmore was adopted by the Arikara tribe. $^{9}$

\footnotetext{
${ }^{9}$ George F. Shafer, “Dr. Orin Grant Libby,” North Dakota History, XII (July
} 
When Gilmore left in 1923 to join the staff of the American Museum of Natural History in New York City, Lewis F. Crawford became curator. The next year, the society moved into spacious quarters in the new Liberty Memorial Building. In 1926, after putting out seven volumes of the Collections, it began to publish the North Dakota Historical Quarterly, also edited by Libby.

In 1930, Crawford was succeeded by Russell Reid, a young man of thirty who had begun working for the society while still in high school. Rather shy and retiring, quite tall, an outdoor man, Reid was an excellent photographer of wildlife and an expert ornithologist. Determined to do his best by the state and the society, he visited eastern museums, reorganized the society's collection, prepared dioramas and otherwise raised the museum to a high level, built up the library (under the charge of Mrs. Florence Davis for many years and then cared for by Miss Margaret Rose), wrote many scholarly articles, and edited the quarterly after Libby's retirement, renaming it North Dakota History.

Reid also took the lead in the great expansion of the state parks in the 1930's. The camps of the Civilian Conservation Corps, a federal relief agency, were in need of outdoor work for young men, and the legislature appropriated funds for more parks. Reid bought acreage to expand the existing parks or to make new ones, and the C.C.C. boys made roads and trails, reconstructed military posts and Indian earth lodges, and built museums, recreational buildings, dormitories, picnic grounds, and bathing beaches. Reid's largest purchase was some 48,000 acres for the Theodore Roosevelt parks in the Badlands, made between 1934 and 1937. In 1947 they became the Theodore Roosevelt National Memorial Park through the efforts of Congressman William Lemke. By 1960 the society held six state parks, six recreational parks, forty-nine historic sites, and five archaeological sites. ${ }^{10}$

With its parks and historic sites, its unexcelled library on North Dakota, its Collections and quarterly, its museum, and its archaeological work in cooperation with the Smithsonian Institution and the National Park Service, the State Historical Society was educating North Dakotans in the state's

1945), 107-110; State Historical Society of North Dakota, Illustrated Handbook (Bismarck, 1937); Russell Reid, "Museum of the State Historical Society of North Dakota,” North Dakota Teacher (February 1949), pp. 14-15.

${ }^{10}$ Russell Reid, “The Annual Report of the Superintendent of the State Historical Society of North Dakota," North Dakota Historical Quarterly, V (April 1931), 166171; Russell Reid, “The State Park System,” North Dakota Historical Quarterly, VIII (October 1940), 63-78; Dale J. Strand, "The History of the Theodore Roosevelt National Memorial Park" (Unpublished M.A. thesis, University of North Dakota, 1962), pp. 8, 64-66. 
history. A good deal of the understanding of that history was the result of the efforts of George F. Will, a Bismarck seedsman and president of the State Historical Society from 1942 until his death in 1955. Will was born in Bismarck in 1884, the year his father founded a pioneer seed house, Oscar $\mathrm{H}$. Will and Company. Oscar Will gathered corn and vegetable seeds from the Mandan Indians, propagated them, and selected the best for his customers. In doing so, he played an important part in the introduction among the white settlers of early-maturing native plants adapted to the Northern Plains environment.

As George Will grew up, he joined his father in the seed business, became acquainted with the Indians (frequent visitors to his father's store), saw the significance of adapted plant life, and went off to Harvard to study botany and anthropology. In the summer of 1905, young Will and three Harvard classmates (one of them was Herbert J. Spinden, who was to have a distinguished career as an anthropologist) excavated the Double-Ditch Village site on the Burgois farm fourteen miles north of Bismarck. It was the first such archaeological work in North Dakota. Will's and Spinden's report on the summer's work, The Mandans: A Study of Their Culture, Archaeology and Language, was published the next year by the Peabody Museum of Harvard University. That year, 1906, Will received a B.A. and went back to Bismarck to help his father run the seed business.

Although Will worked with the business the rest of his life, as president after his father's death in 1917, his interest in adapted plant varieties, Mandan archaeology, and the early history of the Upper Missouri Valley continued until his death. He was a quiet, modest, stocky, ruddy-faced man who liked to take long Sunday walks over the prairies around Bismarck. Will also played an important role in Bismarck civic life, arranging for the painting of murals of native scenes by his friend Clell G. Gannon in the new Burleigh County Courthouse, and serving as a member of the school board for thirty-nine years. He kept in touch with the work of neighboring experiment stations (at Mandan and Fargo, North Dakota, and Morden, Manitoba) and distributed their newest and best varieties of seed developed for cold weather and a short growing season.

Will did much scholarly work. In 1917, with George E. Hyde, he wrote Corn Among the Indians of the Upper Missouri, an important book dedicated to his father as the person who first saw the value of native varieties and who "began the work of selecting and breeding them to the lasting benefit of the farmers of the Northwest." He translated from the French both General Philippe-Régis de Trobriand's journal at Fort Stevenson, published as Army Life in Dakota (1941), and the North Dakota portion of a biography of the Marquis de Mores. He compared the growth rings of a bur oak, cut near Bismarck, with those of timbers taken from 
prehistoric Mandan earth lodges, dating the timbers as far back as A.D. 1406. Before his death, a list of his published books, articles, and book reviews on Indians, botany, archaeology, and history numbered 117 items, an astonishing record for a man conducting a large business enterprise.

\section{PROGRESS IN HEALTH AND MEDICAL CARE}

North Dakota, with its cool, dry climate, has always been a naturally healthful place. Even in the 1880's pamphlets booming settlement had boasted of the low death rate. Doctors came in with the settlers, and before long a few hospitals were established. In those early days typhoid fever was the great scourge. As settlement was completed, the number of doctors reached its peak, with 604 in 1918.

In the 1920's, however, villages in both the state and the nation began to lose their doctors. In North Dakota, as in all rural areas, the sparsity of population tended to concentrate physicians in the larger towns, and the total number declined. As a result, where 268 towns and villages had doctors in 1918, only 194 places had doctors in 1930, only 161 in 1942, and only 99 in 1960, when the state had 109 towns of more than 500 population. Moreover, the number of physicians had declined. By 1960 about half of the state's 451 doctors were in the four largest cities; Fargo had 73, Grand Forks 56, Bismarck 51, and Minot 44. Still, all the larger towns had doctors, and more than half of those with populations of 500 to 1,000 also had them. Even some places with less than 500 population had physicians. ${ }^{11}$

Yet many people became concerned as the villages lost their doctors. Most of the graduates of the two-year medical school at the University of North Dakota did not return to the state after completing their training elsewhere. By 1950 only 111 of 660 graduates were practicing in North Dakota. Some people believed that if medical students could complete their training at the University of North Dakota, more of them would remain in the state to practice and more of the villages would have physicians.

That belief led to the establishment of a state medical center at the university in 1945. The law, drafted by Harold Shaft of the university alumni association, required the center's advisory council to make plans for the improvement of public health and for the "means of bringing about the

\footnotetext{
${ }^{11}$ H. E. French, "The Number and Distribution of Physicians in North Dakota," Quarterly Journal of the University of North Dakota, XVI (November 1925), 39, 47; American Medical Directory, 1918, (6th ed.); 1958 (20th ed.); Lee O. Lantis, "Distribution of Physicians in North Dakota," Quarterly Journal of the University of North Dakota, XXI (Summer 1931), 339; North Dakota State Medical Center, "North Dakota Medical Facilities” (Mimeographed; [Grand Forks, 1960]); pamphlets in the office of Dean Theodore H. Harwood, School of Medicine, University of North Dakota.
} 
complete training of adequate numbers of qualified physicians and surgeons for the people of North Dakota."

The next step was securing funds. In 1948 the voters (asked to "VOTE YES FOR MORE DOCTORS”) approved a constitutional amendment providing for an annual one-mill levy on all taxable property for the medical center. The income from the levy, about $\$ 500,000$ a year, was expected to finance expansion of the university's two-year medical school to four years and thereby supply more doctors for rural areas. In 1951 and again in 1953, the legislature passed resolutions that the four-year school should be put in operation "with all possible dispatch."

But the four-year school did not materialize. Many of the state's physicians doubted that North Dakota had adequate clinical facilities for teaching third-year students or that it could afford a four-year school. However, the Medical Center did build a new medical school and enlarged its faculty; the school regained full accreditation in 1952. The center also began to train nurses and medical technicians, built a rehabilitation center, and established a blood bank.

The revitalized School of Medicine began to train more doctors, and more of them began to come back to the state to practice. By 1957-1958, North Dakota had more first-year medical students in proportion to its population than all but two of the states (Utah and Nebraska). A North Dakota youth, for example, had one and a half times more opportunity to go into medicine than a Massachusetts youth. In 1957 the legislature authorized the Medical Center to lend a student up to $\$ 2,500$ a year. If he returned to practice in a North Dakota town of less than 3,000, his debt would be canceled at the rate of $\$ 1,000$ a year.

Other developments improved medical care in the postwar years. Even though more of the state's doctors were located in the larger centers, the large increase in the number of hard-surfaced highways made them more accessible to the whole population. Four principal medical centers (Fargo, Bismarck, Grand Forks, and Minot) and seven lesser centers (Williston, Rugby, Devils Lake, Harvey, Dickinson, Jamestown, and Valley City) cared for the larger part of the medical needs of the people. All of them had well-equipped clinics, with specialists in group practice, and well-staffed hospitals. Thus the Fargo Clinic had 30 doctors, the Quain and Ramstad Clinic (Bismarck) 28, and the Grand Forks Clinic 24. The number of physicians rose from 416 in 1950 to 451 in 1959. That year, 241 of them were specialists, many of them licentiates of the American boards. Practically everybody in the state lived within one hundred miles-a twohour drive- of one of the eleven medical centers. Many smaller towns also had good doctors, often in group practice. With good roads, telephones, and automobiles, every North Dakotan was within easy reach of medical care, 
although he might live many miles from a doctor.

Yet 169 villages which once had a doctor were without one. Feeling deprived, some of them worked hard to attract a physician. They commonly offered a new medical building, with modern facilities at free or low rent, and sometimes even money for X-ray and other equipment, as well as the prospect of a profitable practice. Some of the new clinics were empty in 1960, when seventeen towns without a doctor were seeking one.

Many small towns built hospitals in the postwar years. The Hill-Burton Act (1946) gave them federal funds, and by 1960 it had aided in building, replacing, or enlarging twenty-three general hospitals, adding 749 beds and 90 bassinets. Federal grants also helped to construct a nurses' residence (St. Luke's, Fargo), two chronic-disease hospitals (Valley City and Minot), a mental-hospital unit (Jamestown), two rehabilitation centers (Grand Forks and Jamestown), and five nursing homes. The total cost was over $\$ 23,000,000$, of which $\$ 7,500,000$ was federal money. ${ }^{12}$

Other hospitals were built without federal aid. At Grand Forks in 1952, Deaconess Hospital spent \$750,000 enlarging its facilities, and the Sisters of St. Joseph of Carondelet dedicated a new \$4,000,000 St. Michael's Hospital with two hundred beds. At Fargo, St. Luke's made a \$500,000 addition. By 1960 the state had sixty-one hospitals and nineteen nursing homes. In the early 1960's the Good Samaritan Hospital Association, an organization of thirty-two Lutheran congregations in the Rugby area, was carrying out a $\$ 1,600,000$ program to modernize and expand Rugby's medical facilities.

Medical care was also advanced by the formation of large health districts, a notable adaptation to the sparsity of the population. In 1943 the legislature authorized counties to unite in order to form such districts, thus pooling their limited resources. By 1959, thirty western and northern counties with a population of 290,000 had united in five health districts. These employed fifty-five full-time and twenty-six part-time nurses, technicians, and doctors, numbers which would have been far beyond the means of the counties if they had acted individually.

There were other improvements in public health. By 1959 some 69 percent of the urban population was drinking water treated with fluoride, twice the national average, and fluoridation was decreasing tooth decay. The public milk supply was being handled in more sanitary ways. In the

${ }^{12}$ Materials from State Health Department: "Summary of Federally Aided Hospital and Medical Facilities, October 27, 1960” (mimeographed); “Facts about the Health of Children and Youth in North Dakota, July 31, 1959” (mimeographed); North Dakota Health News (State Health Department, Bismarck), March, 1954, December, 1954, September, 1959: reports of the State Health Department. 
1950's, stream pollution declined rapidly as 66 communities installed new sewage systems; 41 others replaced out-dated treatment works. A total of 179 towns and villages had sewage collection systems by 1960, although only 109 of them had populations of more than 500. Thirty-two communities installed new water-supply systems. Thirty-four built swimming pools, bringing the total to 78 pools in 1960 . 


\section{CHAPTER 22}

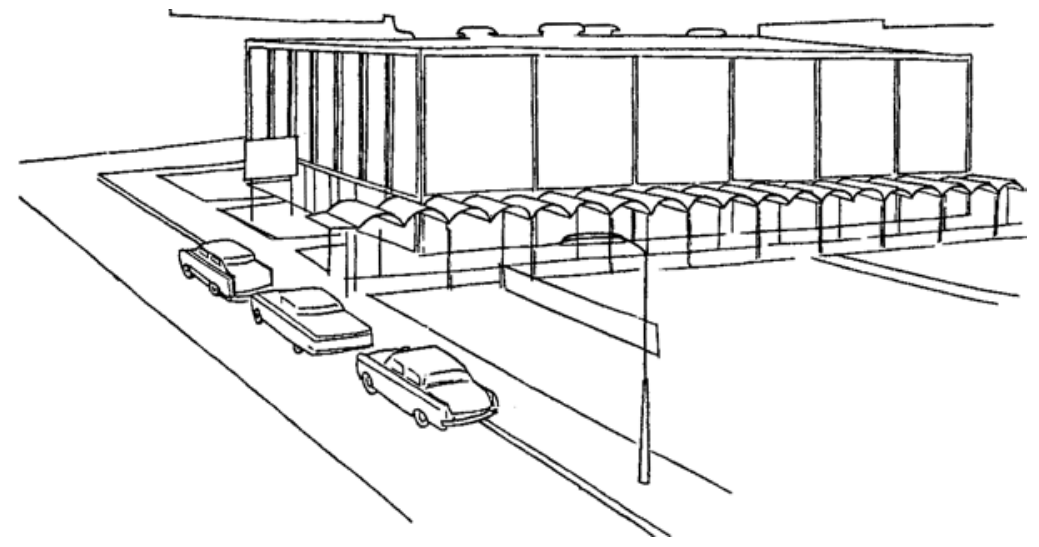

\section{Cultural Growth and Adaptation: The Arts, Libraries, Newspapers, and Churches, 1920-1960}

IN THE YEARS AFTER the First World War, both North Dakota and the nation witnessed the same cultural trends: the growth of high school and college enrollments, the decline of rural churches and the union of larger church bodies, increased use of libraries, the expansion of daily newspapers, the rapid acceptance of radio and, later, television, and a growing interest in the arts. In North Dakota, as in the nation, the larger urban places were the centers for cultural activities, and women and women's clubs played a leading role in promoting many of them.

While national trends were important, the cultural life of North Dakota was primarily shaped by the state's rural character. Outside a dozen urban centers, the population was spread very thinly over a large area. Churches, newspapers, and libraries faced the problem of serving small numbers of widely separated people. To meet these needs, the pioneers had established many country churches, many weekly newspapers, and many library associations, so that by 1920, North Dakota had an oversupply of these and other cultural agencies. Many were too small and weak to survive or do effective work. What was needed was to tie the cultural life of the larger towns more thoroughly and intimately to the rural areas, to create in some way the large communities which automobiles and improved roads made possible. In other words, the state's cultural life had to be adapted to existing environmental conditions. 
Adaptation, however, was slow and difficult. During the 1920's and 1930's, hard times, many bank failures and farm foreclosures, and the pressing problems of relief for the unemployed and the drought stricken farmers brought about conditions and attitudes which prevented much adaptation, except the simple and inescapable measure of reducing the excessive supply of cultural agencies. Thus the number of churches declined from 2,500 in 1916 to 2,147 in 1936, the number of weekly newspapers from 347 in 1915 to 177 in 1936.

Much more progress was made in the prosperous, optimistic years following the Second World War, when cultural adaptation was aided by the building of thousands of miles of hard-surfaced roads. In the 1950's, civic leaders began to organize county and intercounty libraries and to send out "bookmobiles" to serve widely scattered readers. As country churches closed, those in town came to have many rural members. More and more the music and art departments of the colleges and universities became centers for those interested in such activities. The surviving newspapers increased in distribution in their respective areas, and the Fargo Forum and the Minneapolis Sunday Tribune built up circulation over the whole state. Cultural adaptation, a notable achievement, was bringing about a more satisfying life.

\section{THE ARTS}

Aside from the various efforts of the native tribes, the arts have had a long history in North Dakota. George Catlin, a famous early painter of the American Indian, visited the country along the Missouri River and sketched or painted numerous scenes at Fort Union in 1832; a collection of his paintings is now in the National Museum at Washington, D.C. Maximilian's artist-companion, the Swiss Karl Bodmer, executed a large number of drawings and paintings of the Indians and the scenery of the Missouri in 1833-1834. The Bodmer album, published with Maximilian's journal in 1839-1841, is an artistic treasure. In 1962, the Northern Natural Gas Company of Omaha purchased the Maximilian-Bodmer collection of early American paintings and documents, including Maximilian's American diaries and 427 original water colors and drawings by Bodmer. In 1843, John James Audubon, the ornithologist, spent a busy summer at Fort Union painting wildlife. Rudolph Friederich Kurz, a Swiss, made sketches at Missouri River fur posts in 1851. And General Philippe Régis de Trobriand amused himself by making sketches at Fort Stevenson in the late 1860's.

In the pioneering stage of white settlement, some North Dakotans began to pay attention to the arts. Budding towns put up buildings with some architectural pretensions, especially public buildings, such as the capitol at Bismarck, in the 1880's. One of the territory's first artists was John D. Allen, 
a New Yorker who settled in Mandan in 1881. He opened a taxidermy shop, mounted hunting trophies for Theodore Roosevelt and the Marquis de Mores, and later turned to painting. He knew Sitting Bull, Rain-in-the-Face, and other Sioux, and his canvases of wildlife, Indians, encampments, and the buffalo hunt pictured the Slope country better than the work of any other artist. Indeed, they were to become collectors' items throughout the nation.

Another early artist was Frank B. Fiske. Born at old Fort Bennett in southern Dakota in 1883, he grew up along the Missouri and spent most of his life at Fort Yates. In time, he became a photographer, painter, writer, newspaperman, and raconteur. His immense collection of 3,600 Indian photographs, showing life at Standing Rock Reservation up to 1950, was eventually acquired by the State Historical Society. It is probably the finest in the Northwest.

After 1900 some of the boys and girls growing up on homesteads and in the small towns of North Dakota became interested in sculpture, drawing, and painting. Often they were the sons and daughters of Icelandic and Norwegian immigrants. Some of the notable ones were Paul Fjelde, Kristinn P. Armann, Clell G. Gannon, Blanche Lillebridge, Elmer Halvorson, Laura Taylor, Levon West, James A. Kirkpatrick, Jon Magnus Jonson, and Ida Prokop. Paul Fjelde was the son of a sculptor who had died when Paul was four. His mother, a musician, always had sculptor's clay at hand for the boy in their farm home near Wing in Burleigh County.

Most of the young people, however, received their first art instruction in the state colleges. There they often had well-trained teachers fired with a missionary spirit. One of these was Mary Goodrich Deem, Paul Fjelde's first teacher, who taught art at Valley City Normal for twenty-eight years. In 1910, Margaret K. Cable, trained at the New York State College of Ceramics of Alfred University and also in the potteries of East Liverpool, Ohio, began a teaching career of thirty-nine years at the University of North Dakota. In 1916, Jean M. Hay, a Kansan who had studied at the École des Beaux Arts in Paris and also in Italy, began a teaching career of eighteen years at Mayville Normal. In 1919, Erwin O. Christensen, a Missourian who had earned advanced degrees in architecture and the fine arts at Harvard, joined the faculty at the University of North Dakota. He later became curator of the Index of American Design and Decorative Arts at the National Gallery of Art, Washington, D.C. In 1927, Eva Valker Hartnett, a native of Wahpeton who had studied at the University of Minnesota, began to teach art at Minot State Teachers College. In 1928, Paul E. Barr, an Indianan who had studied at the Sorbonne, came to the University of North Dakota. In 1931, Zoe Beiler, an Ohioan trained at the Art Institute of Chicago, began to teach at Dickinson State Teachers College. In 1934, Ann Brown Bolin, who was 
trained at Columbia University and who studied under such famous artists as Grant Wood, came to the Agricultural College.

Teachers like these, however, did not have a hand in the art education of all North Dakotans who were to become professional artists. Some of the latter, such as Ida Prokop, Einar H. Olstad, and Levon West, were largely self-taught. But the teachers did arouse much interest in art, and they sometimes sent their students on to larger centers of learning. North Dakotans went to the Minneapolis Art Institute, to New York City, and even abroad, but most frequently they studied in Chicago. Jon Magnus Jonson and Paul Fjelde, for example, studied at the Lorado Taft Studio there; Fjelde went on to New York, Paris, and Copenhagen.

In North Dakota, as in the nation, interest in art grew in the years after the First World War. Pioneering, with its primary preoccupation of earning a living, was over; the towns were growing; the institutions of higher education were increasing in size and influence. In the 1930's, Works Progress Administration art projects gave painters more opportunities. After the Second World War, amateur painting became a popular hobby. Perhaps thousands of North Dakotans, stimulated by the nation-wide vogue and such teachers as Paul Barr, found art an interesting diversion.

Besides the amateurs, a considerable number of people reached professional status. When Barr wrote North Dakota Artists (published posthumously in 1954), he included sketches of forty-seven persons. They frequently chose the prairie, the Badlands, Indians, and the buffalo as subjects; they carved wood and stone, painted with oils and water colors, shaped wrought iron and clay. They exhibited their work in local and national shows and even abroad. Bismarck, through the enthusiasm of Marion J. Piper in conducting American Art Week exhibitions in 19451947, became the center of interest in the state. All North Dakota artists created something of beauty, and some received considerable recognition. A dozen won places on the honor roll of the American Artists Professional League.

The best-Paul Fjelde, Jon Magnus Jonson, Emile Walters, and Levon West—had national careers and reputations. Fjelde carved panels depicting industrial life for the Federal Street Building in Boston. Jonson's sculpture adorned Music Hall on the campus of Purdue University. Walters' paintings of the mountains of Iceland earned him the Knight's Cross of the Order of the Falcon from the Icelandic government. West's etching of Charles A. Lindbergh in 1927 won that artist national fame while he was still in his twenties. Then, under the name Ivan Dmitri, he became a master of color photography, making a series of more than 180 Americana color pictures for the Saturday Evening Post. 
But many artists who worked in the state, though not so well known, also made contributions to North Dakota culture. In 1940, Paul Barr's Ranch and Rider and Zoe Beiler's Cowboy were chosen to represent North Dakota in the International Business Machines All-State Exhibition in New York City. In 1946, Ann Brown Bolin's sculptured Bison was purchased by the Walker Art Center in Minneapolis. In 1951, Margaret K. Cable won a medal for outstanding achievement in ceramic art from Alfred University. Clell G. Gannon, a poet (Songs of the Bunch Grass Acres) as well as a painter, did backgrounds for habitat groups in the State Historical Society's museum, murals in Burleigh County Courthouse, and covers for the Oscar H. Will and Company seed catalogs. Gannon, a perceptive, thoughtful person in precarious health, became one of the best interpreters of the Great Plains.

Blanche Lillebridge Harding of Dickinson worked in ceramics, painted, and, with her husband, created a troupe of marionettes. Laura Taylor Hughes and her husband organized a pottery company to turn out Rosemeade ware at Wahpeton. James A. Kirkpatrick, himself a son of homesteaders near Sentinel Butte, painted homesteaders, ranch scenes, and buffalo hunts. Chicago-trained Louise Minert Kelly, a housewife at Carrington, won a prize at a Washington, D.C., exhibition with one painting and had another, executed during a trip to southern France, hung in a Paris salon. Beautyloving Ida Prokop Lee, working in her Prairie Studio near Valley City, sculptured a series of portrait busts of men and women of the five Indian tribes in North Dakota. Versatile Julia E. Mattson, both a painter and a talented potter on the faculty of the University of North Dakota, exhibited tile plaques of North Dakota scenes at the Chicago Century of Progress.

Norway-born Einar Hanson Olstad, painter and sculptor, fashioned three wrought-iron cowboys for the gateway to Theodore Roosevelt National Memorial Park. Ole A. Olson of Valley City and Thelma Rudser of McKenzie carved beautiful pieces in wood. Ralph Waldo Smith was a homesteader and then for thirty-two years an agronomist at the Dickinson Branch Experiment Station. The father of a wheat experimenter at the Agricultural College, he got his first art training in his sixties and produced a series of paintings on the progress of farm machinery for the State Historical Society. In 1933-1934, Isabel P. Snelgrove, water colorist at the university, exhibited one hundred abstract designs at the Chicago Century of Progress.

Icelander Thorarin Snowfield and Syrian Henry J. Tanous painted the American scene for a Works Progress Administration project, producing such canvases as County Fair, Threshing Crew at Noon, and Jack Rabbit Round-Up. Tall, gentle Ernest V. Wenner, a teacher of engineering drawing at the university as well as a commercial artist, sculptor, and diorama 
builder, made a mural map for the foyer of the Charles R. Robertson Lignite Laboratory at Grand Forks. At the university, Robert A. Nelson painted a huge mural of the state's development for the Chester Fritz Library, and Stanley O. Johnson created a wrought iron sphere symbolizing the wide influence of the university to memorialize Old Main.

North Dakota artists, creating things of beauty and interpreting the life and moods of the plains and prairie country, not only developed their own talents but also enriched the cultural life of the rural, sparsely settled state, adding another dimension to its variety.

\section{THE EXTENSION OF LIBRARY SERVICE}

Reading is a universal cultural activity, and so the easy availability of books is of primary importance for a satisfying cultural life. To have books means that a society must provide libraries. North Dakota had Carnegie libraries in most of its larger towns before the First World War, generally through the efforts of clubwomen, and the state legislature had set up the Public Library Commission in 1907 (renamed the State Library Commission in 1920) to meet the needs of the rural areas.

Yet library service was inadequate in the years after the First World War. The enemies of the Nonpartisan League charged the State Library Commission with the dissemination of socialist literature, a part of North Dakota's "red scare," and nearly put it out of business with their investigations. The seventeen public libraries in the state in 1922 were quite small. Fargo had the largest, with some seventeen thousand books, and Grand Forks was second with nine thousand. Few librarians in the state had any formal training. In addition to the public libraries, there were some forty libraries organized by associations without any tax support. ${ }^{1}$

The 1920's witnessed a remarkable growth. About 1923 or 1924, Miss Lillian E. Cook became the director of the State Library Commission. A knowledgeable librarian with great energy and devotion, she extended the reach of the commission, increasing the circulation of its traveling libraries, each a case of twenty-five books, to schools and communities. By 1930, thirty libraries were receiving public money.

In the 1930's, although the depression cut library budgets, people had time for reading, and circulation continued to climb, reaching an all-time high in 1939-1940. Works Progress Administration projects helped in several ways. They gave the State Library Commission 2,800 books, employed women for work in the libraries, remodeled the Fargo library, and added a wing to the Dickinson library. In Grand Forks the labor administration, elected in

${ }^{1}$ North Dakota State Library Commission, Biennial Reports, 1918-1920 and 1920-1922, pp. 9, 11, 15. These reports are the principal source on libraries. 
1934, increased that city’s library budget.

In an effort to meet the needs of small villages and rural areas, a number of associations organized libraries which gave free service and later received tax money. By 1940 there were thirty-seven, but most of them had only small collections of books and were open only a few hours a week. There were, in addition, twenty-five associations which charged nominal fees, but these were commonly given a room by the municipal government. At Cavalier, for example, the library was housed in the fire hall, the Masonic Temple, the old jail, and the Presbyterian Church before it put up its own building in 1956. Most of the association libraries were quite small, but the Langdon association had 6,600 books and the Watford City association some 5,000. By 1940 the State Library Commission, still being run by Lillian E. Cook, had 15,000 books in its 414 traveling libraries.

The Second World War saw a general decline in the number of libraries and in reading. By 1946 the State Library Commission had only 367 traveling libraries, and in the 1946-1948 biennium it added only 65 books to these units. Grand Forks was an example of both the poor condition of even the larger public libraries and the low level of reading. In 1945-1946 the people of Grand Forks were drawing only about two books per capita per year, or about 23 percent of the standard circulation of nine books per capita for a city of its size. The Grand Forks Public Library had only 21,000 books, or about one book per person for the population. This was only half the minimum established by the American Library Association.

A more serious problem, however, was that of making books available to the people of the sparsely settled prairie, where most North Dakotans lived. The State Library Commission and the public and association libraries simply could not give either the people of the countryside or village residents access to the variety of books which would enrich their lives by widening their intellectual horizons. In the early 1920's a committee had spent much time preparing a county-library bill, which was introduced in the 1923 legislature. That year, however, was a time of severe deflation, with bank failures reaching an all-time high. No county was ready to undertake a public-library program, and the idea was dropped. In the late 1930's the Works Progress Administration made an abortive effort to start a bookmobile program for rural areas.

With the return of optimism after the war, there was again talk of county libraries. Norwegian-dominated Divide County in the dry, sparsely settled northwestern corner of the state, where the population was only 4.6 persons per square mile, established a library in 1947, the first county library in the state. Stutsman County, largely German and German Russian, with 10.6 persons per square mile, established the second in 1954. By 1957-1958 the 
library in Stutsman County was spending $\$ 4,271$ annually on books and periodicals, more than any of the state’s other libraries except those in the largest towns. It was also operating the first bookmobile in North Dakota.

The county libraries met a real need, for most rural areas did not have adequate library service. In the mid-1950's, Hazel Webster Byrnes, the dynamic, idealistic director of the State Library Commission who had taken Lillian E. Cook's place about 1948, wrote that the commission "does not and never would be able to give adequate service to the entire rural areas of the state.” In 1953 only 27 percent of the population of North Dakota, the percentage living in urban areas, had adequate public-library service; another 11 percent had public libraries, but these were far from adequate; and 62 percent had no library service at all except that from the State Library Commission in Bismarck.

Many people were concerned. "Citizens for the Library," a movement started at Edgeley in 1950 by crusading Mrs. Emil G. Bloedow, worked to unite all sorts of community organizations to build up support for public libraries. In Williston, Judge Eugene A. Burdick, son of Congressman Usher L. Burdick, took the lead in reviving the James Memorial Library, winning a citation for his efforts from the American Library Association in 1956. With the advent of bigger budgets, new books, and a renewed enthusiasm for reading, library circulations increased rapidly. At Bismarck, the most reading town, and also at Grand Forks, circulation increased fourfold from 1945-1946 to 1959-1960. By 1960 the public library circulation in Bismarck was about fourteen books per person per year, in Grand Forks about seven, and in Fargo about five.

The big advance in rural library service, however, came only after passage of the Library Services Act of 1956. It provided federal funds, to be matched by state funds, for promoting the development of library services in rural areas. The law was a boon to North Dakota, for, among the states, it had the largest percentage of population without local library service. In 1957 the state legislature appropriated matching funds and authorized any county or combination of counties, after a petition had been signed by 51 percent of the voters, to establish library services and to levy up to two mills for their support.

Progress came quickly. By 1960, state-federal money (\$43,304 state, $\$ 156,370$ federal) had helped to establish five county and regional libraries in the western part of the state. The North Dakota Federation of Women's Clubs also helped by giving $\$ 5,000$ for a demonstration bookmobile. Williams, Mountrail, and McKenzie counties established the West Plains Library at Williston and bought two bookmobiles. McLean and Mercer counties organized a library at Riverdale and bought a bookmobile. 
LaMoure and Logan counties set up a library at Edgeley, and Ward and Morton were moving toward the establishment of county libraries.

\section{WEEKLY NEWSPAPERS}

By furnishing the bulk of all reading matter, newspapers played a leading role in the intellectual life of North Dakotans. They were, however, affected by the same problem which influenced all other aspects of North Dakota life: sparsity of population. As in the case of other institutions, the few large, influential newspapers were found in the large centers of population, the many small and less influential ones in the scattered towns and villages. Where they served too small an area, that is, where they were too close together, they could not prosper, and yet the process of settlement had naturally brought about the establishment of a considerable number of weekly papers. By 1915 there were 347 weeklies in North Dakota, and some very small places had two papers. With the completion of settlement, the number began to decrease, so that by 1919 it was down to 293, almost half of which, 145 papers, were published in towns of less than 500 people. The steady decline, especially strong in the 1920's, continued into the 1950's. By 1960 there were only 101 weeklies and 3 semiweeklies. Only 18 of them were published in towns of less than 500, and no town had two weekly papers.

As the smaller papers disappeared, the circulations of the survivors grew. By 1960 some 45 of the weeklies and semiweeklies had circulations over 1,400 and were prosperous businesses. They commonly took in a third of their gross income from job printing. About 25 papers, however, were struggling along with circulations under 500. The smaller weeklies were often the ones too close together or too close to a city with a daily paper. The larger weeklies, better adapted to the sparsely settled prairie, had large circulation areas with little competition. In 1961 the largest ones were the Langdon Republican with a circulation of 3,210, the Bottineau Courant with 3,478, and the Williston Plains Reporter with 3,721. The three semiweeklies all had large circulations: the Walsh County Record (Grafton), 4,563; the Richland County Farmer-Globe (Wahpeton), 6,426; and the Bismarck Capital, 11,988.

The weeklies were important. In the early years, when only a small part of the population saw a daily paper, they reported both national and international news. They were plain papers (advertising on the front page, few illustrations), and their editors were plain spoken. Seeking to clean up Minot, George W. Wilson wrote in the Reporter: "The selling of liquor and the bawdy house go hand in hand.” The weeklies were generally owned by their editors, seasoned newspapermen who took a real interest in the development of their communities and the state. By the 1940's and 1950's, 
many were prosperous businessmen and conservative Republicans, though a few papers, like the Renville County Farmer (Mohall), had Democratic leanings. Some editors took an active part in public life; Ralph Beede (Grant County News), Rilie Morgan (Walsh County Record), and Harry O'Brien (Walsh County Press) were repeatedly re-elected to the state legislature. Henry P. Sullivan (Renville County Farmer) and John Conrad (Bismarck Capital and Morton County News) were appointed to the Board of Higher Education by Governor William Guy.

Back in 1886 the newspaper publishers had organized the North Dakota Press Association to promote their mutual interests. One of its leaders in the 1920’s and 1930's was Mark I. Forkner, editor of the Langdon Republican. The association secured the establishment of a practical printing course at the Wahpeton School of Science in 1922, worked closely with the Department of Journalism (started in 1921) at the University of North Dakota, and set up an advertising agency in 1936 to help weeklies get national advertising. In 1958 it placed its head- quarters at the university, where its manager, Paul C. Schmidt, also taught courses in journalism. ${ }^{2}$

\section{DAILY NEWSPAPERS}

After 1919 the weekly papers declined relatively as the dailies expanded. In 1919 the weeklies had an estimated circulation of more than 200,000, as compared to about 60,000 for the dailies, less than 50,000 of it within the state. ${ }^{3}$ Thus nearly two-thirds of the people in North Dakota did not see a daily paper. The circulation of the dailies grew substantially in the 1920's, modestly in the 1930's, and then rapidly in the 1940's and 1950's. By 1961, North Dakota dailies had a circulation of nearly 164,000, about 136,000 of it within the state.

In addition, the circulation of the Minneapolis Tribune in North Dakota had increased. In 1941 the Tribune sold some 2,600 copies of its daily edition and some 17,000 Sunday editions in the state; in 1961 the figures were 9,500 for the daily and 44,000 for the Sunday papers. Moreover, the Wall Street Journal had 1,445 subscribers in North Dakota in 1961.

Thus by 1961 the daily circulation within the state was about 147,000 papers, or 85 percent of the 173,000 households. In the United States the daily newspaper circulation was about 109 percent of the number of

2John C. Sim, “The History of the North Dakota Press Association, 1886-1940" (Unpublished M.A. thesis, University of Minnesota, 1940), pp. 7, 221, 161-162, 175-176.

${ }^{3}$ Such figures can only be estimates. The circulations of the weeklies were mostly not certified, and the Audit Bureau of Circulation breakdowns on circulation are not available for that early date 
households. In North Dakota the circulation of weekly papers had fallen to some 150,000 by 1961, or 87 percent of the number of households; in the nation the circulation of weeklies amounted to 40 percent of the number of households. Large numbers of the North Dakota weeklies went to former residents living outside the state. Because North Dakotans lived in a rural state with a sparse population, they read fewer daily papers and more weeklies than did Americans generally.

Although the circulation of the dailies and the weeklies was roughly the same, the dailies, larger papers issued from five to seven times a week, had become much more important. The growth of daily circulation, nearly 200 percent from 1920 to 1960 while the population of the state actually declined, brought about a silent revolution in North Dakota. The daily papers, growing ever more influential, tended to break down the remoteness and isolation of life on the sparsely settled prairie, to bring urban ways and attitudes to a rural people, and to exert a pervasive conservative influence upon the thinking of a population with a long tradition of radicalism.

Among the dailies, the most influential were the five leading papers: the Fargo Forum (1961 circulation 54,664), the Grand Forks Herald (34,751), the Minot Daily News $(27,563)$, the Bismarck Tribune $(14,400)$, and the Minneapolis Morning Tribune (North Dakota circulation 9,445). By 1961 they had 79 percent of the daily circulation -within the state; the six other dailies in North Dakota (the Devils Lake Daily Journal, the Dickinson Press, the Jamestown Sun, the Mandan Pioneer, the Valley City Times-Record, and the Williston Herald) had together only 20 percent of the circulation, and the Wall Street Journal had about 1 percent. The Minneapolis Morning Tribune, though published some two hundred miles outside North Dakota, gave excellent coverage of developments in the state; it had a circulation in every county (over a thousand copies in Burleigh County alone, or nearly twice as many as the Fargo Forum), and was the fifth leading daily in North Dakota. Moreover, in 1961 the Minneapolis Sunday Tribune had the largest circulation of any Sunday paper in North Dakota: 43,773 to 41,246 for the Fargo Forum and 26,272 for the Grand Forks Herald, the only Sunday papers published in the state. But the Forum sold 13,035 Sunday papers in Minnesota and the Herald sold 7,855 in that state.

Probably the most notable thing about the larger dailies in North Dakota was the vast areas over which they circulated. Each served a retail trading zone equal to a fourth or a fifth of the state (fifteen to twenty thousand square miles); the zones for the Herald and the Forum reached far into Minnesota. But each pushed out beyond the retail trading zone of its city and competed with dailies published in the smaller trading centers, thereby restricting the circulations of the latter. The bigger the paper, the farther it reached beyond 
its own retail trading zone. Thus in 1961 the Bismarck Tribune sold an average of 1,675 papers outside its retail trading zone, the Minot Daily News sold 3,077, the Grand Forks Herald 4,308, and the Fargo Forum an astonishing 13,596. The Forum was the newspaper for the whole state. It sold many papers, not only in the counties where smaller dailies were published, but even in counties where there were other large dailies. Each morning, some 21,000 copies of the Forum were mailed to subscribers, and on Sundays trucks carried the paper to more than 194 towns.

Because the big dailies were distributed over such wide areas, they had much larger circulations than were usual for papers in cities of the same size in other parts of the nation. In Iowa, for example, the Ames Tribune, published in a city about the size of Bismarck, had a circulation less than half that of the Bismarck Tribune. One consequence of serving a large territory was that distribution costs were some three times greater than they were in a state such as Iowa, another instance of the cost of distance in a sparsely settled country.

\section{THE CHARACTER OF THE LARGER DAILIES}

The Forum, Herald, Daily News, and Tribune became large, stable, prosperous, and well-managed business enterprises partly because of the disappearance of competitors. In 1910 the state had a dozen daily paperstwo each in Fargo, Grand Forks, Jamestown, Minot, and Valley City, and one each in Bismarck and Devils Lake. Some soon died, but in 1919, Fargo, Grand Forks, and Devils Lake each had two dailies. Within a few years, however, each city had only one. Later, two papers became dailies in the western end of the state: the Williston Herald in 1930 and the Dickinson Press in 1942.

As the dailies grew, they changed in many ways. They quite naturally became more conservative. They constructed large facilities: the Forum put up a five-story building. They installed the most modern high-speed presses: the Daily News's Goss press weighed 130 tons, could print 35,000 papers an hour, and consumed over 1,000 tons of newsprint a year. The dailies bought teletype setting equipment, which set type by running perforated tape through the Linotypes. They put out larger papers: the Daily News grew from an average of 9 pages in 1943 to an average of 21 in 1961. They employed large staffs: the Bismarck Tribune, the smallest, had nearly 100 employees by the 1950's. They had round-the-clock wire service from the Associated Press, and some of them also from United Press International: by 1953 the Forum was spending \$3,000 a month on wire-service news. They carried syndicated features by the leading writers of the nation: the Herald had Walter Lippmann, Drew Pearson, Joseph Alsop, Dr. Walter C. Alvarez, Ann Landers, David Lawrence, Sylvia Porter, George E. Sokolsky, 
and Westbrook Pegler among the dozen or so syndicated columnists it published. Two newspapers, the Forum and the Herald, owned radio stations for a time.

Moreover, the papers played an important role in their cities. "They are the herald, the band, and the big drum that make the noise for a city and keep it before the rest of the country," wrote Roy P. Johnson, veteran reporter on the Forum. "They shout and exult over its accomplishments, howl down the critics, and often growl at those citizens who hurt the city. They put the city's best foot forward." 4

Each of the four big dailies had some special distinction. The Herald had the most syndicated features. The Tribune won a Pulitzer prize for "the most disinterested and meritorious public service rendered by an American newspaper" in 1937—a series of articles and editorials entitled "Self-Help in the Dust Bowl.” It was the smallest newspaper ever to receive that honor. By the late 1950's the Daily News was generally thought to be doing the best job of covering the legislature.

But the Forum had the best coverage of state news and the greatest editorial influence. Twice it won awards as the best newspaper published in a city under 50,000; for its coverage of Fargo's tornado in June, 1957, it won a Pulitzer prize for local reporting to meet a deadline.

Each paper's success was the work of capable men. For nearly fifty years, George D. Mann and, after his death in 1936, his widow, Stella Hilleboe Mann, the daughter of Traill County pioneers, controlled the Bismarck Tribune. Mann, born in Ontario and a graduate of the University of Minnesota, had worked on St. Paul papers before coming to Bismarck as editor of the Tribune in 1914. He purchased the paper from the Marshall $\mathrm{H}$. Jewell estate in 1917 and in 1930 made Kenneth W. Simons the editor. Then thirty-two, Simons was an able Ohioan who had come to Bismarck in 1923 as a correspondent for the Associated Press. He not only brought a Pulitzer prize to the paper but also became active in civic affairs, a leading advocate of irrigation, and the friend of many public officials. One of the inner circle of the John Moses Administration, he masterminded the campaign which elected Moses to the Senate over Gerald P. Nye in 1944. ${ }^{5}$ When Simons died in 1948, Mrs. Mann appointed John O. Hjelle editor. Thirty-five and a graduate of Luther College, Hjelle had been Senator Milton R. Young's administrative assistant for three years before he became editor.

\section{THE HERALD AND THE FORUM}

Just as ownership by the Manns gave stability to the Tribune (it has had 
only three owners since its founding in 1873), so, too, did the tenure of George B. Winship, W. P. Davies, and Melvin M. Oppegard give stability to the Grand Forks Herald. Davies was born on a farm in Ontario and came to North Dakota in 1882 to work on a railroad surveying crew. Later he farmed, taught school, and worked as a carpenter. Not until he was thirtyfour did he begin his long career as a newspaperman, taking a job with the Grand Forks Northwest News in 1896 and soon moving to the Grand Forks Plaindealer. In 1897 he joined the Herald. Serving an informal apprenticeship under George B. Winship, he learned the trade and rose from reporter to editor in chief. Davies was a small, slight man with a short beard, quiet ways, a love for circuses and gardening, and a keen, analytical mind. He became a civic leader, promoted city parks and better schools, and with his daily column "That Reminds Me" won a following of thousands. When he died in 1944 after forty-seven years on the Herald, Governor John Moses said: "The state has lost one of its finest citizens, universally admired and loved by all." 6

In 1911, Winship sold the Herald to a group headed by Jerry Bacon, who combined it with the Grand Forks Evening Times. In 1917, Bacon's younger brother, Julius F. Bacon, became general manager of the Herald; he was president of the company when Melvin M. Oppegard bought the paper in 1929. Oppegard, a stocky Minnesotan well known in northwestern newspaper circles, was then thirty-eight. He had studied at Macalester College, worked on Twin City papers, and had been with the Associated Press over fifteen years, eight of them in charge of its operations in Minnesota, South Dakota, and North Dakota. He had the financial backing of the Ridder brothers of New York City and of Leo E. Owens, publisher of the St. Paul Dispatch and Pioneer Press. The Ridders owned a string of newspapers, including the New York Staats-Zeitung, the Aberdeen American-News, and the St. Paul Dispatch and Pioneer Press among others.

Oppegard, gratifying, as he said, "a life-long ambition to become the publisher of an important newspaper of the Northwest," became president of the Herald company as well as the editor and publisher of the paper. He was familiar with the problems of the region and, as he wrote upon taking over, "earnestly desirous of having a real part in their solution.” A good boss and a genial storyteller, he won the respect of the community. Oppegard soon set W. P. Davies to writing his well- known column, began to add syndicated features, such as O. O. McIntyre's "New York Day by Day,” built new quarters for the Herald, modernized its equipment, and expanded its circulation.

The most influential newspapermen in the state, however, were those who

${ }^{6}$ Obituary in Grand Forks Herald, May 20, 1944. 
ran the Fargo Forum. Their leader was Norman B. Black. Born of Scottish stock in Ontario and raised, as he liked to say, "with the atmosphere of a print shop in my nostrils," Black had run papers in small Wisconsin towns before coming to Grand Forks in 1906 as business manager of the dying Press. The following year, he became manager of the Grand Forks Evening Times and put it on its feet. After the Times was consolidated with the Herald in 1911, Black managed the Herald, at that time the largest paper in the state. With him on the Herald were his son, Norman D. Black, who worked on the production end, and Holger D. Paulson, who became city editor of the paper at the age of twenty-four. Paulson had begun as a youngster with the Grand Forks Plaindealer at four dollars a week.

Restless for larger opportunities, the elder Black had long talked of buying a paper in Fargo. In 1916-17 the three men left the Herald. Early in 1916 Paulson became city editor of the Forum. About a year later the elder Black bought the paper; after some months the younger Black joined the enterprise as circulation manager. Norman B. Black was publisher and majority stockholder; Paulson was the editor. ${ }^{7}$

In 1920 they expanded their operations. Joining with Hal S. Davies, the advertising manager of the Forum, they bought the Minot Daily News. Davies moved to Minot as the publisher. Then thirty-four, he had already worked for many years on papers in Crookston, Devils Lake, St. Paul, and Fargo. During his first ten years in Minot, he raised the circulation of the paper from less than two thousand to more than nine thousand. A short, friendly, enterprising man, he was soon taking a leading part in civic affairs. In 1938 the Fargo men sold their News stock to Davies, and Raymond C. Dobson became a stockholder. Dobson had joined the paper in 1921 when he was only nineteen, working at first as city editor and reporter. In 1955 he became the publisher, while Davies continued as president of the company. In the 1950's the circulation of the Daily News grew much more rapidly than that of the other dailies, increasing almost 50 percent from 1949 to 1961. Its quality improved markedly, and its influence increased throughout the northwestern part of the state.

After purchasing the Forum in 1917, the Blacks and Paulson, a great team, made it the leading paper in the state. The Blacks were unusually capable businessmen. Norman B., the father, was a man of middle stature with blue eyes and pink cheeks. Friendly, he knew all of the Forum employees personally and loved to sing at service clubs. He became active in Rotary, the Masons, and welfare organizations (president of the North Dakota Society for Crippled Children, chairman of an advisory committee for the

${ }^{7}$ The best account is in the Fargo Forum, November 17, 1953, which has a special supplement on the history of the paper. 
Salvation Army), and was made a director of Northwest Bancorporation, a bank holding company. Devout Presbyterians, he and his wife gave a $\$ 30,000$ organ to the Fargo Presbyterian Church. when he died in 1931, Judge John Burke called him "a power for good through the medium of his daily paper." ${ }^{8}$ His son, tall, big-boned Norman D. Black, became the publisher of the Forum. Forty-four and with a quarter of a century of newspaper experience, he met the challenge of the hard depression years. Upon his death in 1944, his son, Norman D. Black, Jr., thirty-one, became the publisher. A quick-witted graduate of Northwestern University, short, spare, ambitious, friendly, he continued the family tradition of civic concern.

The business capacity of the three Blacks was matched by the journalistic genius of Holger D. ("Happy”) Paulson. Short, stocky, brainy, a born newspaperman, full of bustling energy, he was only thirty when he became editor of the Forum. Still, he had fifteen years of newspaper experience behind him and had begun to report the state legislature as early as 1909 . With his ever present cigar and his unblinking stare, he was a demanding, curt, brusk taskmaster on the job, intent on getting accurate and thorough coverage of the news. Although he sometimes looked to his employees like Charles Laughton playing Captain Bligh in Mutiny on the Bounty, he was actually a generous, impulsive, warmhearted person. J. Fred Essary of the Baltimore Sun, on an assignment in North Dakota, decided that Paulson was one of the great reporters of the age, and P. W. Lanier, Sr., a Democratic leader in the state, rated the Forum high: "Fargo has a better newspaper than most cities four or five times its size." Without question, Paulson and the Forum had become a real force in North Dakota politics. After fifty-five years in journalism, Paulson retired in 1957, and his son John became editor of the paper.

Through the years the Blacks and the Paulsons met with much success. When they took over in 1917, the Forum's circulation was only a little more than two-thirds that of the Grand Forks Herald. But the Forum overtook the Herald, until then generally the state's leading paper, in the early 1920's, and by 1929 it had nearly trebled its 1917 circulation. The Forum held its own in the 1930's and then grew rapidly after the Second World War, reaching a circulation of about 55,000 by 1961. In 1917 it had one-sixth of the daily circulation of the various newspapers published in North Dakota; by the 1950's it had one-third.

The reading-matter supplied by the Forum and other newspapers was generously supplemented, not only by national magazines, but also by many periodicals published within the state. After 1919 there were from ten to

${ }^{8}$ Obituary in Grand Forks Herald, January 9, 1931. 
twenty such periodicals. Almost all of them were put out by organizationschurches, women's clubs, the North Dakota Stockmen's Association, and similar groups. In 1961, for example, the North Dakota Education Association published the North Dakota Teacher (circulation 8,231), the Greater North Dakota Association the North Dakotan (6,024), the Diocese of Fargo Catholic Action News (20,400), the North Dakota Association of Rural Electric Cooperatives North Dakota Rural Electric (41,582), the North Dakota State Game and Fish Department North Dakota Outdoors $(20,000)$, and the North Dakota Farmers' Union the North Dakota Union Farmer (about 43,000).The last, a well edited semimonthly, was probably one of the most influential publications in the state.

\section{RADIO AND TELEVISION}

The work of the newspapers was supplemented by radio and television. These new means of communication came quickly to North Dakota. Earl C. Reineke, an inventive young Fargoan fascinated by wireless and electricity, became the state's pioneer in radio. He built his first transmitter in his bedroom when he was thirteen years old. When KDKA (Pittsburgh) inaugurated commercial broadcasting in the United States in 1920, Reineke, then twenty-seven, and some Fargo associates began to manufacture radio receivers. To increase sales, Reineke secured a license for WDAY and began to broadcast with a fifty-watt transmitter from the cupola of Cass County Courthouse on May 22, 1922. There were then fewer than fifty radio stations in the nation and none in the Twin Cities.

Others, however, were soon established, and by 1930, North Dakota had six stations. The important ones were WDAY and KFYR (Bismarck), both of which operated with 1,000-watt transmitters. The other four (KDLR at Devils Lake, KGCU at Mandan, KLPM at Minot, and KFJM at Grand Forks) were permitted only 100 watts. At WDAY, Reineke encouraged many amateur entertainers who were clamoring to donate their talent to radio. The early stations brought not only news and entertainment to their audiences but also weather reports, saving many lives by issuing storm warnings. When blizzards stopped all other communication, they would stay on the air day and night, giving business and personal messages of all sorts.

Reineke and other broadcasters, such as Frank E. Fitzsimonds of KFYR, sought to expand the range of their stations over the sparsely settled prairie, a vital necessity if they were to reach many people and increase their advertising revenues. WDAY was a leader. It steadily increased its powerto 1,000 watts in 1928, when it moved the transmitter to West Fargo. In 1929 the Sioux made Reineke a chief, naming him "Chief Voice in the Sky." In 1931 the station affiliated with the National Broadcasting Company; its studio occupied the top floor of Fargo's new skyscraper, the eight-story 
Black Building. The next year, WDAY had three 265-foot towers. In 1935 its power was increased to 5,000 watts and it became associated with the Fargo Forum.

Progress was slower at Grand Forks. In 1923 the University of North Dakota purchased the transmitting equipment of the Electric Construction Company (which was abandoning its short-lived radio venture) for $\$ 750$ and began broadcasting a few hours a week as KFJM. In 1930, Dalton LeMasurier, then only twenty, began to manage the station as a commercial operation under an agreement with the university, but the educational broadcasts still used one or two hours in the afternoon. Elmer O. Hanson soon became Grand Forks' chief announcer. In 1936, KFJM constructed a 165 -foot tower and increased its power to 1,000 watts for daytime broadcasting and 500 watts at night. In 1941, LeMasurier organized a new station, KILO, which shared the use of the KFJM transmitter until 1956. The Grand Forks Herald purchased KILO in the spring of 1947.

An important new leader appeared when John W. Boler moved from Minneapolis in 1939 to buy a struggling little station in Jamestown. Boler changed its call letters to KSJB, secured a low wavelength, joined the Columbia network, and increased the power of the transmitter to 5,000 watts, the maximum allowed a regional station by the Federal Communications Commission. These improvements greatly expanded the range and hence the income of the station. Boler formed the North Dakota Broadcasting Company, acquired KCJB in Minot, and then went into television in the 1950's.

Boler's station KCJB-TV began operations in 1953, inaugurating television in North Dakota, but later that year, WDAY-TV and KFYR-TV also began telecasts. The following year, Boler installed a 1,000-foot tower and antenna sixteen miles northeast of Valley City for a new station, KXJBTV. It had studios in both Valley City and Fargo and began telecasting over Channel 4 in August, using Columbia network programs. KXJB-TV was one of the largest television stations in the nation with regard to area served a large part of eastern North Dakota. Boler soon had another television station in Bismarck and an affiliate in Dickinson. His network was connected by a privately owned microwave system.

Although Baler's operation was the largest in the state, others also expanded their facilities. In its first years, WDAY-TV was using a transmitter with a 433-foot tower and 66,000 watts of power (located just south of Fargo), and its telecasts were reaching some 100,000 homes. In 1955 it took over three floors of the newly constructed American Life Building. In February, 1959, it began to use a new transmitter with a 1,206foot tower and antenna and 100,000 watts of power just east of Amenia. The 
high tower, built at a cost of $\$ 150,000$, allowed its telecasts to reach some 150,000 homes, or an estimated population of 485,000 in an area stretching from east of Detroit Lakes to west of Jamestown, and from north of Grand Forks to the South Dakota line. In 1961 the Forum Publishing Company, acquiring Reineke's stock, became the sole owner of WDAY, Inc., but Reineke continued as chairman of the board of directors.

In November, 1963, the Pembina Broadcasting Company was completing its 2,063-foot tower and antenna near Blanchard for KTHI-TV. The tower, the highest man-made structure in the world, would transmit a powerful signal for more than one hundred miles in all directions.

The high towers and antennas enabled the various stations to reach many people with their broadcasts and telecasts, even though these listeners and viewers were widely scattered over the vast plains and prairie country. By 1962 North Dakota had twenty-three radio and eleven television stations, more television stations in proportion to population than any other state. They put North Dakotans in instant touch with public events, cultural activities, and entertainment throughout the nation and also of much of the world. ${ }^{9}$

\section{CHURCHES}

Churches were an important part of North Dakota life, for they served as the chief cultural institutions for adult North Dakotans. After the First World War, secularism, denominational rivalry, shifts in population, and the economic cycle affected churches in both North Dakota and the nation. In North Dakota, however, the churches were also affected by the ethnic origins and rural character of the population.

North Dakota's churches were largely immigrant churches because its population, by the 1920 census, was 67 percent foreign-born or had foreignborn parents. Only Massachusetts and Rhode Island had larger percentages. Moreover, the state's population was 86 percent rural in 1920, living in the country or in villages of less than 2,500. Except for Mississippi, North Dakota was at that time the most rural state in the nation. It had more churches in the countryside and in small villages than did any other state.

All of this meant small congregations, dependence on outside aid, and

${ }^{9}$ Frank E. Fitzsimonds, "Historically Speaking": A Short History of Broadcasting in North Dakota [Bismarck: Conrad Publishing Company, 1958]; Fargo Forum, November 7, 1958; Douglas E. Williams, "The History of KFJM" (Unpublished M.A. thesis, University of North Dakota, 1958), pp. 1-89; The Number 1's Go Together, Fargo-the Number 1 Market in North Dakota! WDAYTV-the Number 1 Station in Fargo (Advertising folder, ca. 1962); WDAY, Mike Notes (May 1962); North Dakotan (August 1965), pp. 2-3. 
often irregular services with a consequent loss of interest. It was easy for automobiles and movies to take young people away from the Church. In the 1920's, rural congregations averaged about 110 members, and one minister often had to care for three or four churches. ${ }^{10}$ For example, the Norwegian Evangelical Lutheran church, the largest Lutheran synod in the state, had 538 congregations but only 162 pastors. It had more churches in the open country than any other denomination.

Rural churches were often in difficult straits. Pastors were hard to find and hard to keep, especially for the weaker denominations. ${ }^{11}$ In the depression of the 1930's, Pastor Lambert J. Mehl, a young man serving several Missouri Synod Lutheran congregations in northwestern North Dakota, found himself taking in only forty dollars a month in salary but spending fifty dollars a month on the automobile which took him from one church to another. His people, however, brought him meat and staples, and he gave music lessons on the side for milk and butter.

Small salaries, constant traveling, and a rapid turnover of ministers were not merely a result of the rural character of the population. They were also a heritage of the over optimism of pioneer missionaries, who often founded churches which could not thrive. Stimulated by denominational rivalry, they established too many churches for the people to support. When settlement was completed in 1916, the state had 50 denominations and more than 2,500 churches. The result was a precarious existence and a high mortality rate. From 1926 to 1936, for example, many village churches and almost half the churches in the open country died, a total of 721 abandoned churches. But 546 new churches were born during the decade. Thus the total number declined only slowly, down to about: 2,000 by 1960 .

The high mortality rate and the relative weakness of the small churches tended to impoverish the social and spiritual life of many people. This was truer for the older American stock. who were members of the stronger denominations in the eastern United States, than for the immigrant stock. In

\footnotetext{
${ }^{10}$ Richard M. Lunde, "A Statistical Summary of the North Dakota Denominations" (Seminar paper, Department of History, University of North Dakota, 1961), pp. 9-10.

${ }^{11}$ Accounts of several denominations are found in unpublished M.A. theses: Marian E. McKechnie, "Spiritual Pioneering: A History of the Synod of North Dakota, Presbyterian Church, U.S.A.” (University of North Dakota, 1955); Richard M. Lunde, "History of the Evangelical United Brethren Church in the Dakotas" (University of North Dakota, 1959); Earl E.G. Linden, "The History of Congregationalism in North Dakota" (University of Chicago, 1939); Lambert J. Mehl, "Missouri Grows to Maturity in North Dakota: A Regional History of the Lutheran Church-Missouri Synod of North Dakota" (University of North Dakota, 1953).
} 
North Dakota these denominations were forced to close more than half their churches. Thus the Congregationalists dropped from 236 churches in 1916 (the peak year for most of the denominations) to only 97 in 1960, the Methodists from 278 to 138, the Episcopalians from 88 to 36, and the Presbyterians from 182 to 96 . Too few members closed the churches; in 1920 more than half the Congregational churches had less than 26 members. But with much larger congregations, the number of Lutheran churches only dropped from 1,060 in 1916 to 859 in 1960, and the number of Catholic churches from 352 to 320. Stability in the number of Catholic churches resulted from a large membership per church. Although there were many Catholic mission churches without resident priests, in 1936 the average membership of Catholic congregations in North Dakota was 348, compared with only 147 for all denominations.

The contrast in mortality is explained by the ethnic origins of the population. Scandinavians and Germans settled North Dakota, and they were largely Lutheran or Catholic. In 1916 there were 96,000 Catholics and 76,000 Lutherans in North Dakota, and they made up 76 percent of all church members in the state. Some other churches (German Baptist, German Congregationalist, Evangelical, and others) also appealed to the immigrants, and in 1960 the so-called "immigrant churches" had 87 percent of all church members in North Dakota, a larger percentage than they had in any other state.

Consequently, foreign languages were used more in North Dakota church services before the First World War than in those of any other state. At that time, 54 percent of the state's churches - with 63 percent of the church members-had foreign-language services, using thirteen languages. Language was a basis for the fourteen Lutheran synods in the state; there were several Norwegian and German synods, as well as one each of Finnish, Danish, and Swedish origin. Sometimes Catholic parishes were organized by language; for years the village of Minto had two Catholic churches, one with sermons in Polish and one, called "the Irish,” with sermons in English. Dickinson had three Catholic churches, with sermons in English, Bohemian, and German. ${ }^{12}$

The language of the service became an emotion-charged issue in many churches. It often divided the older members, who wanted services in the language of the Old World home, from the younger members, who wanted services in English. During the First World War, strong popular feeling forced the elimination of German services, but many congregations resumed them after the war. The war, however, intensifying American nationalism,

${ }^{12}$ Catholic Action News, Golden Jubilee Edition, Diocese of Fargo, 1889-1939, p. 57. 
hastened the transition to English services. Church leaders realized that they must Americanize their churches or lose the younger generation to older American denominations, such as the Methodists and Presbyterians.

When immigration virtually ceased in the 1920's, those denominations which had sought out the immigrants needed a new policy. In 1918 the Norwegian Evangelical Lutheran church adopted a resolution looking toward English services, and in 1924 the district convention of the Lutheran Church-Missouri Synod adopted a policy of more emphasis upon English and more work among non-Germans. The change was a gradual one, sometimes made under pressure from church leaders. Some services in English and some in an Old World language was usually a halfway stage. Norwegian services began to go before the First World War and pretty well disappeared in the 1920's.

German services held on longer, but in most churches using German, the English services predominated by $1936 .{ }^{13}$ Even in the 1930's in some German-Hungarian communities (Lefor, for example) the children did not learn English until they started school. As late as 1940, older members of the Evangelical church were saying: "If they don't like the German services, let them go elsewhere.” Some of the younger people were going elsewhere. Not until the end of the Second World War did more North Dakota members of the Evangelical church subscribe to the church magazine published in English than to the one published in German.

After the war, it became more difficult to secure bilingual pastors, but the Catholic Diocese of Fargo met the need in Bohemian and Polish parishes with priests who had fled from Communist persecution in eastern Europe. In the early 1960's, some churches still held services in German.

But there had been a general shift to English services, which demonstrated the work of church leaders in Americanizing both the churches and their immigrant members. Every denomination had capable and energetic leaders. Among the Methodists were President Edward P. Robertson of Wesley College, a liberal who opposed revivalism; Frank Lynch of Casselton, a bonanza farmer who established a pension fund for ministers; the Reverend C. A. Armstrong, for many years the executive secretary of the North Dakota Council of Churches, an organization founded in 1919; and the Reverend C. Maxwell Brown, a thoughtful pastor of churches in Grand Forks and Fargo.

A Presbyterian layman, Ed Seblen of Bathgate, represented the kind of Christian leadership which improved community life in many North Dakota

${ }^{13}$ Richard P. Uhlman, "Die Deutsche Kirkenarbeit in Nord Dakota" (Unpublished M.A. thesis, University of North Dakota, 1937), pp. 23, 34, 39, 141143. 
towns. At seventy-one in 1962, he was a powerfully built, broad-shouldered, modest retired farmer with an unruly thatch of white hair. He was an elder of his church and taught an adult Sunday School class. With his own money, his leadership in rounding up volunteer workers, and even his own labor, he sparked a whole series of projects for Bathgate (population 175): the rebuilding of a dam on the Tongue River, the conversion of the empty School for the Blind into a rest home, additions to the Presbyterian Church, and a new Masonic Temple. ${ }^{14}$

In the Evangelical church (Evangelical United Brethren after 1946), the Reverend C. F. Strutz (a zealous evangelist), the Reverend A. W. Heidinger (a big, strong, happy, outgoing person), and the Reverend A. G. Martin (a conference superintendent at thirty-six) were outstanding leaders. As conference superintendents, they carried their church through the trying days of the depression and then led in its rapid postwar growth.

There were many devoted Lutheran leaders. Four men served for many years as presidents of the North Dakota District of the Lutheran ChurchMissouri Synod: Tietje Hinck (1910-1924), Joseph Klausler (1924-1941), Arnold H. Grumm (1942-1950), and Walter H. Crodts (1950-). After 1917, when the Norwegian Evangelical Lutheran church was organized, three men served as presidents of its North Dakota District: I. D. Ylvisaker (1917-1926), David Stoeve (1926-1950), and Loyal E. Tallakson (1950-).

These were able men, but probably the most influential church leaders were the Catholic Bishops. One, Vincent Wehrle, became something of a legend in his own lifetime, loved and respected by Catholic and Protestant alike. After a long career as a missionary abbot of Assumption Abbey, he was Bishop of the Diocese of Bismarck from its creation in 1910 to his resignation in 1939 at the age of eighty-four. His fifty-two years as missionary and Bishop in North Dakota and his boundless energy and zeal for the cause of religion made him the leading churchman in the history of the state. Short, heavy-set, sharp-eyed, outspoken, Bishop Wehrle loved to rule and command. As Bishop he lived frugally in the old Thompson mansion in Bismarck, once called "the most elegant residence" in North Dakota. A man of deep convictions, he opposed the Nonpartisan League because of its socialist organizers and warned his people against following pro-German leaders in the First World War. He also loved and understood the German Russians and German-Hungarians of his flock. Bishop Wehrle's successor was Vincent J. Ryan, a leader in the National Catholic Rural Life Conference. As head of the Diocese of Bismarck, Bishop Ryan became a great builder - ten million dollars' worth of new construction in eleven years.

${ }^{14}$ Grand Forks Herald, July 15, 1962. 
The Diocese of Fargo also had capable Bishops. John Shanley's successor in 1910 was James O’Reilly. Born in Ireland and ordained before emigrating to the United States, he was a pastor in Minneapolis and a friend of the famous Archbishop John Ireland for many years before coming to Fargo. Impatient with sham and pretense, he was a gentle person devoted to the faithful in the distant prairie parishes. In spite of the hard times, the diocese grew wonderfully under his care: 34 new parishes, 56 new churches, 24 schools, 7 hospital buildings, and 54 rectories. At Bishop O’Reilly's funeral in 1934, Bishop Welch said: "He loved the quiet of his study and the companionship of books."

Bishop O’Reilly was followed by the Right Reverend Aloisius J. Muench. Born in Milwaukee the son of German immigrants, Bishop Muench did graduate work at the University of Wisconsin and at the University of Fribourg, Switzerland, before joining the faculty of the Seminary of St. Francis, his alma mater. A driving perfectionist, he was rector of the seminary and only forty-six when Pope Pius XI made him Bishop of Fargo in 1935. A small man and a professor, he had a tireless energy and a German thoroughness, as well as a real knowledge of the problems of rural people.

However, Bishop Muench won the greatest recognition for his work in Germany. He went to that country after the Second World War, first as an intermediary between the United States Army and the Catholic hierarchy and soon as the representative of Pope Pius XII. When the West German Federal Republic came into being in 1951, the Pope made Bishop Muench Papal Nuncio, and he became the dean of the diplomatic corps at Bonn. For his work in Germany, Pope John XXIII elevated him to the College of Cardinals in 1959, the only instance in the history of the Catholic Church in the United States when the Bishop of a small diocese has been so honored. When Bishop Muench went to Germany in 1946, he remained Bishop of Fargo, but the administration of the diocese went to the Auxiliary Bishop, the Right Reverend Leo F. Dworschak, a graduate of St. John's University at Collegeville, Minnesota, and a tall, efficient administrator who had been in the diocese since 1926.

Other clergy, though not holding positions of such authority, also served the churches of North Dakota long and well. Preaching the Gospel and living by its precepts, they often left a deep impression upon their communities. One such man was the Reverend Homer R. Harrington, rector of St. Paul's Episcopal Church of Grand Forks for twenty-eight years (1930-1958). After growing up in Jamestown and seeing suffering and death on the battlefields of France, he had attended Seabury Theological Seminary (Faribault, Minnesota) and then, as a traveling archdeacon, won the affection of both Indian and white Episcopalians over the state before going to St. Paul's. A 
liberal who was a member of the Church League for Industrial Democracy, he took part in mitigating the hardships of the 1930's, soliciting work for the unemployed, helping to bring about the hiring of a trained social worker by Grand Forks, and acting as an unofficial adviser to the unions, which put a victorious labor ticket in the 1934 municipal election. Through the years he was a diligent visitor of his hospitalized parishioners, wisely counseled people in all walks of life, gained the respect of the whole community, Catholic and Protestant alike, and near the end of his ministry built a new St. Paul's with jewel-like stained-glass windows.

The Reverend Mr. Harrington's liberalism, however, was a minority position. In 1934 the North Dakota clergy, according to a Literary Digest poll, opposed the New Deal of President Franklin D. Roosevelt, although a majority of the bankers, businessmen, and educators in the state favored it.

Strong church leaders brought about increased church membership. The rural character of the population and its need to overcome the isolation of the lonely prairie also contributed to growth. No other social organization bringing people together was nearly as important as the Church. In 1936, for example, the state had 212 women's clubs, 1,078 Farmers' Union locals, 1,390 secret fraternal societies, and 2,097 churches. The schools brought only children together, and school enrollment was only a fraction of church membership.

The growth of church membership was rapid, much more so in North Dakota than in the nation and probably than in any other state. By 1960 the state's population was only a few thousand more than in 1916, but church membership had doubled. It rose from 225,000 in 1916 to 450,000 in 1960. In 1916 only 36 percent of the population were church members, a figure well below the national average of 42 percent. But in 1960 an impressive 71 percent were church members, a figure well above the national average of 63 percent. Such a great increase in church membership must have changed profoundly the tone of North Dakota life.

The growth was neither evenly divided throughout the period nor among the denominations. The number of Lutherans increased very rapidly from 1916 to 1926, the years of federal censuses of religious bodies. Only the Catholics had much growth in the hard years from 1926 to 1936, and the Presbyterians and Episcopalians lost heavily. Then, in the postwar years, the Lutherans had by far the largest increase, some 60 percent of the total growth. A comparison of figures for 1916 and 1960 shows that some denominations, such as the Congregationalists, grew hardly at all; many important ones (Roman Catholics, Methodists, Baptists, Presbyterians, Evangelical United Brethren, Episcopalians) grew about 50 percent; but the Lutherans grew an astonishing 184 percent. 
Two things may help to explain the great Lutheran increase: the dying out of resentments toward state Lutheran churches brought over from the Old World, and the strength and wide distribution of Lutheran churches in North Dakota. In 1916 the membership of the Lutheran churches consisted of only one-third of the people with Lutheran backgrounds living in the state. It may be that strong feelings against the state Lutheran churches in their Old World homes kept many of the immigrants from becoming church members when they settled in North Dakota, but that when those feelings faded with the passing years, they joined the Lutheran synods established in America in large numbers. ${ }^{15}$ Whatever the reason, the Lutheran churches experienced an astonishing growth from 1916 to 1926, adding nearly 59,000 members, or three-fourths of the total gain in membership of all churches.

The Lutheran churches also grew rapidly in the years after the Second World War. By that time the various synods had lost their character as distinctly the churches of Norwegian, Swedish, and German stocks; many people of other nationalities were joining the Lutheran churches. It was entirely natural for them to do so. There were Lutheran congregations in virtually every community in the state; in 1950 there were 930 Lutheran churches but only 346 incorporated places in North Dakota. Moreover, in nearly every community a Lutheran church was the largest and most thriving Protestant congregation. Size and vigor naturally attracted new members. Little wonder that in the 1950's, although the Lutheran churches had less than half of all the church members in the state, they had 58 percent of the growth in membership.

The uneven rates of growth changed the relative strength of the various denominations. In 1916 the Catholics had made up 42 percent of the membership, the Lutherans 34 percent, and all other denominations 24 percent. But by 1960 the Catholics made up 34 percent, the Lutherans 48 percent, and all other denominations only 18 percent. Nearly half of all church members were Lutherans; by percentage, North Dakota was the most Lutheran state in the nation and was steadily becoming more so.

Although the doubling of church membership was the most significant change, there were others-responses to population shifts and economic conditions. Starting in the depressed 1930's, hard-pressed country churches were consolidating with larger village churches, and farmers were becoming members of churches in town. The Evangelical United Brethren and the

\footnotetext{
${ }^{15}$ On religious conflict in Norway and Sweden, see Theodore C. Blegen, Norwegian Migration to America (2 vols.; Northfield. Minn.: NorwegianAmerican Historical Society, 1931-1940), I, 17, 30-31, 156-167; George M. Stephenson, Religious Aspects of Swedish Immigration: A Study of Immigrant Churches (Minneapolis: University of Minnesota Press, 1932), pp. 2-6, 24-25.
} 
Lutheran Church-Missouri Synod, which had formerly concentrated their work in rural areas, began to establish town churches. The figures show the trend: in 1926 North Dakota had 877 open-country churches, in 1960 only 466.

Another change was the increase in the number of Lutheran Sunday Schools and Catholic classes in Christian doctrine. When they realized that children of their families were often attending the Sunday Schools of the Methodists and other denominations, they themselves began to stress religious education. The Lutheran increase in such work started in the 1920's, the Catholic increase in the 1940's; the programs of both grew in the 1950's, and the membership of Methodist and other Protestant Sunday Schools declined steadily from their 1916 peaks. Membership in Catholic Christian-doctrine classes, often held on Saturday, increased 400 percent from 1936 to 1960.

With the passing years, all of the churches became more cosmopolitan, less the organizations of particular nationalities. The mixing of such groups by intermarriage played an important part in the process. In 1961, for example, the Catholic clergy of the Diocese of Fargo performed 550 Catholic marriages and 298 mixed marriages.

A result of growing cosmopolitanism was the union of several Lutheran synods. In 1917, three Norwegian synods in the United States had merged to form the Norwegian Evangelical Lutheran Church of America. It was the largest synod with congregations in North Dakota. In 1946, the word "Norwegian" was dropped from the name, a sign of advancing cosmopolitanism. In 1960 and 1962 it was one of the Norwegian, German, and Danish synods in the United States which merged to form the American Lutheran Church. The new name was significant. With 170,000 members in North Dakota, it became the largest church in the state, a position previously held by the Catholic church, which had about 153,000 members.

The memberships of other leading denominations were: Lutheran Church-Missouri Synod, 27,000; Methodist, 20,000; Lutheran Church in America, 15,000; Presbyterian, 14,500; Congregational Christian, 7,000; Evangelical United Brethren, 6,000; North American Baptist, 5,000; and Protestant Episcopal, 3,500. Ten of the fifty-nine denominations in the state had 94 percent of all church members. In 1962, German, Swedish, Finnish, and Danish synods in the United States merged to form the Lutheran Church in America, thereby reducing the number of Lutheran synods in North Dakota from eleven to five. The Lutheran Church-Missouri Synod, the second largest synod in the United States, was not involved, but one of its North Dakota pastors, Lambert J. Mehl, wrote in 1953: “The transition from a German-speaking semi-foreign body in the beginning to a truly American 
church has been accomplished.”

Cosmopolitanism was furthered by the radio broadcast of services, for such broadcasts extended the outreach of the larger churches. In September, 1927, the United Lutheran Church in Grand Forks, later the largest congregation in the state, began a regular broadcast of its Sunday service. About 1930 the Lutheran Church-Missouri Synod began regular broadcasts over WDAY in Fargo and KFYR in Bismarck.

Other changes grew out of postwar prosperity. Giving per member increased markedly; in the Evangelical United Brethren church, which ranked high in this respect, it rose from \$57 per member in 1947 to \$94 per member in 1958. The number of ministers increased by 136 from 1950 to 1960. Everywhere congregations were building new churches. The Roman Catholics, for example, completed the Cathedral of the Holy Spirit and the million-dollar St. Mary's High School in Bismarck, the Priory of the Annunciation nearby on Apple Creek, Sacred Heart Convent in Minot, and many new schools and churches. The Diocese of Bismarck received $\$ 90,000$ from the Catholic Church Extension Society for the building of churches and rectories in the weaker missions. Since 1910 the society had given the diocese $\$ 258,000$.

Such outside aid came to most of the denominations in the state. The scattered population, the many competing denominations, and the many small congregations made it a necessity. Thus the national council of the Protestant Episcopal church gave its missionary district in North Dakota a large annual subsidy; it was $\$ 75,000$ in 1958, even though Episcopal giving in the state had increased 300 percent in recent years.

In the prosperous postwar years, however, the trend was toward financial independence. The Lutheran Church-Missouri Synod achieved it in 1945 and the Evangelical United Brethren Church in 1955. Independence was more difficult for the 3,500 Episcopalians in North Dakota, but it was the principal goal of the Right Reverend Richard R. Emery. A stocky, sincere churchman as well as a former hockey player at the University of Minnesota, he had been rector of St. Paul's, Minneapolis. Then in 1951 he was made Bishop of the Episcopal missionary district of North Dakota at the age of forty-one. Finding that only four of the thirty-one Episcopal congregations in the state were able to support themselves, he bluntly told North Dakota Episcopalians that it was "high time that the church in North Dakota left behind its depression philosophy and adopted an aggressive attitude." Bishop Emery soon launched a campaign for a \$500,000 episcopate endowment fund to make the missionary district self-supporting. 


\section{CHAPTER 23}

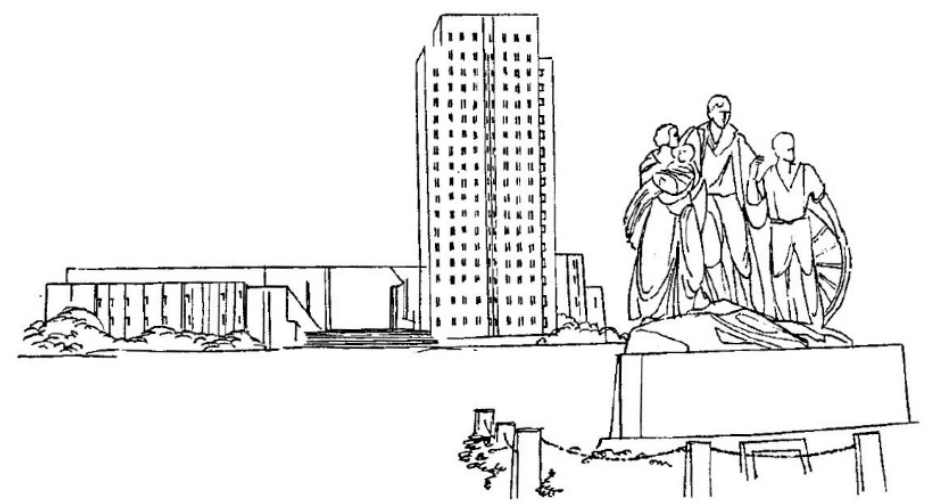

\section{The Character of a People}

WHAT DETERMINES THE CHARACTER of a people? As far as North Dakota is concerned, this question can be answered in terms of common experience: the conditions of existence, reflected in the history of the state, shaped the character of its people. Although there were many similarities, the North Dakota frontier was not exactly like earlier frontiers to the east or later ones to the west. Nor were the people who settled the state precisely the same mixture of diverse elements, foreign and native, who settled other parts of the nation. Inevitably, then, the character of North Dakotans had to be different in some ways from that of other Americans.

\section{NEW HOMES, NEW PEOPLE}

Formative experiences began with the arrival of the pioneers. Eric Ramstad, the first settler at Minot, remembered: "It was a wilderness; no preachers, no doctors, no neighbors, nothing; but we came out all right." Conditions in the new land soon began to change habits and attitudes. Norway-born immigrant Andrew Vatne saw the changes clearly after revisiting his homeland. In North Dakota, he thought, the Norwegian folk-long known for their honesty, hospitality, and thrift-had acquired good manners, a greater respect for women, more democratic ideas, and less regard for class distinctions. "In Norway," he wrote, "we were in many respects a helpless tool in the hands of the state. There we had the state church. The child must be baptized or a fine must be paid.” Another Norwegian immigrant, Ole Lima, believed that settling in the United States produced "a more wide-awake people and more independent thinking.... The Norwegian, who has lived a while in America, is more civilized than if he had not been here. He has seen more, experienced 
more, thought more, and all this has opened his eyes and broadened his view."1 Thus Lima, farming near Cooperstown in 1907, felt that life in the New World offered abundant opportunities for self-improvement.

Long before the coming of white men, migration to the plains and prairie country had influenced the character of eastern Indian tribes. Dr. James H. Howard, an anthropologist who worked for a time at the State Historical Society and then taught for some years at the University of North Dakota, has noted that even the psychology of the Ojibways changed when they moved from their woodland home to the semiarid grassland:

[The Plains Ojibways] possess a frankness and openness of character quite different from the habitual reserve of the Woodland Ojibwa and Ottawa.... From the sparkling atmosphere of the Northern prairies, it seems, the Bungi [Ojibways] have acquired an optimism and swagger which contrasts quite sharply with the world-view of the Woodland Algonquians. It might be said to reflect the dazzling sunlight, the blue sky and waving "sea of grass" of the Plains. ${ }^{2}$

When white settlers came to North Dakota, they created a rural society, so that by the end of the First World War they were spread thinly over the state, with some 86 percent of them living in the country or in small towns. The population was only eight persons per square mile outside the dozen urban centers, and even the largest of these were only exaggerated country towns. Most of the people, of course, were farmers, and of those who were not, many were engaged in businesses, trades, or professions which served the farm population.

The influence of ruralism on the North Dakota character was matched by that of foreign origin on the population. North Dakota was unique in the extent to which these two factors were combined. In 1920 only four states had a higher percentage of foreign-born in their populations: New York (27.2 percent), Connecticut (27.4 percent), Massachusetts (28.3 percent), and Rhode Island (29 percent). Both North Dakota and Minnesota had 20.4 percent foreign-born, South Dakota 13 percent. The states with higher percentages were all much more urbanized and industrialized. In 1920, New York's population was 82.7 percent urban, Connecticut's 67.8 percent, Massachusetts' 94.8 percent, and Rhode Island's 97.5 percent. Minnesota's was 44.1 percent urban. In North Dakota only 13.6 percent of the population was urban in 1920.

The foreign stock included not only the foreign-born but also native-born persons of foreign and mixed parentage. They made up 66.8 percent of North

${ }^{1}$ North Dakota Historical Society Collections, II (1908), 198-201.

${ }^{2}$ James H. Howard, "The Identity and Demography of the Plains-Ojibway," Plains Anthropologist: Journals of the Plains Conference, VI (August 1961), 172. 
Dakota's population in 1920. Only Rhode Island with 69.8 percent and Massachusetts with 67.l percent had larger percentages. None of the Great Plains states had nearly as large a proportion of foreign stock as North Dakota, none were as rural. The closest was South Dakota, whose population was 48.8 percent foreign stock and 16 percent urban. Montana's was 47.5 percent foreign stock and 31.3 percent urban, Nebraska's 40.3 percent foreign stock and 31.3 percent urban.

The large foreign stock in North Dakota's population meant that most North Dakotans were undergoing the process of casting off old, traditional ways of living and thinking and adopting new ones. Part of the change was in language. In 1920 more than half of its people were bilingual, speaking both English and the language of an Old World homeland. ${ }^{3}$

Many people were not very much at home in North Dakota. Over half of the population in 1920 had not been living in the state in 1900. There were other reasons for uneasiness. Those of German descent, torn by conflicting loyalties during the First World War, had passed through an emotional crisis. Moreover, conservatives stirred up anger with loose charges that the Nonpartisan League was pro-German.

The influence of emotionalism in North Dakota history can be traced through cycles of elation and depression, experienced first by the Indian inhabitants and then by the white settlers. For the Indians, elation sprang from the presence of great herds of buffalo, from the acquisition of horses, from victory in war, from the vigor of health; depression came from absence of the herds and consequent hunger, from losing horses, from defeat in war, from the havoc of epidemics. For their part, the white traders feared the Indians and the wilderness, hoped for profits from the furs brought in by their customers.

When farmers, speculators, and railroad builders rushed into the area, they were excited by the prospects of making a fortune from wheat and rising land values. Elation gave way to depression when the Great Dakota Boom ended with drought, low prices, and a mass exodus of settlers in the late 1880's. After 1898 a second boom brought a new wave of optimism. But hope was soon replaced with feelings of being exploited by outside interests. This helped to make the Nonpartisan League a success, and when the League gained control of the state government, farmers experienced sensations of elation and power. Triumph gave way to despair and feelings of helplessness when the League failed and the 1920's and 1930's brought a long farm depression with bank failures, low prices, mortgage foreclosures, crop failures, and drought. The emotional tone of North Dakota life changed with the economic revival of the Second World War and the prosperous postwar years. Then optimism again

${ }^{3}$ United States Bureau of the Census, Fourteenth Census of the United States, 1920, Vol. II, Population, General Report and Analytical Tables, pp. 982-985. 
released the energies of the people and brought a new wave of progress.

\section{FEELINGS OF INFERIORITY AND DEPENDENCE}

While cycles of elation and depression were intermittent, other emotions were persistent. Anxiety about the weather-fear of blizzards, hail, cold, searing heat, and drought — continued through the years. Many North Dakotans felt either that their state was in a weak and inferior position in the nation or that it was so held by the majority of Americans. They felt alienated from the main stream of American life, as if they were looked down upon as inferior by the rest of the American people. Feelings of inferiority or of being considered inferior were long an important part of the emotional life of thousands of North Dakotans. People of a rural state, they felt like country cousins toward the city folk of the nation.

Indeed, something of the same feeling was a part of the undercurrent of antagonism between country and town people within the state. Many country people felt that townsmen considered themselves superior; country women were not always at ease in groups of more fashionably dressed town women. Realizing the harm such feelings might bring to their enterprises, perceptive businessmen deliberately tried to cultivate good will among farmers. Politicians discovered they could attract votes by not dressing too well. John Burke campaigned in an old sheepskin coat; William Lemke wore a cap; William Langer's suit looked as if he had slept in it for a week.

Not all country people experienced antagonism (family and business ties between town and country were often close), nor did all North Dakotans feel that they and their state were inferior. But certainly thousands of them did resent the patronizing attitude toward the state and its people that they so often met. Eric Sevareid, the well-known news commentator, remembered thinking "Why are we here on the cold, flat top of our country?" when as a boy in Velva he traced on a map "the meaningless rectangle of Dakota."

Compensation for such feelings of inferiority was natural. Many North Dakotans were, as Dr. Edward C. Blackorby has written of William Lemke, "urged on by a desire for success in the grand style." As was the case with all Americans, what North Dakotans desired were the standard American values and equality of status in the nation. Such strivings, for example, marked the “white-kid-glove era” of the 1880's in Grand Forks. Although the frontier had barely passed, the elite built Victorian homes with tile fireplaces and parquet floors and set them in deep lawns. They filled them with Haviland china, silver, cut glass and crystal, flowered carpets, pianos, and velvet draperies. Men dressed their wives in gowns and jewels from Chicago and New York and led a gay social life-balls, dinners, theatricals, imported orchestras, races with 
blooded trotters, and formal calling to leave engraved cards. ${ }^{4}$

Striving for equality of status permeated North Dakota life. There was, of course, nothing unusual about either the feelings of inferiority or the compensations for them. When North Dakotans felt patronized and belittled, weak and inferior, they were feeling what all minority groups have always felt. But universality made such feelings no less real and significant in the history of North Dakota. They were solidly based upon North Dakota's status as a rural, sparsely settled, semiarid plains and prairie state, a colonial hinterland exploited by and dependent upon outside centers of trade, manufacturing, and culture. "We are so heartily disgusted with our dependent condition, with being snubbed at every turn in life," wrote the Yankton Press and Dakotaian in 1877. And in 1882 the Grand Forks Herald commented on a rebel leader in Egypt: "Arabi Pasha feels like a Dakota patriot."

\section{TRAITS FOR A NEW COUNTRY}

Conditions in early North Dakota strengthened the traits needed for its development - courage, optimism, warmhearted neighborliness, energy, individualism and self-reliance, democratic ways, and often loyalty and a sort of agrarian radicalism. These were natural qualities for a rural society in a new country.

Courage, the great primitive frontier virtue, was an old story with North Dakotans. The Indians had made a religion of courage; the Mandans diligently cultivated it by the self-tortures of the Okipa, and the Sioux did the same thing with the Sun Dance. No fur trader could have survived without it. The settlers who gave up the familiar surroundings of their old homes to move to the Dakota frontier had to have courage. And life on the prairie, with its isolation and loneliness, was not for cowards.

Even optimism was a kind of courage; only optimists moved to the frontier, for there men lived mainly by faith in the future. In 1883, James Bryce, the British statesman, attended the laying of the cornerstone of the capitol at Bismarck. Describing the event in The American Commonwealth (1888), he commented that "the confidence of these Westerners is superb" and continued:

It is the same everywhere from the Mississippi to the Pacific. Men seem to live in the future rather than in the present: not that they fail to work while it is called to-day, but they see the country not merely as it is, but as it will be, twenty, fifty, a hundred years hence.

After revisiting Velva in 1955, Eric Sevareid wrote:

${ }^{4}$ Vera Kelsey, Red River Runs North! (New York: Harper and Brothers, 1951), pp. 262-265. 
It was a trial of the human spirit just to live there, and a triumph of faith and fortitude for those who stayed on through the terrible blasting of the summer winds, the merciless suns, through the frozen darkness of the winters when the deathly mourn of the coyote seemed at times the only signal of life.

Gertrude Anderson, one of his older friends, said of the early days in Velva: "It was so awful here, then-think of it, from Berlin I came as a bride, to here!" Yet it was wonderful, Mrs. Anderson remembered, because of the warmhearted folk in Velva.

The very sparsity of the population made for a neighborly, helpful people given to hospitality. Certainly it placed a value upon the individual; where there were so few, each person counted, each was needed. All of this had a beneficial effect upon the North Dakota character. It helped to define the accepted system of values, made a more decent and humane society, made life more satisfying. If the prairie were lonely, it was better than the loneliness of the great cities, where many people were, or seemed to be, faceless, valueless, unwanted, and unneeded.

North Dakota's cool, dry climate seemed to infuse people with energy and ambition. Though often maligned, it undoubtedly produced the hustle which marked the typical North Dakotan. He was willing to work hard, and he took pride in being able to withstand the rigors of the cold winters.

Although farming encouraged individualism and conservativism in North Dakota, the feelings of being exploited by the grain trade, the railroads, and the banks stimulated cooperation and an agrarian radicalism. Concentration on wheat, the universal crop, gave all North Dakotans a common interest and a common set of enemies in the Twin Cities. So wheat unified a state made up of diverse elements and strengthened radicalism. The strong farmers' cooperatives demonstrated the point.

Not all North Dakotans, of course, were agrarian radicals, nor were they all courageous, energetic, neighborly, self-reliant individualists. Yet many were just such persons, and while times and conditions changed, the North Dakota character seemed to remain much the same. Especially did courage persist. Through the years the leaders of the state were marked by it-from James J. Hill and Pierre Bottineau to Usher L. Burdick and William Langer. Admiring courage, North Dakotans cherished and often celebrated the epic of pioneer settlement. The story of struggle against frontier hardship became the folklore of the people.

North Dakota's political leaders were famous for their independence. In 1961, for example, Senator Milton R. Young, who often defied his own party, denounced the John Birch Society, although it was strong in North Dakota, with, as he said, "some of the most able and influential people in each community." 
Optimism, too, persisted, although there were expressions for the ways in which a man might lose his farm: he might be "hailed out," "dried out," "blown out," or "starved out." And other traits lived on. In 1940, newspaperman Mart Connolly, a worker for the Greater North Dakota Association with a strong affection for the state, wrote:

I like the democracy of North Dakota, the state without a millionaire and with fewest paupers; where rich and poor find a common meeting ground in the fight for improvements in the home state.... There is something of the broadness of its prairies in the mental makeup of its people. A radical is not so radical nor a conservative so conservative in this rather free-and-easy non-eastern state. ${ }^{5}$

In 1947, Governor Fred G. Aandahl said: "We live in an atmosphere of western cordiality. We have the spirit of wholesome consideration and helpfulness one to another."

Another aspect of the North Dakota character was noted by the Reverend Dr. Carroll E. Simcox, a native of Lisbon who grew up at Park River and became an Episcopal priest and the author of many books. He told the graduating class at the University of North Dakota in 1961 what North Dakota life did to North Dakotans:

The children of these prairies do not grow up expecting that all the bonbons of this world are going to be fed them with a runcible spoon by pampering destiny. Here you sweat by summer and shiver by winter and work and pay for everything you get, so that by the time you are an adult you are spiritually prepared for more hard work... North Dakota life has been meant to make of you a tough fighter, a hard worker. ${ }^{6}$

\section{LOYALTY AND THE HUMANE VALUES}

The harsh realities of North Dakota life, the sense of exploitation and minority status, and the unifying influence of the concentration on wheat all gave many North Dakotans a feeling of community, a feeling of identification with the state. Moreover, because they were building a new society, they developed a strong loyalty to it, a strong state patriotism when the state was still very young.

One aspect of loyalty was praise for the land. It began in 1800 when Alexander Henry noted that the Red River Valley Was "as pleasant a country as there is in America.” In the 1880's, Mary Dodge Woodward praised Cass County, "covered with No. 1 hard wheat and the wayside all abloom with goldenrod and asters," and the Marquis de Mores liked the Badlands because

${ }^{5}$ North Dakotan, XV, 10 (October 1940), 7.

${ }^{6}$ From a tape recording made by Professor Robert P. Wilkins. 
there was, he said, "room to turn around." Young Theodore Roosevelt, glorying in ranch life on the Little Missouri, wrote to his sister: "The country is growing on me more and more; it has a curious fantastic beauty of its own."7 In the 1940's, Professor John M. Gillette wrote: “The short spring and fall and the three months of summer are a delight. Most of the days are blessed by sunshine.... The atmosphere is radiant and invigorating, seeming to consist of pure ozone.” In 1958, Don L. Short, rancher and congressman from Medora, called North Dakota "a state with more future than past and one that holds tremendous opportunity for its people if they use it right."

The state abounded with loyal, humane, warmhearted, outgoing people. A typical example was the Reverend Eldred D. Murdoch, the tall, slender, redheaded chaplain of the Episcopal student center at the University of North Dakota. After growing up at Wimbledon, he served as school superintendent for a score of years at Lidgerwood and other towns. Then, turning to a new calling, he read for holy orders and entered the ministry. His honesty and candor, his ready smile, his enthusiasm and zest for life, his sympathetic insight into the problems of mixed-up young people, and his willingness to spend his time and energies in helping them in their troubles won him a host of young friends before his death in 1962.

Although they were the leaven of society, the Eldred Murdochs were not, of course, well known beyond their own communities, but one North Dakotan was familiar to millions of Americans. While he was individual, not a type, Lawrence Welk, the orchestra leader, gave all Americans an image of the North Dakota character. Of Alsatian stock, he grew up on a farm near Strasburg, North Dakota, learned the accordion from his father, and in the 1920's began to play at churches, country dances, and then on the radio station at Yankton. After the Second World War, he and his orchestra, playing his famous "Champagne Music," attained success with long engagements at hotels, many recordings, and a weekly television show. The honest, friendly, and unsophisticated Welk and his wholesome show gave millions of viewers some understanding of North Dakotans. During his rise he had met ridicule and contempt, and so courage and energy played a part in his success. His loyalty to North Dakota was obvious to those who watched his program.

Many North Dakotans expressed loyalty in other ways. Alumni and friends of the University of North Dakota, for example, gave or pledged some five million dollars to that institution in the dozen years after 1950; such gifts were without parallel in the region. Each summer, North Dakotans living on the Pacific Coast held a series of picnics. In 1962 some fourteen thousand persons attended the North Dakota picnic near Seattle.

${ }^{7}$ Elting E. Morison et al. (eds.), The Letters of Theodore Roosevelt (8 vols.; Cambridge: Harvard University Press, 1951-1954), I, 74. 
The support of welfare and education also revealed loyalty, as well as generosity, community spirit, and devotion to democratic, humane values. In 1915 the legislature abolished capital punishment. In 1957, North Dakota ranked fifth among all the states in the amount it spent on public schools in proportion to its income, eighth in the amount spent on higher education. In 1960, North Dakota stood far above the national average in monthly payments to recipients of old-age assistance, although its per capita personal income was well below the national average.

Other actions, too, revealed something of the people, their energy and values, and the changing circumstances of their lives. Every community had persons with cultural interests who cherished books and music. The Scandinavian countries published and consumed more books in proportion to the population than any other people, and the Scandinavian stock was the largest element in North Dakota. In Nelson County in the early 1920's, for example, the homes of Norwegian families had many books, such as the classics of Ibsen and Bjornson, while Germans owned the Works of Goethe and Schiller. In the 1950’s, Orville Bakken, a farmer near Northwood, built up a private library of one thousand volumes, and a neighbor, Olaf Jorde, had a collection of three thousand records, mostly classical music.

Many were interested in preserving recollections of the early days. Mary A. Barnes Williams of Washburn, for example, wrote the stories of Fifty Pioneer Mothers of McLean County, North Dakota (1932). In the 1950's, communities everywhere were celebrating the seventy-fifth anniversary of their founding, putting on elaborate programs and publishing substantial histories. Though small as American cities go, the largest places offered a rich cultural fare: concert series, symphony orchestras, art exhibits, and lectures. Newcomers to Fargo-Moorhead were happy to find, as President John J. Neumaier of Moorhead State College said, "a great variety of cultural opportunities, far greater than may be found in most areas of our population."8

If North Dakotans had cultural aspirations, they also liked sports. Many took a great interest in basketball, skating, curling, baseball, swimming, and horseback riding. Hunting, a natural pastime in a sparsely settled country, was popular. Men and women shot deer, antelope, sharp-tailed grouse, pheasants, ducks, and geese. Boys young and old trapped fur bearers: mink, beaver, muskrat, skunk, jackrabbit, and now and then a coyote, wolf, or red fox. Fishing, an old sport in the state, was stimulated by the construction of Garrison and other dams; the large lakes thus created also increased interest in boating and water sports.

Although they played hard, North Dakotans were, more than most Americans, a sober, family-loving, churchgoing, moral people. During the first

${ }^{8}$ Fargo Forum, February 24, 1960. 
twenty-five years of statehood, 147 bills dealing with moral issues were introduced in the state legislature-an average of more than 12 per session. ${ }^{9}$ In 1961, North Dakota had the second lowest crime rate among all the states (only New Hampshire was lower). While legal grounds were broad and divorces could be had for the asking, North Dakota had the third-lowest divorce rate in the nation; it was less than half the national average. In reality it had the lowest rate, for the two states below it (New York and New Jersey) had such narrow grounds that their people commonly established a legal residence in another state to obtain a divorce.

\section{VARIETIES OF NORTH DAKOTANS}

North Dakotans differed in moral standards, character traits, and ideas and outlook, just as they differed in occupation, residence, education, income, and national origin. For many years more of the foreign-born and their children were farmers, more of the older American stock lived in town.

Among the foreign stock there were differences springing from national origins. The German Russians, for example, coming later than the Scandinavians and Canadians, lived on poorer land and were not as well off as other groups. Profoundly influenced by their years in Russia, where they were cut off from stimulating contacts, they considered themselves a downtrodden class, had larger families than the Scandinavians, did not believe so much in schooling, looked upon their womenfolk as inferior, and were slow to diversify their farms. Even in the 1930's, few German Russian young people were attending high school.

There were always exceptions. Sebastian Schweitzer was one. He had served as a court official in Russia before emigrating and homesteading on the Knife River. In his new home Schweitzer became a community leader, played the church organ for twenty-five years, read day and night, and encouraged his children to go to college. In 1934 his son Adam was the first person of German Russian descent from a school district in eastern Dunn County to attend college. But by the 1940's many young German Russians were going to college and entering business and the professions.

Other differences were related to geography. Just as rainfall, topography, the size of farms, and the sparsity of the population differed from east to west in North Dakota, so did the character of the people. Those of the Red River Valley seemed more reserved, more conservative, more formal; those of the Missouri Plateau seemed more friendly, more liberal, more informal. Western North Dakotans liked to gamble, called their ministers and other dignitaries by their first names, and dressed in western-style clothes. Many of them were a hard

${ }^{9}$ Mariellen M. Neudeck, “Morality Legislation in Early North Dakota, 1889-1914” (Unpublished M.A. thesis, University of North Dakota, 1964), pp. 1, 94-99. 
drinking, poker-playing, free-and-easy lot. One outsider thought that they had “a Western friendliness, and a quiet, devil-may-care attitude,” that they seemed leaner and fitter than people in other places. In a way, the Drift Prairie, lying between the Missouri Plateau and the Red River Valley, was a transition zone in human characteristics, just as it was in rainfall, native vegetation, and farming.

All North Dakotans were conscious of the state's minority position; no one wanted to see it lag behind the other states or below the national average. All wanted standard American values, but they held one of two attitudes: they were either loyal to North Dakota and proud of its achievements or critical of the state and ashamed of its status.

The critics, the disloyal ones, were numerous and of long standing. They complained about the climate, the cold, the long winters, the dust storms, and the uncertain rainfall. They disparaged the achievements of the state and talked about its cultural deficiencies. In short, they accepted as valid outsiders' low valuation and patronizing attitude. Sometimes, when traveling outside North Dakota, they were reluctant to admit that it was their home. They fell into the habit of comparing the state's weak points with the strong points of other states. Although no rational person would ever expect a farm state such as North Dakota, with its small population, to have or to do all the things possible for a thickly populated, industrialized state, North Dakotans often slipped into disparaging comparisons which implied just such unreasonable expectations.

Some of the disparagement did have a basis in reality. What society actually does all it might do with its resources? But much of it was the result of ignorance or unreason. For example, such a well-educated person as Dr. Edwin H. Rian, then president of Jamestown College, was reported as saying in 1957 that North Dakota's chief drawback was its cultural deficiencies and adding: "There isn't a research library in North Dakota."10

Although no library in the state was nearly as large as those of the big cities or the great universities of the nation (the implied but unreasonable expectation in Rian's statement), much research was in actual fact then being done in libraries at the University of North Dakota, the Agricultural College, and the State Historical Society, and scholars from outside the state were using their special collections. In 1960 only about 150 colleges and universities and about 80 cities in the United States had larger libraries than the University of North Dakota. The scholarly George F. Will believed that those who disparaged the state and the region did so out of ignorance and the mistaken "feeling that the Northern Plains are a barren waste.”

\section{THE ACHIEVEMENTS OF NORTH DAKOTANS}


George F. Will and thousands like him were loyal to North Dakota and proud of its achievements. They believed in the state and felt that the distinctions won by many North Dakotans were proof that criticism of the state was unjustified. Probably the greatest North Dakotan, a sort of adopted son, was Theodore Roosevelt, who once said: "I never would have been President if it had not been for my experiences in North Dakota."11

Roosevelt was only one of many, for North Dakotans distinguished themselves in many fields. In athletics, Steve Myhra from Wahpeton won the national professional football championship for the Baltimore Colts with his place kicking in 1958; Cliff Cushman from Grand Forks placed second in the high hurdles in the Olympic Games at Rome in 1960; Roger Maris, a Fargo boy playing with the New York Yankees, broke Babe Ruth's home-run record in 1961; and the University of North Dakota hockey team won the intercollegiate championship in 1963. In 1965 the North Dakota State University football team ranked first in the nation among small-college teams. The Tescher brothers (Jim and Tom), Alvin Nelson, and Dean Armstrong—all cowboys from Sentinel Butte-won top honors on the national rodeo circuit.

In business, Harold L. Schafer from Stanton and Bismarck built up a multimillion-dollar glass-wax enterprise, winning the Horatio Alger Award in 1953 for his storybook rise. John M. Hancock from Emerado became president of Jewel Tea, a partner of the Wall Street firm of Lehman Brothers, and a director of some twenty large corporations.

In exploration, Vilhjálmur Stefansson from Mountain sought the secrets of the Arctic; Carl Ben Eielson from Hatton won fame as an Arctic flier. In engineering, Maxwell Upson from Cummings developed prestressed concrete pile and built up an international construction company; Thomas C. Barger from Linton played a part in the discovery of oil in Saudi Arabia and became president of the giant Arabian-American Oil Company. In journalism, Edward $\mathrm{K}$. Thompson from St. Thomas became the editor of Life magazine; Eric Sevareid from Velva reached the top as a radio and television commentator.

In music, Paul Yoder from Grand Forks won fame as a band arranger and composer; Leigh Gerdine of Sheyenne went to Oxford University as a Rhodes Scholar in 1938 and later became chairman of the music department at Washington University, St. Louis. In education, Elmer Ellis from Towner became president of the University of Missouri. Frederick L. Hovde starred on the Devils Lake High School football team; as a member of the University of Minnesota varsity, he led the Western Conference in scoring in 1928. Hovde went to Oxford as a Rhodes Scholar from North Dakota and later became president of Purdue University. In government service, Howard R. Huston

${ }^{11}$ Dakota Territorial Centennial, a supplement to North Dakota daily newspapers, February 28, 1961, p. 17. 
became chief of internal service with the League of Nations (and later vicepresident of American Cyanamid); David E. Bell became director of the United States Bureau of the Budget and a lecturer on economics at Harvard. Bell was born in Jamestown; Huston's parents homesteaded Northwest of Granville, and he taught school at Surrey before graduating from the University of North Dakota in 1917. In religion, Bishop Aloisius J. Muench of Fargo became a Papal Nuncio and a Cardinal in the Roman Catholic church.

In medicine, Dr. John S. Lundy from Inkster became head of anesthesiology at the Mayo Clinic; Dr. Cushman D. Haagensen from Hillsboro became a famous cancer specialist at Columbia University. In show business, Dorothy Stickney from Dickinson played the mother in the Broadway hit Life with Father; Angie Dickinson from Kulm became a popular show girl and actress. Peggy Lee from Wimbledon and Jamestown found fame as a singer with Benny Goodman's band, on Capitol Records, and on radio and television.

In literature, Maxwell Anderson from Jamestown wrote prize-winning plays for the New York stage; James W. Foley from Medora and Bismarck wrote poetry published in the New York Times, Century, and Saturday Evening Post. In agriculture, Tom Campbell, born in a sod shanty near Grand Forks, acquired a 95,000-acre wheat ranch in Montana and a 500,000-acre cattle ranch in New Mexico; Wilse Richards of Dickinson developed outstanding herds of purebred Angus and Hereford cattle and was elected to the Cowboy Hall of Fame. In law, Judge Ronald N. Davies from Grand Forks made a far-reaching decision at Little Rock, Arkansas, upholding integration of the schools; Edward H. McDermott from Cooperstown became one of the nation's leading experts on tax law.

While merely the names of those who won recognition outside the state would fill pages, those who provided leadership to communities within the state played a more important role in North Dakota history. Many communities had outstanding leaders. One example was the Albert J. Christophers of Pembina. While Mrs. Christopher became an authority on the history of the region, her husband served as mayor for thirty-two years and in the state legislature for ten. As mayor, Christopher, a tall, silver-haired man with a disarming smile, secured a water system, a sewage lagoon, a new city hall, hard-surfaced streets, and a historical museum. He won Pembina a Community Betterment Award in 1962.

In 1959 the North Dakota Economic Development Commission began to give awards in a Community Development Contest. Stimulated by the competition, with its recognition and cash prizes, civic clubs undertook to beautify their towns, to improve recreation with parks, swimming pools, playground equipment, and museums, and to develop industrial opportunities and tourism. Forty-four communities entered the first year's contest, and in the 
first three annual contests, first prizes in the various population divisions went to Minot, Rugby, Parshall, Carrington, Larimore, Gackle, Wahpeton, Pembina, and Manvel. In addition, a grand prize was given to the outstanding community in North Dakota. Parshall, led by Gary Lerberg, won it in 1959; Gackle, led by Mrs. E. K. Remboldt, won in 1960; Manvel, led by Odin C. Hoverson and Mrs. Duane Olsen, won in 1962 (there were no awards in 1961). Manvel, population 313 , also won fourth place and two thousand dollars in a national communityimprovement contest sponsored by the American Federation of Women's Clubs.

Each year, a community leader received the Governor's Award as the outstanding citizen of North Dakota. In 1959 the award went to William S. Davidson, Jr., of Williston, in 1960 to Mrs. E. K. Remboldt of Gackle, and in 1962 to Albert J. Christopher of Pembina. Such recognition demonstrated that many communities had a progressive spirit and able, civic-minded leadership.

Yet for all their abilities and achievements, North Dakotans often met a patronizing attitude. Thus when big, ruddy John Simonson of Grand Forks set a national automobile speed record (208 miles per hour) at Bonneville Salt Flats, Utah, in 1962, he said: "It really shakes 'em up to have a North Dakotan come down there and do that." Although a score of young North Dakotans went to Oxford on Rhodes scholarships and hundreds were graduate students at universities all over the nation, they often found an expectation that they could not do the work because of their origin. But they also found themselves winning a standing at or near the top.

Not all outsiders patronized North Dakotans. The English actor Sir Cedric Hardwicke toured the United States with Charles Laughton, Agnes Moorehead, and Charles Boyer, reading George Bernard Shaw's Don Juan in Hell. He recalled the experience in his "irreverent memoirs," A Victorian in Orbit (1961):

I discovered that it was hard to discern where we were. All the towns merged into an homogenized blur of Main Street, stoplight at the crossroads, drug-store on one corner, movie house down the block. An exception must be Grand Forks, North Dakota, which gave us the liveliest and most sensitive audience including the two seasons we subsequently did on Broadway.

In 1933, North Dakota ranked a proud fifteenth among the states on an index of cultural-intellectual development prepared by Frederick Osborn of the American Museum of Natural History in New York City. Osborn used seven tests, including mental tests for school children, army intelligence tests, illiteracy percentages, and magazine readers per one hundred of population, to assign each state a single index number. For all its isolation, ruralism, and its position of economic disadvantage as an exploited farm state, North Dakota 
ranked ahead, among others, of Pennsylvania, Indiana, Illinois, Michigan, Wisconsin, Utah, Nebraska, Kansas, South Dakota, and Iowa, as well as all the southern states. ${ }^{12}$

Such abundant evidence of the ability and worth of the North Dakota people eased the irrational and unjustified feelings of inferiority forced upon them by the status of their state as a colonial hinterland. North Dakotans got satisfaction from other sources. Many of them loved the flat, fertile Chernozem soils of the Red River Valley, the sweep of the vast, rolling prairie with its endless expanse of grass and sky, and the awesome, silent grandeur of the scarred Badlands. They looked with pride upon their handiwork: the rippling fields of grain; the herds of cattle; the magnificent skyscraper capitol; the exhibits of the State Historical Society; the campuses of the institutions of higher education, with their libraries, laboratories, classrooms, dormitories, student unions, and playing fields; the many fine public schools and churches; the railroads and highways; the newspapers; the radio and television stations; the clinics and hospitals; the state welfare institutions; the strong cooperatives; and the towns, with their business enterprises, parks, and handsome homes set in flowerbordered lawns. All these represented the attainment of standard American values.

Proud of the present, North Dakotans looked back upon a long record of achievement which had turned an empty, semiarid wilderness into a civilized country with much of the equipment of a modern society. So, on the onceempty prairie, hundreds of thousands of people, endowed with energy, knowledge, and a great variety of skills, lived, and each year, in spite of blizzard and drought, produced much wealth, enough to net annually some one billion dollars of personal income by the late 1950's.

\section{THE TRANSFORMATION OF NORTH DAKOTA LIFE}

North Dakota life changed in many ways from the 1920's to the 1950's. There were important shifts in occupation and residence. By the 1950's the majority of those gainfully employed were for the first time making a living in nonagricultural employment. Thirty-five percent lived in urban centers (2,500 or more population) by 1960 and 47 percent in places of over 1,000. More and more farmers were living in town.

Many forces were breaking down the rural isolation and remoteness which had characterized North Dakota life for so long. The telephone helped. Fortyone percent of North Dakota's farms in 1930 had telephones, and the figure was up to 66 percent in 1959. In the 1920's radio and in the 1950's television put North Dakotans, in spite of distance and scattered population, in instant touch with ideas, news, and entertainment from all over the world. In 1930, 
when radio was only a decade old, 40 percent of North Dakota farm families owned receiving sets, a percentage nearly double that of the farm families of the nation. Good roads and automobiles also did much to break down isolation.

North Dakotans really took the automobile to their hearts. Like the people of other states in the West, they owned far more automobiles in proportion to the population than did Americans generally. North Dakotans drove fast, and distance came to mean little to them. Its conquest, creating an enlarged community, made possible a reorganization of social institutions (schools, churches, newspapers, health and library services) to reach more people and so avoid the handicaps imposed by sparsity of population.

With the dispersal of North Dakotans over the nation, most families had relatives in other states and frequently traveled outside North Dakota. If they had prospered, it was not uncommon for the Scandinavian immigrants to visit their Old World homes. By the 1950's many high school and college students, as well as older people, were making European tours; and in 1959 a group of North Dakota leaders visited Russia.

Moreover, people were more at home on the prairie than ever before; the earlier uneasiness had passed away. By 1960 only a few of the foreign-born were still living, and most North Dakotans belonged to families which had been in the state for three generations or more. The people were also steadily becoming more alike as intermarriage mixed the many original stocks. Then, in the postwar years, with prosperity, with hard-surfaced roads and new schools, with rural electrification, with better hospitals and more libraries, with the young going in ever larger numbers to colleges and professional schools, and with all the goods and services which made up the American standard of living, the psychology of North Dakotans underwent a marked change. Memories of the terrible 1930's faded in the minds of the older people, and the young had no recollection of those years. By 1960 nearly half the population had been born since 1939. So many North Dakotans lost the feeling of being exploited, second-class citizens separated from the main stream of American life. With the change came a growing conservatism. The once-radical North Dakota Farmers' Union moderated, and its television voice argued for the identity of interests between the farmer and main street.

\section{THE LESSON OF ADAPTATION}

When North Dakotans think about the history of their state, they are thinking about a usable past, for it reveals a steady adjustment to the physical environment. Just as native plant and animal life had adapted to conditions on the Northern Plains and just as Indian tribes from more humid lands to the east had adapted to the same environment, so, too, did the white pioneers and their successors, the North Dakotans of later years, respond to the imperatives of the grassland. 
In 1907, biologist Wallace Craig, then a teacher at Valley City Normal School, first pointed out the manifold adaptations of North Dakota plant, animal, and human life to the dry, cold, level plain. He wrote:

But more impressive, to my mind, than all the isolated facts, is the deep-lying sympathy between the plants, the animals, and the men, that must all adapt themselves to the same hard conditions; the consequent similarity of behavior in even the most diverse forms of life; and, finally, the extent to which the most wonderful products of plains civilization have been foreshadowed, and in some cases, I may say, even excelled by the work of the primeval inhabitants. ${ }^{13}$

North Dakotans can look upon their accomplishments with satisfaction. They can feel at home in a world. of change and look forward with optimism to a continuation of the still-incomplete work of adapting their society and its institutions to the environment. In the future, as in the past, they will deal with the problems of scanty rainfall and the sparsity of population which it has produced. They will seek to raise and stabilize their income, to diversify their economy, to conquer distance, to counteract in some way the social cost of space, and to adjust school, college, and church to meet their economic, cultural, and spiritual needs. By such adjustment they can, in the future, as they have in the past, continue to attain the ever rising standard American values and at the same time be themselves-moral, courageous, outspoken individuals, lean and fit, friendly, democratic and hospitable, energetic and aggressive. For they live, not in the urban world with its lonely crowd, but on the prairie, where the sparsity of population emphasizes the worth of the individual, where each is needed and each can do his part in the upward struggle of a rural society.

${ }^{13}$ Wallace Craig, “North Dakota Life: Plant, Animal and Human,” Bulletin of the American Geographical Society, XL (July 1908), 415. 


\section{Bibliographical Essay}

\section{MUSEUMS AND MANUSCRIPT COLLECTIONS}

The principal collection of artifacts reposes in the museum of the North Dakota State Historical Society in Bismarck. There are also substantial collections in the museum at Fort Abraham Lincoln State Park five miles south of Mandan, in the Theodore Roosevelt National Memorial Park Museum, and at the Chateau de Mores in Medora. Smaller collections are maintained at Camp Hancock in downtown Bismarck, at Fort Abercrombie, Fort Totten, Fort Buford, Fort Pembina, Whitestone Hill Battlefield, and by a number of local historical societies and private collectors. The older museums, as well as many historic buildings and sites, are described in Federal Writers' Project of the Works Progress Administration for the State of North Dakota, North Dakota: A Guide to the Northern Prairie State (2nd ed.; New York: Oxford University Press, 1950). That work also contains a useful list of books on North Dakota.

There are three large collections of unpublished manuscript materials dealing with North Dakota. That of the North Dakota Institute for Regional Studies at North Dakota State University, Fargo, is especially valuable for its records of bonanza farms. The Orin G. Libby Historical Manuscript Collection in the Chester Fritz Library at the University of North Dakota, Grand Forks, is notable for the papers of William Langer, William Lemke, John Moses, Milton R. Young, and the North Dakota Wheat Growers Association. Its holdings are described in Glenn L. Brudvig (comp.), "The Catalog of the Orin G. Libby Historical Manuscripts Collection, University of North Dakota Library,” North Dakota History, XXXI (January 1964), 79-90. North Dakota's largest manuscript collection is owned by the State Historical Society and is described in Margaret Rose (comp.), "Manuscript Collections of the State Historical Society of North Dakota," North Dakota History, XXX (January 1963), 17-61. The society has a file of more than fifteen thousand photographs.

\section{PRINTED SOURCES}

Printed sources of North Dakota history are largely comprised of three types of 
materials: (1) federal, territorial, and state government documents; (2) daily and weekly newspapers published in the state: and (3) the Collections of the State Historical Society (7 vols.; Bismarck, 1906-1925), edited by Orin G. Libby, the quarterly of the State Historical Society, North Dakota Historical Quarterly (11 vols., 1926-1933 and 19401944), also edited by Libby, and North Dakota History (21 vols., 1945-1965), edited by Russell Reid.

A law passed by the legislature in 1905 requiring that each newspaper published in the state deposit two copies of each issue with the State Historical Society, laid the foundation for the excellent newspaper files in the Society's library. In addition to primary sources, the Collections and quarterly of the society contain many scholarly articles. The results of much research, often partly historical in nature, have appeared in bulletins issued by the North Dakota Agricultural Experiment Station at Fargo. By 1965 the experiment station had published over 450 bulletins.

\section{UNPUBLISHED THESES AND DISSERTATIONS}

A large amount of research by candidates for graduate degrees has been performed at institutions of higher education both within and outside the state. The resultant master's theses and doctoral dissertations, though generally not published, make valuable contributions to knowledge of North Dakota history. The following unpublished theses and dissertations were used in the preparation of this volume.

Anderson, Robert S. “A Social History of Grand Forks, North Dakota, 1880-1920.” M.A. thesis, University of North Dakota, 1951.

Baglien, David B. "The McKenzie Era: A Political History of North Dakota from 1880 to 1920.” M.S. thesis, North Dakota Agricultural College, 1955.

Bahmer, Robert H. "The Economic and Political Background of the Nonpartisan League.” Ph.D. dissertation, University of Minnesota, 1941.

Barsness, Lowell A. "The History of High School Track and Field in the State of North Dakota.” M.S. thesis, University of North Dakota, 1958.

Blackorby, Edward C. "Political Factional Strife in North Dakota from 1920 to 1932." M.S. thesis, University of North Dakota, 1938.

Blikre, Clair. "The Positive and Negative Factors Involved in Successful and Unsuccessful School District Reorganization Proposals in North Dakota.” Ed.D. dissertation. University of North Dakota, 1960.

Bowers, Alfred W. “A History of the Mandan and Hidatsa.” Ph.D. dissertation, University of Chicago, 1948.

Brudvig, Glenn L. “The Farmers' Alliance and Populist Movement in North Dakota, 1884-1896.” M.A. thesis, University of North Dakota, 1956.

—. "Public Libraries in North Dakota: The Formative Years, 1880-1920.” M.A. thesis, University of Minnesota, 1962.

Carey, Kenneth J. “Alexander McKenzie, Boss of North Dakota, 1883-1906.” M.A. thesis, University of North Dakota, 1949.

De Long, Darrell. “A History of Fort Yates.” M.A. thesis, University of North Dakota, 1956.

Glaab, Charles N. "John Burke and the North Dakota Progressive Movement, 19061912.” M.A. thesis, University of North Dakota, 1952.

Gross, Fred W. “Type and Nature of the German Publications in North Dakota.” M.A. thesis, University of North Dakota, 1934.

Hagen, E. Bruce. "The North Dakota State Mill and Elevator Association: History, Organization, Administration, and Operation.” M.A. thesis, university of North Dakota, 1955. 
Hanson, Norman H. "History of Consolidated Schools in North Dakota." M.S. thesis, University of North Dakota, 1946.

Holen, Eugene O. “The Election of 1928 in North Dakota.” M.A. thesis, University of North Dakota, 1959.

Horne, Robert M. “The Controversy over the Seating of William Langer, 1940-1942.” M.A. thesis, University of North Dakota. 1964 .

Jacobson, Harvey K. “A Study of Novels About North Dakota.” M.A. thesis, University of North Dakota, 1956.

Jobes, Richard J. "Saint Peter, Minnesota: The History of a Frontier Community, 18511905.” M.A. thesis, University of North Dakota, 1956.

Johnson, James D. “A History of the Midland Continental Railroad, 1906-1950.” M.A. thesis, University of North Dakota, 1952.

Johnson, Kenneth C. “The Bank of North Dakota: An Analysis of Its Value.” M.A. thesis, University of North Dakota, 1957.

Kane, Ralph J. “Edwin Fremont Ladd, North Dakota’s Pure-Food Crusader.” M.A. thesis, University of North Dakota, 1960.

Koenker, William E. "The Rural Land Tax Problem in North Dakota with an Appraisal of the Income Value of Land as a Measure of Taxation.” M.A. thesis, University of North Dakota, 1938.

—. "Banking Trends in North Dakota, 1922-1947.” Ph.D. dissertation, Ohio State University, 1949.

Korthal, Jesse C. "The Growth and Decline of Incorporated Farm Trade Centers in North Dakota, 1900-1920.” M.S. thesis, University of North Dakota, 1935.

Kuhn, Bertha M. "History of Traill County, North Dakota." M.A. thesis, University of North Dakota, 1917.

Lantis, Lee O. "Rural Socio-Economic Conditions in Ward County and the Relations between Farmers and Townspeople.” Ph.D. dissertation, University of North Dakota, 1935.

Larson, Paul A. “A History of Farm Mortgage Indebtedness and Direct Farm Mortgage Relief in North Dakota From 1920 to 1950.” M.A. thesis, University of North Dakota, 1963.

Linden, Earl E. G. “The History of Congregationalism in North Dakota.” M.A. thesis, University of Chicago, 1939.

Lunde. Richard M. "History of the Evangelical United Brethren Church in the Dakotas.” M.A. thesis, University of North Dakota, 1959.

McKechnie, Marian E. "Spiritual Pioneering: A History of the Synod of North Dakota, Presbyterian Church, U.S.A., 1885-1954." M.A. thesis, University of North Dakota. 1955.

Mehl, Lambert J. "Missouri Grows to Maturity in North Dakota: A Regional History of the Lutheran Church-Missouri Synod.” M.A. thesis, University of North Dakota, 1953.

Milligan, Edward A. “The Standing Rock Sioux, 1874-1890.” M.A. thesis, University of North Dakota, 1948.

Morrison, Paul W. “The Position of Senators from North Dakota on Isolation, 18891920.” Ph.D. dissertation, University of Colorado, 1954.

Ness, Ordean G. "Gerald Prentice Nye: An Illustrative Analysis of Persuasive Technique.” M.A. thesis, University of Wisconsin, 1947.

Neudeck, Mariellen M. “Morality Legislation in Early North Dakota, 1889-1914.” M.A. thesis, University of North Dakota, 1964.

Norman, Richard M. "The Election of 1912 and the Progressive Party in North Dakota.” M.A. thesis, University of North Dakota, 1950. 
Phillips, William W. "The Growth of a Progressive: Asle J. Gronna.” M.A. thesis, University of North Dakota, 1952.

—. "The Life of Asle J. Gronna: A Self-Made Man of the Prairies.” Ph.D. dissertation, University of Missouri, 1958.

Putnam, Jackson K. “The Socialist Party of North Dakota, 1902-1918.” M.A. thesis, University of North Dakota, 1956.

Reitan, Milton W. "North Dakota Editors and the Cuban Crisis, 1895-1898.” M.A. thesis, University of North Dakota, 1957.

St. Clair, Robert L. "Progressivism in North Dakota, 1924.” M.A. thesis, University of North Dakota, 1960.

Schaff, Dominic. “The History of the North Dakota Oil Industry.” M.A. thesis, University of North Dakota, 1962.

Schweitzer, Adam J. "John Moses and the New Deal in North Dakota.” M.A. thesis, University of North Dakota, 1954.

Sigerseth, P. Olaf. "Pure Food Legislation of 1900.” M.A. thesis, University of North Dakota, 1936.

Sim, John C. “The History of the North Dakota Press Association, 1886-1940.” M.A. thesis, University of Minnesota, 1940.

Stee, Agnes McCorkell. "History of the Minot State Teachers College.” M.S. thesis, University of North Dakota, 1948.

Strand, Dale J. "The History of the Theodore Roosevelt National Memorial Park." M.A. thesis, University of North Dakota, 1962.

Strinden, Earl S. "The North Dakota Legislative Research Committee.” M.A. thesis, University of North Dakota, 1958.

Talbot, Ross B. "The Politics of Farm Organizations in North Dakota.” Ph.D. dissertation, University of Chicago, 1953.

Tweton, D. Jerome. “The Election of 1900 in North Dakota.” M.A. thesis, University of North Dakota, 1957.

Uhlman, Richard P. “Die Deutsche Kirkenarbeit in Nord Dakota.” M.A. thesis, University of North Dakota, 1937.

Voeller, Joseph B. "The Origin of the German-Russian People and Their Role in North Dakota.” M.S. thesis, University of North Dakota, 1940.

Weber, Gerald M. “John Shanley: First Bishop of Fargo.” M.A. thesis, St. Paul Seminary, 1951.

Wilkins, Robert P. "North Dakota and the European War, 1914-1917: A Study of Public Opinion.” Ph.D. dissertation, West Virginia University, 1954.

Williams, Douglas E. “The History of KFJM.” M.A. thesis, University of North Dakota, 1958.

\section{SOURCES FOR STATISTICAL DATA}

Quantitative measurements are of prime importance in the history of a state. To understand certain situations, one must know how many, how much, what percentage. Only statistics can measure growth, change, and accomplishment; only statistics can show clearly the nature of a society and the direction in which it has moved. In history, quantity is often the only available measure of quality.

The great source of quantitative information is United States Department of Commerce, Statistical Abstract of the United States, published annually since 1878. A supplement is United States Department of Commerce, Historical Statistics of the United States, 17891945 (Washington: Government Printing Office, 1949). For North Dakota history, the Statistical Abstract is much more useful, for it generally breaks down the data by states. It contains up-to-date statistics on population, health, mortality, immigration, education, 
crime, climate, public lands, income, roads, agriculture, industry, transportation, and virtually every other aspect of American life. More detailed information, often by counties and for population by townships, is given in the decennial censuses. Because it came shortly before the completion of settlement, the 1910 census is particularly important in North Dakota history. The volume entitled Thirteenth Census of the United States: 1910, Abstract of the Census with Supplement for North Dakota, pp. 568 ff., lists not only population by minor civil divisions but also the number of foreign-born by national origin and their children living in each county (pp. 598-608). The Fourteenth Census of the United States: 1920, III, Population, 764, gives the country of birth of the foreign-born whites for each of the counties in the state for that census year. Data on the mother tongue of foreign white stock for 1910 is found in Thirteenth Census of the United States: 1910, I, Population, 998, 1000-1001, and for 1920 in Fourteenth Census of the United States: 1920, II, Population, General Report and Analytical Tables, 996.

The volumes of the decennial census up to and including 1950 have full data on agriculture. In 1954, Congress provided for mid-decade censuses of agriculture. There was one in 1954 and a second in 1959. Statistics for agriculture in North Dakota are also given in Baldur H. Kristjanson and C. J. Heltemes, Handbook of Facts about North Dakota Agriculture, North Dakota Agricultural Experiment Station Bulletin 357 (Fargo, 1950), and in Fred R. Taylor, C. J. Heltemes, and R. F. Engelking, North Dakota Agricultural Statistics, North Dakota Agricultural Experiment Station Bulletin 408 (Fargo, 1957).

Since 1957 the North Dakota Crop and Livestock Reporting Service, a joint venture of the United States Department of Agriculture's Agricultural Marketing Service and the North Dakota Agricultural Experiment Station, has issued an annual report entitled North Dakota Crop and Livestock Statistics. It has also published other valuable statistical works: Price Trends in North Dakota, 1910-1957 (Fargo, 19.58); North Dakota Wheat (Fargo, 1960); Barley, Oats, Rye: County Estimates, 1919-1954 (Fargo, 1960); North Dakota Livestock: County Estimates, 1925-1961 (Fargo, 1962); Corn, Potatoes, Hay (Fargo, 1963); Prince Trends in North Dakota, 1950-1963 (Fargo, 1964).

The Statistical Abstract and some of the publications dealing with agricultural statistics contain data on income. There is more in Glenn W. Fisher, Income in North Dakota, 1929-1956, North Dakota Institute for Regional Studies Social Science Monograph No. 1 (Fargo, 1958), and United States Department of Commerce, Personal Income by States since 1929: A Supplement to the Survey of Current Business (Washington: Government Printing Office, 1956). Current income data is published annually in the Department of Commerce's periodical Survey of Current Business.

Statistics on churches and church membership are found in the decennial census of 1890 and in the United States Bureau of the Census, Religious Bodies, 1906, 1916, 1926, and 1936. In 1936 the Bureau of the Census stopped gathering data on religious bodies. The North Dakota Council of Churches has put out leaflets, Religious Census of North Dakota, for 1955 and 1960.

Statistics on the finances of the state government are found in the annual or biennial reports of the state treasurer, the state tax commissioner, and the state budget board. Auto registrations by counties are on a mimeographed sheet from the office of the state vehicle registrar; data in the Statistical Abstract allows a comparison between states. That volume also gives figures on highways. More detailed information is found in the United States Bureau of Public Roads, Highway Statistics, and in North Dakota Highway Department, North Dakota Highway Statistics, both annual publications. Statistics on railroad traffic are issued in mimeographed form (Railroad Freight Commodity Statistics) by the North Dakota Public Service Commission. Election returns by counties have been published, beginning with the 1914 election, in North Dakota Secretary of State, Compiled Election 
Returns. For earlier elections they were published in North Dakota Secretary of State. North Dakota Blue Book, a biennial volume from 1897 to 1919.

Statistics on cooperatives are given by counties in North Dakota Department of Agriculture and Labor, Division of Cooperatives, Annual Statistical Report. The number of newspapers and their circulations are found in N. W. Ayer and Son's Newspaper Annual and Directory (Philadelphia: N. W. Ayer and Son, Inc., 1880-), in North Dakota Press Association, Directory and Rate Book (Grand Forks), an annual, and for dailies in the Audit Bureau of Circulation Reports. Statistical data on libraries are in the biennial reports of the State Library Commission. Statistical data on schools are in the biennial reports of the Department of Public Instruction. Yearly precipitation and other climatic data have been compiled by Frank J. Bavendick in Climate and Weather in North Dakota (2nd ed.; Bismarck: North Dakota State Water Conservation Commission, 1952).

\section{GENERAL HISTORIES OF NORTH DAKOTA}

Probably the first attempt to write a general history of the state was the Compendium of History and Biography of North Dakota (Chicago: Geo. A. Ogle and Company, 1900), a fat leather-bound volume of 1,410 gold-tipped pages which was largely made up of the biographical sketches of the subscribers to the work. The second, William B. Hennessy, History of North Dakota... including the Biographies of the Builders of the Commonwealth (Bismarck: Bismarck Tribune Company, 1910), was a similar venture, but the historical section, more than a third of the total, was more extensive. Clement A. Lounsberry wrote a much more detailed and scholarly history, which profited from both his long interest in the subject (he had been publishing The Record, a historical magazine on the state, for a number of years), and from his active part in North Dakota life (he had founded the Bismarck Tribune, the state's first newspaper, in 1873). First published in 1913, Lounsberry's history was then combined with two volumes of biographical sketches of the subscribers as North Dakota History and People: Outlines of American History (3 vols.; Chicago: S. J. Clarke Publishing Company, 1917). It was later published separately, with some additional chapters (645 large pages in all), as Early History of North Dakota: Essential Outlines of American History (Washington: Liberty Press, 1919).

The biographical sketches in the Compendium, the Hennessy, and the three-volume Lounsberry, although invariably laudatory, did preserve much information on those who settled the state and their experiences. Unfortunately, many important people did not subscribe to these works and so were omitted.

Children were introduced to North Dakota history by William M. Wemett, a teacher at Valley City State Teachers College, in The Story of the Flickertail State (Valley City: The Author, 1923). and by Herbert Clay Fish and R. M. Black, A Brief History of North Dakota (New York: American Book Company, 1925). Fish was the former curator of the North Dakota State Historical Society Museum, and Black was the president of the state normal school at Ellendale. These early elementary texts were finally replaced by Conrad W. Leifur, Our State: North Dakota (New York: American Book Company, 1942), an excellent brief account written for eighth-grade pupils.

Two important books were published in the 1930's. Lewis F. Crawford, History of North Dakota (3 vols.; Chicago: American Historical Society, Inc., 1931), and Federal Writers' Project of the Works Progress Administration for the State of North Dakota, North Dakota: A Guide to the Northern Prairie State (Fargo: Knight Printing Company, 1938; 2nd ed., New York: Oxford University Press, 1950). Crawford's history, like Lounsberry's, was one volume of historical narrative and two volumes of biographical sketches of subscribers-an effective way of making historical scholarship pay. One edition even had gold-tipped pages. Although Crawford's work lacked some of the detail 
found in Lounsberry's, it was better organized and thus marked clear-cut advancement. Crawford, trained in history and political science at Harvard, had been a rancher and banker at Sentinel Butte, and hi, chapter on ranching history was a distinct contribution to scholarship. North Dakota: A Guide to the Northern Prairie State, edited by talented Ethel Schlasinger, was well planned and well written. The best book on the state yet written at the time of its publication, it listed a wealth of interesting historical information on virtually every North Dakota community in its descriptive tours section.

All of the histories published before 1946 dealt largely with the Indians, exploration, the fur trade, and the epic of pioneering. Neither Lounsberry nor Crawford, writing from a conservative point of view, gave any indication of the sense of exploitation felt by a large part of the population, or of the bitter strife against outside interests which had marked North Dakota history. The break with the conservative-and, in a way, romanticized and ancestor-admiring - style of writing came in Bruce Nelson, Land of the Dacotahs (Minneapolis: University of Minnesota Press, 1946). Nelson, a young North Dakota newspaperman and something of a radical, was awarded a University of Minnesota Fellowship in Regional Writing to assist him with the work. A more gifted and exciting writer than any who had yet attempted a historical work on the state, Nelson used much colorful material on the Indians and the fur trade, but he also wrote a long and sympathetic chapter (the best in the book) on the Nonpartisan League revolt and another, very realistic one on the controversy over Missouri River development.

Most of the histories have been illustrated, Lounsberry and North Dakota: A Guide to the Northern Prairie State being notable in this respect. A much fuller photographic record is found in Marion J. Piper, Dakota Portraits: A Sentimental Journal of Pictorial History (Mohall: The Author, 1964). An interesting text is combined with some 425 pictures, many of them never published before. About the same number of pictures are reproduced in Erling N. Rolfsrud, The Story of North Dakota (Alexandria, Minn.: Lantern Books, 1963), a new and attractive history for young readers.

Several books and articles dealing with the frontier and the Great Plains should also be mentioned. The meaning of the frontier experience has been dealt with in the essays of Frederick Jackson Turner, The Frontier in American History (New York: Henry Holt and Company, 1920). Walter P. Webb, The Great Frontier (Boston: Houghton Mifflin Company, 1952), took an even broader view of the meaning of the frontier. His earlier volume, The Great Plains (Boston: Ginn and Company, 1931), sees the history of the region as a matter of adaptation to a level, treeless, semiarid environment. This idea was expanded by Carl F. Kraenzel, rural sociologist and native of North Dakota, in The Great Plains in Transition (Norman: University of Oklahoma Press, 1955). Kraenzel, who became a sort of prophet of adaptation on the Plains, drew upon A.H. Anderson's "Space as a Social Cost: An Approach toward Community Design in the Sparsely Populated Areas of the Great Plains,” Journal of Farm Economics, XXXII (August 1950), 411-430. Taking something from Webb, I first developed my own interpretation in "The Themes of North Dakota History,” North Dakota History, XXVI (Winter 1959), 5-24.

As an explanation for the remainder of the Bibliographical Essay, it should be noted that documentation of the text consists of the footnotes and the books and articles described below for each chapter, except that the statistical sources and the general works described earlier are not usually cited. The purpose is not to give a specific source for each statement, but to show generally the principal sources for each chapter and those which a reader might most profitably consult.

\section{CHAPTER 1}

\section{THE GRASSLAND SETTING}

There are three general accounts of the topography and geology of North Dakota. The 
oldest, an out-of-date classic, is Daniel E. Willard, The Story of the Prairies; or, The Landscape Geology of North Dakota (9th ed.; Kalamazoo, Mich.: Printed for the Author by Ihling Brothers, Everard Company, 1921). A more comprehensive account is A. W. Gauger et al., Geology and Natural Resources of North Dakota, University of North Dakota Departmental Bulletin 11 (Grand Forks, 1930). This bulletin, however, has been largely replaced by John L. Hainer, The Geology of North Dakota, North Dakota Geological Survey Bulletin 31 (Grand Forks, 1956).

An excellent booklet on climate is Frank J. Bavendick, Climate and Weather in North Dakota (2nd ed.; Bismarck: North Dakota State Water Conservation Commission, 1952). There are several useful works on grass: Warren Whitman et al., Grass, North Dakota Agricultural Experiment Station Bulletin 300 (Fargo, 1941); John E. Weaver, North American Prairie (Lincoln, Nebr.: Johnsen Publishing Company, 1954); John E. Weaver and F. W. Albertson, Grasslands of the Great Plains: Their Nature and Use (Lincoln, Nebr.: Johnsen Publishing Company, 1956). Orin A. Stevens, Handbook of North Dakota Plants (Fargo: North Dakota Institute for Regional Studies, 1950), is a comprehensive scientific work. Vernon Bailey, A Biological Survey of North Dakota, United States Bureau of Biological Survey, North American Fauna No. 49 (Washington, 1926), contains much interesting information concerning the adaptation of animal life to the environment. The same theme of adaptation is carried out by Wallace Craig, a young biologist at Valley City who drew upon Darwinian concepts to write "North Dakota Life: Plant, Animal, and Human,” Bulletin of the American Geographical Society, XL (JuneJuly 1908), 321-332, 401-415. Craig's essay is one of the best pieces ever written on North Dakota.

\section{CHAPTER 2}

\section{INDIANS OF THE PLAINS AND PRAIRIES}

Two valuable books on prehistoric Indians are Hannah M. Wormington, Ancient Man in North America (4th ed.; Denver: Denver Museum of Natural History, 1957), and Waldo R. Wedel, Prehistoric Man on the Great Plains (Norman: University of Oklahoma Press, 1961). Wedel is now the leading scholar on Great Plains archaeology. Alfred W. Bowers, Mandan Social and Ceremonial Organization (Chicago: University of Chicago Press, 1950), is a scholarly anthropological study. The approach of a valuable older work by George F. Will and Herbert J. Spinden, The Mandans: A Study of Their Culture, Archaeology and Language, Peabody Museum of Archaeology and Ethnology Papers, Vol. III, No. 4 (Cambridge, Mass., 1906), is more historical. Raymond F. Schulenberg, "Indians of North Dakota," North Dakota History, XXIII (July-October 1956), 119-230, is equivalent to a small book. Lawrence J. Burpee (ed.), Journals and Letters of Pierre Gaultier de Varennes de la Vérendrye and His Sons (Toronto: Champlain Society, 1927), contains translations of these interesting and important documents, the earliest dealing with the region that was to become North Dakota.

\section{CHAPTER 3}

\section{A STRUGGLE FOR THE INDIAN TRADE}

The earliest accounts of trade on the Missouri River are published in Abraham P. Nasatir (ed.), Before Lewis and Clark: Documents Illustrating the History of the Missouri, 1785-1804 (2 vols.; St. Louis: St. Louis Historical Documents Foundation, 1952). The journals of trading trips to the Missouri from the Assiniboine River forts by John McDonnell, Charles MacKenzie, and François-Antoine Larocque are in Louis F. R. Masson (ed.), Les Bourgeois de la Compagnie du Nord-Ouest: Recits de Voyages, Lettres et Rapports Inédits au Nord-Ouest Canadien· (2 vols.; Quebec: A. Coté et Cie, 1889- 
1890). Many important documents are included in Reuben Gold Thwaites (ed.), Original Journals of the Lewis and Clark Expedition, 1804-1806 (8 vols.; New York: Dodd, Mead and Company, 1904-1905). The original manuscript journals, together with the text prepared by Nicholas Biddle (first published in 1814), for the time the expedition was in North Dakota were edited by Russell Reid in "Lewis and Clark in North Dakota," North Dakota History, XIV (1947), 5-45, 73-145, 173-241, 287-391, and XV (1948), 15-74.

Two accounts of the Upper Missouri in 1811 have been republished as Volumes V and VI of Early Western Travels, 1748-1846, edited by Reuben Gold Thwaites: John Bradbury, Travels in the Interior of America in the Years 1809, 1810, and 1811 (Cleveland: A. H. Clark Company, 1904), describes the Mandans and Hidatsas; Henry M. Brackenridge, Journal of a Voyage up the Missouri, Performed in 1811 (Cleveland: A. H. Clark Company, 1904), is a notable account of Manuel Lisa and keelboat travel. A description of the Mandans and Hidatsas by a North West trader is found in Joseph B. Tyrrell (ed.), David Thompson's Narrative of His Explorations in Western America, 1784-1812 (Toronto: Champlain Society, 1916).

Two histories of the fur trade written by scholars are Gordon C. Davidson, The North West Company (Berkeley: University of California Press, 1918), and Hiram M. Chittenden, The American Fur Trade of the Far West (2 vols.; Stanford: Academic Reprints, 1954). First published in 1902, Chittenden's work is a classic.

\section{CHAPTER 4}

\section{INDIAN, MÉTIS, AND WHITE IN THE RED RIVER VALLEY}

A number of unusually interesting sources are available for this chapter. Extracts from an early journal are found in Roy P. Johnson, "Fur Trader Chaboillez at Pembina," North Dakota History, XXXII (April 1965), 83-99, which was first published in the Dakota Territorial Centennial, a supplement to all North Dakota dailies for February 28, 1961. The outstanding primary document, however, is the diary of Alexander Henry: New Light on the Early History of the Greater Northwest: The Manuscript Journals of Alexander Henry... and of David Thompson... 1799-1814, ed. Elliott Coues (3 vols.; New York: Francis P. Harper, 1897). The letters of Catholic missionaries in Grace Lee Nute (ed.), Documents Relating to Northwest Missions, 1815-1827 (St. Paul: Minnesota Historical Society for the Clarence Walworth Alvord Memorial Commission, 1942), are full of revealing details on the métis and the fur trade. So is the contemporary account of the Stevens expedition: William H. Keating, Narrative of an Expedition to the Source of the St. Peter's River... Performed in the Year 1823 (2 vols.; Philadelphia: H. C. Carey and I. Lea, 1824).

There is much of interest in Alvin C. Gluek, Jr., Minnesota and the Manifest Destiny of the Canadian Northwest: A Study in Canadian-American Relations (Toronto: University of Toronto Press, 1965), in Wilson P. Shortridge, The Transition of a Typical Frontier with Illustrations from the Life of Henry Hastings Sibley (Menasha, Wis.: George Banta Publishing Company, 1922), and in the outstanding work by William W. Folwell, A History of Minnesota (4 vols.; St. Paul: Minnesota Historical Society, 19211930), which is full on the early years of the region. The best history, however, is John P. Pritchett's The Red River Valley, 1811-1849: A Regional Study (New Haven: Yale University Press, 1942).

\section{CHAPTER 5}

\section{THE UPPER MISSOURI COUNTRY}

The journals or recollections of two traders, two observant travelers, a steamboat man, and an army officer have been published for the third of a century from the 1830's to the 
!860's. Chardon's Journal at Fort Clark, 1834-1839, ed. Annie Heloise Abel (Pierre, S.D.: Privately printed, 1932), covers the smallpox epidemic. Forty Years a Fur Trader on the Upper Missouri: The Personal Narrative of Charles Larpenteur, 1833-1872, ed. Elliott Coues (2 vols.; New York: Francis P. Harper, 1898), gives an account of the trade at Fort Union. Hiram M. Chittenden, an army officer fascinated by western history, used the recollections of a steamboat captain in History of Early Steamboat Navigation of the Missouri River: Life and Adventures of Joseph La Barge (2 vols.; New York: Francis P. Harper, 1903). A summer at Fort Union in 1843 is recorded in Audubon and His Journals, ed. Maria Audubon and Elliott Coues (2 vols.; New York: Charles Scribner's Sons, 1897). Military Life in Dakota: The Journal of Philippe Régis de Trobriand, trans. and ed. Lucile M. Kane (St. Paul: Alvord Memorial Commission; 1951), has much on the Indians at Fort Berthold as well as the soldiers garrisoned at Fort Stevenson. The best of the primary sources, however, is Maximilian, Prince of Wied, Travels in the Interior of North America in the Years 1832 to 1834 (Vols. XXII-XXIV of Early Western Travels, 1748-1846, ed. Reuben Gold Thwaites; Cleveland: A. H. Clark Company, 1905-1906). Maximilian spent the winter of 1833-1834 at Fort Clark.

Thorough research went into two articles by Ray H. Mattison, then a historian with the National Park Service: "Old Fort Stevenson—A Typical Missouri River Military Post," North Dakota History, XVIII (April-July 1951), 53-91, and "Fort Rice-North Dakota's First Missouri River Military Post,” North Dakota History, XX (April 1953), 87-108. Adrian R. Dunn, “A History of Old Fort Berthold," North Dakota History, XXX (October 1963), 157-240, is a master's thesis. The military campaigns of the 1860's and 1870's and much else are recounted with exciting detail in Joseph Mills Hanson, The Conquest of the Missouri: Being the Story of the Life and Exploits of Captain Grant Marsh (Chicago: A. C. McClurg, 1909).

\section{CHAPTER 6}

\section{THE BEGINNINGS OF SETTLEMENT}

Two general accounts include the beginnings of Dakota Territory. The older and broader is Harold E. Briggs, Frontiers of the Northwest: A History of the Upper Missouri Valley (New York: D. Appleton-Century Company, 1940). It contains much that is omitted in a newer and more specialized volume by Howard R. Lamar, Dakota Territory, 1861-1889: A Study of Frontier Politics (New Haven: Yale University Press, 1956). Early transportation is dealt with in Arthur J. Larsen, "The Northwestern Express and Transportation Company,” North Dakota Historical Quarterly, VI (October 1931), 4262. The interest of Minnesotans in the British Northwest receives major attention in Theodore C. Blegen, “James Wickes Taylor: A Biographical Sketch,” Minnesota History Bulletin, I (November 1915), 154-173, and in Alvin C. Gluek, Jr., Minnesota and the Manifest Destiny of the Canadian Northwest: A Study in Canadian-American Relations. There are sections on railroad building in Henrietta M. Larson, Jay Cooke, Private Banker (Cambridge: Harvard University Press, 1936); Joseph G. Pyle, The Life of James J. Hill (2 vols.; Garden City: Doubleday, Page and Company, 1917); Eugene V. Smalley, History of the Northern Pacific Railroad (New York: G. P. Putnam's Sons, 1883); and William W. Folwell, A History of Minnesota, the most useful of the four. Although it is an old work, the best scholarship on all aspects of the development of eastern North Dakota is found in John Lee Coulter's "Industrial History of the Valley of the Red River of the North,” North Dakota Historical Society Collections, III (1910), 529-672. 
The most useful work is the one by John Lee Coulter mentioned above. Its material on the big farms is supplemented by Hiram M. Drache, The Day of the Bonanza: A History of Bonanza Farming in the Red River Valley of the North (Fargo: North Dakota Institute for Regional Studies, 1964), a thorough study based on manuscript materials never used before. Henrietta M. Larson, The Wheat Market and the Farmer in Minnesota, 18581900, Columbia University Studies in History, Economics and Public Law, Vol. 122, No. 2 (New York, 1926), contains much that is essential to an understanding of the development of eastern North Dakota. Herbert S. Schell, "Official Immigration Activities of Dakota Territory,” North Dakota Historical Quarterly, VII (October 1932), 5-24, is interesting.

\section{CHAPTER 8}

\section{PIONEER LIFE}

Of the many reminiscences of pioneer life, I found the following the most interesting and enlightening: A. G. (Guy) Divet, The Divet Story, published as a supplement to the Fargo Forum, March 1, 1950; Mary Barnes Williams, Fifty Pioneer Mothers of McLean County, North Dakota (Washburn, N.D.: The Author, 1932); Nina Farley Wishek, Along the Trails of Yesterday: A Story of McIntosh County (Ashley, N.D.: Ashley Tribune, 1941); and Aagot Raaen, Grass of the Earth: Immigrant Life in the Dakota Country (Northfield, Minn.: Norwegian-American Historical Society, 1950). Two items by Usher L. Burdick take on added interest because of his subsequent political career: “Recollections and Reminiscences of Graham's Island," North Dakota History. XVI (1949), 5-29, 101-130, 165-191, deals with his boyhood, and A Short History of Munich, North Dakota, Western Cavalier County (Langdon, N.D.: Cavalier County Republican, 1953) with his young manhood. Mary Dodge Woodward, The Checkered Years (Caldwell, Idaho: The Caxton Printers, Ltd., 1937), is the diary of a perceptive woman living on a bonanza farm near Fargo in the 1880's—a very special book.

\section{CHAPTER 9}

\section{THE OPENING OF THE MISSOURI PLATEAU}

Where the best things on pioneer life are primary sources, the best items for this chapter, with one exception, are scholarly syntheses. The exception is the autobiography of Indian Agent James McLaughlin, My Friend the Indian (Boston: Houghton Mifflin Company, 1910), a significant document. McLaughlin's experiences at Fort Totten are rounded out by Charles De Noyer, “The History of Fort Totten,” North Dakota Historical Society Collections, III (1910), 178-236, which reproduces some documents. Hermann Hagedorn's Roosevelt in the Bad Lands (Boston: Houghton Mifflin Company, 1921) is a readable book by a friend of Roosevelt. Father Louis Pfaller, O.S.B., of Assumption Abbey has written an important article entitled "Fort Keogh to Bismarck Stage Route," North Dakota History, XXI (July 1954), 91-125.

A large part of the recent scholarly writing on the Missouri Plateau region has been done by Ray H. Mattison while he was a historian with the National Park Service. With Olaf T. Hagen, he wrote "Pyramid Park-Where Roosevelt Came to Hunt," North Dakota History, XIX (October 1952), 215-239; alone he brought out a whole series of carefully researched articles: "The Military Frontier on the Upper Missouri," Nebraska History, XXXVII (September 1956), 159-182; "Indian Missions and Missionaries on the Upper Missouri to 1900,” Nebraska History, XXXVIII (June 1957), 127-154; “The Army Post on the Northern Plains, 1865-1885,” Nebraska History, XXXV (March 1954), 1-27; “The Indian Reservation System on the Upper Missouri, 1865-1890,” Nebraska History, XXXVI (September 1955), 141-172; "Ranching in the Dakota Badlands: A Study of 
Roosevelt's Contemporaries,” North Dakota History, XIX (April-July 1952), 93-128, 167-206; "Roosevelt and the Stockmen's Association," North Dakota History, XVII (April-July 1950), 73-95, 177-209; “Roosevelt's Dakota Ranches,” North Dakota History, XXII (October 1955), 147-161; and "An Army Wife on the Upper Missouri: The Dairy of Sarah E. Canfield, 1866-1868," North Dakota History, XX (October 1953), 191220. Another valuable article is Arnold O. Goplen, "The Career of the Marquis de Mores in the Badlands of North Dakota," North Dakota History, XIII (January-April 1946), 570 .

\section{CHAPTER 10}

\section{THE MAKING OF A STATE}

Howard R. Lamar, Dakota Territory, 1861-1889: A Study of Frontier Politics (New Haven: Yale University Press, 1956), is the best account of the movement for statehood. The sources on the making of the constitution are Official Report of the Proceedings and Debates of the Constitutional Convention of North Dakota (Bismarck, 1889), which contains the full debates, and the Journal of the Constitution Convention (Bismarck, 1889), which records the votes. There are two good accounts of the convention. R. M. Black, "History of the State Constitutional Convention of 1889," North Dakota Historical Society Collections, III (1910), 111-157, is not as analytical as John D. Hicks, The Constitutions of the Northwest States, University of Nebraska Studies, Vol. XXIII, Nos. 1 and 2 (Lincoln, 1923), which is a comparative treatment of constitution making in 18891890. The constitution itself, with amendments, has been published frequently by the North Dakota Secretary of State.

\section{CHAPTER 11}

\section{THE DEPRESSION NINETIES}

Very little has been published on the 1890's. The best account is the unpublished master's thesis on the Farmers' Alliance and the Populist movement by Glenn L. Brudvig cited earlier in the Bibliographical Essay and in the footnotes; it is an excellent piece of research and synthesis. There is some material in Paul R. Fossum, The Agrarian Movement in North Dakota, Johns Hopkins University Studies in Historical and Political Science, Vol. XLIII, No. 1 (Baltimore, 1925), a small book on a large subject.

\section{CHAPTER 12}

\section{THE SECOND BOOM}

Some railroad matters are covered in Joseph G. Pyle, The Life of James J. Hill. Ties with Minneapolis and St. Paul are treated in Mildred L. Hartsough, The Twin Cities as a Metropolitan Market, University of Minnesota Studies in the Social Sciences, No: 18 (Minneapolis, 1925). For western settlement and land speculation, see Mary Wilma M. Hargreaves, Dry Farming in the Northern Great Plains, 1900-1925, Harvard Economic Studies, Vol. 101 (Cambridge, 1957), a piece of unusually thorough research, and E. A. Willson, H. C. Hoffsommer, and Alva H. Benton, Rural Changes in Western North Dakota, North Dakota Agricultural Experiment Station Bulletin 214 (Fargo, 1928), the most important study of settlement on the Missouri Plateau. A vital subject is dealt with in Theodore E. Stoa, "A Brief History of Wheat Variety Changes on Farms in North Dakota,” Bimonthly Bulletin, North Dakota Agricultural Experiment Station, VII, 6 (JulyAugust 1945), 21-26. 
There is an excellent biographical sketch of Edwin F. Ladd in Erling N. Rolfsrud, Lanterns over the Prairies (2 vols.; Brainerd, Minn.: Lakeland Press, 1949-1950). For Ladd, see also Ralph J. Kane, "Populism, Progressivism, and Pure Food,” Agricultural History, XXXVIII (July 1964), 161-166. Charles N. Glaab has two good articles: "The Revolution of 1906-N. D. vs. McKenzie,” North Dakota Quarterly, XXIV (Fall 1956), 101-114, and "The Failure of Progressivism in North Dakota," Mid-America, XXXIX (October 1957), 195-209. The daughter of a leading progressive writes on her father in Beulah Amidon Ratliff, “Charles Fremont Amidon,” North Dakota Historical Quarterly, VIII (January 1941), 83-100. There are three good articles on the struggle with the marketing problem: Robert H. Bahmer, "The American Society of Equity,” Agricultural History, XIV (January 1940), 33-63; Theodore Saloutos, "The Rise of the Equity Cooperative Exchange,” Mississippi Valley Historical Review, XXXII (June 1945), 3162; and Theodore Saloutos, "The Decline of the Equity Cooperative Exchange," Mississippi Valley Historical Review, XXXIV (December 1947), 405-426.

\section{CHAPTER 14}

\section{THE LIFE OF THE MIND AND THE SPIRIT}

There is a good deal of cultural history in the interesting biographical sketches by Erling N. Rolfsrud in Lanterns aver the Prairies. Two excellent works on Norwegian immigrants are Theodore C. Blegen, Norwegian Migration to America (2 vols.; Northfield, Minn.: Norwegian-American Historical Society, 1931-1940), and Einar I. Haugen, The Norwegian Language in America: A Study of Bilingual Behavior (2 vols.; Philadelphia: University of Pennsylvania- Press, 1953). Unfortunately, there is less scholarly work on the German Russians. Two valuable recent volumes are Monsignor George P. Aberle's From the Steppes to the Prairies: The Story of the Germans Settling in Russia... Their Resettlement in the Americas (Dickinson, N.D.: The Author, 19631 and Adolph Schock's In Quest of Free Land (San Jose, Calif.: San Jose State College, 1964).

There is some material on the German Russians in Louis Pfaller (ed.), The Catholic Church in Western North Dakota, 1738-1960 ([Bismarck]: Diocese of Bismarck, 1960). C. A. Armstrong, History of the Methodist Church in North Dakota (Fargo: The Author, 1946), has much of interest, but by far the best history of a denomination in the statescholarly, well researched, and well written-is Robert P. and Wynona H. Wilkins, God Giveth the Increase: The History of the Episcopal Church in North Dakota (Fargo: North Dakota Institute for Regional Studies, 1959). Some revealing letters are reproduced in Louis Pfaller, "Bishop Wehrle and the German Immigrants in North Dakota," North Dakota Quarterly, XXIX (Summer 1961), 93-97.

Two scholarly works include much of the history of higher education: William C. Hunter, Beacon Across the Prairie: North Dakota's Land-Grant College (Fargo: North Dakota Institute for Regional Studies, 1961), and Louis G. Geiger, University of the Northern Plains: A History of the University of North Dakota, 1883-1958 (Grand Forks: University of North Dakota Press, 1958). The Geiger volume fits its subject into the larger history of the state and also of higher education in the nation. A document of prime significance for its objective analysis is United States Bureau of Education, State Higher Educational Institutions of North Dakota, Bulletin (1916) No. 27 (Washington, 1917),

\section{CHAPTER 13}

\section{THE GREAT SOCIALIST EXPERIMENT}

The Socialist background of the Nonpartisan League is shown in Jackson K. Putnam, “The Role of NDSP in North Dakota History,” North Dakota Quarterly, XXIV (Fall 1956). 115-122. Probably more has been written on the early years of the Nonpartisan 
League than on any other phase of North Dakota history except the epic of settlement. Two of the early books, vibrant with the emotions of the author-participants, are Herbert E. Gaston's The Nonpartisan League (New York: Harcourt, Brace and Howe, 1920) and Charles E. Russell's The Story of the Nonpartisan League: A Chapter in American Evolution (New York: Harper and Brothers, [1920]). The best account is Robert L. Morlan, Political Prairie Fire: The Nonpartisan League, 1915-1922 (Minneapolis: University of Minnesota Press, 1955), but it should be used with Edward C. Blackorby, Prairie Rebel: The Public Life of William Lemke (Lincoln: University of Nebraska Press, 1963), for the latter is based upon the Lemke manuscripts, which were unavailable to Morlan. See also Alvin S. Tostlebe, The Bank of North Dakota: An Experiment in Agrarian Banking, Columbia University Studies in History, Economics and Public Law, Vol. 114, No. 1 (New York, 1924).

\section{CHAPTER 16}

\section{A SOCIALISTIC STATE IN THE FIRST WORLD WAR}

The Quarterly Journal of the University of North Dakota, X (October 1919), is entirely devoted to the articles on North Dakota during the war. See also Aaron McGaffey Beede, “The Dakota Indian Victory-Dance,” North Dakota Historical Quarterly, IX (April 1942), 167-178, and Robert P. Wilkins, "The Peace Issue in the General Election of 1914,” North Dakota History, XXX (April-July 1963), 97-100.

\section{CHAPTER 17}

\section{THE TWENTIES: BEGINNINGS OF READJUSTMENT}

Theodore Saloutos and John D. Hicks, Agricultural Discontent in the Middle West, 1900-1939 (Madison: University of Wisconsin Press, 1951), places the North Dakota situation in a broader perspective. Harold V. Knight, Grass Roots: The Story of the North Dakota Farmers' Union (Jamestown: North Dakota Farmers' Union, 1947), is useful on the beginnings. Eric Sevareid's, Not so Wild a Dream New York: A. A. Knopf, 1946), has something of Sevareid's boyhood in North Dakota.

\section{CHAPTER 18}

\section{THE THIRTIES: DROUGHT AND DEPRESSION}

Blackorby's Prairie Rebel is available for both the 1920's and 1930's, as is Knight's Grass Roots. Roy L. Miller, “The Gubernational Controversy in North Dakota," American Political Science Review, XXIX (June 1935), 418-432, is a good article on Langer's ouster. Adam J. Schweitzer, “The Political Campaign of John Moses,” North Dakota History, XXXII (January 1965), 19-39, is based on research in the newspapers. An important document is Rupert N. Richardson (ed.), "The 'Summary Foreword” of the Future of the Great Plains,” Mississippi Valley Historical Review, XXX (June 1943), 4968.

\section{CHAPTER 19}

\section{THE IMPACT OF THE SECOND WORLD WAR}

Compared with those concerning earlier years, there are few books or articles dealing with North Dakota history since 1920. Blackorby's Prairie Rebel and Knight's Grass Roots both cover a wide span of years. Wayne S. Cole's Senator Gerald P. Nye and American Foreign Relations (Minneapolis: University of Minnesota Press, 1962) is a good treatment of the subject. See abo Robert P. Wilkins, "The Nonpartisan League and Upper Midwest Isolationism,” Agricultural History, XXXIX (April 1965), 102-109. 
Organization and Administration of the State Government of North Dakota (2 vols.; Chicago: Public Administration Service, 1942) throws much light on the subject.

\section{CHAPTER 20}

\section{REVOLUTIONARY CHANGE IN THE POSTWAR YEARS}

On politics, see Lloyd B. Omdahl's detailed and comprehensive Insurgents (N.p.: The Author, 1961) and Ross B. Talbot, “North Dakota-A Two-Party State?” North Dakota Quarterly, XXV (Fall 1957), 93-104. On the economy, see Arvid C. Knudtson and Rex W. Cox, Upper Midwest Agriculture: Structure and Problems, Upper Midwest Research and Development Council and the University of Minnesota, Upper Midwest Economic Study, Study Paper No. 3 (Minneapolis, 1962); William E. Koenker and Glenn W. Fisher, Tax Equity in North Dakota, Bureau of Business and Economic Research, University of North Dakota, North Dakota Economic Studies No. 4 (Grand Forks, 1960). On the oil boom, see Stanley W. Voelker, Mineral Rights and Oil Development in Williams County, North Dakota, North Dakota Agricultural Experiment Station Bulletin 395 (Fargo, 1954); Robert B. Campbell et al., The Williston Report: The Impact of Oil on the Williston Area of North Dakota (Grand Forks: University of North Dakota, 1958). On wheat, see Theodore E. Stoa, "History of Wheat Variety Changes on North Dakota Farms for Years 1945 to 1960,” North Dakota Farm Research, XXI; 8 (November-December, 1960), 17 21. For the effects of irrigation, see L. W. Schaffner, An Economic Analysis of Proposed Irrigation in Northern North Dakota, North Dakota Agricultural Experiment Station Bulletin 404 (Fargo, 1956).

\section{CHAPTER 21}

\section{CULTURAL GROWTH AND ADAPTATION: EDUCATION, RESEARCH, WRITING, AND MEDICINE, 1920-1960}

The most important books on education are Louis G. Geiger, University of the Northern Plains: A History of the University of North Dakota, 1883-1958; William C. Hunter, Beacon Across the Prairie: North Dakota's Land-Grant College; United States Office of Education, Higher Education in North Dakota: A Report of a Survey for North Dakota Legislative Research Committee and State Board of Higher Education (2 vols.; N.p., 1958); and Barend H. Kroeze, A Prairie Saga (St. Paul: North Central Publishing Company, 1952).

Some articles on aspects of cultural history are Irene P. Norell, "Prose Writers of North Dakota,” North Dakota Quarterly, XXVI (Winter 1958), 1-36; Robert P. Wilkins, “Orin G. Libby: His Interests, Ideas, Opinions,” North Dakota Quarterly, XXIV (Summer 1956), 71-93; Russell Reid, “The State Park System," North Dakota Historical Quarterly, VIII (October 1940), 63-78; Harlow L. Waister, “George Francis Will,” North Dakota History, XXIII (January 1956), 5-25; H. E. French, "North Dakota Medicine-A 70-Year Span,” Journal-Lancet (Minneapolis), 71, 1 (January 1951), 2-8. There is much social history in Erling N. Rolfsrud's readable Lanterns over the Prairies.

\section{CHAPTER 22}

\section{CULTURAL GROWTH AND ADAPTATION: THE ARTS, LIBRARIES, NEWSPAPERS, AND CHURCHES, 1920-1960}

An atlas volume of Karl Bodmer's drawings and paintings was published with Maximilian's Travels in the Interior of North America. Many of George Catlin's paintings are reproduced in his North American Indians, Being Letters and Notes on Their Manners, Customs, and Conditions, Written during Eight Years' Travel amongst the Wildest Tribes of Indians in North America, 1832-1839 (2 vols.; Philadelphia: Leary, Stuart and 
Company, 1913). Some drawings are reproduced in J. N. B. Hewitt (ed.), Journal of Rudolph Friederich Kurz, Bureau of American Ethnology Bulletin 115 (Washington, 1937). Paul E. Barr, North Dakota Artists, University of North Dakota Library Studies, No. 1 (Grand Forks, 1954), is very useful. E. A. Willson, Social Organizations and Agencies in North Dakota, North Dakota Agricultural Experiment Station Bulletin 221 (Fargo, 1928), and Donald G. Hay, Social Organizations and Agencies in North Dakota: A Study of Trends, 1926 to 1936, North Dakota Agricultural Experiment Station Bulletin 288 (Fargo, 1937), have material on churches. See also Stanley W. Voelker, Economic and Sociological Trends Affecting Town and Country Churches in North Dakota (Fargo: North Dakota Council of Churches, 1962). C. A. Armstrong, History of the Methodist Church in North Dakota, Louis Pfaller (ed.), The Catholic Church in Western North Dakota, 1738-1960, and Robert P. and Wynona H. Wilkins, God Giveth the Increase: The History of the Episcopal Church in North Dakota, are especially valuable for the history of denominations in the state.

\section{CHAPTER 23}

\section{THE CHARACTER OF A PEOPLE}

Materials on the North Dakota character are, of course, scattered. Yet some interesting insights can be gleaned from Edward C. Blackorby's fine book on William Lemke, Prairie Rebel, and from a number of articles. Beverly Smith wrote on William Langer as “The Most Baffling Man in the Senate,” Saturday Evening Post, January 23, 1954, pp. 26-27, 101-103. Mark Murphy, “The Cities of America: Minot, North Dakota,” Saturday Evening Post, November 12, 1949, pp. 38-39, 152-156, has some shrewd observations, but the best item is Eric Sevareid's “You Can Go Home Again,” Collier's, May 11, 1956, pp. 38-39, 58-67. 


\title{
Postscript
}

\author{
DAVID B. DANBOM
}

NORTH DAKOTA STATE UNIVERSITY

THE PERSONALITY of a human being is formed early in his or her existence and, while experiences frequently modify it in some ways, its basic outlines remain generally the same throughout life. And so it is with institutions and with political entities. While North Dakota has changed in some ways in the thirty years since Elwyn Robinson wrote this book, the main characteristics of the state that he delineated have proven to be remarkably durable.*

This book was a product of its times and was thus shaped in part by the historical trends of the 1950s and early 1960s. In those days, most history was political history, and that reality was reflected in Robinson's emphasis. 
Robinson stressed how the state's remoteness, dependence, and colonial economic status shaped its politics, especially, and most remarkably, by giving it a vital agrarian radical tradition. During the past generation, dependency and economic colonialism have continued to shape the politics of the state, but agrarian radicalism has disappeared, largely because the relationship between North Dakota and the federal government has changed dramatically.

Before the 1930s, the federal government frequently served as an impediment to what North Dakotans wanted to accomplish. It carried them into war when they wanted peace, it helped a conservative minority undermine the Nonpartisan League, and, while it encouraged manufacturing with tariffs, it did little to sustain agriculture. Small wonder that North Dakota Congressmen cultivated the image of outsiders battling against an oppressive national government.

Franklin Roosevelt's New Deal significantly altered the relationship between North Dakota and the federal government by making the state a ward of the nation. Federal entitlement and emergency programs, especially for agricultural subsidization and relief, poured massive amounts of money into the state. After World War II more money flowed in, for defense installations, highways, education, welfare services, and numerous other purposes. The result was that North Dakota enjoyed an enormously favorable fiscal relationship to the federal government, receiving two or three dollars each year from Washington for every dollar it sent back in taxes and counting itself among the leading states in federal expenditures per capita. Today government is second-and a close second, at that - to agriculture as a source of income for the state.

The changed relationship between the federal government and North Dakota required a new political style, though politicians steeped in the agrarian radical tradition were slow to grasp that reality. Even as William Lemke and Wild Bill Langer continued to play the outsider role, Milton Young represented the prototype for the post-war North Dakota politician on the national stage. Young was quiet and unobtrusive-quite the opposite of his senior colleague, Bill Langer-but was effective at shifting money out of the rest of the country and into North Dakota. Other successful North Dakota Senators (because states are represented equally in the Senate, North Dakota enjoys disproportionate influence there), such as Kent Conrad and the late Quentin Burdick, have been equally adept at maintaining and increasing the flow of federal dollars into the state.

By taking much of the price risk out of farming and by redistributing resources from industry to agriculture and from rich states to poor states such as North Dakota, the federal government inadvertently addressed the grievances that formed the heart of agrarian radicalism in the state. As a consequence, the state has become conservative in the sense that it is interested in preserving a set of arrangements under which it has prospered.

Compounding the irony represented by growing conservatism in a traditionally radical state is the fact that the party most devoted to preserving North Dakota's relationship with the federal government-the Democratic Nonpartisan League party-carries the name of the state's most famous agrarian insurgent organization.

In contemporary politics North Dakota finds itself in the unaccustomed position of 
being in step with much of the rest of the country. On the one hand, like many others, North Dakotans are critical of excessive government spending. They are attracted to such ideas as term limits and the balanced budget amendment that promise to curb Congress' wasteful ways, and self-proclaimed budget-cutter H. Ross Perot ran well enough there in 1992 that Newsweek proclaimed North Dakota part of "Perot Country." On the other hand, North Dakotans define any federal expenditures that benefit them as absolutely essential, and they react with fear and anger when Congress discusses ending the honey subsidy or closing an air base. When it means matching the high level of political immaturity demonstrated by so many Americans, getting in step with the rest of the country is not necessarily good.

Other political changes have been more positive. For example, the past thirty years have seen Indians - the main non-white minority in the state with four percent of the population - and women play a much more significant role in state and local politics. Such Indian leaders as Louise Defender Wilson and Richard LaFromboise have become prominent in the Democratic party, and women have played an increasingly active and visible role in both parties. The election of Sarah Vogel to the traditionally male post of Agriculture Commissioner in 1988 and Heidi Heitkamp’s 1992 election as Attorney General were especially important indications that women's abilities were finally receiving some recognition from the state's electorate.

In a number of ways, though, the political culture described by Elwyn Robinson thirty years ago remains intact. North Dakotans continue to be part of the "commonwealth" political tradition. They take their responsibilities as citizens seriously, and they vote in large numbers - 65 percent or better in most presidential contests. They are civil to one another, and distrust the negative, sound-bite campaigning that plays such an important role in contemporary politics in the United States. North Dakotans continue to expect that their elected officials will be honest, forthcoming, and accessible. North Dakota leads the nation in elected officials per capita. Robinson would see this as a particularly graphic illustration of the "too-much mistake," but it can also be interpreted as showing the willingness of some North Dakotans to serve their communities and the desire of others to have them accessible and responsive.

The commonwealth political tradition is also reflected in the remarkable vitality of the initiative and referendum process. In the past twenty years voters have restructured the tax system, legalized charitable gambling, disapproved-then approved-Sunday opening for retail stores, and cancelled a series of tax increases, among other actions. Those most closely identified with the initiative and referral processes, such as Kent French, John Gosbee, and Russell Odegard, have become major public figures, capable of influencing legislation simply by threatening to initiate or refer. What they perceive as abuses of the system have led some legislators to propose constitutional amendments making it more difficult to initiate and refer legislation, but most citizens remain devoted to these devices that allow them to govern directly.

Robinson recognized the intimate relationship between economics and the character of the state of North Dakota. Remoteness was an important impediment to industrial development, and helped tie the state to dependence on a relatively undiversified agriculture. The lack of economic diversification, in turn, gave North Dakota a colonial position relative to the rest of the country, as it exported raw commodities to be processed elsewhere and imported capital and manufactured products from outside the state. 
The past thirty years have seen relatively little change in the basic structure of the state's economy. Agriculture continues to be the main generator of wealth in North Dakota, and the retail sector-most of it directly or indirectly serving agricultureremains significant, but manufacturing continues to be relatively unimportant.

Since 1980 the attraction of manufacturing to the state has become an increasingly significant public concern. The administrations of Allen Olson and George Sinner saw a growing emphasis on the state's economic development endeavors, and Ed Schafer, son of famous North Dakota entrepreneur Harold Schafer of Gold Seal Products, was elected governor in 1992 mainly because of the public belief that he could improve the state's record in attracting manufacturing.

The results of these efforts have thus far been somewhat disappointing for several reasons. First, the state continues to labor under the disabilities of remoteness from major markets and an unattractive climate, though its proximity to supplies has made it attractive to some food processors. Second, neither investment capital nor skilled workers are abundant in the state. Third, the manufacturing sector is shrinking in the United States as a whole, compounding the difficulty of attracting firms. Finally, as the Greater North Dakota Association discovered in preparing its Vision 2000 report on the future of the state's economy in 1989, the state suffers from a failure of entrepreneurial imagination and an intense aversion to taking risks. Banks are reluctant to lend to startup companies in endeavors with which they are unfamiliar (Great Plains Software of Fargo, probably the most spectacular new company in the state in the past thirty years, was unable to borrow seed money from North Dakota banks), and entrepreneurs are unwilling to try anything new. This reluctance is based in the correct perception that the North Dakota economy has punished risk takers more often than it has rewarded them, but it clearly complicates efforts to diversify the economy.

Diversification has occurred in areas other than manufacturing, albeit slowly. Its reserves of fossil fuels meant that North Dakota enjoyed a boom during the energy crisis of the seventies, when lignite production nearly tripled and oil production nearly doubled, but coal and petroleum are commodities subject to a boom-and-bust cycle, as the state learned to its deep regret in the eighties. Tourism continues to enjoy steady growth. Legalized gambling and the continuing development of retail and medical facilities, especially in Minot, Grand Forks, and Fargo (which has also constructed a large, multi-purpose indoor facility, the Fargodome), have been effective in drawing visitors from Canada and other surrounding areas. Unfortunately, though, North Dakota lacks the natural wonders that might make it a major tourist mecca.

Agriculture remains the key to North Dakota's economy, but it is an enterprise that has changed dramatically over the past half century. In the years after World War II, and especially after 1960, many of the risks were taken out of agriculture. Price risk was mitigated by government loan programs, enacted initially in the 1930s, that effectively put a floor under prices. Production risk was diminished by a number of factors. Sophisticated farm machinery, such as tractors and combines, allowed timely field operations. Anhydrous ammonia dramatically eased the task of nitrogen fertilization, allowing yields to rise impressively. Insecticides such as DDT, and herbicides such as 2,4-D diminished losses to pests. Area-specific crop varieties, many developed by the North Dakota Agricultural Experiment Station, were more dependable producers than their predecessors. Finally, federal crop insurance protected farmers against weather- 
related losses. The result was that by the 1960s North Dakota farmers had what their parents and grandparents never had: high assurance that they would produce a crop of predictable size and would receive at least a predictable minimum price for it.

The problem was that, as is usually the case in our free-market system, declining risk was accompanied by diminishing rewards. American agriculture in general was highly productive throughout the postwar period, meaning that surpluses were ever-present and that crop prices did not rise in step with the general price level. At the same time, farmers' costs for expensive machinery, seed, and chemicals did increase, narrowing margins.

Farmers sought to escape some of the effects of the cost-price squeeze by achieving economies of scale. Modern machinery facilitated larger farms and modern economic realities compelled them. As farmers bid aggressively for the acres of neighbors who were retiring or otherwise leaving agriculture, the price of land rose more rapidly than the profits it could produce. At the end of World War II the average North Dakota acre returned over 18 percent of its value to its owner. In 1961 it returned just over 10 percent. and only 9 percent in 1971. A decade later the average acre returned a paltry 4.25 percent. Ironically, the decline in per acre returns further fueled farmers' desires to add more acres, with the result that there were fewer and larger farms all of the time. In 1960, there were 55,000 farms in the state, averaging about 760 acres in size. By 1980 there were only 40,000 farms in the state, and they averaged over 1040 acres in size. Twelve years later there were only 33,000 farms left in North Dakota, and their average size was about 1225 acres.

North Dakota agriculture has enjoyed periodic booms, and the 1970s saw a remarkable one resulting from the favorable conjunction of several factors that spurred exports. First, production shortfalls hit a number of major world agricultural producers, including some of our competitors. Second, high world prosperity, particularly pronounced in developing countries, allowed customers to purchase more of our products. The détente policy with the Soviet Union and the initiation of relations with China opened markets that had been restricted previously. Finally, President Richard Nixon's devaluation of the dollar in 1971 made American exports more attractive throughout the world.

Farmers in North Dakota and across the United States responded to the ensuing price surge with enthusiasm. They welcomed the Nixon Administration's "fencerow-tofencerow" policy removing production restrictions, broke previously unbroken lands, were cheered by the assurance of Agriculture Secretary Earl Butz that prosperity would be permanent, and expanded their operations in every way possible. Expansion in a time of prosperity resulted in a dramatic inflation of land values. In 1971 the average North Dakota acre was worth $\$ 96$, but ten years later it was worth $\$ 424$, an increase of 342 percent.

By the late seventies the boom was faltering, and had clearly ended by 1981 . The boom busted mainly because world production patterns returned to normal, but other factors also played a role. The Gerald Ford and Jimmy Carter export embargoes-the first in response to high domestic grain prices and the second in retaliation for the Soviet invasion of Afghanistan in 1979-raised questions about our reliability as a supplier. Also in 1979, the Paul Volcker-led Federal Reserve Board decided to fight inflation by raising interest rates. That action both increased the value of the dollar and imperiled debtors who had benefited from low real interest rates in the sixties and seventies. The 
Ronald Reagan tax cuts of the early 1980s inflated the deficit and helped assure that real interest rates would remain high, with all of the negative consequences for agriculture that implied.

These developments brought an agricultural depression in the eighties that rivaled that of the thirties in severity. Despite massive infusions of federal money, thousands of North Dakota farmers lost their land. Especially vulnerable were young farmers just getting into agriculture and those who had expanded through the use of complex and risky leveraging strategies.

The eighties compelled farmers to re-appreciate the risks of their enterprise. They have become very conscious of their costs, even showing a willingness to sacrifice some yield to keep expenses down. They have shown a new commitment to diversification, both by adding new crops and animals to their production mix and by adding more incomes to the family. Some have switched to organic systems to exploit the vibrant niche market for natural foods. They have also demonstrated an interest in capturing food production profits that presently go to processors. The Dakota Growers Pasta Company at Carrington, opened in 1993, is the best known of several cooperative processing enterprises that aim to return more profits to their farmer members.

The predominance of agriculture in the North Dakota economy meant that the changes through which it passed would inevitably have significant social effects. As agricultural productivity rose, the number of farmers and the number of on-farm jobs declined. Because alternative local job opportunities were limited, shrinking agricultural employment translated into migration from the countryside to urban places, both inside North Dakota and outside the state.

The 1990 census revealed several significant effects of this rural-urban migration. First, it showed that North Dakota's overall population had declined since 1980 and that the state had the dubious distinction of being the only one in the Union with fewer people than it had in 1920. Second, the census showed that several counties in the western part of the state had fewer than two people per square mile, a significant number because a century ago the Census Bureau had used it as an indication of an area's emergence from frontier status. The North Dakota Census Data Center predicted that half of the counties in the state would have fewer than two people per square mile in 2000. Third, the census showed that a majority of North Dakotans - 53.3 percent to be exact-now lived in urban places, for the first time in the state's history. And finally, while the census showed solid growth in bustling centers such as Bismarck, Fargo, Grand Forks, and Minot, it also carried the melancholy news 80 percent of the incorporated places in the state had lost population since 1960, and that some had disincorporated.

Not only is the population of rural North Dakota declining, it is also aging. The rural birthrate has fallen to the point that the average farm household is only slightly larger than the average urban household. There are many reasons for this decline, but two of the most important are the diminishing need for labor on modem farms and the increasing difficulty of providing viable farms to more than one or two heirs. A second major cause of the aging of rural communities is the reality that young adults are the most likely to migrate, often using college or military service as a conduit out of the community and out of the state. As a result of these two factors, the percentage of North Dakotans over the age of 65 has risen from 10.7 in 1970 to 14.3 in 1990, with the most dramatic 
increases in rural areas.

In combination, out-migration and the aging of the residual population has devastated many communities. Institutions that are of great significance to North Dakotans have become difficult for many communities to maintain. North Dakotans prize education, and are among the nation's leaders in high school degrees per capita, but country towns find it challenging to keep small schools open in the face of declining enrollments and more demanding state requirements. The loss of a school has an economic effect, but because schools are sources of local pride, identity, and unity, the impact on morale is more devastating. Churches are another institution prized in North Dakota, where over three-fourths of the people profess church membership. But shrinking population has made it difficult to maintain churches.

Communities also find it difficult to provide basic services. Small towns and counties have a harder time fulfilling their basic obligations to citizens. Rural residents, especially older ones, are disturbed that medical care is no longer available locally. The loss of retail stores and cafes further weakens service centers, and has a spiraling effect, diminishing traffic and the value of remaining main street businesses. In one sense, all of this might be seen as confirmation of Robinson's “too-much mistake” insight that there are simply too many towns, schools, counties, retail stores, and so forth to be supported adequately. But that provides no consolation for people who face the loss of identity that a disappearing community entails.

One result of this dismal process has been a sharpening of the contrast between the two North Dakotas. The first is rural, aging, declining, often pessimistic and sometimes fearful of the future. The second is urban, growing, vital, optimistic, and hopeful. The first often regards the second with bitterness and anger, while the second demonstrates little understanding of what the first is going through. The urban-rural split, older than the state itself, has thus been intensified by the social and economic stresses of the last generation.

The continuing salience of the rural-urban split is one of the characteristics that sets North Dakota apart from most other states. In many other ways, however, North Dakota has overcome the handicap of remoteness to become more like the rest of the country. North Dakotans are more fully a part of the national culture than ever before. They read the same books and magazines as people elsewhere, watch the same television programs, carried by cable systems or picked up by satellite dishes, wear the same styles of clothing, consume the same types of foods, and shop at the same national chain retail stores. They travel more widely than their parents and grandparents, visiting throughout the United States and in foreign lands and frequently wintering in Arizona or elsewhere.

In gender relations, as well, North Dakotans have shown themselves to be in step with national trends. Women are more assertive, not only in the political arena but at home and in the workplace as well. More North Dakota women than ever choose to be single, and women and men are less reluctant to divorce than their parents were. Indeed, the percentage of North Dakotans over fifteen who were divorced nearly quadrupled between 1970 and 1990, to 6 percent. Married women are the fastest growing segment of the work force, in both rural and urban North Dakota, and working women frequently have young children at home. 
Other ways in which North Dakota has become more like American society in general are less benign. In recent years, North Dakotans have been stunned when drug rings were uncovered in cities and even small towns. Teen suicide, pregnancy, substance abuse, and even crime appear there, as they do elsewhere. Citizens in Fargo, Grand Forks, and Grafton were shocked to learn in 1993 that incipient youth gang activity was taking place in their communities. North Dakota has had its share of securities frauds and financial scandals, including a large kickback scheme involving Housing and Urban Development Department funds. Nor are North Dakotans immune to intolerance of Indians, Hispanics, gays, East Asians, Middle Easterners, and other minorities. North Dakotans are reluctant to acknowledge such problems, and, indeed, most are less pronounced there than elsewhere, but they do exist.

For good or ill, then, modem communications and transportation have diminished the physical remoteness that so impressed Elwyn Robinson. Still, a sort of "mental remoteness" remains. Because they share an ethnic heritage, or because they share a physical place and a political entity, or because they experience the same environment and social milieu, or because of some combination of these, North Dakotans feel that they have something in common that distinguishes them from other Americans.

For many, being a North Dakotan means feeling inferior. It is not surprising that this feeling should arise, when national comedians make North Dakota a synonym for nowhere, or when the state appears on the national news only when there is a blizzard or flood. Nor is it hard to feel inferior when more people move out of your state than move in, or when all of your famous native sons and daughters live outside North Dakota.

But there is more to what Robinson called "the character of a people" than just a sense of inferiority. There is also devotion to the old virtues of hard work and personal integrity. There is also loyalty to family, friends, and community. And there is also a general decency, civility, and tolerance in human relationships. Many North Dakotans believe that it is these characteristics that make them remote-perhaps increasingly sofrom the rest of the nation, and in these things they have no desire to overcome their remoteness. 


\section{Index of Northern Plain Heritage Foundation Sites}

Many areas discussed in Robinson's History of North Dakota exist today as public sites in the Northern Plains National Heritage Area (NPHNA). Many of these sites are open to visits from the public. Below we provide a site index connecting mentions of NPHNA sites in the text to their current websites and locations.

\section{Audubon National Wildlife Refuge}

Significance: Audubon National Wildlife Refuge is located near Coleharbor, ND. The Refuge is in the Prairie Pothole Region; it contains many small wetlands that resemble potholes. The wetlands and surrounding grasslands provide food, shelter and nesting sites for birds. The Refuge is named after ornithologist John James Audobon.

Website : https://www.fws.gov/refuge/audubon/

\section{Mentions in Text :}

Chapter 14: "John James Audubon, world-famous ornithologist, in 1813..."

Chapter 22: "In 1843, John James Audubon, the ornithologist, spent a busy summer at Fort Union painting wildlife..." $\underline{\unlhd}$

\section{Belle Mehus Auditorium}

Significance: First opening in 1914, the Belle Mehus Auditorium has hosted many events for the Bismarck community. It has seen everything from Italian operettas to screenings of "Birth of a Nation". It is now mostly used for the Bismarck Symphony Orchestra. The auditorium is named after a local piano teacher Belle Mehus.

Website : http://www.bismarckeventcenter.com/p/planner/belle-mehus

\section{Mentions in Text :}

Chapter 8: "Towns were quite naturally centers for diversion and entertainment. Fargo, Grand Forks, and Bismarck had theaters." $\underline{\Perp}$ 


\section{Big Hidatsa Village}

Significance: Occupied from about 1740 to 1850 , it is the largest of three Hidatsa communities near the mouth of the Knife River. It is comprised of 120 circular earthlodges. The Corps of Discovery wintered there in 1804.

Website : https://www.nps.gov/nr/travel/lewisandclark/big.htm

\section{Mentions in Text :}

Chapter 2: "But one band of Hidatsas, although they had a large earthlodge village on the north bank of the Knife and raised corn, generally lived as wandering hunters." $\Perp$

Chapter 2: "Six large Mandan villages had been reduced to two small ones, and there were also two Hidatsa villages and one village made up of both Mandan and Hidatsa families at the mouth of the Knife."

Chapter 3: "The forts traded mainly with the Assiniboins, Plains Chippewas, and Crees, but they also sent merchandise to the Mandan and Hidatsa villages on the Missouri River at the mouth of the Knife." $\underline{4}$

Chapter 5: "Although at first he had chosen the mouth of the Yellowstone, he decided to put the army post for the Missouri beside the Mandan and Hidatsa villages at the mouth of the Knife River."

\section{Bill Mills Nature Trail}

Significance: 1.5 Mile nature trial in Bismarck, ND that is along the Missouri River.

Website: http://www.bisparks.org/parks-trails/educational-trails/

Mentions in Text: N/A

\section{Bismarck-Deadwood Stage Trail (Historic Marker)}

Significance: From 1877 to 1880, a thriving stagecoach and supply line ran between Bismarck, the western terminus of the Northern Pacific Railroad, and the Black Hills gold town of Deadwood in Dakota Territory. The Historic Marker is located on Highway 21 a mile east of Flasher and describes the history of the trail and the economic boom associated with the trail. 
Website: http://history.nd.gov/historicsites/bdst/index.html

\section{Mentions in Text:}

Chapter 9: "In 1877 stagecoaches and freight wagons began to travel from Bismarck to Deadwood to accommodate gold seekers rushing into the Black Hills."

Chapter 9: "Don Stevenson, the army freighter and contractor, and his employees started ranches near the Bismarck-Deadwood Trail on the

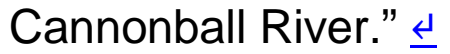

Chapter 9: "The Marquis de Mores' enterprises had already failed: the

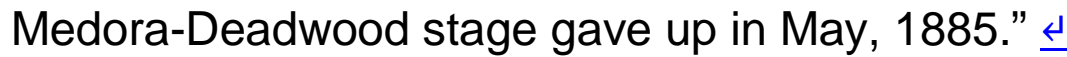

\section{Bismarck Mandan Community Cooperative}

Significance: Cooperatives were established in the 1880 s by immigrants who came to farm in the region.

\section{Mentions in Text:}

Chapter 13: "The wheat farmer, hauling his crop to town, might sell it to a line operator, to an independent elevator, to a cooperative elevator..." 4

\section{Camp Hancock State Historic Site}

Significance: The historic site provides a history of the policies of the government, including westward expansion. The site served as a US military post established along the Northern Pacific Railway. The purpose of the post was to protect supplies, equipment, and engineering crew of the Northern Pacific Railroad, as well as the citizens of Edwinton, which was renamed Bismarck in July of 1873 . By 1883 , the post had added duty to serve as a storage station for the quartermaster's supplies, which were shipped by rail, wagon, or steamboat, to posts up and down the river and points further west.

Website: http://history.nd.gov/historicsites/hancock/

\section{Mentions in Text:}

Chapter 6: "In 1872 the army located Camp Greeley (later Camp Hancock) there to protect the construction crews." $\Perp$ 
Chapter 9: "It abandoned Fort Ransom in 1872, Fort Seward and Camp Hancock in 1877." $\Perp$

Bibliographical Essay: "Smaller collections are maintained at Camp Hancock in downtown Bismarck." $\lrcorner$

\section{Cathedral Area Historic District}

Significance: Located in Bismarck, it is also known as "the Hill". The Cathedral Area Historic district was a residential development in the 1900s that had a variety of architectural styles and was home to many of North Dakota's early leaders and influencers.

Website: n/a

\section{Mentions in Text:}

Chapter 10: "In 1882, McKenzie and an associate, perhaps in anticipation of removal, bought a 160-acre tract on the northern edge of Bismarck." $₫$

\section{Chief Looking's Village}

Significance: The village is located in Bismarck and is named after the Mandan chief, Chief Looking. The Mandans who lived here built a walled village with a lookout tower and earth lodges for homes and community rituals. Chief Looking's Village contained about 48 earth lodges. The locations of some of the lodges are still visible as depressions in the earth. The archaeological site of the village includes cultural significance of overlooking the River and Native Life.

Website: http://www.ndtourism.com/bismarck/attractions/chief-lookingsvillage

\section{Mentions in Text:}

Chapter 2: "They constructed most of their small, unfortified villages on the west bank of the Missouri..." $\underline{4}$

\section{Cross Ranch Archaeological District, Cross Ranch State Park}

Significance: Located near Hensler, it is an archaeological site of the Mandan-Hidatsa culture and other period findings dating from 6,000 B.C. to 1 
A.D. The excavated sites show that there was evidence of architectural practices of the residence of that area.

Website: http://www.parkrec.nd.gov/parks/crsp/crsp.html

Mentions in Text:

Chapter 2: "Archaeological remains of their culture are widely scattered over the Plains." $\underline{\rfloor}$

\section{Cross Ranch Preserve}

Significance: The only free-flowing area of the Missouri River in North Dakota, it is located north of Mandan. The views are similar to what Lewis and Clark saw with the Discovery Corps in 1804.

Website: http://www.nature.org/ourinitiatives/regions/northamerica/unitedstate s/northdakota/placesweprotect/cross-ranch-preserve.xml

\section{Mentions in Text:}

Chapter 1: "When the Lewis and Clark Expedition entered what is now North Dakota in the fall of 1804, they saw large herds of buffalo, elk, and antelope as well as many grizzly bears, along the Missouri River..." $\Perp$

\section{Crowley Flint Quarry State Historic Site}

Significance: The Knife River flint (KRF) quarries are located in the center on North America. The primary source area is in west-central North Dakota, near the Knife River and Spring Creek in Dunn and Mercer Counties. For 11,000 years Native Americans traveled to the quarries to procure high-quality lithic material for tool-making and trade.

Website: http://history.nd.gov/historicsites/cfq/index.html

\section{Mentions in Text:}

Chapter 2: "Some of them dug a smoky, dark-brown flint from quarries or bowl-like depressions along the Knife River (the name is a translation of an

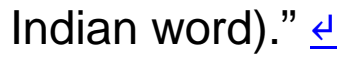




\section{Custer Park}

Significance: After the demise of Lt. Col. George Custer in 1876, Custer's widow, Elizabeth Custer, took up residence in the City of Bismarck, Dakota Territory, across from where she and her husband quartered at Fort Abraham Lincoln. Elizabeth, or 'Libby,' lived there for decades in Bismarck, and her relationships with the community strengthened. Just after the turn of the $19^{\text {th }}$ century, "Custer Park" was formed as Bismarck's first park. It is located within the Cathedral Historic District.

Website: http://www.bisparks.org/custer-park/

\section{Mentions in Text:}

Chapter 14: "After Custer's death at the Little Big horn, his widow, Elizabeth Bacon Custer, wrote..." $\underline{\Perp}$

\section{Double-Ditch Village/Earth Lodge Village Site/State Historic Site}

Significance: The location of a Mandan earth lodge village from approximately 1490 to 1785 A.D. It was abandoned after the North American smallpox epidemic. After the epidemic, the Mandan tribe banded together with other tribes to create the Like-A-Fish-Hook Village (now under Lake Sakakawea).

Website: http://www.history.nd.gov/historicsites/doubleditch/index.html

\section{Mentions in Text:}

Chapter 2: "During the epidemic the Dakotas attacked two Mandan villages (Slant Village in present-day Fort Abraham State Park and Double-Ditch Village, now a state park, a few miles north of Bismarck)" $\leftrightarrows$

Chapter 21: "In the summer of 1905, young Will and three Harvard classmates (one of them was Herbert J. Spinden, who was to have a distinguished career as an anthropologist) excavated the Double-Ditch Village site on the Burgois farm fourteen miles north of Bismarck." $\underline{\Perp}$ 


\section{Downtown Bismarck Historic District}

Significance: A series of warehouse and transportation buildings along the North Pacific Railway that cover a broad continuum of Bismarck and North Dakota's past.

Website: https://downtownbismarck.com/

\section{Mentions in Text:}

Chapter 6: "The company had begun to build westward... and reached

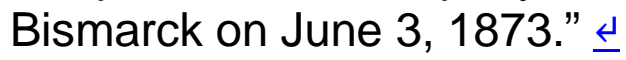

\section{Five Nations Art}

Significance: Resource for artists and consumers of Native American art that connects the native tribes of North Dakota through art.

Website: http://www.fivenationsarts.org/

\section{Mentions in Text:}

Chapter 21: "The institute also sponsored exhibitions of regional art." $\underline{4}$

Former Governors' Mansion State Historic Site

Significance: Constructed in 1884, the Victorian house was home to North Dakota governors' from 1893-1960. The house is located in Bismarck and has been restored to most of its original style of when it was first built.

Website: http://history.nd.gov/historicsites/fgm/

\section{Mentions in Text:}

Chapter 11: "large appropriations for state institutions: the penitentiary, the capitol, the governors' mansion..." $\underline{\Perp}$

Chapter 13: "denounced Governor Sarles for serving liquor in the executive mansion..." $\Perp$ 


\section{Fort Abraham Lincoln State Park/Fort Abraham and Fort McKeen Infantry Post/On-A-Slant Indian Village}

Significance: Located near Mandan, the sites are home to Mandan and Native American policy and military history. It was from this fort that Lt. Col. George Armstrong Custer and the Seventh Cavalry rode out on their ill-fated expedition against the Sioux at the Little Big Horn. On-A-Slant Indian Village includes reconstructed earth lodges depicting the lifestyle of the Mandan Indians, who occupied this site from about 1575 to 1781.

Website: http://www.parkrec.nd.gov/parks/falsp/falsp.html

\section{Mentions in Text:}

Chapter 2: "The most famous was Slant Village, located in what is now Fort

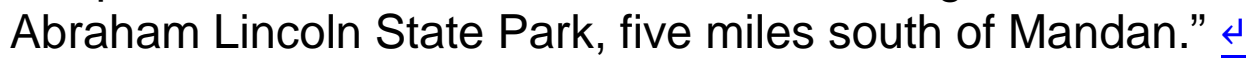

Chapter 2: "During the epidemic the Dakotas attacked two Mandan villages (Slant Village in present-day Fort Abraham State Park and Double-Ditch Village, now a state park, a few miles north of Bismarck)"

Chapter 5: "The latter was renamed Fort Abraham Lincoln that fall and enlarged in 1873."

Chapter 14: "At Fort Abraham Lincoln, while his fellow officers drank and played cards, Colonel George A. Custer..."

Chapter 18: "The work on the North and South Roosevelt..."

Chapter 21: "by 1919 the society had six such places as state parks, including Fort Rice and Fort Abraham Lincoln." \lfloor

Bibliographical Essay: "There are also substantial collections in the museum at Fort Abraham Lincoln State Park five miles south of Mandan."

\section{Fort Clark Trading Post Historic Site}

Significance: The fort exemplified the meeting of two cultures - the interaction between the fur trade forts and the village. More than 150 years ago, it was the scene of a devastating smallpox and cholera epidemics that decimated the inhabitants of a Mandan and later Arikara Indian village. The fort is one of the most important archaeological sites in the state located near 
the town of Fort Clark. The remains of the large earthlodge village, cemetery, and fur trade posts are protected at the site.

Website: http://history.nd.gov/historicsites/clark/index.html

\section{Mentions in Text:}

Chapter 5: "Kipp built Fort Clark at the Knife River villages..."

Chapter 5: "The American Fur Company steamboat St. Peter's brought the disease from Fort Clark and Fort Union in June, 1837."

\section{Fort Mandan and Lewis \& Clark Interpretive Center, Fahlgren Park}

Significance: Fort Mandan is a replica of the fort in which the Lewis and Clark Expedition wintered over 1804-1805. The fort was where the Expedition spent more time than anywhere else on their journey and it is the place where relationships between the US and the tribes of the Upper Great Plains began. Fort Mandan is the key example of the crossroads of culture and commerce interpreted at the Lewis \& Clark Interpretive Center.

Website: http://www.fortmandan.com/

\section{Mentions in Text:}

Chapter 3: "So they built Fort Mandan, their winter camp, as strong as

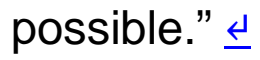

Chapter 3: "Before these events, however, the expedition had spent an interesting winter (1804-1805) at Fort Mandan." $\underline{4}$

\section{Fort Mandan Overlook State Historic Site}

Significance: This site overlooks the area where Lewis and Clark established their headquarters, called Fort Mandan, in the winter of 1804-1805. It is located 14 miles west of Wasburn and overlooks the Missouri River. The original site of Fort Mandan was on a low terrace and is thought to have been destroyed due to erosion.

Website: http://history.nd.gov/historicsites/fmo/index.html 


\section{Fort Rice Campgroud}

Significance: N/A

Website: N/A

Mentions in Text: N/A

\section{Fort Rice State Historic Site}

Significance: Established in 1864, the site houses US Native American and western land policy. Fort Rice was the first of a chain of forts intended to guard Northern Plains transportation routes and encourage settlement and protection for Euro-American settlers. Fort Rice became one of the most important military posts on the Missouri River.

Website: http://history.nd.gov/historicsites/rice/index.html

\section{Mentions in Text:}

Chapter 5: "This time, Fisk's train and another one took a more southerly route through Fort Rice."

Chapter 5: "In 1864, Sully had built Fort Rice, the first military post on the

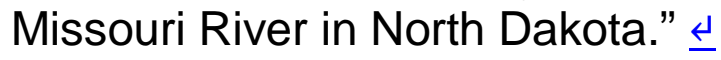

Chapter 18: "The work on the North and South Roosevelt..."

Chapter 21: "By 1919 the society had six such places as state parks, including Fort Rice and Fort Abraham Lincoln." $₫$

Fort Stevenson State Park and Lake Sakakawea (Like-A-Fish-Hook Village)

Significance: The Mandan, Hidatsa, and Arikara Village (Like-A-Fish-Hook Village) was inundated by the Garrison Dam, as was Fort Stevenson (once New Fort Berthold). Fort Stevenson was turned over to the Fort Berthold Indian Agency for a school. Both currently lie under the waters of Lake Sakakawea.

Website: http://www.parkrec.nd.gov/parks/lssp/lssp.html 


\section{Mentions in Text:}

Chapter 5: "In 1845 the Hidatsas began to build Like-A-Fish-Hook Village (so named for a bend in the Missouri) about forty-two miles above the mouth of

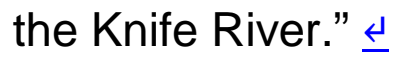

Chapter 5: "During the next few years, the Mandans also moved to Like-AFish-Hook Village, and in 1862 the Arikaras joined them." $\Perp$

Chapter 5: "Fort Stevenson, on the north bank of the Missouri about

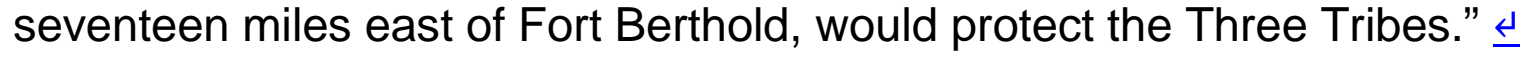

\section{General Sibley Campground and Park}

Significance: The site of a series of conflicts between settlers and Native Americans, later called the Sioux wars. Named after General Sibley, a leader of settler troops. The park is located south of Bismarck and is now used as a campground and park.

Website: http://www.bisparks.org/facilities/general-sibley-park-campground/

\section{Mentions in Text:}

Chapter 4: "In 1834, Henry Hastings Sibley..." $\underline{\Perp}$

Chapter 5: "When an army under Henry Hastings Sibley crushed the uprising..."

\section{German Days}

Significance: A celebration of German and Russian-German settlers in Bismarck (first settled in 1872).

Website: http://bismarckgermandays.com/

\section{Mentions in Text:}

Chapter 7: "Of those settlers who were immigrants, most came from Norway and Canada, but there were also some from Germany, England and Ireland, Sweden, and Russia." $\rfloor$ 


\section{Germans from Russia Heritage Society}

Significance: Bismarck's headquarters have become a Research Center for the Black Sea Germans from Russia. Their ancestors migrated in great numbers to the Dakota Territory beginning in 1873. By the end of the century, they became a predominant ethnic group of this area.

Website: http://www.grhs.org/

Mentions in Text:

Chapter 7: "Over half of those from Russia (the German Russians) $\rfloor$

\section{Huff Indian Village}

Significance: A classic prehistoric Mandan settlement from about AD 1450. The village is a very large, well-planned community where perhaps a thousand or more people once lived. It is located near Huff, ND.

Website: http://www.history.nd.gov/historicsites/huff/index.html

\section{Mentions in Text:}

Chapter 21: “...doing field work on Indian village sites.” $\underline{\Perp}$

\section{Kneelboat Park}

Significance: In Bismarck, the 55' kneelboat replica of the Lewis and Clark boat is located along the Lewis and Clark Legacy Trail with a self-guided interpretive trail.

Website: http://www.bisparks.org/keelboat-park/

\section{Mentions in Text:}

Chapter 3: "... moved up the Missouri River in a 55-foot kneelboat and two pirogues." $₫$

\section{Knife River Indian Village National Historic Site}

Significance: Hidatsa, Mandan, and Arikara pioneered agriculture on the Knife River banks and their villages were linked to trade routes (Knife River 
Flint). Lewis and Clark enlisted Sakakawea's help at Knife River. This site was a Native American trade center for hundreds of years prior to becoming a market place for fur traders. It is located near Stanton.

Website: https://www.nps.gov/knri/index.htm

\section{Mentions in Text:}

Chapter 2: "...now and then a village would be abandoned and a new one built." $\underline{\Perp}$

Chapter 2: "There some of them settled near the Mandans, built earth-lodge villages at the mouth of the Knife River and at Painted Woods..." $\underline{4}$

Chapter 3: "First the British, coming from Hudson Bay and Montreal, dominated trade with the Knife River villages..."

\section{Lewis and Clark Riverboat}

Significance: The Lewis and Clark Riverboat is a riverboat that cruises along the Missouri River. This tour can be comparable to what Lewis and Clark would have seen when they first came up the Missouri River with the Corps of Discovery.

Website: http://www.lewisandclarkriverboat.com/

\section{Mentions in Text:}

Chapter 6: “...transferring freight from riverboat to railroad..."

\section{Mandan Commercial Historic District}

Significance: The City of Mandan was founded in 1881 as the center for western expansion of the iron rail. In 1883, a railroad bridge spanning the mighty Missouri River linked the east and west. The slogan for Mandan was "Where the west begins."

\section{Mentions in Text:}

Chapter 9: "When the railroad crossed the Missouri River in 1879, Mandan sprang up." $\underline{\Perp}$ 


\section{Mandan Depot}

Significance: The Mandan Depot, completed in 1929-1930, served as a major Northern Pacific Railroad junction and Missouri Division headquarters. The original depot and railroad has been in operation since 1884, immediately following the completion of the Northern Pacific Railroad Bridge spanning the Missouri River at Bismarck-Mandan. From 1929-1930, the Depot continued serving as a north-south branch line connector to the smaller towns throughout Morton County.

Website: http://www.mandanhistory.org/arealandmarks/nprailwaydepots.html

\section{Mentions in Text:}

Chapter 7: "Mandan was laid out early in 1879 around the depot and roundhouse of the Northern Pacific..." $\Perp$

\section{Menoken Village}

Significance: It is a small community consisting of 30 oval-shaped, earth covered houses. This settlement was built and used by the Late Plains Woodland people. This village was connected to some of the early European exploration. It is located near the city of Menoken.

Website: http://www.history.nd.gov/historicsites/menoken/index.html

\section{Mentions in Text:}

Chapter 2: "The village was probably the one whose ruins can now be seen

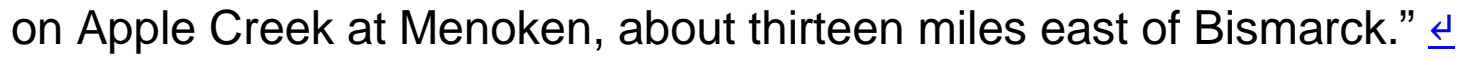

\section{Missouri River Natural Area and Trailhead}

Significance: Located on the east side of Mandan along the Missouri River; this area encompasses 157 acres of preserved floodplain woodlands and is home to a variety of wildlife and plants.

Website: http://www.parkrec.nd.gov/naturepreserves/mrna/mrna.html

\section{Mentions in Text:}

Chapter 1: “...along the Missouri River...” $\Perp$ 


\section{Molander Indian Village State Historic Site}

Significance: The Awaxawi Hidatsa Indians lived in this village overlooking the Missouri River around 1764. Nearly 40 houses were protected by a fortification ditch. A wooden palisade stood on the inside edge of the ditch. The tribe showed change and adaptability over time: after the smallpox epidemic, the Hidatsa community moved north to the Amahami Village at the mouth of the Knife River. The tribe also showed the benefits of community by having a more secure location to move to when needed. The site shows settlement change over time with the Hidatsa village and later the early Euroamerican homestead.

Website: http://history.nd.gov/historicsites/molander/index.html

\section{Mentions in Text:}

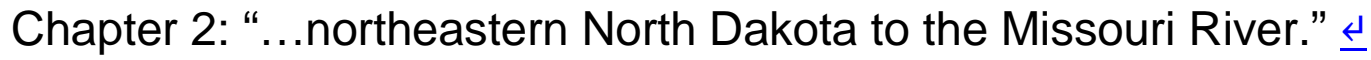

\section{North Dakota Heritage Center and State Museum}

Significance: The State Museum at the ND Heritage Center tells inspiring stories of North Dakota from its earliest geologic formation to contemporary times. Collections in the four galleries span more than 600 million years. The State Museum aims at sending people out across the state to the places where they can walk the grounds and visit the places where history happened, traditions continue, and innovations become reality.

Website: https://statemuseum.nd.gov/

\section{Mentions in Text:}

Chapter 1: "They have also been frequently used as gravel pits, supplying

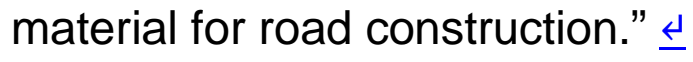

\section{North Dakota Lewis and Clark Interpretive Center and Harmony Park}

Significance: The interpretive center has many state of the art interactive exhibits and collection of artifacts that honor the history of North Dakota and the time that Lewis and Clark spent in North Dakota. This center is also home of the reconstructed Fort Mandan which vistors are welcome to explore.

Website: http://www.fortmandan.com/plan/lewis-and-clark-interpretive-center/ 


\section{Mentions in Text:}

Chapter 3: "After the Louisiana Purchase, Lewis and Clark claimed the Upper Missouri for the United States, and Americans from St. Louis began to seek trade there." $\underline{\Perp}$

\section{Northern Pacific Railroad}

Significance: Transcontinental railroad that operates across Minnesota to the Pacific Coast. A lot of the railroad connects farms in North Dakota to trading throughout the North West. It was finished being built in 1883 and has over 6800 miles of track.

Website: http://www.nprha.org/Pages/Home.aspx

\section{Mentions in Text:}

Chapter 5: "The coming of the Northern Pacific Railroad to the Missouri River opened a new era." $\underline{\Perp}$

Chapter 9: "The Deadwood station had a life-size painting of Custer..."

\section{Pioneer Overlook Park}

Significance: Located "below" Chief Looking's Village, this park has many walking trails and native wildlife.

Website: http://www.bisparks.org/pioneer-park/

\section{Mentions in Text:}

Chapter 7: "The pioneers also had a good hold on the counties just to the west..." 4

\section{Pulver Mounds State Historic Site (within the Coal Lake Wildlife Management Area)}

Significance: Pulver Mounds State Historic Site preserves two low, conical burial mounds on a small bluff above Coal Lake. Burial mounds such as these were typically constructed during the Woodland period from approximately $100 \mathrm{BC}$ to $600 \mathrm{AD}$. 
Website: http://history.nd.gov/historicsites/pulver/index.html

\section{Mentions in Text:}

Chapter 2: “...Indians with a Woodland culture..."

\section{Old Railroad Bed - Mandan to Fort Rice}

Significance: Connecting a reservation (Standing Rock Sioux Reservation) with the wider world by use of an old unused railroad. Elders described it as a connection to the outside world. People traveled to visit family, go to war and, especially before the late advent of the car, it was the only connection with the outside.

\section{Mentions in Text:}

Chapter 5: "Sioux accepted as a reservation roughly the portion of presentday South Dakota lying west of the Missouri River." $\rfloor$

\section{Steamboat Park, Steamboat Plaza, Kneelboat Park}

Significance: $60 "$ replica of the steamboat Yellowstone on the Lewis and Clark Legacy Trail overlooking the Missouri River.

Website: http://www.bisparks.org/steamboat-park/

\section{Mentions in Text:}

Chapter 5: "They had the Yellowstone built. It was 130 feet long, had a draft of

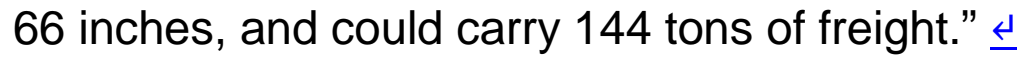

\section{Steamboat Warehouse State Historic Site (Historic Marker)}

Significance: The site commemorates the Northern Pacific Railroad warehouse built to store goods in transshipment between steamboats and freight trains. The 300-foot long stone and frame warehouse was constructed in 1883 on the east bank of the Missouri River in Bismarck, and was torn down in 1925.

Website: http://history.nd.gov/historicsites/steamboat/index.html

\section{Mentions in Text:}


Chapter 6: "As the Northern Pacific built westward in 1872 and 1873, small villages sprang up at Valley City on the Sheyenne River, Jamestown on the James, and Bismarck on the Missouri." $₫$

\section{The Bismarck Depot}

Significance: Turn-of-the-century Northern Pacific Railroad depot. Historic events and people often graced the Depot and adjoining green space-in large part because political figures, on national tours, traveled by train and arrived to Bismarck on train.

Website: http://www.bismarckhistory.org/?id=32

\section{Mentions in Text:}

Chapter 12: "In 1900 the Great Northern built large shops in Minot; the

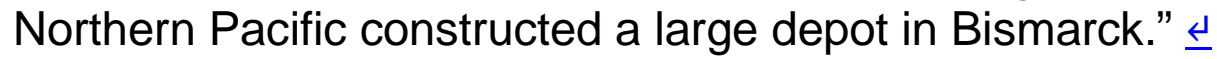

Chapter 16: "Crowd waiting to see World War I soldiers leave for the draft, Bismarck, c. 1917-18." $\Perp$ 